1.

$x$
$x$
4
4
7
$y$
$y$

3

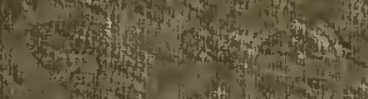

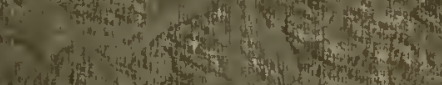

$8 x^{4}$

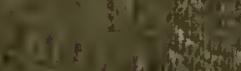

tis

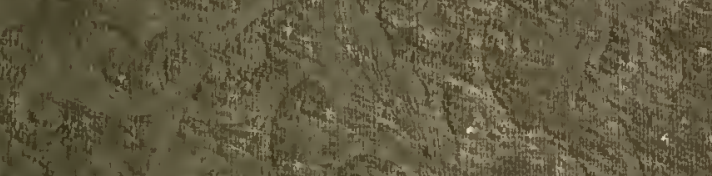

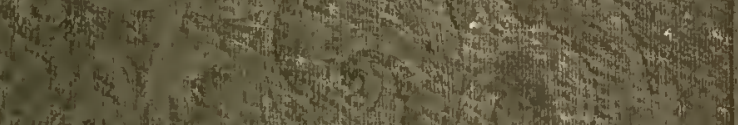

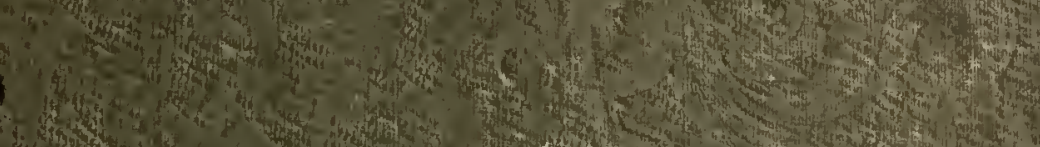

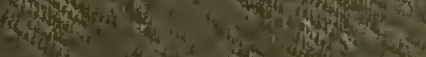

(2)

$2 \pi$

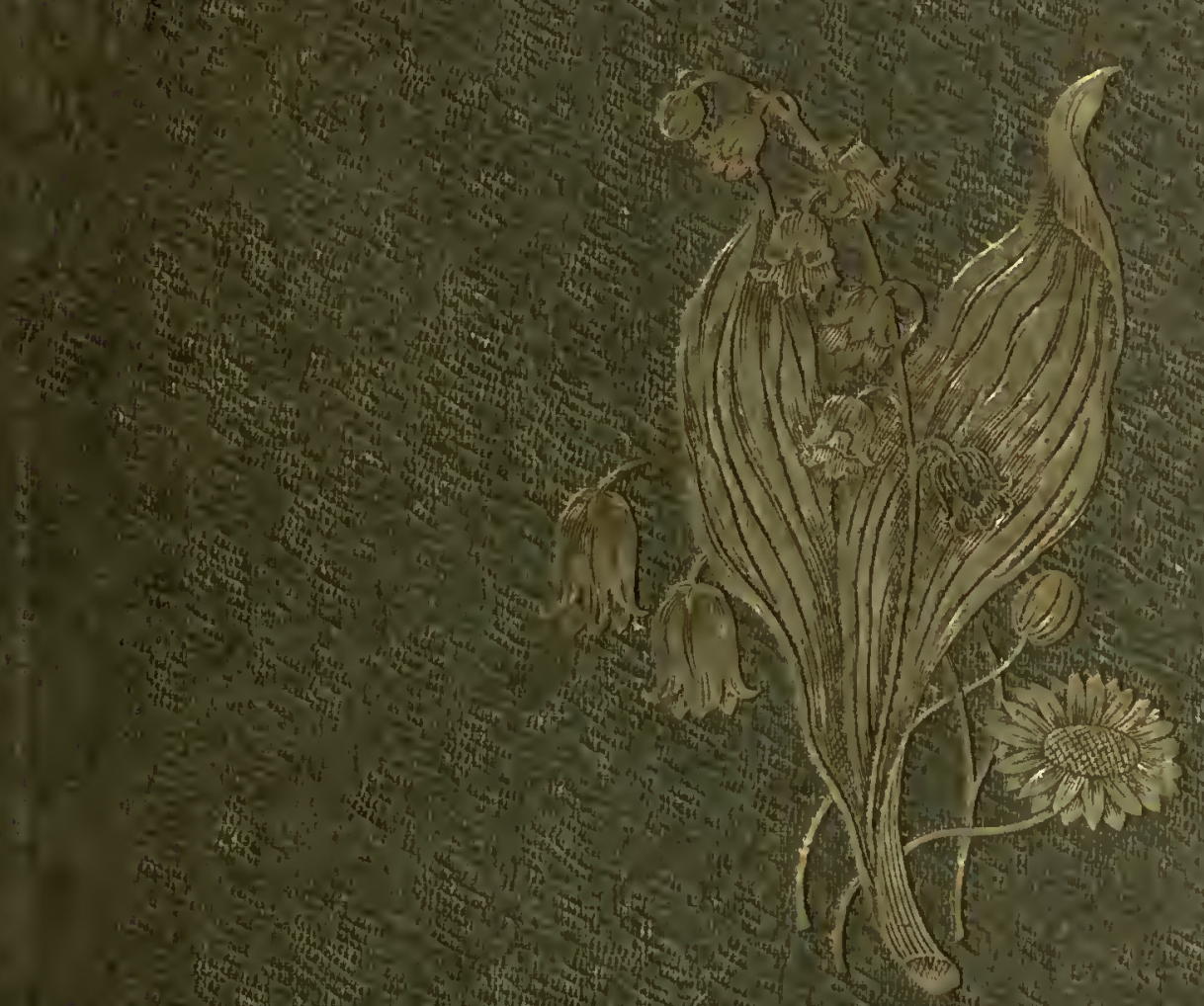

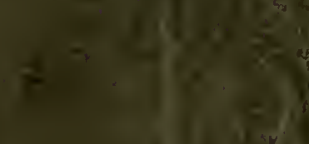


$(20)$ 

THE

LADIES' FLOWER-GARDEN

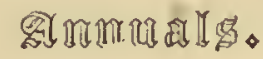





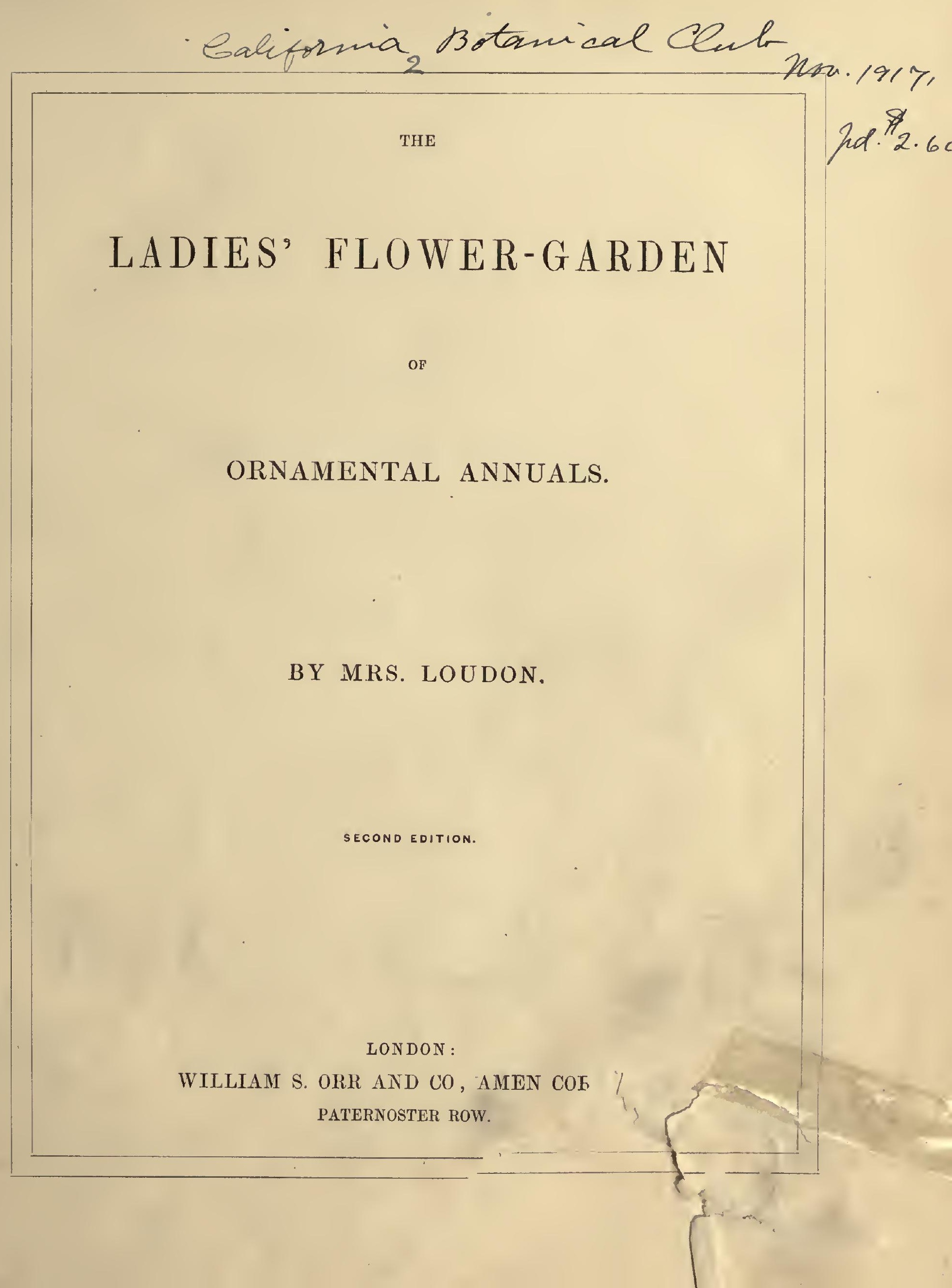




$$
\begin{aligned}
& \text { Dotany } \\
& 5 B^{\circ} 422 \\
& \angle 68 \\
& 1849
\end{aligned}
$$


TO IHE RIGHT HONOURABLE

\section{THE C O U T ESS OF RA D OR, \\ ALIKE DISTIXGUISII BD POH}

HER IOVE OF ELOWERS AND TASTE YOR THE FINE ARTS,

This relork is 现edicated

(WTTI PHRMISSION)

BY IIER OBEDIENT SERYANT,

THE AUTHOR. 



\section{PREFACE.}

IT had long been my intention to publish a series of works, fully describing and illustrating in coloured groups, the most ornamental flowers-grown both under glass and in the open airof our British gardens. In the Preface to the first Edition-it was stated that the present work-the first of the series-would comprise the hardy and half-hardy annuals; that the second would contain all the hardy and half-hardy bulbs; that these would be followed by the biennials and perennials; the greenhouse plants; the hothouse plants, including the orehidacere and the cacti ; and, lastly, the flowering-trees, with the roses and other ornamental shrubs.

As each of these works was to be complete in itself, the proprictor of a small towngarden, growing annuals or bulbs, might confine his purchase to tho volume, or volumes, describing the plants he cultivated; while the possessor of a conservatory or hothouse, would find in the volumes treating of their productions, the flowers best adlapted to his purpose, and ample directions for their culture. Further, each work being arranged according to the natural system, the whole series forms a more comprehensive illustration of the different orders than has yet been published. It will, moreover, be useful in affording general ideas concerning the arrangement of plants, as well as in facilitating the study of botany.

It is seldom that an author can accomplish the no easy task of publishing a series of volumes. This, however, has happily not been my case. I have already published four of 


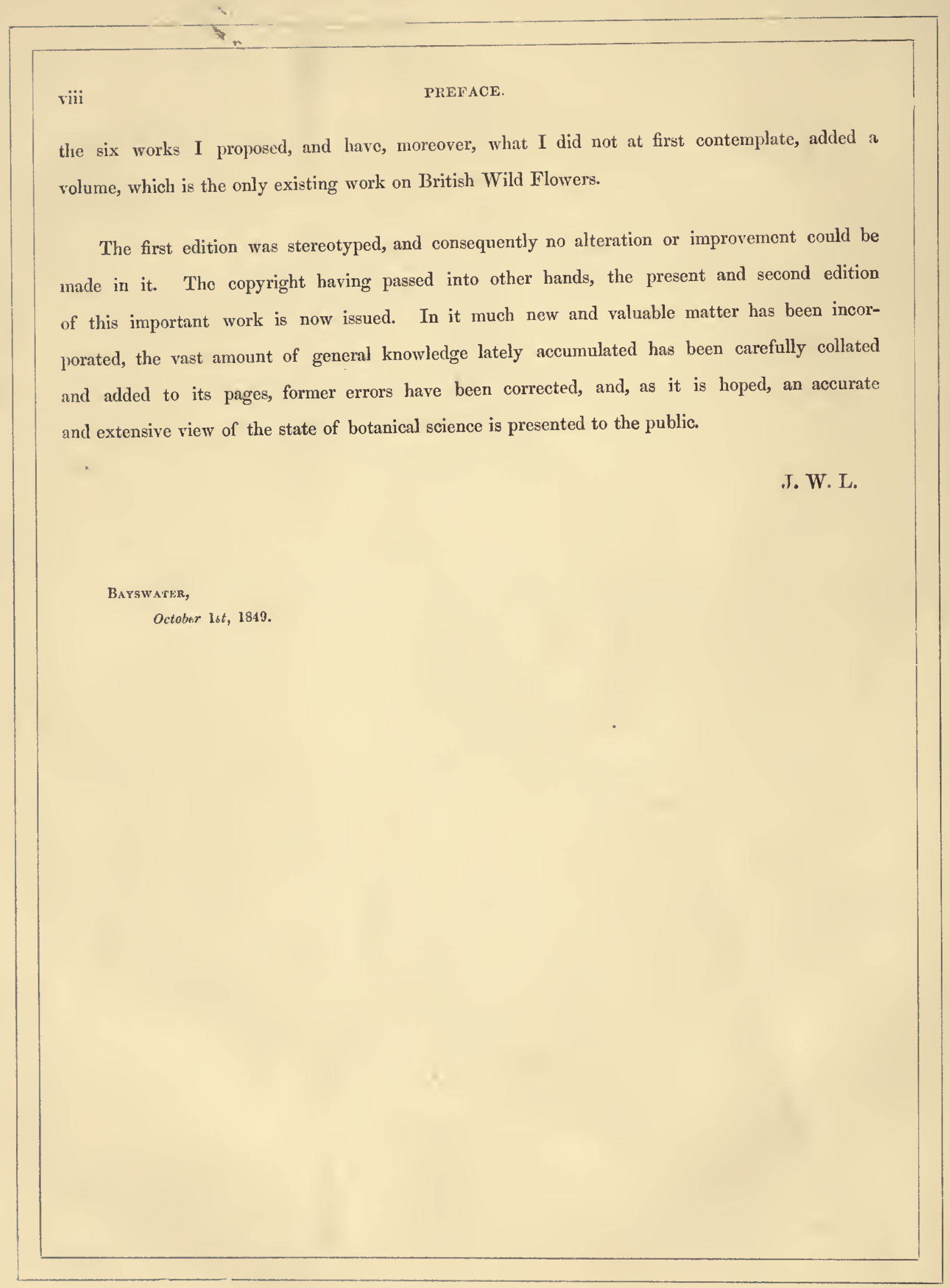




\section{INTRODUCTION.}

“THe love of flowers," says Dr. Lindley, " is a holy feeling, inseparable from our very nature; it exists alike in savage and eivilized soeicty; and it speaks with the same powerful voice to the great and wealthy, as to the poor and lowly." The truth of these observations must be felt by every one. We love flowers from our earliest childhood, and even in extreme old age the sight of them recalls something of the glow of youth. The love of flowers is calculated to improve our best feelings, and subdue our bad ones; and we ean hardly contemplate the beauty and richness of a flower-garden without feeling our hearts dilate with gratitude to that Almighty Being who las mado all these lovely blossoms, and given them to us for our use.

Of all kinds of flowers, the ornamental garden annuals are perhaps the most generally interesting; and the easiness of their culture renders it peeuliarly suitable for a feminine pursuit. The pruning and training of trees, and the culture of culinary vegotables, require too much strength and manual labour; but a lady, with the assistance of a common labourer to level and prepare the ground, may turn a barren waste into a flower-garden with her own hands. Sowing the seods of annuals, watering them transplanting them when neeessary, training the plants by tying them to little sticks as props, or by leading them over trellis-work, and eutting off the dead flowers, or gathering the seeds for the next year's crop, are all suitable for feminine oceupations; and they have the additional advantage of indueing gentle exereise in the open air.

It is astonishing low much beauty may be displayed in a little garden only a few yards in extent by a tasteful arrangement of annual flowers. All that is required is a knowledge of the colours, forms, and habits of growth of the different kinds. Many of the flowers now grown in our gardens are not worth culture, but they are grown year after year, because their cultivators know them and do not know anything better. Many very beautiful flowers have been introduced, grown for a season or two, and then thrown out of cultivation from there being no demand for them; and this want of demand has arisen from very few flower-growers being aware of their existenee. It is true that most of these flowers were figured on their first introduction in one or other of the botanical periodicals; but in 
these works they are mixed up with greenhouse and hothouse plants and shrubs, which, of course, the mere grower of annuals can feel little interest in ; so that a person wishing to get coloured figures and botanical descriptions of all the finest annual flowers, must now purchase plates and descriptions of hundreds of other flowers that he has no need of.

The culture of annuals has two great advantages over the culture of all other flowers whatever. In the first place, it is attended with less expense than any other description of flower culture; and in the sea)nd, all the enjoyment of which it is susceptible is obtained within the compass of six or eight months. Bulbous or tuborous-rooted flowers, like annuals, produce their blossoms in the first year; but they are attended with an enormously increased expense. Perennial herbaceous flowers are never in perfection till the second year; and, like bulbs, can only be beneficially purchased by such as anticipate retaining the occupation of their garden for several years in succession. The seeds of annual flowers, on the other hand, cost a mere trifle; and the expense of stirring the soil, sowing them, and thinning them when they come up, is also very little; while the effect produced is as great or greater than that of many bulbs or tubers, and most perennials. The flower of a choice hyacinth, the bulb of which will cost five or six shillings before planting, is not much more beautiful than that of a double rocket larkspur, which may be reared to perfection in three months, from a seed which will cost about the fiftieth part of a penny. Annual flowers therefore are, above all others, suitable for the gardens of suburban residences which are hired for not more than a year ; while they are equally fit for decorating all other gardens whatever, and peculiarly so for such as are defective in soil, situation, or exposure to the sum, as is amply shown in the Villa Gardener.

Mr. Paxton, the chief manager of the gardens of His Grace the Duke of Devonshire, in an early Number of his excellent Magazine of Botany, observes, "Considered as the principal ornaments of the flower-garden throughout the most delightful period of the year, and during a considerable portion of it as the most interesting features in the greenhouse, annual plants have great claims to our attention, and should be very extensively cultivated in every pleasure-garden. But the vast number and variety of sorts that are now known in our collections, the whole of which it is almost impossible to introduce into even the most extensive gardens, renders necessary a judicious selection of the best kinds, in order to compensate for any deficiency in number or variety, by the superior beauty of those which are admitted."

Such a sclection it is my object to offer to the public in the following pages. I shall endeavour to comprise in it all the ornamental annuals that the best judges whom I have consulted on the subject think really deserving of culture in a flower-garden; and as my descriptions will be illustrated by flates by an able artist, lithographed and coloured from nature, the grower of annuals, by turning over this volume, may be enabled to select those which appcar most suitable for his particular purpose. 
In the arrangement of the present work, I intend to follow on a small scale the plan adopted by my late husband, in his well known Encyclopadia of Trees and S/rubs; and it will be my ambition to give as clear and full an account of the annual flowers, as he has there done of the trees and shrubs of Britain. In pursuance of this plan, I shall first give the Botanic and English names; next the synonymes, if any, and then the names of the modern English books in which the flower has been figured. To this, 1 shall subjoin a short botanical character, which will be followed by a popular description, with the geography, history, properties and uses, culture, and in short, everything worth knowing of the plant.

An important feature of this work will be the directions for the culture of each flower, as on this, in a great measure, the appearance of the flowor-garden will depend. It is a common error, to suppose that all that is necessary to make a showy flower-garden is to sow the ground with a great many different kinds of flower-seeds. A few flowers of the most brilliant and ornamental kinds, arranged so as to harmonize in their colours and habits of growth, cultivated with care, and trained and pruned into regular and compact shapes, will produce more effect than three or four times the number sown injudiciously, and afterwards comparatively neglected. On looking into most flower-gardens, it will bo found that the annuals are crowded together, each tuft having been left unthinned; and that the plants, having been neither trained nor pruned, present, as they grow up, the most tawdry appearance, withont either the grace and elegance of wild nature, or the trimness and neatness of art. A flowergarden is essentially artificial; not only from the avowed art displayed in its general shape, and in the artistical forms of its beds, but in the flowers of so many different countries, and even climates, being brought together in the samo locality; everything, in short, in the flower-garden, shows that it was planted by the hand of man; and the flowers themselves, to be in keeping with the garden, should show also the hand of man in their training. Solne excellent observations on this subject by $\mathrm{Mr}_{\mathrm{r}}$. Loudon, will be found in his different works on Gardening, and more particularly in the Villa Gardener

The botanical names of the flowers in the following pages will be those by which they are most generally known by the seedsmen, but I shall give the best known of the other names as synonymes, with their authoritios, always noticing the latest; and when practicable, without entering too much into detail, slightly mentioning the botanical reasons for the change. Notwithstanding this, I intend the botanical part of the work to be quite a subordinate feature, as I merely wish to give general ideas on the subject, and to render the work popular rather than too scientific. The botanical characters, however, though short, will be prepared with great care, and made as intelligible to the general reader as possible. The arrangement followed will be that of the Natural System, and I shall adopt that modification of it given by Dr. Lindley, in his excellent Ladies' Botany. The great advantage of the Natural System to a general observer, or to any one who does not wish to go deeply into the science 
of botany is, that it presents the plants in groups ; each group consisting of plants which resemble one another in all their external features, as well as in their internal 'structure and properties. Hence, if any one knows at sight a plant belonging to any one group, he will have a general idea of all the other plants belonging to it. The advantage of this to a person who is beginning the study of plants, or who has even no higher ambition than to learn the names of a few of them, may truly be said to be inealculable; as whenever he sees a new plant, he has only to consider what group it most resembles, to be able to form a general idea of all that is necessary to be known respecting it. As the interest felt in flowers is much increased when we know something of their structure, and of the functions which the several parts are destined to perform, I would advise such of my readers as have leisure for the pursuit, and as are not already acquainted with the subject, to study Dr. Lindley's Ladies' Botany, in which they will find the rudiments of the science explained in a most elegant and agreeable manner; and so clearly, as to divest botany of that harsh repulsive form, in which it appears "to those who only know it through the uninviting medium of systematic works."

For the benefit of those who have studied the Linnæan System, the class and order to which each plant belongs according to linnæus, or the latest improvements on his system, will be given immodiately after the botanic and English names.

A glossary of the botanic terms used in the work will be given at the end of the volume; and in the mean time, the most difficult will be explained the first time each word occurs. An alphabetical list of tho authorities, explaining the abbreviations, such as $L$. for Linnæus, Dec. for De Candolle, \&c., will be subjoined to the glossary; and there will be a copious index to the whole work.

J. W. L.

\section{Baygwater,}

October $18 t, 1849$. 


\section{CONTENTS.}

arkus

\section{CHAPTER I.}

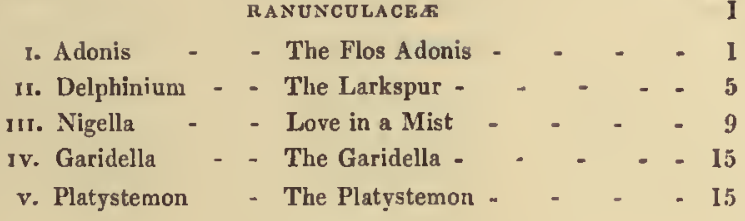

\section{CHAPTER II.}

PAPAVERACEAS

I. Papaver - - The Poppy - - - - - 17

ir. Argemone - - The Prickly Poppy - - - 27

Iir. Glaucium - - The Horned Poppy - - - 28

Iv. Rœmeria - - The Purple Horned Poppy - - 30

v. Platystigma - - The Platystigma - - - - 30

v1. Eschscholtzia - $-\{$ The Eschscholtzia, or Californian

vir. Hunnemania - The Hunnemania - - - - - 31

\section{CHAPTER III.}

FUMARIE

I. Hypecoum - - The Hypecoum - - - 39

I., Corydalis - - The Corydalis - - - - $4 \mathrm{I}$

IIi. Fumaria, Discocapnos, Cysticapnos, and Diclytra - 42

\section{CHAPTER IV.}

UMBELLIFERAT

I. Didiscus, or Trachymene. The Didiscus - $\quad-43$

CHAPTER V.

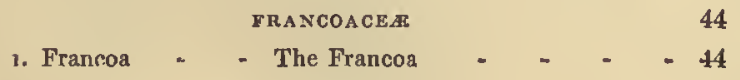

\section{CHAPTER VI.}

ONAGRACEAE

45

1. Euothera - - The Evening Primrose - - $\quad 46$

11. Godetia - - The Godetia, or Purple Enothera - 52
orNus

111. Clarkia - - The Clarkia - _ _ _ - 56

1v. Encharidium - - The Eucharidium - - - - 58

v. Gaura - - - The Gaura - - - - - 58

vi. Lopezia - - . The Lopezia - _ _ _ 59

CHAPTER VII.

LOASACEAE?

I. Loasa - - - The Loasa - - - - 60

11. Blumenbachia - The Blumenbachia - - - 63

III. Bartonia - - The Bartonia - - - 64

Iv. Scyphanthus - The Scyphanthus - - - 65

\section{CHAPTER VIII.}

CRUCIYERE

1. Mathiola - Annual, or Ten-week, Stock - 66

II. Malcomia - - Virginian Stock - - - 68

111. Iberis - - Candy-tuft - - - - - 69

Iv. Arabis - - - Wall-cress - - - - - 73

v. Koniga - - Sweet Alyssum - - - - 73

vi. Vesicaria - - The Vesicaria - - - - 74

vir. Streptanthus - The Streptanthus, or Arkansas-cabbage 75

virr. Moricandia - - The Moricandia - - - 76

Ix. Heliopbila - - The Heliophila - - - - 76

x. Schizopetalon - - The Schizopetalon - - - 77

xı. Biscutella - - Buckler Mustard - - - - 78

xil. Menonvillea - - The Menonvillea - - - 78

xır. Cakile - - Sea Rocket - - - - - 78

xIv. Ricotia - - - Syrian Honesty - - - 79

xv. Erysimum - - Treacle Mustard - - - 79

\section{CHAPTER IX.}

CapPaRInEA

I. Cleome

CHAPTER $\mathrm{X}$.

MALESHERBIACEAS

I. Malesherbia - The Malesherbia - - - 82 


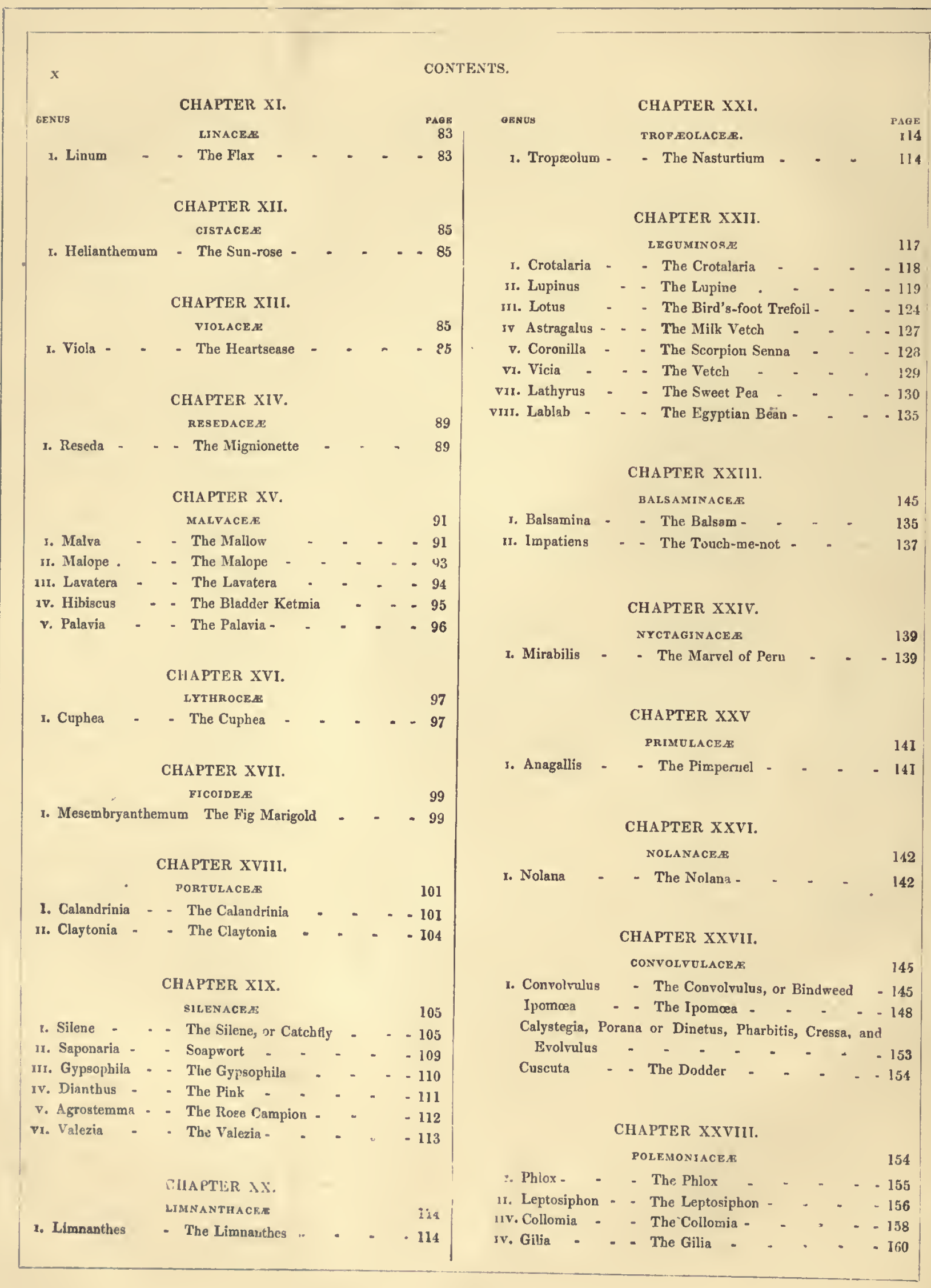




\section{CoNTENTS.}

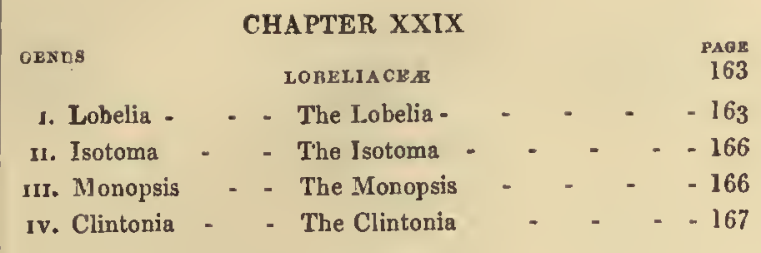

\section{CHAPTER XXX.}

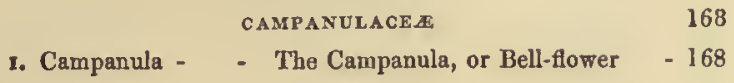

\section{CHAPTER XXXI.}

AMARANTHACEAS

171

c. Amaranthus - Love-lies-bleeding, \&c. - - 172

r. Celosia - - - The Cockscomb - - - - 173

III. Gomphrena - The Globe Amaranth - - 174

\section{CHAPTER XXXIT.}

CHENOPODIACEA

The Strawberry Blite

\section{CHAPTER XXXIII.}

POLYGONACEAE

I. Polygonum - - The Persicaria \& - - . 176

\section{CHAPTER XXXIV.}

COMPOSIT 2

1. Ageratum - - The Ageratum - - - - 178

11. Aster - - - The Aster, or Star-wort - - 178

111. Kaulfussia - The Kanlfussia - - - 180

Iv. Dracopia - - The stem-clasping Rudbeckia - 180

v. Calliopsia, or The Calliopsis Coreopsis - $\xi$

vI. Helianthus

- The Sunflower -

v11. Bidens - - - The Bur-marigold - - -184

vil. Cosmea - - The Cosmea - - - . - 184

IX. Sanvitalia - - The Sanvitalia - - - 185

x. Tagetes - - The French and African Marigolda 186

x1. Gaillardia - - The Gaillardia - _ _ - 187

Xı1. Lasthenia - - The Lasthenia - _ _ - 188

xif. Burrielia - - The Burrielia - - - 188

xiv. Helenium - - The Helenium - - - 189

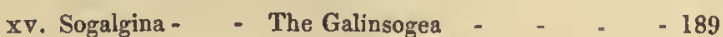

Xv1. Sphenogyne - The Sphenogyne - - - - 190

xvi1. Oxyura - - The Oxyara - - - - - 191

xvirI. Madia - - The Madia - _ . . - 191

xix. Madaria - . The Madaria - - . 192

xx. Callichroa - The Callichroa - _ _ - 193

xxı. Bæria - - - The Bæria - - . - - 193

xxir. Cladanthua - The Cladanthus - . - 194
GQRUT - PAGE

xxil. Chrysanthemum The Chrysanthemum - . . 19.1

xxiv. Dimorphotheca - The Cape-marigold - . - - I90

xxv, Cotula - - - The Cotula - _ - - 197

xxvi. Lonas - - The Annual Athanasia - - 197

xxvir. Ammobium - - The Ammobium - - - - 198

Xxvi1. Rhodanthe - The Rhodanthe - - - 198

xxıx. Morna - - The Morna - - - - 199

xxx. Podolepis - - The Podolepis - - - - 200

xxxı. Helichryaum - The Everlasting-flower - - 201

xxxı. Cacalia - - The Cacalia - - - - 202

xxxir. Senecio - - The Ragwort - - - -202

xxxı. Zinnia - - The Zinnia - - - - 203

xxxv. Calendula - - The Marigold - - - 205

Xxxvi. Cryptostemma - The Cryptostemma - - - -206

Xxxvi1. Echinope - - The Glohe Thistle - - 207

xxxvil. Xeranthemum - The Xeranthemum - - - -207

xxxix. Centaurea - - The Centaury - - - -208

xI. Amberboa - The Sweet Sultan - - - 209

xLI. Carthamus - - The Safflower - - - 209

XLII. Kentrophyllum - The woolly Carthamus - - -210

xน11. Tolpis - - - Yellow Hawkweed - - -210

xlrv. Boerckhausia - Pnrple Hawkweed - - - - 211

xLv, Picridium - - The Scorzonera, or Viper'a-grass - 211

Centratherum or Ampherephis, Isagascea, Evax or Filago, Micropus, Ambrosia, Partlenium, Simsia or

Ximensia, Matricaria, and Arctotis _ . 212

Chardinia, Triptillion, and Scolymus . . . - 213

CHAPTER XXXV.
pIPsace 2
r. Knautia - $\quad$ - The Knautia $\quad-\quad-\quad-213$

\section{CIIAPTER XXXVI.}

\begin{tabular}{|c|c|c|c|}
\hline & & VALERIANACEA & \\
\hline 1. Fedia & - & - Horn of Plenty & - \\
\hline
\end{tabular}

\section{CHAPTER XXXVII.}

\begin{tabular}{|c|c|c|c|c|c|c|}
\hline & & HYDROPGALLACEAE & & & & 215 \\
\hline 1. Ellisia & - & The Ellisia - & - & - & s & -215 \\
\hline 11. Nemophils & a - & The Nemophila & - & - & - & -216 \\
\hline II. Eutoca & - & The Eutoca - & - & - & - & -218 \\
\hline 1v. Phacelia & - & The Phacelia & & - & - & \\
\hline
\end{tabular}

\section{CHAPTER XXXVIII.}

\begin{tabular}{|c|c|c|c|c|c|c|}
\hline & & BORAGINACEAE & & & & 223 \\
\hline I. Cerinthe & - & - Honeywort - & - & $=$ & - & -222 \\
\hline IJ. Echium & - & Viper'a Bugloss & - & - & - & -222 \\
\hline III. Nozea & - & $\begin{array}{c}\text { - The Alkanet } \\
\text { h } 2\end{array}$ & - & - & - & -224 \\
\hline
\end{tabular}




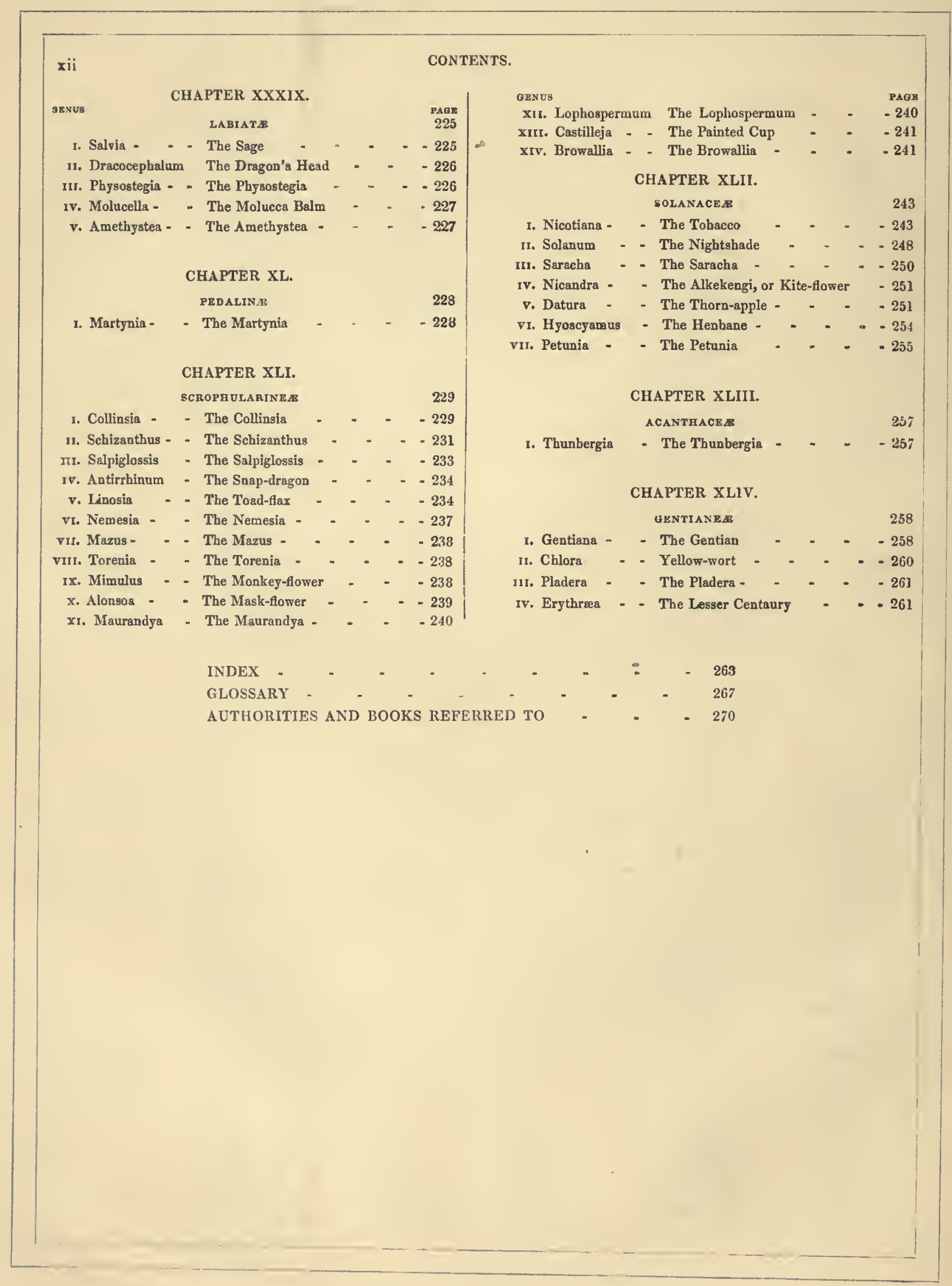




\section{LIST OF PLATES.}

\section{PLATE I.}

1 1. Platystemon leiocarpua. Smooth-fruited Platyatemon.

2 2. Garidella Nigellastrum. Nigella-like Garidella.

3 3. Adonis autumnalis. Autumnal Flos Adonis.

\section{PLATE II}

4 1. Nigella nana. Dwarf Nigella.

5 2. N. involucrata. The involucred Nigella.

6 3. N. Hispanica. The Spanish Nigella.

7 4. N. H. var. alba. The white Spanish Nigella.

8 5. N. Damascena. The common Love in a Mist.

9 6. N. orientalis. The oriental, or yellow Nigella.

\section{PLATE III.}

10 1. Delphinium tenuissimnm. Slender Larkspur.

11 2. D. Ajacis flore-pleno. Double-flowered Rocket Larkspur.

12 3. D. A. fl. pl. purpurascens. Purple Rocket Larkspur.

13 1. D. A. fl. pl. albo. White Rocket Larkspur.

14 5. D. consolida. Branching Larkspur.

PLATE IV.

15 1. Papaver horridum. The horrid, or New Holland Poppy.

16 2. P. setigerum. The Bristle-pointed, or Grecian Poppy.

17 3. P. nudicaule. The naked-stemmed, or Siberian Poppy.

18 4. P. somniferum. The Opium, or garden Poppy.

19 5. P. Rhoeas. The Corn Poppy.

20 6. P. Persicum. The Persian Poppy.

\section{PLATE V.}

21 1. Rœmeria hybrida. Purple Horned Poppy.

22 2. Glancinum luteum. Yellow Horned Poppy.

23 3. G. phoniceum. Scarlet Horned Poppy.

24 4. Argemone Mexicana albiflora. The White-flowered Prickly Poppy.

25 5. Argemone Mexicana. The common or Mexican Prickly Poppy.

\section{PLATE VI.}

26 1. Eschscholtzia californica. Californian Eschscholtzia. 27 2. E. crocea. Saffron-coloured Eschscholtzia,

28 3. Platystigma lineare. Linear-leaved Platystigma.
PLATE VII.

29 1. Francoa anchifolia. The Sow-thistle-leaved Francoa.

30 2. F. appendiculata. The common Francoa.

31 3. Didiscns cœrulea. The blue Didiscus or Trachymene.

32 4. Hypericum procumbens. The procumbent Hypericum.

PLATE VIII.

33 J. Godetia vinosa. The wine-atained Godetia.

34 2. Enothera sinuata. The acalloped-leaved Evening Primrose.

35 3. Godetia rubicunda. The ruddy Godetia.

36 4. G. lepida. The agreeable Godetia.

37 5. CEnothera humifusa. The trailing Evening Primrose.

38 6. CE. cheiranthifolia. The wallfower-leaved Evening Primrose.

39 7. $\mathrm{E}$. tetraptera. The four-angled Evening Primrose.

40 8. Godetia roseo-alba. The rose-coloured and white Godetia.

11 9. CEnothera Drummondi. Drummond's Evening Primrose.

42 10. Godetia Romanzovii. Count Romanzow's Godetia. 43 11. Enothera concinna. The neat Evening Primrose.

\section{PLATE IX.}

44 1. Clarkia pulchella. The pretty Clarkia.

45 2. C. p. alha. The white variety.

46 3. C. elegans. The elegant Clarkia.

47 4. C. e. rosea. The rose-coloured variety.

48 5. C. rhomboidea. The rhomboid Clarkia.

49 6. Eucharidium concinnum. The neat Eucharidium.

\section{PLATE X.}

50 1. Loasa aurantiaca. Orange Loasa, or Chilian Nettle Plant.

51 2. L. ambrosiafolia. Ambrosia-leaved Loasa.

52 3. L. Placei. Mr. Place'a Loasa.

53 4. Blumenhachia insignis. The showy Blumenbachia.

54 5. Bartonia aurea, The Golden Bartonia.

\section{PLATE XI.}

55 1. Mathiola annua atriata. The atriped annual, or tenweek Stock. 
56 2. M. a. purpurea. A. pl. The double-flowered purple variety.

57 3. M. a. alba fl. pl. Double-flowered white rariety.

58 4. M. a. lateritia fl. pl. Double-flowered brick-red var.

59 5. Malcomia maritima. The Virginian Stock.

\section{PLATE XII.}

60 1. Iberia umbellata. The common purple Candy tuft.

61 2. I. u. var. sanguinca. The new scarlet Candy tuft.

62 3. I. u. var. alba. The white variety.

63 4. I. pinnata. The dwarf Candy tuft.

64 5. I. corouaria. The Rocket Candy tuft.

\section{PLATE XIII.}

65 1. Vesicaria grandifiora. Large-flowered Vesicaria.

66 2. V. gracilis. Slender Tesicaria.

67 3. Streptauthus obtusifolius. Arkansas Cabbage.

68 4. S. Hyacinthoides. Hyacinth-like Streptanthus.

69 5. Schizopetalon Walkeri. Mr. Walker's Schizopetalon.

70 6. Heliophila stricta. The upright Heliophila.

71 7. H. Arabiodes. The Arabian Heliophila

72 8. Arabis verna. The spring Wall Cress.

73 9. Alyssum calycinum. The Sweet Alyssum.

\section{PLATE XIV.}

74 1. Violu tricolor. The common Heartsease.

75 2. V. lutea. The yellow Heartsease.

$76-803,4,5,6$, and 7 . Hybrids and varieties of Heartscase.

\section{PLATE XV.}

81 1. Linum usitatiasimum. The common Flax.

82 2. L. Berendieri. Bereodieri'a yellow Flax.

83 3. Malesherbia coronata. The crowned Malesherbia.

84 4. M. linearifolia. The linear-leaved Malesherbia.

85 5. Cleome pentaphylla. The five-leaved Cleome.

86 6. C. spinosa. The spiny Cleome.

87 7. Ilelianthera guttatura. The hlotched Sun-rose.

\section{PLATE XVI.}

88 1. Ilibiscus Africanus. The African Bladder Ketunia

89 2. Malope trifida, var. alba. White Malope.

90 3. Palavia rhombifolia. Rhomhoid-leaved Palavia.

91 4. Malope grandiflora. Large-flowered Crimson Malope.

92 5. Lavatera trimestris. Common Lavatera.

y3 6. Malva moschata, var, alba. The white Musk Mallow.

\section{PL.ITE XVII.}

94 1. Cuphea Llarca. La Llave'a Cuphea.

95 2. C. viscosissima. The most clammy Cuphea.

96 3. C. lanceolata. The lanceolate-leaved Cuphea.

\section{PLATE XVIII.}

97 1. Calandrinia speciosa. The showy Calandrinia.

98 2. C. dlsculor. The two-coloured Calandrinia.

99 3. C. Arenaria. The Sand Calandrinia.

100 4. C. grandiflora. The Jarge-flowcred Calantrinia.
PAGF

101 5. Mesembryanthemum Pomeridianum. The Afternoor, or large yellow Fig Marigold.

102 6. M. tricolor. The three-coloured Fig Marigold.

\section{PLA'TE XIX.}

103 1. Silene quinquevulnera. Five-wounded Catchfly.

104 2. S. pendula. Perdulous Silene.

105 3. S. purpurea. Purple Catchfly.

106 4. S. Armeria. Lobel's Catchfiy.

107 5. S. vespertina. Evening Silene.

108 6. S. picta. Painted Silene.

109 7. Saponaria Vaccaria. Cowherb Soapwort.

73

110 1. Dianthus chinensis. The Chinese Pink.

111 2. Agrostemma coli-rosa. Smooth Rose Campion, or Rose of Heaver.

112 3. Limnantbes Douglasi. Douglas'a Limnantbes.

PLATE XXI.

113 1. Tropæolum majus, var, venustum. The beautifullymarked large Nast urtiurn.

114 2. T. m. var, atrosanguineum. The dark red variety.

115 3. T. minus. The lesser Narsturtium.

116 4. T. m. f. pl. The double-flowered variety.

117 5. T. peregrinurn. The Canary bird flower.

\section{PLATE XXII.}

118 1. Lupinus mutabilis. The changeable Lupine.

119 2. L. m. Cruikshanlii. Mr. Cruiksbank'a Lupine.

120 3. L. nanus. The dwarf Lupine.

121 4. L. leptophyllus. The meagre-leaved Lupine,

122 5. L. luteua. The common yellow Lapine.

\section{PLATE XX111.}

123 1. Lathyrus odoratus. The sweet Pea.

124 2. L. Tingitanus. The Tangier Pea.

125 3. L. sativus. The Chickling Vetch.

126 4. L. articulatus. The Jointed or winged Pea.

127 5. L. Nissolia. The Crimson Grass Vetch.

128 6. L. amphicarpos. The Earth pea.

129 7. Vicea Onobrychoides. The Saintfoin-like Vetch.

130 8. Vicia atropurpurea. Dark Purple Vetch.

131 9. Lotus Tetragonalobus. Dark Crimson Winged Pes.

13210 . L. Jacobrus. Black-flowered Lotus.

133 11. Astragalus sinicus. Rose-coloured Milk Vetch. 134 12. Lablab vulgaris. The Egyptian Bean.

\section{PLATE XXIV.}

135 1. Balsamina Mastersiana. The Nipal Balsam.

136 2. Mirabilis Jalapa. The Marvel of Peru.

\section{PLATE XXV.}

133 1. Anagallia Movelli, var. liliacea, Lilac Pimpernel. 159 2. A. latifolia. Broad-leaved Blue Pimpernel. 
IIG.

140 3. Nolana paradoxa. Paradoxical Nolana.

141 4. N. atriplicifolia. Spinach-leaved Nolana.

142 5. N. prostrata. Prostrate Nolaua.

PLATE XXVI.

143 1. Convolvulus elongatus. Broussonet's trailing Bindweed.

144 2. C. tricolor. The mioor Convolvulus.

145 3. Ipomøa Bona Nox. The Night-flowering Ipomoea.

146 4. Convolvulus sicalus. Sicilian Convolvulus.

147 5. Ipomcea barbigera. The Beard-bearing Ipomœa.

148 6. Convolvulus purpureus, var. elatior. Peacock Convolvulus.

I49 7. Ipomœa rubro-cœrulea. The Mexican Ipomœa.

150 8. Convolvulus involucrata. Guinea Bindweed.

151 9. Ipomøa coccinea. The Scarlet I pomcea.

152 10. I. Quamoclit. The Quamoclit, or winged lpomoea.

\section{PLATE XXV11.}

153 1. Phlox Drummondi. Drummond's Phlox.

154 2. Leptosiphon densiflorus. The dense-flowered Leptosiphon.

155 3. L. Androsaceus. The Androsace-like Leptosipbon.

\section{PLATE XXVIII.}

156 I. Gilia capitata. The cluster-flowered Gilia.

157 2. G. c. alba. The white variety.

158 3. G. Achillæfolia. The Millfoil-leaved Gilia.

159 4. G. tricolor. The three-coloured Gilia.

160 5. G. bicolor. The two-coloured Gilia.

161 6. G. tenuiflora. The slender-flowered Gilia.

\section{PLATE XXIX}

162 1. Clintonia pulchella. The pretty Clintonia.

163 2. Isotoma axillaris. The axil-flowered Isotoma.

164 3. Lobelia bypocrateriformis. The salver-shaped Lobelia.

165 4. L. ramosa. The Branching Lobelia

1665 . L. gracilis. The slender Lobelia.

167 6. L. g. var. rosea. The Pink variety.

\section{PLATE XXX.}

168 1. Campanula pentagonia, The large-flowered Venus's Looking-glass.

16!) 2. C. dichotoma. The forked branch Campanula.

170 3. C. divergens. The spreading Bell-flower.

171 4. C. speculum. Venus's Looking-glass.

172 5. C. Loreyi. Lorcy's Campanula, or new Venus's Looking-glass.

\section{PLATE XXXI.}

17.3 1. Ageratum Mexicana. The Mexicas Ageratum.

174 2. Cacalia coccinea. The scarlet Cacalia.

175 3. Kaulfusssia amelloides. The Amellus-like Kaulfussia.

176 4. Calendula (or Dimortheca) pluvialis. The Great Cape Marigold.

177 5. Arctotis (or Sphenogyne) Anthemoides. The Chamomile-like Sphenogyne.

178 6. Tolpis barbata. The Yellow Hawkweed.

179 7. Oxyura Chrysanthemoides. The Chrysanthemum-like Oxynra.

\section{PLATE XXXII.}

190 1. Cosmea tenuifolia. Slcnder-leaved Cosmea.

191 2. Boerkhausia rubra. Red Hawkweed.

192 3. Madaria (Madia) elegans. The elegant Madia.

193 4. Cbrysanthemum aurea. The golden Chrysanthemum.

194 5. C. tricolor. The three-coloured Chrysanthemum.

195 6. Dracopis (Rudbeckia) amplexicaulis. Stem-clasping Dracopis.

1967 7. Gaillardia Drummondi. Drumınond's Gaillardia.

197 8. Tagetis patula, 2 var. French Marigold.

198 9. Senecio elegans. The Jacobæa, or purple Ragwort.

199 10. S. (Cineraria, or Pericallis) tussilagenis. The Coltsfoot-leaved Ragwort.

200 11. Cosmea lutea, (or Bidens grandiflora.) The largeflowered Bur-marigold.

\section{PLATE XXXIII}

201 1. Centaurea Crocodylium. The Blush Centaury.

202 2. C. (Amberboa) moschata alba. The white sweet Sultan.

3. C. (Amberboa) moschata. The purple sweet Sultan.

4. C. (Amberboa) suaveolens. The yellow sweet Sultan.

5 to 8 . C. cyanus. The Corn Bluebottle and varieties.

209 9. Ammobium alatum. The winged $A$ mmobium.

PLATE XXXIV.

2101 and 3. Rhodanthe Manglesii. Captain Mangles's Rhodantbe.

211 2. Podolepis gracilis. The slender Podolepis.

212 4. Morna nitida. The sbining Morua.

213 5. M. nivea. The Spowy Morna.

214 6. Helichrysum bicolor. Two-coloured Everlasting.

215 7. H. macranthus. Large-flowered Everlasting,

216 8. H. bracteatum. The common Everlasting.

217 9. Xeranthemum annuum, fi. pl. The double purple Xeranthemum.

218 10. X. a., var. album. The white Xeranthemum.

\section{PLATE XXXV.}

219 1. Zinnia revoluta. Revolute-flowered Zinnia.

220 2. Z. grandiflora. Large-flowered Zinoia.

221 3. Z. sulphurea. Sulphur-coloured Zinnia.

222 4. Z. verticillata. Wborl-leaved Zinnia.

223 5. Z. elegans purpurea. Crimson Zinnia.

224 6. Z. e. alba. White Zinnia.

225 7. Z. e. violacea. Violet:coloured Zinnia.

226 8. Z. e. coccinea. Scarlet Zinnia.

227 9. Z. multiflora lutea. Yellow Zinnia. 


\section{LIST OF PLATES.}

ro.

\section{PLATE XXXVI.}

228 to 232 Aster chinensis. The China-aster, five varieties.

\section{PLATE XXXVII.}

233 1. N. aurita. The eared-leaved Nemophila.

234 2. N. insignis. The showy Nemophila.

235 3. N. Phaceliodes. The Phacelia-like Nemophila.

236 4. N. atomaria. The dotted Nemophila.

237 5. N. Discoidalis. The disk-flowered Nemophila.

238 6. N. maculata. The spotted Nemophila.

\section{PLATE XXXVII.*}

239 1. Eutoca Wrangeliana. Baron Wrangel's Eutoca.

240 2. E. viscida. The clammy Eutoka.

241 3. E. Menziesii. Mr. Menzies' Eutoka.

242 4. E. Franklinii. Captain Franklin's Eutoka.

243 5. Nonea versicolor. The many coloured Nonea.

244 6. Anchusa Italica. The Italian Anchusa.

PLATE XXXVIII.

245 1. Phacelia vinifolia (vitifolia). Vine-leaved Phacelia.

246 2. P. congesta. Cluster-flowered Phacelia.

247 3. P. tanacetifolia. Tansy-leaved Phacelia.

248 4. Fedia cornucopiz. Horn of Plenty.

249 5. Cerinthe major. Larger Honeywort.

250 6. Echium australe. Southern Viper'a Bugloss.

PLATE XXXIX.

251 1. Physostegia truncata. The blunt-calyzed Physostegia. 252 2. Amethystea cœrulea. Blue Amethystea.

253 3. Dracocephalum canescens. Hoary Dragon's-head.

254 4. D. nutans. Nodding Dragon's-Head.

255 5. Salvia foliosa. Leafy Sage.

256 6. Mazus rugosus. Wrinkled or Chinese Mazus.

\section{PLATE XXXIX*}

257 1. Mimulus Harrisonii. Harrison's Mimulus.

258 2. Maurandya Barclayana, Mr. Barclay's Maurandya.

25.9 3. M. semperflorens. The ever-flowering Maurandya.

260 4. Lophospermum erubescens var. spectabile. The showy Lophospermum.

\section{PLATE XI.}

261 1. Martynia proboscidea. The Horny Martynia.

262 2. M. Diandra. Pink Martynia.

263 3. M. lutea. Yellow Martynia.

\section{PLATE XLI.}

264 1. Collinsia grandiflora. Large-flowered Collinsia.

265 2. C. heterophylla. Various-leaved Collinsia.

266 3. C. bicolor. Two-leaved Collinsia.

267 4. C. parviflora. Small-fiowered Collinsia.

\section{PLATE XLII.}

268 1. Schizanthus pinnatus. Pinnate-leaved Schizanthus.

269 2. S. porrigens. Spreading Schizanthus.

270 3. S. pinnatus humilis. Dwarf Schizanthus.

271 4. S. retusus. Scarlet Schizanthus.
PAGE
178

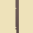

273 6. S. porrigens Stracbani. Mr. Stracban'a Scbizanthus.

274 7. S dpiglossis picta. Painted Salpiglossis.

275 8. Sal atropurpurea. Purple Salpiglossis.

276 9. Sal. straminea. Straw-coloured Salpiglossis.

\section{PLATE XLIII.}

277 1. Linaria tristis. Sad-coloured Toad-flax.

278 2. L. spartea. Branching or Broom-like Toad-Flax.

279 3. Antirrbinum glandulosum. Glandnlar Snapdragon.

280 4. Linaria triphylla. Three-leaved Snapdragon.

281 5. L. speciosa. Showy Toad-flax.

282 6. L. Canadensis. American Toad-flax.

283 7. Nemesia floribunda. Abundant-flowered Nemesia.

PLATE XLIV.

284 1. Browallia grandiflora. Large-flowered Browallia.

285 2. B. Elata. Tall Browallia.

286 3. B. demissa. Dwarf-spreading Browallia.

287 4. Mimulus floribundus. Abundant Monkey-flower.

288 5. Castilleja coccinea. Scarlet Painted-cup.

289 6. Torenia cordifolia. Heart-leaved Torenia.

290 7. Alonsoa linearis. Linear-leaved Mask-flower.

\section{PLATE XLV.}

291 1. Nicotiana Tabacum. Virginian Tobacco.

292 2. N. acuminata. Pointed-leaved Tobacco.

293 3. N. noctiflora. Night-flowering Tobacco.

294 4. N. multivalvis. Many-valved Tobacco.

295 5. N. longiflora. Long-flowered Tobacco.

296 6. N. glutinosa. Clammy Tobacco.

297 7. N. Persica. Persian or Shiraz Tobacco.

298 8. N. Langsdorff. M. Langsdorf's Tobacco.

\section{PLATE XLVI.}

299 1. Datura Tatula. The Tatula or Purple Thorn-apple.

300 2. D. ceratocaula. The Horny-stemmed Thorn-apple.

301 3. Nicandra Physaloides. The Alkekengi or Kite-flower.

302 4. Saracha viscosa. Clammy Saracha.

303 5. Solanum Fontanesianum. Desfontaines' Nightshade.

304 6. Solanum campanulatum. The Bell-shaped Solanum.

PLATE XLVII.

305 1. Petunia nyctaginiflora. Common White Petunia.

306 2. P. phœnicea. Purple Petuuia.

307 3. Thunbergia alata albiflora. White Thunbergia.

301 4. Thunbergia alata. Common winged Thunbergia.

309 5. Hyoscyamus niger. Common Black Henbane.

310 6. H. aureus. The Golden Henbane.

\section{PLATE XLVIII.}

311 1. Erythræa aggregata. Cluster-flowered Lesser Centaury.

312 2. Chlora perfoliata. Perfoliate-leaved Yellow-wort.

313 3. Pladera (Cascona) decussata. The angnlar Pladera.

314 4. Gentiana quinqueflora. Five-flowered Gentian.

315 5. G. (Ericala) nivalis. Snow Gentian.

316 6. G. (Eurythalia) amarella. Bitter Gentian.

317 7. Erythrae littoralis. Sea-shore Lesser Centaury.

318 8. E. centaurium. Common Lesser Centaury. 



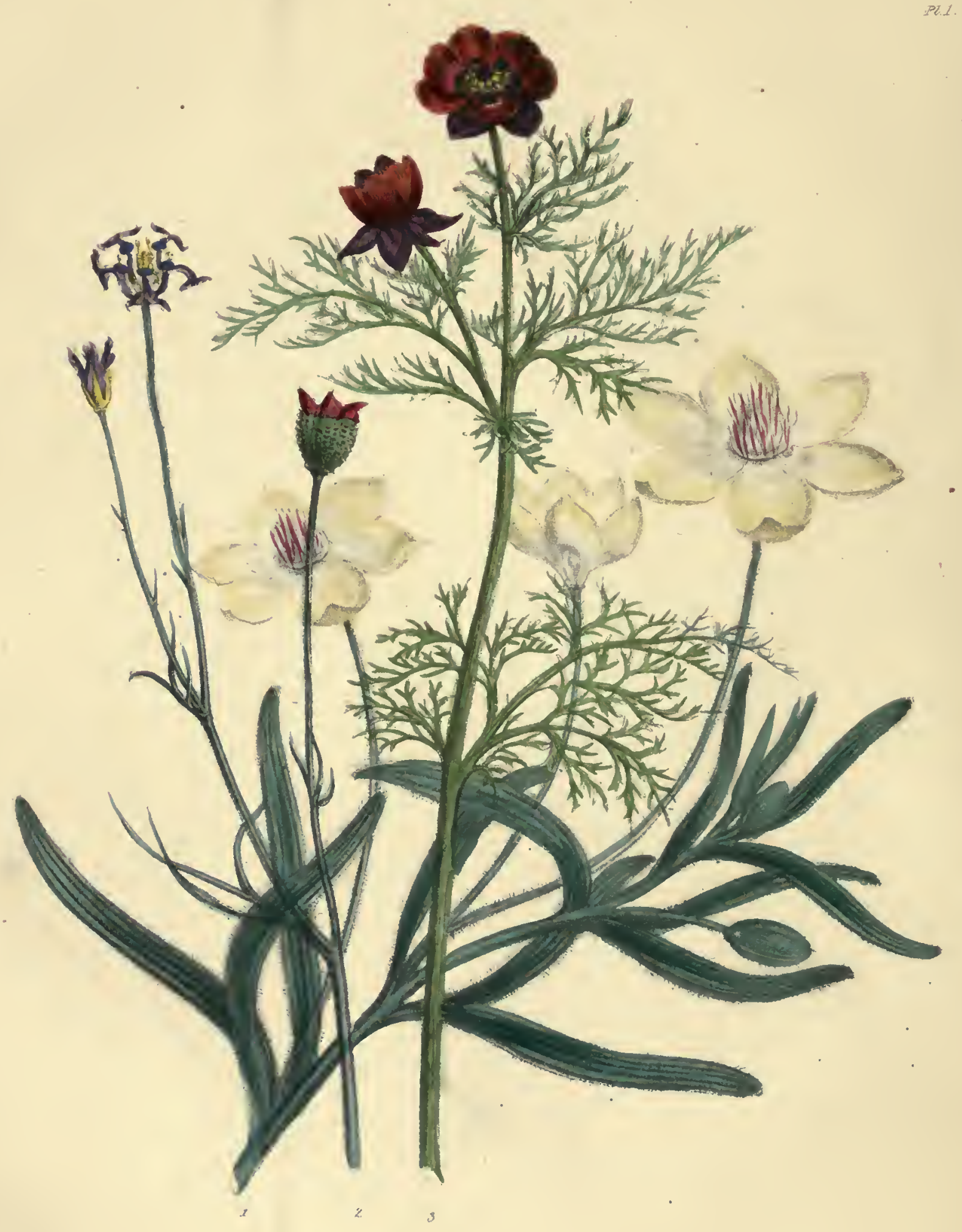






\section{A D I E S' F L O W E R - G A R D E N}

OF

ORNAMENTAL ANNUALS.

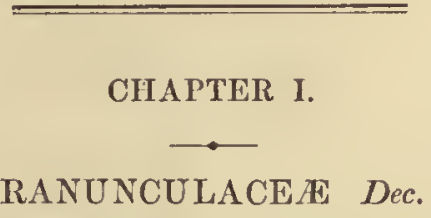

Botanical Chanacter of The Ondfa. - Sepals and petals numerous. Into petals, and the petals into nectaries. Herbs aud shruba with Stamens hypogynous (grewing from beneath the pistils), numerous. Oraria numerous, aggregrate. In many genera the sepals are changed ? alternate leaves. Acrid and venomous. - (G. Don.)

nescriprion, \&c.-Axi the plants belonging to the order Ranunculacex, partake more or lcss of the character of the common crowfoot, or Ranunculus; that is, they have all several distinct carpels or seed-vessels growing close together, and their stamens grow from beneath these carpels. They have generally handsome flowers of brilliant colours. The stems of all these plants discharge, when broken, a thin watery juice, which is very acrid, so much so indeed that in some specics it blisters tho skin. The bruised leaves of seme kinds, beund tightly on a slight wound, will produce an nlcer, and the secds are poisonous if taken internally; these qualities are much stronger in some of the plants belonging to the order than in ethers, but they exist to a certain degree in all. Nearly all the kinds are perfectly hardy, and will grew in any soil, but most of them prefer a semewhat damp leam. They are nearly all very tenacious of life, and their seeds will keep sevcral years without losing their vitality. The genera belonging to this erder which contain ornamental garden aunuals, are, Adenis, Delphinium, Nigella, Garidella, and Platystemon; the last forming the connecting link between Ranunculaceæ and Papaveracex, and being by many betanists classed in the latter erder.

\section{GENUS I. \\ ADONIS Lin. THE FLOS ADONIS, OR PHEASANT'S EYE. \\ Lin. Syst. POLYANDRIA POLYGYNIA.}

Geverio Cranacter.-Calgz of 5 sepals, generally attached at the $\mid$ pinnate, parted into multifid lobes, with linear lobules. Flowers base. Petals 5 to 15, with a naked claw. Stamens numerous. Carpels, selitary on the points of the stem and branehes.-(G. Don.) numerous, two-seeded, spiked, ovate. Cotyledens distant. Leares

Description, \&c.-The Fles Adenis is rcmarkable for its slender brancli-like leaves, and its small terminal flowers, the petals ef which are smooth and shining, and peep from amidst the bushy lcaves like little gems. Its 
identity with the order Ranunenlaceæ is shown by the numerous black stamens growing from beneath the heap of little green carpels in the centre, and by the distinetness of the carpels, which yet grow close together on the end of the flower-stalk, so as to form a head when the petals lave fallen. Botanists enumerate seventeen different species of Adonis, besides varieties; and ten of these species are said to be annuals. Only two or threc, howeyer, áre cultivated in British gardens; and all the annual kinds are, probably, only varieties of the eommon Flos Adonis (Adonis autumnalis), as they only differ in the size and colour of the flower, and the leight of the plant.

\section{1.-ADONIS AUTUMNALIS Lin. THE AUTUMN-FLOWERING FLOS ADONIS, OR PHEASANT'S EYE.}

Engratisas.-Smith's Eng. Bot. t. 308; 2nd edit. vol. v. t. 781; ( conniving (that 1s, lying close together), scareely larger than the calyx; Curt. Fl. Lond. vol, ii. t. 37 ; and our $f g .3$, in Plate 1. carpels crowned by very short styles, and collected into an ovate Specific Cuaracter.-Calyx smooth. Petals 6 or 8 , concave, head. Stems branched.-(G. Don.)

Description, Geograpiy, History, \&c.-The common Flos Adonis is a plant about a foot high, with numerous very finely eut leaves. These leaves grow in so bushy a manner, that they would almost coneeal the flowers were it not for their intensely deep blopd-red colour, which las obtained for the plant its French namo of Goutts de sang. These flowers are small, cup-shaped, and produced at the extremities of the stem and branches, like, little ruby crowns. The plant is found growing wild in corn-fields in every part of Eurépe, though it is by no means so common in England as on the Continent. Its prineipal British habitat is in Kent, on the borders of the Medway, between Rochester and Maidstone. It was cultivated in British gardens before 1597; as Gerard tells us in his Herbal, published in that year, that he brought the seed from the west of England, where it was growing wild among the corn, and sowed it in his garden "for the beautie of the flowres sake." This garden was in Holborn, which was then considered to be in the suburbs of London! In Gerard's time the Flos Adonis was called Red Mathes, and Red Camomile; but he adds, "our London women call it Rose-aRubie." Parkinson, in his Garden of Pleasant .Flowers, published in 1629, mentions that it was then generally "brought into gardens for the beanty-sake of the flower;" and he adds that some. considered it a kind of Camomile, and others, a kind of Anemone. The legendary history of the flower tells us that it sprang from the blood of Adonis, when he was wounded by the boar, and lenee received its Latin name. The plant was dedieated to Venus; and, in the language of the flowers, it is considered the emblem of tender grief and melancholy recollections.

Culture. - Though the Flos Adonis, as we have already seen, has been cultivated in our flower-gardens for mere than two hundred years, it has but little to recommend it as a garden flower. It should, indeed, never be eultirated, unless there be abundance of room; as the smallness of its flowers, and bushiness of its finely-cut leaves, give it rather a weedy appearance, and all plants of this kind.ought to be earefully avoided in small gardens. In suitable situations, however, it is in some respects a desirahle plant; as it requires very little culture, and will grow in any common gardon soil. It will also grow in any situation that is not too high and dry: and the plants will thrive very well in a shruhhery, or under the drip of trees; though they will 
not flewer quite so seon if grown in the shade; as they will in an open border where they have thie advantage of light and air. The seeds of this species sold in the seed-shops are, 'in fact, the carpels; and when they are quite in a fresh state they may be cut:open, when the little black seed will be found attached en one side to the lower part of the carpel, which it does net a quarter fill. The carpels seld in the seed-shops are however generally too dry to be cut open, and they may' be sown entire, as the earpel will open at its 'natural division in the greund when the seed begins to germinate. The dry carpels are quite as geed as the fresh ones for sowing, as the seeds are not at all injured 'by keeping. Then' the plaee where the seeds are to be sown' is fixed on', the greund sliould be loesened with a fork and 'breken vèry fine'; after which' it should'be'made perfectly level, and raked. . Several little circles - sheuld - then be made (their number, and the distance they are frem each ether, depending on the quantity of flowers. wanted), and if the ground be tolerably dry, this may be done by pressing on it the bettom of a flower-pot saucer, abeut three inches or feur inches in diameter, in every place where a circle is to be made. On the smooth level surface of the circles thus fermed, a very ferv seeds (not more than six or eight in each patch) should be spread; the saucer sheuld then be again applied, se as to press them gently into the soil, and thu's to fix each seed in its. proper place. The operation of sowing is cencluded by drawing the, earth displaced by the saucer over the sceds, so as to cever them about twice their own thickness, or -say, about the eighth of an inch. In dry sandy seils, the covering may. also receive a slight pressure from the sancer ; but this is unnecessary unless the soil sheuld be very loese. If the seil should be wet, the saucer must not be used at all, as part of the soil would stick to it, and thus the circle ceuld neither be rendered smooth before sewing, ner the seeds be pressed firmly into it afterwards., In spring, when the seil is very dry, a slight watering may be given to the seeds after sowing, by a watering-pot having a very fine rose ; but this must be dene very carefully, as too much water would wash the seeds out of their places. When the sowing is 'finished, a flat piece of weod, called a name-stick or label, should be inserted in the centre of each patch, with the name of the plant, or a number marked upen it; or a reund stick may be used witl a eleft at the tep, in which the paper that centained the sceds, if it has the name upen it, may be stuck, having been first neatly folded up. When danger is apprehended from birds, or vermin, or from the scorching effect of the sun, a flewer-pet may be whelmed over the patch, and kept on till the seeds are abeve ground, when it should be 'taken off immediabely, and not put on again. 'The reasen for instantly remeving it when the seedlings appear above greund, is, that if it were kept on even fer a few days, the yeung plants weuld be drawn up, and their stems weuld beceme se elongated, and consequently se weak, that they weuld never 'recover it. It is always an object te keep flewering plants streng and bushy, as whien the stems are leng and weak they have net only an unhealtliy and untidy appearance, but the flowers are never se large or se rich in colour as they are when the plants are well grown. An inverted flower-pot is better than any-other covering for protecting seeds, not only from its cheapness and simplicity, and frem its having the advantage ef being almost always at hand in a garden, but because, while its sides shade the greund from the sun, and oxclude the pewerful action of the air, thus lessening evaperatien and kecping the seil meist, the hele in the bottom admits a sufficient quantity of light and air fer the purposes of germination. After the plants have obtained two or three leaves each, they should be thinned out, so as te leave not more than three or at mest four plants in each patch ; or if the soil be goorl and the plants vigorons, even one or two plants in each patch will be sufficient to ferm a handsome tuft or hush.l In general the fewer plants, that are allowed to remain in a patch, the more vigorous and handsome will be the B 2 
bush or 'tuft of leaves and flowers produced. The plants of Flos. Adonis which are pulled up in thinning, may be thrown away, as they rarely suceeed when transplanted. The plants being naturally stiff and bushy, they will not require either pruning or training; but as to look handsome they should have plenty of room to spread on every side, the plants left after thinning should be as far from each other as possible; and a space of at least a foot or eighteen inches should be, left elear round the patels. After this, they will need no other culture than an oceasional watering if the weather should be very dry. As the Flos Adonis will stand the winter perfectly well, the time of sowing may depend on the time when. it is wanted to flower. If sown in September, it will be in full flower by, the middle or end of April; and if sown again in March, say the first week, it will come into flower about midsummer. If some seeds are sown on light soils in wet weather in July, they will flower from October to INebruary if the weather be mild: Seeds may be proeured at any seed-shop.

\section{OTHER ANNUAL KINDS OF ADONIS.}

These as' before 'observed are all probably only varieties of $A$. autumnalis; and the only one of them, the name of 'which' is to be found in nurserymen's catalognes, is A. castivalis, the summer-flowering Pheasant's Eye. A. vernalis, a pretty dwarf plant with large handsome yellow flowers, is marked in many catalogues as an annual, but it is a perennial.

\section{2.-A. ASTIVALIS Lin.; A. A. MINIATA Jacq.; A. MACULATA Waltr.,}

has the stem elongated and the flowers on footstalks. It flowers rather sooner than the eommon kind; but as the flowers are much smaller, and as the long unbranched stem has a straggling untidy appearance, it is not worth cultivating. It is a native of England, and also of the continent of Europe, but it is not so common as A. autumnalis.

\section{3.-A. MicrocarPa Dec.}

This is a dwarf plant with orange-coloured flowers, and numerous very small carpels. It is a native of Spain, and also of the island of Teneriffe, whenee it was brought to this country in 1824. It is a neat bushy little plant, flowering in June and July, and is well deserving of cultivation, but it is very seldom fonnd in British gardens.

\section{4.-A. CITRINA Hoff.,}

has the stem not branehed, and the flowers small and yellow It is a native of Franee, and was introduced into England in 1819 ; but it was soon lost in this country, and has not been thonght worth a re-introduction.

\section{5.-A. FLAMMEA Murr.,}

has flame-coloured flowers, which are not so eup-shaped as those of the comnon kind. It is a native of Austria, and was introduced into England in 1800 , but it does not appear to have been mucl cultivated.

In addition to these kinds which have been introduced into Britain, we may mention one, which, though it has not yet been introduced, appears well worthy of so being. This is called $A$. dentata; it has yellow petals with black claws (tho claw is the part that is nearest the stalk), and the earpels are tootled, or rather crested, on 



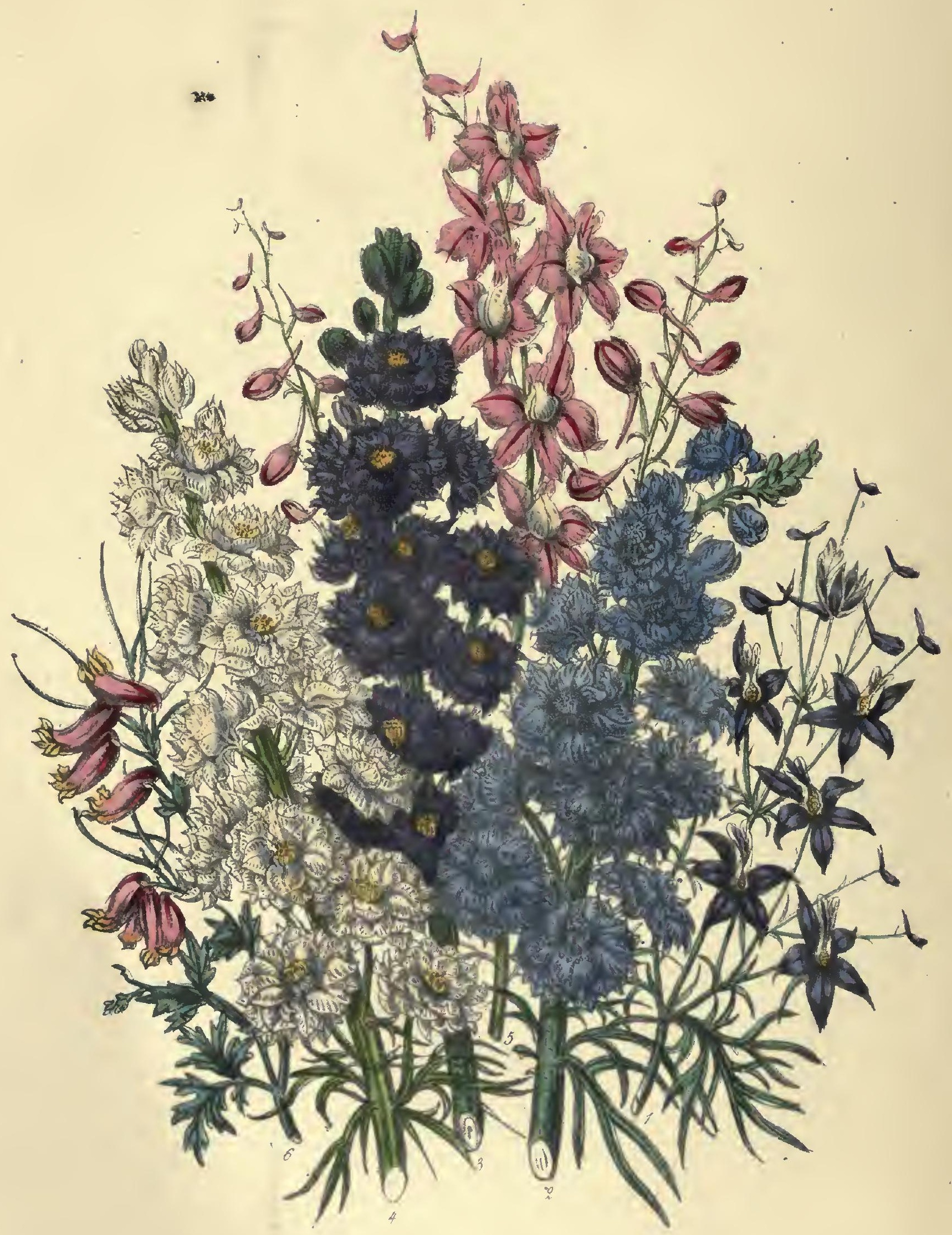



the back, whence the name. It is a native of Egypt and the isle of Cyprus, and from the deseription appears to be the handsomest of the geuus. Decandolle, in his "Prodromus," calls it $A$. dentata var. orientalis, and mentions another $A$. dentata, a native of France, which has flame-coloured flowers, but which resembles tlee Egyptian plant in its crested sced-pods.

.

\section{GENUS II. \\ DELPHINIUM Lin. THE LARKSPUR.}

\section{Lin. Syst. POLYANDRIA TRIGYNIA.}

Gexeric Character.-Calyx deciluous, petal-like, irregular, with the upper scpal drawn out below into a spur. Pctals $4 ; 2$ upper nncs drawe out at the base into appendages, within the spur.-G. Don. Erect, or branching herbs, with palmately-multifid leavcs, and showy flowers. Twenty-three species are annuals. Natives of the south of Europe, and north of Africa ; also, of Asin Mlinor, and Nepaul in Asia, and Penusylvania and Virginia in North America.

Description, \&ro.-The flowers of the larkspur are so common that they do not excite half the attention that their curious construction well deserves. In them the sepals of the calyx, and the true petals of the flower, at first sight, can scarcely be distinguished from each other. When examined closely, however, the ealyx will be found to be composed of five sepals, one of which forms a kind of lorn, and the shape of which is visible in the bud. When the flower expands, the true petals show themselves : they are four in number, and two of them have long tails, which are hidden in the horned sepal. This curious construction has given rise to both the English and botanic names; the horned sepal being something like the hind claw of the foot of the lark, and the bud bearing a fancied resemblanee to a dolphin; delphinium signifying a dolphin. The old English name was lark's-heels; and the Nasturtium ('Tropæolum majus) was ealled yellow lark's-heels.

\section{1.-DELPHINIUM CONSOLIDA Lin. THE BRANCHING, OR WILD LARKSPUR.}

SYNonyme.-D. segetum. Lam.

Engravings.-Eing. Bot. t. 1839 ; 2nd edit. vol. v. t. 769 ; and our fig. 5, iu Plate 3 , of the single pink variety.

Sprcific Character.-Stem erect, smoothish, with spreading branches; flowers few, loosely racemose; pedicels (footstalks) longer than the bracteas; carpels smooth.-(G. Don.)

Varteties. - Tbese are very numernus, even in a wild state. D. consolida is found with red, palc-reddish, lilac, pinkish, and whito flowers, though tho usual colour is a very dark blue. The garden varieties aro generally double, and thcy consiat of the white, blush, rosecoloured, lilac, light purple, dark purplo, and striped, which last is sometimes also ealled unique.

Description, \&c.-The branching larkspur, in good soil and farourable situations, will grow to the height of two feet or three feet, with numerous, slender, spreading, alternate branches. The lcaves spring from the branches without footstalks; they are downy, and are divided into numcrous linear segments. The flowers are thinly set on the raceme, and being on footstalks, hang much more loosely than those of the rockct larkspur ( $D$. Ajacis). The sepals in the wild flower of D. consolida are of a dark-blue on one side, and have a pinkish tinge on the other: the petals are pinkish, and form a curious kind of hood in the centre of the flower. Thre carpels grow generally two together; thoy contain numerous seeds, which are black and shining, and the taste of which 
is acrid. These seeds are poisonous. The stem is ratber slender, in proportion to its height, and widely-spreading branches, and the plant has a long tap root, more like that of a perennial than that of an annual. It is said to flower in a wild state in June and July; but in gardens it is muclı later than the dwarf larkspur, and seldom comes inte flower before August.

The branching larkspur is generally found in com-fields, and is a native of Eurepe, and some parts of America. In England, Sowerby tells us, "it abounds in the open chalky or sandy fields in some parts of Cambridgeshire, Suffelk, and Kent." It was known to the Greeks and Romans, as it is deseribed by Dioscorides and Pliny. In England it is mentioned by Tusser, in his list of garden flowers in 1572; se that the single kind has been in cultivation since the time of Elizabeth. The deuble kind is first mentioned by Parkinson, who says, "Of larkes'-heeles there are two principall kindes; the wild kinde is of two sorts, oue whieh is with us noursed up ehiefly in gardens, and is the greatest; the other, which is smaller and lower, often found in our plowed landes, and elsewhere. Of the former of these wilde sorts, there are double as well as single; and of the tame, or more upright, double also and single, and each of divers colours, as shall be set downe." The "wilde sert" is evidently $D$. consolida; and "the tame, or more upright," $D$. Ajacis. The branching larkspur was formerly called $F l o s$ regius, and Consolida regius; the latter name, which signifies joining or uniting, being given to the plant, as some say, from its supposed power of healing wounds; but, as from its aerid properties, it would be more likely to inflame wounds if applied to them than to heal them, the name more probably alludes to the growing together of the earpels. The bruised plant is said to be still used as the principal ingredient in some kinds of cosmetics; but it ought to be employed cantionsly, as though its aeridity may at first clear the skin, it cannot fail, if its use be persevered in, to destroy it.

'The French names for this plant, of Dauphinelle, Pied d'Alonette, and Eperon de Chevalier, are evidently derived frem the shape of the flower; and it is remarkable, that the German, Italian, and Spanish names for the plant all signify knight's spur.

Cultune. - The seeds of the branching larkspur should be sown in the same manner as directed for those of the Flos Adonis; and the young plants should be thinned out in the same inanner, the plants drawn out being thrown away, as from their tap roots they will not bear transplanting. There should never be more than three left in a pateh, and they should be as far asunder as possible, as if the plant be not allowed abundance of reom, it will from its spreading babit become deformed, and one side will be much larger than the other. When the plant has attained its full size, it will be necessary, unless the plant should be very strong, to support it by tying it to a neatly-painted stake, to keep it upright, and to prevent it from being broken by the wind. The branehing larksjur should never be sown with the rocket larkspur, as they de not flower at the same time, and their different habits of growtl do not harmonise. In some situations the single wild kind is very ornamental, from the intense blue of the centre of its flowers, while the violet, or pinkish tinge on the back, gives them somewhat the effeet of shot silk. Dr. Lindley, speaking of one of the perennial species which resembles this kind in colour, says, "All plants of this deseription are seen to the greatest advantage on the skirts of shrubberies, or ou banks; where it is required to produce a wild and rough effect. If it can be so contrived that their flowers are shaded during the day, and brightly illuminated by the setting sun, or that they are placed so as to droop over streams of water, where the freshness and meisture of the air prevent their rapid fading, a brilliancy of coleur is effected by masses of them, which we shall in vain attempt to procure in any other way."-Bot. Reg. for 1838, t. 52. 


\section{2.-DELPHINIUM TENUISSIMUM sib. et Fis. THE SLENDER-BRANCHED LARKSPUR.}

Synonymes.-D. divaricatum Ledeb. D. pubescens Dec. Exgrivings. - Swt. Brit. Flow. Gard. 2nd Serics, t. 366, and our
fig. 1, in Plate 3.

Description, \&c.-The whole plant is covered with a fine down. The stem is slender, growing about a fuot high, and spreading into numerous branches. The flowers are small, and of a reddislt-purple, and are not on a raceme, but on very long footstalks. This gives the plant a peculiarly liglit and elegant appearance. The plant was found by Pallas, on the banks of the Volga, and by Dr. Sibthorp, on Mount Hymettus, near Athens. This species is quite hardy, and it was raised in the Botanic Garden, Chelsea, in 1837, from secds sent there by Dr. Fischer, Dircctor of the Imp. Bot. Gard. at St. Petersburgh. It is most nearly allied to D. consolida.

\section{3.-DELPHINIUM AJACIS Lin. THE UPRIGHT, OR ROCKET LARKSPUR.}

Engruving.-Our figs. 2, 3, and 4, in Plato 3.

Specific Снанscter.- Stem erect, smoothish, almost simple, with the beanches hardly diverging. Flowers in long dense racemes. Pedicels the length of the bracteas. Carpels pubescent.-(G. Don.) Erect plants, natives of Tauria.

VAristies. - These are very numerous, not only differing in the colouc and doubleness of the flowers, but in the hoight of the plant. The principal kinds enumerated in the ourserymen's catalogues, are, the tall rocket, the dwarf rocket (sce fig. 2, in Plate 3), the double white (see fig. 4), blue, rose, flesh-eoloured, dark purple (see fig. 3), and variegated, tho common striped, the unique (red and white), the เall German, and the dwarf German; all which kinds are very ornamental, and quite hardy. Parkinson, speaking of the double varictics of this species, snys, their flowers "stand like little double roses, laid or spread broad open, without any lieeles behinde them, very delightrul to behold, consisting of many small leaves growing togetler, and after they are fallen, there comes up in their places threo or four small pods set togetber, wherein is contained, here and there (for all aro not full of scede, as the single kindes), blacke scede, like unto all the rest, but smaller, which being sowen, will bring plants that will bare both singlo and double flowers againe; and it often happeneth, that it variably altereth in colours from its owno sowing; for nono of then hold constantly his owne eolour (so farre as ever I could observe), but fall into others, as nature pleaseth." The justico of theso remarks must bo acknowledged by every one who bas raised double larkspurs from secd, as they vary very mueh. All, bowever, are beautiful, and their variety is consequently an advantage rather than the roverse. Our figures were drawn from specimens in Lee's nursery, Iammersmith.

DESCRIPTION, \&c.-The rocket larkspur is of a compact habit of growth, with nearly scssile flowers, which indeed appear set round the raceme, instead of depending from it; and this dense mass of blossom lias made tlis species a great favourite in flower-gardens ever since its introduction, now above two hundred and fifty ycars ago. It was the custom in the last century to fill jars or vases witlı large flowers, and to sct them in the grates or freplaces during summer; and we find all the early writers on flower-gardens mentioning, as an inducement for cultivating particular flowers, that they would be suitable for this use. The double larkspur was a favourite chimney flower; so mucl sc indeed, that Miller, speaking of it in his Dictionary, says, "For gatlering, to make flower-pets to adorn rooms, there is scarcely any so proper; because, by their upright growtl and long spikes (of flowers), they rise to a proper height above the pots; and when their several colours are skilfully introdtced, they make a rich appearance, and continue a long time in beauty."-(Mart. Miller.) This species, when grown. in gardens, flowers nearly a month before $D$. consolida, if both are sown at the same time; so that whicn they are wanted to flower at the same time, it should be sown much later. It is not however desirable to grow them together, as from the partial resemblance of their flowers, and great dissimilitude of their growtl, they produce a heterogeneous effect.

The rocket larkspur is a native of Tauria in the Crimen; but it is now found to come up spontaneously in 
many parts of Europe. It was brought to England in 1573 from Switzerland, and on this aecount it is frequently described in bouks as a native of that country. The specific name, Ajacis, is taken from some spots or streaks observable in the flower, which have been supposed to resemble the letters A. J. A., and to stand for Ajax. The legend is that when Ajax stabbed himself in a fit of frenzy, this flower sprang from his blood.

Coltune.-The rocket larkspur requires a very rich soil to bring it to perfection; and, if possible, it should be fresh soil, that is, soil that has not been before used for flower-beds. As, however, it would be very expensive to renew all the soil in the beds or borders where the rocket larkspur is to be sown, an experienced gardener, eminent alike for lis practical and scicntific knowledge, who has been so kind as to give us his advice on the subject of eultnre, tells us, that the best way is "to tako rich soil-say turfy friable loam, with one half quite rotten dung, in a barrow or basket; and, with a liglit flower-border spade, to take out six inches or eight inches square of the common soil, and to the deptl of at lenst twelve inches. The hole thus formed must be filled with the rich soil, the surface of which should be smoothed, and the seeds sown immediately." $-D$. B. The seeds may be sown in the same manner as those of $D$. consolida; or they may be sown in lines, a deep furrow being mado with a planting-stick, and filled in with the compost, and the seeds sown on it. "If you are fanciful," says the same excellent gardener whom we have before quoted, "you can level the surface of a bed, draw tho initials of your name, or the full name, with a stick; and, taking out the soil according to the sliape of the lettcrs, you can fill in the hollow with compost, and then sow the seeds. Or any other device may be exeeuted with these plants, they are of such neat and symmetrical growth. For example, a rainbow might be formed of the donble dwarf varieties, by arranging them according to their diffcrent colours." - Idem. In all eases, and particularly when compost is used, the seeds should be carefully sheltered from heavy rains, either by a flowerpot, or in some other manner, as will be hereinafter directed. When the young plants come up, they should not be much thinned, as from the compact habit of the plants they require but little room; and they shonld be seen in masses to produce an effect. They must always be sown where they are intended to remain, as they will not bear transplanting. This species will not require staking. The usual tine for sowing is from the middle of March to April, in which case the plants will flower in July, and they slould never be sown at any other season when compost is used; but grown in the common ground, they may be sown in autumn, and Rea tells us, that "one of these winter plants is worth ten of those raised in spring, and will yield more good seed." - (Rea's Flora, Ceres, \&c., p. 187.) Like all the Ranunculacces, the seeds (which are black and rough) will keep good several years. The seeds of Delphinium consolida and $D$. Ajacis may be purehased in any seed-shop; but those of D. tenuissimum can only be had from a botanic garden.

\section{OTHER SPECIES OF LARKSPUR.}

The following kinds have been introduced, but we do not know where they are in enltivation. Probably some of tho names may prove to be synonymes, and some of tho kinds only varieties of $D$. consolida.

\section{4.-D. OlIVERIANUM Dec.,}

las the stem ereet, and not much branched; the flowers are few, and hang loosely on longish pedicels; they are very large, and of a bluish purple. The plant is a native of cultivated fields near Bagdad, and was introduced in 1825 . 


\section{5.-D. ACONITI Lin.}

Stem erect, much branched, pedicels (footstalks) very long, spur horizontal, incurved and cleft at top. The flowers are of a livid hue, variegated with purple and green on the inside. It is a native of the Levant, and is said to have been introduced in 1801 , but it has probably been much longer in the country.

\section{6.-D. AMBIGUUM Lin.}

has the flowers in loose racemes; their colour is blue, and they resemble those of $D$. consolida, except tha they are downy on the outside. It is a native of Mauritania, and was introduced in 1759. The name of this species is in some of the London nurserymen's catalogues, but the seeds sold for it are often those of $D$. consolida.

\section{7.-D. CARDiopetaluM Dec.}

The flowers, which are crowded on the racemes, are of a dull bluish violet, and the petals are somewhat heart-shaped at the base. It is a vative of the valleys in the Pyrenees, and was introduced in 1818.

\section{8.-D. JUNCEUM Déc.; D. PEREGRINUM Lin.}

is a handsome species with bluish violet flowers, the petals of which are variegated with white. It is of the branching kind, with the flowers in lax racemes. It is a native of the south of Europe and the shores of the Mediterranean, and was introduced in 1629.

\section{9.-D. VIRGATUM Poir.}

Another branching larkspur, a native of Syria; with pale green leaves, and bluish purple flowers. It was introduced in 1823 .

All these kinds, with the exception of $D$. cardiopetalum, are nearly allied to $D$. consolida; and may possibly be only distant varicties of that species.

\section{GENUS III.}

NIGELLA Tourn. THE GARDEN FENNEL FLOWER, OR IOVE IN A MIST.

\section{Kin. Syst. POLYANDRIA PENTAGYNIA.}

Generic Character,-Calyx of 5 coloured, petal-like sepals. fennel. The flowers are solitary, at the points of the stem and branches; Petals suall, from 5 to I0, two-lipped, with a hollow, honey-bearing claw. Stamens numerous. Carpels more or less connected together, and terminated hy the elongated styles, opening on the ingide; manysecded.-(G. Don.) Erect plants with the lesves finely cut like and the seeds have an acrid aromatic taste like pepper. They are natives of tho south of Europe, Asia Mlinor, and the north of Africa. All the species are aunual. There are several kinds in cultivation in British gardens.

Drscription, \&c.-All the specios of this genus are remarkable for the feathery lightness of their leaves, and thicir very ornamental capsules. They are all quite hardy, and will grow in any soil or situation. 
1.-NIGELLA DAMASCENA Lin. TIIE ROMAN, OR DAMASCUS NIGELLA, OR CONMON FENNEL FLOWER.

-.Srnonrurs.-Nigella Romana Hort. Love in a Mist, Devil in a | Specific Crunacter.-Anthers blunt. Carpels 5, 2-celled, conBush, St. Katherine's Wheel, \&c.

Evgravisgs.-Bot. Mag: t. 22 : and onr fig. 5 , in Tlate 2. nected even to the summit into an orate globose capsule; flowers surrounded by a leafy involucre; aepals spreading.-(G.Don.)

Description, mistory, \&c.-This is, by far, the most common kind of Nigella. It grows gencrally ahout a foot ligh, with numerous fennel-like leaves, and a very pale blue solitary flower at the extremity of each slioot. It was mentioned in the general botanic character of the order Ranunculacea, that some of the genera belonging to it, laad the sepals changed into petals, and the petals into nectaries. This is the case with tho present genus. The pale blue leaves which constitute the ornamental part of the flower, are, in fact, the sepals of the calyx, while the real petals are rolled up into what look like little bags for secreting hower, and are called nectarics. The earpels in the whele genus of Nigella, differ from thoso of most of the Ranunmelacea, in growing partly tegether; and in this genns they are so united as to form one head, or capsule, each carpel containing numerous seeds, which are slightly attached to it like peas in a pod. When ripe the carpels becomo dry, and open at the top, to discharge their seeds. These seeds are not poisonous unless taken in great quantitics, though they have a sharp, acrid, biting taste. The capsules, when the petals have dropped, are, from their elegant vase-like form, almost as ornamental as the flowers. There are several varieties of N. Damascena, some with pure white, and some with double flowers; but they do not appear sufficiently distinct to merit separate descriptions, as they will all spring up from sceds of the same pod. In all the flower is surrounded by a leafy involucre, which remains on, and surreunds the capsule after the petals are gone.

The common Nigella is a native of Italy, and of the sonth of Europe generally, where it is found wild in cornficlds, whence its popular name of Nigella Romana. It is also called $N$. Damascena, because it is said to bave been brought to England from Damascus in 1570. It was probably, however, introduced before that period, as in the edition of Tusser's Five Hundred Pointes of Good Husbandry, published in 1572, which included semo directions for gardening; Nigella Romana is enumerated among the flower-seeds directed to be sown in March, as though it were then a common plant, which it could hardly have been if it had been only two years in the country. The generic name of Nigella is supposed to be derived from Niger, in allusion to the blackness of the seeds; but London and Wise, in the Retired Gardener, tell a legend of a wicked nymph, who was changed into this plant, which was afterwards called Nigella, to commemorate the blackness of her heart. In fleral language the Nigella signifies doubt and uncertainty, or embarrassment.

Perlaps no plant had ever more popular names than the Nigella. It is called the Devil in a Bush, from the appearance of its horned carpels peeping through its bushy leaves; Love in a Mist, from its pale bluc flowers being surreunded by a mist of leaves, blue being the colour dedicated to true love; Love in a Puzzle, a name which seems to ceme from the same origin; St. Katherine's Wheel, in allusion to the shape of the flower when fully expanded; Gith, that being the Saxon for a weed growing among corn; and GardenFennel-flower, which appears the most appropriate name, from its leaves resembling those of fennel. It was formerly also called Bishop's Wort in Cambridgeshire, perhaps from the projecting styles which rise above the flower, bearing some slight resemblance to a crosier; and in the time of Gerard, Melanthium, from the Greek word melania, blackness, though now the 
name of Melanthium is given to a Cape of Good Hope bulb. In the Kike manner, in the West Indies, the name of love in a mist is given to a kind of passion flower (Passiflora foetida), which resembles the Nigella in having a leafy involucre surrounding the flower. The French names for the Nigella, of Chereux de Venus, Patte d'araignce, and Barbe blene, are all evidently derived from the eireumstance of the flower being surrounded by leaves.

The Roman Nigella is a very common flower in gardens, and it is found in all the published lists of flowerseeds from the time of Tusser to the present day. Gerard praises it for its medicinal virtucs, and tells us that it was mentioned both by Hippocrates and Galen as a stimulant. London and Wise, in 1706, give particular directions for its culture as a border.flower; recommending it to be sown in sheltered beds in autumn, and planted out into the open border in spring. Its value as an ornamental flower, however, appears to have sunk during the succeeding fifty years; as in a little tract called the London Gardener, published in 1760 , it is only mentioned as a flower no one would be without "for the sake of its strange appearanee." This strange appearance is probably the reason why it is still cultivated, though now so many much more beautiful flowers have becn introduced. It is eertainly not worthy of a place in a small garden.

Curture.-This is extremely simple. It may be sown in the same manner as the Flos Adonis; and, like that plant, it requires a somewhat moist and sheltered situation. When it has been once introduced, if care be not taken to cut off the seed-pods before they are ripe, the seeds will sow themselves, and the plant come up like a weed. Its compaet bushy shape and erect stem render training and pruning unneeessary; but thinning is essential, as, if the plants are left thiek, they will be drawn up with naked stems, and have that untidy and tawdry appearance we have already alluded to. The seeds are generally sown in Mareh; but when wanted to flower particularly carly, they may be sown in autumn, as they will stand perfeetly well through the winter.

\section{2.-NIGELLA NANA Hort. THE DWARF NIGELLA.}

Synowymes.-N. coaretata Gmel.; N. Damascena var. Hortus | Speciric Canructer.-Anthers blunt; flowers of a greenish white, Kewensis.

Enarating.-Our fig. 1, in Plato 2. and with a leafy involucre.-(G. Don.)

Descriptron, \&c.-A little bushy plant, seldom above six inches high; very neat and eompact in its babit of growth, and having very large flowers in proportion to its size. These flowers are of a greenish white, and are generally semi-double. There is another kind of dwarf Nigella with blue flowers, the seeds of whieln are sometimes sold in the seed-shops as those of $N$. nana; and another ealled by the seedsmen the new white Nigella, both of whieh are only varieties of this kind. The origin of the dwarf Nigella is not known, but it is probably only a variety of $N$. Damascena, as its capsules exactly resemble those of that species. There is a figure in Gerard of a plant which he calls Nigella fore albo multiplici, which strongly resembles this; but the date assigned for its introduetion in the Hortus Britannicus is 1793; and it does not appear in any of the nurserymen's catalogues of flower-seeds prior to that time. It is a pretty littlo plant, very suitable for small front gardens; or for any. situation where it will be near the eye; though, like the common Nigella, it may be considered as more curious than beautiful. Its culture is exactly the same as that of the common kind. 


\section{3.-NIGELLA, HISPANICA Lin. THE LARGE.SPANISH NIGELIA.}

Sหพохหมะ. -N. latifolia.-Mill. Dict.

Engruvings. - Bot. Mag. t. 1265, and our fig. 3, in Plate 2.

Spreiric Conracter.-Anthers pointed; styles from 8 to 10 , spreading. Carpels with a crested ridge running down the back, partly distinct, but connected below the middlo into an obconical fruit.
Stem erect, smooth, and with the branches pointing upwards. $-(G$. Don.)

VAkAETY. -N. Hispanica, 2 alba Hort., sce fig. 4, in Plate 2 This very showy and distinct variety has white, or rather ereamcoloured flowers.

Description, History, \&c.-This is, in fact, the only beautiful species of the genus. The flower is very large and handsome, with the carpels rising boldly like a pillar in the centre. The petals of this spccies are of a dcep rich mazarine blue; and when they fall, the carpels are almost, if not quite, as ornamental. They are strongly marked with a brownish red dotted crest, which runs up the back of each; and their points spread out so as to form a kind of radiated crown to the vase-shaped capsile formed by their union below. The plant is about a foot and a half high, and is of a bushy compact habit of growth. The Spanish Nigella is a native of the south of Spain, and Barbary, where it is common in the corn fields. It is perfectly hardy, and will grow in any soil ; yet notwithstanding this, its beauty; and the circumstance of its having been in cultivation since the days of Parkinson (1629), it has never - been common in British gardens; and, while the common Nigella is known to everybody; comparatively few persons have ever even heard of the Spanish kind. It flowers in $J$ unc and July, nearly a month carlier than the common species, and is very ornamental. " There were beautiful specimens of it in flower in the summer of 1838 , at Ronald's nursery, Brentford, and Lee's nursery, Hammersmitl, from the latter of which our drawings were made.

Culturs.- The soil for the Spanish Nigella should be loamy, rather rich than otherwise, and the situation somewhat sheltcred. If the soil be poor or dry, and the situation too much exposed, the plants will not take handsome shapes, and the flowers will neither be large nor richly coloured, without a great deal of watcring. The ground may be prepared and the seeds sown in the same manner as directed for Flos Adonis; and the young plants thinned out when they are two or three, inches high. There is however this difference, that as the plants of the Flos Adonis, which are taken out of the patches when they are thinned, are to be throwi away, they may be pulled up by hand; whcreas the plants of all the Nigellas will bear transplanting, and as it is worth taking this trouble with those of the Spanish kind, they must be taken up with more care. For this purpose, the plants to be transplanted should be carcfully raised with a trowel, and taken up, if practicable, with a little mould attached; at all events care should be taken not to injure the fibrous roots, the spongioles at the cxtremities of which are the mouths of the plant through which it takes its food. Should any of the fibrils be bruised, or otherwise injured; they should be cut off above where they are hurt; as this will induce the plant to throw out ncw ones, instead of wasting its strength in fruitless efforts to heal the wounds. Before the plant is taken up, a hole should be made with a stick, or small dibber, in the ground to which it is to be transferred; and when the root of the plant is put into this hole, the mould should be crumbled in round it, and afterwards pressed down with the hands, in such a manner as to give the root, especially at its lower extremity, a firm hold of the soil. 'It may here be observed that if the plant be only made firm by pressing the earth round its collar, that is, just at the surface of the soil, it will in all probability die, or at least it will not thrive; whereas if the root be made firm at its lower extremity; and the earth filled closely in upon it, the plant will grow and prosper; even though the earth should be quito loose round the collar. The common way in which gardericrs transplant 


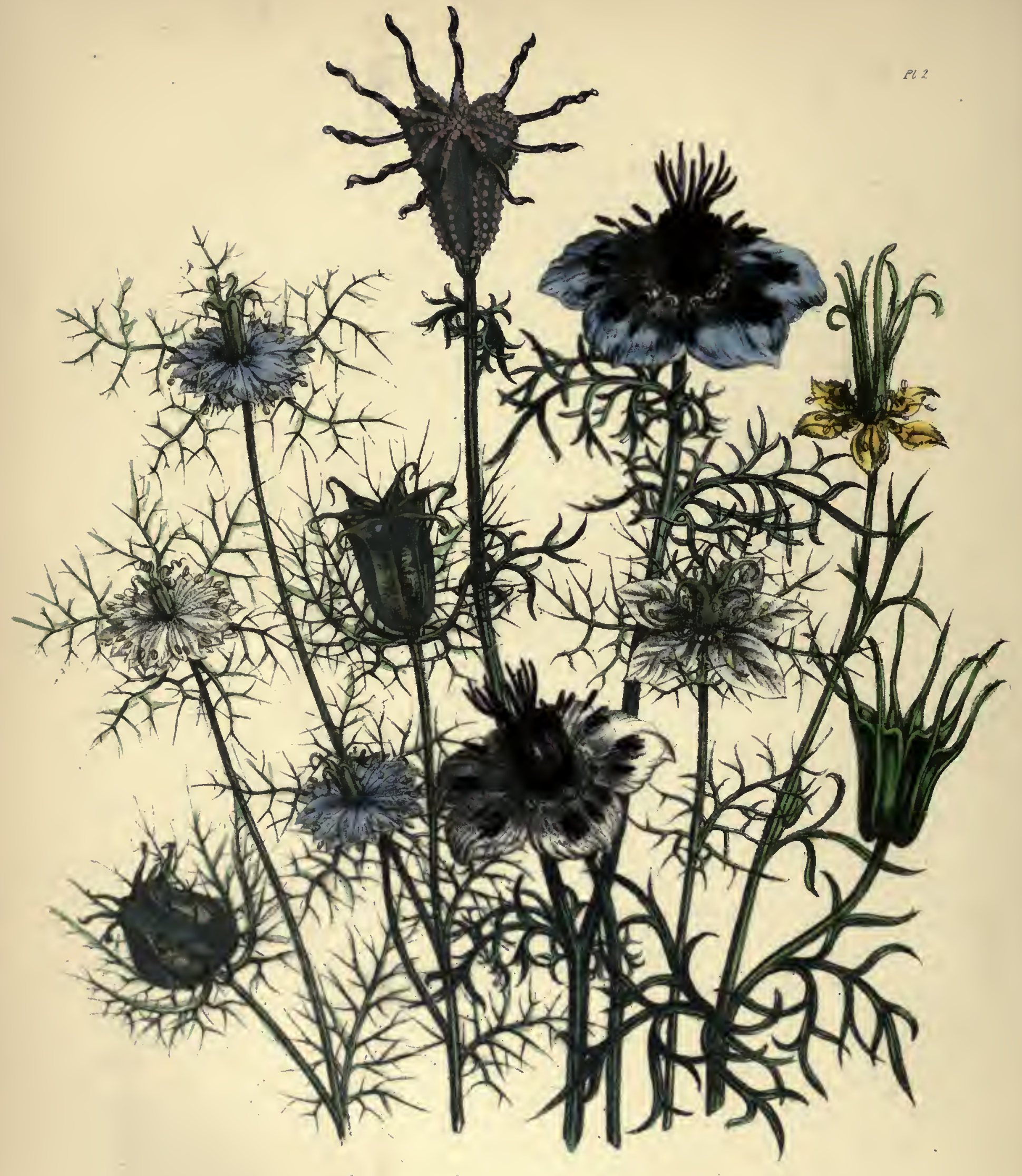


, 

hardy annuals, is by making a hole with a dibber, or planting-stick, the form of which is conical, then inserting the plant, and holding it with the left hand, while with the right another hole is made about an inch from the first, and the dibber moved in such a manner as to close the first bole, and in so doing to press in the earth against the root of the plant from the bottom to the top : the second hole is then closed by a little earth drawn into it by the point of the dibber. In this way a great number of annuals may be transplanted in a comparatively short time; but as it requires some dexterity, which can only be acquired by practice, to avoid bruising the tender stem and root of the young plant with the dibber, the novice in gardening had much better nse the first method we have described, and make the roots firm with the hands. When a plant is transplanted in wet weather, it does not require so much care as when the weather is dry. As soon as the young plant is fixed in its new situation, unless the weather be wet, it should be watered; not only to wash the small particles of earth in amongst the fibrils, but to afford nourishment to the plant; as when a plant is transplanted its root requires to be kept moist to preserve the elasticity of the spongioles. When a plant is transferred to a dry soil without watering, the spongioles wither up, and the plant dies; on the contrary, if too much water be carelessly given to the root, it will most probably rot the spongioles. If the weather be dry, the newly-transplanted plant should be shaded from the sun for a day or two, hy a flower-pot, put on in the morning and taken off at night, to prevent the evaporation from the leaves being greater than the moisture taken up by the root. When a plant is firmly established in the soil, the quantity of moisture absorbed by the root, and that carried off by the leaves, is exactly proportioned;- but transplanting of course weakens the root, and renders it incapable for a day or two of performing its usual functions.

The Spanish Nigella is so handsome a flower that it may be planted in any garden; and when tho dark-blue kind is combined with the whito variety, a splendid effect may be produced. Could the following species; $N$. orientalis, be procured and planted in the same group, its yellow blossoms would form a striking contrast with the above. 'The seeds of the Roman, dwarf, and Spanish Nigellas, may be purchased in any seed-shop.'

\section{4.-NIGELLA ORIENTALIS Lin. THE ORIENTAL, OR YELLOW-FLOWERED NIGELLA.}

Evarivings.-Bot. Mag. t. 1264, and our fig. 6, in Plate 2." | straight. Secds flat, orbicular, and girded with a membranous Specific Character.-Carpels from 5 to 10 , smooth, connected together from the base almost to the middle, hardly diverging. Styles

Descriptron, \&c.-This species is remarkable for the colour of its flowers, and the long styles that stand up in their centre: Tho flowers themselves are small, but thcir colour is a bright yellow, and thus they form. a striking contrast to those of the other species of the genus. The carpels are very remarkable when the petals have fallen, though they are not so ornamental as those of $N$. hispanica. The carpels of $N$. orientalis are quite distinct, except at their inner edge, where they are slightly attached from the base to about the middle. This species is a native of Asia Minor, and Syria, and it is common in the corn-fields near Aleppo, and in Eastern Caucasus, and Middle Iberia. It was introduced in 1699, and was grown in Lee's nursery, and other places, within the last twenty years; but it appcars to have gradually fallen out of cultivation for want of a demand, and it is probably now lost. It might however be easily again procured if it were much asked for; and it is worth growing, for the sake of the effect it would produce in patclics with the white and blue Spanish Nigella. 


\section{OTHER SPECIES.}

Though all the kinds of Nigella mentioned below are mentioned in betanical werks as having been introduced, and even the dates of their introduction given, we think it very doubtful whether the seeds of any of them would be procured for sowing from any of the seed-shops. We enumerate them, however, in case any one curious in plants should wish to grow them, as it may be safely taken for a rule, that a demand for any given article in such a country as Britain will always be followed by a supply. In this case, nurserymen may easily get the seeds, as it is one of the characteristics of the order that the seeds of the plants belonging to it may be kept a long time without losing their vitality; and by writing to the directer of seme betanic garden in the country of which the plant is a native, a few seeds may always bo obtained, which the nurseryman will soon multiply sufficiently to enable him to supply the demand.

\section{5.-NIGELLA SATIVA Lin.}

This is a tall-growing plant, with bluish flowers, which have no involucre. It is found wild in corn-fields near Montpelier, and on the opposite African coast of the Mediterranean. It is a plant of no beauty, but it is said to be cultivated to some extent in the south of France for its seeds, which are used in adulterating pepper. They have a pleasant aromatic smell, and a het acrid taste, not unlike that spice; and they were formerly in general use instead of it, and also as a carminative medicine. N. sativa was the frst species of the genus grown in British gardens, for Tnrner mentions it in his Names of Herbes, published in 1548, as being then growing at Syon Gardens, near Brentford. There are two varieties grown in France, and one in the East Indics; but except one, which has blue flowers, they only differ in some trifling particulars from the species.

\section{6.-N. CORNICULATA Dec. THE HORNED FENNEL FLOWER.}

This species bas the points of the carpels very stiff, and arched -outwardly, like horns. It is a dwarf plant, with yellow flowers, and round flat seeds. It is said to have been introduced in 1820 , but it is not stated of what country it is a native.

\section{7.-N. ARVENSIS Lin. THE FIELD FENNEL FLOWER.}

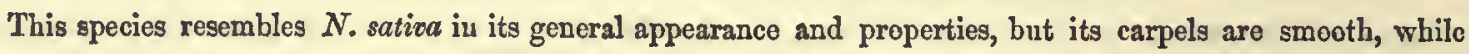
those of N. sativa are warted. It is a native of the shores of the Mediterranenn, and was introduced in 1683.

$$
\text { 8.-N. ARISTATA Sib. and Smith, Fl. Grac., t. } 510 \text {, }
$$

has the anthers pointed, and the carpels connected into a turbinate fruit; the stem is smeoth, and the flowers, which are blue, are surrounded by a leafy involucrum. It is a native of the country near Athens, and bas almost the babit of $N$. Damascena, grewing about a foot and a half high. It may be the same as N. incolucrata Hert., soe our fig. 2, in Plate 2, a kind grown in the Hammersmith nurscry, but which we have been unable to find under the name of $N$. involucrata in any of the botanical catalogues.

\section{9.-N. INVOLUCRATA Hort. Ourfig. 2, in Plate 2.}

This species or variety does not appear to have been described in any books, and we are not aware of its being grewn in any nursery except that of Messrs. Lee, at Hammersmith. It appears, from the form of its capsule and its flower, to be nearly allied to $N$, nana, and it may possibly be the blue variety of that species. It is however a much taller plant, being from a foot to a foet and a half high. 


\section{GENUS IV. \\ GARIDELLA Tourn. THE GARIDELLA.}

Lin. Syst. DECANDRIA TRIGYNIA.

Greneric Character.-Sepals five, hardly petal-like. Petals five, herns.-(G. Don.) There aro two species, only one of whicb has two-lipped, bifid. Stamens ten to forty. Carpels two or three, many- $\mid$ been introdaced inte Britain."

seeded, connected together into a capoule with two er three very short

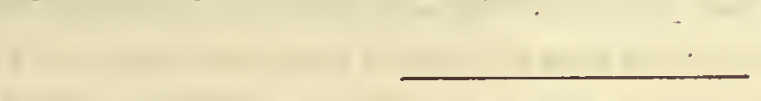

\section{1.-GARIDELla NigellastruM Lin. THE NIGELLA-LiKE GARIDELLA.}

Engravings.-Bot. Mag. t. 1266 ; and onr fig. 2, in Plate 1.

Spscivic Chlarcter, - Petals sessile, spreadieg. Stamens from teb to twelve,-(G. Don.)

Description, \&c.-This curious little plant is very nearly allied to Nigella orientalis. It grows about one foot or eighteen inches in height, with a very slender stem, and multifid leaves, with linear divisions. The flowers are small, but when closely cxamined they are pretty. It is a native of "sunny places among the olives and vines of Provence, \&c." It was introduced in 1736, but has been long out of cultivation, except in botanic gardens. The generic name was given to it by Tournefort, in honour of Dr. Garidel, a physician at Aix, and the author of a work on the Plants of Provence, published in 1719. The culture of the Garidella is similar to that of Nigella; except that the seeds may be sown closer, and the plants need not be so much thinned out; as they will look best in a mass, on account of the slenderness of the stems and smallness of the flowers.

\section{GENUS $\nabla$. \\ PLATYSTEMON Benth. THE PLATYSTEMON. \\ Lin. Syst. POLYANDRIA POLYGYNIA.}

"Yineric Churucter. Sepals three, ovate, deciduens, hairy. Petals six. Stamens numerous. Filaments dilated, membranous, and eicordate. Anthers linear, erect. Carpels from nine to twelve ranged side by side. Stigmas linear, orect, and simple. When mature, slightly cohcring, iedehiscent, cartilaginous, twisted, separatód into one-seeded transverse jeints. Seeds smooth, not crested. Albumen oily.-(Benth.)

Description, \&c.-This is a most remarkable genus; it forms the connecting link between the Ranunculaceo and Papaveracea, and is by many botanists considered as belonging to the latter order. Dr. Lindley, however, in the last edition of his admirable Introduction to the Natural System, has placed it in Ranunculacexe, to which order, indeed, it appears naturally to belong, from the yellow watery juice discharged by its stems when broken, and by its petal-like filaments-a great peculiarity of the order Ranunculacese consisting, as Dr. Lindley observes, "in the strong tendency exhibited by many of the genera to produce their sepals, petals, and stamens, in a state : different from that of other plants." Only two species of Platystemon are kuown, both of which are annuals; . and they are natives of North America, and the north of Europe. 


\section{1.-PLATYSTEMON CALIFORNICUM Benth. THE CALIFORNIAN PLATYSTEMON.}

Fingruvina. -Bot. Reg. t. 1679.

Srecific Character. - Tho wholo plant hairy and spreading. Leaves $\mid$ lemon-colour; carpels hairy:-(Benth.)

Description, \&c.-The stem spreads about three feet or four fect from the roots; but instead of rising ereet, it reclines on the ground, gracefully eurving upwards at the extremity of the shoots, whicli produce the flowers. The leaves and stem are of a pale bluish green; and the flowers, which are fragrant, vary in different situations from cream-colour to a pale yellow. The whole plant has a remarkably elegant and delicate appearance, withont being fragile. The stem is somewhat sueculent; and when it is bruised, there issues from it a thin yellow juice. The leaves are long and narrow, and grow always three together; and they aro quite hairy, as well as the stenı. The flower-stalk is very long. The calyx, which is of a reddish-brown, is divided into three sepals, which fall off as soon as the flower is expanded. The filaments are very remarkable, as instead of being long and threadlike, they look like $\dot{V}$ andyke-shaped petals with the points uppermost. The carpels are numerous; they are placed side by side, and when young they are slightly united at the edges, but when they become mature they separate, and each will be found to consist of numerous jointed cells, each containing one seed, slightly attached to one side. In this curious construction of the carpel, Platystemon bears a elose resemblance to the genus Hypecoum, which we shall speak of hereafter.

The Platystemon californicum was discovered by Mr. Douglas, botanical collector to the London IIorticultural Society, in California, and seeds and dried specimens of it were sent home by lim in 1832, under the name of Boothia; but there being another plant with a neally similar name, Mr. Bentham, who first described it in the Horticultural Society's Transactions, called it Platyslemon, from two Greek words signifying broad stamen, in allusion to the extraerdinary breadtl of the filaments. 'The seeds sown in the Horticultural Society's garden came up, and flowered but very sparingly the following year; and, as the plants died without maturing thicir seed, the species was supposed to be lost. It has, however, been re-introduced, and is now abundant in the nurseries and seed-shops.

Couture.-The Platystemon, being a native of the colder part of California, is quite hardy, and will grow in any common garden soil. 'It may be sown as directed for Flos Adonis, but when it comes up it should be thinncd out, and only one or two flowers left in each patch, as it spreads very much; and in favourable situations one plent will eover a space three feet or four feet in diameter. It flowers abundantly, and in situations where it is not too far from the eye, it is very ornamental. The plants taken out in thinning may be transplanted.

\section{2.-PLATYSTEMON LEIOCARPUM Fisch. et Meyer. THE SMOOTH-FRUITED PLATYSTEMON.}

Engrapings.-Floral Cabinet, vol. ii. p. 129; and our fig. 1, in Plate 1, copied from it. Spectic Charactsr. - Carpels smooth.

Descripiriox, \&c.-This plant, though deseribed as a species, appears to be nothing more than a smooth:fruited variety of $P$. californicum. 'It was raised in the Birmingham botanical garden, from seeds sent there in 1836 by Professor Fischer from St. Petersurgh. It is not stated of what country it is a native, but though the seeds were scrit from the Russian enpital, it is supposed to be a native of New California. It grows and flowers as luxuriantly as $P$. californicum, and ripens its seeds equally well. It flowered for the first time in the summer of 1838 , in the Birmingham botanic garden. 



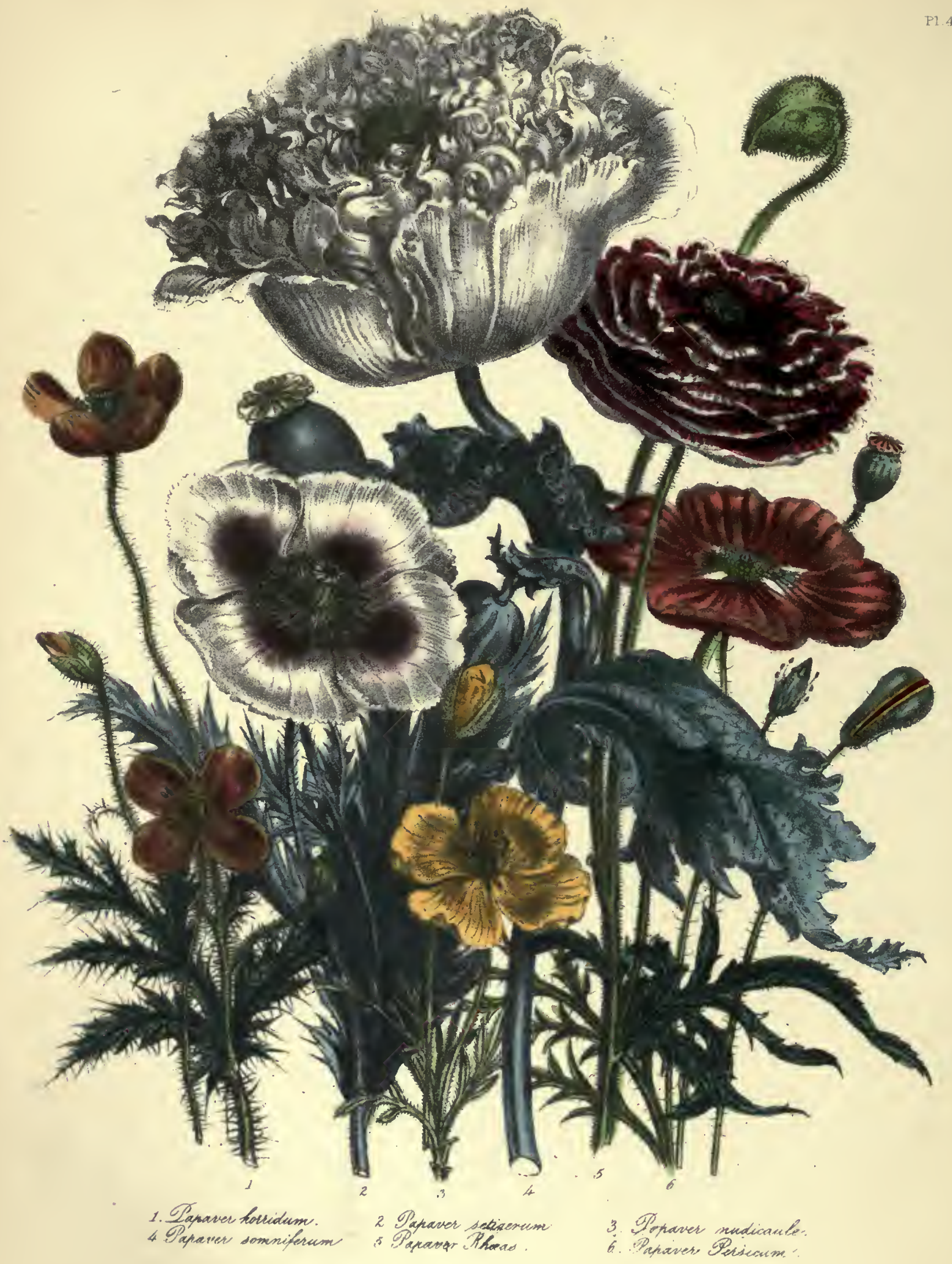






\section{CHAPTER II.}

\section{PAPAVERACE}

Botanicil Charaeter or the Ordrr. -Scpals 2. Pctals 4 or 8. globose, or elongated and silique-formed. Herbs yielding milky Etamens numerous, hypogynous. Capsulo valveless, and nearly juice.-(G. Don.)

Description, \&c.-The plants belenging to this order are easily distinguished by a common observer from those belonging to Ranunculaces by their juice being milky instead of watery. Botanically, they differ in the calyx, which separates into only two sepals, as may be seen by the bud of the peppy, instead of three or six; and in the number of the petals of their single varieties, which are always either twice two, or twice four. The seeds also are numerous, and contained in one capsule or pod, instead of being in several distinct carpels growing near together. The stamens grow bclow the seed-vessels, in tho same manner as those of the Ranunculacex. Plants belonging to this order are poisonous, but not in the same degree as those belonging to Ranunculaccx, and their poison is narcotic or stupifying, and not acrid. Tho poison of the Papaveraceæ is confined to their milky juice. They are natives of Enrepe, Asia, America, and the south of Africa.

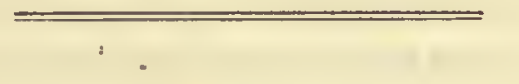

GENUS I.

\section{PAPAVER Lin. THE POPPY.}

\section{Lin. Syst. POLYANDRIA MONOGYNIA.}

Geseric Churactrr._-Petals 4. Stamens indefinite; style wanting. Stigmas $4-20$, radiating, sessile, connected, crowning the top of tho ovarium. Capsules obovate.-(G. Don.)

Description, \&C.-All the poppies are strong vigorous-growing plants, bearing their showy flowers on very long footstalks. These flowers never last long, many of the kinds dropping their petals the very day that they expand, and all leaving a large obovate capsule which contains an cnormous number ef seeds. These seeds, when young, are disposed along some thin shelf-like divisions, enclosed in the capsules, but as they ripen they become loose, and the outside of the capsulc, from being grecn and succulent, becomes of a pale brown, and hard, dry, and brittle. The points of the stigmas remain and form a sort of cover over this capsule; and immediately imder each stigma-peint is a little valve-like opcning, through which the seods fall out when the poppy-head is reversed. The milky juice of the poppy is more narcotic than that of any other genus of the order. 


\section{1.-PAPAVER SOMNIFERUM Lin. THE OPIUM BEARING, OR LARGE WHITE GARDEN POPPY.}

ENGRavings._Eng. Bot. t. 2145; 2nd edit. vel. v. t. 756 ; Wood. Med. Bot. t. 185; and our fig. 4 in Plate 4.

Spectric Character.-Capsules obevate, or glebese, smooth. Calyx smeoth. Stem smoeth and glauceus. Leaves stem-clasping, repand-toothed, teeth bluotish.-(G. Don.)

VARIETIEs.-De Candolle mentions twe distiact kiads; oac having white seeds, and the other blaek. There are, bewever, many garden varictics, some deuble and seme semi-deuble; some with frioged petals, and ethers having white petals, delicately berdered with some dark coleur; some are variegated, er streaked, and others of only ene

celour ; all the rariatiens, however, eonsist of different sbades of red or purple, mixed with white, and withent the slightegt tinge of either blue er yellew. All the kinds aro very ernamental, and whon judicieusly intermixed, they produce a fice effect is a tolembly large garden; theugh they take up toe much reem to leok well in a very small oee. The siagle wild kied has white petals, with a very dark purple or almest blaek spet, at the base of each ; and this is the kind priseipally cultivated in France and Belginm fer its seed to make eil, and in Turkey and India fer epirm. The Paparer Marsellei sold in seme of the seedsheps is the white-seeded variety of this poppy.

Description, \&c.-The white garden, or opium poppy, grows in favourable soils to the height of three or four fcet. Its leaves are oblong, and sometimes eight inehes or ten inches in length, embraeing the stem at their base, and placed alternately; they are smooth, rather thiek, and of a bluish green. The flowers are produecd singly at the extremities of the stem and branches. The bud, before it opens, hangs down, but when the flower expands, the part of the stem whieh supports it beeomes erect, as thongh better to display the splendour of its colours, and the beauty of its form. The flowers do not last long, either when left in a growing state, or when gathered, and they have a disagreeable snell. The eapsule is very large, and it is quite smooth. When the flowers fall, it is green and sueculent, and if wounded yields a milky juiee, whieh, when dry, is the opium of the shops. The eapsule is surmounted by a kind of lid formed by the extrenities of the stigmas; and this cover remains on, even after the seed is ripe, and the eapsule beeomes hard, dry, and brittle. Under this lid are eight or ten little openings, formed by a little point of each division of the eapsule turning down immediately under the projeeting point of each stigma; these little openings are to discharge the seed. "When the seeds are first formed they are in slight divisions, but when they beeome ripe they are quite loose, and may be easily shaken out through the little openings without breaking the eapsule. The quantity of seeds produced is enormous. Linnæus states that he found 32,000 seeds in one single head. The seeds of the kind most eommonly grown in gardens are black, or very dark brown, and very small; but those of the white-seeded variety are much larger, and are flat and oval. The seeds should be used as fresh as possible, as they do not keep.

The opium poppy is a native of the warmer parts of Asia, but it has been so long grown in Europe that it has beeome, in a great degree, naturalised; and it is found in a wild state not only on the eontinent, but occasionally in Britain. It is extensively grown in Flanders for the oil whieh is made from its seeds, and it is also cultivated for this purpose in the south of Europe. It is cultivated in India for its opium, but the best opium is grown in Turkey, and Asia Minor. Opium las been occasionally produeed from poppies grown in the south of France and in Britain. In 1796, Mr. John Bull, of Williton, obtained a reward from the Society of Arts for eultivating the poppy, and obtaining opium from it, "in no respeet inferior to the best Eastern opium." Mr. Bull calculated that each poppy produeed about a grain of opium, and that more than 50 lbs. of this drug might be collected from a statute acre. (See Trans. Soc. Arts, vol. xiv., p. 260-3). Some years afterwards, Mr. Young, a surgeon at Edinburgh, also suceeeded in procuring opium of exeellent quality, and in eonsiderable quantity; and he found that an aere of poppies yielded $56 \mathrm{lbs}$. of opiun, and the seeds 375 quarts of oil. (See Trans. Soc. Arts, vol. xxxvii.) These results, however, eould only bo produced in favourable seasens, and with extraordinary care; and consequently, all attempts to grow opium on a large seale as a profitable speeulation in Britain, have 
failed. It is, indecd, much to be lamented; that time, energy, and capital, should be wasted in striving to overcome difficulties of climate. The art of the cultivator should rather be directed to assist nature than to oppose her; and it is only when it is thns employed that it ean be attended with success.

The name of Papaver is said to be derived from the Celtic word pap, from the decoction of the poppy being mixed with the food of children. Somniferum is sleep-bearing. The French call this species le parot des jardins.

\section{THE COMMERCIAL PRODUCTS OF THE WHITE, OR OPIUM POPPY.}

These are opium, oil, the seeds as an article of food, and the dried capsules. When the poppies are grown for opium, the ground is well plonghed and carefully manured before the sceds are sown; and when they come up, the plants are regularly watered till the petals of the flowers drop, and the capsules are about half ripe. At this period, and while they are yet quite green and succulent, they are in a fit state for yielding the opinm. In the evening, a number of persons, each armed with a sharp lancet, pass along the rows of poppies, making in each head two or four incisions, according to its size, and taking care not to penctrate through the rind to the inner carity of the capsule. The milky juice that exudes from these incisions laardens during the night, and the following morning it is scraped off with an iron tool. This substance, which is called tears of opium, is the drug in its purest state, before it is prepared for the market. When a sufficient quantity has been collected, it is kneaded with a wooden spatula in the sunshine till it becomes like dongh; it is then, in Turkey, formed into flat cakes, and covered with the reddish capsules of a species of Rumex, after which it is wrapped in numerous poppy or tobacco leaves. In India, after kncading, it is put into saucers, or shallow earthen basins, and kept in a sliady place till it is dry ; and when packed up for exportation it is only wrapped in leaves, without being covered with capsules. There is an inferior kind of opium, formed by boiling all the remains of the plant after, it has ripened and discharged its seeds, and evaporating the moisture, which is used for adulterating the purer kind; and the Indian opium is also adnlterated by mixing it with cow-dung and othor substances, while it is being kneaded.

The best opium is that called Turkey opium, which is produced from poppies cultivated in Turkey and Pcrsia. This kind forms a compact semi-transparent substance, which is brittle, and easily broken when dry, but which is rendered soft and pliable by a gentle heat. The opium made in the East Indics is, on the contrary, soft, and opaque, and some inferior kinds are about the consistence of tar. It is much cheaper than the Turkey opium, and not above half the strength.

Opium is used medicinally, to allay pain and procure sleep; but it is also taken as an intoxicating drug. It was known to the ancients, its medical preperties having been described by Dioscorides, who mentions also, that too large a dose will kill. Galen ranked it among his cold medicines. At the present day it is principally used in Turkey, where, as the Mussulman religion forbids wine, it is taken solely for its intexicating properties. In Turkey it is frequently mixed with rich syrup or candied fruit, and made into lozenges, which are stamped with the words Mash Allah, literally, "the work of God." In this state it is taken by women, and even children ; but never without producing a most injurious effect upon the constitution. The Turkish men gencrally take it raw; and there are certain coffee-houses in Constantinople set apart for those who have habitnated themselves to the use of this drug. In these places, stupid, heavy-looking men may be seen sitting on a bench, waiting for tine effects it will produce. The time which elapses between the taking of the opium and its effects, varies from about twenty minutes to two hours, and as soon as it begins to operate, these stupid, heavy-looking 
beings become animated with the wildest passions. Madden, in his Travels in Turkey, speaking of them, says, "Their gestures were frightful ; those who were completely under the influence of the opium talked incolierently; their features were flushed; their eycs had an unnatural brilliancy; and the general expression of their countenances was horribly wild." This violent excitement soon wears off, but the exhilarating effects of the opium remain for four or five hours, after which they return to their coffee-house for another dose. The horriole effects produced by this constant use of opium have been frequently described by travellers. "The debility," says Mr. Madden, "both moral and physical, attendant on its excitement, is terrible; the appetite is soon destroyed, and every fibre in the body trembles; the nerves of the neck become affected, and the muscles get rigid: several I have scen in this place who have wry necks and contracted fingers, but still they cannot abandon the custom. They are miserable till the hour arrives for taking their daily dose." The quantity of raw opium taken by the Turks is almost incredible:-one man, from constantly increasing his dose, has bcen known to take a hundred grains of opium a-day; though four or five grains are sufficient to kill a person not accustomed to it.

In England, where opium is principally used for medicine, it is generally taken in the form of laudanum or morphine. Laudanum is made by steeping the raw opium in spirits of wine, or white brandy; and it is from the addition of the alcohol still more exciting than the drug alone. Morpline is the narcotic principle of the opium, and it possesses the sedative properties of that drug without its exciting ones. The possibility of decomposing the opium so as to separate its narcotic principle from its intoxicating ones, was disçovered by an cmincnt German chemist, M. Sertürner, in 1817; and the morphia thus separated has since been in general use in medicinc. The commonest preparation of it is called acetate of morphine, and one grain of it is equal to about three grains of laudanum. Too large a dose would produce death by stopping all the secretions. The Turkish opinm is considered the best for making morphine, as it is found to contain three times more of that principle in any given quantity than the opium of India.

The oil of poppies is made from the sceds, which, as we have before remarked, do not contain any narcotic properties; and the growing of poppies for the purpose of making oil from their seeds, forms a regular article of field culture in France and the Netherlands. The ground chosen for the culture of the poppies destined for this purpose, should be rich (as is required for all oil plants) and yet light; as the poppy has a long tap root, and grows best in soils which it can penetrate to a great deptl. The sceds are sown in rows, in the south of France in September or October, but in the northern Frencl provinces, and in the Netherlands, they are not sown till Fehruary or March. In dry seasons the plants are watered; and, at all events, they are frequently weeded, and the carth hoed up to them.

When the capsules begin to liarden, and the little valves under the stigmas to open, the scason of the harvest is arrived; and the proprietor repairs to his field, followed by lis wife, children, servants, and in short every one belonging to his farm, to gather the seeds. For this purpose they take table-clotlis and sheets, which they spread out between the lines of poppies as well as the space will admit, several persons lolding the cloth at eacli end. Then a person goes on the other side of the line of poppies and bends cach head so that the seeds it contains may fall into the clotl.. This is done with great rapidity, and as soon as the poppies growing opposite one length of cloth have discharged thcir seeds, the cloth is slifted to another length; and cach cloth as it is filled is tied up for carrying away the seeds. Great care is taken not to suffer any broken part of the capsules to 
fall in with the seeds, as, if any such matter were taken to the mill, it would absorb and waste the oil. When all the seeds have been gathered that will fall out of the poppy-heads by bending them, the heads are cut off, with a portion of stalk to each, with a reaping-hook; and every handful as it is gathered is shakcn over a table-cloth spread on the ground, in case any seeds should remain in it. These heads tied up in bundles are afterwards hung up in the granary with a cloth under them, that the unripe seeds may become dry and drop upon it; but these seeds are very inferior to those of the first barvest.

When all the seeds are gathered, they are taken to some convenient place, where they are spread out on linen for several days to dry, being frequently removed. They are aftcrwards put into sacks, each standing separately, and removed sercral times from one sack to another for about a fortnight, till they are sufficiently dry for taking to the mill. This.mill is constructed something like the cider mills of England, and the seeds are ground in it by a cylindrical wheel which moves round in a kind of trougl, passing ovcr the seeds, and crusling them as it rolls along. The trough has one or two little spouts descending from it, through which the oil runs as it is expressed from the crushed seeds, into vessels placed to receive it. When the seeds aire reduced to a mass, or what is called the mare, it is wrapped in clean lair cloths, and taken to the press, where as much oil as possible is obtained from it. The marc is then taken to another place, where it is plunged in boiling water, when the oil remaining in it rises to the surface, and is skimmed off. This last kind of oil is, however, considered very inferior to that which flows from the secds when they are being ground, or pressed.

The oil thus obtained is used extensively on the continent for mixing with olive oil, and it is frequently sold, without any mixture, instead of it. The inforior kind is nsed in making soap, and for mixing with different kinds of scent by the perfumers. A prejudice existed some time since in France against this oil, from an apprehension that the seeds partook of the narcotic properties of the juice of the plant, and the government issued an edict forbidding any grocers or oilmen to keep oil of poppies, unless it was mixed with spirits of turpentine, so as to render it unfit for human food. The consequence of this injudicious regulation was, that the French farmers could get no sale for their oil of poppies while they called it by its true name; while those who were not so scrupulous, and called it oil of olives, found a ready market. It has been calculated that the olives grown for oil do not yield above a fourth of the oil sold as olive oil in Europe, the remaining quantity being oil of poppies, and purified oils of beech, rape, turnip secd, walnut, \&c. Some of these oils are mixed with clarified fresh butter to make them more like olive oil. Of all the substitutes for olive oil, oil of poppies is undoubtedly the best, and by far the lenst injurious to the stomach. The poppy oil is known by the name of Huile d' oillets in commerce.

In Italy, Germany, and Poland, the seeds of poppies are used in confectionary. In Italy, they are made into a kind of sugar-plum, like what we call carraway comfits. In Germany they are boiled in milk, snd eaten in this state like sago, which they very much rescmble, or made into a kind of open tart. In Poland they make a thick porridge of the meal of buck-wheat, and strew poppy seeds over it. The ancient Greeks used these seeds as an article of food; and the Romans made a kind of cake of them mixed with honey and flour, exactly similar to what is made of them in some parts of France at the present time. They contain a great deal of mucilage, and are not only agreeable to the taste, but very nourishing. Tho seed of the poppy in England, is principally used for feeding birds, and it is sold in the shops for that purpose under the name of maw-seed. It is used in Germany principally for feeding nightingales; and it forms the principal part of that colebrated composition for singing birds, called German paste. 
Tho poppy heads, or dried capsules, after they have discharged their seeds, are also kept for sale. They are used for fomentations and poulticcs to allay violent pain. A strong decoction of them mixed witl sugar boiled down to a syrup, forms the medicine called syrup of poppies, which was formerly much given to children to soothe them during the pains of tecthing. It is, however, a very dangerous preparation, as some of the capsules contain more opium than others, froin their different degrecs of dryness, the soil they are grown in, and a variety of other sources not perceivable by the outward appearance of the heads. Thus one half-a-dozen of lieads may contain two or three grains more opium than another lalf-dozen, and consequently the syrup preparcd from the first will be much stronger than the second. There is but too much reason to fear that many children who are supposed to lave died in teetling, may liave fallen a sacrifice to an injudicions nse of this medicine. The best poppy heads are obtained from abroad, and they are very much larger than those grown in this country. Poppics are, however, cultivated for their heads at Mitcham, in Surrey. They are sent to market in bags, eacls containing about 3000. The white-seeded variety is considered in France to be the best to grow, for poppy heads. This kind is called by the French farmers the blind poppy, because it has only two or three apertures for the discharge of its secds, and these are so small as to be scarcely visible. It is also fancied by some to be the best for opium; but both kinds produce that drug, and both are cultivated by the regular opium growers. The poppy heads sold by the druggists as from the Levant, are almost all those of the blind poppy grown in the south of France.

Culture.-The poppy requires a very rich and yet light soil to grow it to perfcetion. When it is wished to have the flowers very fine, a bed should be.. prepared by trenching it one foot or two feet deep. A layer of cow-dung should be spread along the bottom of the trench, and it slould bo filled in with the soil taken out, mixed with regetable mould composed of rotten leaves. The seeds may be sown either in autumn or early in spring, according to the time they are wanted to flower. All the black-seeded varietics are quite hardy; and as they will stand the winter uninjured, they, will produce the finest and best flowers if sown in antumn. The seeds of tho poppy, like all oily seeds, will not keep well; and though some have been known to vegetate after having been kept in paper three years, yet those of the current year are much to be preferred. When the ground has been properly prepared by digging and manuring, and the surfaco rendered quite level, the places may be marked for the seeds to be sown. If the plants are to be in patches, circles may be marked by pressing the ground lightly with the bottom of the sancer of a flowcr-pot of the required size, as directed for sowing the seeds of Flos Adonis; but if they are to be in lines, the lines may be marked with a smooth rod laid along the bed, or with a piece of rope. The secds should then be strewed on the smooth part thus formed, much thicker than was dirceted for any of the other flowers; as, if the seed is more than a year old, it is probable that not more than one in twenty, or even one in fifty, will come up. As the poppy seed, however, is very fine, it may easily be sown too thick; but this should be guarded against by taking care that the seeds are spread evenly along the line, or over the cirele. When the young plants come up, they must be thinned out; and when they are about six or eiglit inches high, they may be thinned again, so as to leave only the strongest plants; and these should, in rich soils, be a foot or eighteen inches apart; or if the flowers be wished to be very fine, two feet apart, as a strong root will throw up many flower-stems, and abundance of leaves. In poorer soils, the distance between the plants may be less. The plants pulled up in thinning out must be thrown away, as the opium poppy is one of those annuals which will not bear transplanting. As the plants increase in sizc, the ground should be occasionally loosened about them, and drawn up to the stems with a small hoc. They should also be watered in dry. weather. It may appear 
useless to bestow so much culture on a flower which, if left to sow itself, will spring up like a weed; but the difference between the cultivated plant and the self-sown plant, will amply compensate the lover of flowers for the trouble bestowed. Double poppies, treated as we have directed, will produce flowers very nearly as large as those of the Pcoonia Moutan, and as regularly formed as those of the Persian ranuneulus.

\section{2.-PAPAVER RHEEAS Lin. THE CORN POPPY.}

Engravings.-Eng. Bot. t. 645, 2nd. edit. vol. v. t. 755 ; Curt. F. Lond. vol. iii. t. 32 ; Wood. Med. Bot. t. 186 ; and our fig. 5 , in Plate 4.

Stem many-flowered, scabrous, with spreading bristles. Leaves pinnate-parted. Lobes elongated, deèply-toothed, acute.-(G. Don.)

VARIETIEs. - These sre very numerous, but the most beautiful are Specific Character.-Capsules smooth, obovate. Sepals pilose. the double white, and the double striped.

Description, \&c.-The corn poppy is about one foot or two feet high. The leaves are alternate, long, downy, and deeply cut. The flowers in the single kind are of a brilliant scarlet, and there is a blackish spot at the base of each petal. The double flowers vary from scarlet to pink, and white. The flowers are solitary, and are produced at the extremities of the stem and branches. The capsules are very much smaller than those of the opium poppy ; they are oval, and are crowned with a flat lid, under which are some very small openings, to admit of the discharge of the seeds, which are very small, brown, and almost transparent. This species is a common weed in corn fields, whence it derives its popular name of the corn poppy ; it is also called the corn-rose, red-weed, and by many other names. It is one of the few British plants that have scarlet flowers.

In some places where the farmers are negligent, whole fields may be seen in summer so covered with this weed, as to resemble a carpet of various brilliant colours; but where this is the case, the poppies are found seriously to injure the corn; and they are very difficult to eradicate, as one poppy-head contains seeds enough to sow a whole field. The French name for this poppy is coquelicot, and it is from its colour in a wild state that the coquelicot colour takes its name. The capsules, stem, and leaves of the corn poppy are slightly narcotic, and an extract from them is sometimes used as a sedative, and sold as syrup of poppies. The petals also afford a colouring matter, which is frequently mixed with the syrup made from the opium poppies.

CuLtore. - The garden varieties of the corn poppy are very beautiful, but unfortunately they seldom come true from sced; so that a happy mixture of their colours must depend on chance rather than the taste or skill of the gardener. As this poppy is of lower growth and less vigorous habit than the opium poppy, it does not require so rich a soil. The seeds not being so full of oil, will keep better than those of the opium poppy, and consequently more are likely to be good in a given quantity. For this reason, they need not be sown so thickly as those of the opium poppy, though they will still require to be sown thicker than those of most other kinds of flowers. Seeds of all the varietics of corn poppy may be purcbased in any seed shop. The specimen from which uur drawing was made, grew in the Hammersmith nursery, and it is one of the kind called the double dwarf carnation poppy. A bed of these poppies, thinned out so as to leave the plants at regular distances, has a beautiful effect when in flower, and, if the plants are kept dwarf, looks almost as well as a bed of ranunculuses. To keep the plants dwarf, the bed should be thinned out, so as to leave the poppies 18 inches apart, every way; the bed should be carefully weeded and watered in dry weather; and any shoot that appears likely to ascend too ligh should be cut off. 


\section{3.-PAPAVER HORRIDUM Dec. THE BRISTLY, OR NEW HOLLAND POPPY.}

Engravings.-Swt. Brit. Fl. Gard. t. 173, and our fig. 1, in Stem fow-flowered, and covered with stiff bristles. Leaves somewhat plate 4. stem-elasping, glaweous, sinuately pinnatifid ; lobules bristly at tou top

Spacific Charueter._Capsules smooth, elliptic. Sepals bairy. of the acrves.-(G. Don.)

Description, \&c.- This is a very remarkable poppy, as its stem and leaves are covered all over with very stiff, strong bristles, which actually wound the fingers when the flower is gathered. The flower is small and of a brick-red; and the leaves, which are deeply cut, are of a bluish green, and have the nerves on their backs and margins covered with bristles. This poppy is a native of New Holland, from which country it was brought in 1825, and it flowered for the first time in the Fulham nursery. It is quite hardy, and only requires sowing in common soil ; but it is scarcely worth growing as an ornamental plant, from the smallness of its flowers, and its bristly stem and leaves. It is, however, curious, as being the only poppy which has been fonnd in New Holland. Its flowers, which are very numerous, are produced in July; and as it ripens its seeds freely, it was very abundant for a few years after its introduction. It does not, however, appear to have been much grown, and we do not know where secds are now to be procured.

\section{4.-PAPAVER SETIGERUM Dec. THE BRISTLE-POINTED, OR GRECIAN POPPY.}

Engravings.-Swt. Brit. Fl. Gard. t. 172, and our fig. 2, in | setose. Stem smooth, few-flowered. Leaves stcm-elasping, glaucous, plate 4.

Sprcific Cijaractrr.-Capsules smooth, obovate. Sepals rather toothed, each tooth terminated by a bristle. (G. Don.)

Description, \&c.-As the last species bore considerable resemblance to the corn poppy, so this is nearly allied to the opium poppy. The Grecian poppy has a very elegant flower of a pale violet or lavender colour, with large, rich purple spots at the base of each petal. The stems and leaves are bristly, but neither so mnch so, nor with such rigid bristles, as those of the New Holland poppy. It was introduced in 1826, by seeds received from Gibraltar, but it is a native of Grecce and the Islands of tho Archipelago. It is distinguislied from $P$. somniferum by the greenness of its leaves, and the long slender bristles with which they are covercd, and its much smaller capsules, which have never more than six or eight rays. It is quite hardy, but, like the opium poppy, it requires a ricl soil to grow it to perfection. We do not know where seeds are now to be procured, but when first introduced it was grown in Colville's nursery, King's Road, Chelsea.

\section{5.-PAPAVER GARIEPINUM Burchell. THE GARIEP, OR SOUTH AFRICAN POPPY.}

\begin{tabular}{l|l} 
Escruving.-Curtis's Bot. Mag. t. 3623. & hairy. Stem covered with numerous bristly hairs. \\
Specific Cnaraetrar.-Capsules smooth, obovate-oblong. Scpals & hispid, sinuately pinnatifid. Lobes ovate and distant.
\end{tabular}

Description, \&c.-This poppy closely resembles $P$. horridum in the shape of its flowers and leaves. It differs, however, in the colour of the flowers, which are of an orange colour, and the shape of the lid of the capsule, which is like that of the roof of a pent-house, with large arch-shaped openings below like windows. The lcaves of loth this poppy, and that of New Holland, are remarkable for the shortness of their lobes and the distance at which tliey aro apart. The stems and leaves of the African poppy are covered with bristles; bnt though 
they are long and strong, they are neither so sharp nor so rigid as those of $P$. horridum. The South African poppy was found by Mr. Burchcll, the celebrated African traveller, on the banks of the Orange River, which is there called the Gariep, that is the river, par eminence. In its native country this poppy grows to the height of four feet, but in the Glasgow botanic garden, where it flowered for the first time in May 1836, it was not above a foot and a half high. It appeared rather tender, and was kept under a frame. It is probable that in the open air its bristles would be harsher and stronger, and the colour of the flowers darker. We do not think that seeds can be obtained in any of the London seed-shops, but they might be procured from the botanic garden, Glasgow. The poppy, however, docs not appear worth cultivating except as a curiosity.

\section{6.-PAPAVER PERSICUM Lindl. THE PERSIAN POPPY.}

Engruvings.-Bot. Reg. t. 1570, and our fig. 6, in Plate 4. | pinnatifid, hairy, the laciniated part often terminating in bristles Specific Canructrr.-Capsule bispid, oval. Sepals bairy. Leaves $\mid$ Stems branched and leafy.-(Lindl.)

Description, \&c.- This very elegant poppy was sent from Persia to Berlin, and from the botanio garden of that city it was sent to the Horticultural Society of London, where it flowered for the first time in 1833 . Seeds may be procured from the garden of the London Horticultural Society by the members, and they may be purchased at the seed-shop of Mr. Charlwood, Covent Garden. The flower is very pretty, and it would be highly deserving of cultivation if the petals did not fall so soon after expanding. In a botanical point of view it is interesting, as, from the shape and construction of its capsule, it forms a connecting link between tho poppies and the genus Argemone, of which we shall speak in a futurc page.

\section{7.-PAPAVER NUDICAULE Lin. THE NAKED-STEMMED POPPY.}

Escrurings._Bot. Mag. t. 1633 ; Eng. Bot. 2nd edit. vol. v. t. | beset with bristles. Peduncles radical, very long. Leaves pinnately $753^{*}$, and our fig. 3, in Plate 4.

Spectric Craracter._Capsules hispid, obovate-oblong. Sepals

lobed. Lohes toethed or cut, acute.-( Lin.)

Description, \&c.-This poppy is, properly speaking, a perennial; but it may be grown as an annual, by treating it in the same manner as will be hereinafter directed for the Hunnemania. The naked-stemmed poppy is a nativo of Sibcria, but it is also found in North America, and it has been discovered in one place in Ireland. There are two or three varieties, one of which has yellow flowers, another white, and another purple. Seeds are to be bought in any seed-shop. When the plant is well grown, the flowers are nearly twice as large as that shown in plate 4, and they are worth cultivating on account of their colour, as yellow contrasts well with scarlet, which is the gencral colour of the corn poppy, and all its varicties and allied species.

\section{OTHER KINDS OF POPPY.}

Though perhaps none of the following kinds are worth growing as ornamental flowers, we shall enumerate them, as they are found in the lists of annnal poppies contained in botanical works. We do not think that thicir seeds can be purchased at the seed-shops, but they can gencraily be procured at botanic gardens, and many of the plants are natives of Great Britain. 


\section{8.-P. HYBRIDUM Lin.}

The flowers are small and scarlet, each petal having a dark spot at the base. It grows about a foot high, and is a native of England, in corn-fields where the soil is chalky, in the southern counties. The capsule is covered with bristles, and it is from this circumstance that this species takes its popular name of the rough-headed poppy. Tlie petals are wrinkled, and soon drop.

\section{9.-P. ARGEMONE Lin.}

This species is found wild in corn-fields in England, in a sandy or gravelly soil. The petals, which are smooth and long, are of a pale scarlet, with a small black spot at the base of each. The capsules are long, and have a kind of crown of bristles at their summit; and it is from this peculiarity that this specics is called the prickly long-headed poppy.

\section{0.-P. DUBIUM Lin.}

A native of sandy fields in England, and other parts of Europe. The flowers are large and handsome, though not so much so as those of Papaver Rhoeas. The flower-stalks are covercd with soft silky hairs, but the capsule is smooth; and hence its popular name of the smooth long-headed poppy. There is a variety with white flowers.

\section{1.-P. OBTUSIFOLIOM Desf.}

This species bas small flowers with rose-coloured petals, and is a native of the north of Africa. It was introduced in 1828.

\section{2._P. TRILOBUM spreng.}

A native of Halle, resembling P. Rhceas, but with smaller flowers. Introduced in 1827.

\section{3.-P. LeEVIGATUM Bieb.}

A native of the hills near Odessa, and about Cancasus. The flowcrs resemble those of $P$. dubium. Introduced in 1823.

$$
\text { 14.-P. ROUBIAI Vig. }
$$

A native of sandy places near Montpelicr. Resembling the corn poppy, but with flowers of a paler red. It was introduced in 1823.

$$
\text { 15.-P. ARENaRium Bieb. }
$$

A native of sandy fields in the Caucasus. The flower is red, with a dark centre. Introduced in 1828.

\section{6.-P. FLORIBUNDUM Desf.}

A branching, very frec-growing species. The leaves are glaucous, and covered with hairs. The flowers are very large and handsome, and from their great abundance the plant makcs a splendid appearance. Their colour is an orange red, witl a yellowish circle at the base of each petal. The plant is a native of Armenia, whence it was introduced in 1815. It is well deserving of cultivation, but wo do not know where seeds are now to be purcliased in England, though they might easily be procured from the Botanic garden, Moscow. 


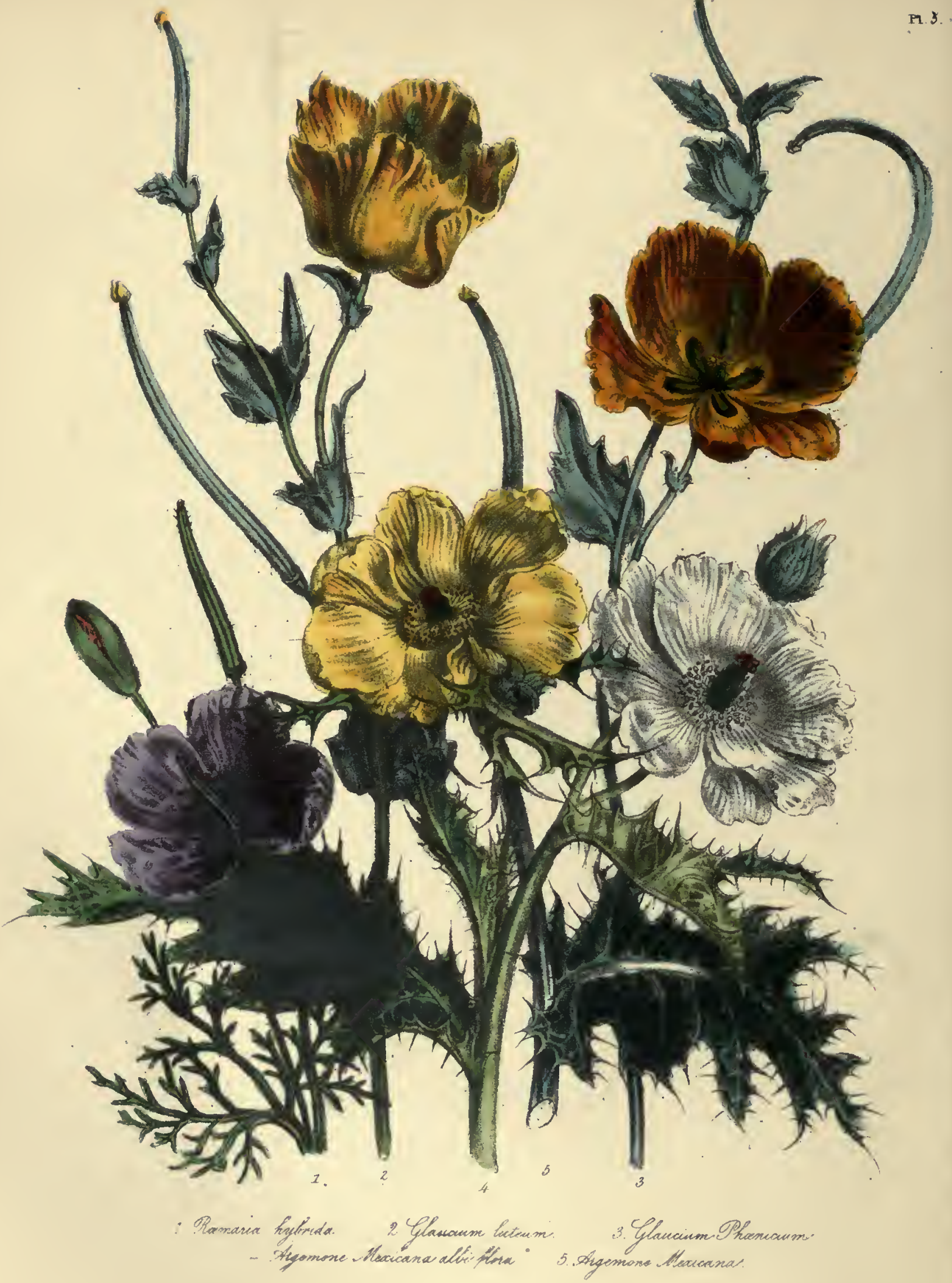





\section{GENUS II.}

\section{ARGEMONE Tour. THE PRICKLY POPPY.}

Lin. Syst. POLYANDRIA MONOGYNIA.

Grnfric Characrer.-Petals 4-6. Stamena indefioitc. Style almost wanting. Stigmas 4-5, rsdiating, conoave, free. Capsulu obovite, prickly, 4-5-vslved.-(D. Don.)

Description, \&c.-The different kinds of Argemone have all flowers resembling in slape the single corn poppy, but varying in colour from bright yellow to pure white. The leaves are wrinkled, and they are curved up at their margins like those of the helly, and armed with numerous sharp prickles. The capsule, which is also armed with prickles, is in four or five valves; and the points of the stigmas, instead of heing bound down like cords over the lid of the capsule, form a kind of crass at the top. The stem when broken exudes a yellow juice, resembling that of the poppy in thickness though net in colour. 'There are three species in Britisli gardens.

\section{1.-ARGEMONE MEXICANA Lin. THE MEXICAN, OR COMMON PRICKLY POPPY.}

Engraving.-Bot. Mag. t. 243, and our fig. 5, in Plate 5.

Sezcific Charactzr. - Leaves profoundly repand-sinnated, spiny, blotched with white; flowers solitary; calyx smooth; capanles flowers white. Sce fig. 4 , Plste 5.

Deseription, History, \&c.-The commen prickly poppy grows about twe feet high, with strong, vigereus, and erect stems. The leaves are large, deeply eut, and prickly; and they are of a bluish green, blotched, er rather painted with white, up the mid-rib and principal veins. The flowers are of a bright yellow, and are about the size and shape of those of the corn poppy. The capsules are ebleng, and armed with strong prickles. The white-flowered variety, fig. 4, which is by many botanists censidered a distinct species, differs not only in the celour of the flowers, but in the leaves being much narrower, and not blotched with white.

This species is a native of Mexico, where it was found by the Spaniards on their first invasion of that country, and called by them Figo del Inferno, the devil's fig, from the shape of the capsule somewhat resembling that of a fig, and its being armed with streng spines. It is also found in the West Indics, where it is called tho golden thistle of Peru. It was brought to England in 1590, and is mentioned by Gerard among the plant3 cultivated in his garden. The prickly peppy is used in medicine. Its yellow juice, when reduced to the eonsistence of a gum, can scarcely be distinguished from gambege, and is applied to the same uses. It is also considered an excellent medicine for the eyes, and is supposed to form the prineipal ingredient in Singleton's Gelden Ointment. The seeds are a powerful narcetic, and an eil is expressed from them which is used in Mexico, not only by painters, but for polishing wood. The culture is very simple, as the seeds will only require to be sown in the open flower border ahout the end of March or the beginning of April, the plants, though natives of a warm country, being quito harly. Seeds are to be obtaired in every seed shop. 


\section{2.-ARGEMONE OCHROLEUCA Swt. THE CREAM-COLOURED PRICKLY POPPY.}

Engrutina.-Bit. Fl. Gard. t. 242.

Specific Character.-Leaves profoundly sinuated or pinnatifid, glaucescent; nerves with prickly bristles; flowers solitary; stamens

few ; capsules oblong, deeply 5-6-furrowed, covered with somewhat reflexed prickles ; stigmas 5-6, distinct, spreading, purple.-(G. Don.)

Description, History, \&c.-This species differs from the common kind in having large cream-coloured flowers, a prickly stem, and narrower leaves, which, instead of being blotched with white, are only marked with a paler green. The valves of the capsule are also more deeply marked. The plant grows from two fcet to four feet high; aud from the vigour of its growth and the large size of its flowers, it is very ornamental. It was introduced from Mexico in 1827, by the late Mr. Barclay, of Bury Hill; and as it seeds abundantly, it is common in the nurseries and seed-shops. It may be sown in the open border in April or May, when it will come into blossom in August, and will continue flowering till October; but if treated as a tender annual, as will be directed in a future page for Hunnemania, it will come into blossom much sooner, and will produce finer flowers. The seeds are brown, glossy, rugged, and winged on the side that they are attached to the capsule.

\section{3.-ARGEMONE GRANDIFLORA swt. THE LARGE-FLOWERED PRICKLY POPPY.}

Enoraving. -Brit. Fl. Gard. t. 226.

Nerves unarmed. Flowers panicled, polyandrous. Calyx smooth. Specific Characrer.-Leaves sinusted, smooth, spiny-toothed. Capsules bluntly quadrangular, almost unarmed.-(G. Don.)

Description, \&o.-This is by far the handsomest of the genus. The flowers are of a pure white, and very large, heing frequently above four inches across when fully expanded; they are also produced in clusters, which gives the plant a splendid appearance when in flower. The stem, which is hrown, tinged with purple, is smooth, strong, and branching, and the plant generally grows about four feet high. The leaves are large, not blotched, and only spiny at the margins. This very handsome plant is, properly speaking, a perennial, but if sown in autumn, and treated as we shall direct for the Hunnemania, it may be planted out in May, and will form a most splendid object all summer. It is a native of Mexico, and seeds of it were sent to Mr. Barclay from that country, at the same time that he received the seeds of Argemone ochroleuca. The seeds of both species were sowed in spring on a hot-bed, and Argemone grandiflora flowered at Bury Hill the following October. Seeds may now be procured in most of the London seed-shops.

\section{GENUS III. \\ GLAUCIUM Tourn. THE HORNED POPPY.}

Lin. Syst. POLYANDRIA MONOGYNIA.

Genkric Character.-Petals four. Stamens indefinite. Stigma bilsmallate. Capsules elongated, two-valved and two-celled from the cellular dissepiment. Secd without a glandular crest.-(G. Don.)

Description, \&c.-These very curious plants havo large showy flowers and remarkably long horn-like pods, whence the English name of horned poppy. They are natives of the sea-coast, and the leaves are of the 
same peculiar bluish green as the sea which washes the British cliffs. They abound in a copper-coloured acrid juice, which is poisonous, and is said to occasion madness.

\section{1.-GLAUCIUM LUTEUM Smith. THE YELLOW HORNED POPPY.}

Exorapres. -Eng. Bot. t. 8 ; 2nd. edit. vol, $\nabla$, t. 748 ; and our fig. 2 in P!ate 5.

Syмonymes.-Chelidonium Glaucium Lin Glaucium flavum sules scabrous, with tubercles.-. (G. Don.)

Description, \&c.-Every one who has travelled from Brighton to Shoreham must have been struck with the splendid flowers of the yellow horned poppy, which grows on the cliffs almost into the sea, and the leaves of which look, as Dr. Lindley remarks, as though they were encrusted with the salt spray. The horned poppy, in favourable situations, forms a large plant from two feet to three feet high, and spreading widely in proportion. The flowers are very large, and of a most brilliant golden yellow; and though they do not last long, they are produced in such abundance that there is a constant suceession of them. When the petals fall they are succeeded by immensely long pods, which stick out like horns, and which are, in fact, elongated capsules. These lorn-like pods, which are often above a foot in length, consist each of two valves, and contain the seeds arranged along the sides like peas in their shells. The leaves and calyx are both rough and prickly; and the leaves, which are of a very bluish green, are eovered with a kind of glaucous bloom, which makes them look as though they were powdered, or covered over with very fine salt.

The Culture of the horned poppy requires very little care. It will grow in any common garden soil, but it prefers sand, as it is always on sandy shores that it is found. Its root is very long, so that it should have a soil eufficiently loose to enable it to penetrate it. It will not bear transplanting, and consequently, when the seeds are sown, it should be sparingly, as the plants will require to be at a considerable distance from each other to look well when in flower, and thoso that are taken up in thinning must be thrown away. As the plants ripen abundance of seeds, they are quite common, and to be procured at every seed-shop. The specimen figured in our plate is much less than the ordinary size of the flower.

\section{2.-GLAUCIUM PHENICEUM Smith. THE SCARLET HORNED POPPY.}

Engravings._Eng. Bot. t. 1433 ; 2nd edit. จ. t. 749 ; and our fig. 3 , in Plate 5.

Synonymes.-Chelidonium corniculatum Lin. C. phœiceum

Lam. C. aurantiacum Sal. Glaucium corniculatum var, phæui-

DEscription, \&c.-A pretty little flower witl bright scarlet oblong petals, each of which has a black spot at its base. It closely resembles the yellow horned poppy both in its habits and culture, but it is a much smaller plant. It is a native of the south of Europe, but it has been found wild in the Isle of Portland and in the county of Norfolk, in sandy places. Its culture is the same as that of the yellow horned poppy, and seeds of it may be procured at any seed-shop.

There is a variety of this species with yellow flowers; and another species called $G$. tricolor, which closely resembles it. Both are said to have been introduced into England, but we have nerer seen either of them, and do not know where they are to be proeured. 


\section{GENUS IV.}

ROMERIA Medik. THE REMERIA.

Lin. Syst. POLYANDRIA MONOGYNIA.

Generic Charuetra.-Petals four. Stamens indefinite. Stigma one. Cspsules elongated, 3-4-vslved, - J-eelled.-(G. Don.)

\section{1.-REMERIA HYBRIDA Dec. THE HYBRID REEMERIA, OR PURPLE HORNED POPPY.}

Emgravisgs.-Eng. Bot. t. 201 ; 2nd edit. v. t. 750 ; snd our fig. 1, in Plate 5.

Sxnonymzs.-Giauclum bybridnm Dum.; G. trivalve Mench;
G. vlolaceum Suss.; Chelidonium hybridum Lin.; C. violaceum Lam.; Romeria violaces Medik.

Specific Caractra.-Siliques 3-4-valved, erect, beset with stift bristles st the top.-(G. Don.)

Description, \&c.-This is a very beautiful flower, and would be well deserving of cultivation, were not the flowers so very short-lived. They not only do not last more than a day, but it is difficult to find a flower with all its four petals on at once. One or two drop almost as soon as the flower expands. We had great difficulty in getting a perfect flower for our engraving to be made from, and at last, could only accomplish it by gathering the bud, and letting it expand in water. It is a native of the South of Europe, and North of Africa, in cornfields and vineyards; and it is also occasionally found wild in England, in Norfolk and Cambridgeshire. Its culture is the same as that of the horned poppy, and its seeds are to be procured at evcry seed-shop. It is frequently called Glaucium violaceum in the seed-shops, that being the name Linnæus gave to the species. It was divided from Glaucium, and formed into n new genus, called Roemeria, because its capsule was found to have three or four valves, and one cell, whereas the capsules of all the other Glauciums have two valves and two cells. The stigma is also entire in the Reemeria, and cleft in the Glaucium, and the seeds are somewhat different.

GENUS V.

\section{PLATYSTIGMA Benth. 'THE PLATYSTIGMA.}

\section{Lin. Syst. POLYANDRIA TRIGYNIA.}

Genarie Craracten.-Sepals 3, ovate, deciduose, hsiry. Petals 2-5. Stsmens numerous. Filamentв thread-like. Anthers lincar, 2.celled, opening sideways. Stigmas 3, ovate, acute, erect-divergent.

Capsule oblong, attenuated at the base, 1-celled, 3-furrowed, 3-valved, opening from the top to the base. Seeds numerous, minute, oggshaped, black, smooth, shining.-(Benth.)

\section{1.-PLATYSTIGMA LINEARE Benth.}

Engravings.-Bot. Reg. t. 1954; Bot. Mag. t. 3575 ; and our fig. | deusely covered with leaves. Leaves linear, entire, stemeelssping, 13, In Plate 6.

Specifie Charsetza.-Plant small, tufted. Stems very short, and

Description, \&C.-This pretty little plant has slender and delicate stems rising out of a donse mass of leaves. The flowers consist of three outer petals, which are broad and yellow, and thrce inner onee, which are narrow 


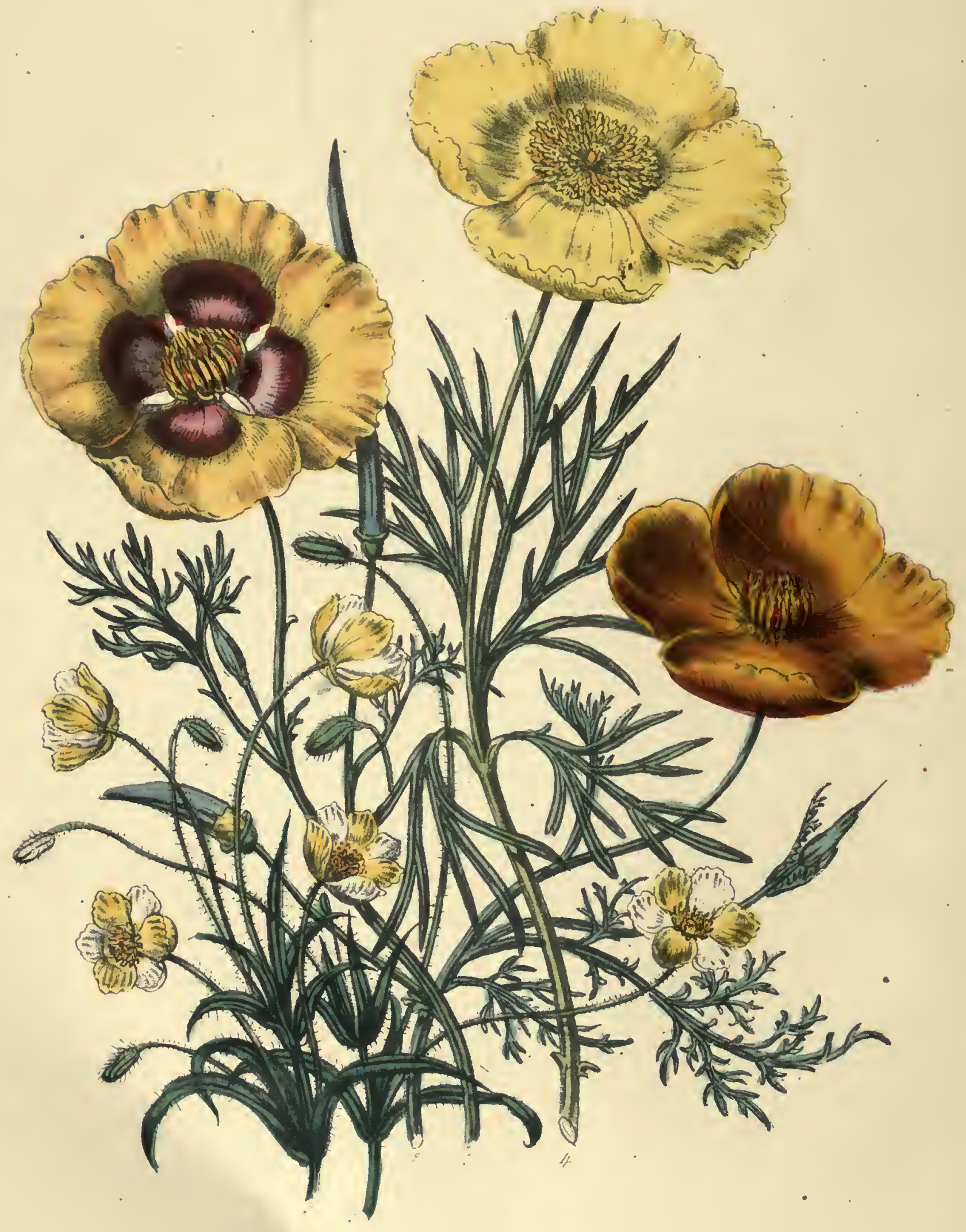



and white. The calyx consists of three sepals, which generally fall off as soon as the flower begins to expand, but which sometimes wither, and yet remain on. The buds hang drooping, but the flower becomes erect before its expansion. The flower stems are very long, and covered with hairs, and a great number spring from one root. The plant takes its name from the breadth of its stigma, which divides into three at its extremity. The plant was first described in 1835, by Mr. Bentham, in the Horticultural Society's Transactions, vol. i. 2nd Series, from dried specimens, sent home from California by Donglas, but no seeds were then received.

In 1836 seeds were sent from St. Petersburgh to the Glasgow Botanic Garden, where some plants flowered in the open garden in August and September of that year. The plant thus proves to be quite hardy, and it may be sown in the flower borders, as directed for the Flos Adonis. We do not think seeds are as yet common in the seed-shops, but they may be had at Mr. Charlwood's, or from any botanic garden.

GENUS VI.

ESCHSCHOLTZIA Cham. THE ESCHSCHOLTZIA, OR CALIFORNIAN POPPY.

Lin. Syst. Icosandria? Polyandria? Trigynia.

Grneric Character. - Petals 4. Stamens indefinite. Stigmas 4, Showy flowcrs, which though they will occasionally last several years 2 short and 2 long. Capsules elongated, silique-formed, 2-valved, as perennials, are generally grown as annuals, and which are great 1-celled. Calyx calyptrate. Receptacle expanded.-(G. Don.) favourites in the flower-garden.

\section{1.- ESCHSCHOLTZIA CALIFORNICA Cham. THE COMMON ESCHSCHOLTZIA, OR CALIFORNIAN POPPY.}

Engravings,_Bot. Reg. t. 1168; Bot. Mag. t. 2887; Swt. Brit. Flow. Gard. t. 265; and our fig. 1, in Plato 6.

Sумомумะ,_Chryseis californica._L Lindl.

Specific Character.-Stigmas 4, two larger than the others. Seeds globose, almost black.-(G. Don.)

Description, \&c.-The common Eschscholt $\approx$ ia is a splendid golden yellow flower, with glaucous-green finelycut foliage, and long horn-like pods. The calyx is entire; and instead of opening at the side to permit of the expansion of the flower, it detaches itself at the base, and gradually rises till at last the swelling flower fairly pushes it off, leaving a fleshy disk below. The Eschscholtzia.was first discovered by our highly esteemed friend Archibald Menzies, Esq., who accompanied the expedition under Vancouver, and who discovered it in Monte Rey Bay, in California, in the autumn of 1792 . He brought specimens to this country, from some seeds in which plants were raised at $\mathrm{K} e w$, but they do not appear to bave ripened seed, and the species was soon lost. It was afterwards again discovered in Captain Kotzebue's expedition, by Chamisso, who named it in compliment to his fellow traveller. Dr. Eschscholtz, and described and figured it in his work, entitled Horce Physica. It remained, however, for Donglas, to whom we owe so many new and valuable plants, to introduce it into general culture, and by lim seeds were sent to England in 1826, since which time it has been a general favourite in our flower- 
gardens. In 1837, Dr. Lindley, when describing a new species, Eschscholtzia compacta, in the Botanical Register, inscrted a note from a botanical friend, in which it was proposed to change the name of the genus to Chryseis, under the supposition that the name of Eschscholtz was the same as that of Elsholtz, after whom another plant had been named. As however it has since been proved by M. Otto, of Berlin, that the names are quite distinct, that of Eschscholtzia will, we suppose, be retained. (See Allgemeine Garten Zeitung, vol. v. p. 221.)

In its native country this plant grows on the sandy banks of running streams, and this may give a hint for its culture. It will, however, grow in any soil, and may either be treated as a bardy or as a tender annual, the advantage of the latter mode being that it will come into flower much sooner, and consequently its season of flowering will be prolonged. Seeds are abundant in all the seed-shops. The specimens that our figures of this, and the following species, were drawn from, were from His Grace the Duke of Bedford's villa at Camden Hill.

\section{2.-ESCHSCHOLTZIA CROCEA Benth. THE SAFFRON-COLOURED ESCHSCHOLTZIA.}

Exgratisgs.-Bot. Reg. t. 1677; Swt. Brit. Flow. Gard. 2d. Ser. S Sprchric Character.-Stem branching and leafy. Segments of tho t. 299 ; and our fig. 2 in Plate 6.

Synowyme-Chryseis crocea.-Lindl. leaves linear; peduncle with a funnel-shaped appendage; limb much dilated. Calyx long and acuminated.-(G. Don.)

Description, \&c.- In general habit and appearance this species strongly resembles the last; but the colour of the flower, instead of being yellow, is orange. It is quite hardy, and a most abundant flowerer. It was introduced in 1833 by Douglas, and it seeds so abundantly that it is now common everywhere. There is a double variety, which is very beantiful, and which was shown at one of the London Horticultural Society's Exhibitions, in 1837. The principal difference between this species and $E$. Californica, consists in an enlargement of the fleshy disk below the flower, which remains on after the petals have dropped; and in the calyx being longer and more pointed. The fleshy disk shown to the secd-pod of E. Californica, in plate 6, is much too small; and that of $E$. Crocea is nearly four times as large.

\section{3.-ESCHSCHOLTZIA COMPACTA. THE DWARF ESCHSCHOLTZIA.}

ENGruving. - Bot. Reg. t. 1948.

S NoNYME.-Chryseis compacta, - Lindl.

Specific Churacter.-Stem dwarf, densely branched. Segmenta of the leaves linear, wedge shaped, tridentate at the apex. Cun of the peduncle funnel-shaped, with its large limb nearly fat.-(Lindl.)

Description, \&c.-This plant only differs from Eschscholtzia Californica in its much more dwarf and compact inabits, in the segments of its leaves being very slightly toothed instead of deeply lobed, and in its flowers being much smaller. The sceds of this species were sent home by Douglas in 1835 . Dr. Lindley suggests, that the three kinds of Eschscholtzia may be only varieties of one species, as the differences are very slight between them. All of them thrive best when the seed is sown in March in pots placed in a hotbed. When the young plants are removed to the open border, they should be taken ont of their pots and planted, without breaking the cake of earth round their roots. They will not bear any after transplanting, as the root is "very fleshy and brittle, and bleeds copiously when broken."-(See Bot. Reg. t. 1168.) Eschscholtzia compacta flowered first in 1835 in the Horticultural Society's Garden at Turnham Green ; but it is now in several nurseries, and in the autumn of 1838 was in great abundance in the nursery of Mr. Rogers, in Eaton Square, Pimlico. 
GENUS VII.

\section{HUNNEMANIA, Swt. THE HUNNEMANIA.}

\section{Lin. Syst, POLYANDRIA MONOGYNIA.}

Genenre Character.-Petals four. Stamons indefinite. Stigma peltato, four-furrowed, slightly four-lobed. Capsules silique-formed, mather compressed, ten-ribbed, onc-celled, two-valved.-(G. Don.) There is only one species.

\section{1.-HUNNEMANIA FUMARIEFOLIA, Swt. THE FUMITORY-LEAVED HUNNEMANIA.}

Enaravinas,-Bot. Mag. t. 3016 ; Lodd, Bot. Cab. t. 1779 ; Brit. Flow. Gard. t. 276 ; and our fig. 4, in Plate 6. Specific Character.-Leares decomponnd and tritcrnate; glancous. Leaflets lincar, bluntish. - (G. Don.)

Description, History, \&c.-The Hunnemania may be treated either as a shrubby, or suffruticose plant, as a perennial, or as an annual ; and as it will flower beantifully according to the latter mode of treatment, we have included it in our list. The foliage of the Hunnemania bears a considerable resemblance to that of the Eschsenoltzia, but it is more stiff, and upright; it is also of a darker bluisl green. The flower is large, resembling in slape a single poppy, and of a most brilliant yellow. The capsule is a pod, and resembles that of the Eschscholtzia. The stem, which grows about three feet ligh, is erect and brancling, bearing a solitary flower at the extremity of each branch. It is a native of Mexice, and was introduccl in 1827, by the late Robert Barclay, Esq. of Bury Hill, to whom the Floricultural world is indebted for so many valuable plants.

Couture.-The Hunnemania like the Esclischeltzia belongs to a class of plants for which we want a definite name. It may be treated as an annual, and suffered to die after it lias flowered and ripened its secds; but if protected during winter, it will live three or four years, flowering every summer; and if trained against a wall, and carefully protected from frost, it will live several years, and will soon become woody at the lower part of the stem near the root. The Calandrinias, and other Californian and Mexican plants, are of the same habit; but as they are all generally sold in the seed-sheps as annuals, and bear splendid flowers, we have included them in this work.

Though the Hunnemania continues in blossom nearly the whole summer, and is certainly one of the most splendid flowers that can be grown in the open ground, it is comparatively but seldom found in flower-gardens. This arises principally from its being considered as a perennial, and consequently, as difficult to keep througli the winter. After it is planted out, it rapidly becomes a large plant, and, of course, very troublesome to protect; but if it is treated as an annual, that is, raised from secd every year, and suffered to die as soon as it has flowered and ripened its seed, it only requires protection in a cold frame the winter after it is sown, when, of course, tlie plants are quite small, and a great many may be kept in one pot. As this is the first tender annual wo have treated of, we shall give a detailed account of its cnlture, as a similar mode of treatment will be suitable to several other plants; and we shall first say a few words on the general treatment of tender annuals raised in pots on a hot-bed.

All tender annuals, to be flowered in the highest degree of perfection, must be raised on a hot-bed; and 
therefore, before giving any directiens respecting sowing these plants, wo shall say a few words on the manner of making a hot-bed suitable for raising them.

To FORM A HOT-DED. - $A$ hot-bed is a mass of any fermenting material, that in its deeompesition produces a degree of heat considerably above that of the atmosphere in which it is placed. There are various matters which will answer for this purpose; some animal, others vegetable, and some even mineral, as for example, certain kinds of coal dress, containing pyrites. For gardening purposes, however, the material in general use, not only in Britain, but on the Continent of Europe, and in North America, is stable manure. This may be used either alone, or mixed with the dung of cows, pigs, or poultry; or with leaves, grass, straw, or any otler readily-decompesed vegetable substance; or with animal matters, such as hairs, the parings of leather, hern shavings, featliers, \&c. The sweepings of streets, as they generally contain a great variety of vegetable and animal matters, used either alone, or mixed with stable manure, will form a very durable liet-bed. In the nursery of Messrs. Wilmot, of Lewisham, the sweepings of the streets of the Borough, and of Green wieh, have been used alene for many years, as the formenting material on which melons are grown; this manure being found to produce a more equable heat, and that for a greater length of time, than any other material hitherto tried. Spent tanners' bark, such as is used for growing pines, also forms a very excellent hot-bed, either used alone, or mixed with some of the other substances mentioned. Fallen leaves, swept together in autumn, and laid in heaps under cover, will ferment with or without other materials, and will make a very durable hot-bed; and the sprays of trees cut off in the summer time, with the leaves on, such as the clippings of liedges, will also be a material that may be used with great advantage, aleng with autumnal leaves, or tan. The same may be said of weeds, the refuse of vegetables, pea haulm, short grass, \&e.

A general idea may thus be formed by the inexperieneed reader, of the materials which may be used in making lot-beds; but as the most commen, and that which is generally most easily within the means of the amateur whe has but a small garden, is stable manure, we shall confine ourselves to giving directions for the management of that material. When ebtained from the stables in, say a cart-load, which is quite sufficient for a small hot-bed large enough for rearing annuals, it consists of two parts, the dung of the horse, and long litter, or in other words, straw, moistened and disceloured, but not decayed. When the mass, thus formed, is laid in a leap, it generally produces a very powerful lieat, teo streng for being nsed as a hot-bed; for it should never be forgotten that too het a bed is worse for the plants than sowing them in the open air. If the bed be much tooliot, the plants will be blackened, and ultimately destroyed; and even if only a little hotter than is neeessary, the plants will be drawn up, and become too weak to have any chance of suceess when afterwards transplanted into the open air. As it is the fermentation eecasioned by the decompesition of the straw contained in the manure which produces the violent heat, the heap should be turned over with a dung-fork two or three times in the course of a fortnight, till the decomposition is censiderably advanced, the whole mass of one colour, and the straws, which were before tough, rendered sufficiently tender to be easily torn to pieces with the dung-fork. When the mass is arrived at this stage, it may then be formed into a bed, which may be of any convenient length and breadth, according to the situation and other circumstances.

In general, such a bed is covered with what is called a hot-bed frame. This consists of a bex without a bottom, and with a moveable tep, formerl of a glazed sasl or sashes. For a small garden, a bex three feet wide, and four feet from the back to the front, will be sufficient. The back of the box may be two feet high, and the 
front one foot. The hot-bed may be formed in an open situation, on a surface raised six inches above the general level; and it should be three or four inches wider on every side than the box that is to be placed on it. The eartload of manure, which bas been fermented and prepared for making up this hot-bed, should now be regularly spread over the base of the intended bed, and raised by successive layers to such a beight as the quantity of manure will admit. If, in building the bed by these successive layers of manure, cinder siftings, and the animal and vegetable refuse of the kitchen, are mixed along with it, the heat will be the less violent at first, but it will be retained for a much greater length of timo; and if a part of the contents of a cess-pool of the water-closets of the house could be added to the ashes and regetable refuse, the heat would probably be maintained during the whole summer; and a good crop of melons miglit be obtained after the seedling annuals were removed.

The time for making a hot-bed for raising seedling annuals need not be earlier than the middle of Marcl, since the plants which are raised in it cannot in general be turned out into the open air sooner than the middle of May. As soon as the manure is formed into a bed, and the upper surface rendered quite level, the frame and the sash shouid be set on it. In two days the disturbed fermentation will have reconmenced, and a steam will be observed under the glass. The surface of the bed may now be covered three or four incbes deep with any light garden seil, and the different kinds of seeds may be sown in pots and placed on its surface; or if there slould net be much leat, or likely not to be mucl, the pots may be sunk into the manure. In other cases, where it is not thought necessary to sow the different kinds in pots, the covering of soil may be six or eight inclies deep, and the seeds may be sown on it, in little square or round patches. This indeed is the common practice.

In such a hot-bed as we have described, formed of only ono load of stable manure, there is very little danger of over-heating the soil; but it may be proper to observe, that neither the temperature of the soil, nor the atinosphere over it, should ever much exceed 60 degrees. It may fall as low as 48 degrees, or even 40 degrees, without the slightest injury to the plants; and it may be raised as high as 80 degrees, or even 90 degrees, without killing them; but any degree above 60 degrees is decidedly injurious, by increasing the rapidity of the growth of the plants, and rendering them weak and sickly, and unfit to be turned out into the open ground.

When the plants have come up, and shown two or three leaves, in addition to the cotyledons or seed-leares, they require to be transplanted; and this may either be done into small pots, or into a bed of earth, placed on a lot-bed, formed in the same manner as the first, but with a smaller quantity of material, as mucl less heat is required. For a small garden, however, a second lot-bed is unnecessary; and all the transplanting and other processes preparatory to removal to the open ground, may be carried on in one hot-bed; care being taken to inure the plants to the open air by degrees, by tilting the sash up bohind at all times, night and day; and after the plants are up, removing it altogether, during fine days. The great object to be kept in view, is to make the plants as strong and vigorous as possible before turning them into the open ground, and to give them air, or to thin and transplant them whenever they slow symptoms of becoming weak or drawn up.

The above directions for making a hot-bed, will not apply to tan or dead leaves, as these substances are not sufficiently compact to allow of their being built up into a rcgular bed. When they are used, a kind of box must be formed of bricks, boards, layers of turf, or stiff earth, and the tan or leaves filled in so as to make a bed. Ali the rest is exactly the same. Where neatness is a paramount object, the hot-bed of stable manure may be thatehed with straw, so as to make the outside perfectly neat and clean; or the outside may be covered with bass mats, pegged down to keep them close. A hot-bed for tender annuals, will never want what are called linings;

$$
\text { F } 2
$$


as it is for the advantage of the plants that the heat should decline gradually as they increase in size, that they may be the more fit for transplanting, when the season arrives for them to be removed to the open ground.

The sorl For growing teNDEn ANNUALs.-The soii used for filling the pots in which tender annuals are sown, should be as rich as possible, and yet quite open in its texture: it should also be free from grubs and the eggs of insects. As soil of this description is not to be procured without some trouble, we shall give the following directions for preparing it, which have been kindly sent to us by the same excellent practical gardener to whom we were indebted for directions respecting the larkspurs. He says, that the best soil is turf, but as this is usually full of worms and the eggs of insects, it will require the following preparation:- "Take a spade deep of the surface of some good rich pasture; or if only the turf two or three inches thick, so much the better. Lay this up in a ridge, eighteen inches wide at bottom, three feet high, and of whatever length may be required. Then take the fresh stable manure, which is to be used in making the hot-bed, before it has been turned over, and lay it all round the turf and over it, distributing it as equally as possible. If there is plenty of manure, in proportion to the quantity of turf, the turf may be easily heated to 200 degrees, which will not only destroy all the insects, \&c., but all the roots and herlage, and moreover wonderfully enrich the soil, by the distillation of the gas evolving from the manure, during its fermentation. The manure must be turned over once or twice, while covering the turf, to prepare it for making the hot-bed; and when it is ready, the ridge of turf must be removed to some shed, or airy place, to dry it, when it will be fit for use. This is the best possible soil for annuals; but when put into the pots, it must be mixed with a little vegetable mould, (formed of dead leaves laid in a heap, and turned over from time to time till they rot into mould,) and sand. An old hot-bed, or decayed dung of any kind, is not good for tender plants, as it is apt to turn the whole soil sour, or soddened (at lenst if much watered). In the summer turf may be seasoned without manure, by covering it with the short grass moivn off the lawn, which will ferment; but this plan is very far inferior to the other, though it is superior to the old method of laying up the turf for a year or more bcfore it was uscd. By the hot-dung process, it will be ready in ten days; and not more should be prepared than will be wanted for one season's sowing and transplanting." $D . B$.

Sowing AND TnANSPLANTING.--If the soil has been properly prepared, it will be found, when dry, though very rich, to be perfectly light and fine. The next step is, to fill the pots with it. These should be of a moderate size, and filled about an inch deep with rather small pieces of broken pots, or potsherds, as they are called. This is to ensure drainage, as, if the water be suffered to lodge, the coil will soon become black and sodden, and the seedlings will turn yellow, and drop off. As the pot is filled with earth it should be shaken, to make the earth settle, and then more earth put in ; as, if this is not done, the first watering will make the earth sink a considerable depth down the pot. The pots being properly filled, the next step is to procure the seed. Of chnice and delicate sorts, it is always advisable, if possible, for ladies to save their own seed, and nothing can be more easily done. When the seed is ripe, it only requires to be gathered, and put in little paper trays in some warm place to dry ; when dry, it should be freed from the sced pod, and put into little paper bags, or wrapped in paper with the names written upon it, and kept till wanted for use. If it is intended to kecp for a year ar two, it may remain in the pod; but it is always best to sow the seed when it is quite fresh. No oily seed will keep well ; and the sceds of all tender anruals generally soon iose their vegetative powers. One of the great advantages of saving seed is, to know its exact age; and to be able to judge from that, as to the probability of its coming up. Nothing is more provoking than, after all the tronble of sowing, \&c., to be disappointed by the seeds 
being bad. "When seeds are saved, it should only bo from the strongest and liealthiest plants, and the largest pods only should be chosen. It is from not attending to these rules, that plants of the same species are found so much more difficult to raise some seasons than others." $-D . B$. The seeds of tender annuals are generally sown thick, except of such kinds as will not bear transplanting.

In every plant there is a part called the collar, from which the stem and leaves shoot upwards, and the root downwards; but some plants, if encouraged by earthing up, or transplanting deeper, will throw ont roots above the collar, such as the balsam, Frencli marigold, \&c.; and these plants are improved by transplanting, as every additional root which they throw out will afford an additional mouth for enabling them to imbibe nourishment. Other plants which do not throw out roots above the collar are, on the contrary, checked by transplanting; and annuals of this kind slould be sewn as thin as possible. In all cases where the young seedlings are beginning to interfere with each other in their growtl, they should be thinned out to one, three, or five plants in a pot, according to the habits of the different kinds; and these, transplanted into single pots, should be frequently removed into larger pots, till they are ready to be turned into the open border, or to flower in a room or greenlouse. "When tender annuals are to be grown in pots during winter, they should be sown early in autumn, so as to get them strong, and once transplanted, at least, before the beginning of November; after which no tender plants should be potted (unless under extraordinary circumstances), until the beginning of February, or even till the middle of that month." $-D . B$.

WATERING.-There are few points in which lady gardeners are so apt to err as in watering; and the general fault is, that they give their plants too much. This is a fatal error for plants in pots, since over-watering will soon bring on the evils we have already described, as attendant on imperfect drainage; it is even dangerous to syringe the plants too much, though a little water thrown over their leares oscasionally is very useful in refreshing them. "If the plants should become dnsty, or infected with insects, the pot should be carefully turned on its side before the syringe is applied; and this plan lias not only the advantage of saving the soil in the pot from becoming sodden with too mueh water, but also of enabling the operator to wash the lower sides of the leaves, where the red spider, one of the greatest enemies of plants in pots, generally commences its depredations. When the plant is too large or too delicate to admit of the pot being laid on its side, two pieces of board with a notch cut in each, to allow room for the stem of the plant, and wider than the rim of the pot, should be laid over the earth, so as to carry off the water that falls from the leaves." $-D . B$.

\section{THE CULTURE OF THE HUNNEMANIA.}

- Though this plant, when treated as a tender annual, will flower all the summer when planted out into the open border, and though its splendid flowers are produced in great abundance, yet, as we have already observed, it is very scarce in gardens. This arises from its being treated as a perennial, and when it dies off (which according to its nature will be in two or three years) from its not being renewed. The seeds of the Hunnemania do not long retain their vegetative powers, and therefore the sooner they are sown after ripening the better. When they are bought at a seed-shop, as their exact age cannot be ascertained, they must be sown very thiek, as it is very probable that not more than one in fifty or a hundred will come up.

The seed-pods of the Hunnemania may be kept in a cool dry frame, where the young plants, when they come up, may have plenty of air. When they are large enough to be s'ansplanted they should be potted off eingly into 
thunb-pots filled with light sandy peat. The pots in which no young plants appear should not be thrown awny till the fellowing May, as after remaining dormant so long, the seeds will sometimcs come up; and even after that period the earth should be carefully turned out of the pot, and the ball sunk in a shady situation in a well-drained bed or berder, taking care that the seeds are not deeper than they were in the pot. The pots should then be turned ever them; and, if looked at from time to time, the scedlings will be found sometimes to have come up after they have been for several months in the ground.

"The young plants of the Hunnemania, if in a greenhouse, should be kept in an airy place near the glass; and if the seeds were sown as seon as they were ripe, the young plants by the beginning of Octeber ought to be transplanted inte one size larger pots, in which they should remain till the end of March, when they should be potted into rich soil, and inured to the air as much as possible, in order to prepare them for boing planted into the open border by the end of May. They will come into flower almost immediately, and will continue flowering from the lst of June till killed by the autumnal frosts. They do not seed freely out of doors, and therefore a plant or two should be kept in the greenhouse or frame for seed. These plants should be kept in small pots and a poor soil in order to tllrow them into seed. Argemone grandiflora, when grown as an annual, may be treated exactly like Hunnemania; except that it may be planted out by the beginning of May, from which time it will flower to the end of September. When grown as a perennial it will not require any protection during winter, as it is quite hardy." D. B.

Seeds of Hunnemania are rather scarce, but they may be obtained at Mr. Charlwood's, Tavistock Row, Covent Garden.

\section{CHAPTER III.}

\section{SUB-ORDER FUMARIEAE.}

Ensential Character.-Sepals 2, deciduous. Pctals 4, cruciate, parallel; the two outer either one or hoth saccate at the base; the two inner callous and coloured at the apex, where they cohere and enclose the anthers and stigma. Stamens 6 , in two pareels, opposite the outer petals, very seldom all separate; anthers membranous, the outer of each parcel 1-celled, the middle one 2-celled. Ovary supe- rior, l-eelled; ovuleg horizontal ; style filiform; stigma with two or more points. Fruit various; either an indehiscent 1 or 2 -seeded nut, or a 2-valved or succulent indehiscent polyspermous pod. Sceds horizontal, shining, crested. Albumen fleshy. Embryo minute, out of the axis; in the indeliscent fruit straight; in those which dehisce some. what arcuate. (Lindl.)

Onservations, \&c.-The Fumitory tribe is made a distinct order by Professor De Candolle and many other botanists; while Bernhardi and others consider the plants included in it as belonging to Papaveracer; and Dr. Lindley has made Fumarieæ a sub-order of Papaveraceæ. We have followed the latter arrangement. "The arguments of Bcrnbardi," Dr. Lindley ebserves, "for the combination of Papaveraceæ and Fumarieæ are remarkably unsatisfactory; and certainly have produced no impression on my mind. But the seeds, and very often the fruit of these plants are so much the same, and the genus Hypecoum is so exactly intermediate between the two, 


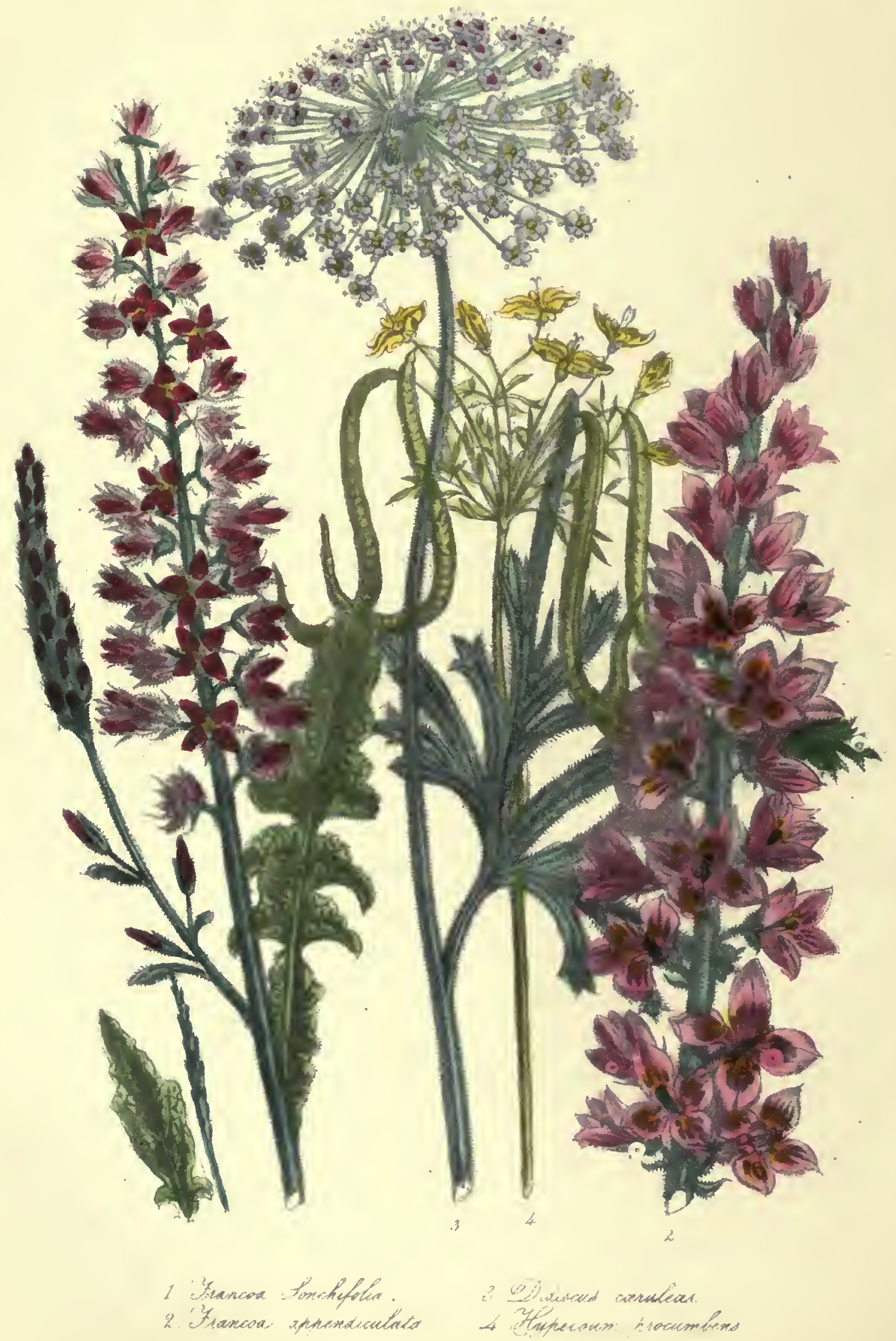




that I think it is more advisable on the whole to consider Fumariea as a reduced and irregular form of Papareraceæ than a distinet natural erder." (Lindl. Nat. Syst. of Bot., $2 d$ edit. p. 10.)

The prineipal popular distinctions between the Fumitory tribe and the Poppies are that the juice of the former is watcry, and the latter milky, and that the stems of the Fumitory are very brittle. The petals of the most common kinds of fumitory are also tubular and curiously slaped, somewhat resembling the flower of the larkspur, while those of the poppy tribe are eup-shaped.

\section{GENUS I.}

\section{HYPECOUM, Tour. THE HYPECOUM.}

\section{Lin. Syst. TETRANDRIA DIGYNIA.}

Geneale Cunracter.-Petals 4, inner ones usually 3-lobed. Stamens 4. Stigmas 2. Capsules elongated, 2-valred, knottod or jointed transversely.-(G. Don.)

Description, \&c.-Snall plants with yellow flowers, and very remarkable seed-pods, natives of the south of Eirrope and Asia ; which have been long since introduced into Britain, but which are very seldom seen in flowergardens. The name of Hypecoum is derived from the Greek word hypecheo, to rattle, from the seeds rattling in the pods when shaken.

\section{1.-HYPECOUM PROCUMBENS, Lin. THE PROCUMBENT HYPECOUM.}

Srnonymes.-FI. nodosum, Lam. ; HI. areuatum, Manch. Engravikgs.-Swt. Brit. Fl. Gard. t. 217, and our fig. 4 in Plate 7. petals largest. Central segment of the inner petals toothed.-(G. Specific Character.-Capsules articulated, compressed, arched ; Don.)

DESCRIPTION, \&C.-This curious little plant is interesting in a botanical point of view, as forming the conneeting link between the poppies and the fumitery tribe; plants so different, however, in their external appearance, that no common observer who has seen the commen fumitory and the corn poppy growing near each other in a corn-field, would ever imagine that there was the slightest relatienship between them. The Hypecoum, though resembling the fumitory in its leaves, eertainly at first sight appears much more like a poppy in its flowers; but upen examination, even its flowers will be found very different from these of any of the poppy tribe. They are not produced singly, each on a long flower-stalk rising from the root-leaves, like those of the peppy, but in little heads, each somewhat resembling an umbel when the flewers first expand, but forming afterwards a kind of raceme. The flowers are produced semetimes two together, and sometimes singly, on the short foot-stalks, whieh united form this head or umbel; and each flower is small, of a bright yellow, and rather curiously formed, being composed of four petals, three-lebed and toothed at the edges, the two outer ones of wnich are much larger than the others, sometling like those of the Platystigma which we mentioned in a former page. 
The seed-pods of the Hypecoum are very curious; they are very long, and curve downwards like those of the horned poppy, and they are jointed like those of tho Platystemon, so that this plant is extremely interesting, as showing some of those mysterious links by which the Almighty Creator of the universe has bound all the vegetable world together, in the same way as He has united it with the animal world through the walking-leaf and the zooplyytes, and the different kinds of animals with each other. The leaves of the Hypecoum are glaucous and deeply cut, closely resembling those of the fumitory. The stems are procumbent, and lie on the ground unless trained up.

The Hypecoum is a native of the South of Europe, from Spain to Astracan ; but it is only found in sandy places. It was introduced before 1594, and it is mentioned by Gerard under the name of horned wild Cummin. Parkinson calls it the true Hypecoum of Dioscorides, as described by Clusius, and he has given a very good figure of it. It has always been partially in cultivation since its introduction, though it is now seldom scen but in botanie gardens. When cultivated, the seeds slould be sown in very light or sandy soil where they are to remain, as the plant has a long deseending or tap root, and will not bear transplanting. When the plants come up, if they are to be left in their natural procumbent state, they should be thinned out to at least six or eight inches apart; but if they are to bo trained they may be left nearer. Before the seeds are sown they should be divested of their fungous covering; as, if this preeaution be omitted, they will not germinate until it is decayed. From this being neglected, the seeds of the Hypecoum will sometimes remain two or three years in the ground before they vegetate. When required to flower early, the seeds may be sown in autumn, as the plant is quite hardy, and will stand the winter in the open ground without any protection. It seeds freely, and would, no doubt, soon have become conimon, were it not for the peculiarity we have just mentioned, of the seeds. Trained over a bank, by occasionally forking down the branches, or drawn through a wire ring or hoop, raised by three slender supports about six or eight inches from the ground, it makes a very pretty bush covered with its bunches of yellow flowers, and long horn-like pods.

Seeds may be purchased at Mr. Charlwood's seed-shop, Covent Garden. The specimen our figure was taken from grew in the Horticultural. Society's Garden at Turnham Grcen, where the plant, in the autumn of 1838, formed a large mass as it lay procumbent on the ground.

\section{OTHER SPECIES OF HYPECOUM.}

These are quite hardy, and are marked in the botanical works as having been introduced, but we have never seen them growing, and we do not know where they are to be procured.

\section{2.-H. PENDULUM, Lin.}

The flowers are large and of a pale yellow, and the cdges of the petals are entire. The capsules are knotted, and hang straight down without any curvature. A native of Europe, from Spain to the Caspian Sea. Introduced before 1640, as it was mentioned and figured by Parkinson in that year. Procumbent like the ccmmon kind. 
3.-H. ERECTUM, Lin.

This species has the largest flowers of any of the genus. Its eapsules are not jointed, and instead of hanging down, they stand erect. The plant itself grows rather higher than the other kinds, It is a native of the Crimea, spreading across Asia to the mountains of China.

\section{GENUS II.}

\section{CORYDÁLIS, Dec. THE CORYDALIS.}

Lin. Syst. DIADELPIIA HEXANDRIA.

Genaric Character.-Petals four; one of which is furred at the base. Silique two-valved, compressed, many-seeded.-(G. Don.)

Descriptron, \&c.-This genus has been divided from the genus Fumaria (the eommon Fumitory), on aceount of its eapsule opening when ripe, into two valves, and eontaining many seeds; while the capsule of the Fumaria does not open, and eontains only one seed. The name of Corydalis is derived from the Greek word korydalos, a lark, because the shape of the flower somewhat resembles that of the larkspur.

\section{1.-CORYDALIS GLAUCA, Pursh. THE GLAUCOUS-LEAVED CORYDALIS.}

Svnonymes.-Fumaria sempervirens, Lin. F. glauca, Curs. Specipic Craracter.—Stem erect, branched. Leaves bipiunale, Corydalis sempervirens, Pers.

Evamavings.-Bos. Reg.t. 179 ; and our fig. 6, iu Plate 3, glaucous; pinnulæ somewhat pinnatifid. Segments stalked, c rrvated, trifid. Bracteas oblong, acute, shorter than the pedicels. Capsules linear.-(G. Don.)

Description, \&c.-A low plant, with very small glaneous, or bluish green leaves, and little pink and yellow flowers. The seed pods are rather long, and so very slender, that they look more like long stamens than seed pods. The manner of growtl of the plant, from its very small leaves, whieh are few and far asunder, and its small, oddly-shaped flowers, which are luddled together at the extremity of the sloots, render it far from ornamental; yet it is frequently found in flower-gardens from its seeding freely, and sowing itself. Indeed, where it has been onee sown, it is not easily got rid of. It is a native of rocks in Canada, and of the Alleghany mountains. It was introducerl in 1683, and its seeds may be had in most of the seed-shops.

\section{2.-CORYDALIS CLAVICULATA, Dee. THE WHITE CLIMBING CORYDALIS.}

Synonyme.-Fumaria claviculata, Lin.

ENGRAvings.-Eng. Bot. t. 103; 2nd edit. vol. vi. t. 985.

Description, \&c.-A pretty little elimbing plant with very slender stems, and small white or pale yellow flowers. It is a native of Britain, where it is very common in woods and in shady places, in a sandy or gravelly soil ; but where, from its very slender feeble stems and inconspieuous flowers, it is seldom noticed, except loy botanists. Sown in a garden, and its slender stems and branching tendrils trained up a treliis, it makes a very 
pretty object, frem its feathery lightness and gracefully drooping habit of grewth. We do not know whether any seedsman has thought it worth while to gather the seeds fer sale, but it is very common in the woods of some parts of Stussex, and, in short, wherever the soil is sandy or gravelly.

\section{OTHER SPECIES OF THE SUB-ORDER FUMARIEבE.}

There are several kinds of annual Corydalis which are said to have been introduced, but whiel, from their flewers possessing but little beauty, have not been mueh cultivated. The most remarkable of these is C. impations, Fiseh, a native of the Crimea, with yellow flowers, and capsules which burst and rell up when they are touched, like these of the Noli me tangere. All the kinds of Corydalis require a light seil, and sheuld be sown where they are to remain.

FUMARIA, Lin.

Of the different annual kinds of Fumaria, the handsomest is $F$. caprcolata, the flewers of which are white tipped with dark purple. F. officinalis, the common fumitory, is that little pale red flower so cemmon in corn fields. An infusion of its leaves was formerly thought an admirable cosmetie, and their expressed juiee was taken twice a day in whey as "a sweetener of the blood." What this phrase (which was in constant use, even in medieal boeks fifty or a hundred years ago) means, is not exaetly knowu; but as the leaves of the fumitory are exeessively bitter, they probably act as a tonic. $F$. Vaillanti and $F$. densifora have dark purple flowers; and $F$. leucantha white ones. They are all weedy-looking plants, and scareely worth eultivating. The best place for sowing them is under a bedge, wliere they will climb up ameng the branches, and their flowers only being seen will leek telerably well. Some of the kinds are very suitable for roek work. The name of Fumaria aliudes to the disagreeable smell of the plants, which resembles that of smoke.

\section{DISCOCAPNOS MUNDTII, Schlec. MUNDT'S DISCOCAPNOS,}

only differs from Fumaria in the fruit being unembranous, and girded with a wing. The leaves are of a bluish green, and furnished with tendrils; and the flowers, which are in racemes of from five to eight flowers each, are red.

\section{CYSTICAPNOS AFRICANA, Gœrt. THE BLADDER FUMITORY,}

is a native of the Cape of Good Hope. It is a slender elimbing plant, with small white flowers tipped with red. It was introduced in 1696, but we de not know where it is now to be proeured. It takes its name from its eapsules, which are bladdery, and eentain many seeds.

\section{DIELYTRA SCANDENS, $\boldsymbol{D}$. Don. THE CLIMBING DIELYTRA,}

is a elimbing anuual, a native of Nepaul. The flowers, which are yellow tinged with brown, differ from those of the Fumaria in liaving twe horns. This plant has not yet been introduced; but from the descriptions which have been given of it, il appears well deserving of eultivation. 
CHAPTER IV.

\section{UMBELLIFER $Æ$.}

Essental Chanarter, -FJowers usually disposed in umbels. Calyx superior. Disk epigynous, very thiek, in two ot more picces. Carpels always 1-seeded. Stems nsually hollow.-( Lindl.)

\section{GENUS I.}

DIDISCUS, Dec. THE DIDISCUS.

Lin. Syst. PENTANDRIA DIGYNIA.

\section{1.-DIDISCUS CærRULEUS, Dec. TIIE AZURE DIDISCUS.}

Genfare Cuanacter.-Margin of the calyx obsolete. Petals oval, bluntisl, imbricate in astivation. Fruit didynous, onarginate at the lase. Merjearps reugh from pilose strigx, 5-ribbed, two middle ribs appreximating tbe cemmissure. Involucrum of many lenves, which are conerete at the base.-(G. Don.)

Synenymes.-Trachymene cyanæa, Cunn.; T. cærulca, Graham; Bugelia eyanma, Rehb.
Fingravings,-Bot. Mag. t. 2875 ; Bot. Reg. t. 1225 ; ard our fig. 3 , in plate 7.

Spferfic Cunnicter. - Plant hairy; leaves petiolate, 3-parted; having the partitions 2-3-eleft, and the lobes 2-3-toothed; umbels simple, on long peduncles; involucrum of many leaves, when young refiexed.-(G. Don.)

Description, \&c.-A very beautiful half-hardy annual, with azure blue flowers, produced in umbels. When the flowers drop, the little stalks on which they grew twist inwards and enclose the seed as in a cage. The leaves are lobed and large, and the stem erect and rather tall. This beautiful plant is a native of New Holland, and was introdnced in 1827. It was first raised in England in the Horticultural Society's Garden, from seeds sent home from Sydney by Mr. Charles Frazer. It is frequently called Trachymene cærulea in the seed-shops, from its lhaving been thus designated in the Botanical Register for 1829. In the first volume of the Ladies' Botany, however, published in 1834, Dr. Lindley has called it Didiscus cærnlea (p. 32). It must be cultivated as a lialfhardy annual; and if the seeds are sown in a lotbed in March, they will be ready for planting out in June, and will flower in August or September, and continue beautifully in bloom till November, or till they are killed by the frost. "If sown in August, the plants should be potted in small pots in October, and kept rather dry than otherwise during the winter. Thus treated, and removed into larger pots in spring, they will flower beautifully in a frame or greenhouse, and much better than in the open ground. These plants sbould never be lieaded down, as their flowers are produced at the extremity of the main stem and branches." $-D$. B. If kept in the greenhouse, and constantly changed into larger pots as they grow, they will become very fine, and flower beautifully; and our drawing was made from a plant in the nursery of Messrs. Osborn at Fulham, which had been treated in this manner; but we have since seen some equally fine specimens growing in the open air.

G 2. 


\section{CHAPTER r.}

\section{FRANCOACE E.}

Essential Character.-Calyx deeply 4-cleft. Petals 4, inserted ncar the base of the calyx. Stamens sub-hypognyous, four timea as numerous as the petals, alternately rudimentary. Ovary superior, with four cells, opposite the petals; ovules numorous; stigms 4-lobed, aessile; capsule membraneus, 4-valved, with a loculicidal or septicidal dehiscence. Seeds numerous, minute, with a minute embryo in the base, of fleshy albumen.-( Lindl.)

\section{GENUS I.}

\section{FRANCOA, Cav. THE FRANCOA.}

\section{Lin. Syst. OCTANDRIA TETRAGYNIA.}

Gesenic Charactzr.-Calyx 4-parted. Petala 4. Stamens distipct 16,8 of which are fertile; anthers 2-celled. Stigma 4-lobed. Capsule tetragonal, 4-celled.-(G. Don.)

Description, \&c.-All the kinds of Francoa are, properly speaking, perennials, but treated as the Hunnemania, they make beautiful half-hardy annuals; and they are more useful in this way than in any other, because, as perennials, they are too tender to live through the winter in the open air without protection, and of course occasion considerable trouble and expense. Bosides this, it bas been found that they can only be propagated by seeds.

\section{1.-FRANCOA APPENDiCULATA, Cav. THE COMMON FRANCOA.}

Exgravings._Bot. Mag. t. 3178 ; Bot. Reg.t. 1645; Brit. Flow. | sccund; calycine segments lanceolate, acute; lobes of stigma curvated, Gard. $2 d$ Ser. t. 151 ; aud our fig. 2 in Plate 7.

Speciric Character.-Stemless; leaves petiolate; racemes loose, emarginate.-(G. Don.)

Descriptron, \&c.-The plant is without a stem, properly so called, but it sends up its long flower-scapes from a mass of large deep green leaves, shaped like those of the turnip. The flower stems or scapes rise nearly two feet ligh, and terminate in a spike of pale pink flowers, beautifully marked with spots of a deeper pink in the middle. This plant is a native of the island of San Carlos de Chiloe, in South America; and it was introduced in 1830, by Mr. Anderson, who accompanied Captain King, as botanist, in his expedition to survey the coasts of South America. The plant had been before diseovered by Don Luis Nee, naturalist to the Spanish expedition under Masalpina, and it was from dried specimens of it that Cavaniles founded the genus Francoa. It flowered for the first time in England in Mr. Low's nursery at Clapton. It is properly a perenuial, but if cultivated as directed for the Hunnemania, it will inake a beautiful border annual. When plants are reserved for seed, they should be kept in pots in a frame or greenhouse; but the flowers are never so fine or so lighly coloured on plants grown in pots, as on plants in a warm border in the open air. Seeds may be had at Charlwood's. 


\section{2.-FRANCOA SONCHIFOLIA, Cav. THE SOWTHISTLE-LEAVED FRANCOA.}

Engrapings._Bot. Mag. t. 3309; Brit. Flow. Gard. 2nd Ser, t. | loose, nodding; calycine segments dilated; petals with involute mar169 ; and our fig. 1, in Plate 7.

Speciric Charscter.-Plant caulescent; leaves sessile; racemes

gins ; stigmas elliptic, entire.-(G. Don.)

Description, \& o. - This plant rises with a stem covered with leaves about a foot high, and then sends up its flower-scape which throws out many branches. The flowers are small and of a dark purple. Altogether this kind of Francoa is net so handseme as the other; and its large leaves hanging down from the stem give it an untidy appearance. It was raised from seeds cellected near the city of Conception, in Chile, and brought lome by Mr. Andersen in 1830. It flowered for the first time in England, in the Chelsea Botanic Garden. Dr. Lindley, and Siz W. J. Hooker, censider this kind as only a variety of $F$. appendiculata. The culture is the same as of that plant; and seeds are to be procured at Charlwood's.

\section{3.-FRANCOA RAMOSA, D. Don. THE BRANCHED, OR WHITE-FLOWERED FRANCOA.}

\begin{tabular}{l|l} 
Engraving.-Brit. Flow. Gard. 2d Ser. t. 223. & spirate, erect; calycine segments lanccolate, obtuse, nerveless; lobes
\end{tabular} Sfecific Cuaracter. - Plant caulescent; learcs petiolate; racemea 1 of stigma curvated.-(D. Don.)

Description, \&C.-This species of Francoa is so different from the others, as scarcely to be recognised by a general observer as belenging to the same genus. The stem is erect and branched; the leaves are small and of a pale green. The flowers are white, with small round petals, and they form loosely-branched racemes rather than spikes. This plant was first discovered near San Jago in Chile, and described from dried specimens by Professor Den; but it was afterwards found on the hills near Valparaiso, where seeds were collected by Mr. Iugh Cumming, and brought to England by him in 1831. It flowered for the first time in England in Mr. Knight's exotic nursery, King's Road, Chelsea, having been grown in a mixture of sandy peat and loam. All the Francoas require light dry soil ; and if grown in pots, to have abundant drainage. Wo suppose seeds may be obtained from Mr. Knight, but we have not seen the name of the plant in any seed catalogues.

\section{CHAPTER VI.}

\section{ONAGRACE $\mathrm{E}$.}

Flswntul, Character.-Calyx superior, tubular, 4-cleft ; petals 2 or 4, convolute in æestivation. Stamens 2, 4, or 8, perigynous. Fruit brecato or capsular, - (G. Don.)

Description, \&c.-All the species belonging to this order are ornamental, and the annual kinds are particularly splendid. It may appear strange to those whe are not acquainted with botany, to find that the evening primrose and the Clarkia belong to the same natural order as the Fuchsia; yet such is the case, as they all resemble each other in a botanical point of view. As some of the pepular distinctive marks of this order, we 
may mention the position of the capsule, which, being below the calyx, looks like the foot-stalk of the flower, and that all tire parts of the flowers are in even numbers-such as twice two, or twiec four. For example, in the genus Winothera there are four scpals, four petals, and eight stamens. The capsule is also four-celled, and the stigma four-lobed. This constant adlerence to even numbers is peculiar to the Onagracea.

GENUS I.

CENOTHERA, Lin. THE GENOTHERA, OR THE EVENING PRIMROSE.

Lin. Syst. OCTANDRIA MONOGYNIA.

Genzar, Cualeactelu. - Limb of calyx 4-parted. Petals 4. Capsule oblong-linear, bluntly tetragonal or clavate, 4-colled. Sceds naked.(G. Don.)

Description, \&.c.-The beantiful plants which used formerly to compose the genns Enothera, have lately been divided by M.E. Spach, a German botanist residing in Paris, into no less than fourteen genera (see Annales des Sciences Naturelles.-Botanique, $2 \mathrm{~d}$ Ser. tonı. iv. p. 161); but many of these genera are founded on sueh rcry sliglit distinctions, that they lave not been adopted by botanists in general. Godetia is the only one of M. Spach's genera which has been adopted by Dr. Lindley, and it ineludes all the purple and lilac-flowered Enotheras, as they all have a part of their seeds bordered by a feathery margin, so small however as to be quite imperceptible without a very powerful microscope, as the seeds themselves are not larger than grains of sand. Spach's genus Boisduvalia has also been adopted by some botanists: it contains two species, CEnothera densiflora, Lindl., and Enothera concinna, $D$. Don; and the distinctive mark is, that the four stamens opposite the petals are much shorter than the others. Dr. Lindley, however, rejects this genns. We have entered more at length into these botanical distinctions than we should otherwise have done, because the name of Godetia has been generally adopted for the three new lilac-flowered specimens introduced in 1835, while the other purple and lilac kinds are all still called in the seed-shops by their original name of CEnothera. For this reason, and because Dr. Lindley states (Bot. Reg. t. 1829), that he consiủers the purple-flowered kinds distinet, and that they will not mix with the true yellow-flowered evening primroses, we shall follow him in calling the purple and lilac-flowered species Godetia, and arranging all the other kinds under the general name of CEnothera.

Tho name of evening prinrose was given to the CEnotheras becanse $C E$. biennis (a yellow-flowered biennial species), which was the first introduced from Anserica, has the habit of closing its flowers during sunshine, and not opening them till evening, or during eloudy weather, and this is the case with several other species. The name of CEnothera (which is said to be derired from two Greek words, signifying wine inducer) is also supposed to be taken from CEnothera bienuis; as, when that plant was first introduced, its roots were eaten like olives, to give a relish to wine. CE. biennis, in the old catalogues of plants, is called the tree primrose of Virginia. 


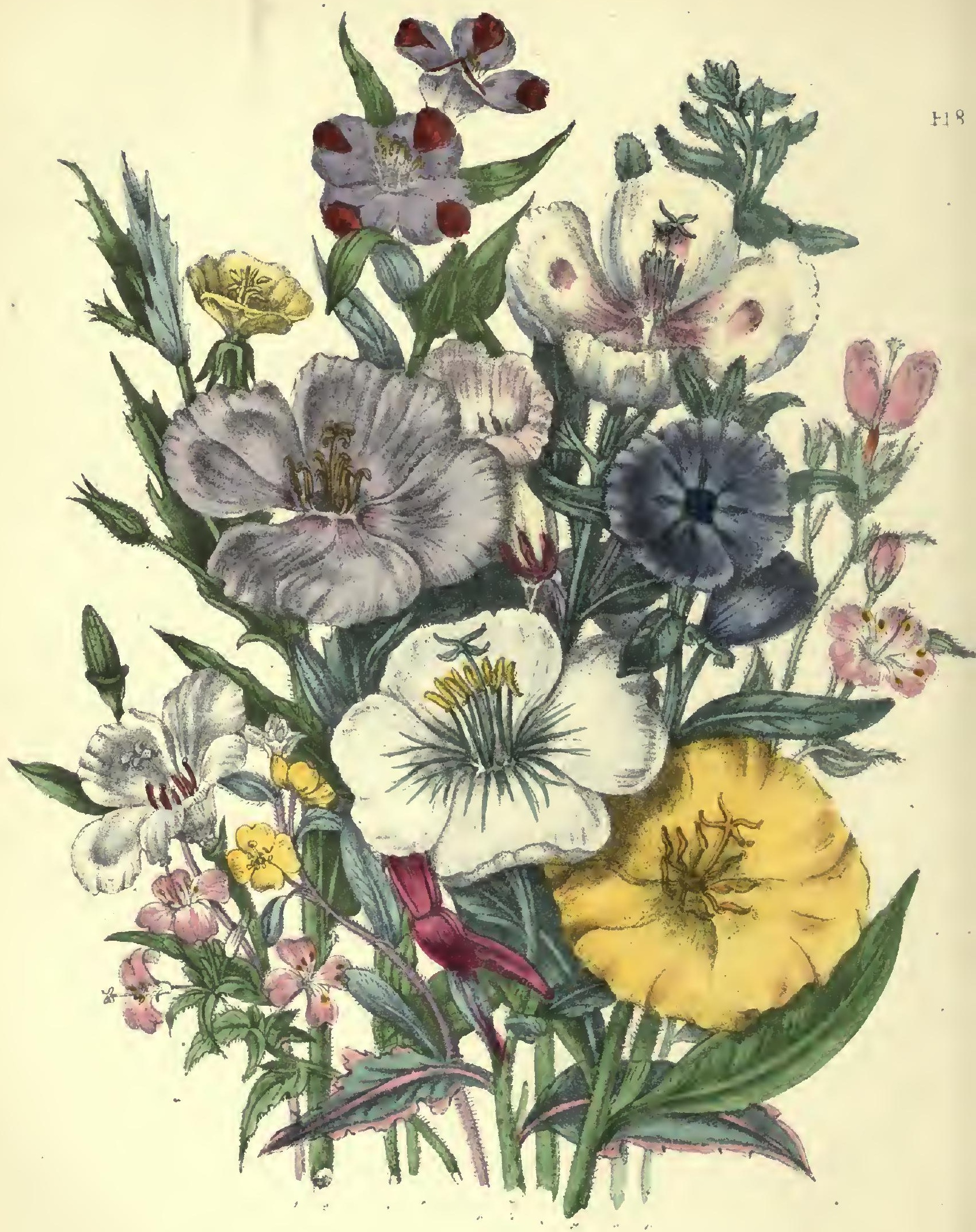

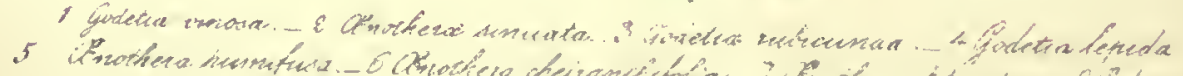

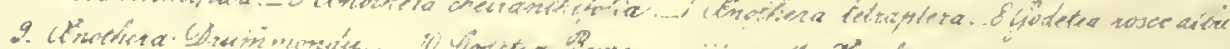




$$
\text { - }
$$



FLOWERS WHITE.

\section{1.-FNOTHERA TETRAPTERA, Cav. THE WHITE-FLOWERED EVENING PRIMROSE.}

SynonyMr.-Hartmaunia macrantha, Spach.

Evgravinos.-Bot. Mag. t. 468, and our fig. 7, in Plate 8.

Specific Character.-Stem branched, pilose. Leaves lanceolate, pinnatifio, or teothed, somewhat ciliated, hardly pctiolate; sube of calyx almost wanting. Pctals obcordate, entire. Stamons and filetil shorter than the eorolla. Antbers and stigma narrow and long. Capsule obovate, 4 -winged, ribbed, pilose, tapering into a pediccl at tho baso. Seeds ovate, acuto, smooth, pale.-(G. Don.)

Description, \&c.-The plant is of a compact laabit of growth, and it is beautiful from its large sweet-scented white flowers, which change to pink as they fade. Its capsules are very curious, having distinctly four wings; and its leaves are also remarkable from their pinkish tinge. There are so very few annual white evening primroscs, that this species deserves to be in every garden. It is a native of Mexico, and was first raised in the Cambridge Botanic Garden, from seeds sent, in 1796, to the Marchioness of Bute, by Professor Ortega, of Madrid. It is quite hardy, and may be sown in the open border as directed for Flos Adonis, in Mareh or April, in which case it will flower in June or July. If treated as a tender annual, and raised in pots on a hotbed, in the same months, its flowers will be much larger and finer after it is planted out. It is a true evening prinrose, its flowers never expanding in the sunshine, but generally opening about six o'clock in the evening, and fading before morning. It flowers abundantly, and will continue producing a succession of blossoms during the wholo summer. Seeds may be had at Cliarlwood's, or any seed-shop.

\section{2.-CENOTHERA PURShi, G. Don. PURSH'S EVENING PRIMROSE.}

Synonymrs.-Ge. albicaulis, Pursh ; CE. pinnatifida, Nutt.; Anogra pinnatifida, Spach.

Sprcific Cанастет.-Pubescent. Stem decumbent, white; radical leaves nearly entire, cauline ones pinnatifid, with lincar, acute, divarieate segments. Nerves of leaves white, like the stom. Flowers fow, disposed in a kind of spike. Petals ebcordate, white, large, longer than the stamens. Style filiform. Ovaries sessile, prismatic, furrowed.-(G. Don.)

Descriptron, \&rC.-A trailing species, with white stems and pinnatifid leaves. The flowers are large and white, and they are disposed in a kind of spike. It is a native of North America, on the plains of the Missouri. It is said to have been introduced in 1811 , but we have never seen it, and do not know where seeds of it are to be procured. There are two other kinds of annual white evening primrose, one a native of Mexico, CEnothera latifolia, Moc. et Sess.; and the other CE. Boothii, Dougl., a native of California; but they have not yet been introduced.

FLOWERS YELLOW.

\section{3.-GENOTHERA CHEIRANTHIFOLIA, Horn. THE STOCK-LEAVED OENOTHERA.}

Synonym. - Holostigma cheirantbifolium, Spach. Enghavings. - But. Reg. t. 1040, and our fig. 6, in Plate 8.

Sprcific Cuaracter.- Stem decumbent, round, red, hairy, and bianched. Leaves glancous, pubeseeut, of several shapes; the lower spatulate, on long stalks, distant, the upper ciose together, somewliat sessilo or stalked, sometimes oblong, sometimes ovate, and rather cordate, all obtuse. Flowers solitary, axillary, a little longer than the leaves, bright yellow becoming tawny. Ovarium subulate, a littlo bowed, villous. Sepals villous. Stigma capitatc.-(Lindl.)

Description, 8tc.-A very pretty and perfectly hardy speeies, "distinguished by its trailing habit, briglit red stems, very glaucous leaves, and bright lively yellow flowers."-(Bot. Reg. t. 1040.) A native of Chili, from 
which country it was first sent to Denmark, and thence to M. Otto, at the Botanic Garden, Berlin, from whom seeds were received by the London Horticnltural Society in 1825. It flowered in the Horticultural Society's Garden the following year, producing an uninterrupted suceession of blossons from July, till destroyed by frost. We do not know where seeds are to be procured, as it has been lost by the Horticultural Society; but seedsmen might casily obtain them from Berlin. It should be raised in pots on a hotbed, and planted out in May, without breaking the balls of earth that had formed round the roots while they were in the pots.

\section{4.-CENO'THERA DRUMMONDII, Hook. MR. DRUMMOND'S EVENING PRIMROSE.}

Engravinga.-Bat. Mag. t. 3361, and our fig. 9, in Plate 8.

Specific Cinaracter. - Stem branched, succulent, soft with down,

as is the whole folinge. Stamens rather declining. Leaves oblong,

elliptic, somewhat obtuse, and slightly sinuately-toothed, attenuated towards the petiole. Flowers axiliary, petals large and yellow. Capoulc (immature) cylindrical, striped, and pubescent, with hairs.-(Hook.)

Description, \&c.-This very beautiful species has large yellow flowers, and bluish-green leaves. When the flowers fade, they assume a rich orange colour. It was found by Drummond in Texas, near the mouth of the River Brazos, in 1833; and was sent by him to the Glasgow Botanic Garden, where it flowered abundantly in the open border. Sir W. J. Hooker calls it perennial, or suffruticose; but some seeds which we had from Mr. Charlwood, and which were sown in a warm border at Bayswater, in May 1838, produced their splendid large yellow flowers in the August and September following. The flowers, however, were not numerous, and the seeds did not ripen; so the plant would probably succeed best if treated as a tender annual, and sown in pots on a hotbed in March or April, and planted out, without breaking the balls, in May. Even in the way we grew the plants, they werc well deserving of cultivation, from the size and rich colour of their flowers.

\section{5.- CENOTHERA SINUATA, Michx. THE SCALLOP-LEAVED EVENING PRIMROSE.}

Encravings. - Bot. Mag. t. 3392 ; and our fig. 2, in Plate 8. | Scpals unguiculate towards the apex. Capsules cylindrically tetragonal, Specific Character.-Plant dccumbent, clothed with soft pubescence. Leaves lanceolate, sinuately-toothed or cut. Flowers small. somcwhat incurved, pilose, length of the bracteas.-(G. Don.)

Description, \&r.-A decumbent plant, witl stems one foot or two feet long, and much branched; they are round, covered with pubescence, and often tinged with purple. The leaves are large, and so deeply cut as to give rise to the name. The flowers are rather small and cup-shaped; the capsules are long, four-sided, and hairy. This species is said, in the Hortus Keroensis, to have been introduced in 1770, by M. Richard. It appears, however, to have been neglected, and probably lost; and it was re-introduced in 1833 by Drummond, who sent seeds of it from Texas to the Glasgow Botanic Garden, where it flowered in the open border in September, 1834. CE. minima, Pursh, is a variety of this species. Seeds of both kinds are to be obtained at Charlwoed's; and should be sown in the open border, in March or April. 


\section{6.-CENOTHERA DENTATA, Cav. THE TOOTHED-LEAVED CENOTHERA.}

Synonymrs._QE. Chamissonis, Link. Holostigma heterophyllum, Spach. Speifie Charucter._Leaves linear, denticulatcd, glabrous. Capsule cylindrical, very narrow.-(G. Don.)

Description, \&c.-A prostrate species, with rather large yellow flowers, a native of Chili and Peru, introduced in 1818. We lave never seen the plant, and do not know where it is to be procured.

\section{7.-OENOTHERA HIRTA, Link. THE HAIRY CENOTHERA.}

Srvonymes._QE. micrantha, Horn. Holostigma micranthum, ceolate, denticulated. Flowers sessile, minute. Capsules curved, Spach. round.-(G. Don.)

Spretpic Character.-Hairy. Stem branched, ercet. Leaves lan-

Description, \&c.-A low, hairy plant, with small yellow flowers, and round, curved capsules. A native of California, introdueed in 1823. Seeds may be had, under the name of $\mathscr{E}$. micrantha, at Charlwood's.

\section{8.-ENOTHERA SALICIFOLIA, Desf. THE WILLOIV-LEAVED EVENING PIRIMROSE.}

Synonymss.-CE. elata, Kunth. E. crassipes, Hort. Berol. lanceolate, acute, nearly entire, rather pilose, thickish. Stamens and Onsgra Kunthiana, Spach.

VARIETY.-CE. 2 undnlata, Hort. CE. odorata, var. Hort. pistil equal in length to the corolla. Lobes of atigma oblong-linear, large, thickish. Capsule obleng, tetragonal. Valves lincar, with red

Sercific Character.-Stem tall, simple, angular. Leaves eblong- nerves.-(G. Don.)

Description, \&c.-A tall, handsome species, growing to the height of two feet or three feet, or more, with pale, yellow flowers. The leaves are long, and somewhat fleshy; and the eapsules, which are four-winged, are ornamental, from their valves laving red nerves. This species is a native of Mexieo, and was introduced in 1824. Seeds may be proeured at Mr. Charlwood's, and they should be sown on a slight hotbed, in September, if they are wanted to flower in June. They may also be sown in the open ground in May, in which ease they will not flower before August or September. This kind of CEnothera is tall, and rather untidy in its habits of growth ; there should therefore be three stakes forming a triangle at the bottom, and fastened together at top, put over each patch, to tie the plants to. This may be considered as a true Evening Primrose, as the flowers expand only at night, and shrivel up before morning. Its leaves are mueh thicker and more fleshy than those of any of the other kinds. $E$. salicifolia, and the three followings pecies, are frequently marked as biennials in botanieal works, but they may be grown as annuals.

\section{9.-OENOTHERA GRANDIFLORA, Ait. THE LARGE-FLOWERED EVENING PIRIMROSE.}

Srnonymes.-W. biennis, var. grandiflors, Lindl. CE. suaveolens, Desf. Onagra vulgaris, var. Spach.

Engravinas. -Bot. Mag. t. 2068 ; Bet. Reg.t. 1604.
Sprcific Charnctrr. - Pubescent. Stem simple. Leaves lanceolate, remotely toothed. Stamens deflexed. Petals large, obeordate. Capsule sessile, cylindrical.-(G. Don.)

Description, \&c.-A plant, growing about two feet high, with large, bright, yellow, solitary flowers, whieh spring from the axils of the leaves. This species, which is a native of North America, introduced in 1778, must 
not be confounded with the $E$. grandiflora of Ruiz and Pavon, a South American perennial species, with very large white flowers, and which has been since called $E$. taraxacifolia. Seeds of the yellow $E$. grandiftora may be procured at Charlwood's. The seeds should be sown in autumn as soon as they are ripe in the open ground, if the plants are wished to flower in June. If the seeds are not sown in the open ground till March or April, the plants will not flower before August or September. The best way of obtaining fine plants when the sowing has been neglected till spring, is to sow the seeds in pots in a hotbed in March or April, and to turn the plants out in May, taking care, in transplanting them, not to break the ball of earth round the roots.

\section{0.-ENOTHERA MOLlissima, Lin. THE SOFtest EVENING PRIMROSE.}

Sy Nosyme.-Ge. nocturna, Willd.

Spectfic Character.-Stem branched. Leaves lanceolate, a littlo undulated, repandly-toothed, and clothed with soft down. Petals obovate, entire, shorter than the calyx. Stamens and pistil hardly the length of the petals. Lobes of stigma, filiform. Capsule cylindrical striated, very long, downy, somewhat tetragonal, a little thickened at the apex.-(G. Don.)

Description, \&c.-This species strongly resembles the commen biennial Evening Primrose (GE. biennis) in its habit of growth. Its flowers are yellow when they first expand, but they change to red as they fade. The plant is a native of Buenos Ayres, Monte Video, and Chili, where it grows wild in the fields. It was introduced in 1732. Seeds may be had in any seed-shop.

\section{1.-CENOTHERA LINEARIS, Michx. THE LINEAR-LEAVED EVENING PRIMROSE.}

Sprensic Cuuracrer.-Plaut slender, pubescent. Leaves linear, entire. Capsules on longish stripes, roundish, tetragonal, villous.--(G. Don.)

Descriptron, \&rc.-A native of Upper Carolina, growing a foot high, with very narrow leaves, and yellow flowers. Introduced in 1822. Seeds may be had at Charlwaod's.

\section{2.-CENOTHERA TRILOBA, Nutt. THE THREE-LOBED EVENING PRIMROSE.}

Sxnosymes. - G. rhizocarpa, Spreng. Lavauxia Nuttalliana, Spach.

Eneratixg,-Bot. Mag. t. 2566.

Specific Charactrar.- Stemless. Leaves interruptedly pinnatifid, toothed, glabrous. Petals ohovate, slightly 3-lobed at the apex, the middle lobe mucronate. Capsules almost 4-winged, large, scssile at the root. $-(G$. Don.)

Description, \&rc.-The flowers are of a pale yellow, and are very sweet-scented in the evening. They are remarkable for the length of the tube of the calyx, which often exceeds two inches, and for springing from the root; they are at first produced without any footstalk. and growing to the crown of the root, but under cultivation, after the flowers have dropped, stems bearing the capsules rise about two inches. Dr. Sims, in the Botanical 
Magazine, calls this species the Dandelion-leaved Evening Primrose, from the leaves resembling those of the Dandelion, but this name has been since given to another species. The leaves all spring from the root. This species was first discovered in 1819 in the arid prairies of the Red River, in North America, by Professor Nuttall, who gave seeds of it, with the name attached, to Robert Barclay, Esq., Bury Hill, in whose collection it flowered in September 1821. The name of triloba alludes to the petals, which are slightly three-lobed. We do not know where seeds are to be procured of this very singular species.

\section{FLOWERS REDDISH.}

\section{3. - ENOTHERA DENSIFLORA, Lindl. THE CLOSE-PLOWERED CENOTHERA.}

Sצnомуме.-Boisduvalia Douglasii, Spach.

Engratixg. - Bot. Reg. t. 1593.

Sprcific Character. - The whole plant woolly. Leaves linearlanccolate, scssile, acumioate, toothed. Branchlets with small corymbs of flowers, rising from the axils of the leaves. Ovary eylindrical, with very short bractcas. Sepals sub-coloured, smooth within. Petals bilobed, obtuse. Stamens four, shorter ones fertile; four longer ones often sterile.-( Lindl. $)$

Description, \&c.-This very remarkable plant bears but little resemblance to the other kinds of Enothera, and certainly it has only its singularity to recommend it. The colour of its flowers is a reddish-lilac, or rather dirty rose-colour, and they are so small that they are almost hidden by the leaves. "Its peculiar habit," says Dr. Lindley, " arises from each of the axillary buds of the main stem, which usually produce a single flower, being developed into a short branch, that itself bears flowers in the axilla of its leaves."-(Bot. Reg. t. 1593.) It is a native of New California, from which country seeds were sent by Douglas in 1831. It ripens seeds abundantly, and they may be purchased at Charlwood's, and in most other seed-slops. It is quite hardy, and requires no particular care in its cultivation.

\section{4.-- CeNOTHERA HUMifUSA, Nutt. THE TRAILING EVENING PRIMROSE.}

Synonymes.- E. concinna, D. Don. Boisduvalis concinna, Spach. $\mid$ oval at the base, sharply pointed, toothed. Flower-spikes terminal, and Exgruvisgs. - Bot. Reg. t. 1829, and our fig. 5, in Plate 8 ; Brit. Flow. Gard. 2nd Series, t. 183 ; and our fig. 11, in Plate 8.

Sfecirie Cruracten.-Clothed with hairs. Stcm prostrate. Lcaves surrounded with leares. Calyx of the tube slender, and twice as long as the ovary. Petrls bilobed, veined, longer than tho stamens. Lobes of the stigmas forming a small cross. Capsules prismatic.-(Lindl.)

Description, \&c.-A pretty little hardy annual with trailing stems, and small hairy leaves. Its flowers are flesh-coloured when exposed to much light, but in the shade they become of a beautiful pink. The tube of the flower is of a deep rose-colour. The species is a native of North America, and was discovered by Dr. Baldwin on the sea coast near Cumberland, in Florida. Introduced in 1824. E. concinna, D. Don, figured in Sveet's British Flover Garden, is supposed to be the same species; but as the two figures are somewhat different, and as Professor Don states that the plant which his figure was taken from, was raised from seeds brought from Chili by Mr. Hugh Cuming, we have copied both figures in our Plate 8. Both names are in Charlwood's Seed Catalogue. 


\section{GENUS II.}

\section{GODETIA, Spach. THE GODETIA.}

Lin. Syst. OCTANDRIA MONOGYNIA.

Gen gac Character. - Limb of the calyz reflexed. Capsule opening at the angles. Placenta persistent. Stameng all alike. Chalaza of the seed erowned round the margin by a fringe. $-($ Spach. $)$

Description, \&rc.-This new genus, as we have already observed, we have followed Dr. Lindley in adopting. It eontains all the species with purple flowers, which Dr. Liudley informs us will not mix with the yellowflowered kinds so as to form hybrids. The two kinds are indeed obviously distinct to the unbotanical observer, not only from the difference in the colour of their flowers, but from the circumstance of the purple kinds not closing up their petals in the sunshine, and thus forfeiting all title to the name of Evening Primrose. The botanical difference is, as we before observed, so minute as to be only perceivable by the aid of a powerful microscope.

\section{1.-GODetia pURPUREA. THE PURPLE GODETiA.}

Sxnonymes. - Enothera purpurea, Curtis. ๔.. humilis, Don. Godetia Willdenoviana, Spach.

Engraving.-Bot. Mag. t. 352.

Specific Character.-Plant glaucescent. Leavcs lanceolate, attcnuated at both ends, bluntish; tube of calyx shert. Petals obovate, crenulated. Stamens and pistil exserted, much shorter than the corolla. Lobes of stigma thick, short, dark purple. Anthers yellow. Capsule avate, triquetrous, sessile, angular, pilose. Seed irregularly angular, and coyered with dots when examincd with a lens. $-(G$. Don.)

Description, \&c.-This species grows to the height of two fect; its leaves are of a very glaucous or bluish green, and its flowers of a reddish purple. It is also remarkable for the reddish hue of its stems, and the very dark purple of the lobes of its stigma. It is a native of the north-west coast of North America, whence the seeds were sent to Kew, in 179I. It has always been a favourite in our gardens, and is yet perhaps more common than any of the other purple-flowered kinds. Its seeds are to be proeured in every seed-shop; and they should be sown in March, April, or May, according to the time they are wanted to flower. Perhaps the best time to sow them is in April, or the beginning of May, in which case they will flower in June or July, according to the warmth of the season, or the nature of the situation. It may be observed that, though seeds sown in March will certainly be earlier in flower than those sown in April or May, the difference will not be equal to the difference in the time of sowing; that is to say, seeds sown a month, earlier will not be in flower more than a fortnight earlicr, and in some cases not so much. All tise Godetias require a dry soil, not too rich; and indeed the poorer the soil is, the brighter will be the colours of the flowers-though if it be very poor, the foliage will not be good. The seeds may be sown in the manner directed for those of Flos Adonis, lut not too thin, as many of the seeds are always bad; and besides they are frequently destroyed by insects. When they come up they should be thinned out, so as to leave about five or six plants in every patch of six inches in diameter; and the plants taken out may be transplanted. 


\section{2.-GODETIA ROMANZOVII, Spach. ROMANZOW'S GODETIA.}

Sysosyme.-GEothera Romanzovii, Ledebour.

Enctrutras. - Bot. Reg. t. 562 ; and our fig. 10, in Plate 8.

Specrpic Character.-Glaueous. Stem ereet. Leaves lanccolateoblong, mucronate, tapering into the petiole. Tube of calyx very short. Limb one-half shorter than the corolla. Petals broad-ohovate, crenulsted. Stameos much shorter than the corolla. Anther green. Stigmas nearly sessile, eoclosed, dark purple. Capsulo oblong-cylindrieal, somewbat tetragonsl, pilose. Seeds hoary, and ratler acaly when examined with a lens.-(D. Don.)

Desconiption, \&c.-The flowers are small, but of a rich dark bluish colour; and the leaves are of a glaucous huc. The stigma is much shorter than in any of the other kinds, and of so very dark a purple, as to look almost black. The growth of the plant is also rather different from that of the other kinds; the stem is decumbent, but it has numerous "soft, flexile, ascending branches." This species is a native of the north-west coast of North America, where it was discovered by Chamisso, who found and named the Eschscholtzia, during the same voyage. The specific name of this Godetia was given in honour of the Russian minister, Count Romanzow, at whose expense the expedition under Captain Kotzebue, with which Chamisso sailed, was sent out. The seeds of the Godetia Romanzovii were sent to Moscow in 1817; and soon afterwards some were forwarded to England, and sown in the Botanic Gardcn, Chelsea, where the plant flowered for the first time in this country in 1820. It is now common in all the nurseries, and its seeds may be had in every seed-shop. It is quite hardy, and only requires the same troatment as G. purpurea.

\section{3.-GODETIA DECUMBENS, Spach. THE DECUMBENT GODETIA.}

Synony ur. - E. deeumbens, Doug. .

Enonavinas.—Bot. Mag. t. 2889 ; Bot. Reg. t. 1221.

Sprcific Craractrn.-Leavcs glaueous, quite entire, pubcscent, lower oncs broadly ovate; upper ones ovate-lanceolato. Petals emarginate, crenulated. Stigmas purple, with reflexcd segments. Cspsule bluntly tetragonal, tapering from the hase, villous.-(G. Don.)

Descriprios, \&C.-This species has hairy glaucous leaves, and small purple flowers of no great benuty. It is a native of California, and was introduced by Douglas in 1837. To a botanist it is interesting, because its stigmas differ greatly in form from all its allies; but it is scarcely worth cultivating as an ornamental flower, when so many much handsomer can be procured. Seeds may be had at Mr. Charlwood's; they should be sown, and afterwards treated in the same manner as directed for G. purpurea.

\section{4.-GODETIA ROSEO-ALBA. THE ROSE AND WHITE GODETIA.}

Sysonymes._G.Lehmanuia, Spach. GEnothera roseo-alba, Bernl. |late, bluntish, slightly toothed, glaucous. Petals three timea looger E. amœena, Lehm.

Engravinga.-Brit. Flow. Gard. t. 268 ; and our fig. 8, in Plate 8.

Specjetc Charactert-Pubescent. Stem round. Lcaves laoceothan the calyx, obovate, slightly emarginate, undulately crenated, capsule eylindrically tetragooal. Lobcs of stigma semicylindrical. (G. Don.)

Descriptron, \&C.-A very beautiful species, with very delicate whitish petals deepening into rose at the base ; and each petal marked in the ccntre with a rich reddish-purple blotch. It is rather remarkable that the native country of this beautiful plant is not known; some botanists supposing it to come from North America, and some 
from Nepaul!! The latter appears very improbable, as no other species of the genus has ever been fonnd in India. It was sent to England from Germany, in 1827; and it appears most probable, as is suggested in Sweet's British Flower Garden, that it is a hybrid, originated in Germany. Godetia bifrons, commonly called Enothera bifrons, is a hybrid raised in the London Horticultural Socicty's Garden, between G. roseo-alba, and G. Lindleyana. The seeds of hoth G. roseo-alba and G. bifrons are to be procured in every seed-shop; and the plants will require the same culture as directed for G. purpurea. Professor Don, in Sweet's British Flower Garden, has called another species $E$. bifrons, but it is a biennial and has yellow flowers; and besides, we do not know where seeds of it are to be met with. The seeds commonly sold under the name of $E$. bifrons, are those of Godetia bifrons, the hybrid we have above mentioned.

\section{5.-GODETIA QUADRIVULNERA, Spach. THE FOUR-SPOTTED GODETIA.}

Sysoryme.-Enothera quadrivulnera, Dougl.

Exgruving.-Bot. Reg. t. 1119.

Specific Cuaractrm. - Stem declinate, branched, weak, puberulous.
Leaves linear-lanceolate, somewhat denticulated, puberulous. Petals with crenulated margins. Capsule tetragonal, attenuated at the apex, villous.-(G. Don.)

Description, \&c.-A pretty little flower, of a pale lilac, marked with spots of a reddish lilac of a much darker colour. The plant has slender stems, and small leaves. ' It is a native of the north-west coast of North America, where it was found by Douglas growing on the banks of streams, in 1826. From its delicate habit of growth, it is a very good kind for growing in a pot, as it will become " a dense tuft of stems, about six inches high, which are almost covered with leaves, and elegant lilac flowers."-(Bot. Reg. 1119.) When sown in the open border, it may be treated like G. purpurea, but from its low labit of growth it will not require much thinning, as it must be grown in masses to produce a proper effect. This species does well sown in September, either in pots in a slight hotbed, or in the open ground to stand through the winter and to flower early in spring.

\section{6.-GODETIA LINDLEYANA, Spach. DR. LINDLEY'S GODETIA.}

Srroxyme. - Enothera Lindleyii, Douglas.

Engruvisgs.-Bot. Mag. t. 2832.

Specific Character._Stem ascending, diffuse, branched. Leaves linear-lanceolato, quite entire, glabrous. Capsules round, elongated, acute, larger than the lcaves. Petals entire, twa-coloured.-(Douglas.)

Descniption, \&c.-A very handsome species of Godetia, very closely resembling G. quadrivulnera, but with larger flowers, and growing a foot or eighteen inches high. Its eapsule is also smooth, instead of furrowed, and its leaves are on short footstalks. It is a native of the north-west coast of North America, where it was found by Douglas in 1826, growing in a dry open situation. It is quite hardy, and if the seeds (which are to be procured in all the seed-shops) are sown in March or April, it will come into flower in June, and will continue flowering till killed by frost. As it requires a dry soil and an open situation, it is not suitable for sowing in small close gardens full of trees, the soil in which is generally rich and damp. It does best in a poor soil ; as, where the soil is rich, the colours become so faint as to make the flowers look almost like those of G. roseo-alba, or G. bifrons. 


\section{7.-GODETIA TENELLA, Spach. THE DELICATE GODETIA.}

Synonyme.-CEnothern tenella, Cav.

Enoravisg.-Bot. Mag. t. 2424.

Spectric Character.-Stem branched, erect. Lueaves linear, spatulate. Potals obovate, rather retuse, violaceous. Style longer than the stamens, which are crect, hut much oliorter than the petals. Segments of stigma narrow, short. Capsule furrowed, cylindrical, curved, downy, longer than the bracteas.-(G. Don.)

Description, Scc.-Rather a pretty species, with glaucous leaves, and purple flowers. It seldom grows more than six inches or eight inches high, and is rather tender, being a native of Chili. It was introduced in 1823. The kind called in the seed-shops Enothera tenuifolia, differs so very little from this specios, that it appears only a variety. Both kinds slould not be sown till the latter end of April or May, as eold winds would injure the delicate young plants. They will begin to flower in July, and will continue flowering till killed by frost.

\section{8.-GODETIA VIMINEA, spach. THE TWIGGY GODETIA.}

SYNoNYME-GEothers viminea.

Enerating.-Bot. Mag. t. 2873.

Speciric Character.-Stem erect and glabrous, with long, slender,

rod-like branches. Leaves lanceolate, glaucous, entire. Capsules eylindrical, attenuated, furrowed, pubescent. - (Douglas.)

Description, \&c.-This is a very distinct species. It grows three or four feet high, with a " pale, almost white, and polished" stem, and numerous long slender branches. The flowers are rather large, of a pale purple or lilac, with long yellow anthers, and a deep rich purple stigma. It was found by Douglas in the Californian prairies, flowering in dry situations in April ; but in the low moist meadows, near the rivers, it flowered all the summer. In the dry ground, the plant was comparatively small, but its flowers were highly coloured; and in the low moist ground, the plant, though it had paler flowers, grew so large and strong, that Dr. Lindley calls it a sort of woody annual. It was introduced in 1826. It is perfectly hardy, and may be sown at almost any season. If sown in September, it will flower very early in spring, and if sown in spring, it will flower in about two months after sowing. In rieh soil, it grows very large and strong, and requires abundance of room.

All these kinds of Godetia are generally called CEnotheras in the seed-shops; but the common specific names are the same as those here given. All the purchaser lias to do, therefore, in case of any difficulty occurring, is to change the name of Godetia into Enothera, when any specics is asked for.

\section{9.-GODETIA RUBICUNDA, Lind. THE RUDDY GODETIA.}

Enoravines.-Bot. Reg. t. 1856; and our fig. 3, in Plate 8.

Spectric Charactzr,-Erect. Leaves linear-lanceolate, slightly toothed, grecn. Petals roundish or wedge-shaped, nudulate, of ono colour. Alternato stamens less than the others. Anthers of a fiery red, but yellow at the apex, where they are turned back. Stigmas pallid. Capsules lincar, sessile, truncated. Sceds elongated and wedge-shaped.—(Lindl.)

Description, \&c.-A very showy species, witl. a branching stem, growing about two feet high, and pernaps the handsomest of all the kinds of Godetia. The flowers are large, and of a glowing ruddy hue, dcepening into flame-colour in the centre. The stamens are also flame-colour, recurved and tipped with yellow; and the stigma is large and nearly whitc. This very handsome flower was introduced by Douglas, who sent its seeds home from California, in 1835. It is quite hardy, and though so recently introduced, its seeds ripen in such abundance, that 
they are to be found in every seed-shop. As it is rather tall-growing, it will, in confined situations, Iook better if tied up than if left loose. It is, however, of a very robust habit; and if allowed' plenty of air and room, it will be found strong enough to stand alone.

\section{0.-GODETIA LEPIDA, Lindl. THE PRETTY GODETIA.}

Evcrunings.-Bet. Reg. t. 1849 ; and our fig. 4, in Plate 8. | than the petals, the alternate oncs shorter than the others. Capsules Specific Character. - Erect. Leaves ovate-lanceolate, entire. sessile; ovate-oblang, hairy.-( Lindl.) Petals subrhomboid, obtusely denticulated. Stamens one-third shorter

Description, \&c.-A pretty flower, a native of California, introduced by Douglas in 1835. It is remarkable for the dark spots on the upper part of its petals, and for the rich dark purple of its stigma ; its capsules are short and hairy ; and its leaves, which are of a bluish green, are also covered with a kind of down. The plant grows about a foot ligh; and its seeds may be procured in every seed-shop. It is more suitable for small gardens than G. rubicunda, on account of its more compact habit of growth; and where sown in large patches, and each plant after thinning allowed sufficient room to spread, it forms a dense mass of flowers, and is very ornamental.

\section{1.-GODHTIA VINOSA, Lindl. THE WINE-STAINED GODETIA.}

Evgriving._-Bot. Reg. t. 1880 ; and our fig. 1, in Plate 8. |alternate stamens less. Anthers crimson, yellowish at the summit. Specific CuLractrr.-Erect. Leaves linear-obleng, subdentated, Tube of the calyx not more than one-third tho length of the limb. glabrous. Petals roundish, wedge-shaped, undulated, witheut blotehes; $\mid$ Sceds of a dark brown and self-coloured.—(Lindl.)

Description, \&c.-A plant somewhat resembling G. rubicunda in its habit of growth, but differing in being much more slender. The flowers are white, slightly tinted with a reddish lilac, as though stained with port wine. It was introdnced at the same time as G. rubicunda and G. lepida; and, like those plants, it is a native of California. All these plants are quite hardy, and very ornamental ; and they may all be sown in September to flower early in spring; in March, to flower in May; and in May to flower in July and Aygust. G. vinosa requires the same treatment as G. rubicunda; but being of a more slender habit of growth, it should always have some support.

\section{GENUS III.}

\section{CLARKIA, Pursh. THE CLARKIA.}

Lin. Syst. OCTANDRIA MONOGYNIA.

Generic Craructer.-Limb of the calyx 4-parted. Petals 4, tripartite. Capsule 4-celled. Seeds net pappous.

\section{Clarkia PUlChella, Pursh. THE FAir Clarkia.}

Engruvings.-Bot. Mag. t. 2918; Bot. Reg. t. 1100; and our fig.

1, in Plate 9.

Variety.-C. p.2. alba. Hert., our fig. 2, in Ptate 9.
Specific Cuaructer.-Leaves linear. Petals deeply 3-lobed.(G. Don.)

Description, \&c.-This pretty annual was first discovered by Captains Lewis and Clarke, in 1803, though it was not introduced into England till 1826. In 1803, when Jefferson was president of the United States, he 


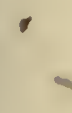

i

-

4

-

t.

s

1 


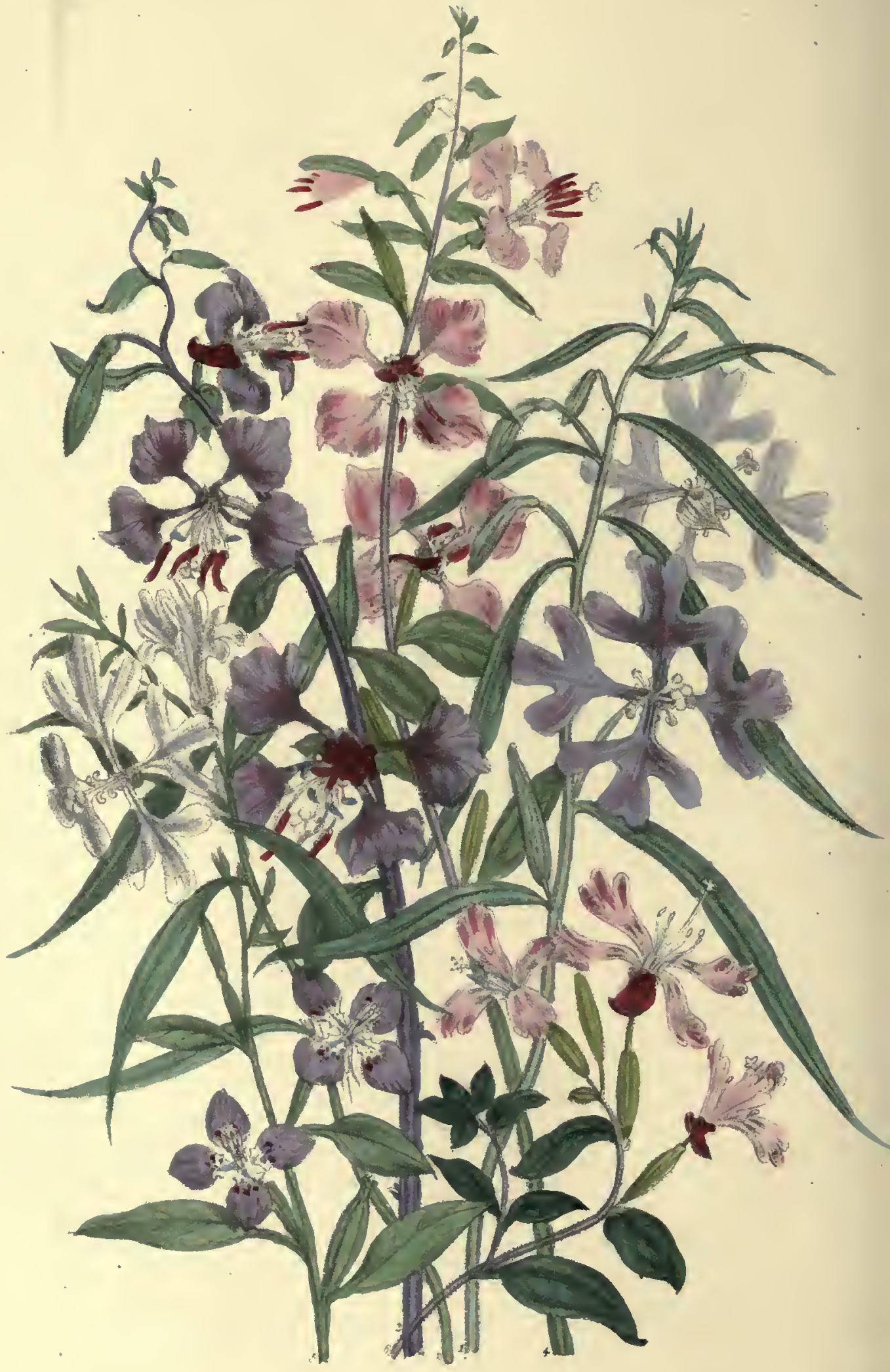

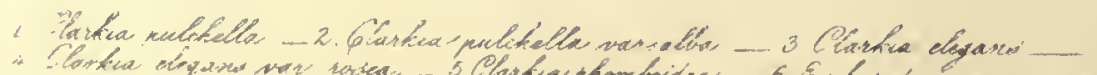




proposed to Congress to send some competent persons to ascend the Missouri, cross the Stony Mountains, and explore the western part of North America. The persons chosen wore, Lewis, who had been two years private secretary to Jefferson, and William Clarke, hoth of whom received captains' commissions before their departure. The expedition occupicd three years, and was very successful; and during the course of it, the Clarkia was discovered by Captain Clarke, and dried specimens of it were sent to Pursh, the naturalist, who described and figured it in his Flora of North America. No seeds were however collected, and nothing more was heard of the Clarkia in England till 1826, when it was again discovered, and seeds of it sent home, by Douglas. It was one of the first Californian annuals imported. The Clarkias may be sown like the Godetias, in September, March, and $\mathrm{May}$; and they require the same treatment. Clarkia pulchella looks very well mixed with mignonette. In this case, the seeds should not be sown in patches, but a bed of rather poor soil should be levelled, and sown all over thialy with Clarkia, and then with mignonette. When the plants come up, both kinds should be thinned out so as to leave the plants about two inches apart and not more, all over the bed; and when they come into flower they will form a rich mass, and have a very pretty effect, the bushiness of the mignonette hiding the maked stalks of the Clarkia.

\section{2.-CLARKIA ELEGANS, Douglas. THE ELEGANT CLARKIA.}

Engrayings.—Bot. Mag. t. 3592 ; Bot. Reg. t. 1575 ; Brit. Flow. Gard. Second Series, t. 209; and our fig. 3, in Plate 9.

ธิчnомyмe.-Pbeostoma Douglasii, Spach.

Varieties.-C. $\varepsilon_{0}$ 2. rosea Hort.; our fig. 4, in Plate 9, has the tlowers of a pale brick-red, rather than rose-colour. It is very handsome.
C. e. 3 fl. pl. Hort. bas the flowers semi-double.

Sercific Character.-Leaves avate, dentated and entire. Stem glaucous and branching. Petals rhomboid, undivided. Stigma pubescent, ovary hairy.-( Lindl.)

Description, \&c.-This elegant flower was introduced by Donglas from California, in 1832. It is rather different in its habit from C. pulchella, as it produces its flowers on a long raceme; the raceme growing longer, and expanding fresh flowers at the top, as those below drop and give place to ripe capsules. Clarkia elegans may be sown in April or May, and will continue in full beauty and continually opening fresh flowers from July to October. Its seeds may be procured at every seed-shop.

\section{3.-CLARKIA RHOMBOIDEA, Doug. THE RHOMBOID CLARKIA.}

SyNoNYME.-C. gauroides, Hort.

Evgravings.-Bot. Reg.t. 1981; Brit. Flow. Gard., Second Series, t. 379 ; and our fig. 5 , iu Plato 9.
Specific Character.-Petals entire, rhomboid. Leaves lanceolate. (G. Don.)

Descriptions, \&c.-This species is easily distinguished from the other kinds by the shape of its petals. It has slender stems, and grows from one foot to two fect high. It was discovered by Douglas at the same time as C. pulchella, and his description of it was published in Sir W. J. Hooker's North American Flora; but le did not send sceds of it home till his last expedition, and these being found among somo of his seed-papers in 1836, they were sown in the Horticultural Society's Garden, and produced flowers. Mr. Douglas discovered another species of Clarkia at the same time, of which he was unable to procure seeds, but wlich he named C. unguiculata, the clawed Clarkia; this species has not yet been introduced. The seeds of Clarkia rhomboidea, under the name of Clarkia gaueroides, may be had at Charlwood's Covent Garden, Carter's Holborn, and most other seed-shops. 
Carter has the names of three other kinds of Clarkia, one large-flowered, and two fringed varieties of C. pulchella, but we have never heard of them anywhere else, and do not know what they are.

Clarkia rhomboidea, Dr. Lindley observes, "is interesting in a botanical point of view, on account of its flowers indicating the nearest approach yet known among the Onagraceous plants to the indefinite stamens of the Myrtaceə."

\section{GENUS IV. EUCHARIDIUM, Fisch. et Mey.}

Generic Character.-Tube of the calyx above the ovarium, elongnted, filiform, with a four-parted deciduous limb. Petals fonr, clawed, trifid. Stamens four. Stigma two-lobed. Capsule four-celled, four-valved, dehiscent. Seeds numorous.-(Fisch. et Meyer.)

\section{1.-EUCHARIDIUM CONCINNUM, Fisch. et Meyer. THE NEAT EUCHARIDIUM.}

Engravings.-Bot. Mag. t. 3589; Bot. Reg. t. 1962; and our fig. 6, in Plate 9.

Specific Character.-Pubescent. Leaves petiolate, ovate, entire. Flowers axillary, solitary.

DesCription, \&c.-A pretty and very neat little plant, growing about six or eight inches high, and flowering freely. It was found near the Russian colony of Ross in New California, and sent to the London Horticultural Society from St. Petersburg in 1836. Seeds may be procured of Mr. Charlwood, and at Mr. Henderson's nursery, Pine Apple Place, Edgeware Road, where our drawing was made in the autumn of 1838 . The plant, from its neat and compact habit of growth, is well adapted for growing in a pot, or in a small garden, and the seeds may be sown at any period of the spring or summer, as they will generally flower at any time in six weeks after sowing.

GENUS V.

\section{GAURA, Lin. THE GAURA.}

Lin. Syst. OCTANDRIA MONOGYNIA.

Generic Chanactrr.- - Limb of calyx 3-4-parted. Petals four. Ovary 3-4-sided, ono-celled. Seeds naked.

\section{1.-GAURA TRIPETALA, Cav. THE THREE-PETALLED GAURA.}

\begin{tabular}{l|l} 
Synonyme -G. hexandra, Ortega. & Flowers hexandrous. Sepals three, defiexed. Petals three, rose-enloured,
\end{tabular} SPEcific Canacter. - Leaves lanceolate-linear, a little toothed.

Description, \&c.-A half-hardy annual, with whitish flowers, that turn pink as they fade. It is a native of Mexico, introduced in 1804. It is very inferior in beauty to the perennial species of Gaura, and is only desorving of cultivation where there is abundance of room. Seeds may be had at Charlwood's. They should be sown in May, and will flower in August. 
GENUS VI.

LOPEZIA, Cav. THE LOPEZIA.

Lin. Syst. MONANDRIA MONOGYNIA.

Genersc Charactra, - Limb of the calyz four-parted. Petals four, irregular. Stamens two, only one of which is fcrtile. Capsule subglobose, four-cellcd.-(G. Don.)

\section{1.-Lóopezia RACEMOSA, Cav. THE BRANCHING LOPEZIA.}

Engraving.-Bot. Mag. t. 254.

Synonyme.-L. Mexicana, Jacq.

Specific Character. - Leaves alternate, ovate-lanceolate, serrated, tapering to the baso. Racemes terminating the branches. Bracteas much shorter than the pedicels.-(G. Don.)

Description, \&o.-A slender plant, terminating in a brawehed raceme of very small pinkish flowers. The petals of the flowers are very narrow, and one of them is darker than the others. The capsules are small and reund, and they leok rather pretty, hanging like single berries on their leng footstalks. The plant is a native of Mexico, and was introduced in 1792. Seeds may be precured in any seed-sbep, and if sown in March or April, they will flower in September and October. The Lepezia is a dangerous plant to grow in a hotbed, as in that case it is generally attacked by the red spider (Acarns telarius).

\section{2.-LOPEZIA CORONATA, Andr. THE CROWNED LOPEZIA.}

Engraving.-Bot, Rep. 551 .

Sимомуме.-L. Mexicana; var. coronata, Dec.

Specific Character.-Plant glabrous. Branehes angular. Leaves

alternate, ovate, serrated, attenuated at tho base. Bracteas exceeding to pedicels.-(G. Don.)

Descriptron, \&t.-The flowers of this kind of Lepezin (which is also a native of Mexico, introduced in 1804) are larger and censequently handsemer than those of L.racemosa; but they have the same disadvantages. They are too tender to stand the winter, or bear to be sown very early in spring in the open greund; and if raised in a hetbed, they are almest sure to be attacked by the red spider; which not enly destreys the beauty of their leaves, but will infest every other plant in the hetbed. The Lepezias are alse undesirable plants to grow in a small garden, frem the grcat length of time (generally five er six months) which elapses between the time of sowing the seeds and the flowering of the plants; and frem their flowers appearing so very late in the seasen, that they can only display their beauty a short time before they are destreyed by frost. 


\section{CHAPTER VII.}

\section{LOASACE $\mathbb{E}$.}

Essentua Ciranacter. .Calyx superior, fivo-eleft. Petals five, cucullate. Stamens perigynous, or partly adelphous. Styles combined. Plamebtas parietal. Fruit capsular, or succulent.-(G. Don.)

\section{GENUS I.}

\section{LOASA, Adan. THE LOASA.}

\section{Lin. Syst. POLYADELPHIA POLYANDRIA, OR POLYANDRIA MONOGYNIA.}

Gengric Character.-Tube of the calyx not twisted, limb five- sterile and free; inner ones disposed in five bundles, but distinct. parted. Petals ten; five outer ones cucullate, five inner oncs scaleformed, bearing two sterile filaments inside. Outer series of stamens

Description, \&xc.-The flowers of the plants belonging to this genus are so ornamental, that the plants would be general favourites were it not for their stings, which are much worse than those of the nettle. Great confusion exists respecting the different species of Loasa, some botanists giving to almost every species the name of some other species as a synonyme, though the plants, when seen together, appear quite distinct. The fact is, all the Loasas assume very different appearances according to the kind of soil in which they are grown. Seeds sown in rich ground produce plants differing not only in the size, but in the colour of the flower, from plants produced by seeds out of the same seed-pods, sown in poor ground; and the specimens thus raised have occasionally appeared so different, that some botanists have taken them for distinct species. It is probable, however, that all the ycllow-flowered kinds are varieties of one or two species-probably of $L$. nitida and L. Placei-and that $L$. alba is a variety of L. nitida. L. incana is described by Dr. Grabam as a perennial and suffruticose, and therefore we have omitted it in our described species, though we may here mention that its flowers are white, and its leaves covered with a kind of mealiness, which makes them look as though they were powdered. The plant called Loasa lateritia, or L. aurantiaca in the nurseries and seed-shops, is probably not a Loasa at all ; or, at any rate, as it is a tall climbing plant, it can hardly be the Loasa lateritia described as almost stemless by Dr. Arnott in Cheek's Edinburgh Journal. This description was taken by Dr. Arnott from the MS. notes of Dr. Gillies, who was well acquainted with South American plants, as he resided for many years at Mendoza at the foot of the Andes, and thence made frequent excursions across the Cordilleras to the shores of the Pacific on the one side, and across the Pampas to the Atlantic on the other. All the plants belonging to the genus Loasa have the tube of the calyx not twisted, but the plant called Loasa lateritia has the tube of the calyx twisted, and indeed strongly marked with spiral ribs. These spiral ribs form one of the distinctive marks of the genus Caiophora Presl, so that probably the true name of the plant in question may eventually be found to be Caiophora punicea, 



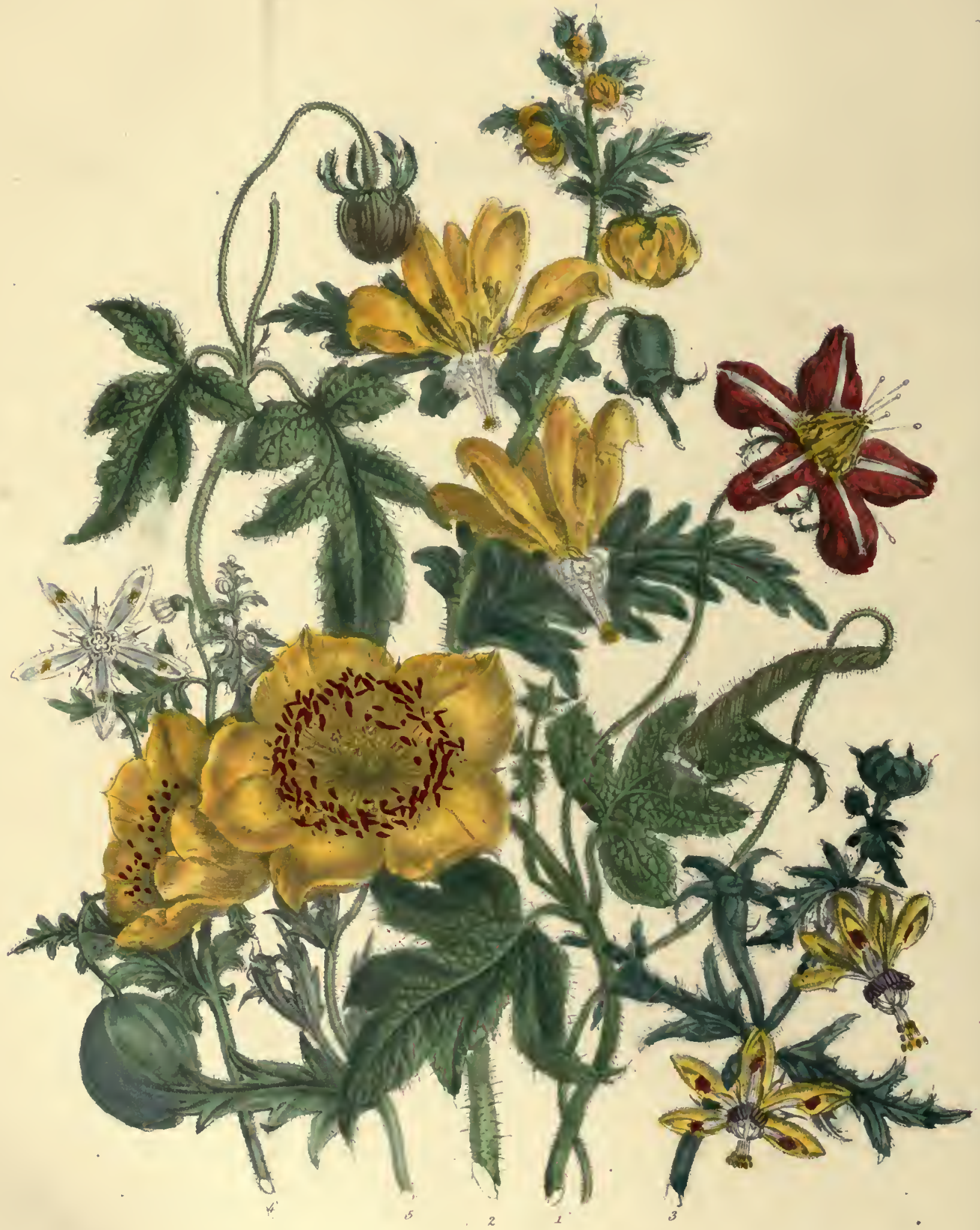




the Blumenbachia punicea of Mr. G. Don, and the Loasa punicea of Ruiz and Pavon. As, however, the plant is now generally known by the name of Loasa lateritia in the seed-shops, and as it has been called so by Dr. Lindley (Bot. Reg. 1838, fol. 22), we shall describe it by that name in the following page.

\section{1.-LOASA NITIDA, Lam. THE SHINING LOASA, or CHILIAN NETTLE PLANT.}

Exgravings.-Brit. Flow. Gard., Second Seriea, t. 195; Bot. Mag. | Spectric Charactzr.-Prostrate. Leavea cordate-lobate, dentated, t. 2372.

VARIETY.-L.n. 2.tricolor, G. Don. syn. L. tricolor, Bot. Reg.t.667. shining above, upper ones aessile. Peduncles axillary.-( Lam.

Description, \&cc.-The flowers of this species are yellow, and the leaves of a bright shining green. The flowers of the variety have rather more red in them, but the difference is very trifling. The stem is covered with long rigid hairs, which have each " $a$ small bag or vesicle at the base, containing the liquor for transfusion through the sting when in action." This liquid stings severely, and the burning pain it occasions continues generally for a week or ten days, and the red mark often remains for weeks and even months. Loasa nitida is a native of Chili, and was introduced in 1822. In its native country it grows wild among rocks; and if grown in Engiand in a poor sandy soil, it will have slender stems, which lie upon the ground, and very richly coloured flowers; but if grown in rich soil, the stem will be strong and upright, and the flowers pale. Seeds of both $L$. nitida and L. tricolor are common in the seed-shops; and if sown in the open ground in May, they will flower in July, and continue in flower till September or October.

\section{2.-LOASA PLACEI, Lindl. MR. PLACE'S LOASA.}

Enoranngs.-Bot. Reg. t. 1599 ; and our fig. 3, in Plate 10.

VARIETY. -L. P. 2 acanthifolia, syn. L. acanthifolia. Ker in Bot. Reg. t. 785 . apper onea sessile. Pedicels axillary. Sepala hardly touthed, reflcxcd, length of the petals. Wings of the corolla scsgile and quite entire, the longcst of the stamens aa long as the petals. Style bent, longcr than the atamens.- (G. Don.)

Description, \&c.-A tall strong-growing plant, rising to the height of two feet or more, with a thick, erect stcin. It is a native of Chili, and was introduced in 1800. It requires a poor dry soil, and yet abundance of moisture, for the colours to have their full brillinncy. In rich soil the flowers become larger and paler; and the plant assumes the appearance of L. acanthifolia. This species is generally raised on a hotbed, and planted out in May; but it may be sown in May in the open ground.

\section{3.-LOASA AMBROSIÆFOLIA, Juss. THE AMBROSIA-LEAVED LOASA.}

Engravings.-Bot. Reg. t. 1390 ; and our fig. 2, in Plate 10. SxNowyses,-L. hispida, Graham. ? L. bryoniæfolia, Schrad. 8 L. grandiflora, Lam.
Sprcific Charactrr. - Lea ves alternate, bipinnatifid, lobes bluntiah. Pedicela extra-axillary. Lobes of the calyx lanceolato-linear, acute, shortcr than the petalo.-(Dec.)

Description, \&c.-A very handsome, strong-growing species, with large yellow flowers, and a very short ovate seed-vessel. It is a native of Lima, from which country it was introduced in 1829. It grows about two and a half fect high, and may be sown in the open border in May, when it will flower from July to September, and ripen abundance of sceds. The seeds are sold in some of the sced-shops under the name of $L$. bryonicefolia. 


\section{4.- LOASA ALBA, D. Don. THE WHI'TE LOASA.}

Engraving.-Brit. Flow. Gard., Second Series, t. 192.

Specific Character.-Canescent. Leaves opposite, paluiate, tootlıed.

Calyx in segments, long and linear. Exterior appendages hatehetformed and awned.-(D. Don.)

Descniption, \&c.-A slender-stemmed plant, with white flowers, introduced in 1832, by Mr. Hugh Cuming, from Clili. Sceds of this species are now common in the seed-shops, and like the others, they may be sown in the open border in May.

\section{5.-LOASA LATERITIA, Hook. THE BRICK-RED LOASA.}

Synoxymes-? Caiophora punicea P C. ccrciifolia or C. carduifolia, Presl.; ? Blumenbachia punicea, G. Don ; ? Loasa punicea, Ruiz et Pavon ; L. aurantiaca, Hort. ; L. coccinea, Hort.

Engravincs.-Bot. Mag. t. 3632 ; Bot. Reg. 1838, t. 22 ; and our fig. 1 , in Plate 10.
Specific Character.-Climbing. Leaves cordate, palmate, lobate. Petals sessile, keeled, and of a brick-red colour. Appendages 3-lobed, truucate; each furnished, inside, with two membranous bristles. Capsule eylindrical, with spiral ribs.

Description, 8cc.-A climbing plant, with large dark red flowers and very curiously twisted capsules, which are long and ornamental. It is a native of Tucuman (lying between the Rio do la Plata and the Andes), where it was discovered by Mr. Tweedie, a botanieal collector, and seeds of it sent to the Glasgow Botanical Garden in 1836. It was at first supposed to be tender, and grown in a hothouse, but it was soon found to suceeed perfectly well in the open border, where it ripened seeds so abundantly as to be now common in every seed-shop. The seeds may either be sown in the open border in May, or in a hotbed in March; but perhaps the best way for the amateur to procure fine plants, is to purchase, in the month of May, young plants which have been raised by a nurseryman on a hotbed, and are just ready for planting out in the open border. This is indeed perhaps the best method to be pursued by persons, not keeping a regular gardener, with regard to all annuals which should be raised on a hotbed; as in this manner laalf-liardy plants may be procured for a mere trifle, compared with the expense and trouble of a hotbed, at the very time when they are wanted.

The Loasa lateritia may be trained in many different ways. A plant in Lee's nursery, Hammersmitl, which had been raised on a hotbed, and planted out in May, was in August, 1838, a splendid pyramidal mass of flowers six or eight feet high; it having been trained to three stakes tied together at the top. From this plant our spccimen was taken, and the species is called Loasa aurantiaca in our Plate 10, from that being the name given to the plant in the Hammersmith nursery. At Mrs. Lawrence's villa, at Drayton Green, it was trained over lattice-work fourteen feet or fifteen feet high. In other places, banks were covered with it, the stems being pegged down in various places to keep them elose to the ground; and in others the plants were drawn througln hoops, like those used for Dahlias, and suffered to hang loosely over them. In every case the plant was found to grow vigorously in the open air, and to continue flowering abundantly till killed by frost. It was grown in any common garden seil; but it was found to thrive best in a sandy loam.

All the kinds of Loasa have very showy flowers, and produce a good effect in a garden when trained over a trellis. For this purpose L. lateritia, L. alba, and $L$. nitida, may be sown at the foot of a low trellis: and as the plants grow they may be trained over it. No lady, however, should attempt to train or gather a Loasa, without wearing leatheru gleves; with this precaution, all the plants belonging to the genus are well suited to female culture, as they are easily made to assume any form that may be desired, and their beauty principally depends on the manner in which they are trained. They also amply repay attention in watering, \&c., by their inereased beauty. 
GENUS II.

\section{BLUMENBACHIA, Schrad. THE BLUMENBACHIA.}

\section{Lin. Syst. POLYADELPHIA POLYANDRA.}

Grasric Cunacter.-Tube of the calyx spirally twisted. Limb $\mid$ stamens disposed in five bundles. Fruit dividing into ten parts at the five-parted. Petals ten; fire outer ones cucullate, and the five inner base. (G. Don.)

ones scale-formed, each scale enclosing two sterile filaments. Fertilo $\mid$.

\section{1.-BLUMENBACHIA INSIGNIS, Schrad. THE SHOWY BLUMENBACHIA.}

Engravisgs.-Bot. Mag. t. 2865 ; Brit. Fl. Gard. t. 171; and our | L. patula, Graham.

fig. 4, in Plate 10.

Srwonymes.-B. parviflora, Gill. Loasa palmata, Spreng. times five lobed, upper ones deeply bipinnatifid.-(G. Don.)

Description, \&c.-The stem is much branched, espeeially near the bottom, and both stems and branehes are thickly covered with bristles, which inflict a slight sting when touched. The leaves are deeply cut, and also clothed with a short pubescence. The flowers are white, and are produced in great abundance. It is a native of Chili and Brazil, and it was introduced in 1826. It will grow perfectly well in the open air, if sown in a rich light soil in May; or in a sheltered situation it may be sown in autumn, to stand throngh the winter. It flowers in June or July, and continues to unfold its blossoms in suceession, till September or October. It is well adapted for raising on a hotbed, and growing in pots, to flower early in the season in a greenhouse, or living room; as it makes a bushy little plant, six inehes or eight inelies high, and is covered witl flowers. Its eurious flowers may indeed be seen to best advantage in this way of treating it, as it cannot well be gathered for a nosegay, on account of its stings. It is seldom seen in flower-gardens, though last year (1838) there was a beautiful bcd of it in the garden of Thomas Harris, Esq., Kingsbury, from which the specimen for our drawing was obtained. Seeds may be purchased at Charlwood's, Carter's, and other seed-shops. The plant may also be propagated by euttings, which, if kept through the winter, will flower early the following summcr.

\section{2.-BLUMENBACHIA MULTIFIDA, Hook. MULTIFID-LEAVED BLUMENBACHIA.}

Exgravisc:-Bot. Mag. t. 3599.

Specific Churactrr.-Leavcs palmate, with bipinnatifid lobes. Flowers bibracteated. Petals hispid.-(Hook.)

Description, \&c.-A more vigorous-growing speeies than $B$. insignis, with larger flowcrs, and mueh larger leaves. It was discovered by Mr. Tweedie, in the Pampas of Buenos Ayres, and seeds were sent home by him to the Glasgow Botanie Garden in 1837, when the plants raised from them proved quite hardy, and flowered in the open borders abundantly. The footstalks of the flowers are very long, and though they are erect, the flowers at their extremity bend gracefully. Every part of the plant, however, including the flowers, is eovered with hairs, which sting nearly as severely as those of Loasa. We have never seen this plant in the gardens ncar London; and we do not suppose the seed can be obtained anywhere but from the Botanie Garden, Glasgow. 


\title{
GENUS III.
}

\section{BARTONIA, Nutt. THE BARTONIA.}

\author{
Lin. Syst. ICOSANDRIA MONOGYNIA.
}

Generac Cyaracter.-Tube of the calyx cylindrical. Limb five-parted. Petals 5-10, about equal in shape. Stamens uumerous. Capsule 3-7-valved, each placeata beariog two rows of sceds.-(G. Don.)

\section{1.-BARTONIA AUREA, Lindl. THE GOLDEN BARTONIA.}

Engúanings.-Bot. Reg. t. 1831 ; Brit. Fl. Gard. 2 ad Series, $t$. 357 and our fig. 5 , ia Plate 10.

Specific Character.-Leaves ovate-lanceolate, pionatifid; segments

of the lower unes decply serrated. Bractens ovato, or pinaatifid. Petals five, obovate, poiated. Filamcats numerous, filiform.(Lindl.)

Descriptron, \&c.-One of the most beautiful of all the beautiful plants introduced from California by the unfortunate Douglas. This excellent botanist, who was killed a few years since, by falling into a pit placed to entrap wild cattle in the Sandwich Islands, introduced more ornamental annuals than any other collector. The Bartonia aurea (which was introduced in 1835) is incleed one of the most beautiful of garden flowers; but " it is only beneath the bright sunshine," Dr. Lindley observes, "that its splendid flowers unfold. In the early morning, the plant is a shabby bush, with pale, greenish-grey branches, and weedy leaves; but as the sun exercises his influence, the petals gradually unroll, as if in acknowledgment of his power, till every branch is radiant with gold : and so metallic is the lustre of the inside of its petals, that one would really think they must be composed of something more solid and enduring than the delicate and perishable tissue of a flower."-(Bot. Reg. fol. 1831.) This description so admirably depicts the plant, that we could not resist the temptation of quoting it entire. Dr. Lindley adds, that the seeds should be sown in a sheltered situation, as the branches are very brittle, and easily broken by the wind; and that the plants require a rich moist soil. We sowed some seeds, procured from Mr. Charlwood, in a warm rich border, in the open air, in May 1838, taking care to give the young plants plenty of water, and in the latter end of June they were splendidly in flower, producing a succession of blossoms till the plants were killed by the frost. This frost was a very slight one; and though it killed the Bartonia, and a Calandrinianear it, did not hurt even the Geraniums (Pelargoniums), which were trained against a wall behind the Bartonia; while a crimson Verbena (Verbena Tweedieana)lived even after the Geraniums were killed. We Inention this, to give some idea of the relative degree of hardiness of the plants, though, of course, even this degree will differ greatly in different situations.

\section{2.-BARTONIA ALBESCENS, Gill, and Arnott. THE WHITE-STALKED BARTONIA.}

Enoravino.-Brit. Fl. Gard. 2ud Scries, t. 182.

Specific Charmetzr,-Ifeaves siauated. Petals scarcely longer than $\mid$ mata three, scparate.-(D. Don.)

Descriprios, \&c.-A weedy-looking plant, with large, coarse-growing leaves, and very small flowers of a dingy white and yellowisl tinge. The plant is a native of Chili, introduced in 1832, and as it reguires to be raised on a lotbed, it is not Jikely to be much grown in flower-gardens in England. 
GENUS IV.

\section{SCYPHANTHUS, Swt. SCYPHANTHUS.}

\section{Lin. Syst. POLYADELPHIA POLYANDRIA.}

Genenc Cumueren.-Calyx deeply five-parted. Pctals five, on short claws. Appendages peltate at the apex, lobed, and three-horned. Stamens numerous, the ten outer ones sterilo. Capsule prismatic, silique-formed, crowned by the tube of the calyx, three-valved at the apex.-(G. Don.)

\section{1.-SCYPHANTHUS ELEGANS, Swt. THE ELEGANT SCYPHANTHUS.}

Eneraving,-Brit. Flow, Gard, t. 238.

Specific Churactzn.-Stem dichotomous. Segments of lcaves obtuse, cilinted.-( G. Don.)

Description, \&c.-A climbing, or rather twining plant, with long slender stems, forked at every joint, and twisting round each other, or round anything within their reach. The flowers are yellow, and curiously formed, but not very beautiful. It is a native of Chili, and would require to be raised on a hotbed; but it was lost soon aftcr its introduction in 1827, and we have not heard of its having been re-introduced.

\section{CHAPTER VIII.}

\section{CRUCIFER Æ.}

Essextul Craracter.-Sepals four. Petal, four, cruciate. Stamens six, bypogynous, tetradynamous. Fruit a silique, or silicle, rarely a valveless pericarp. - (G. Don.)

Description, \&c.-The Cruciferous plants are easily distinguished from all others by the four petals, of which their single flowers consist, being always placed in such a manner as somcwhat to resemble a Malteso cross; and lence tley take the name of Cruciferous, which signifies cross-bearing. To this order belong several of our commonest vegetables; for cxample, all the cabbage tribe, turnips, mustard and cress, radishes, \&c. All the Cruciferous plants abound in nitrogen; and lencc, when they decay, they not only emit an unpleasant odour like that of decaying animal matter, but they are cqually injurious to the health. Some years ago a fever was occasioned at Cambridge, by a number of cabbages being left above-ground, in a confined space, to rot. None of the plants belonging to this order are poisonous; on the contrary, most of them are considered wholesome and antiscorbutic. The roots of some, such as the horse-radish, are pungent, but none of them are injurious.

The most interesting characteristics of the order, as regards the annual flowers belonging to it, are--that the plants are generally tap-rooted, like the radish, and therefore do not bear transplanting well; that they are nearly all natives of the temperate zones, and thereforc tolerably hardy; that their seeds retain their vegetative 
power for a long time, and therefore that nearly all the seeds that are sown are likely to produce plants; and lastly, that from the quantity of nitrogen they contain, they want foed which produces it, and therefore they require nourishment with animal manure. These are all very important points to be kept in view by the grower of Cruciferous annuals-the first shows that the seeds should be sown where they are to remain, or, if transplanted, that a ball of earth should be kept round their roots; the second, that they may be sown safely in the open air; the third, that the seeds need net be sown very thick; and the fourth, that they will require a rich soil, well manured.

\section{GENUS I.}

\section{MATHIOLA, R. Br. THE STOCK.}

\section{Lin. Syst. TETRADYNAMIA SILIQUOSA.}

Generic Craracter.-Silique somewhat cylindrical. Stigmas connivent, thickened or horned on the back. Calyz hisaccate at the base.(G. Don.)

Description, \&c.-The splendid flowers called stocks, and stock-gilliflowers, are too well known to require description. Most of the kinds are bicnnial, or shrubby; and, indeed, almost the only annual kind known in British gardens, is the commen ten-weok steck (Mathiola annua), and its varieties. The stocks were formerly included in the genus Cheiranthus (the wall-flewer), but they were separated from it by Dr. Brown, principally on acceunt of a difference in the formation of the stigma.

\section{MATHIOLA ANNUA, Sweet. THE ANNUAL OR TEN-IVEEK STOCK.}

Encravings =-Figs. 1, 2, 3, snd 4, in our plate 11.

Srwonymes.-Cheiranthus incanus, $L$ in. Mathiols incans var, $R$. Br. Hesperis æstiva, Inm.

Varietres,-There aro perhaps few species of which there are more varieties. Sorne of the single kinds are white, some striped (see fig. I, in Plate 11), some spotted, some purple, and some crimson; and of the double kinds the vsriety is still greater. Tho double-flowered purplo (fig. 2), snd the double white (fig. 3), are particularly beautiful. Some of the kinds cslled Germsn stocks aro very curious, particularly tho brick-red variety ( fig. 4). Besides these, there are among the double kinds, the crimson, the blush, the pink, the scarlet, the lilac, the rose- coloured, tho brown, and the hrown-purple. Seeds of sll these kinds, and of many intermediste shades, may be purchascd in the seed-shops. Upwards of sixty sorts were grown for many years in the Hammersmith aursery, including what are called Russian, Prussian, and Germsn stocks; pcrhaps the most curious sre those striped with three distinet colours-white, purple, snd crimson; and perhaps tho hsndsomest tho common double crimson. The new giant stock is a very tall, stronggrowing variety, with enormously large flowcra.

Specizic Character. Stem erect, branched. Leaves lanceolato, blunt, hosry. Pods somewhst cylindrical, without glands. (G. Don.)

Description, \&c.-A plant growing from one to two feet high, with an erect branching stem, heary leaves, and long spikes of flowers; the size and richness of colour of these flowers vary greatly in the different varieties, . and some of them are very splendid. The species is a native of the South of Europe by the sea-shore, whence it was introduced in 1731; but the principal varieties have becn originated in England and Germany. The German varieties are particularly beautiful; and the seed saved in that country, from the greater heat of the 
$\checkmark$

.

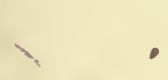

-

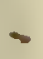

;

$-$ 


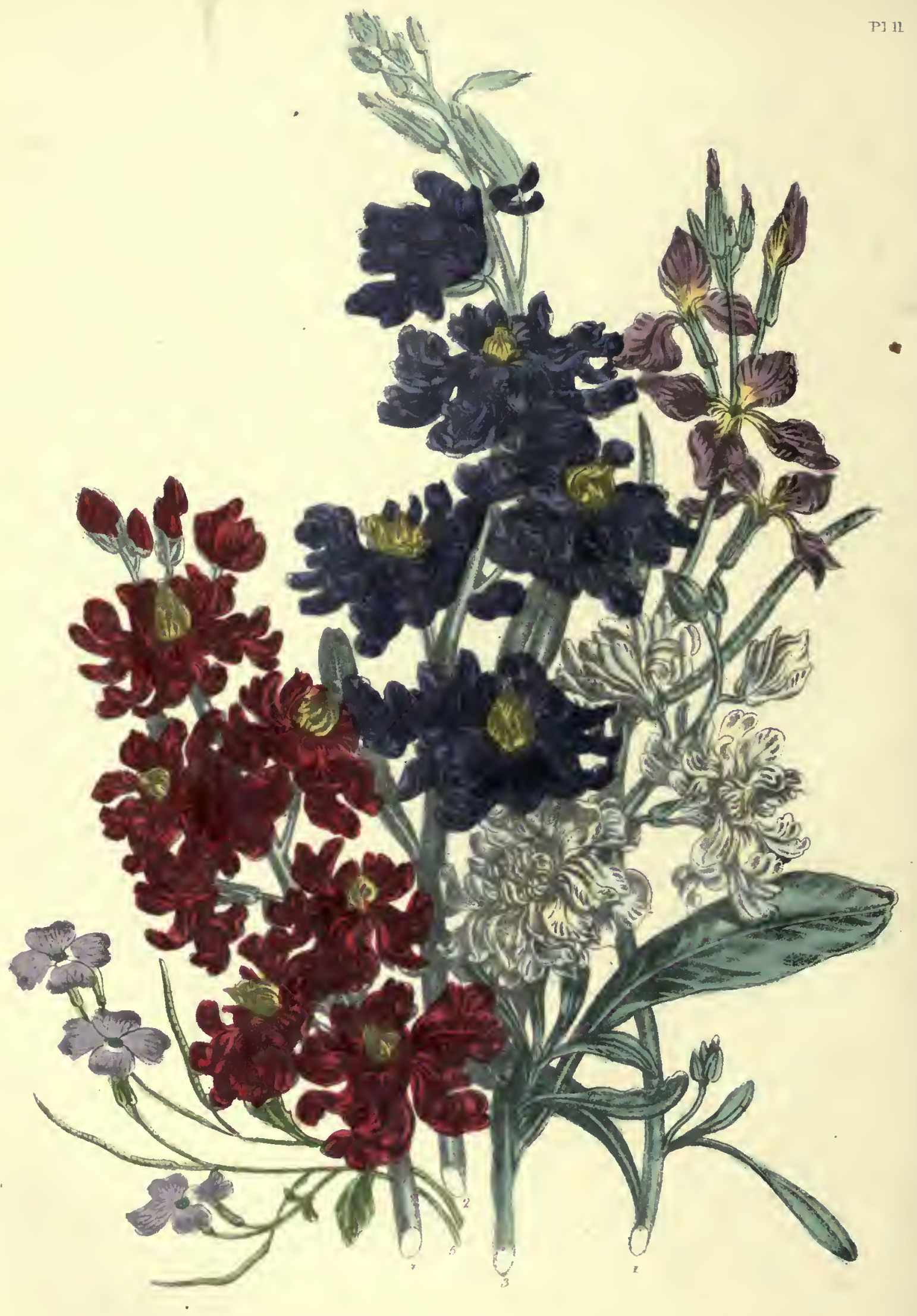



summers, and the great care bestowed by the weavers of Saxony, who are the principal growers of it, is very superior to seed saved in England. What are called the Russian and Prussian varieties, are, generally speaking, all grown in Upper-Saxony by the weavers, who take as much pleasure in growing and saving the seed of their stocks, as the Lancashire weavers do in England in growing their pinks and carnations. Home-saved seed can rarely be depended upon, as, where several varieties are grown near together, spurious varieties are made by the wind carrying the pollen from one plant to another, and the seed can never be kept true. Regular seed-growers preserve only the plants with the best flowers, and throw the other plants away. Russinn and Prussian stocks were so called because they were introduced about tlie time of Bonaparte's retreat from Moscow, when the names of Russia and Prussia were fashionable.

The best seed of the German stocks is said to be procured at Carter"s, Holborn; but very good may be had at Lee's (from whose nursery we have had sixty distinct kinds), and Cliarlwood's.

To produce the finest flowers, the seed should be sown in August, in a bed of rather light soil, which should be covered with a frame; or the seed may be sown in pots, four or five in a pot, and placed in a cold frame. A cold frame means a pit or frame covered with glass, but not heated by manure, or in any other manner. The plants, when they come up, should be kept dry during the winter, to strengthen them, and prevent them from damping off, and in April they should be taken out of their beds, with a ball of earth round their roots, or, if in a pot, tnrned out with the ball entire, and planted in a warm border, in very rich soil. The poor soil that they were raised in will have previonsly elecked their growth ; but planting them in the rich soil after this previons check, will make them grow luxnriantly, and prodnee rich spikes of flowers in June.

Those persons who wish to have fine stocks to flower early in the summer, but who have not a frame to raise them in, or indeed do not like to be troubled with keeping any plants during winter, will find it their best plan to purchase young plants in April or May from a nurseryman, and to plant them in rich soil where they will flower as above stated. These autumn-sown plants have, however, the disadvantage of fading very soon, when exposed to the heat of summer. Their fibrous roots wither, and their dark colours become blotched, or blanched by the sun. The dark purple, in particular, is very apt to become streaked or spotted with white. From this disadvantage, spring-sown plants are free. If sown in February, March, or April, in a dry poor soil, they may be transplanted into a ricls soil in April or May, taking care to preserve earth round the roots, and not to injure the fibres, though in some cases the extreme point of the tap-root may be taken off, to induce it to throw ont more fibres. Other seeds may be sown in May, which will not need transplanting, and which, if preserved from the frost, will continue flowering till Christmas.

Some persons, to make the plants produce larger flowers, take off the side shoots as they appear, and thin the blossom-buds on the spike of flowcrs by taking off every alternate bud; and others water with liquid mannre, \&c., to produce fine plants. In whatever manner they are treated, it must always be remembered that they require great care in transplanting, and that they should be transplanted when quite young. The general rule is, that plants are fit for transplanting whon they have opened their second pair of leaves; and that the transplanting should not be delayed longer than a little after they have produced their third pair. When large plants are removed, it should always be with such a ball of earth attached, that the roots may experience no check from the removal. When the stocks are planted out in the borders for flowering, they are generally placed three together in an angular form, so as to allow ruom for a stake to be placed in the centre to tie them to, if necessary. 


\section{2.-MATHIOLA GRECA, Swt. THE SMOOTH-LEAVED ANNUAL, OR GRECIAN STOCK.}

Srnowyme. Cheiranthus Græcus, Juss.

Spacifie Charucter.-Leaves green, smooth. Pods somewhat compressed.

DEScriptron, \&c.-This kind differs from the common kind in having the leaves smooth and green instead of. hoary. The flowers are purple. It is a native of Greece, and has been long in cultivation in British gardens. Its culture is the same as that of $M$. annua.

\section{3.-MATHIOLA TENELLA, Dec. THE SLENDER ANNUAL STOCK.}

Speific Cauractra. - Stem erect, almost simple. Leaves oblong, sinuately-tootbed, dramn out at the base, eancscent with stellatc pubescence. Siliques pubescent, without glands.-(G.Don.)

Description, \&c.-A slender-stemmed plant, differing from the other annual stocks, in having its stem without branches. Its flowers are of a livid purplish brown, like those of the night-smelling stock (which is shrubby). The slender annual stock is a native of Cyprus, and was introduced in 1820 . There is another kind with livid flowers (M. livida, Dec.), which has a branched stem, and is a native of Egypt, and was also introduced in 1820; but these kinds, and several others made species by botanists, are seldom, if ever, to be purchased under their botanical names, but are sold as different kinds of $M$. annua.

\section{GENUS II.}

\section{MALCOMIA, $R . B r$. THE VIRGINIAN STOCK.}

Lyn. Syst. TETRADYNAMIA SILIQUOSA.

Generue Cuancrsa.-Silique roundish. Stigma simple, ending in a long taper point.-(G. Don.)

Description, \&c.-The Virginian stocks are little free-growing annuals, which were formerly included iu the genus Cheiranthus, but which have been "separated by Dr. Brown on account of a slight difference in the shape of the stigma.

\section{. . 1.-MALCOMIA MARITIMA, R. Br. THE COMMON, OR SEA-SIDE VIRGINIAN STOCK.}

SywoxYMrs.-Cheirantbus maritimus, Lin. Hcsperis maritima, blunt, entire, narrowed at the base. Hairs adpressed, 2-or 4-parted. J.am.

Excratings.-Bot. Mag. t. 166 ; and our fig. 5 , in Plate 11. Pedicels somewhat shorter than the calyx. Pods pubeseent, furnisbed Specifie Character. - Stems erect, brancbed. Leaves elliptical, with a long acumen at the apex.-(G. Don.)

Descriptron, \&c.-The pretty little Virginian stock is so well known for its lively-looking flowers, and from its growing so freely wherever it is sown, that it requires very little description. The flowers are of a pale violet or lilac, varying to white, and there is a variety, the flowers of which are of a pure white. It is a native of the Sonth of Europe, growing in the sand close to the sea-shore; and it was introduced in 1713. Why it is called 


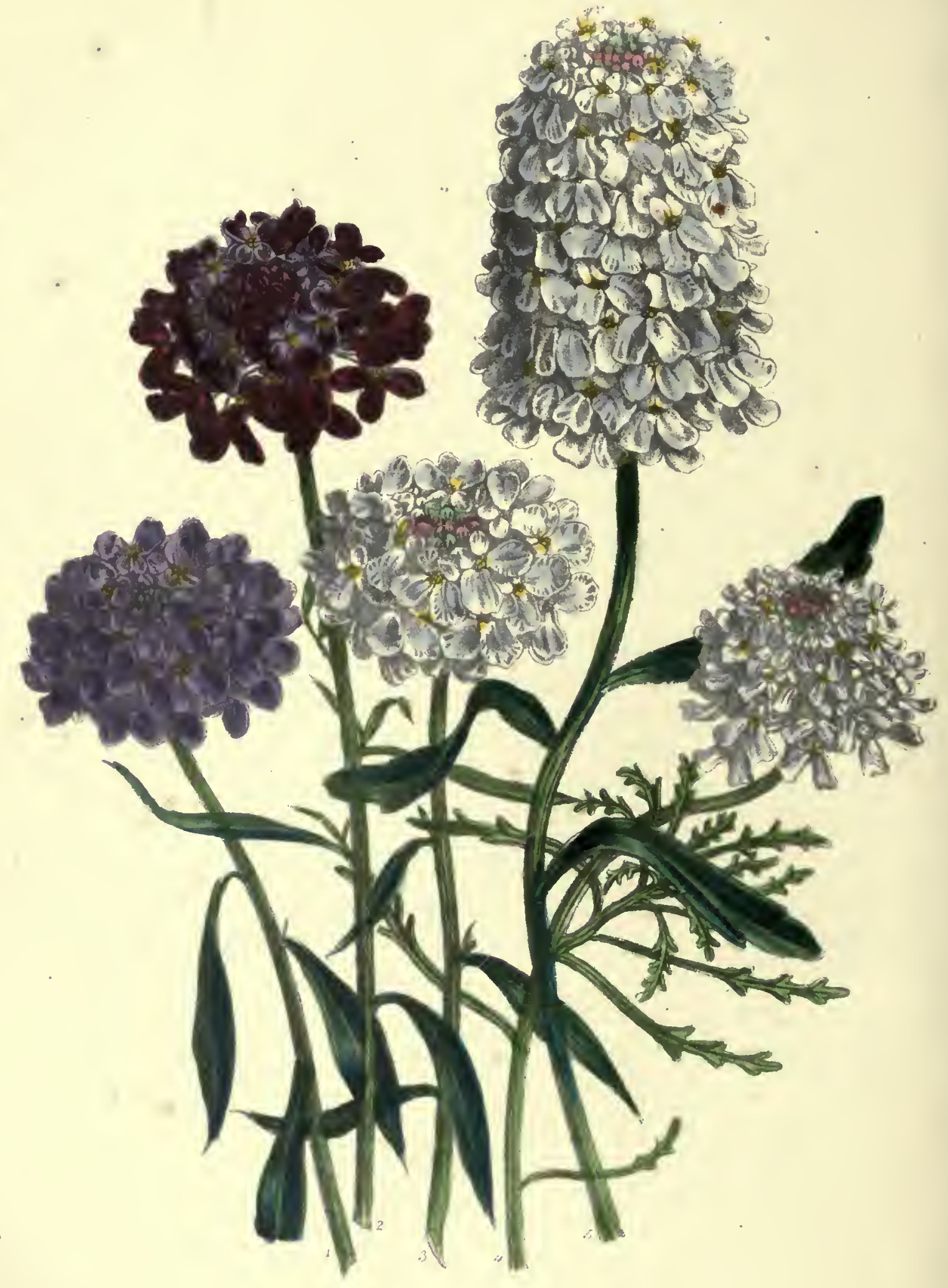




Vurginian, has never been explained; and it seems a very inappropriate name, as the plant is not found wild in America. It may possibly, bowever, be a corruption of Virgin's Stock, the easiness of its culture rendering it fit for the care of young girls ; in the same way as the Garden Rocket was formerly called Dame's Violet. Nothing can be easier than the cultivation. The seeds are generally all good, and wherever they are sown they will come up withent any care being bestowed upon them. It is frequently used in cottage gardens as a border flower.

\section{MALCOMIA CHIA, Dec.,}

diffors very little from the common kind, except in having much smaller flowers. It is a native of the isle of Chio, and was iutroduced in $\mathbf{1 7 3 2 .}$

\section{MALCOMIA AFRICANA, $\boldsymbol{R} . \mathrm{Br}$.}

This species is a native of the south of Europe, and north of Africa, whence it was introduced in 1747. The flowers are small and purplish ; the leaves lanceolato ; and the pods scabrous.

\section{MALCOMIA ARENARIA, Deo.}

A native of the sandy plains of Mauritania, whence it was introduced in 1804. The flowers are violetcoloured, and the leaves long and narrow. Secds of all these kinds may be procured in the seed-shops; but M. maritima is the only kind worth growing.

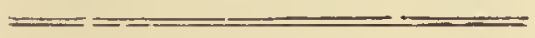

GENUS III.

IBERIS, Lin. THE CANDY TUF'.

\section{Kin. Syst. TETRADYNAMIA SILICULOSA.}

Generic Character, - Two outer petals largest. Silicle much compressed, truncately emarginste.-(G. Don.)

Description, \&c.-The plants of this genus were callod Candy Tuft, because their flowers are produced in tufts, and because Iberis umbellata, the first kind introduced as a garden flower, was brought from Candia. The English species, Iberis amara, was long thought to be a specios of Thlaspi, or wild mustard. The seeds of the Candy Tufts are all very pungent, and were formerly used for mustard; and the leaves and young stems both of the Candy Tufts and stocks may be boiled and eaten as pot-herbs.

\section{1.-IBERIS UMBELLATA, Lin. THE COMMON PURPLE CANDY TUFT.}

Srronyurs.-Iberis corymbosa, Manch. Thlaspi Umbellatum, 12, has the flowers much larger than tho species, and of a rich dar's Crantz.

Engravines.-Bot. Mag. t. 106 ; and our fig. 1, in Plato 12.

VARIETiss.-I. u. 2 alba, $f g .3$, in Plato 12 , only differs from the specics in having white flowers. I. u. 3 sanguinea, fig. 2, in Plate

Specryic Charactrr. Smooth. Leaves lanceolate, acuminated, lower ones serratcd, upper ones quite entire; pods umbellate, very scutely 3-lobed.-(G. Don.)

Description, \&c.-The Purple Candy Tuft is a plant growing to the height of about a foot, with spreading branches and large heads of purple flowers. The white and dark crimson varieties only differ in the size and 
colour of their flowers, and the latter kind has been grown to nearly three times the size of the specimen represented in fig. 2, in Plate 12. The species is a native of Candia, from which country sceds wore brought of it to England by Lord Edward Zouch, about 1590, and given by him to Gerard, who grew it in his garden in Holborn. It was, as we have before mentioned, at first supposed to be a kind of wild mustard, and was called Candia mustard, but when it flowered it excited great admiration. From that time to the present, Purple Candy Tuft has been a general favourite in British gardens; and it well deserves to maintain its place there, from its beauty and the ensiness of its culture.

The Purple Candy Tuft, though it is generally found in a wild state on rocks in sunny places, like all the rest of the Cruciferm, does best on a rich soil, if not too moist; and, as it will not bear transplanting withont serious injury, it should be sown where it is to remain. As it looks well in masses, it may be sown in square beds, mixed with mignonette, as directed for the Clarkias (p. 57); or, a row may be sown at the back of a border, and smaller flowers planted or sown in front of it. It may be sown in autumn, or in February, March, April, or May; and in warm sheltered situations in June and July, when it will, if protected from frost, remain in blossom all the winter. When it is wished to have the flowers very fine, the seed should be sown rather thinly in August or September; and when the plants produce their second pair of leaves, they should be thinned ont. They should be kept rather dry during the winter, and, where convenient, protected from severe frost. In spring, as soon as tho plants begin to grow, they should be thinned again, and a third time when they begin to branch. After this they should be watered with liquid manure, taking care not to let the liquid touch the plants, but to let it sink into the ground, so as to afford nourishment to the roots. When the plants are going into flower, the heads should be examined, and if they appear too numerons, the weakest should be removed. By this treatment, and occasionally loosening the ground round the plants, and keoping it free from weeds, flowers of the common Purple Candy Tuft have been grown three inches across, most beautifully coloured, being of a very dark purple on the outside, and softening to nearly white in the centre; and flowers of the dark crimson variety have bcen grown nearly four inches across. The great points are, thinning the plants gradually as they increase in size, and supplying their roots with abundance of rich food when they are going into flower.

Spring-sown flowers never attain so large a size as those sown in autumn; but, by the same mode of treatment, much finer flowers may be grown than those usually seen in our gardens.

\section{2.-IBERIS PINNATA, Lin. THE PINNATE-LEAVED CANDY TUFT.}

SrNosYME.-I. odorata, Hort.

Engruving.-Our fig. 4, in Plate 12.
Specific Character. - Leaves pinnatifid; raccmes corymbose, but after flowering a little elongated.-(G. Don.)

Description, \&c. -A rather low-growing plant with white flowers and pinnate leaves; the calyxes are slightly tinged with purple. The heads of flowers are generally somewhat raised in the centre, as if approaching the shape of a raceme; and the flowers have occasionally a tinge of purple, or pinkish hue. This species is generally grown and sold under the name of $I$. odorata in the nurseries, but it is very slightly sweet-scented, and very frequently not at all. The specics is a native of Spain, from which country it was introduced a few years later than I. umbellata, by the same Lord Edward Zouch; and Gerard had both species growing in his garden in 1596. I. pinnata was called Spanish Tuft, because it came from Spain, as I. umbellata was called Candy 
Tuft, because it came from Candia; and under these names we find both species frequently mentioned by our early florists. The name of Iberis is derived from Iberia, the ancient name for Spain. I. pinnata is also found wild in the south of France and Italy. It requires no particular care in its culture, and it may be sown in March, April, or May. The heads of flowers do not become broader under careful culture, but have a tendency to elongate; so that their beauty, instead of being improved, is rather lessened.

\section{3.-IBERIS ODORATA, Lin. THE SWEET-SCENTED CANDY TUFT.}

Evcraving.-Brit. Flow. Gard. t. $50 . \quad$ dilated at the top; pods roundish, emanginate, lobes acute, spreading, Specific Character.-Leaves linear, toothed, clliated at the base, $\mid$ shorter than the style.-(G. Don.)

Description, \&c.-This species is frequently confounded with 1 . pinnata, but though there is a general resemblance, there are several points of difference. The flowers of $I$. odorata are whiter, and smaller and looser, than those of $I$. pinnata, and its calyxes are more purple; its stem-leaves are only toothed, and its pods are acutely lobed; its leaves are bordered with hairs, and it is very sweet-scented. It grows about a foot high. The small size and looseness of its heads of flowers, and its straggling habit of growth, prevent it from being considered ormamental, and it is comparatively but little grown. It is a native of Crete, and was introduced in 1804. It requires no particular care in its culture, but does best in a rather poor soil, as, in this case, the soent of its flowers is stronger; though this is perhaps no recommendation, as it is of rather a sickly sweetness, and not very agreeable. The seed ripens abundantly, but we do not know where it is to be procured true; as that generally sold in the seed-shops for $I$. odorata is the seed of $I$. pinnata.

\section{IBERIS AMARA, Lin. THE BITTER CANDY TUFT.}

Engtuving. - Eng. Bot. t. 52.

Flowers corymbose, finally racemose. Peds orbicular, narrowly emarSpecific Character. - Leaves lanceolate, acute, somewhat toothed. ginate-(G. Don.)

Description, \&c.-A little plant about six inches high, with small tufts of white flowers, which have a tendency to form racemes. It is a native of England, and is found in considcrable quantities in corn-fields, ncar Henley in Oxfordshire, Wallingford in Berkshire, and other places. It is also found wild in corn-fields in nearly every part of Europe. It is a pretty little plant, and looks well in a garden, from its low and compact habit of growth, and from the whiteness of its heads of flowers, which, though not large, are very numerous. The whole plant has a bitter taste, from which it takes its name.

\section{5.-IBERIS CORONARIA, D. Don. THE ROCKET CANDY TUFT.}

Engrutngs.-Brit. Flow. Gard., Second Series, t. 359; and our | dentated. Pods corymbose, acutely 2.lobed, margins eroded, crenated. fig. 5 , in Plate 12.

Speciric Craractra.-Pubescent. Leares wedge-sbaped, obtubely-

Seeda winged. Stem strictly branebed. $-D$. Don.

Description, \&C.-By far the most splendid of the genus. The plant, if carefully treated, grows about two feet high, branching widely, and each plant producing three or five racemes of flowers, the side ones being eight 
or ten inches long, and the centre one ten inches or a foot. Large as these dimensions may seem, they are by no means uncommon. A plant grown in a pot, which was exhibited in Charlwood's shop in the summer of 1838, was considerably larger; and there was a bed of these flowers at Claremont, (grown by the late gardener therc, Mr. M'Intosh, not one of which was less than the size we have mentioned, and some were much larger. These plants were treated in the manner already directed for Iberis umbellata, being sown in August or September, and gradually thinned out six or sqgen times till the plants were left a foot and a half, or two feet asunder, so as to allow them to be as near each other, when fully spread out, as they could be without touching. It is rather curious that but little is known of the history of this splendid plant. The only British botanical periodical in which it has been figured, is Sweet's British Flower Garden; and this was in 1836. In the description annexed to the figure, it is not stated of what country it is a native, or when it was introduced; but it is suggested that it is probably a hybrid between Iberis Lagascana (to which it is nearly allied) and some other species. It appears, however, to have been long in cultivation in France, as it is mentioned in the Bon Jardinier for 1831, as a variety of $I$. umbellata, and as being then cnltivated by M. Vibert, a Parisian nurseryman. The French call it Iberide Julienne, literally, the Rocket Candy Tuft.

\section{OTHER KINDS OF IBERIS.}

The following kinds have all been introduced, but as they are seldom grown in gardens, or sold in seed-shops, we have not thought it necessary to give lengthened details respecting them.

\section{6.-I. SPATULATA, Berg., I. COMOSA, Willd, I. ROTUNDIFOLIA, Lam.}

A native of the Pyrenees, in calcareous stony places, irrigated at certain seasons by the melting of the snow. The plant grows about six inches high, and the flowers are purplish. It was introduced in 1820.

\section{7.-I. VIOLACEA, R. Br.}

A very dwarf plant, with violet-coloured flowcrs; introduced in 1782 , hut its native country unknown.

8.-I. LAGASCANA, Dec.

A native of the mountains of Spain, resembling 1 . coronaria, but with much smaller flowers. Introduced in 1822.

$$
\text { 9.-I. PYRENAICA, Lap. }
$$

A native of the Pyrenees, with white racemose flower's, probably the same as I. Lagascana, or a variety of that species. It grows a foot high, with an erect, branched, reddish stem. 



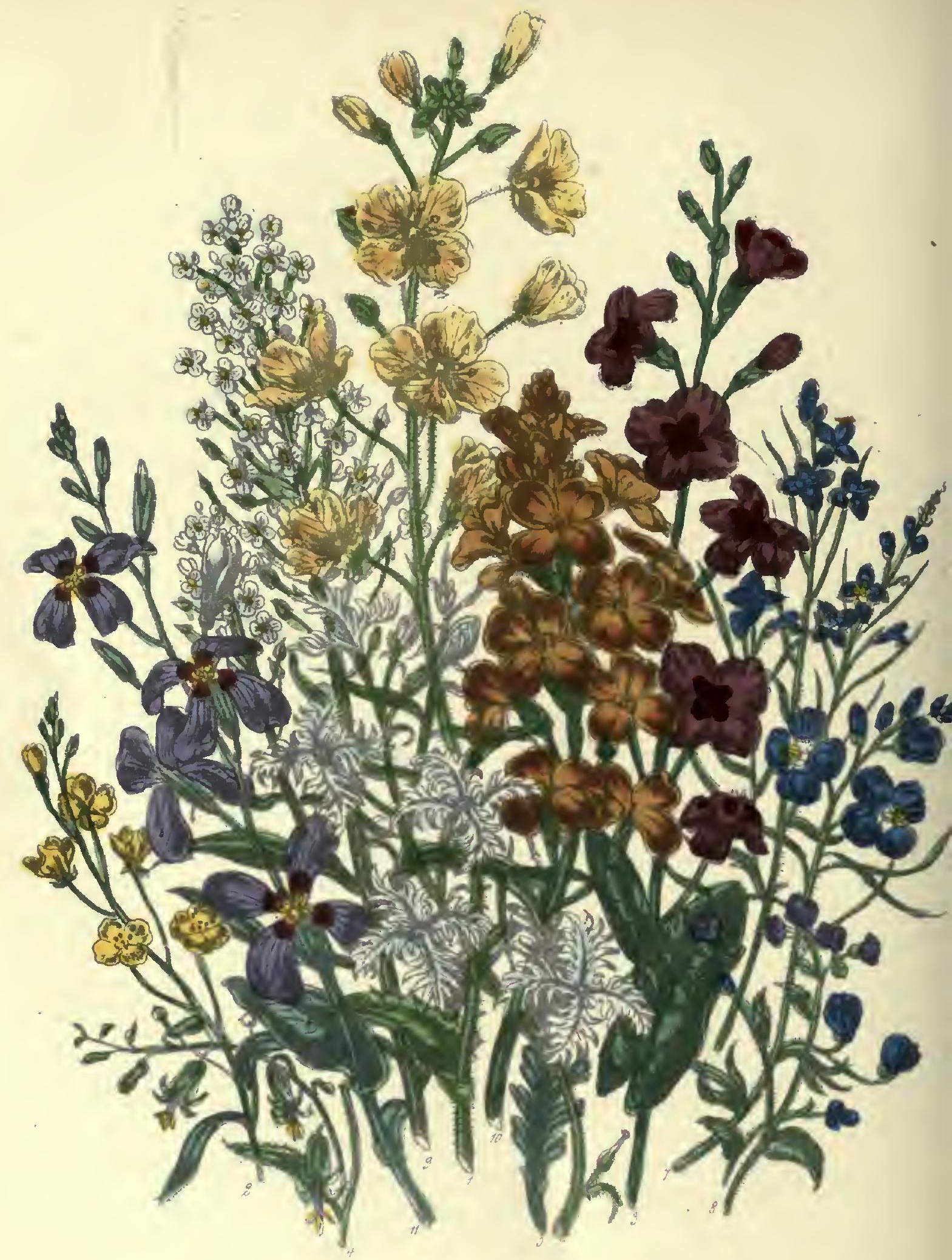


,

. 



\title{
GENUS IV.
}

\author{
ARABIS, L. THE WALL-CRESS. \\ Lin. Syst. TETRADYNAMIA SILIQUOSA.
}

Generic Charactrn. - Silique linear; valves flat, with a nerro in the middlo of each. Seeds in one row in each cell.—(G. Don.)

\section{1.-ARABIS VERNA, $R$. Br. THE SPRING WALL_CRESS.}

SrNonymes.-Hesperia verna, $\boldsymbol{L}$. Arahis violacca, Mænch. Turritis purpurea. $\boldsymbol{L} a \mathrm{~m}$.

Engravings.-Bot. Mag. t. 3331 ; and our fig. 8, in Plate 13.
Sptcific Charsctrr.-Stem leaves eordate, clasping the stcm, toothed, seabrous with 3-parted hairs. Pedicels shorter than the calyx. Stigma aomewhat emarginate.-(G. Don.)

Description, \&c.- - pretty little annual, with very bright purple flowers, which are whitish in the centre. It is common in the South of Europe, particularly near Naples; where its tufts of flowers, which are produced in great abundance in March, have a very good effect. It was first introduced in 1710 ; but having been long lost, it was re-introduced by Professor Tenore, of Naples; who sent seeds of it to the Glasgow Botanic Garden in 1833. The name of this species is in inost nurserymen's catalogues; but we have never been able to get tho seeds.

\section{OTHER KINDS OF ARABIS.}

The other annual species of Arabis are seldnm grown in gardens, though they are generally found in seedsmen's catalogues; we sball therefore say only a few words on each.

\section{A. STENOPETALA, Willd.}

A native of Kamtschatka, introduced in 1826 . The flowers are white, with very long petals.

\section{A. UNDULATA, Link.}

$\Lambda$ native of the South of Europe; somewhat resembling the common wall-cress of the gardens, A. allida.

\section{A. THAliaNA, $L$. SisYMBRIUM THALIANUM, Hook. COMMON THALE CRESS.}

A native of Britain. A very pretty delicate little white flower, found generally on walls or cottage roofs, or on banks of dry gravelly soil.

\section{A. PENDULA, $\boldsymbol{L}$.}

A native of Siberia, but found also in North America ; introduced in 1752. This species has white flowers and drooping pods.

\section{GENUS $\nabla$.}

\section{KONIGA, $\boldsymbol{R}$. B. THE SWEE'T ALYSSUM.}

Lin. Syst. TETRADYNAMIA SILICULOSA.

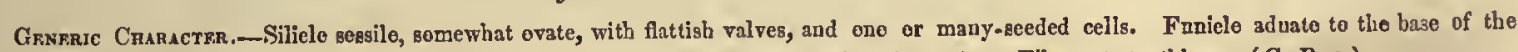
dissepiment. Seeds nsually marginate. Calyx spreading. Petals quite entire. Filaments tootbless.-(G. Don.)

\section{1.-KONIGA MARITIMA, $R$. $B r$. THE SEA-SIDE KONIGA, OR SWEET ALYSSUM.}

Synonymes.-Alyssum cadycinum, Fort. A. halimifolium, Curtis. | Everuvings.-Bet. Mag. t. 101; Eng. Bot. 2nd. edit. vol. v. A. maritimum, Lam. Lepidium fingrans, Willd. Glyce maritima, t. 919; and our fig. 9, in Plate 13.

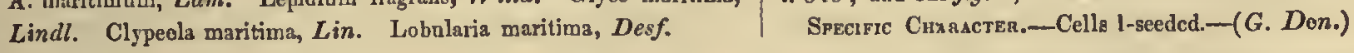

Description, \&c.-Perhaps no plant had ever more botanical names than this; and as it is generally called Alyssum calycinum in the nurseries, we have given it that nane on our plate; though we have here adopted 
the name now generally applied to it in botanical books. It is also frequently called Alyssum halimifolium in the nurseries. The genus Koniga was separated by Dr. Brown from that of Alyssum, on account of the stamens being toothless, instead of toothed like the other kinds of Alyssum, the petals entire instead of emarginate, and some other slight differences, only to be detected by the eye of a botanist. It is a pretty little plant, very liardy, and the seeds are generally so good, that every one sown will come up. This renders it very suitable for making edgings to beds in gardens. It is also very sweet, having a fragrance like new hay. It is found wild on the shores of the Mediterranean, where it becomes shrubby; and it has been found (either wild or naturalised) on cliffs and stony places near the sea, in Aberdcenshire, Devonshire, and Cornwall. There are two varieties of it; one a native of the Canary Islands, and the other with variegated leaves, both of which are grown in England as greenhouse shrubs. It may be sown in March, April, or May, in the open borders ; and will continue in flower from July to September. Seeds may be obtained at any seedsman's.

\section{GENUS VI.}

VESICARIA, Lam. THE VESICARIA.

\section{Lin. Syst. TETRADYNAMIA SILICULOSA.}

Geseric Character._Silicle globose, inflated; valves hemispherical. Seeds numerous, mere than 8. Petals entire.-(G. Don.)

\section{1.-VESICARIA GRANDIFLORA, Hook. THE LARGE FLOWERED VESICARIA.}

Evoravings._Bot. Mlag.t. 3464 ; and our fig. 1, in Plate 13.

Srecific Chanacter.-Stellately pubescent. Stem erect, flexible. Leares oblong. Root-lcaves subulate, pinnatifid, petiolated. Stemleaves sinuately-dentate, and sessile. Racemes elongated, and many- flowercd. Petals rounded, spreading, with very sbort claws. Pod partly surrounded by a membrane, globose, very smooth, containing 4-6 seeds, larger than the style. Stigma capitate.-(Houk.)

Descriptron, \&c.-A very showy flower, discovered in Texas, Mexico, by M. Berendieri, in I828. No seeds were then sent to Europe; but in 1834, it was again discovered by Mr. Drummond, from whom sceds were received at the Glasgow Botanic Garden, in 1835. It is a handsome plant, with brilliant yellow flowers. The seed-pods are curious, as they look like little globes, or rather bladders; and it is from this bladdery appearance of the seed-pods, that the genus takes the name of Vesicaria. This is a valuable plant for flowergardens, from the great abundance of its flowers, their brilliant colour, and their long duration. The raceme will also continue elongating, and fresh buds opening at the summit, while below, where the petals have dropped, they have been succeeded by the globe-like seed-pods. The size of the flowers may be greatly increased by rich soil and cultivation; and under favourable circumstances, the raceme has been known to grow from eight or ten inches to a foot long. The stems are generally so weak as to require support, and as there are frequently several from the same root, tine plant may be trained so as to form a large and handsome bush. The species having only been introduced in 1835 , is yet rather scarce; but seeds may be procured from Mr. Charlwood, and at the principal seed-shops.

\section{2.-VESICARIA GRACILIS, Hook. THE SLENDER VESICARIA.}

Engravings.-Bot. Mag. t. 3533 ; and our fig. 2, in Plate 13.

Specific Consthulate, peticles entirely bare. Raceme elongated. Petals spread. scabrous scabrous. Leaves lanceolate, entire or subangulate, lower oncs sub- $\mid$ smootb, and four-seeded. Style capitate,-(Huok.)

Description, \&c.-A light graceful plant, with very slender thread-like stems, and small bright yellow Howers, which are produced in succession nearly all the summer; and which are succeeded by very small, and 
quite round seed-pods. The stems are so very small and weak, that they lie on the ground if not supported; and this habit makes the plant very suitable for rock-work. It was discovered in Texas at the same time as $V$. grandiflora, and its seeds were sent home by Drummond with those of that species in 1835 . Seeds may be procured at Charlwood's.

\section{GENUS VII.}

\section{STREPTANTHUS, Nutt. THE STREPTANTHUS.}

\section{Lin. Syst. TETRADYNAMIA SILIQUOSA.}

Gengric Character.-Sepals of the calyx ereet, acuminate, eoloured, | pressed. Seeds in one series, compressed, marginate. Cotyledons saceate at the base. Filaments of the stamens awl-shapod and short. lying down. Flowers purplish._(Hook.)

Anthers elongated, acuminate. Siliques very long, 4-sidedly eom-

Descriptron, \&c.-A new genus of härdy and very ornamental plants, natives of North America; the only species yet discovered of which are annuals. They are very unlike most other cruciferous plants in their flowers, but agree with them in their long siliques or seed-pods. They bear considerable resemblance to the genus Moricandia; but on examination it will be found that the sepals of the calyx are hollow, or what botanists call saccate, at the base, and that the petals have very long claws, each of which has a peculiar twist. This twist is allnded to in the name of the genus, which is combined of strepho, to twist or turn, and anthos, a flower. The species from which the genus was constituted by Nuttall, in North America, is called Streptanthus maculatus, and has not yet becn introduced iuto England.

\section{1.-STREPTANTHUS OBTUSIFOLIUS, Hook. THE BLUNT-LEAVED STREPTANTHUS, OR THE}

\section{ARKANSA CABBAGE.}

Engravines._-Bot. Mag. 3317; and our fig. 3, in Plate 13.

Seecific Cuaracter._Leaves elliptic, very obtuse; deeply two-lobed at tho base; stem-clasping.-(Hook.)

Descriptron, \&c.-A showy plant with rose-coloured flowers, having each a very dark red spot at the base. The calyx leaves or scpals, which are of the same colour as the petals, are sharply pointed, and swell out below, so as to give the flower a very singular shape. The leaves are of a bluish green, and so deeply lobed as to make the stem appear to be growing out of the middle of them. The filaments of the stamens are very short, and the anthcrs, which are of a dark purple, are remarkably long and sharp-pointed. The seed-pod is from three inches to four inclies long, very narrow, and having distinctly four sides; and the sceds, which are numerous, are flat with a distinct margin. Altogether the plant is a vcry remarkable one. The seeds were sent to Sir W. J. Hooker, early in 1833, from the hot springs of the Arkansa territory, under the name of the Arkansa cabbage. The plant is quite hardy, and may bo sown in the open border in April or May. Seeds are not common, but may be procured at Charlwood's.

\section{2.-STREPTANTHUS HYACINTHOIDES, Hook. THE HYACINTH-LIKE STREPTANTHUS.}

Engravines.-Bot. Mrg. t. 3516 ; and our fig. 4, in Plate 13. | linear, with a reflexed limb. Filaments short, one pair united and Spectric Craraetra.-Leaves oblong, linear, acuminato. Petals $\mid$ abortive. Flowers pendulous.-(Hook.)

Description, \&c.-This species is still less like a cruciferous plant than the other, as the flowers bear a great resemblance to those of a small hyacintl. It is a native of Texas; from which country it was sent by Drummond, in 1835, to the Glasgow Botanic Garden. Sceds may be obtained at Charlwood's. 


\section{GENUS VIII.}

\section{MORICANDIA, Dec. THE MORICANDIA.}

\section{Lin. Syst. TETRADYNAMIA SILIQUOSA.}

Grarac Craructra.-Silique tetragonal, somewhat 2-edged. Seeds disposed in two rows. Calyx bisaccate at the base,-(G. Don.)

\section{1.-MORICANDIA ARVENSIS, Dec. THE FIELD MORICANDIA.}

Symonymes.-Brassica arvensis, Linn.; Turritis arvensis, $\boldsymbol{R} . \mathrm{Br}$. Sprciric Charucter.-Pods somowhat tetragonal. Stem-leaves In Hort. Kew.

Exgruvings. -Bot. Mag. t. 3007 ; and our fig. 11, in Pl. 13. cordate, stem-clasping, and entire.-( Hook. $\left._{\text {. }}\right)$

Descriptron, \&c.-Strongly resembling at the first glance Streptanthus obtusifolius, though it is more beautiful; and when closely cxamined, the construction will be found very different. The flowers are large and handsome ; and they are disposed at some distance apart along a terminal raceme. The petals are lilac, with a bright crimson stain at the base of each. It is a native of Greece, and the shores of the Mediterranean, and quite hardy; but thouglh it was introduced just a hundred years ago (in 1739), it is very little known. Seeds may be liad at Charlwood's, and at other seed-shops.

\section{GENUS IX. \\ HELIOPHILA, N. Burm. THE HELIOPHILA. \\ Lin. Sys. TETRADYNAMIA SILIQUOSA. \\ Generic Caracter.-Silique elongated. Calyx equal at the base.-(G. Don.)}

\section{1.-HELIOPHILA ARABOIDES, Sims. THE ARABIS-LIKE OR Club-POINTED HELIOPHILA.}

Srsonyms. - II. pilosa, Dec. H. integrifolia, $L$ in.

Engrapings.-Bot. Mag. t. 496 ; and our fig. 7, in Plate 13.

Sfreific Cuaracter. - Siliques round, uneven, club-pointed, and

mucronate. Leaves linear, fleshy; sometimes trifid at tep, and sometimes simple.-(Sims.)

Descriptron, \&c. - A very beantiful little plant with pale-blue flowers, and very slender stems. It is a native of the Cape of Good Hope, and was introduced in 1768. It should be raised on a hot-bed if wanted to flower early, or it may be sown in the open border in May. It likes a warm open situation, as is implied by its name, Heliophila signifying a lover of the sun.

\section{2.-HELIOPHILA DIGITATA, Lin. THE FINGER-LEAVED HELIOPHILA.}

Synosyme,-H, coronopifolia, Thun.

Enaruving.-Bot. Reg. t. 838.
Specrfic Craracter. - Stem hispid frem spreading hairs. Pods lincar. Lcaves oval, entire, or here and there grossly toothed.-(G. Don.)

Description, \&c.-Greatly resembling the preceding species, of which it is probably ouly a variety. The stems are, however, much stronger, and the plant more decidedly prostrate. From this habit of growth, its bright-blue flowers produce a beautiful effect when grown in masses. It is a native of the Cape of Good Jope, whence it was introduced in 1819. We do not know where seeds are to be procured, bnt the specimen figured in the Botanical Register for 1821, was grown in Colvill's nursery, King's Road, Chelsca. 


\section{3.-HELIOPHILA STRICTA, Sims. UPRIGHT HELIOPHILA.}

Escruvisgs.-Bot. Mag. t. 2526 ; and our fig. 6, is Plate 13. | tifid, upper ones linear, quite entire. l'ods straiglth, mucronate, Spegrfic Character. - Leaves hairy, lower ones lanceolate, pinna- pubescent.-(G. Don.)

Description, \&C.-This is a curious little plant with very dark blue flowers, and a stiff upright habit of growth. It is a native of the Cape of Good Hope, and was introduced in 1820. We do not know where seeds are to be procured.

\section{OTHER SPECIES OF HELIOPHILA.}

Besides the above, there are sixteen otlier species of Heliophila which are marked as having been introduced. They are all natives of the Cape of Good Hope, and are said to bear a general resemblance to each otler, differing principally in the colour of their flowers, which are white, pink, purple, and blue. We do not think it necessary to enter into details respecting them, as they do not appear to have been figured in any botanical periodical, and as their names are not in any of the secdsmen's catalogues.

\section{GENUS X.}

SCHIZOPETALON, Sims. THE SCHIZOPETALON.

Lin. Syst. TETRADYNAMIA SILIQUOSA.

Generic Character.-Cotyledons 4, spirally twisted. Petals pinnatifid.-(G. Don.)

\section{1.-SCHIZOPETALON WALKERI, Sims. WALKER'S SCHIZOPE'TALON.}

ENGratiscs.-Bot. Mag. t. 2379 ; Bot. Reg. t. 752. Sweet's Brit. | white, io loog racemes. Pedicels each furnished with a linear bratea. Flow. Gard. 2nd Scrics, t. 387 ; and our fig. 5 , in Plate 13.

SPECIFIC Charscter.-LLeaves al ternate, sinnately pionatifid. Flowers -(G. Don.)

Description, \&c.-A very remarkable plant, with fragrant white flowers, from the curious sliape of which it takes its name, Schizopetalon signifying cut petal. The leaves are also cut; and thic whole plant is covered over with short forked hairs. The stem is rather slender, and requires support; and the root, which rcsembles that of a young carrot, is very long, and furnished with a deep fringe of fibres at its lower extremity. It is a native of Chili, from which conntry Mr. Walkor of Arno's Grove, near Hornsey, received its seeds in 1821. It is hardy, and will sometimes grow well in the open border, while at others, it dies off without any apparent cause. The reason of this is the length of its root, which requires a light sandy soil that it can easily penetrate. To raise this plant, the seeds should be sown in light sandy soil where they are to remain; or sown in pots in a hotbed, and when planted out the whole of the earth should be taken out of the pot together, and planted in a lole made in the bordcr, without disturbing the roots in the sligittest degree. The seeds shonld be sown thickly, and not thinned ont; they are rather scarce, as they will only ripen in warm dry summers, but we procured 8omo from Mr. Charlwood in March last, which, sown in a pot in a hotbed, came up very well in about a week; while others came up in about three weeks in the open ground. 


\section{GENUS XI.}

\section{BISCUTELLA, Lin. THE BUCKLER MUSTARD.}

\section{Lin. Syst. TETRADYNAMIA SILICULOSA.}

Geveric Cвancter.-Silicle flat, biscutate. Cells adnate laterally to the axis. Style leng, permanent. Embrye inverted.-(G. Don.)

\section{1.-BISCUTELLA HISPIDA, Dec. THE HAIRY BUCKLER MUSTARD.}

SywonYmps.-B. macrocarpa, Hort. ? B. auriculata, Lin.; ? B. erigerifolia, Dec. B. coronopifolia, Hort.

Engratina.-Bot. Mag. t. 2444.

Spectfic Character. - Calyx acutely 2-spurred. Pod smooth, rough in the eentre from elevated dots, not overhanging the style at the top. Stem hispid.-(G. Don.)

DESCRIPTION, \&rc.-A little plant, with bright yellow flowers, very much like those of the common mustard, and very curious seeds, that look like two little shields fastened together. There are several kinds named in the seed catalogues, but they all appear to be varieties of one kind. The seeds should be sown in a light sandy soil, at any time during the spring and summer, and they will generally flower six weeks after sowing. Seeds may be procured in any seed-shop, as they ripen abundantly.

\section{GENUS XII.}

MENONVILLEA, Dec. THE MENONVILLEA.

\section{Lin. Syst. TETRADYNAMIA SILICULOSA.}

Gramerc Characten.-Style somewhat stipitate, biscutate. Cello with the margin expanded into a wing, ending in the parallel disk.-(G. Don.) -

1.-MENONVILLEA FILIFOLIA, Fisch. et Meyer. THE THREAD-LEAVED MENONVILLEA.

Engraying.-Sweet's Brit. Flow. Gard, Second Series, t. 371.

Sprcific Character. - Leaves thread-like, undivided or laciniated.

Description, \&rc.-A slender but rigid plant, growing erect abont a foot high. The flowers are white, and of no great beanty; the leaves are long and narrow like grass. It is a native of Chili, and was introduced in 1837 by A. B. Lambert, Esq., who received the seeds from the Botanic Garden at St. Petersburg. It requires a light loamy soil, and similar treatment to Schizopetalon, but we do not know where to procure seeds.

\section{GENUS XIII.}

\section{CAKILE, Tourn. THE SEA ROCKET.}

\section{Lin. Syst. TETRADYNAMIA SILICULOSA.}

Gremric Character,_Silicle two-jointed, compressed, upper joint ensiform. Seeds solitary in the cells, upper one erect, lower on pendulous. - (G. Don.)

\section{1.-CAKILE MARITIMA, Scop. THE COMMON SEA ROCKET.}

Synosymrs.-Bunias Cakile, Lin. Isatis pinnata, Forsk. Rapio- | Specric Craracter.-Upper joint of pod ensiform. Leaves pinnatotrum maritimum, Berg.

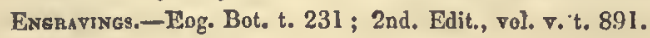
parted. $-(G$. Don. $)$

Descriptiox, \&c.-A very ornamental British plant, found on the sea-shore. Its stem is much branched 
and bushy, and its branches spreading or zigzag. Its leaves are of a bluish green, and its flowers, which are large and handsome, and produced in bushy racemes, are purple or white. It requires a sandy soil, and flowers from June till September.

\section{GENUS XIV.}

\section{RICOTIA, Lin. THE RICOTIA, OR SYRIAN HONESTY.}

\section{Lin. Syst. TETRADYNAMIA SILICULOSA.}

(irseric Craractbr._Silicle sessile, oblong, adult ones l-celled, in consequenco of the dissepiment haviog ranished. Valves flat. Calyx valvular, bigibbous at the base. Petals emarginate. Stamens toothless.-(G. Don.)

\section{1.-RICOTIA LUNARIA, Dec. SYRIAN HONESTY.}

Srnonyses,-R. Ægyptiaca, Lam. Ludaria Ricotia, Gartn. Car- | Series, t. 4 Il.

damine Lunaria, $\boldsymbol{L}$.

Specific Charactrr., Leaves almost bipinnate. Lobes oblong, Engravings.—Bot. Reg. 49 ; Sweet's Brit. Flow. Gard. Second siauated, angular.—(G. Don.)

Descriptron, \&c.-A pretty little plant with dark purple flowers, resembling in every respect, except colour, those of the Virginia stock. It is a native of Syria, and was first introduced in 1757. It was soon after lost, and has since been frequently introduced, and lost after a season or two, from its not ripening its seeds. It is now grown successfully by Messrs. Booth of Hamburgh ; Mr. George Booth having collected the seed on rocky situations in Palestine, where it flowers in $A$ pril. The seeds should be sown very thickly on rock-work in autumn; and in favourable situations, that is, such as are warm and dry, the rock-work will be covered with a profusion of flowers, which from their dark purple, and white centre, will have a very striking cffect.

\section{GENUS XV.}

ERYSIMUM, Gørt. THE TREACLE MUSTARD.

Lin. Syst. TETRADXNAMIA SILIQUOSA.

Generuc Cuaructer.-Silique tetragonal. Calyx olosed. Cotyledons flat, oblong.--(Dec.)

\section{1.-ERYSIMUM PEROWSKIANUM, Fisch. et Meyer. PEROWSKI'S ERYSIMUM, OR THE PALESTINE} TREACLE MUSTARD.

Engravings. - Floral Cabinet, vol. iii. p. 19 ; and our fig. 10, in $\mid$ toothed. Petals obovate. Seed-vessel bowed. Stigmats somePI. 13.

Specific Cuaracter, - Leaves petiolate, lanceolate, remotely what globose, fleshy. - Know. et West.)

Descriprion, \&c.-A ratlıer coarse-growing plant, with very large and showy bright orange, or golden yellow flowers. It is a native of India, whence it was sent to St. Petersburgl, and afterwards to Englisl Gardens, in 1838. The name is now in all the London nurseryınen's catalogues, and seeds may probably be proeured in every part of Great Britain. The plant is quite hardy, and requires no partieular care in its cultivation. The speeific name is pronounced Perófskianum. 


\section{CHAPTER IX.}

\section{CAPPARIDE $\approx$.}

Fssemtial Characten.-Calyx of 4 to 6 sepals. Corolla of 4 to 6 one-celled capsule which opens at top. or a one-colled many-sceded petals. Stamens 6 or more, almost perigynors, rarely tetradynamous. berry. Placentas inter-valvular.-(G. Don.) Torus usually glandular; stipe of ovarium slender. Fruit a siliquose

Description, \&c.-Most of the plants belonging to this order are shrubby, like the common caper, and it only contains a few annuals, most of which belong to the genus Cleome. It is somewhat remarkable, that while the seeds of the caper, and the genera most nearly allied to it, are apt soon to become rancid; those of the different species of the genus Cleome, and of the other annuals, will keep in a vegetative state for several years, and may thus be easily introduced from any part of the world. The annual plants bclonging to this order are all very splendid, and many of them hardy, though but very few of them have been introduced.

\section{GENUS I.}

\section{CLEOME, Lin. THE CLEOME.}

\section{Lin. Syst. TETRA-HEXANDRIA MONOGYNIA.}

Generic Churacter.-Calyx of 4-spreading dearly equal sepals. Petals 4. Rcceptacle somewhat hemisphcrical. Stamens 6, rarely 4, free. Silique stipitate, or sessile.-(G. Don.)

\section{1.-CLEOME SPINOSA, Sims. THE SPINY CLEOME.}

Syмonyme, -Cleome pungeds, Willd.

Evgravings.-Bot Mag. t. 1640 ; aod our fig. 6, in Plate 15. with $5-7$ leaflets. Floral ones simple, sessile, and cordate. Silique Specific Churscter. -Covered with a clammy pubescence. Leaves smooth and shorter than the stipe.-(G. Don.)

Description, \&c.-A rery slowy annual, which was formerly supposed not to live out of the stove; but which is now found to succeed perfectly well if raised on a moderate hot-bed in Fcbruary or March, and not planted out till the latter end of May or June. It requires a warm sheltered situation; but if planted in front of a sontl wall, or in a sunny corner, it will flower beautifully from July to September. It is a native of South America and the West Indies, and was introduced in 1731. It may he observed that the plants now grown, being brought from South America, are much hardier than those first introduced, which were brought from the West Indies. Seeds may be obtained in all the seed-shops.

\section{2.-CLEOME PENTAPHYLLA, Lin. THE FIVE-LEAVED CLEOME.}

Synonyme.-Gypandropsis pentaphylla, Dec.

Engravisg8.-Bot. Mag. t. 1681 ; and our fig. 5, in Plate 15.

Icaflets, the lowest and floral ones with 3 leaflets. Loaflets entire, and Sprerfic Churacter. - Smoothish. Leaves on the stem with 5

Description, \&c.-A very beautiful species with white flowers. It is a native of India and Souch America, and is generally grown in the stove; but may be raised in a hot-bed, and planted out in a warm dry border, where it will flower better than in a hot-house. It was introduced in 1640 , and seeds may be had in any seedshop. 


\section{3.-CLEOME ROSEA, Vahl. THE ROSE-COLOURED CLEOME.}

Engravino. - Bot. Reg. t. 980. Specific Curricter.-Unarmed, smooth. Leaflets quinate, lower length of stipe.-(G. Don.)

Description, \&c.-An upright and rather stiff plant, growing about a foot and a half high, with stiff rosecoloured flowers. It is a native of Rio Janeiro, introduced in 1824. Seeds may be had at Charlwood's, and at Carter's, Holborn.

\section{OTHER SPECIES OF CLEOME.}

The following kinds, though some of them much hardier than those we have enumerated, are not in any nurseryman's catalogue; but we mention them in the hope that a demand may be created for them, in which case nurscrymen will take care soon to procure the seeds.

\section{PUBESCENS, Sims. Bot. Mag. t. 1857 .}

This species has white flowers, and bears some general resemblance to $C$. pentaphylla, though it differs in botanical construction. Its seeds were sent to England from Paris, in 1815; but it is not known of what country it is a native. It is half hardy.

\section{SPeciosissima, Deppe. Bot. Mag. t. 1312.}

A splendid plant with bright rose-eoloured flowers; perhaps the handsomest of all the species. A native of the country near Xalapa in Mexico; introduced in 1829. It may be treated as a common border flower, and it will ripen its seeds in the open air.

\section{MONOPHYLLA, Lin.}

$\Lambda$ native of Ceylon, with yellow flowers, and greenislı blue anthers. Introduced in 1759 .

\section{TETRANDRA, Banks.}

A native of New Holland, with yellow flowers, whicl would probably prove hardy in England, but which is not yet introduced.

\section{VIOLACEA, Lin.}

A native of Portugal, quite hardy, introduced in 1776. The flowers are purple, spotted with yellow.

\section{ARABICA, Lin.}

A native of sandy places in Arabia. Introduced in 1794. The flowers are white, with yellow veins, and tinged with purple at the extremity; the filaments are yellow.

There are many other kinds of Cleome, all beautiful and well worthy of cultivation. They may all be sown on a lotbed early in Spring, and planted out into a warm dry border about the middle of May. They will then flower splendidly, and ripen abundance of 'seeds. The seeds, as already observed, will keep well, and are therefore suitable for being sent from a distant country. 


\section{CHAPTER X.}

\section{MALESHERBIACEE.}

Essentuc Charucten.-Calyx tubular, membraoous, ioflated, 5lobed. Lobesimbricated in estivation. Petals 5, alternating with the segments of the caly $x$, persistcat coavulute in astivation arising on the outside of 3 short membranous rim or corona. Stamens 5 or 10 , perigynous. Filsments filiferm, distinct or cennected with the stipe of the evarium. Anthers versatilo. Ovarium superior, stipate, 1-celled, with the placentas st the base, from which the ovules arise by the intervention of unbilical cerds. Styles 3, fliform, very loug, arising from distinct peiats of the spex of the ovarium. Stigmas clavate. Fruit capsular, 1-celled, 3-valved, membranous more or lcss, manyseeded. Seeds attached by umbilical cords to placentas srising cither from the axis of the valves, or from their base. Testa crustaceons, brittle, with a fleshy crcst, and no arillus. Embryo round, in tho centre of flesby albumea, with the radical next the hylum.- (G. Don.)

\section{GENUS I.}

MALESHERBIA, Ruiz et Pavon. THE MALESHERBIA.

Lin. Syst. PENTANDRIA MONOGYNIA.

Genknic Chaructes. - The same as that of the Order.

\section{1.-MAlesherbia CORONATA, D. Don. THE CROWNED MALESIIERBia}

Enguvings.-Sweet's Brit. Flew. Gard, 2nd Serics, t. 167 ; aud | Leaves linear, sianately toethed; throat of the calyx dilated; erown our $\mathrm{fg} .3$, in Plate 15.

Specinic Crumactar. - Plant clothed with glandular pubescenco. simple, toothed.-(G. Don.)

Description, \&c.-A very singular and ornamental plant, a native of Chili at Valparaiso, raised from seeds brought over by Mr. Hugh Cuming, in 1832. The seeds are not common in the seed-shops, but they may be had from Mr. Charlwood, and at some other places. They should he sown in pots in light rich earth, in February or March, and placed in a hotbed; and when they come up they should he transplanted several times into larger and larger pots, till the middle of May, or beginning of June, and then planted out into a ricl, warm, and well-sheltered border, where, if allowed plenty of room, and occasionally watered, they will grow two feet or three feet high, and spread in proportion, flowering abundantly.

\section{2.-Malesherbia linearifolia, Poir. the linear-Leaved Malesherbia.}

Synonymes.- Gynopleura linearifolia, Cav. : Malesherbia paniculata, D. Don.

Engravings.-Bot. Mag. t. 3362 ; and eur fig. 4, ia Plate 15.
Specific Character.-Clothed with glaadular pubescence. Leaves linear, toothed, stipulated at the baso. Stipules tripartite. Throst of the calyx dilated. Ovarium subglebose.-(Hook.)

Description, \&c.-A slender delicate plant, growing about a foot high, and bearing panicles of pale-blue flowers. It is a native of the Andes, whence seeds of it were brought by Mr. Huglı Cuming. It flowered, for the first time in Britain, in September 1834, in the Glasgow Botanic Garden, where it was kept in the greenhouse. From the mountainous situation, however, which it occupies in its native country, it would probably succeed well if sown in May in the open ground in the neighbourhood of London. We do not know where sceds are to be procured. 


\section{CHAPTER XI.}

\section{LINACE $\mathbb{E}$.}

Essenital Charactef -Sepals 3-5. Petals 3-5, hypogynous. Stamens 3-5, hypogynous, combined at their bases. Styles $3-5$. Capsule 10-celled. Cells 2-seeded. Seeds compressed.

\section{GENUS I.}

IJINUM, Bauh. THE FLAX.

Lin. Syst. PENTANDRIA PENTAGYNIA.

Grạeric Charactzr.-Scpals 5, entire. Petals 5. Stamens 5. Styles 5, marely 1 or 3.-(G. Don.)

\section{1.-LINUM USITATISSIMUM, Lin. THE COMMON FLAX.}

Engrafiscs.-Eng. Bot. t. 1357, 2nd Edition, vol. iii., t. 453; and linesr acute, psnicle corymbose. Sepals ovate, acute, or mueronate, our fig. 1, in Plate 15.

Specific Character.-Plant erect, glabrous. Leaves lanccolate or with scarious or membranaceous inargins. Petals rather crensted, three times larger than the calyx.-(G. Don.)

Description, \&c.-How many persons are there who wear linen, who have no idea of the simple beauty of the flower of the plant producing it. The common flax has large clear blue flowers; and where it is allowed room to spread, it makes a handsome plant. The flax, though now found wild in Britain, is supposed to have been originally introduced from Egypt; and it liąs been in cultivation for its fibre from almost the earliest period of civilisation. When grown entirely for its fibre, the secds are sown as thickly as possible, in order that the plants may be drawn up with long and slender stems, and have a fine fibre; and this is the case in Holland and the Netherlands, where it is cultivated extensively. When it is grown partly for its fibre, and partly for the seed which is called linseed, and used to make linsecd oil, to feed birds, \&c., it is sown much thinner and enceuraged to form a branching head. If the fibre be the sole object, the plant is pulled green and instantly tied in bundles, which are placed in water to macerate; but when the seeds are thought valuable, they are suffered to ripen, and when the plant is pulled, the head is drawn through an instrument like a rake, or coarse comb, called a rippling machine, in order to separate the seeds from the stalks before they are laid in water. When the stalk is sufficiently decayed for the fibrous matter to be separated, it is what is called dressed; that is, the fibre is separated from the woody part, which is called the harl, by scutching, and hacking or breaking, and heckling or combing. It is afterwards spun and woven into linen.

When grown in gardens, the seeds should be sown as thinly as possible; and when the plants come up they should be thinned out, so as to leave only three in a patch; and these should stand at a sufficient distance asunder to allow them room to branch. The soil should be deep, ricl, and rather stiff. 


\section{2.-LINUM VERTICILLATUM, Lin. THE WHORLED-LEAVED, OR ROMAN FLAX.}

Specific Character.-Leaves in whorls, linear-lanceolate, upper ones as well as the calyces villous.-(G. Don.)

Descriptrox, Scc.-A pretty delicate little plant, resembling the common flax, but smaller in all its parts, and with very pale flowers, which are rather of a French grey than blue. The seeds of this species are more common than those of any other in the seed-shops; and they require no particular care in their culture, except that they should be sown in rich loamy soil. Like all oily seeds they do not keep well, so should be used as soon as practicable after ripening. The plant is a native of Italy, near Rome; and the date of its introduction is unknown.

\section{3._LINUM BERENDIERI, Hook. BERENDIER'S YELLOW FLAX.}

Sxмомуме.-L. Plotzii, Hook.

Engravings,-Bot. Mag. t. 3480; and our fig. 2, in Plate 15.

Leaves altcrnate, linear and smootb, mucronatc-acuminate, margin even. Flowers sul-eorymbose. Bracteas lanceolate-acuminate, bristly. Sepals Speciric Character. - Stems angular, numerous and branching. Toughly sertulated at the margin. Capsules globose acute.-( $H$ ook.)

Description, \&c.-A very beautiful yellow-flowered flax, growing about a foot high. A native of Mexico, from which country it was sent by Mr. Drummond in 1835 to the Glasgow Botanic Garden. It requires a rich light soil ; and to blossom at its natural season, March, it should be sown the previous August or September, either in the open ground covered with litter, or in pots under glass. It succeeds very well, however, if sown in March or April, when it will blossom in August. Seeds may be had at Charlwood's, and other seed-shops, where it is frequently called a biennial, from the practice we have alluded to of sowing it in the autumn.

\section{4.-LINUM GRANDIFLORUM, Decaisne. THE LARGE FLOWERED FLAX.}

Enonavings.-Revue Horticole, 3rd series, vol.ii. t. 24; and flowering branches linear-oblong, accumiaate. Flowers terminal; our fig. 8, in Pl. 15.

Specific Cha ancren. - Stem glabrous, cylindrical, leafy. Leaves of the sterile branches oblong, obtuse, almost sessile; those of the peduncles upright, cyliodrical; segments of the calyx unequal, oval, acute, keeled, the inner ones membranaceous at the base, and finely

Description, \&c.-This very showy plant is a native of the country near Algiers, whence it was introduced in 1848. It begins to flower about the middle of July, and continues producing blossoms till about the end of October. 'The seed should be sown very early in the spring.

\section{OTHER SPECIES OF ANNUAL FLAX.}

The following species are all very ornamental; and they are all said to have been introduced, but we do not know where seeds of them are to be procured.

L. Gallicum, Lin.-A native of France and Spain. A low-growing plant with yellow flowers. Introduced in 1777.

L. A ureum, Walds. et Kit.-A very low plant, with golden yellow flowers; a native of Hungary. Introduced in 1820.

L. Virginianum, Lin.-A native of North America on dry sunny hills, witl snall pale yellow flowers.

L. Striatum, Walt. - A native of Carolina, with stripcd blue and white flowers. Iutroduced in 1817. 
• 


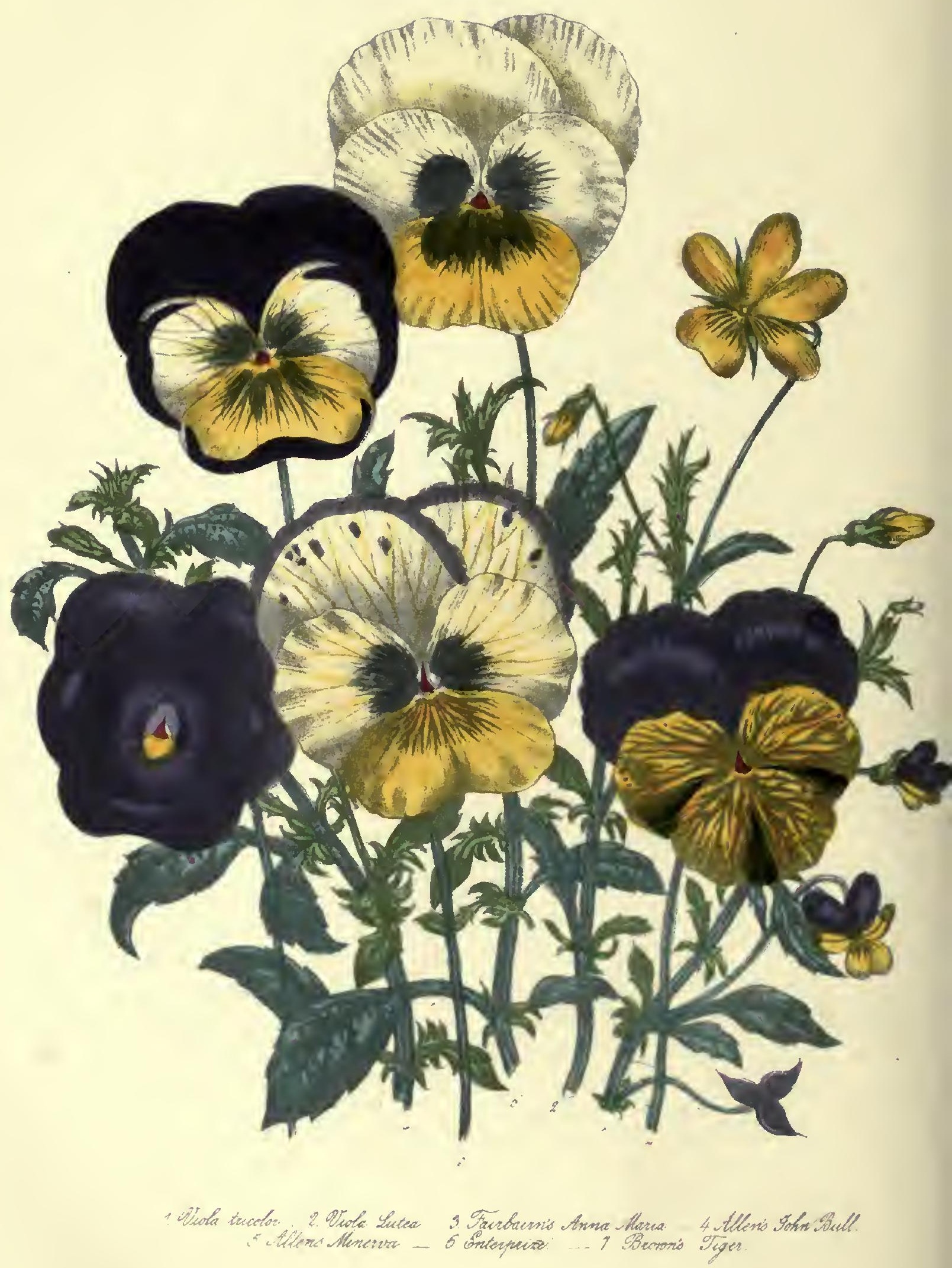




$$
\text { - }
$$





\section{CHAPTER XII.}

CISTACEA.

Essrantua Charactir.-Calyx of five unequal sepals. Petals fivc. Stamena definite or indefinite, typogynous. Capaule 3-5-valved, 1-5-celled, many-aeeded. Placentas parietal.-(G. Don.)

GENUS I.

HELIANTHEMUM, Tourn. THE SUN-ROSE.

Lin. Syst. POLYANDRIA MONOGYNIA.

Gexeric Characrkn.-Calyx of three equal scpals or of five unequal sepals. Capsulo trignetrous, l-celled, 3.valved, with a narrew dissepiment or a placentarioua nerve in the middle of each valve.-(G. Don.)

\section{1.-HELIANTHEMUM GUTTATUM, Mill. THE SPOTTED SUN-ROSE.}

SYNonymea.-Cistns guttatua, Lin. C. scuminatua, $V i v$. linear, 3-ncrved, villously-hairy, uppermost onea alternate. Racemes Engravings._Eng. Bot. 544, 2nd edition, vel. v. t. 758; and $\mid$ lnose, bractless. Pediccls filfform, almost naked; outer aepals one our fig. 7 , in Plate 15.

Specific Cuaracter. - Rather hairy. Leavea oppeaite, aeasile, oblong. half shorter than the inner ones.-(G. Don.)

Description, \&c.-A very pretty little flower, almost the only annual of all the extensive genus to which it belongs. There are several varieties of it, differing very little from eaeh other. It is a native of Britain and the whole of Europe; its seeds may be had in any seed-shop, and they may be sown in March or April.

\section{CHAPTER XIII.}

VIOLACEA.

Essentual Canracter.-Sepals 5, equal or unequal. Corolla spurred, irregular flowera are furnished with an appendage each, which are of 5 petals, regular or irregular. Stamens 5, perigynoua. Filaments drawn within the spur. Capsule one-eellcd, three-valved, manydrawn out carth into a scale beyend the anther; two of the filaments in $\mid$ seeded. Placentas three, parietal_-(G. Don.)

\section{GENUS I.}

VIOLA, Tourn. THE VIOLET.

\section{Lin. Syst. PENTANDRIA MONOGYNIA.}

Genrarc Cuaracrer. - Calyx with unequal scpals, all drawn out at | anterior anthers furnished with leng awl-like appendagea. Capsule

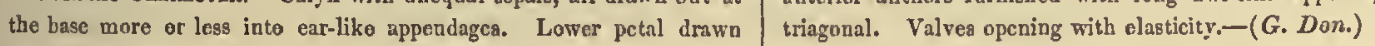

out at the base into s hollow apur. Stamens appreximate, the two

\section{1.-VIOLA TRICOLOR, Lin. THE THREK-COLOURED VIOLET, OR COMMON HEARTSEASE.}

Exchuvings.-Eng. Bot. t. 1287, 2nd edit. vol. ii. l. 333; and onr figs. $1,3,4,5,6$, and 7 , in Plate 14 .

VARIETIEs. -These are very numereua; amounting indeed to above a thousand, most of which can scarcely be called varietiea, aa they are In fact lyybrids between the annual speciea $V$. trienlor, and the perennial in as much of the character of $\mathrm{V}$. tricalor, that they will all blosaom about two montlis after anwing their seed; while they bave ae much of the perennial about them, that they may be propagated by cuttings, \&c., and thus kept slive several yeara. Among tho varietiea now in cultivation are, Allcn's John Bull ( $f g .4$ ), Allen's Minerva ( $f g .5$ ), Enterprise (fig. 6), Fairburn's Anna Maria ( $f i g .3$ ), Brown'a Tiger, kinds V. grandiflora, V. sltaica, V. amena, \&c. These hybrids partake

(fig. 7), which are all old kinds, and to which may bo added many others. The best new kinds in 1838, we sre told by Mr. Hopgond, wero Victoria with a white ground; Trafilgar atraw colour snd purple ; Venua fine eye; Chimpanzee fine purple; Gem; and Desdemona superb yellow. To these might be added many others, but a fresh onea are brought ferward every season, it would be of little use to enumerate them.

Specric Characten.-Roet somewhat fusiform. Stema branched, diffure. Lew cr leavca orate-curdate, deeply crenate. Stipulea run. cistely-pinnatifid, with the middle lobe crenated. Potals incumbent, with short clawa; apur thick, obtuse, not stretched out; noctaries ahort. Sceds obleng-ovate.-(G. Don.)

DESCRIPTION, \&e.-The flowers of the wild Heartsease consist of five petals; the two upper of which are mueh larger than the lower ones, and of a different colour. The two upper petals are generally purple, and the 
three lower ones yellow; the centre one being broader than the others, and streaked with dark brown. What appear to be the leaves, consist each of one long real leaf, and two deeply cut stipules. The stamens are very curiously formed ; they have no filaments, but two of them have long tails, and they are all bordered by a fringe of hairs. The style is short, fleshy, and funnel-shaped; and at the top there is a hole, to which there is a small lip. The seed-pod is oblong, and when ripe, it splits into three parts to discharge the seeds. The root is carrotshaped; and if eaten, it acts as an emctic.

This heartsease, notwitlistanding its curious internal construction, is so small, so simple, and apparently so unpretending, that it is scarcely possible to imagine that the large and magnificent flowers now called Heartseases by florists, can have sprung from it. "The cultivated heartsease," Mr. Gorrie tells us, "should have large and round petals, the flower forming nearly a circle, not much undulated; the colours distinct and permanent; the eye rather small, and not deeply pencilled; the flower-stalk strong and straight; and the stigma filling the open part of the eye." (Gard. Mag. viii. p. 575.) Though this change is entirely the result of cultivation, it must not be supposed that the mere circumstance of transplanting a wild heartsease into rich garden soil, and carefully watering it, \&c., will at once change it into a florist's flower. This is only the first step. Seeds are taken from a plant thus improved, and grown with great care; and the largest and finest of the seedlings thus raised, are selected to yield seed in their turn. Sometimes hybrids are raised by fecundating the stigma of one kind by the pollen of another; and these plants generally possess, in a great degree, the qualities of both parents. Viola grandiflora is frequently used for producing hybrids with the common heartsease; and this species has very large flowers, which peculiarity is preserved in all its seedlings. $V$. amoena is another parent, with very large flowers, the upper petals of which are of dark purple, and the lower ones of a paler bluish tinge; and all the lybbrids raised partly from it, preserve these peenliarities more or less. The descendants of the common heartsease, have dark purple and bright yellow flowers; and those of $V$. lutea are generally nearly all yellow, with blackish, branched radiating lines. The hybrids raised from $V$. altaica are of a very pale yellowish hae; and the petals are generally somewhat undulated at the margin: those from $V$. rothomagensis or hispida are of a pale bluish lilac, and those from $V$. bicolor are white, slightly veined with purple, and tinged with yellow at the base. All these kinds, of course, vary very much ; as these hybrids are made parents, in their turn, of what may be called sub-hybrids, and these again of others. The number of varieties of heartsease, it will thus be seen, may be said to be unlimited. There are now above a thousand named sorts; and more are being raised every yoar. The variety of forms and colours which appear in the plants raised from seed, is indeed so great, that few floricultural pursuits ean be more interesting, than to sow a bed of pansies, and watch when they come up for the new varieties that may be worth saving. Mr. Wells of Redleaf had a garden set apart for experiments of this kind; and a year or two ago, he described to us with so much vividness the pleasure he took in looking over his beds for new kinds, that he made us long for a garden with sufficient space to follow his example. Even at Bayswater, however, in the gardens of our neighbour, Mr. Hopgood, who raises heartseases for sale, we have seen almost innumerable varieties. During the year 1838, we saw them splendidly in flower from March to Oetober; and we observed that some few flowers, here and there, lingered through the winter of 1838-39.

Geocrapiy 4 ND History.-The heartsease is a native of nearly all Europe and North America. It grows always in sandy loam, and generally in the headlands, and under the hedges in cultivated fields. A curious anecdote related of the first American botanist Bertram, bears reference to this habitat of the plant. Bertram 
-<smiles>[AlH2]</smiles> 



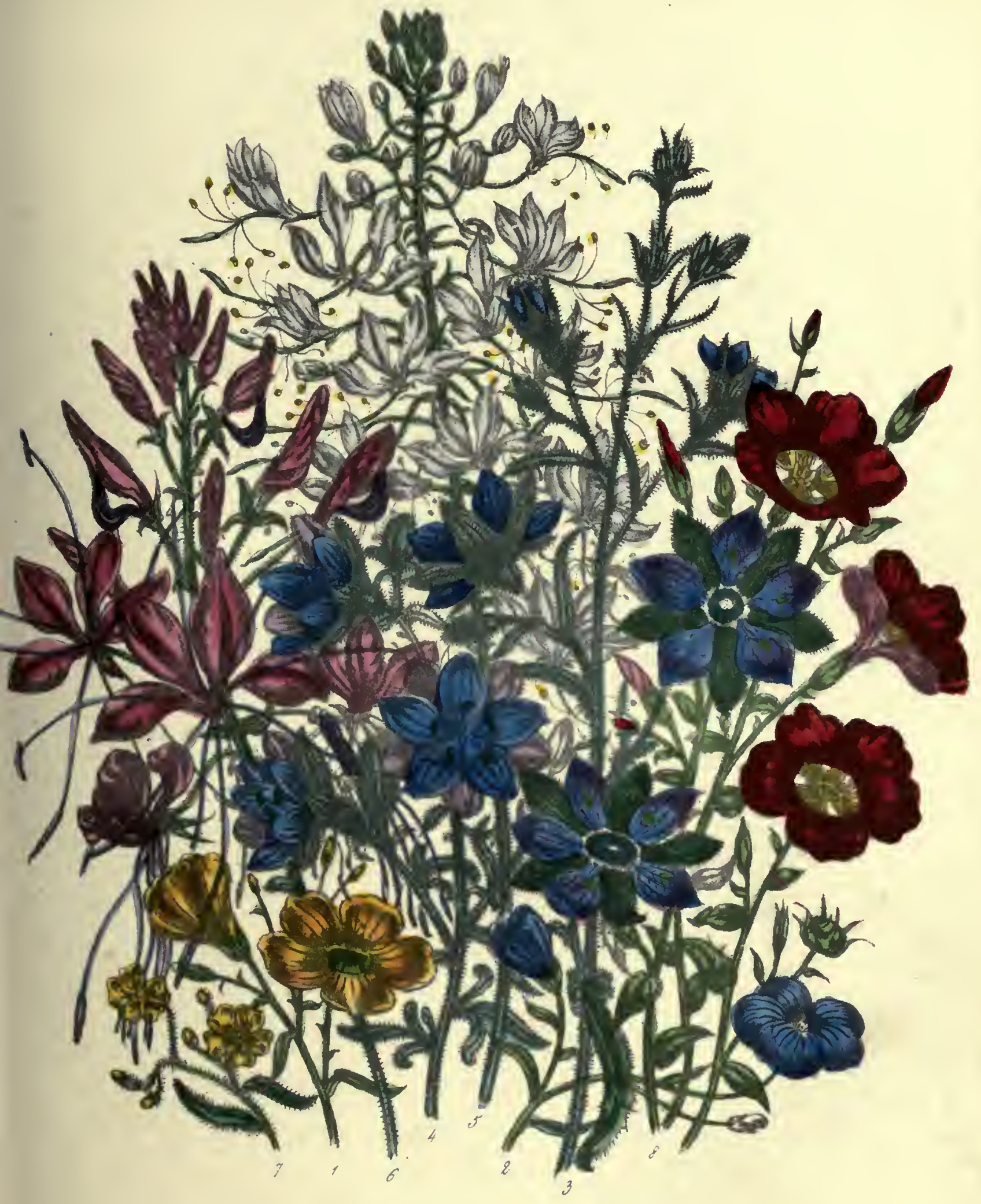

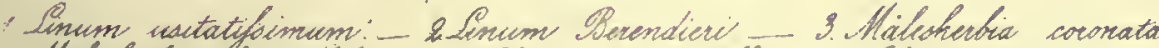

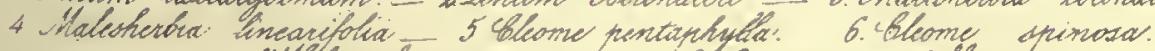

Y. Helianthemum guttatum. 8. Sinum grandifloum. 

was a farmer, and one day while standing on the headland in one of his fields, superintending some farming operations, which were carrying on in the centre, he gathered a heartsease which grew at his feet, and thoughtlessly began to pull off its petals, while he was speaking to his men. We have already mentioned that the stamens and pistil of the heartsease are very curiously constructed; the mass of stamens without filaments huddled together, looks something like the bedy of some small animal; the two that are furnished with tails, rescmble arms; and the style with its round knob-like top, and the hole in its side, bears considerable resemblance to a head. The curious appearance thus formed, canght Bertram's attention; and he took it home with him to examine it more attentivcly. From this slight circumstance Bertram became a botanist; he gave up farming to study physic, as being more congenial with his new pursuits; he entered into correspondence with Linnæus, and all the first naturalists in his time; and he died loaded with honours received from almost every scientifie society in Europe

The heartsease, though long a favourite garden flower, was not valued by florists, till about 1810 or 1812 , when the present Lady Monck, "then Lady Mary Bennet, had a little flower-garden in the grounds of her fathicr the Earl of Tankerville, at Walton-upon-Thames. In this little garden was the figure of a heart, in which this amiable lady used to plant the varieties of Pansies, which she accidentally discovered growing in her father's garden. Aided by the industry and zcal of Mr. Richardson, then, and still gardener at Walton, several pretty varieties were raised and transplanted to this little parterre."-(Gard.Mag. vol. xi. p. 427.) From this small beginning may be traced the rage which has since prevailed for cultivating this flower. Mr. Richardson soon became extremely fond of raising new varieties from seed; and in the year 1813 or 1814, some of his new kinds attracted the attention of Mr. Lee, of the Hammersmith nursery. Mr. Lee instantly perceived the advantage that might be derived from the culture of this flower; and a number of new and beautiful varieties were soon raised in the Hammcrsmith nursery. Other nurserymen followed his example, and in the course of a few years, the heartsease took its place as a florist's flower.

The names of the heartsease are very numcrous. Besides Heartsease and Pansy, by which names it is generally designated in books, it is called Herb Trinity, Love and Idleness, Love in Idleness, Live in Idleness, Kiss behind the garden gate, Three faces under a hood, Kit run in the streets, Call me to you, Jump up and kiss me, Look up and kiss me, Pink of my Jolnn, Flower of Jove, Flamy, \&c. The French call it Herbe de la Trinité, and Penséc, which last name is no doubt the origin of our word, Pansy. The Spaniards also name it Yerba de la Trinidad. The Italians call it Little Flame, Winged Violet and Butterfly Violet (viola farfalla). They also call it Mother and Daughter-in-law; and this strange name accords with that given to it by the Germans, who call it Step-mother.

Culture. - It is the habit of the Heartsease to ripen a succession of seed during the whole of its flowering seasen. As soon as the petals of a flower drop, its seed-pod swells and ripens, while other flowers are expanding; and thus the plant generally bears ripe fruit and flowers at the same time. The seed may be sown of the common sorts in the common soil ; but for the finer kinds it is usual to make a bed in some shady part of the garden. The soil of this bed should be about eighteen inches deep, and it should consist of loam mixed witl sand and regetable mould, and highly manurcd. The seedlings will flower in about two months from the sowing of the seed, whether the time of sowing be autumn, summer, or spring; and as soon as they have flowered, the plants should be all taken up, the best replanted eighteen inchcs apart, and the others thrown away. It must be remembered that though these plants are very liable to bo scorched by the excessive heat of the sun, and 
require constant watering, they are also very liable to be damped off by cold and wet in winter. It must therefore be contrived that the bed in which they are planted shall be well drained, and open to the east and west. The wild heartsease is quite lardy; but the finer sorts, in proportion to the number of generations that they are removed from it, become delicate and liable to disease.

The finest flowers are said to be produced by cuttings, taken off in spring, and grown rapidly"so as to flower the same summer or autumn. These cuttings should be taken from the points of the shoots, cutting them off immediately below a joint. This is done with all euttings, as it is from the joints or buds only that the young roots will grow. The end of the cutting must be made firm in the soil, to induee it to throw out roots; and it must be covered with a bell-glass and shaded, to keep in the moisture and prevent too much evaporation by the leaves, which the eutting, having no roots by which it oan imbibe a fresh supply, would be unable to support. For the same reason the outting is deprived of the greater part of its leaves; as every leaf presents a fresh surface for evaporation. The cuttings of heartsease should cither be struck (that is, induced to strike root) in silver sand or very sandy loam; as soil of this kind by permitting the transmission of water through it, prevents stagnation, and consequently the lower parts of the stems from absorbing it to sucll a degree as to induce rottenness. As soon as the euttings are rooted they should be transplanted to the bed or border, and supplied witl water, and shaded for a day or two till the roots become established.

The finer kinds of heartsease are also propagated by layers. The operation of layering is performed by pegging down the young shoots, and covering them all but their points with rich mould kept moist. When the layers have rooted, they are divided from the parent plant and transplanted. The roots may also be divided into what are called slips, and planted in a shady border, the plants which have not yet flowered being preferred for this operation.

In all eases where heartseases are to be transplanted, or cuttings or layers planted out, it should be done, if possible, in dull rainy weather; and if this is impossible, the newly-transplanted flowers should be well watered and shaded. Where new kinds are to be raised from seed, the seed should be gathered from those plants which produce the largest and handsomest flowers, and at the season when they blossom in greatest perfection; and this season is usually from April till June, as the plants appear weakened by the heat of summer, and generally produce smaller flowers in autumn. Though heartseases may be said to be in flower in favourable situations nearly all the year, they are only in full flower in two seasons-viz. from April to June, and from August or September till the setting in of the winter.

\section{2.-VIOLA LUTEA, Huds. THE YELLOW HEARTSEASE.}

Engravisgs.-Eng. Bos. 1. 721, 2dd edition, vol. ii, t. 334 ; and | simple. Leaves ovate-oblong, crenate, fringed. Stipules palmatifid. our fig. 2, in Plate 14.

Specific Charucter. -Root fibrous, slcnder. Stems triangular, $\mid$ claws. Spur the length of the calyx.-(G. Don.)

Descimption, \&c.-The flower is larger than that of $V$. tricolor, and is yellow marked with blackish, radiating lines: sometimes the upper petals are purple. It is a native of Britain, particularly of the mountains in Wales and Scotland. It is properly a perennial, but it has been introduced here; beeause when raised from seed the young plants will flower almost as soon as those of the common heartsease-that is, in about two months after the seeds are sown. 


\section{CHAPTER XIV.}

\section{RESEDACE $\mathrm{E}$.}

Esgentua Craracter,-Calyx 4-6 parted, or 5-toothed. Petals $\mid$ Stigma 3-4 lobed. Capsule inflated, trigonal; placeatas parietal. $4-6$, open in æestivation, unguiculate, inserted into the base of a dilated disc. Stamens definite, 2 or 3 to each petal; hypogynous. Seeds cochleate.-(G. Don.) This order, and that of Violacece, according to the botanical arrangement, should precede Capparidacesa.

\section{GENUS I.}

\section{RESEDA, Lin. THE MIGNONETTE.}

lim. Syst. OCTO-POLYANDRIA, TRI-TETRAGYNIA.

Generic Crarncter. - Calyx of 4-5-6, narrow segmeats. Petals 4-5-6 cloven. Capsulo bladdery, 3-4 horned, many-seeded.-(G. Don.)

Description, \&c.-This genus consists of numerous species, the most remarkable of which are the Weld; or Dyer's Weed (Reseda luteola), a British plant, used in dyeing yellow, and from which the colour called Dutch pink is made; and the common sweet-scented Mignonette (Reseda odorata).

\section{1.-RESEDA ODORATA, Lin. THE COMMON, OR SWEET-SCENTED MIGNONETTE.}

Everafine,-Bot. Mag. t. 29. | into many club-slsaped divisions; the two lowest simple. Capsulcs Speciric Character.-Leaves lanceolate, bluotish, entire, or trifid. 3-toothed.-(G. Don.)

Calyx 6-parted, equal in leogth to the pctals, which are fiocly cleft

Description, \&co.-The Mignonette, though called an annual, and always treated as sucl in this country, is in fact a shrub, and when carefully preserved through the winter, its stem becomes woody. In this state, it is called the tree Mignonette, and is by many supposed to be a different species. Though its flower is by no means showy, it is a general favourite for its fragrance, and there are few flower-gardens in which it is not sown. It is a native of Barbary, where it has been found, by modern botanists, in the sands near Mascora, a fortified town of Algiers. It is also generally described in books as a native of Egypt, but on what autlority is not known, as there is no reeord of its having been ever found wild in that country. The earliest English writers who mention it (about the middle of the eighteenth century) call it the Egyptian Rocket. It appears to have been first brought from Barbary into Spain, from which country it was carried to the south of France, and thence to Paris. From Paris, its seeds are said to lave becn sent by Lord Bateman to Mr. Bateman, at Windsor, in 1742, though it did not come into general cultivation till 1752, when seeds of it were received by Miller, who was then curator of the Botanic Garden, Chelsea, from Dr. Adrian Van Royen, of Leyden. From the Chelsea Garden it soon passed into those of the London florists, and the "fragrant weed," as Cowper calls it, soon became a favourite.

The name of Reseda is derived from the Latin resedo, to calm, or appease : and it is supposed to bear reference to the healing properties of one of the species. The name Mignonette is literally "little darling." It is said in the little work called Le Langage des Fleurs, that this flower forms part of the arms of a noble family in Saxony, from an ineident in the life of one of its descendants. The legend is that the Count Walsthein was paying his addresses to a beautiful heiress, who trifled with his affections, and who had a dependent cousin secretly in love with tle count. One evening, while walking in the garden, the ladies each chose a fower, and the heiress gaily 
challenged the Count to write the description of each in one line. She had chosen a Wild Rose, and the Count, who had been piqued by her numerous flirtations, wrote-

Charming, but evanescent.

The cousin had chosen Mignonette, and the Count's motto for this flower was-

Your qualitics surpass your charms.

The legend adds, that the Count married the consin, and in compliment to her, inserted the Mignonette in lis coat of arms.

Coltuns. - The Mignonette is so favourite a flower that it is sown at all seasons, and many gardeners contrive to have it in flower every month in the year. To do this, they sow it at four or five different times. If it be wanted to flower in winter, the seed is usually sown in the open ground about the end of July. About the middle of September these plants will be ready for planting in pots, shading them for a few days after transplanting, and protecting them from heary rains. Before the frost sets in, the pots should be placed in frames till the beginning of Novcmber, when some of them will begin to show flower-buds. They should then be removed to the greenhouse, where they will branch out, and continue flowcring till spring. In small gardens, where there are neither greenhouses ner frames, the same effect may be produced by placing the pots in the window of a room without a fire, till they begin to form blossom buds, and then removing them to a warm window in a living room, where they will blossom beautifully. Abundance of Mignonette will be thus produced from November till March ; but it will be more difficult to have plants in flower during the months of March, April, and May. The seeds, in this case, must be sown in pots about the latter end of August. They must be protected from the cold, and heavy rains, and in November they should be thinned out, leaving only eight or ten plants in each pot. The pots should then be sunk in an old hotbed of manure, or tan, and covered with a framc, where they must be kept, and covered closcly at night, till they begin to form flower-buds, when they must be removod to the greenhouse. In a small garden, the seeds may be sown in pots, and during the severe weather, a shallow box, or packing-case, may be filled with coal ashes, into which the pots may be plunged. This will keep the roots moist, and provent the leaves from turning yellow. In very scvere frosts, the plants may be covcred with an old blanket, or piece of carpeting. When they lave formed blossem buds, they may be removed to the window of a room where there is a fire, when they will blossem freely. A third crop may be sown in February, and treated like the last, or raised on a hetbed. These will come into blossom by the end of May, and they will be succeeded by plants sown in April, which will continue in flower till they are killed by the frost. The summer-sown species will then be just ready to flower; and thus a succession of flowcrs will be kept up all the year.

Among the many uses of the Mignonette, may be reckoned that of planting it with Candy-tuft, Clarkias, \&c., as we have alrcady recommended. Boxcs of it are also raised for windows, \&c., and tufts are planted in court-yards. Wherever it may be grown, care should be taken to sow the seeds in a poor sandy soil, as unless this is donc, the Mignonette will have scarcely any fragrance.

The tree Mignonette is nothing but the common Mignonette, preserved throngh the winter, and trained so as to form a tree. It is propagated by cuttings, and is more fragrant than when grown as an annual. Many persons attempt to buy its seeds; but as its real seeds would only produce the common kind, nurscrymen generally sell the sceds of the Dycr's Weed (Reseda luteola), a common British plant, for it. This plant is an annual, with taller and stronger stems than the common Mignonette, and it is cultivated for the yellow dye which it affords; but it certainly is not worth growing in a flower-garden. 


\section{.}




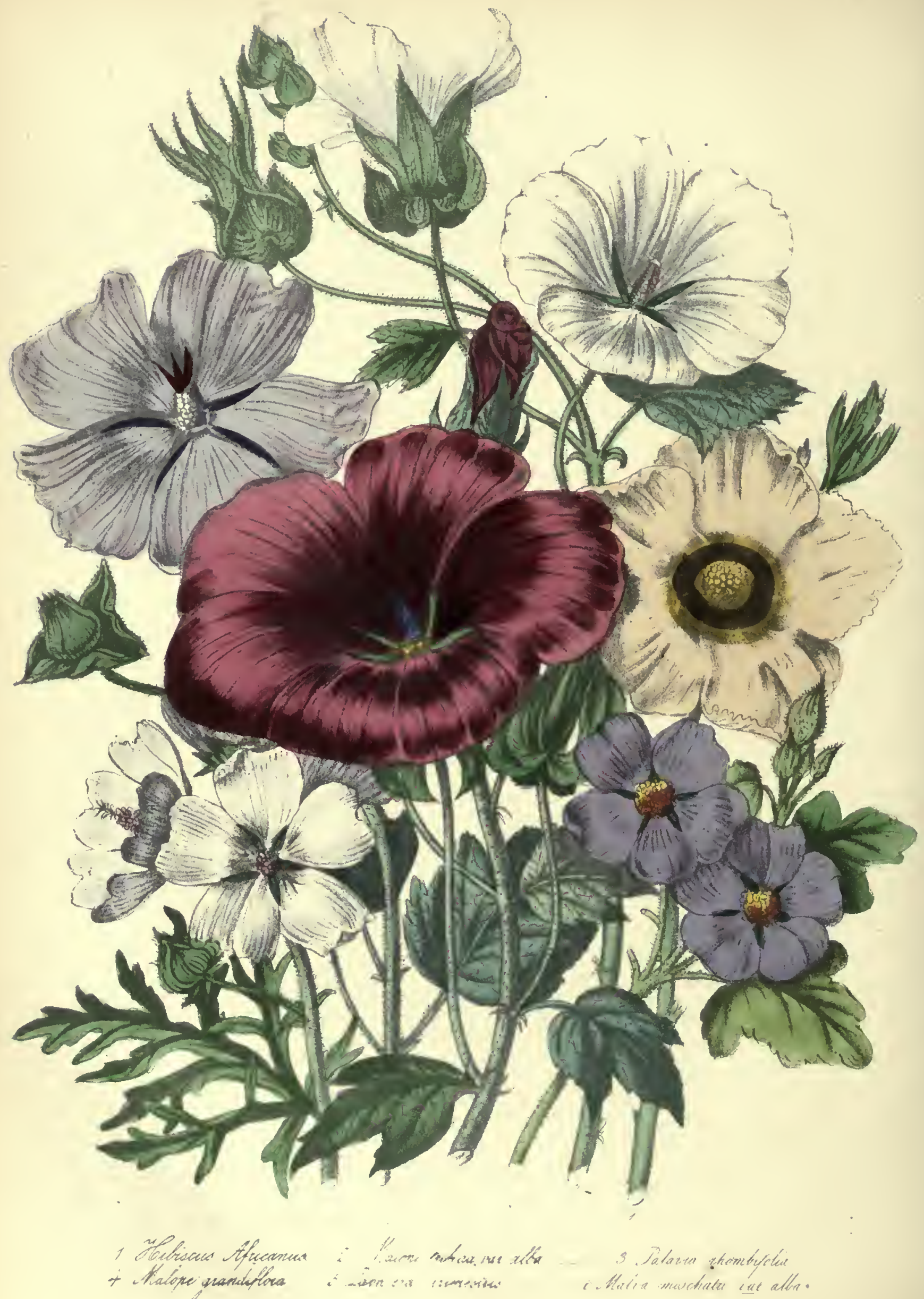


. 



\section{CHAPTER XV.}

\section{MALVACEE.}

Easestur Craracter.-Sepals generally 5, rarely 3-4. Petals and ovaria. Anthers one-celled. Carpels numerous, disposed in a 5, twisted in æstivation. Stamens numerous, hypogynous, and combined with the elaws of the petals into a column, which girds the style whorl around the axis, capsular or baceate.-(G. Don.)

Descruprion, \&c.-All the plants belonging to the order Malvaces are remarkable for their showy flowers and curious seed-vessels, which resemble little cheeses, and are full of a mncilaginous matter, which is reckoned excellent for diseases of the lungs. The name of Malva indicates this quality, as it is derived from a Grcek word signifying soft, or softening. The flowers have several peculiarities in their botanical construction. The petals are euriously twisted together in the bud, and the stamens grow together at the base into a kind of eolumn, bearing at their summits kidney-shaped anthers, eacl containing only one cell, iustead of two, as is the case with most other plants. The carpels grow together in a circle, so as to form a flat plate, with the styles, which are joined together at the bottom, rising like a column in the eentre. "Each carpel," says Dr. Lindley, "contains one sced, with an embryo curiously doubled np and filling the whole cavity; hence, as the carpels are all of the same size, and arranged with the most exact regularity on the same level, if a fruit is cut through, it will present a singularly beautiful arrangement of the parts, which look like a vegetable star."

\section{GENUS I.}

\section{MALVA, Lin. THE MALLOW.}

Lin. Syst. MONADELPHIA POLYANDRIA.

Gengric Character. - Calyx girded by a 3-leaved involucrum, marcly by a 5-6-leaved one; leaflets oblong or setaceous. Carpels eapsular, 1-secded, verticillate, disposed in an orbicular bead.-(G. Don.)

Description, \&c.-The common Mallow of the hedges, and that so abundant in church-yards, are so well known, that but little description is necessary for the genus. A malvaceous plant may indeed be always known at first sight, and the only difficulty is to know which of the genera it belongs to; which is not easily determined, as the differences between the gencra, consisting chiefly in the seed-pods, are not conspicuous to unbotanical eyes. All the kinds of annual plants belonging to this order slıould be sown in warm sunuy situations, and are killed with the slightest frost; they do not bear transplanting well, except when very young, or when a ball of earth is kept round the roots. They have been cultivated in flower-gardens since the time of Parkinson (1620), who says, that "for their bravery, they were entertained everywhere, into every countrywoman's garden."-Paradisus, p. 366. They may all, like the mignonette, be made perennial, or even shrubby, by keeping them through the winter in a grcenhouse, and propagating them by cuttings.

\section{1.-MALVA MOSCHATA, Lin. THE MUSK MALLOW.}

ENGravings._Eng. Bot. t. 547 ; 2nd edit., vol. v. t. 980 ; and our fig. 6 in Plate 16 of the white variety.

$V_{A R I r T Y}-M . m .2 a l b a$, Hort.; syn. M. m. 2 undulata; Sims Bot. Mag. t. 2298, bas white flowers.

Specric Character.-Lower leaves kidney+anaped, cut, caulino ones 5-decply pinnatifid, jagged segments. Stems and calyxes scabrons from simple bairs. $-($ G. Don.)

DEscirption, \&C. - The species has large rose-coloured flowers, and a slender branching stem, with very dceply cut leaves. It grows wild in Britain, on the borders of fields, and by the road side in gravelly soil ; and 
in its wild state it is considered a perennial, though it is treated as an annual in gardens. The whole plant yields a faint musky odour when drawn through the hand. The white is a garden variety, and is not found wild. The seeds of both kinds may be had at Leo's, Hammersmith, and in most other seed-shops.

\section{2.-MALVA MAURITANIA, Lin. THE MAURI'TANIAN, OR IVY-LEAVED MALLOW. \\ Evaraprwa -Brit. Flow. Gard. t. 81. \\ Speciric Character. - Stem erect; leaves 5-lobed, obtuse; pedicels and foot-stalks smoothish.-( G. Don.)}

Descriptron, \&c.-A strong-growing plant, rising nearly six feet high, with pink, crimson, or deep purple Hlowers. A native of Italy, Spain, and Portugal ; introduced in 1768 by John, Earl of Bute. Its seeds may be procured at any seed-shop, and they may be sown in autumn, or in March or April.

\section{3.-MALVA CRISPA, Lin. THE CURLED, OR FRENCH MALLOW.}

Spectric Character.-Stem crect ; leaves engular, toothed, curled, glabrous; flowers axdlary, sessile.-(G. Don.)

Desoription, \&c. - This is one of the oldest foreign Mallows cultivated in our gardens, as it is included by Tusser in his list of garden flowers in 1573. It grows about six feet high, with an erect and vigorous stem; and its flowers are rather small and whitish, tipped with pale purple or rose-colour. The leaves are curiously curled at their margins. It is a native of France. Seeds may be procured in the seed-shops under the name of the curled mallow; and they may be sown in the open border in April or May.

\section{4.-MALVA LIMENSIS, Lin. THE LIMA, OR BLUE MALLOW.}

Specritc Character.-Erect, leaves 7-lobed, wrinkled; spikes axillary; flowers leaning to ono side; carpels smouth.-(G. Don.)

Description, \&c.-A rather small, but erect species, with spikes of blue flowers. A native of Peru, introduced in 1768 . This is a very ornamental species, but wo do not know where seeds are to be procured.

\section{OTHER SPECIES OF MALLOW.}

The following species, though introduced, not being common in the nurseries, we have not thought it necessary to enter into details respecting them.

\section{AMERICANA, Lin.}

A very pretty species only a foot high, witl yellow flowers; a native of the West Indies, introduced in 1756

\section{MAREOTICA, Del.}

A native of Egypt, introduced in 1822; growing 2 feet high, and with red flowers.

M. CAROLINA, Lin.

A trailing species, with red flowers; a native of Carolina, introduced in 1723.

To these may be added M. stricta, the Upright Mallow, and M. Hispanica, the Spanish Mallow; though neither of them possess any remarkable beauty in their flowers.

There are many other annual species of Mallow, but none of them are wortl cultivating. 


\section{GENUS II.}

\section{MALOPE, Lin. THE MALOPE.}

\section{Lin. Syst. MONADELPHIA POLYANDRIA.}

Generrc Character.-Calyx girded by a 3-leaved inveluerum; lenfleta cordate; carpels nunerous, I-seeded, disposed into a head.--(G. Don.)

Description, \&c.-The genus Malope differs from the genus Malva prineipally in the shape of the capsules, and the manner in which they are disposed. In the Malva they unite so as to form a flat capsule, but in the Malope they form a close, aggregate head, resembling that of the raspberry. The flowers of the Malope are generally larger and more showy than those of the Malva, and the texture of their petals is softer and more transparent; whence the name of Malope, from a Greek word signifying tender.

\section{1.-MALOPE TRIFIDA, COv. THE TRIFID MALOPE.}

VAruerses.-M. t. 2 alba, Dec. has white flawers. M. t. 3 gran- Plate 16, of the white flowered variety ; and our fig. 4, in Plate 16, diflora, Syn. M. grandifera Hort., has very large rose-coleured and Paxt. Mag. of Bot. vol.i. p. 177, ef Mralope grandiflora. flowers.

Specific Character, - Leaves three-nerved, trifid, tootbed, glabrous; lobes acuminated. Peduneles axillary, one-flowered.-(G. Don.)

Description, \&c.-The common Malopo trifida is rather a low-growing plant, seldom exeeeding a foot in height, with very brilliant and glossy dark rose-eoloured flowers. The stems are slightly angular and furrowed. The leaves are cordate, and very slightly three-lobed. The peduneles, or flower-stalks, are tinged with purple, and the calyx is surrounded by a large involucre, eonsisting of three cordate leaflets, united at the base. This leafy involucre distinguishes both the flower and the capsule of the Malope at first sight from those of all the kinds of Malva. The eene-like shape of the expsule is also very distinet from the round, flat elieeses of the Mallow.

The large-flowered variety, Malope grandifora, well merits its name; for the flower we have figured, whieh we had from Lee's nursery, is only about the average size. The plant alse grows three feet or four feet high. In the summer and antumn of 1838, an immense quantity of Malope grandiflora was growing in the nursery of Mr. Forrest, at Kensington, where its magnifieent flowers produeed an effect quite dazzling to the eye. The white-flowered variety, on the contrary, has rather small and very delieate flowers; and it does not grow higher than the species.

Malope trifida is generally said to be a native of Barbary, introduced in 1808; but in the plant eatalogne ef Mr. Masters, of Canterbury, it is stated that this Malope "was introdueed in 1806, from the Mauritius, by the writer's father."-(Hort. Duro., 3rd edit. p. 119.) It is not known by whom the splendid variety Malope grandiflora was raised; but it is certainly one of the handsomest of garden annuals.

The seeds of both the species and varieties may be proeured in any seed-shop, and they may either be raised in Mareh in a slight hot-bed, or sown about the middle of $\Lambda$ pril in the open borders; observing that, if the plants are raised in a hot-bed, they should be sown in pots, and transplanted with the ball entire, without disturbing the roots: 


\section{2.-MALOPE MALACOIDES, Lin. THE MALLOW-LIKE MALOPE.}

Specific Character._Leaves ovate, crenated. Stipules obloog-linear. Peduncles axillary, one-flowered._(G. Don.)

Description, \&c.-This species has purplish crimson flowers, strongly resembling those of the common Mallows, but with the seed-pod of the Malope. It grows abont a foot or eighteen inches high. It is a native of the South of Europe and North of Africa, in meadows, and it was introduced in 1710. The culture is the same as that of $M$. trifida. There is a variety of this speeies with deeply sinnated, or pinnatifid leaves; but we believe it has not been introdueed into England.

\section{GENUS III.}

\section{LAVATERA, Lin. THE LAVATERA.}

\section{Lin. Syst. MONADELPHIA POLYANDRIA.}

Generic Chanacter,_Calyx girded by a $3-5$ cleft involucre. Leaflets usually conneeted together to the middle. Carpels capsular, oneseeded, disposed in an orb around tho axis,-(G. Don.)

Description, \&c.-Most of the species of Lavatera are shrubby, but the fow annual kinds are well deserving of cultivation. The generic distinetion consists principally in the leaflets of the involucre being joined to the middle; and in the carpels, which are disposed round the central axis, having it dilated over them. Those who wish to study botanical distinctions, should compare the seed-vessels of the Mallow, the Malope, and the Lavatera. Three dry seed-pods are now before us: those of Malva moschata, Lavatera trimestris, and of Malope grandiflora. The seed-vessel of the Musk Mallow consists of a circle of woolly-looking carpels growing close together, but easily detached with a pin; each fitting into a little groove in the axis, round which they are placed. They are in a loose open calyx, without any involucre, and even the small bracteas which were below the calyx when the plant was in a growing state, have fallen off. The Lavatera has a larger circle in the centre, appearing at first sight to resemble the circle of carpels in the Mallow ; but on examination it will be found to be the dilated axis, which, instead of having grooves in it for the reception of the seeds, is stretched over them and curved down so as to form a cover, under the shelter of which the seeds lie completely concealed. The calyx consists of five sepals, which bend down over the centre, and below which is the large, spreading involucre, consisting of three broad leaflets, which grow together half way up. The Malope has a very long calyx and large sepals, which make its seed-vessels bear the same relation to the others as a filbert does to a common nut. The peculiar shape of the involucre and ealyx are shown in figs. 2 and 6 in plate 16 ; and when these are opened to examine the seeds, they will be found growing on the receptacle in the shape of a raspberry, something like those of the Flos Adonis, or the common Crowfoot.

\section{1.-LAVATERA TRIMESTRIS, Lin. THE THREE-MONTHEY LAVATERA.}

Synonyme.-Stegia Lavatera, Dec.

Engratings.-Bot. Mag. t. 109, and our fig. 5 , in Plate 16.

VARIETY.-L. t. 2. albiflora, $G$. $D$ on, has white flowers.

Sprctfic Character. - Stem scabrous. Leaves smoothish, roundish, cordate, upper ones lobed. Pedicels solitary. Orb of receptacle per. fectly concealing the carpel s.-(G. Don.)

DESCRIPTION, \&c.-The pink and white Lavateras are too well known as border flowers, to need any detailed description. They grow from three to six feet high, and their flowers are delicately and beautifully veined. The situation of the seeds has been already deseribed. The plant is found wild in Spain, and also in Syria. It 
appears to have been introducẹ from Spain about 1600, as, thougl it is not mentioned by Gerard, who wrote in 1597, it is by his commentator Johnson, who wrote in 1633. It was then called the Spanish Summer Mallow. Clusius was the first to apply to it its specific name of trimestris. Its seeds may now be procured in any seedshop. They should be sown in April or May, and when the plants come up, they must be thinned out, so as to leave not more than five or six in a group. In the centre of this group should be placed a stake, to which the plants may be tied loosely, or they may be drawn through a dahlia hoop. They are free-growing plants, and produce abundance of flowers; but they are rather too large for a small garden unless they are kept neatly trained.

\section{OTHER KINDS OF ANNUAL LAVATERA.}

The following kinds are well deserving of cultivation; but we have never seen them in gardens, and do not know where to procure seeds.

L. FLAVA, Desf.

This kind has yellow flowers. It is a native of the north of Africa and Sicily. It was introduced in 1818, but is now apparently lost.

L. PUNCTATA, All.,

is a native of the south of Franee and north of Italy, where it is found in cultivated fields. It has pale violet flowers, and was introduced in 1800 .

\section{CRETICA, Lin.}

This species has pale rose-coloured flowers, with a fringed margin to the petals. It is a native of Crete, and was introduced in 1723.

L. AMBIGUA, Deo,

nas purple flowers. It is a low plant, and grows wild near Naples. It was introduced in 1824.

-

GENUS IV.

HIBISCUS, Lin. THE HIBISCUS.

Lin. Syst. MONADELPHIA POLYANDRIA.

Generic Character.-Calyx girded by a many-leaved, rarely fow- $\mid$ eapsule, with the valves beariog a dissepiment en the inside. Colls leaved involucre, distinct or connected with each other at the base. many, rarely l-seeded. Seeda woelly or smooth.-(G.Don.)

Petals not auricled. Stigmas five. Carpels joined into a 5-celled

Descriptron, \&c.-Most of the annual plants belonging to this genus ean only be grown in England in the stove, and we have therefore omitted them; but an idea may easily be obtained of them from those we shall describe, as they bear a very strong family likeness to each other. The genus Hibiscus is botanically distinguished from the other Malvacece, by the very different shape of its seed-vessel. This consists of five carpels grown together into one capsule, which has the seeds it contains arranged along fivo valves.

\section{1.-HIBISCUS TRIONUM, Lin. THE COMMON OR BROAD-LEAVED BLADDER KETMIA.}

Excrufinc.-Bot. Mag. t. $209 . \quad$ | upper ones 3-parted, blunt. Lobes Ianceolate, with the middlo ono Speciric Charneter.-Leaves toothed, lower ones almost undivided, very long. Calyx infiated, mombranaceousa full of nerves.-(G. Don.)

Description, \&c.-The flower of the Common Bladder Ketmia is about the size of that of the Musk Mallow, and it is of a delicate cream-eolour, with a purple centre; and the anthers are of a rich golden bue The stem is 
weak, and if not supported will lie on the ground. The leaves are broad and three-parted, whence the specific name of trionum. The capsules are inflated, and it is from them that the epitliet bladder is applied to the plant. Ketmia is from the Arabic name of the mallow. This species is a native of Italy and Carniola; it was first called the Venice Mallow, or Good-night-at-Noon, in allusion to the short duration of its flowers, which were supposed to drop exactly at noon. It is mentioned by Parkinson and Gerard; and as the latter speaks of it jn the first edition of his Herbal as well known, it must have been introduced some years before 1596. The culture is very simple, as the seeds may be sown at any time when the ground is not hard with frost, and the plants will not need either thinning ont or tying up, as they look best sown thickly, and with their stems lying on the ground. Seeds are common in every seed-shop.

\section{2.-HIBISCUS AFRICANUS, Thun. THE AFRICAN BLADDER KETMIA.}

Symonyme.-Hibiscus vesicarius, Cav., H. trionum, var. sfricanus, Mill. Dict.

Engraving.-Our fig. 1, in Plste 16.

Specific Character.-Leaves toothed, lower ones undivided, upper oncs 5-cleft, with oblong, blunt lobes. Calyx inflated, menbranaceeus, full of nerves. - (G. Don.)

Description, \&c.-This very beautiful flower is so superior to the common Bladder Ketmia, that it has nearly superseded it in gardens. The petals are of a very pale yollow, or rich cream-colour, and the blotch at the base of each is of a very rich reddish-lorown. The specics is a native of Africa, particularly near the Cape of Good Hope, where it is a shrub. It was first introduced in 1713, and has been frequently lost to our gardens, from its inability to ripen its seeds without abundance of heat. The last date given for its re-introduction is 1826. It requires a light sandy soil ; and when it comes up, it may either be thinned out and tied up, or left to flower as it grows, like $H$. trionum. Mr. Forrest, of the Kensington Nursery, had a variety with larger flowers than the species.

GENUS V.

PALAVIA, Cav. THE PALAVIA.

lin. Syst. MONADELPHIA POLYANDRIA.

Generic Character.-Caly naked, 5-cieft. Carpels capsular, numerons, 1-seeded, disposed into a head without any orlcr. - (G. Don.)

\section{1.-PALAVIA RHOMBIFOLIA, Graham. THE RHOMBOID-LEAVED PALAVIA.}

Engruvings.-Bot. Reg. t. 1375 ; Bot. Mag. t. 3100 , and our fig. 3 , in Plate 16.

Specific Character.-Leaves rhomboidal, lobately-erenate, stel- lately-pilose on the veins, shorter than the pedunelcs. Stipules awlsbaped, ciliated, green. Petals obovately euneated, obliquely-cmarginate. Peduneles longer tban tbe leaves. - (G. Don.)

Drscription, \&c.-A little delicate plant, with a flower of no great beauty, resembling a common Mallow. It is a native of Peru, near Lima, from which country seeds were sent sent home by Mr. Cruickshanks in 1830. It requires a warm situation and a light sandy soil; and its flowers, though short-lived, are produced in great abundance. Seeds may be procured in any of the London seed-shops.

\section{OTHER KINDS OF PALAVIA.}

There are two other kinds of Palavia, both natives of the sandy plains near Lima. One of these, $P$. moschata, has yellow flowers, turning purple as they fade; and the other, P. malocefolia, has small red flowers. Both are said to have been introduced, but we do not know where seeds of them are to be procured. 
.$$
\text { . }
$$$$
\text { e- }
$$ 


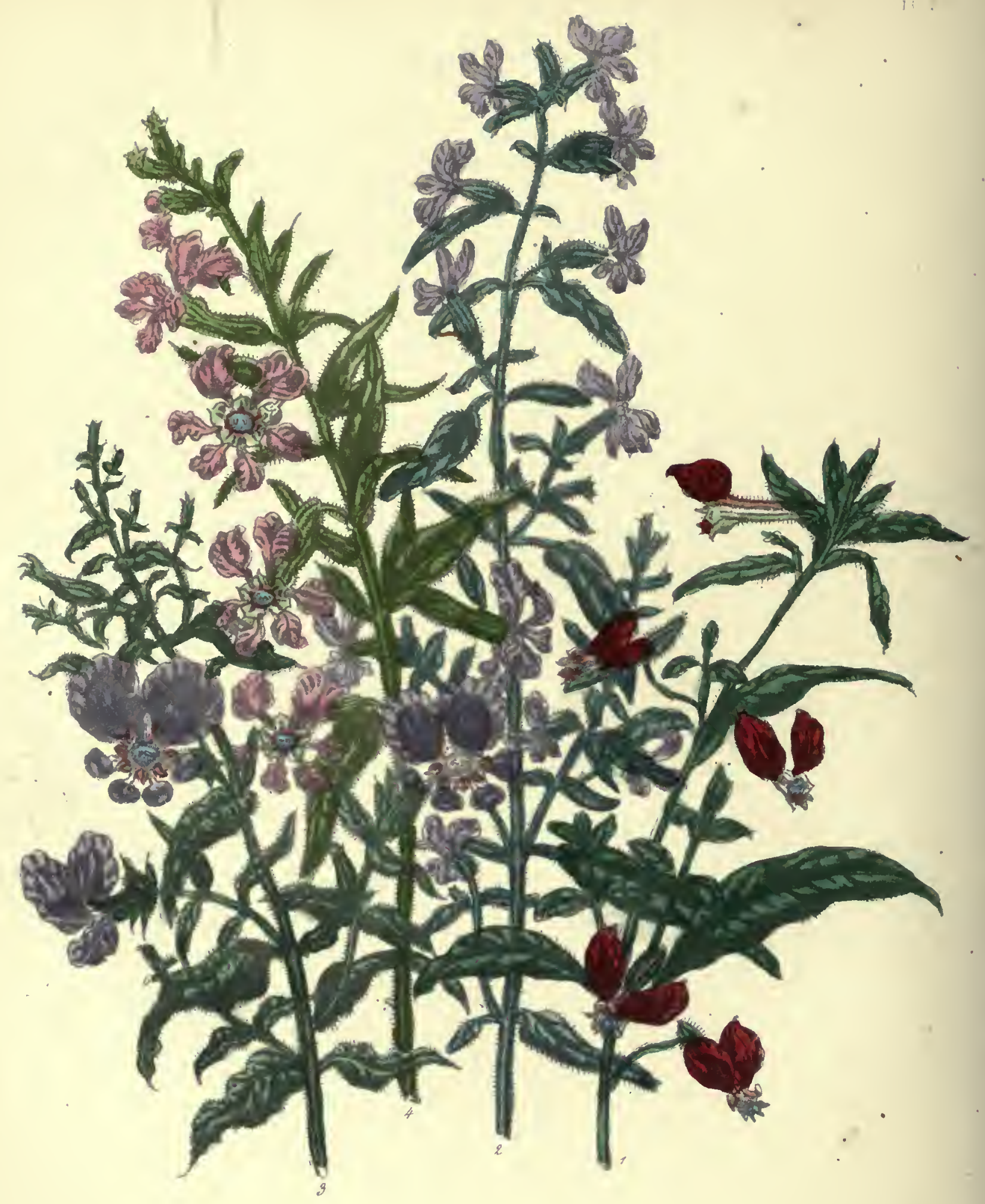

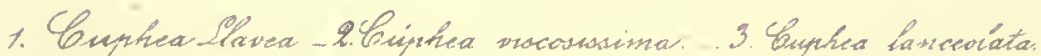






\section{CHAPTER XVI.}

\section{LYTHRACE}

Essential Characten.-Calyx tubular, ribbed, the sinuses between below the petals, varinble in number. Capsule covered by the tube of the lubes sometimes leogthened out into the other lobcs. Petals 4-6, the calyx, l-celled, placenta central.-(G. Don.) inserted into the tube of the calyx. Stamens inserted in tlic tube

Description, \&c.-The order ${ }^{\circ}$ ythracece contains several interesting plants, and among others, the Henna (Lartsonia inermis), so much used by ladies in the East, the Lagerstrœmias, or Pride ef India, and the plant supposed by some to be the Rosewood of commerce, Physocalymna floribunda. The only genera containing annual flowers are Lythrum and Cuphea. The annuals in the first genus are wild British plants, and only those belonging to the genus Cuphea are cultivated in gardens. Even these plants are by no means beautiful, as they have all that peculiarly dark reddish and yet blackish purplc, which has made the name of the order be derived from the word lythron, black blood.

\section{GENUS I.}

\section{CUPHEA, Jacq. THE CUPHEA.}

\section{Lin. Syst. DODECANDRIA MONOGYNIA.}

Generic Cunracter. - Calyx tubular, 12-toothed. Petals 6-7, unequal. Stamens 11-14, rarely 6-7, unequal, inserted in the orifice of the calyx. Capsule 1-2-cclled.-(G. Don.)

Description, \&c.-The plants compusing the genus Cuphea were separated from those forming the genus Lythrum, chicfly because the former have a tubular calyx and unequal petals, while the latter have not a tubular calyx, and the petals are equal. There is likewiso a difference in the stamens, and in the capsule.

\section{1.-CUPHEA VISCOSISSIMA, Jacq. VERY CLAMMY CUPHEA.}

Srvoxymzs.-Lythrum petiolatum, Lin. L. Cuphea. Lin. fil. | pubescence, hispid. Leaves epposite, petiolate, evate-laneeolate, rather

Engravings.-Brit. Flow. Gard. t. 60; and our fig. 2, in scabrous. Flowers pedicellate, solitary, deflezed. Calyz 6-toothed, Plate 17. clothed with clammy down. Petals 6, unequal.-(G. Don.)

Specific Characten.-Stem erect, branched, clothed with clammy

Description, \&c.-An erect plant, growing from a foot to eighteen inches high, with a dark purple stem, and pale dull purple flowers. The stem is branched, and the whole plant is covered with clammy hairs. The flowers begin to appear when the plant is net above six incles high, and as it continues growing, the flowers continue expanding. It is found wild in America, from Brazil to Pennsylvania, in humid shady places. It was introduccd in 1776. The seeds are generally raised on a hotbed, and planted out into a meist shady border in June; or they may be sown in the open air in April.

\section{2.-CUPHEA PROCUMBENS, Cav. THE PROCUMBENT CUPHEA.}

Everavings.-Bot. Reg. t. 182; abd our fig. 4, in Pl. 17. Specific Character.-Stcm assurgent. Braeches procumbent, clothed with elammy hairs. Leaves oppesite, on short petioles, evato. lanceolate, rather hispid. Flowers pedicellate, solitary, deflexed.

Calyx clothed with clammy hairs, 6-toothed. Petals 6 , obevate, two larger than the rest. The two largest stanens are woolly beyond the anthers.-(G. Don.)

DESCRIPTION, \&c.-The petals of the flowers are rese-coloured, and the calyx is of a reddish purple, or rather lilac tinge, tipped with green. The stem is slender, and it is covered with a purplish pubescence; it is only 
partly procumbent. The flowers are numerous, loose, and terminating the stem and branches in leafy racemes. The species is a native of Mexico, and was first raised in Europe by Professor Cavanillcs, in the garden of the Buen Retiro, at Madrid. It was afterwards grown in the Berlin Botanic Garden, whence it was sent both to the Botanic Gardeu, Chelsea, and to the Fulham Nursery, in 1816. The seeds should be raised on a hotbed in April, and the young plants planted out into a moist, rich, shady border, in June.-

\section{3.-CUPHEA LLAVEA, La Llave et Lexarza. LA LLAVE'S CUPHEA.}

Escrastings,-Bot. Reg.t. 1386; and eur fig. 1, in Plate 17. | foliaccous, erect. Petals two, obovate, large, the rest abertive. Specific Characrer. - Stems numerous, hispid. Branches ascend- Stamens eleven.-(G. Don.)

ing. Leaves almest acssilc, ovate-lanceelate, strigosc. Pedicels inter-

Description, \&o. -The petals of the flowers are of a dark scarlet; the calyx has a greenish front, and the back and throat are pinkish. Three of the stamens are very long. Only two of the petals are conspicnons, the others being so small as to be scarcely visible. The stems are numerous, erect, taper, and about a foot and a half ligh. It is a native of the mountains of Central Mexico, where it was discovered by La Llave flowering in March and April. It was introduced into England by Mr. Ackermann in 1829, who gave the seeds to Mr. Tate, in whose nursery they flowered the following August. It is properly a perennial ; but as it will not live through the English winter in the open air, it does best treated as an annual. It may either be sown in a hotbed in Fchruary, and planted out in May, in which case it will flower in June, or be sown in the open air in April, when it will flower in August.

\section{4.-CUPHEA LANCEOLATA, Ait. THE LANCEOLATE-LEAVED CUPHEA.}

SnNoNy ME, -? C. sileneidcs, Hort.

Enoravings._-Brit. Flow. Gard., 2nd Ser. t. 402 ; Floral Cahinet, vol. ii. p. 161 ; and our fig. 3, in Plate 17.

Specific Character. - Stem erect, cletbed with clammy puhescence.

Leaves oppesite, en short petieles, lanceelate, rather pilose. Flewers pedicellate, selitary, deflexed. Calyx beset with clammy pili, 6teothed. Petals 6 , ebevate, twe of which are larger than the rest; tho two longer stamens are woolly beyend the anthers. - (G. Don.)

Description, \&c.-The whole plant is clothed with soft, clammy, purple hairs, and it has a powerful fragrance; the stem is erect and branched, with ascending branches. The leaves are lanceolate, and pale grecn on both sides. The root is fibrous. The flowers are solitary; the petals are of a very dark black-blood colour, with white claws, and the calyx is greenish. The flower is certainly much handsomer than that of any other kind of Cuphea; but still it is more curious than beautiful. Cuphea lanceolata is a native of Mexico, and was first introduced by Mr. Anderson, Curator of the Botanic Garden, Chelsea, in 1796 ; it was, however, soon after lost, till il was re-introduced about 1836, by Messrs. Osborn, of the Fulham nursery, who received the seeds from Messrs. Booth, of Hamburgh. It was first supposed to be a stove plant; but the specimen from which our plate was taken grew in the open border in the Fulham nursery, without the slightest protection. The culture is the same as that of the other species.

\section{OTHER SPECIES OF CUPHEA.}

There are several other annual species of Cuphea, mostly natives of Mexico, which have not yet been introduced; but which, from the descriptions which have been given of them, appear well deserving of introduction. Though not at all showy, they are curious; and though natives of a warm climate, they are found to succed perfectly well in the open air in Britain. 


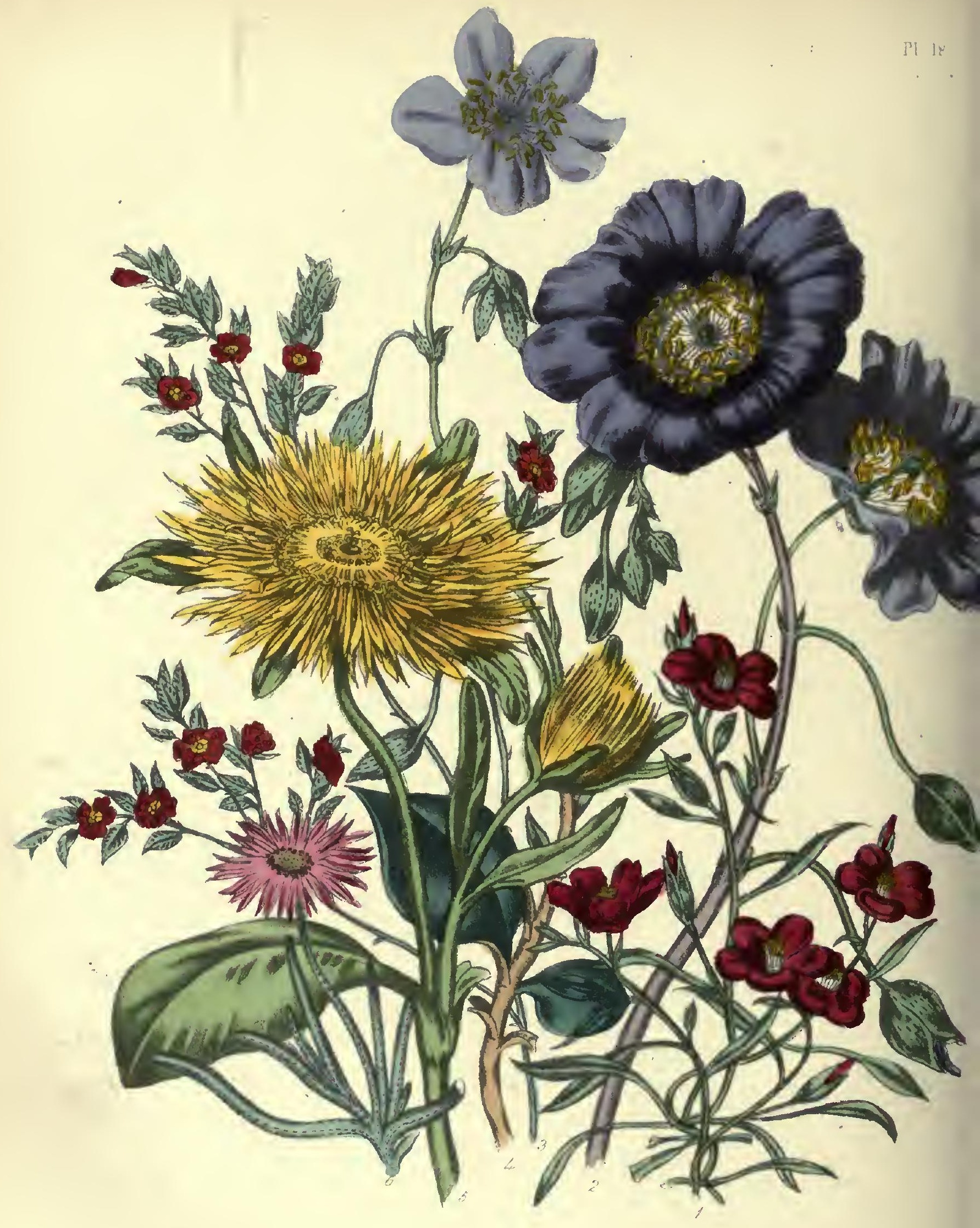

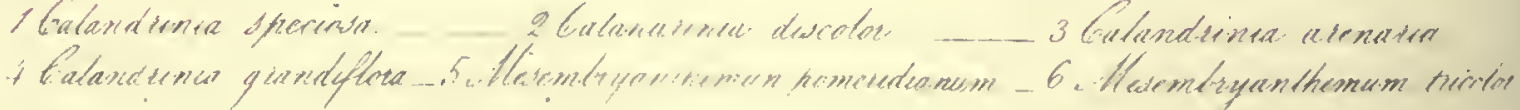




\section{.}





\section{CHAPTER XVII.}

\section{FICOIDEA.}

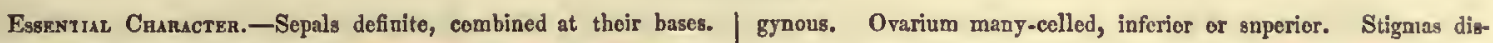
Petals indefinite, rarely wanting. Stamens numerous, distinct, peri- $\mid$ tiact. Capsule dehisciog in a stellate manner at the apex.-(G. Den.)

\section{GENUS I. MESEMBRYANTHEMUM, Lin. THE FIG MARIGOLD.}

\section{Lin. Syst. ICOSANDRIA TETRA-POLYGYNIA.}

Generuc Character.-Calyx of 5, rarely of 2-8 sepals. Petals | along with the petals. Capsule adnate to the calyx, from four to manyindefinite, linear. Stamens indefinite, inserted in the top of the calyx $\mid$ eelled. Cells many-seeded.-(G. Don.)

Description, \&ç. - The name of Mesembryanthemum is derived from mesembria, mid-day, and anthemon, a flower; and this name admirably expresses the babit of the plants. Their flowers seem to live only in the sun. When the sun withdraws its beams, they close their petals, and only expand them in the brilliant light of a summer's day. "I scarcely know a more interesting sight," says Dr. Lindley, in his admirable Ladies' Botany, " than in a summer's day, after a storm, to watch a bush of this genus, which has thrown its weak trailing arms over a piece of rock, and which leans forward to the south, as if to catch the earliest influence of the beams it loves so well. While the sky is darkened by clouds, all its blossoms are shut up so closely, that one would hardly suspect the busls of being more than a tuft of leafy branches, with some withered or unexpanded blossoms scattered over them. But the moment that the bright rays of the sun begin to play upon the flowers, the scene clianges visibly beneath the eye; the petals slowly part, and unfold their shining surfaces, of almost metallic brilliancy, to the sunbeams, and in a few minutes become so many living stars, often of the most gorgeous tints, and so entirely hide the leaves, that scarcely a trace of them is visible, while the whole bush bas burst into a blaze of glittering splendour. In this case, the phenomenon depends on a specific irritability of the petals, the cause of which is one of those inscrutable mysteries that the limited faculties of man are incapable of penetrating; but in the fruit, there is an interesting phenomenon of another kind, the cause of which is more easily explained. The seed-vessels of the Fig Marigold, produced in the sandy deserts of Southern Africa, fall off when ripe, and are driven about by the wind. If they were to open during the wet season, or in wet places, the seeds would fall out and perish, for it is only in a dry soil that thcy are capable of vegetating. Nature, therefore, gives this plant the power, by virtue of its hygrometrical quality, of keeping the seed-ressel fast shut up while exposed to damp; and it is only when it finds itself in a dry station fit for the dissemination of the seeds, that the valves contract and open sufficiently to allow the latter to escape."-(Ladies' Botany, vol. ii. p. 64.) The fruit of the Mescmbryanthemum is shaped like a fig, and is eaten by the Hottentots; hence the name of Fig Marigold. The leaves are extremely succulent, and those of some of the species are caten. The Mesembryanthemums are nearly all natives of the hot sandy plains near the Cape of Good Hope.

\section{1.-MESEMBRYANTHEMUM POMERIDIANUM, Lin. THE LARGE YELLOW-FLOWERED FIG MARIGOLD.}

Encrunswes.-Bot. Mag. t. 540; and our fig. 5, in Plate 18. |nearly distinct. Stems, peduncles, and calyxes, hairy. Petals shorter Serciric Chanacter.-Leaves broad-lanceolate, flat, smooth, ciliated, $\mid$ than the calyx. Stigmas 12.-(G. Don.)

Decscription, \&c.-One of the most splendid of this beautiful tribe of flowers. The broad, thick, fleshy 02 
leaves, and large sun-like flowers, produce a most striking effect. It is a native of the Cape of Good Hope, and was introduced in 1774, by Mr. Masson, who brouglt many plants from that colony. The seeds should be sown on a hotbed in March or April, and the young plants planted out in June, into a dry sandy or gravelly soil, in the open ground, or on rockwork. The plants thus treated, and allowed plenty of light and air, will produce a profusion of flowers, which, from their size and brilliant colour, will have a dazzling effect, and will ripen seed abundantly. This species requires to be planted in the open ground, as it never flowers well in a pot.

\section{2.-MESEMBRYANTHEMUM CRYSTALLINUM, Lin. THE COMMON ICE-PLANT.}

Specific Character.-Plant diffusely procumbent, herbaccous, | plant appcar as if covered with ice. Leaves ovate, altcrnate, stemcovered with large glittering papulæ on every part, which makcs the elasping, undulated. Flowers axillary, almost sessilc.-(G. Don.)

Description, \&c.-The flowers of this species are white, and they are neither so large nor so showy as those of $M$. pomeridianum. The ice plant is, however, remarkable for the little globular protuberances, or rather blisters, filled with a soft, watery matter, which glisten over the whole plant, and make it look as though it were covered with ice. The plant is procumbent. This species is a native of Europe, as well as Africa ; for it is found on the sandy shores of Greece, near Athens, and in the Canary Isles. It was introduced in 1775. Its culture is nearly the same as that of $M$. pomeridianum, though it does not succeed so well in the open border, very frcquently failing to produce flowers. Some persons account for this, by supposing that there are two varieties of this speeies, one a biennial, which is the true $M$. crystallinum, and the other an annual, which is callcd by Haworth M. glaciale. The best way is to grow the plant in very poor soil, or on rockwork, where its glistening leaves and starry flowers produce a very good effect.

\section{3.--MESEMBRYANTHEMUM PINNATIFIDUM, Lin. THE PINNATIFID-LEAVED ICE PLANT.}

Evgrative,-Bot. Mag. t. 67.

Spfecific Character. - Stems diffuse. Leaves opposite, oblong, bluntly pinnatifid, papuloso. Petals slsorter than the calyx, - (G. Don.)

Descriprion, \&c.-Derhaps the least beautiful of this showy family of plants. The leaves are what is sometimes called fiddle-shaped, and though covered with icy globules, they have not the brilliant glistening appearance of those of the common ice-plant. The flowers are yellow, but small, and produced in the forks of the branches; the stems are reddislı. The plant is a native of the Cape of Good Hope; but it is said to be found also in Clili. It was introduced in 1774 .

\section{4.-MESEMBRYANTHEMUM TRICOLOR, Will. THE THREE-COLOURED OR PURPLE-EYED MESEMBRY ANTHEMUM.}

Esaravings.-Bot. Mag. t. 2144; and our fig. 6, io Plate 18. | broadest at the apex, ohtuse, rather scabrous from papula. Flowers Srnonyme,-M. Pyropeum, var. roseum, Dec. M. roseum, Haw. pedunculate. Lobes of calyx 5, obloog, one of them very long. Sprcific Curacter.-Plant almost stcmless, Leaves lizear

Descrirtion, \&c.-A very small species with scarcely any true stem, and deriving nearly all its height from the long upright footstalk of the flower. The petals are pink, becoming whitish at the base, and the anthers are of a very dark purple, almost black. It is not known exactly of what country it is a native, but it is supposed to come from the Cape of Good Cape. Seeds of it were sent by M. Otto, of Berlin, to Mr. Anderson of the Chelsea Botanic Garden, about 1828. 


\section{OTHER SPECIES OF ANNUAL MESEMBRYANTHEMUM.}

There are many other species of annual Mesembryanthemum mentioned in books; but as we know nothing of -them except their specific characters, wo have not thought it necessary to give even their names. The colours of their flowers are stated to be purple, white, rose-colour, and yellow ; and many of them are said to bave been introduced.

\section{CIIAPTER XVIII.}

\section{PORTULACE E.}

Essuntial Character, - Calyx usually of two sepals. Petals sule 5-celled, opening by a lid or 3 valves. Placenta central. Seeds nsually 5 , seldom more or less. Stamens variable in number, peri- i winged.-(G. Don.)

gynous. Anthers appendiculate. Style one. Stigmas nuany. Cap-

Description, \&c.-Succulent plants, many of which have thick, fleshy leaves, and bright-eoloured flowers. Some of the kinds, however, are British weeds, such are the water-chickweed, and the common purslane, the latter of which was formerly eaten as a salad. All the plants belonging to this order thrive best in hot dry exposed places. . The only genera that contain ornamental annuals are Calandrinia and Claytonia.

\section{GENUS I.}

\section{CALANDRINIA, Kunth. THE CALANDRINIA.}

\section{Lin. Syst. DODECANDRIA MONOGYNIA.}

Generic Cunactra._Calyx 2-parted. Petals 3-5, free or rather cennate at the base. Stamens 4-15. Style one, very short, tripartite at the apex. Lobes elavate. Capsulo oblong-elliptie, 3-valved. Sceds wingless.-(G. Don.)

Descriprion, \&c.-The ornamental species belonging to this genus are mostly natives of South America, and like the mignonette and many other plants, shrubby there, though in Britain they are treated as annuals. There are some of the South American species that are positively annuals, as they can never be preserved through the winter; and this is also the case with C. speciosa, which is a native of North America. A great degree of confusion exists as to the names; the Calandrinias of the Bot. Mag. being quite different from those bearing the same names in the London gardens, and figured by Dr. Lindley in the Bot. Reg. We, however, have adopted the names and descriptions given in the latter work. The namo of Calandrinia was given to this genus by Kunth, in honour of L. Calandrini, an Italian botanist, who lived in the beginning of the eighteenth century.

\section{1.-CALANDRINIA PILOSIUSCULA, Dec. THE HAIRY CALANDRINIA.}

Sysosymes. - Talininm ciliatum, Hook. T. lineare, Hoff. Calan- | Leaves linear-spatulate, rather pilose. Pedieels axillary, J-flowered, \begin{tabular}{l|l} 
drinia compressa, Sehrad. C. tenella, Hook, and Arm. & rather adnate to the foral leaves, censtituting a terminal or anb.
\end{tabular} Speorfe Chamacter. - Stems erectish, angular, rather pilose. torminal pasicle.-(G. Don.)

Description, \&c.-This was the first species of the genus known in England; and it was introduced under the name of Talinum ciliatum; the difference indeed between the two genera is very slight, the principal distinction being, that the style in Calandrinia is vory short, while in Talinum the style is filiform. The hairy Calandrinia has small flowers of a purplish crimson. Its stem is short, and partly procumbent, and its loaves are long 
and narrow. It is a native of Chili, from which country seeds of it were received in 1823 by Mr. Place, and by him presented to the London Horticultural Seciety, in whose garden it flowered for the first time in 1824. The seeds were sown in a hotbed in March, and transplanted into the open ground at the beginning of May; the flowers began to appear early in June, and continued till destroyed by the frosts of autumn. It requires a hot, dry, sandy situation, and it is admirably adapted for rockwork. Seeds may be procured in any of the seed-shops.

\section{2.-CALANDRINIA SPECIOSA, Lindl. THE SHOWY CALANDRINIA.}

Engravisgs.-Bot. Reg. t. 1598; and our fig. 1, in Plate 18. Flowers racemose, pedicels aud bractens very short. Petals longer than Specific Chanacter.-Glabrous, diffuse. Leaves spatulate, acnte, the calyx.-(Lindl.) elongated and narrowing at the base, so as to appear petiolated.

Descriptron, \&c.-Few flowers have a more striking effect than this littlo Calandrinia with its brilliant dark crimson or rather maroon-coloured flowers, peeping out from its thick bed of leaves. There was a large bed of it in Mr. Hopgood's garden in the summer of 1838, which in the morning presented as rich a mass of flowers and leaves as could well be imagined, but by four o'clock every little flower was closed. With the exception of the early closing of the petals, this species deserves to bo generally cultivated, as nothing can exceed the rich velvety look of the flowers. It is quite hardy, a true annual, and ripens its seeds in great abundance. It is a native of Northern California, whence its seeds were sent home in 1832 by Douglas. It should be sown in dry and exposed situations, where it can have abundance of light and heat; as the situation in which Douglas found it was a hot, dry bank. It requires very little water, and flourishes best in weather when most other plants are burnt up. It is well adapted for rockwork. It may bo sown twice; in March or April to flower in May and June, and in May or June to flower in August and September. Seeds may be had in all the seed-shops.

The plant figured under the name of Calandrinia speciosa in the Bot. Mag., t. 3379, bears more resemblance to C. grandiflora than to the plant described in the Bot. Reg. as C. speciosa. Sir W. J. Hooker states that he received it under the name of $C$. speciosa from the Epsom nursery, and that he does not know its native country; it is probable that it is a native of Chili, like the other species of the genus which it resembles, but from its woody stem and general appearance it is quite evident that it cannot be the Californian annual described above.

\section{3.-CALANDRINIA ARENARIA, Hook. et Arnott. THE SAND CALANDRINIA.}

Engravings.-Bot. Reg. t. 1605; and our fig. 3, in Plate 18.

Speciric Character.-Plant glaucous. Stems numerous, prostrate,

glabrous, leafy. Leaves linear. Common peduncle terminal, naked,

simple or hrancbed. Racemes corymbose; and pedicels a little longcr than the bracteas. Bracteas oval, membranous, pointed by a dark

Descriptron, \&c.-A little weedy-looking flower, only remarkable for the curious markings of its calyx and bracteas. It is a native of the sandy plains near Valparaiso, whence it was introduced by Mr. Hugh Cuming in 1833. It is quite hardy, and produces abundance of seeds, which will flower in two months after sewing.

\section{4.-CALANDRINIA GRANDIFLORA, Lindl. THE LARGE-FLOWERED CALANDRINIA.}

Everavinos.-Boto Reg. t. 1194; Bot. Mag. t. 3369; and our fig. | acute, petiolate. Raceme simple, loose. Calyx gpotted. Stamens 4, in Plate 18.

Specifio Churacter.-Plant glancous. Leaves feshy, rhomboid, numerous. Petals obcordate.-(G. Don.)

Descriptron, \&c.-The flowers of this species were so much larger than those of the earliest-introduced kinds of Calandrinia, that Dr. Lindley gave it the name of grandiflora, a name which now seems ill applied, 
as the flowers of Calandrinia discolor are more than twice as Iarge. C. grandiflora makes a bushy, glaucous plant, with round, thick stems, and rery succulent leaves, which are broad, but terminate in a sharp point, and are so much elongated and tapering at the base as to seem petiolated. The flowers are produced on long racemes, on which they are disposed at considerable distances from each other, and each on a long footstalk. When the flowers are in the bud, and again after the petals have fallen, these footstalks droop; but when the flowers expand, which they do only one at a time, each pedicel in turn stands erect. The flowers are of a faded rosecolour, and not large, notwithstanding the name. The calyxes are spotted; and they do not drop off when the petals of the flower fade, but close, in a very peculiar manner, over the germen. Though generally treatcd as an annual, this species is properly a perennial, and if preserved through the winter it will in time become shrubby. The flowers remain open only during suushine. This species is a native of Chili, from which country sceds of it were brought to the London Horticultural Society by Mr. M'Rae, in 1826. It requires a warm, dry, calcareous soil, and not too mucl water, as if over watered it will soon damp off, or, in other words, become rotten just at the collar of the plant. When treated as an annual, it is generally raised on a hothed, and planted out in May, when it will begin to flower in Junc, continuing to produce a suceession of flowers the whole sunmer. When treated as a greenhouse plant, it is propagated by cuttings, and kept rery dry during winter.

\section{5.-CALANDRINIA DISCOLOR, Lindl. THETWO-COLOURED CALANDRINIA.}

Enghu visGs.-Bot. Reg. 1839, t. 4; ? Bot. Mag. t. 3357; aad our fig. 2, in Plate 18. . Sprcific Cunactrr.-Leaves fleshy, obovate-obtuse, elongated into
a petiole. Raceme beoding, the pedicel drooping after the falling of $\begin{aligned} & \text { their uader side being sonlewhat discoloured, and in the flowers beiog } \\ & \text { much larger._-(Lindl.) }\end{aligned}$

Description, \&c.-One of the most splendid flowers grown in British gardens, and certainly by far the landsomest species of Calandrinia. The flowers are rose-coloured, with a tinge of purple on the under side; they are very large, and extremely ornamental from the rich mass of golden-coloured anthers in the centre. The flowers are produced in the same manner as those of C. grandifiora, on similar long racemes, at the same, or even greater distances from eacl other, and the flower-stalis droop in the same remarkable manner when the Howers fade, the spotted calyx closing over the remaining petals of the faded flower and the swelling germen. The leaves are very thick and fleshy, and they are of a strangely mottled colour, from which the species is said to take its name of discolor. The numerous and vigorous-growing stems, the thick leaves, and the long racemes of flowers, give this plant a very peculiar appearance; and no one who sees it for the first time could suppose it possible for so massive-looking a bush to spring from the little shining black seed, in the course of a single summer. Though, like C. grandiflora, it is said to bo properly a perennial, or rather, half shrubby, it succeeds perfectly well as an annual. It is not known of what country it is a native, but from the great similitude between it and C. grandifora, it is probably also from Chili. Its seeds were sent to the London Horticultural Society from the Berlin Botanic Garden, in 1835; and, as it seeds freely, they are now common in every seed-shop. The plant figured in the Bot. Mag. t. 3357, appears to be a different species. The flowers are shaped like those of $C$. grandiflora; the leaves are very long, rather narrow, and of a bright pink on the under sidc. The seeds were received at the Glasgow Botanic Garden, from the late Mr. Fischer, of the Botanic Garden, Gottingen, in 1824, under the name of $C$. discolor, but the native country of the plant, or any other particulars, were not mentioned. 
The seeds of the Calandrinia discolor of the London gardens are generally sown in March, on a hotbed, potted off whon they come up into small pots, and afterwards transplanted into the open border in May; or the sceds nay be sown in the open border in May, the only difference being that the first-sown plants will flower earlicr, thougl so little as scarccly to be worth the trouble of transplanting, \&c. This species requires a rich calcareous soil, and an open sunny situation. We sowed some seeds obtained from Mr. Charlwood, in May 1838, in the open ground, in a warm border, sheltered by a wall; and the plants grew luxuriantly, being from a foot and a half to two feet high. The flowers began to expand in July, and in August we had a most brilliant display, which continued till the first frost, which, though a very slight one, destroyed the Calandrinias completely in a single night. When young, the Calandrinias are also liable to be killed by the slightest frost; and for this reason, in gardens where there is but little shelter, it is always safest to raiso the plants on a hotbed.

\section{OTHER SPECIES.}

These are very numerous; but we believe that no others have been as yet introduced that can be treated as annuals.

- GENUS II.

\section{CLA YTONIA, Lin. THE CLAYTONIA.}

\section{Lin. Syst. PENTANDRIA MONOGYNIA.}

Gesersc Cranacter,-Sepals 2, permanent. Petals 5, unguiculated; clarrs connate at the base. Stamens 5. Style 1, trifid at the apex. Lobes stigmatose inside. Capsules 3-valved, 3-seeded.-(G. Don.)

Description, 8co.-Succulent plants with small flowers, usually white or rose-coloured; which, as they are certainly not worth cultivating for their beauty, we shall only say a few words of, without entering into details.

1.-Claytonia Perfoliata, Don. Bot. Mag. t. 1336.

- This species was discovered on the North-west coast of North America, by Archibald Menzies, Esq., and sent by him to the Kew Gardens, in 1796. The flowers are white, and very small; and the leaves, which are rather short and broad, are eatable, like those of the common Purslane.

2.-C. ALSINOIDES, Sims, Bot. Mag. t. I309.

This species resembles the common Chickweed, except in its succulent leaves. A native of North America, introduced in 1794.

-3. -C. SIBIRICA, Sims, Bot. Mag. t. 2243; Sweet, Brit. Flow. Gard. t. 16. C. ALSINOIDES, var. ROSEA, Dec.

A dwarf plant, not growing above six inches high, with pink flowers; very suitable for rockwork. A native of Nootka Sound, and said also to. be found wild in Siberia. Introduced in 1820, and worth cultivating.

4.-C. GYPSOPHILÖIDES Fisch. et Mey.; Brit. Flow. Gard. 2nd Ser. t. 375.

A native of the Russian colony of Ross, in California, whence seeds were first sent to St. Petersburg, and thence, in 1837, to England. It is low-growing, with a great number of grass-like stems, and a profusion of very small bright pink flowers. All the Claytonias require a dry sandy soil, and the last two are worth cultivating for rockwork. 


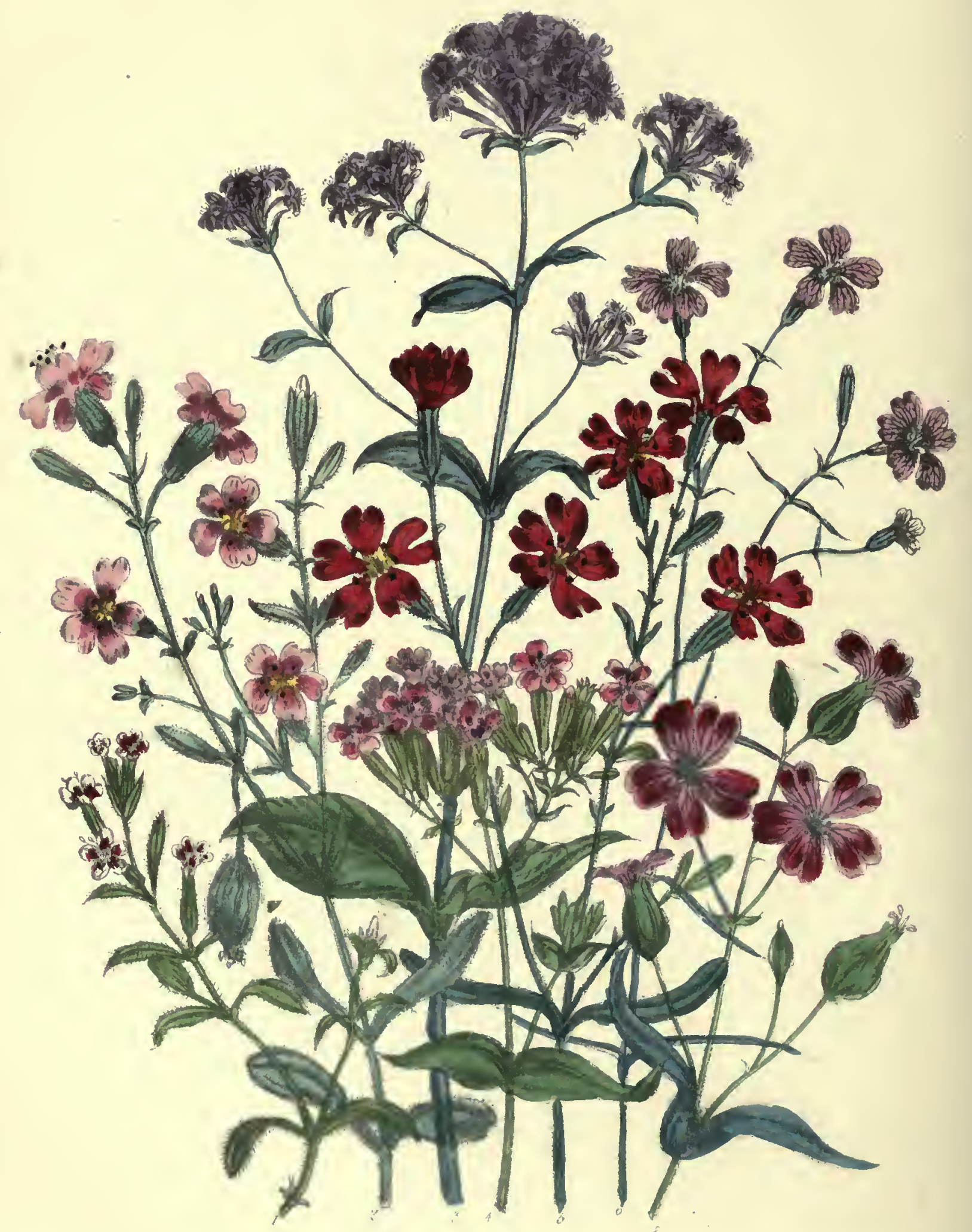




CHAPTER XIX.

\section{SILENACE $\mathrm{E}$.}

Es8remial Charactir.-Calys 5-tootbed, 5-cleft or 5-parted, or | central. Nodose articulated berbs; leaves simple, opposite, or verticilof 5 sepals. Petals $4-5$, unguiculate, rarely absent. Stamens $4-5$, late, rising from the nodi.-(G. Don.)

or 8-10, hypogynous. Capsule 2-5-valvod, 1-5-celled; placenta

Description, \&c.-The order to which the pink and the carnation belong, cannot fail to be an interesting one to every grower of flowers; and, though the annual species it contains are very inferior in beauty to the perennial ones, they are yet all ornamental, and all worth cultivating, either for the open border, or for rockwork. This order formed part of Caryophyllea, according to Jussieu; but that order has been, by modern botanists, divided into Silenacece and Alsinaceos; the former comprising all the genera the flowers of which havo clawed petals, like the pink; and the latter those having flowers the petals of which are not clawed, like the chickweed. The principal genera belonging to this order that contain annual flowers are, Silene, Saponaria, Gypsophila, Dianthus, and Agrostemma.

GENUS I.

SILENE, Lin. THE SILENE, OR CATCH-FLY.

Lin. Syst. DECANDRIA TRIGYNIA.

Generic Character.-Calyx tubular, 5-toothcd, naked. Petals 5, of petal-iike bifid scales in the throat. Stamens 10. Styles 3. Capunguiculate, with an entire or bifid limb, usually furnisbed with a crown $\mid$ sules 3-celled at tho base, opening at the top, 6-toothed.- - (G. Don.)

Descniprion, \&c.-Nearly all the species of this genus have a viscid, frothy moisture on their stalks, in which it is said flies are easily entrapped, and hence their popular English name of Catch-fly. Part of the specics are perennial, and many of them are common British wceds. All the kinds bcar a very strong family likeness to each other; so much so indecd, that when several species are grown in the same garden, they give it an air of monotony. All the annual kinds are very hardy, and require but little culture, except taking care to sow them where they are to remain, as they do not well bear transplanting; and sowing the sceds rather thinly, as they kecp well, and will nearly all vegetate. None of the species have any pretensions to be called handsome, but they are most of them pretty.

\section{1.-SILENE VESPERTINA, Retz. THE EVENING SILENE.}

SYNoNYMEs。_S. bipartita, Desf.; Lyehnis prostrata, Hort.

Engrevings.-Bot. Mag. t. 677, Swt. Bit. Flow. Gard. t. 11, and our fig. 5, in Plate 19.

Specific Character.-Puhescent; stems branched, diffuse. Leaves spatulate, acnte, on eiliated petioles. Racemes secund. Calỵx bladderyclavated. Pctals 2-parted. Lobes obtuse.-(G. Don.)

Description, \&c.-This species has rose-coloured flowers, and diffuse decumbent stems; and it is remarkable for the abundance and duration of its flowers. It is a native of Morocco, where it was discovered by Desfontaines; but it has also been found wild in corn-fields in Portugal and Greece. It was introducod in 1796. On the 12th of June last we had the pleasure of seeing the beautiful flower-garden of R. H. Jenkinson, Esq.: at Norbiton Hall, and we were so much struck with the rich effect produced by masses of this plant on the lawns, that we do not hesitate strongly to recommend its culture in all similar situations. Like all the Silenes, it requires a warm, dry, sandy soil. 


\section{2.-SILENE PENDULA, Lin. THE PENDUI,OUS SILENE.}

Enoravings.-Bot. Mag. t. 114, and our fig. 2, in Plate 19.

Sprafic Character.-Pubesceot, braoched, trailing. Leaves ovatehas the flowers crect and purple. lanccolate. Flowers axillary, pendulous. Calyx inflated. Petals bifid, crowned.-(G. Don.)

Description, \&c.-A procumbent species, with flesh-coloured flowers. It is a native of the south of Europe, and was introduced in 1731. Its culture is the same as that of the preceding species, and it is well adapted for rock-work.

\section{3.-SILENE LACERA, Sims. THE FRINGED SILENE.}

Engraving. -Bot. Mag.t. 2255. Sprciric Cranacter.-Hispid; leaves ovate-lanceelate, undulated, the appendages two-parted. Alternate stamens, deflexed.-(G. Don.)

Description, \&c.-A very handsome procumbent species, with white cut flowers, suitable for rock-work. It is a native of Caucasus, where it grows on rocks. It was introduced in 1818 : bnt, as its name is not now in any of the nurscrymen's seed catalogues, we fear it has been lost.

\section{4.-SILENE ATOCION, Murr. THE ATOCION SILENE.}

Specipic Character.-Stem branched, viscid, pubescent. Leaves rouodish-obovate, lower ones on loog footstalks, upper ones scssile. Panicle fastigiate, trichotomous. Calyx long, clavate. Petals obeordate,

obtuse, with an acnte tooth on each aide at the base, crowned by two protuberances. - (G. Don.)

Deseniption, \&c.-Rather a showy species, with pink flowers; a native of the Levant, whence it was introduced in 1781. Seeds may bo procured in any sced-shop, and they may be sown and treated like those of Flos Adonis.

\section{5.-SILENE PICTA, Pers. THE PAINTED SILENE.}

Encrumings.-Swt. Brit. Flow. Gard. t. 92, and our fig. 6, in | Speciptc Cruracter.-Stems much branched, hardly pubesceot. Plate 19.

Syonyms.-S. Reinwardtii, Roth. S. reticulata, Hort. S. loosely panicled. Calys elavate, striped with red. Petals two-parted, anastomosans, Lag. ? S. bicolor, Thore. reticulated, crowned.-(Don.)

Description, \&c.-A very ornamental species, growing about a foot high, with bcautifully veined flowers. It is a native of the west of France, near Dax, whence it was introduced in 1817. Seeds may be had at all the seed-shops; and, if sown in May, the plants will flower in August.

\section{6.--SILENE MUSCIPULA, Lin. THE TRUE CATCH-HLY.}

Specific Charucter.-Plant smoethish, clammy. Stem erect. I ones linear. Flowers panicled. Calyx amply elavated, netted. Branches alternate, long. Lower leaves lanceolate-spatulate; npper | Petals bifid.-(G. Don.)

Description, \&c.-The flowers are intensely red; and the leaves and stem so clammy, that when flies light upon it they become entangled, so that this plant is a true Catch-fly. It was indeed this plant that gave the naine to the genus, as Clusius, when describing it, called it Muscipula, or Catcl-fly, from this property. It is a mative of Spain; but was introduced into English gardens before 1596. 


\section{7.-SILENE ARMERIA, Lin. LOBEL'S CATCH.FLY.}

Synonymes.-Cucubalus fasciculatus Lam.; Wild Sweet William. Enganvings. - Eng. Bot. t. 1398, and our fig. 4, in Plate 19.

VARLETY, -S. A. 2 alba, Dec. Flowers white.

Specific Character.- Plant quite smooth, glaucous. Stem branched. Leaves ovate-lanceolate, rather cordate at the base. Flower in eorymbose panicles. Calyx long, clavated. Petals obcordate, crowned. - (G. Don.)

Description, \&c.-A well-known flower, which, without much beauty, has kept ite plaee in our gardens since the earliest period in which we have any record of them. It is mentioned by Gerard, and all the early writers on plants. It derives its popular English name from L'Obel, a native of Flanders, who was botanist to James I. In L'Obel's great work on plants, the Adversaria, published in London in 1570, le deseribes this plant as a kind of Muscipula, or Cateh-fly; and as it differs eonsiderably in general appearanee from the true Catcl-fly (Silene Muscipula), which had been previonsly deseribed by Clusius, it was called L'Obel's Catehfly, in order to distinguisl it. It is a native of France and Switzerland, and has been found oecasionally in England, on the banks of fields, or on old walls. Its culture is very simple; as the seeds will eome up, and the plants flower well, in almost every kind of soil and situation. The seed is produced in great abundanee, and if allowed to ripen on the plant it will sow itself. Like all other flowers this species will, however, be improved by being sown carefully as directed for Flos Adonis (see p. 3), and thinned out when the plants eome up.

\section{8.-SILENE QUINQUEVULNERA, Lin. THE FIVE-IVOUNDED CATCH-FLY.}

EsGrupisas.-Eng. Bot. t. 86, and our fig. 1, in Plate 19. Srecific Cyaracter.-Pubescent, viscid. Stems branched. Leaves lanceolate, lower ones obtuse. Spike secund. Calyx very villous,

with short teeth. Petals roundish, entire, with hieuspidate appendages.-(C. Don.)

Description, \&c.-The flowers of this speeies, though small, are very pretty, from the dark crimson spot in the centro of eacl petal. The plant is a native of Eugland, and other parts of Europe, and was formerly a very favourite flower in English gardens. It is now comparatively neglected, but might still be introdueed occasionally with very good effect. The culture should be the same as that of the other speeies.

\section{OTHER KINDS OF SILENE.}

S. RUBELLA, Lin.

This is a smooth glaueous plant, with rose-coloured flowers; a native of Portugal and the Levant; introduced in 1732 .

\section{S. CARNOSA, Mœnch.}

A very pretty speeies, the flowers of which are purple, bordered with white. It is not known of what country it is a native; but it first appeared in English gardens abont 1823.

\section{S. CONICA, Lin.}

A plant with red flowers, growing wild in England. $S$. conoidea, Lin., is supposed by sone botanists to be a variety of this speeies; and there are several other kinds very nearly allied to it.

\section{S. ANGLICA, Lin.}

This kind is very hairy and viseid. It has white petals, oeeasionally marked with a red spot in each, like those of $S$. quinqueoulnera. It is a native of England and France, and is very common in corn-fields on a gravelly or sandy soil. 


\section{S. LUSITANICA, Lin.}

Bears considerable resemblance to $S$. anglica, except in having flesh-coloured petals. It is a native of Spain and Portugal, and was introduced in 1732. There are several other species ncarly allied to the last two kinds, natives of Spain, France, and Africa.

\section{S. NOCTURNA, Lin.}

A species with rose-coloured flowers, a native of the sonth of Europo, introduced in 1683.

S. CINEREA, Desf.

A plant remarkable from its silky-greyish hue, with white flowers, and an almost procumbent stem. It is a native of Algiers, and was introduced in 1818.

\section{S. NYCTANTHA, Willd.}

The leaves are somewhat fleshy, and the flowers are of a greenish-yellow. The plant was introduced abont 1815 , but it is not stated of what country it is a native.

\section{S. DISTACHYA, Brol.}

The petals of the flowers are pale purple above, but green beneath, and so much cut as to appear each in two spikes. The plant is a native of Portngal, near Coimbra, and was introdnced in 1817 .

\section{S. COLORATA, Schousb.}

This species, and S. DIscolon, Smith, very closely resemble $S$. distachya; and all the three kinds are very ornamental.

\section{S. NIC AENSIS, All.}

This species is well adapted for rock-work; it is procumbent, and grows in great abundance on the sandy shores of the Mediterranean. The petals are white on the upper surface; but of a pale yellowish-purple beneath. It is a native of the country near Nice, and was introduced in 1820 . S. RAMosa, G. Don., and S. ARENarta, Desf., are very nearly allied species. They are all very ornamental, and very suitable for rock-work.

\section{S. NOCTIFLORA, Lin.}

This plant is a true Catch-fly, being covered with a clammy puboscence. It-derives its naine from its flowers, which are of a pale blush colour. expanding only at night.

\section{S. CRETICA, Lin.}

This species has deep rose-coloured flowers. It is a native of Crete, on rocks by the sea-side; and it was introduced in 1732 .

\section{S. RETiCUlata, Desf.}

This species is remarkable for its calyx, which is marked with ten prominent dark purple stripes, with network between of the same colour. The flowers are small, and rose-coloured. The species is a native of Algiors, and was introduced in 1804 .

\section{S. ORCHIDEA, Lin.}

The flowers resemble those of some of tho kinds of Orchis, and both the calyx and the petals are rosecoloured. The plant is a native of the Levant, and the Grecian Isles, and it was introduced in $\mathbf{1 7 8 1 .}$

There are many other species, but we have selected the most remarkable. 
GENUS II.

SAPONARIA, Lin. THE SAPONARIA, OR SOAPIVOR'T.

Lin. Syst. DECANDRIA DIGYNIA.

Genzric Chanacter.-Calyx tubular, 5-toothed, naked at the base. Petals 5, unguiculate. Stamens 10. Stylcs 2. Capsule 1-celled.-(G. Don.)

Description, \&c.-This genus approaches very near to that of Silene; the principal differences being in the capsule and in the number of the styles. In Silene the capsule is 3-celled, and in Saponaria it is 1-celled; the petals of Silene are usually furnished with a crown of petal-like scales at the throat, but those of Saponaria are destitute of these appendages; and the former genus has three styles, while the latter has only two. We have mentioned these points of differenee because, to a general observer, the two genera appear very muel alike. The leaves of all the plants belonging to Saponaria are said to produce a lather like that of soap, when bruised and afterwards agitated in water.

\section{1.-SAPONARIA VACCARIA, Lin. THE COW-HERB SOAPWORT.}

Engnavinga.-Bot. Mag. t. 2290, and our fig. 7 , in Plate 19. | Specific Charucrer.—Flowers panicled. Calyxea pyramidal, Srnonyme.-Lychnis Vaccaria, Scop. Gypaphila Vaccaria, Smith. smooth, 5-angled. Bracteas membranaceoua, acute. Leaves ovateVarifty.-S. v. 2 grandiflora, Fisch. Petals broad, naked, lanceolate, sessile.-(G. Don.)

crenate, and emarginate. A native of lberia.-(G. Don.)

Description, \&c.-A strong-growing plant, with red flowers; a native of corn-fields in France, Germany, Switzerland, and the Levant. It was introduced before 1596, as it is mentioned by Gerard. The name of Vaccaria, or Cow-herb, was given to this plant, from its being supposed to increase greatly the milk of cows. The seeds are common in all the seed-shops; they should be sown like those of Flos Adonis (see p. 3), and the plants thinned out when about two inches high.

\section{OTHER SPECIES OF SAPONARIA.}

S. PERFOLIATA, Raxb.

Closely resembling S. Vaccaria, of which it is probably a variety. A native of the East Indies, introduced in 1800 .

\section{S. DIOICA, Schlecht. et Cham.}

A native of Buenos Ayres; is probably another variety of the same species.

\section{S. CALABRICA, Guss.}

This is a very beautiful plant, strongly resembling the perennial species of the genns ( $S$. ocymoides), so often found on rock-work. S. calabrica is, however, of more erect growth, and has beautiful rose-coloured flowers.

\section{S, PORRIGENS, Lin.}

The flowers of this species liave flesh-coloured petals, and long white stamens. It is a native of the Levant; but it has been in cultivation in British gardens since 1680 . 


\section{S. ORIENTALIS, Lin.}

Also a native of the Levant, which has been in cultivation in Britain since 1732 ; it is a low plant, with very snıail purplish flowers.

All the kinds require a light dry sandy soil, and to be sown where they are to remain.

\section{GENUS III.}

\section{GYPSOPHILA, Lin. THE GYPSOPHILA.}

Lin. Syst. DECANDRIA DIGYNIA.

Gemertc Character.-Calyx campanulate, angular, somewbat 5-lobed, with mombranous margins. Petals 5 , not unguiculate. Stamens 10. Stylea 2. Capsulo 1-celled-(G. Don.)

Description, \&c.-This genus differs from Silene and Saponaria in the calyx being campanulatc, and not tubular, and in the petals being not decidedly unguiculate. The name of the genus expresses lime-loving, and consequently all the plants belonging to it prefer a calcareous or chalky soil. Their flowers are generally small but pretty, and the plants themselves are quite liardy and of easy culture.

\section{1.-GYPSOPHILA VISCOSA, Murr. THE CLAMMY GYPSOPHILA.}

Spemic Character. - Flowers fastigiately-corymboso; branebes divaricating; leaves ovate-lanceolate, smooth, cordate at the base, and elasping the stem; space of atem between the leaves elammy in the middle; petals retuse; segments of the calyx braad, obtuse.- ( $G$. Don.)

Description, \&c.-This is the commonest kind of Gypsophila, and it is very frequently planted on rockwork. The flowers are pink or white. It is a native of the Levant, and was introduced in 1773 . The seeds may be purchased in any seed-shop, and they should be sown on the rock-work where they are to remain in April.

\section{2.-GYPSOPHILA ELEGANS, Bieb. THE ELEGANT GYPSOPHILA.}

Specifie Character.-Flowers dichotomously-panicled, glabrous; petals cmarginato, twice as long as the calyx and stamens ; leaves lanceolate, somewhat flesby.-(G. Don.)

Description, \&c.-A very pretty little plant with a pink flower, differing from G. viscosa chicfly in the leaves being narrower, and acute at both cnds. It is a native of Tauria, and was introduced in 1818. The seeds may be procured at Charlwood's, and in other seed-shops; and, like those of all the species of Gypsophila, they should be sown in a dry soil-chalky if possible, but if this be not practicable, it sliould be gravelly or sandy. This species is well grown in Lee's nursery, Hammersmith.

\section{OTHER SPECIES OF GYPSOPHILA.}

\section{G. SAXIFRAGA, Lin.}

This is supposed to be the same as Dianthus saxifraga. It has rose-coloured flowers and fibrous roots. It is a native of Europe in stony or rocky places, and it is well adapted for rock-work. 
$$
\text { . }
$$ 


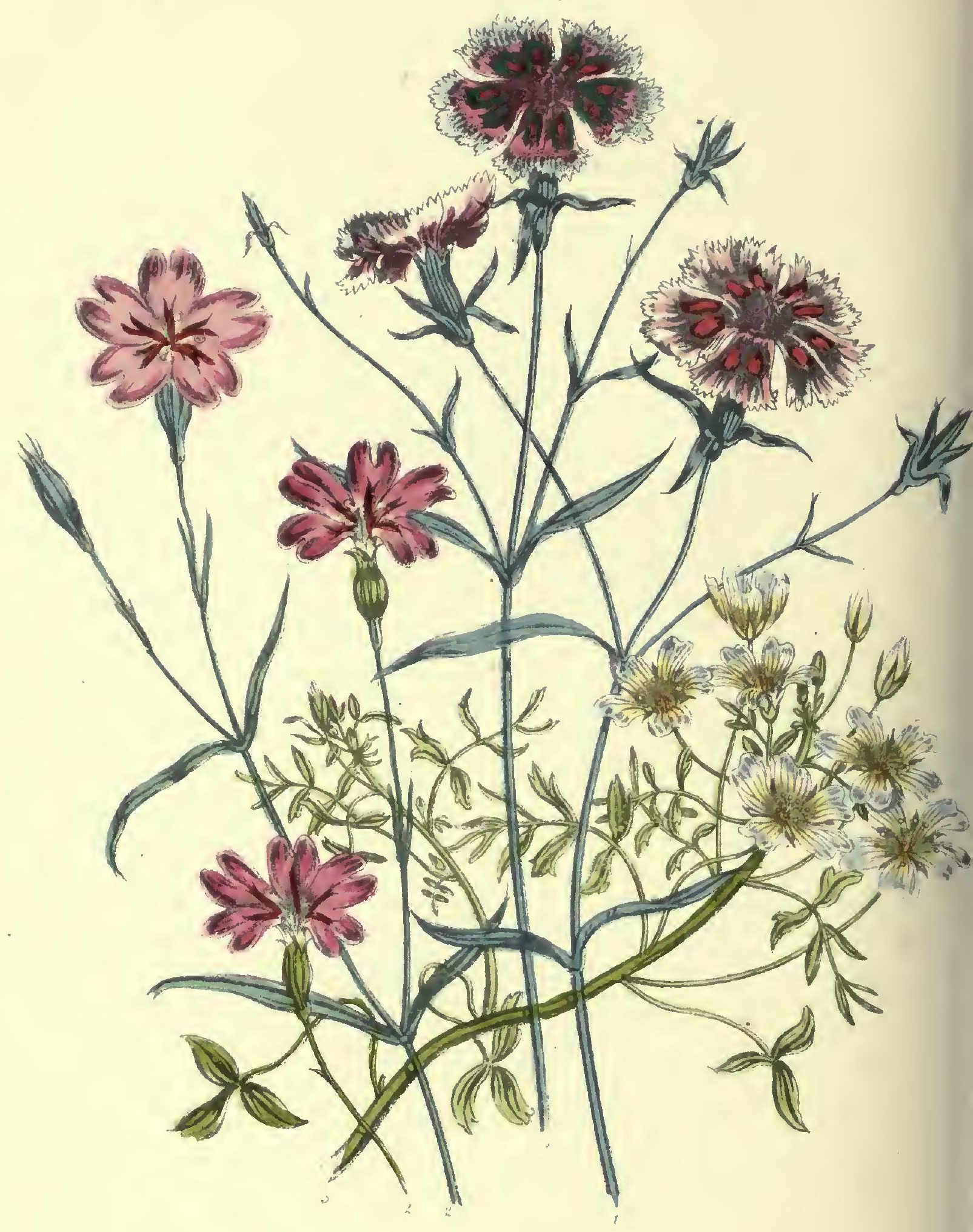




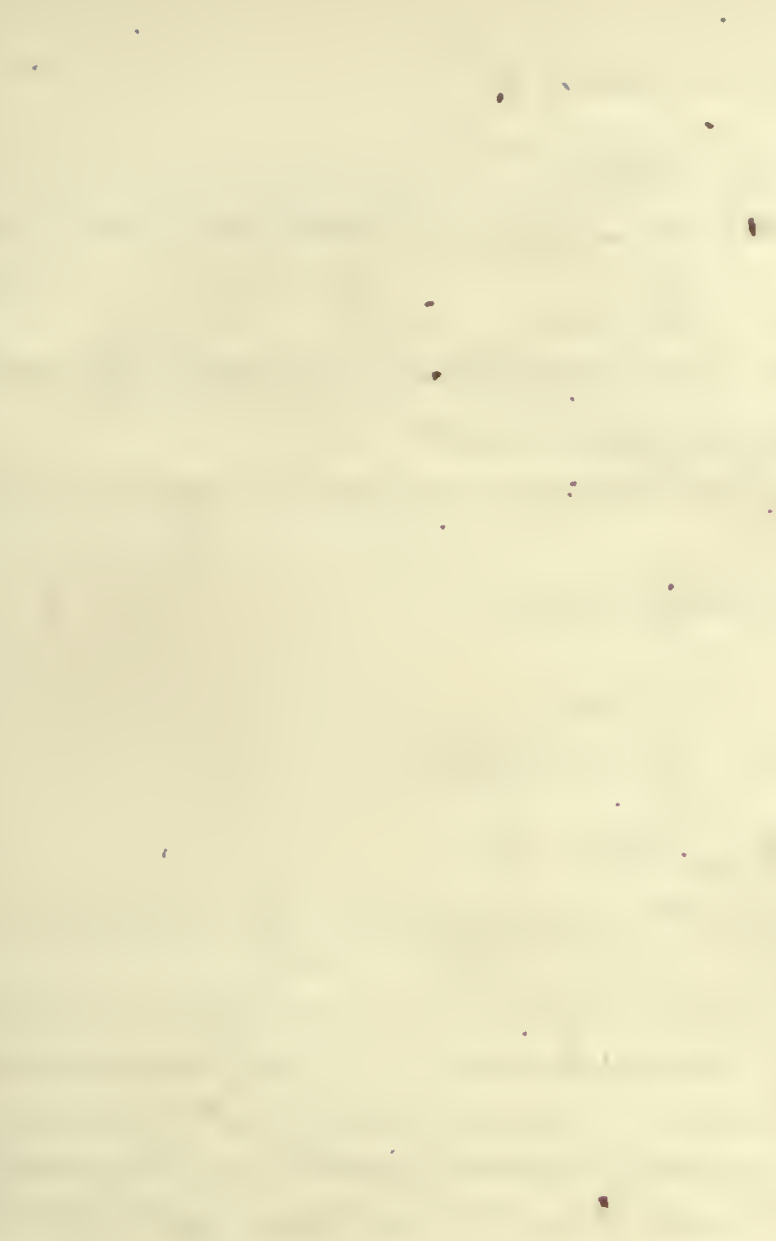





\section{G. TENELLA, Poir.}

A.rock-plant with very slender stems and pink or white flowers; introduced in $\mathbf{1 8 1 6}$, but from what country is not known.

$$
\text { G. ROKEJEKA, Del. }
$$

Flowers white, striped with purple, and capsules globose. A native of Egypt.

G. COMPRESSA, Desf.

Greatly resentbling the preceding species. A native of Barbary.

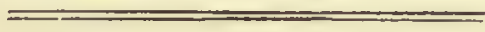

GENUS IV.

\section{DIANTHUS, Lin. THE PINK.}

\section{Lin. Syst. DECANDRIA DIGYNIA.}

GeNeric Cnaracter.-Calyx tubular. 5-toothed, furnished with 2-6 imbricatc, opposite scales at the base. Petals 5, with long clsws. Stamens 10. Styles 2. Capsule l-celled. Seeds compressed.-(G. Don.)

Descrip'rion, \&c.-Perhaps no flowers are better known or more gencrally cultivated than the percnnial plants bolonging to this genus. The pink, the carnation, and the sweet-william, are in every garden, and are universal favourites. The annual kinds are not so well known; and, as they are mostly English wceds, they are but seldom cultivated. The most popular annual garden flower of the genus is the Chinese pink, Dianthus chinensis; which, though generally called a biennial in books, will both produce its flowers and ripen its seeds the same year that it is sown.

\section{1.-DiANThUS CHINENSIS, Lin. THE CHINESE PINK.}

Engruvings.-Bot. Mag. t. 28, and our fig. 1, in Plate 20. | what sggregate; calycine scales linear-lanceolste, leafy, cuspidate, Vanizty.-D.c. 2 flore plene, Hort., has the flowers scmi-double. spreading, equal in length with the tube; petals toethed, purple or Specific Ceraracter.-Stem branched, flowers solitary, or some- white, opotted with red; leaves lanceolate, pale green.-(G. Don.)

Description, \&c.-The variety of colours produced by these flowers is so great, that in a large bed of seedlings, scarcely two will be found alike. Their slıades, however, only vary from a rich dark crimson to pink and white, but the various manners in which these colours are combined and varied almost exceed belief. This astonishing variety renders the Chinese pink very valuable for flower-gardens, though it is entirely destitute of the fragrance of its perennial relations, the carnation and common pink. The Chinese pink is a native of China, from which country it was brought to Paris by some French missionaries in 1705 . It was afterwards scnt to England, according to the Hortus Kewensis, in 1713, and has since been constantly in eultivation. When left to itself it is decidedly an annual, but it may be preserved two or more years by cutting off the seed-pods the moment the flowers begin to decay, and never suffering it to ripen seed. Most annuals, if sheltered from frost during winter, may be preserved in a similar manner. The seeds of the Chinese pink should be sown in a dry warm border in April, or they may be sown in a hot-bed in February and planted out in May. When transplanted, care should be taken not to break the ball of earth round the roots. The plants seldom require thinning, 
as they do not spread much, and produce very little effect unless kept in masses. They loek best in a warm sunny border, backed by evergreen shrubs; as the foliage of the pinks is scarcely secn, and the somewhat gandy celours of the flewers require rclief. Seeds may be procured at any seed-shop.

\section{OTHER ANNUAL KINDS OF DIANTHUS.}

\section{PROLIFER, Lin. THE COMMON WILD PINK.}

This species is found in great abundance in every part of Europe, thongh it is less plentiful in England than on the Continent. The flowers are produced in heads, and are of a pale pink.

\section{ARMERIA, Lin. THE DEPTFORD PINK.}

The flowers are speckled with pink and white, and only one opens at a time in each tuft. It is found abundantly in England and throughout Enrope.

\section{CORYMbosus, Sib.et Smith,}

has the flowers rose-celoured above and spotted, but yellowish-green beneath. It is a native of Asia Minor, and has not yet been introduced.

\section{ARMERIOIDES, Raf.}

A native of New Jersey in North America, with red flowers, introduced in 1826.

\section{GENUS $\mathrm{V}$.}

\section{AGROSTEMMA, Lin. THE AGROSTEMMA, OR ROSE CAMPION.}

\section{Lin. Syst. DECANDRIA PENTAGYNIA.}

Genrric Character.-Calyx 5-toothed, naked. Petals 5, unguiculate, furnished with a crown of petal-like scales in the throat. Stamens 10. Styles 5. Capsule I-celled.

Description, \&c.-The genera Lychnis, Agrostemma, and Githago, are distinguished from each other principally by the shape of the calyx, and the presence or absence of the anthephorum, or receptacle on which the petals, stamens, and ovary, are seated. The plants belonging to these genera are called by different names by different botanists; and, according to the Linnæan system, seme flowers were called Lychnis, that are now considered to belong to Agrostemma; and the reverse. Under these circumstances, we liave not thouglit it worth while to describe the three genera, but shall include the very few annual species belonging to then under the genus Agrostemma.

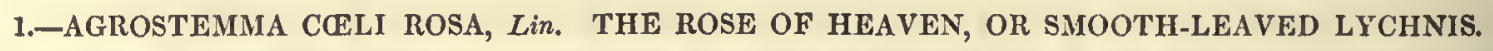

Syмonyms, -Lychnis Ceeli-Rosa, Des.

Engravings.-Bot. Mag. t. 295, and our fig. 2, in Plate 20.

VARIETIEs.-These are numerous; but they differ chiefly in the leaves being smooth or rough, and the stems decumbent or erect.

Sproific Character._-Plant glabrous. Stem dichotomously panicled, erect. Flowers solitary, terminal. Calyx clavated, with ten ribs. Lobes very acute. Petals lobed. Leaves lincar, acute. Anthophorum long.-(G. Don.)

Description, \&c.-A very elegant hardy annual, a native of Sicily and the Levant, which was intrednced in 1739, and first cultivated by Miller, in the Chelsea Botanic Garden. The seeds, which are commen in the seed-shops, should be sown, early in April, where they are to remain, and the plants not thinned out; as, when 
allowed room to spread, they become straggling and untidy. The plants look best when sown so as to form tolcrably large beds, as the vivid colour of the flowers, combined with their want of adequate foliage, makes them look best in masses. When the seed is sown thinly on rather dry soil, the plants will not grow above six inches high, and will produce a fine mass of red for a geometrical flower-garden, in which each bed is of a different colour.

\section{2.-Agrostemma late, ait. The PRETTY ROSE CAMPION.}

Synoxymes.-Lychnis palustris, Brot., L. læta, Ait.

Specific Character. -Flowers solitary. Calyxes with 10 ribs. Petals bifid. Leaves linear-lanceolate, rather ciliated.-(G. Don.)

Description, \&c.-This pretty, joyful-looking little plant, seldom grows above three inches high, and has bright rose-coloured flowers. It is a native of Portugal, and is chiefly found in bogs and moist meadows near Coimbra. It was introduced in 1778; and, when planted in beds, it forms a rich mass of flowers. Seeds may be had at Lee's, Hammersmith; Noble's, Fleet-street; Charlwood's; Carter's, Holborn; Kernan's, James Street, Covent Garden ; and, we believe, most other seed-shops, under the name of Lychnis lata.

\section{3.-AGROSTEMMA GITHAGO, Lin. THE CORN COCKLE.}

Synowxarg.-Githago segetum, Desf., Lychnis Githago, Lam.

Engratino.-Eng. Bet. t. 741.

Specinc Character.-Plant bairy. Stem dichotomous. Flowers on long stalks. Leaves linear. Calyx equal in length to the corolla.-(G. Don.)

Description, \&c,-This, though a troublesomo weed to the British farmer, makes an elegant garden-flower. Its colour is purple, with bluish streaks; and it looks best sown in patches. The French Corn Cockle (A: Nicesensis, Pers.), which grows wild near Nice, has white flowers, which are sometimes streaked with red. It was introduced in 1794. Both plants are rather tall-growing, and requiro training to sticks, or tying up in some way, to make them look neat.

GENUS VI.

VELEZIA, Lin. THE VELEZIA.

Lin. Syst. DECANDRIA DIGYNIA.

Grneric Charucter.-Caly $x$ tubular, 5-toothed. Petals 5, with long filiferm bearded claws, and an emarginate limb. Stamens I0. Styles 2. Capsule 1-eelled.i-(G. Don.)

1.-V. RIGIDA, Lin.

A beautiful little plant, with white flowers, having a rose-coloured border : quite hardy, and well-adapted for rock-work. It is a native of France, and was introduced into Scotland in 1683, whence it, was soon after brought to England; but it is now probably lost, as we do not know where it is to be procured.

\section{2.-V. QUADRIDENTATA, Sib. et Smith.}

has rose-coloured petals, and is a native of Asia Minor. Though the flowers of these plants are small, they are 80 abundant as to produce a very pretty effect. If not intended for rock-work, they should be sown in a dry sandy soil, in a warm open situation, fully exposed to the sun. 


\section{CHAPTER XX.}

LIMNANTHACEA.

Essentua Character. A simple styls. Fruit divided ioto deep lobes. Gynobase pcver fleshy. Stamens perigynous. $-($ Lindl. $)$

\section{GENUS I.}

\section{LIMNANTHES, $R$. Br. THE LIMNANTHES.}

\section{Lin. Syst. DECANDRIA MONOGYNIA.}

Generic Churacter.-Calyx 5-parted. Petals 5. Stamens 10. Capsules 5.-(Hook.)

\section{I.-LIMNAN'THES DOUGLASII, $R$. Br. DOUGLAS'S LIMNAN'THES.}

Engravises.-Bot. Reg. t. 1673, Bot. Mag, t. 3554, and our fig. | axlliary, and about as long as the leaves. Flowers solitary. Calys 3 , in Plate 20.

Speeifie Cinaractrr.-Plant glabrous. Stemis mueh brapched, terete, dceumbent. Leaves altemate on losg petiolss, pinnatn. Lcaflets acute, entire, or iacised, sometimes pinnatifid. Peduncles than the petals. Style single, shortcr than tho stamens. Stigmas of 5 rays each, tipped with a little globose head.

Description, \&c.-A very pretty hardy annual, introduced by poor Douglas, in 1832, from California. Its flowers, which are fragrant, are curious from their colour, which is half briglit-yellow, and half pure white. The stems are much branched and decumbent, so that a single plant covers a large spacc. The leaves are slightly pinnate; and the leaflets are decply cut. The whole plant is rather succulent, and tastes, when bitten, like the Nasturtium, or water-cress. It requires a moist shady situation, having been found near a lake: The name Limnanthes, indeed, signifies a lake-flower. This plant is interesting to the botanist, from its having been made, by Dr. Brown, the type of a new order. The order, indeed, only includes this genus and Floerkea, another Californian annual, not yet introduced. The seeds of the Limnanthes, like those of all the Californian annuals, may be sown at almost any season, when the ground is not hard with frost, and they will generally be in flower about six weeks after sowing. The usual season for sowing it is, however, April, when it will flower early in June. Seeds may be had at any of the seed-sliops, and they should be sown thinly where they are to remain.

\section{CHAPTER XXI. \\ TROP ACOLACE 2 .}

Essentul Character.-Sepals 5, the upper one with a long | Ovules eolitary, penduleus. Fruit iadehiseent, separable into 3 piecen distinet spur; æstivation quincuncial. Petals 5, unequal, irrregular; the 2 upper sessile and reniote, arising from the throat of the calyx, the 3 lower stalked and smaller, sometimes abortive. Strmens 8, perigynons, distinct. Anthers inaate, erect, 2-eelled. Ovary 1, 3-cornered, mado up of 3 carpels. Style 1. Stigmas 3, neute. from a common axis. Seeds large, without albumes, filling the cavity in which they lie. Embryo largs. Cotyledons 2, straight, thick, conisolidated together into a single bedy. Radicle lying within projections of tho cotyledoas.-(Lindl.)

\section{GENUS I.}

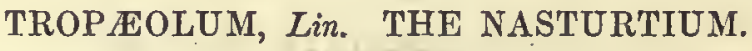 Lin. Syst. OCTANDRIA MONOG YNIA.}

Graneric Character.-Calyx 5-parted, upper lobe furnished with a spur. Petals 5, 3 lower ones smaller or vanished. Stamens 8, free.-(G. Don.)

Description, \&c.-The two commonest kinds of these beautiful flowers are so mucls cultivated, that there is scarcely a clild, who has ever seen a garden, who is not acquainted with them. Tropceolum minus was the 
$-$ 


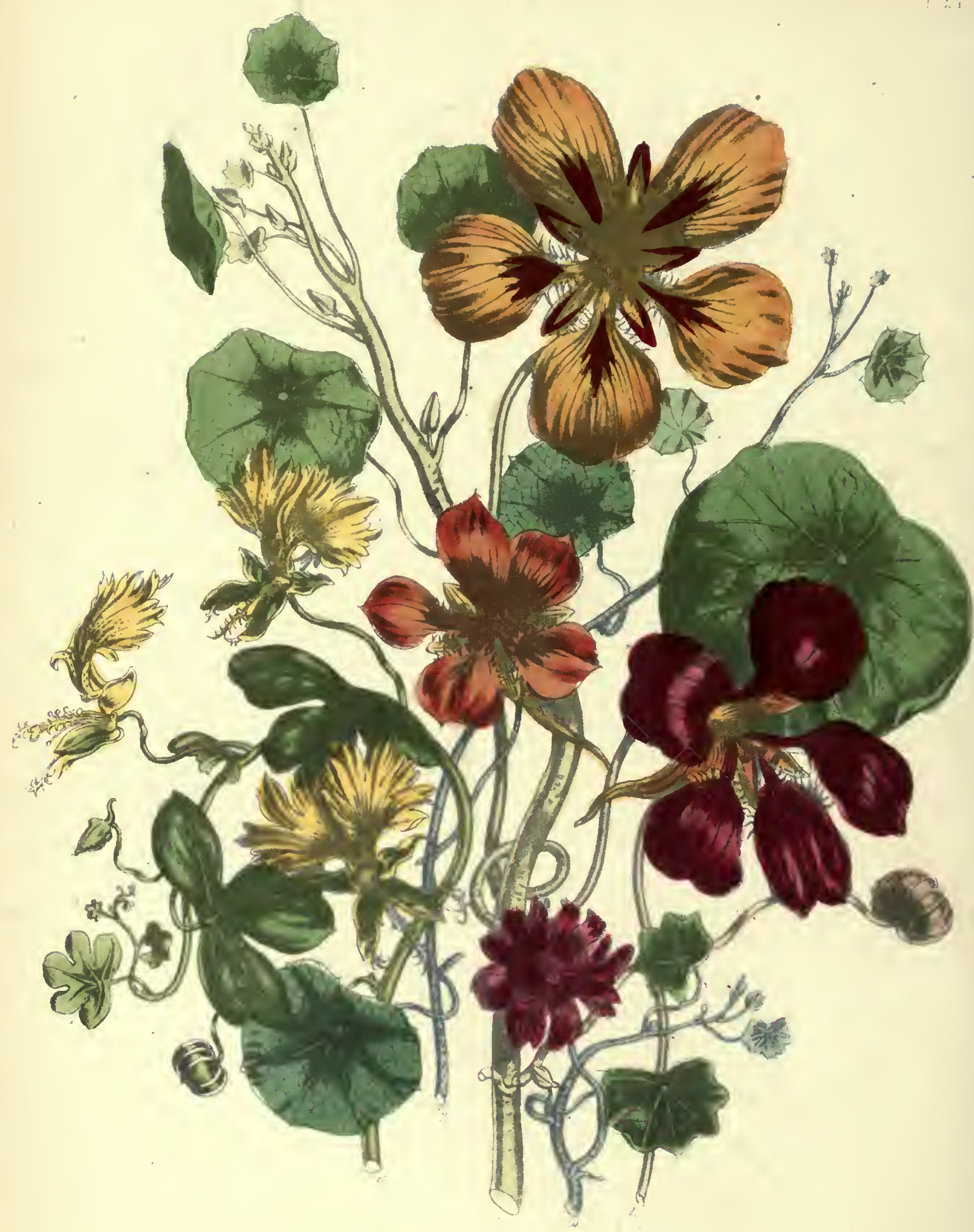


- 

first introdueed, and therefore we shall describe it first. Botanically considered, what we call the flower is in fact a coloured calyx, the real petals boing small, and alternating with the lobes of the calyx, in the mouth of the spur of which they are fixed. The name, Tropcolum, is derived from a Greek word, signifying a trophy; in allusion to the leaves being like bucklers, and the flowers like helmets.

\section{1.-TROPAOLUM MINUS, Lin. THE LESSER NASTURTIUM, OR SMALL INDIAN CRESS.}

Engravings._Bot. Mag. t. 98, and our fig. 3, in Plate 21.

VARIвтY.-T. m. 2 fi. pleno.-(G. Don.) Sec our fig. 4, in

Plate 21. This has double flowers, and is a beautiful plant.
Spreific Character. - Leaves peltate, nerved, orbicular, somewhat repand. Nerves mucronate at the apex. Petals each ending in a bristle-like point.-(G. Don.)

Description, \&c.-This species, though the first introduced, has now become comparatively rare in our gardens; its modest merits having been eclipsed by its more showy rivals. It has smaller flowers, with much less orange and red in them, than the great Nasturtium; the leaves are smaller, of a paler green, and with the nerves ending in small points. The stems also are different, these being much more weak and slender. This plant is a native of Peru, from which country it was sent to Spain early in the 16th century; and Robin, the gardener of Henry IV. in Paris, having obtained seeds of it, sent them to his "loving friend "Gerard, who first grew the plant in England in his garden, in Holborn, before 1596. The plant was described by Dodoneus as Nasturtium indicum, from the resemblanee of its taste to that of the water-cress, the botanic name of which is Nasturtium, and when it was bronght to England, it was called Indian-cress; because in those days the Spanish possessions in South America were known by the general name of the Indies. The plant was evidently highly valued at its introduction; for Gerard gives somewhat uninute directions for raising it on a hotbed, proteeting it with a mat at night, transplanting it, \&c. It is now found, however, to be perfectly liardy, and to sow itself freely if permitted to ripen its sced. In the time of Parkinson, it appears to have beeome quite common, or, as he styles it, "familiar in most gardens of any curiosity." He gives a very particular description of it, and not only praises its beauty, but its smell! The passage is so curious, that we give it, to show the idcas our ancestors had of fragrance. "The whole flower liath a fine small scent, very pleasing, which being placed in the middle of some carnations, or gilliflowers (for they are -in flower at the same time), make a delicate tussimussie, as they call it, or nosegay, both for sight and seent."-(Paradisus, p. 281.)

When the plant was first introduced, some botanists thought it might be a Clematis, or a Conrolvulus; but, as we have before stated, it was afterwards decided to be a cress, "from its taste and smell." About the time of Parkinson it was called yellow Larkes heeles; and it is curious that in some of the works lately published on the language of flowers, those of the Larkspur are said to be yollow, and to signify lightness; the flower meant being evidently not that which we now call the Larkspur, but the Nasturtium. The plant is eatable; the flowers, leaves, and young shoots, being sometimes used in salads; and the fruit, when pickled, being very generally employed as a substitute for capers. The culture is very simple, as the seeds seldom fail to germinate if dropped into the ground without the slightest preparation, and the plant looks best when left entirely to itself. When it is thonght desirable to train it, it should be planted close to a wooden paling, or low wall, and the shoots suffered to grow, or be thrown, over it. It should never be tied, or nailed; as, from its suceulent nature, this could not be done without bruising the shoots, which would instantly wither. The seeds may be purehased in most sced-shops, and they are mueh harder and rounder than those of the larger kind.

Q 2 
It is a curious fact relating to this plant, that the caterpillars of the cabbage butterflies, though in general they feed only on crueiferous plants, will devour it with the greatest avidity.

\section{2.-TROP AOLUM MAJUS, Lin. THE GREAT NASTURTIUM.}

Engratings._Bot. Mag. t. 23, and our fig. 1, in Plate 21.

VArifties.-These are numerous; and most of them are very beautiful, though, till lately, but little attention has bees paid to raising them. The follewing are the most important and beautiful :-

$\boldsymbol{T}$. $\boldsymbol{m}$. 2 flore pleno G. Don, bas double flowers.

T. m. atrosanguineum, Swt. Brit. Flow. Gard. 1. 204, Bot. Mag. t. 3375, Paxt. Mag. of Bot., vol. i. p. 176, has the whole flower of a dark, rich, reddish orsnge; it does not grow so luxariantly as the common kind; but is much more beatiful. This variety may be propagated either by seeds (whieh, however, do not always come true), or cuttings, taken off at a joint.

T. $m .3$ venustum, Hert., Paxt. Mag, of Bot., vol. ii, p. 194. A very beautiful, compact-growing dwarf varicty, with the leaves on very long footstalks, and bearing abundanee of flowers. This variety was imported, from Ghent, in 1835, by Mr. Knight, of the Exotic Nursery, Chelsea. The flowers are of a bright yellow, with one deep erimsou stripe up the centre of each lobe.

T. m. 4 hybridum, sgn. T. hybridum, Lio. A kind with pale yellow flowers, without any mixture of orange or searlet, and wedgoshaped leaves; raised in a garden at Stoekholm.

Specric Character. - Leaves peltate, nerved, orbicular, somewhat 5-lobed. Nerves not mueronate at the apex. Petals ohtuse.(G. Don.)

Descniption, \&c.-This species varies very much in the colour of its flowers; and, as before observed, it has many marked varieties. It may, howevcr, always be easily distinguished from $T$. minus by the leaves, which in the latter specics, and its varieties, always have the nerves of the leaves ending in a mucro, or point, which is never the case with T. majus. The variety, T. m. atrosanguineum, is shown in our fig. 2, in Pl. 21.

-A curions discovery was made respecting this plant by one of the daughters of Linnæus, who died lately at the advanced age of 96 . This lady, in the year 1762, "observed the Tropaolum majus, or Garden Nasturtium. emit sparks or flashes in the mornings before sunrise, during the months of June or July, and also during the twilight in the evening, but not after total darkness came on." Similar flashes have been produced by otler flowers; and it has been observed, that they are always most brilliant before a thunder-storm.—See Paxt. Mag. of Bot., vol. ii. p. 195.

The properties, habits, and culture of this species, are exactly the same as those of $T$. minus; but when it is wished to grow the flowers to the greatest perfection, the seeds should be sown in a light, rieh, warm soil. It may here be observed that, though the species of this genus grow so readily from seeds, they have very small roots, and are easily killed by transplanting. They may all be propagated by cuttings, which, if kept in a greenhouse, will live through the winter, and flower beautifully in spring.

\section{3.-TROPAOLUM PEREGRINUM, Jacq. THE CANARY-BIRD FLOWER.}

Synonymas.-T. aduneum, Smith; $T$. canariense, Hort.

Engruvings.-Bot. Mag. t. 1351, And. Bot. Rep. t. 597, Bot. Reg. 1. 718, Swt. Brit. Flow. Gard. 2nd ser. t. 134, aud our fig. 5, in Plate 21.

Specifle Caunactrr.-Leaves palmate. The two upper petals larger, and much cat; the three lower oves fringed. Spur hooked.(G. Don.)

Description, \&e.-This very beautiful plant is a hardy annual, like the other speeies of the gerus; though, like them, it may be propagated by cuttings, and kept for several years in a greenlouse. The true perennial species, Professor Don observes, have all tuberous roots. T. peregrinum is a native of Peru, from which country it is said to have been imported, in 1775, by Mr. Benjamin Bewiok. It is called Malla by the Indians, and Paxaritos Amarillos, that is, yellow birds, by the Spaniards; and it las been cultivated from time immemorial as an ornamental climber in the gardens of Lima, and other cities of Peru. In England it only requires to be sown, in $\Lambda$ pril, in a rich light soil near a wooden paling, or trellis-work, over which "it may be thrown; and, when thus treated, it will form a splendid ornament to a flower-garden." 


\section{CHAPTER XXII.}

\section{LEGUMINOSA.}

Essentuac Character.-Calys 5-cleft, or 5-toothed, or bilabiate. free, usually stipitate. Segments generally 2-ralved, 1-celled, os Pctals usually 5 , rarely fewer, papilionaceous, or unequal, seldom nearly equal, imbricate in restivatioa, inserted in the bottom of the calyx, rarely in the torus. Stamens inserted with the petals, and generally twice their number, rnonadel phous or diadelphous. Ovarium transversely many-celled. Seeds fixed to the upper suture of the legume by funicles. Albumen noue. Leaves usually alternate, variable, bistipulate. Flowers of various hues.-(G. Don.)

Description, \&c.-The order Leguminose is a very interesting one, from the great number of useful plants which it contains. The number of substances useful in medicine or the arts, which are produced from plants belonging to this order, is very great; and among tbem may be enumerated balsam of Tolu, gum arabic, liquorice, tamarinds, senna, logwood, and indigo. The ornamental trees and shrubs belonging to the order are also very numerous; and among the trees may be mentioned the laburnum, the Judas tree, the Robinia or false acacia, and the true acacias; while among the shrubs are the furze, the broom, the bladder-senna, and many others. Besides these plants, peas, beans, vetches, clover, trefoil, saintfoin, and lucerne, all belong to this important order. All these plants, various as they are, not only in their uses, but in many cases even in the form of their flowers, agree in the important point of bearing their seeds in pods or legumes, which is the circumstance that gives the name to the order; and this is the only point in which all the numerous plants belonging to it agree.

The ornamental annual flowers belonging to Leguminosos are principally comprised in the genera Lupinus and Lathyrus; but there are garden annuals in almost all the genera in it which contain lierbaceous plants, thongh some of those that were formerly favourites are now considered not worth cultivation, such as the different kinds of Medicago. M. satioa, the common lucerne, has a pretty purple flower; but the kinds with yellow flowers are generully not worth growing: of these, Medicago maculata is still to be found in nurserymen's eatalogues, under the name of Snails, the capsules bearing some resemblance to suail-shells; the flower is yellow, but very small and insignificant, and the leaves are small, and of a dingy yellowish green. Medicago minima is called hedgehogs, and $M$. denticulata caterpillars, and both have nothing to rccommend them, either in their flowers or leaves. All these kinds of Medicago are natives of Britain. Scorpiurus loevigata, and other species of the same genus, are also sometimes called caterpillars, and their capsules do bear a striking resemblance to those creatures; bnt the plants of the genus Scorpiurus are all natives of the Grecian Archipelago, and other parts of the south of Europe, and as their flowers are not remarkable for beauty, they are seldom grown in English gardens. Sevcral kinds of Melilotus used formerly to be considered as garden flowers. One species of this genus, M. officinalis, is a native of Switzerland, and is well-known, from its flowers and seeds being the chief ingredients used in flavouring the Gruyère cheese. Some of the kinds of Trifolium (clover) were also grown in gardens. The crimson trefoil (Trifolium incarnatum) is very brilliant in its colour; but its growth is too coarse and untidy to make it suitable for cultivation in a flower-garden. Among the number of flowers belonging to this order, which were formerly cultivated in gardens, may be mentioned the scarlet runner (Phaseolus multiflorus), which is now only grown in our kitchen-gardens as a kind of kidney bean. This plant is found in all the lists of ornamental annuals from the time of its introduction in 1633 , to the middle of the last century; and it was 
thought so beautiful, that (as it is a native of South America) it was thought worth raising on a hotbed before planting out. The genus Crotalaria contains many very showy annual plants, some of which are hardy; and the genera Dorycnium, Lotus, Ononis, \&c., a few each.

\section{GENUS I.}

\section{CROTALARIA, Lin. THE CROTALARIA.}

\section{Lin. Syst. MONADELPHIA DECANDRIA.}

Generic Character. - Calyx 5-lobed, subilabiate. Vexillum | usually many-sceded. Herbs or sbrubs with simplo or palmately. cordate, large. Keel foliate, acuminated. Stamens monadelphous. compound leaves, and usually yellow flowers, rarely purplish.Style bearded laterally. Legume turgid, with ventricose valves, $\mid$ (G. Don.)

Descriptrox, \&c.-Notwithstanding the extraordinary splendour of the flowers of plants belonging to this genus, it is comparativcly little known; and though nearly all the annual species composing it have been introduced, they appear to have been lost; for we have not been able to discover any place where we can procure sceds of them. Under these circumstances, we have not thought it werth while to fill our pages by going into the botanical details of each species; but we have only said a few words on each, so as to give a general idea of the plant. The word Crotalaria signifies a castanet, and alludes to the pods of this genus being inflated, and the seeds rattling in them, when ripe.

\section{ALATA, Ham. et Roxb.}

A plant with pale yellow flowers, and winged stems, growing about a foot high. It is a native of Nepal, and was introduced in 1818.

\section{PLATYCARPA, Link.}

Large yellow flowers, with a rich brownish standard, winged stem, and very broad pods. The plant grows above a foot high. It is a native of North America, and was introduced in 1823.

\section{PURshiI, Deo., syn. C. LAJigata, Pursh.}

A native of North America; introduced in 1800. C. PArvifLorA, Roth., introduced in 1817, and C. sagittalis, Lin., introduced in 1731 , are also natives of North America.

C. ESPADILLA, H. B. et Kunth.

A very remarkable species, described by Humboldt. The leaves, when they first expand, are of a golden yellow, but gradually become green with age; and both the leaves and stem are covered with long silky hairs. It is a native of South America, where it is called Espadilla: It has not yet been introduced.

\section{VerRUCOSA, Lin.; Bot. Rep. t. 308; Bot. Reg.t. 1137; Bot. Mag. t. 3034.}

$\Lambda$ beautiful species, with purple, blue, green, and white flowers, with anthers of a golden yellow. It is a native of the East Indies, and is generally kept in the stove; but if raised in a hotbed, and then planted out into a warm border, it will flower well. It was introduced in 1731 . There is a varicty sometimes called C. acuminata, with blue flowers.

\section{RETUSA, Lin.; Bot. Reg.t. 253.}

A splendid species, with very large golden yellow flowers, the standard of which is sometimes a bright purple. A native of the East Indies, but found also in the Mauritins, and in the West Indian islands. 
Intreduced in 1731. This plant, from its being supposed to live only in a stove, and its taking so much room, from its growing two feet or three feet high, and branching very much, is now very little cultivated; but if the seeds were raised on a hotbed, and planted ont in June, it would be a great ornament to the flower-garden.

\section{LESCHENAULTI, Dec.}

A native of the Neilgherry mountains, where it is called Guili-guedje by the natives. The flowers are of a pure bright yellow.

\section{SPECTABILIS, Roth.}

The flowers are of a rich dark purple, with golden yellow anthers. Plants of this species, and C. retusa mixed, would produce a magnificent effect. C. spectabilis is a native of the East Indies, and was introduced in 1820.

Greatly resembling the common broom. A native of the East Indies, where its fibres are used as a substitute fur hemp, and its young shoots as a food for cows. The flowers are small and yellow, but the pod is cnormously large, being above a foot long and half a foot broad. The plant frequently grows eight feet bigh. It was introduced in 1700. There are several other species very nearly allied to this one; all of which have yellow flowers and rush-like stems.

\section{TECTA, Roth.}

The flowers are yellow, striped with blackish-brown. There are several other species, natives of the Last and West Indies, two of which are dwarf plants; one, C. NANA, Burm, has ycllow flowers; and the other C. PRostrata, Roth. Both are natives of the East Indies, and both have been introduccd. These plants would be suitable for rock-work in a warm situation, and would produce a fine effect.

\section{GENUS II.}

\section{LUPINUS, $L$. THE LUPINE.}

\section{Lin. Syst. MONADELPHIA DECANDRIA.}

Genertc Character.-Calyx bilabiate. Vexillum reflexed on the stigma. Legume coriaceous, compressed, torulose. Erect herbs, with sides. Keel acuminated. Stamens monndelphous, thasheath entire, digitate leaves, composed of 5-9 leafets, rarely simple, and racemosebearing 5 small round anthers, and 5 oblong ones, which are lator in spikes of blue, white or yellow flowers. - (G. Don.)

coming to perfection. Stylo filiform, erowned by a bearded roundish ।

Description, \&c.-The lupine is a very interesting plant to the student in botany, as well as a showy one to the more general observer. It is intercsting to the botanist on account of the largeness of its seed, and the distinct manner in which it shows the progress of germination; and also from its affording an excellent example, on a large scale, of the different parts of a papilionaceous flower. If the seed of a lupine be laid in the upper part of a small crocus "glass, and kept covered with water, the process of vegetation may be distinctly traced. The aril, or skin that covers the seed, will first begin to crack and peel off, to admit the swelling cotyledons, into which the seed divides, to burst forth, and take tho form of what are called the seed-leaves. From the knot in the centre of the seed, the little plumule rises, with the flower-stalk and truo leaves; while the root descends from the same point. The flower consists of five petals, one of which is much longer than the others. This large petal is called the standard or vexillum, and it stands at the back of the others. In front of the standard are two much smaller petals, which are called alæ, or wings; and below them are two petals curiously joined together, which ferm what is called the carina, or lkeel. All papilionaceous flowers are formed in this manner, and they 
all consist of the same number of parts. The leaves of most of the annual lupines are what is called digitate; that is, the leaflets spread out from a cemmon centre like the fingers of the hand, and are not disposed in pairs as leaflets generally are. The leaf of the lupine affords an example of the sleep of plants, as in the evening, the leaflets close, and hang back upon the foetstalk of the leaf. Nearly all the lupines are quite hardy and easily grown, as they require no other eare in their culture than simply sowing them. They generally seed freely, and their seeds keep well, and seldom fail to vegetate. The word Lupine is derived from the Latin word Lupns, a wolf, becanse the lupines, when cultivated for food (as they have been in Rome from the mest ancient times), require an exceedingly rich soil, and indeed devour, like a wolf, all the food they can get.

\section{1.-LUPINUS AlBUS, Lin. THE White LUPINE.}

SYNoNYMe, - L. sativus, Gater.

Speciric Character.-Flowers alternate, pedicellate, destitute of

bracteoles; upper lip of ealyx entire, lower one tridentate; leaflets obovate-oblong, usually 7 or 8 , villous beneath.-(G. Don.)

Description, \&c.-The flowers are white, and with scarcely any footstalk to each. There is a variety with the keel of the flower tipped with violet. This plant is a native of the Levant, but it has been leng cultivated in Italy and other parts of Europe for food, as peas and beans are with us. In the north of Italy and the south of France, it is sown on poor dry soils, in order that, wlien the plants come up, they may be ploughed into the land instead of manure, to increase its fertility, and after this treatment the land is said to bear an excellent crop of corn or grass. The practice is described by the ancient Roman writers on agriculture, exactly as it is performed at the present day. The Romans also frequently mention lupines as articles of food; and Pliny says that persons who lived principally upon them always had a fresh celour and a cheerful countenance. Virgil, however, speaks of their extraordinary bitterness; which, was generally abated by soaking them in hot water, and cevering them with hot ashes. Among the Greeks, lupines were also used as food, and were theught to brighten the mind, and quicken the imagination. Dioscorides recommends them as a cosmetic, as ho says that, when boiled and applicd externally, they serve to clear the skin; and Theophrastus says they require a very bad soil, being of an untameable nature, and delighting most to grow wild. This species was introduced by Gerard, before 1596 ; and it is common in flower-gardens to the present day. Seeds may be procured in any seed-shop.

\section{2.-LUPINUS HIRSUTUS, Lin. THE HAIRY LUPINE.}

SYNoNYME.-L. digitatus, Forsk.

VARIETY_LL. $h .2$ albus, Hort.

Specific Churacter.-Flowers altcrnate, bractcolate; upper lip of

calyx bipartite, lower one trifid. Leaflets 5 , oblong-spatulate, hairy on both surfaces. Legumes very hairy.-(G. Don.)

Description, \&c.-A very distinet kind; the whole plant being covered with ferrnginous hairs. It is remarkable also for its large blue flowers, which have occasioned it to be called in the old books on flewers, the great blue lupinc. Nearly allied to it are the Rose Lupine (L. pilosus), and the Lesser blue Lupine ( $L$. varius). $L$. hirsutus is a native of the sonth of Europe, and was intrednced between 1596 and 1629, as it is not mentioned by Gerard, who wrote at the fermer period, thongh it is by Parkinsen, who wrete at the latter. Its seeds are now seldom found in the seed-shops, as its culture has been partly superseded by the many more beantiful kinds that have been introduced since it was a favourite; but there is a beautiful new white variety of it, the seeds of which may be procured at Carter's, Holborn. Like all the other lupines, it requires a light but rich soil to bring it to perfection. It should be sown in March or April, and will flower in June or July. 


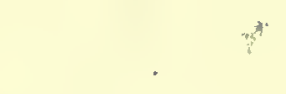




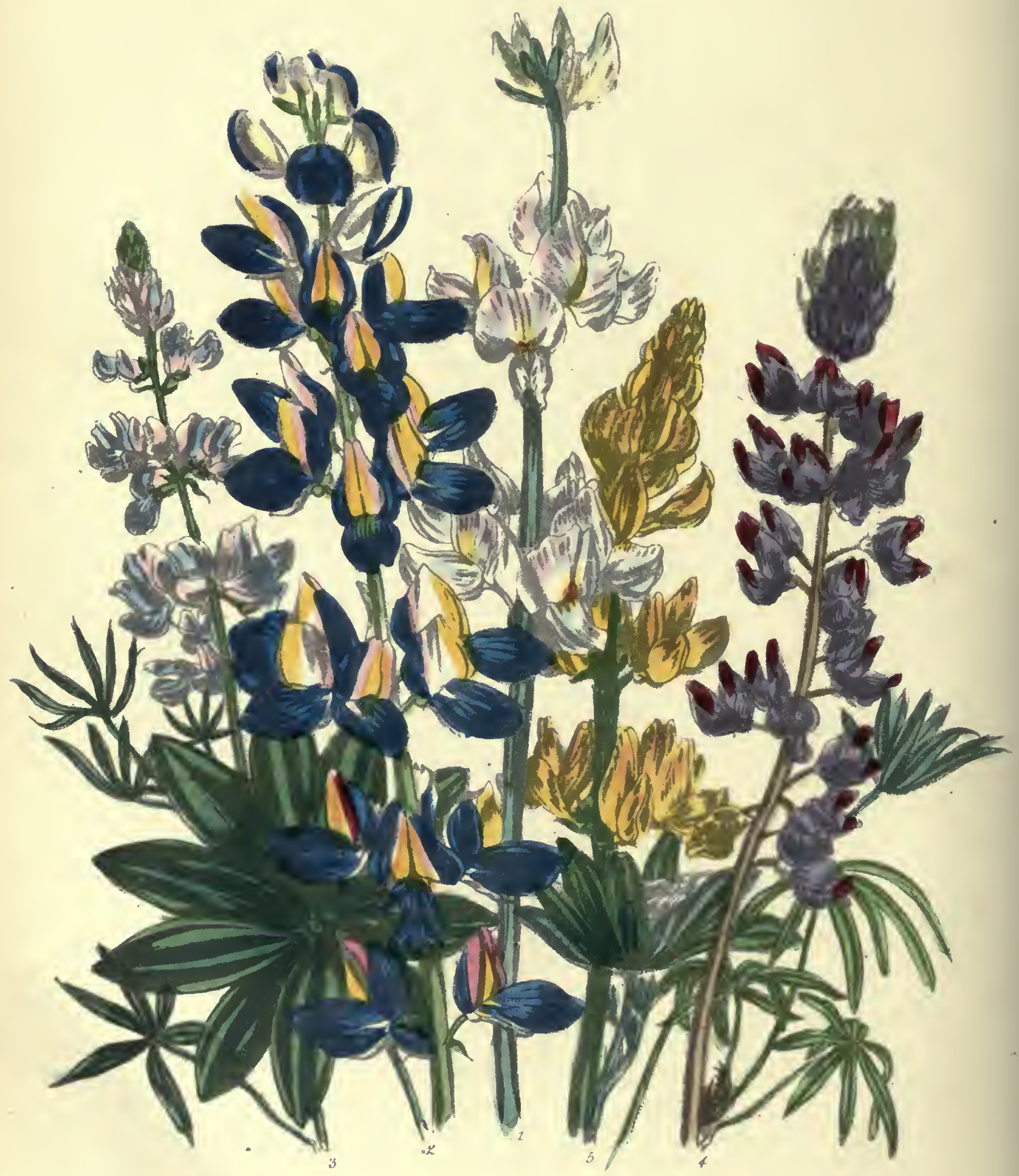

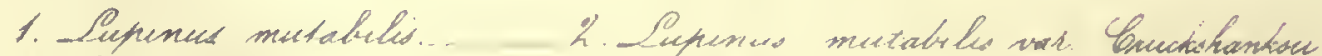

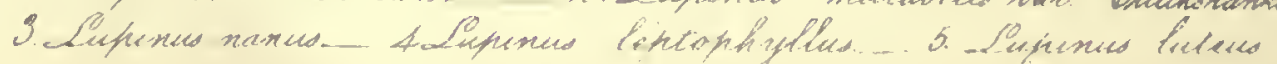



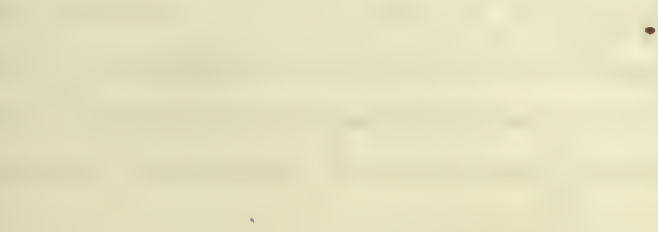

, 



\section{3.-LUPINUS BICOLOR, Lindl. THE TWO-COLOURED LUPINE.}

Engravina.-Bot. Reg. t. 1109.

Specific Character.-Stems branched, corymbose, and, as well as the leaves, clothed with silky pili. Leaflets $5-7$, linear-spatulate.

Flowers few, verticillate. Calyx clothed with silky wool, inappendi- culate, having the upper lip bifid, and the lower one elongated and entire. Wings longer than the vexillum. Legumes many-seeded.(G. Don.)

Description, \&c.-A very remarkable little lupine, which, from the smallness of its flowers, and their peculiar form, scarcely seems to belong to the genus. The standard is smaller than the other petals, and it is wlite, just tinged at the apex with red; the wings and keel are of a very deep blue. The plant is dwarf and bushy, and it produces a constant succession of blossoms from May to October. It is a native of North America, where it was found by Douglas in 1836, near the Columbia river, "always on dry gravelly soils, and especially under the shade of trees." It is quite hardy, and seeds may be bad in any seed-shop.

\section{4.-LUPINUS LUTEUS, Lin. THE YELLOW LUPINE.}

SYNoNYME, -L. gdoratus, Hort.

Enghavings.-Bet. Mag. t. 149 ; and our fig. 5 , in Plate 22.

upper lip of the caly $x$ hipartite, lower one tridentate. Leafets $7-9$, Specrizc Characten.- Flowers vcrticillate, sessile, bracteolate;

Description, \&c.-The yellow lupine seldom grows above a foot high; and its flowers, which are of a bright golden yellow, smell like cowslips. It is a native of Spain, whence it was first brought to England about 1590. Gerard and Parkinson, though they place it among those "flat beanes, called Lupines,". tell us that, when it was first introdueed, it was called the Spanish violet, from the rescmblance in colour between it and Viola lutea. It is, however, of a much brighter and more golden yellow than $V$. lutea. Seeds of this lupine are abundant in all the seed-shops, and the plants produce a very pretty effect if mixed with the Egyptian-white, rose, and dwarfblue lupines. The seeds require no other care in sowing, than to keep them separate, and not to cover them too deeply. All kinds of lupine seeds will indeed vegetate, if mercly dropped in the soil without any covering; but when planted carefully, the vital knot, from which the root and ascending shoot or plumule are to spring, should be turned downwards. The seeds of the yellow lupine are much smaller than those of the other kinds, so this mark is less perceptible. If the seeds are sown at a sufficient distance apart, the plants will be low and bushy; but if the seeds are sown thickly the plants will be slender and drawn up. It is best to sow them as they are to remain, for pulling up some loosens the roots of the remainder, and they will not bear transplanting.

\section{5.-LUPINUS MUTABILIS, Sweet. THE CHANGEABLE LUPINE.}

Engravinag.-Brit. Flow. Gard. 1st Ser. t. 130; Bat. Reg. t. S Sprciric Ciraracter.-Shrubby, erect, braached. Braaches spread1539 ; Bot. Mag. t. 2682; and our fig. 1 , in Plate 22.

VARIETY. LL. m. 2 Cruckshanksii, syn. L. Cruckshanksii, Hook. Bot. Mag. t. 3056 ; Brit. Flow. Gard. 2nd Ser. t. 203 ; and our fig. 2, in Plate 22. ing, glaucous, glabreus. Leafets 7-9, glaucescent and rather pubescent beneatb, lanceolate, bluntish. Flowers somewhat verticillato. Calyx without bractenles, upper lip bifid, lower one somewhat keeled, acute, entire.-(G. Don.)

Description, \&c.-Pcrhaps no flower ever better merited the name of changeable than this, as it, and its variety $L . m$. Cruckshanksii, vary in almost every possible shade, betwcen purple, blute, pink, yellow, and white. It is a tall vigorous-growing shrub, from three feet to six feet high, and it produces abundance of its large showy liandsome flowers from June to August. It is a native of Peru, and was introduced in 1819. It may seem strange to class a shrubby plant among annuals; but the fact is, as Dr. Lindley very justly observes in the Bot. Reg. (new Series, vol. v.), that " it rises with a rigid woody stem to the height of ahout three feet, and has 
all the appearanee of an arborescent species; but as the frost always destroys it, and it flowers and fruits the first year of being raised from seeds, it is for our gardens a mere annual." It is thus considered and treated botlı by gardencrs and seedsmen, and accordingly we have included it in our list. The species was first raised in England in the garden of the late Charles Barclay, Esq. Bury Hill, near Dorking, "frem seeds obtained from Santa Fé de Bogota." L. m. Cruckshanksii was found by Alexander Cruckshanks, Esq., "growing upen the Andes of Peru, in great plenty, net far from Pasco, and near the verge ef perpetual snow." (Bot. Mag. vol. 58.) This magnificent Lupine was introduced in 1829. The seeds of both kinds may be sewn in the open ground in April; but they will be much finer if raised three tegether in a pot plunged in a hetbed in March, and then planted out the first week in May, carefully turning the ball of earth out of the pet witheut breaking it, and planting it in a hele, previously dug fer its reception.

\section{6.-LUPINUS LEPTOPHYLLUS, Benth. THE SLENDER-LEAVED LUPINE.}

Engravings.-Bet. Reg. t. 1670; and our fig. 4, in Plate 22. Specinic Character.-Annual. Stem erect, almost simple, apreading, hairy; lcaflets linear, narrow, hairy or silky on both sides. Flowers

near together or apart; bracteas helow the flower-stalk tufted and somewhat rough; pedicels bracteolated; upper lip of the calyx bipartite; lewer lip longer, and tridentate.-(Benth.)

Description, \&c.-This elegant lupine is remarkable for the singular colour of its flowers, and its very slender leaves. It grows abeut a foot high, and the whole plant is covered witls soft hairs. The flowers, which, disposed in a very irregular manner on the spike, are of a bluish lilac, with a deep rich crimsen spot in the middle of the standard, and the long linear bracts of the mexpanded blessems form a kind of crown on the summit of the whele. The seeds " are unusually small for a lupine, and of a pale brewn, mottled with a darker shadc." Seeds may be procured in the seed-sheps, though they are not produced in much abundance, and they should be sown in a shady place, as this lupine does not flower well if expesed to too much light. It is a native of California, and was intreduced in 1834.

\section{7.-LUPINUS NANUS, Benth. THE DWARF LUPINE.}

Engravings.-Bot. Reg. t. 1705, and our fig. 3, Plate 22. | calyx silky-weolly, villese, appendages obsolete; upper lip bipartite, Specific Character.-A low angual hairy plant, with a decumbent lower one lenger, and obscurely tridentato.-( Lindl.) stem, slightly branched, leaves $5-7$, spathulate; flowers verticillate,

Descniptron, \&c.-A very pretty dwarf plant, with blue or purple flowers intermingled with a tint of roseceleur and white. It may be sewn at any season in masses, and it will eome into blessom in two or three weeks after sewing. It is particularly suitable for sewing to ferm masses in a geometrieal flower-garden, from its low and compact habit of growth, and frem the great abundance and long duration of its blessems. It is a native of California, and was sent lome by Douglas in 1834. It is rather capricious in preducing seed, seme nurserymen finding it frequently to fail. Mest of the London seedsmen, hewever, will probably be able to supply seeds. We have never seen the plant grown in greater perfection that it was by Mr. Forrest, of Kensingten, in 1838.

\section{8.-LUPINUS ELEGANS, Humb. et Kunth. THE ELEGANT LUPINE.}

ENGruving.-Bot. Reg. t. 1381.

Specific Charucter.-Erect; softly pilose; racemcs with elengated peduucles, flowers subverticillate; calyx silky-pilose, lower lip acute,

entire; leaflets lanceolate, acute, covered below with adpressed hairs, stipules bristly.-(Dec.)

Description, \&c.-This species is remarkable for its dreoping leaves, or rather leaflets, which appear to have obtained for it the name of elegant, as it seems to have ne other claim to the title. These leaves, however, do 
not convey any plensant idca to the mind of a casual observer, as they look as though the plant were suffering froin want of water. The flowers also are of rather a dingy reddish-purple, and have nothing particular to recommend them. The plant is a "native of Mexico, whence seeds were sent to the Horticultural Society by Dr. Deppe in 1831." The seeds, whicl the plants ripen frecly, may be procured at any seed-shop ; and if they are sown in the open air in April, the plant will flower in June.

\section{9.-LUPINUS DENSIFLORUS, Benth. THE DENSE-FLOWERED LUPINE.}

Engraving.,-Bot. Reg. t. I689.

Specific Character.-Piloso, stems ascending from a Jeafy baso; leaflets 7-9 oblong-spathulate. Flowers diaposed in whorls consisting of from 6 to 10 cach, placed very closely together, hairy; pedicels bracteate; upper lip of the calyx membranaceons and bipartitc, Iower lip twice as long, tridentate, pilose. Legumes covered with seattered hairs.-(Lindl.)

Description, \&c.-A very heantiful and remarkable little plant. The stem docs not grow above six or seven inches high, and the flower-stalk rises from a ricl tuft of leaves, each of which consists of nine leaflets covered with fine soft hairs. The flowers are white, delicately tinted with pink, and at the base of the standard of each is a little yellow stain, on which are a few black spots. The flowers grow in distinct whorls, but are placed very closely togcther in each whorl. It is a native of California, and was sent home by Douglas in 1834, but as it produces very few seeds, it is still rare. Seeds may, however, be procured of the principal seedsmen, and, like those of all the Californian annuals, they may be sown at any scason when the ground is not hard with frost, witl the certainty of their flowering, if the weatler should be open, in a few weeks.

\section{OTHER SPECIES OF LUPINE.}

Of the following kinds there is so little to be said, that we hare not thought it worth while to give all their botanical details. We shall, however, speak of them moro fully than we generally do in similar cases, as we believe seeds of most of them are to be procured in all the London seed-shops, and as they are common in our flower-gardens.

\section{TENUIS, Forsk., syn. L. PROLIFER, Des. THE EGYPTIAN LUPINE.}

A very handsome plant, growing from one to two feet high, with large white flowers, having the standard beautifully tipped with bluc. This species only differs botanically from $L$. albus in having bracteoles and only five or six leaflets, whereas L. albus has no bracteoles and seven or eight leaflets. It is a native of Egypt, and was introduced in 1802, but we do not know where seeds are 110 w to be procured. The flower-stalks of this plant when peeled, are eaten raw by the Arabians, and the sceds are boiled as a substitute for peas or beans.

L. VARIUS, L.; syn. L. SEMI-VEERTICILLATUS, Des.; L. SYLVESTRIS, var. Lam. THE LESSER BLUE LUPINE.

This is a tall strong-growing plant, generally three feet high, with small blne flowers. It only differs botanically from $L$. tenuis in having the upper lip of the calyx bidentate instead of entire, and the lcaflets somewhat lanceolate instead of oblong. It is a native of the south of Europe and Egypt, and was introduced before 1596. It is very nearly allied to L. hirsutus.

\section{PILOSUS, Lin. THE ROSE LUPINE.}

This also is very nearly allied to L. hirsutus, and indeed Miller considered it only a variety of that species. Subsequent hotanists have made it a distinct species on account of the lower lip of its calyx being entire, whercas 
in $L$. hirsutus it is tridentate, and from its baving from nine to eleven leaflets instead of five. The flowers of this species are of a beautiful rose colour, having the centre of the standard dark red. It is a native of the south of Europe, and was introduced in 1710. There is said to be a variety with bluish-purple flowers. Seeds of the rose lupine may be had in any seed-shop, and if sown in April the plants will flowcr in July and August.

\section{BRACTEOLARIS, Des.}

A native of Monte Video, introduced in 1820. It is said to be allied to $L$. hirsutus, though it does not grow above a foot high, but very little appears to be known about it.

\section{ANGUSTIFOLIUS, Lin. THE DUTCH BLUE LUPINE.}

A native of the south of Europe, nearly allied to $L$. varius, with blue flowers and variegated seed. It was introduced in 1696, and the seeds are frequently to be found in seed-shops.

\section{MICROCARPUS, Sims., Bot. Mag. t. 2413.}

This species is a native of Chili, and was introduced in 1820. It has blue flowers, with a purplish tinge at the apex, and very small pods, there being only two seeds in each. It is a dwarf species, and flowers in May and June.

\section{PUSILluS, Pursh.}

This species also does not exceed six inches in height. It has small blue flowers tinged with red. It is a native of North America near the Missouri, and was introduced in $181 \%$.

\section{MICRANTHUS, Doug.}

A curious little plant nearly allied to $L$. bicolor, and resembling that species in the smallness of its flowers, though they differ from those of $L$. bicolor in their form and colour. The flowers are pale purple, and the centre of the standard is white with four black dots. The leaves are fleshy, and the whole plant is covered with long fine hairs. This species was found by Douglas on the gravelly banks of the Columbia, and was introduced in 1827. Seeds may be had in the seed-shops.

\section{GENUS III.}

\section{LOTUS, Lin. THE LOTUS, OR BIRD'S-FOOT TREFOIL.}

\section{Lin. Syst. DIADELPHIA DECANDRIA.}

Gengric Churacter.-Calyx tubular, 5-clcft-wings and vexillum nearly equal. Keel beaked. Legume cylindrical. Stigma subulate. Herbs, usually with yellow flowers.-(G. Don.)

Description, \&c.-The size and shape of the flowers of plants of this genus, will be familiar to every one who has seen the common Lotus corniculatus, or Bird's-foot Trefoil of the fields. There are many annual species, most of which have yellow flowers, and differ so very little from each other, that we shall not think it necessary to describe above two or three species. The Linnean genus, Lotus, has been divided by modern botanists into two genera differing in the form of the pod, which in Lotus is always without wings; while in Tetragonolobus it is angular, and furnished with four wings. The plant we have called by its Linnean name of Lotus Tetragorolobus, is the type of the latter genus. 


\section{1.-LOTUS EDULIS, Lin. THE EATABLE LOTUS.}

-Sprcific Character.-Plant pilose. Stems erect. Leaflets ovate, | calyx. Legume turgid, arched, glabrocs. Seeds globose, compressed, eiliated. Flowers ]-3. Bractcas ovate, about equal in length to the wrinkled from dots.- (G.Don.)

Descriprion, \&c.-This plant is a native of the South of Europe, particularly of the islands of the Mediterranean, where the pods are eaten when young by the poorer people as kidney-beans are with us. It is a trailing plant with yellow flowers, suitable for rock-work. It was introduced in 1759, but we do not know where seeds are now to be procured.

\section{2.-LOTUS JACOBÆUS, Lin. BLACK, OR ST. JAGO BIRDS'-FOOT TREFOIL.}

Encrupisgs.-Bot. Mag. t. 79; and our fig. 10, in Plate 23. | canescent, mncronate. Bracteas of $\mathrm{J}$ or 3 linear leaflets. Peduncles Specific Character.-Plant rather glaucous. Stems shrubby. larger than tho leaves. Flowers corymbose on very short pedicels. Leaflets and stipules linear, or linear-spatulate, rather pilose and Legume terete, glabrous.-(G. Don.)

Description, 8c.-This is another greenhouse shrub, which succeeds perfectly well when treated as an annual. The flowers are small, and of no great beatry, but the plant is worth growing on account of their colour, which is very nearly black, perhaps more nearly than any other flower. There is a variety with the flowers partly yellow. The species is a native of the Capo de Verd Islands, particularly of St. Jago; and it was introduced in 1714. Seeds may be procured from Mr. Carter, High Holborn, or at Lee's Nursery, Hammersmith ; and the plants may be sown in February or March in a hotbed, and planted out in May; or sown in the open ground in a warm dry border in April.

\section{3.-LOTUS MICROPHYLLUS, Hook, THE SMALL-LEAVED LOTUS.}

Exorurno.-Bot. Mag. t. 2808. $\quad$ few in each head. Legumes short, cylindrical, hairy, 3-celled. Sceds

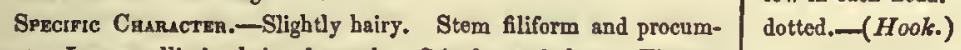
bent. Leaves elliptic, hairy bencath. Stipules subulate. Flowers

Description, \&c.-A curious little plant, with slender stems, and very small pink flowers, disposed in heads, so small as each to appear at a little distance to be composed of only one flower. The species is a native of the Cape of Good Hope, where it was found by the collector to the king of Denmark; and it was sent by Professor Hornemann, of Copenhagen, to Sir W. J. Hooker, at Glasgow, in 1827. The species would be very suitable for rock-work, from its slender, procumbent stems, and bright pink flowers; but we have never seen it in the London nurseries, and do not know where seeds are to be procured.

\section{4.-LOTUS ARENARIUS, Brot. THE SAND LOTUS.}

Engruving.-Bot. Reg. 1488. Speciric Churacrer,-Stems procumbent, branching, pubescent; the calyx. Calyx subulate, teeth two, the upper one the longcst. peduncles branched, erect. Leaflets acute, wedge-shaped; stipules 1 Legumes round, and smooth.-(Dec.)

Descriptrow, \&a.-A very showy species of Lotus, with large golden-yellow flowers, and a prostrate stem. It was found originally in Portugal, on the sandy sca-coast near the month of the Tagus, by Professor Brotero, and since by Professor Salzmann on the sandy coast near Tangiers; but it was not introduced into England, till seeds were sent here by P. B. Webb, Esq., from Teneriffe in 1830 . Sceds are not common in the Iondon seedshops, but they may be had from Mr. Young of the Milford Nursery, near Godalming, Surrey. 


\section{LotUS TETRAgoNolobUS, Lin. THE DARK CRIMSON-WINGED PEA.}

Sxwosymв.-Tetragonolobus purpureus, Monch.

Escrutings.-Bot. Mag. t. 151; and our fig. 9, in Plate 23.

Spectric Churacter.-Plant piloso. Stems rather decumbent.

Leaflets obovate, entire. Stipules ovate. Flowers solitary or twin. Bracteas longer than the calyx. Legume glabrous, with broad wings. Seeds globoso. - (G. Don.)

Description, \&c.-This very curious plant has dark crimson flowers, and large flat pods, which are so deeply winged, that they appear surrounded by a flounce. It is a native of Sicily, and was brought to England in 1769. It is quite hardy, and was long a great favourite in flower-gardens; but it is now seldom grown. It is, however, well deserving of cultivation from the rich colour of its flowers, and its curious seed-pods. The only place where we ever saw it growing, was the Lewisham nursery, in the summer of 1838 ; and we suppose seeds may be procured there, though they are not included in the general lists of the London nurserymen. The seeds should be sown in April, and the plants will come into flower in June.

\section{6.-LOTUS BIFLORUS, Des. 'THE YELLOW TWIN-FLOWERED WINGED PEA.}

Srvonymes.-L. conjugatus, Poir wi Tetragonolobus biflorus, | acuminated. Flowers twin or ternate. Bractera ovate, shorter than the Seringe.

Speciric Cruracter._Plant pilose, rather decumbent. Leaflets obovate, somewhat mucronulate, entire. Stipules orbicularly oblong, calyx. Legumes pilose with narrow wings. Sceda almost globose.(G. Don.)

Description, \&o.-A decumbent plant, with bright yellow flowers; a native of Barbary, and also of tho fields near Palermo. Introduced in 1818 ; and very suitable for planting on rock-work with the preceding and following species. We do not know where seeds are to be purchased, but the seedsmen might easily procure them from Sicily.

\section{7.-Lotus CONJugatus, Lin. THE PURPle TWIN-Flowered WiNGED PEA.}

Sxwonymz.-Tetragonolobus conjugatus, Seringe. $\quad$ in pairs. Bracteas obovate, longer than the calyx, Legume glabrous, Specific Character.-Plant pilose. Stems rather decumbent, pearly round, with very narrow wings, which are hardly cnrled. Seeds leafiets obovato, entire. Stipules ovate, small, acuminated. Flowers

Desoription, \&c.-CThis species bears a very close resemblance to the preceding kind, except in the colour of the flowers, and in the legume being smooth instead of hairy. It is a native of the country near Montpelier, and was introduced in 1759. We do not know where seeds are to be purchased in London, but we suppose they might easily be procured from Paris, through M. Vilmorin, or any other French nurseryman.

\section{OTHER SPECIES OF LOTUS.}

These are very numerous; but not sufficiently distinct to be recognised by any descriptions we could give of them, except by botanists. One of them, $L$. orrithopodioides, has nearly round legumes disposed so as to resemble a bird's foot, and as this was one of the first species described by botanists, the English name for the genus, Bird's-foot Trefoil, was taken from it. Most of the kinds have golden-yellow flowers, but there are some exceptions, and amongst others the following.

\section{GEBELIA, Vent.}

This plant is a native of Mount Gebel-cher, near Aleppo, and was introduced in 1816. It is decumbent, with large rose-coloured flowers; and though marked as a perennial in books, might very probably be grown as an annual; and it would produce a fine effect on rock-work. 


\section{LANUGINOSUS, Vent.}

Has rose-coloured flowers, and a prostrate stem.

L. GLABERRIMUS, Dec.; L. TRICHOCARPUS, Lag. ; and L. COIMBRICENSIS, Brot.

Have white flowers, with the keel more or less purple, and prostrate stems.

L. ODORATUS, Sims.; Bot. Mag. t. 1233.

The flowers are yellow, striped with red, and the plant is sweet-scented. It is a native of Barbary, introduced in 1804 .

\section{GENUS IV. \\ ASTRAGALUS, Lin. THE MILK-VETCH. \\ Lin. Syst. DIADELPHIA DECANDRIA. \\ Geniric Charueter.-Calyx 5-toothed. Keel obtuso.-(G. Don.) \\ 1.-ASTRAGALUS SINICUS, Lin. THE ROSE-COLOURED MILK-VETCH.}

SYnonyme. $-A$. lotoides, Lam.

Engravines.-Bot. Mag. t. 1350; and our fig. 11, in Plato 23.

Specric Charseter.-Plant progtrate, glabrous. Stipules not

known. Leaves with about four or five pairs of obovate, nearly obeor-

date leaflets. Flowers four or five in an umbel. Pedinneles length of leaves. Legumes prismatic, triquetrous, ereet, subulate at the apex, (G. Don.)

Description, \&c.-A very pretty little plant with rose-coloured flowers, well adapted for rock-work. It resembles a Coronilla more than any plant of the genus to which it is considered to belong, as its flowers are produced in an umbel. It is a native of China, and was introduced in 1763. Seeds may bo had at Carter's, Holborn, of three annual kinds of Astragalus, but the specific names are not given in his seed catalogue. It is, however, probable the above species is one of the three, as it is the kind most generally cultivated.

\section{OTHER KINDS OF ASTRAGALUS.}

A. VERRUCOSUS, Moris.

This species is a decumbent plant, with dark purple flowers and warted pods. A native of Sardinia, not introduced.

\section{A. Pentaglotris, Lin. syn. A. Procumbens, Mill.}

A native of Spain and Barbary, on hills, with bright blue and white flowers, and the pods round, and finger or tongue-shaped, in bunches of five together.

\section{A. CRUCIATUS, Link., syu. A. STELla, Bieb.}

Flowers violet-coloured, and the pods disposed in the shape of a cross or star; a procumbent plant fonnd wild both in Egypt and Siberia, and introduced in 1820. There is another plant, called A. stella, Gouan, which is a native of the south of France and north of Africa, and has bluish-purple flowers. This last kind was introduced in 1658. 


\section{A. ANNULARIS, Forsk.}

A spreading procumbent plant, with whitish green leaves, and rose-coloured flowers. A native of Egypt. Introduced in $\mathbf{1 8 0 0 .}$

\section{A. Canaliculatus, willd.}

A native of the south of Europe, with white flowers. Introduced in 1816.

\section{A. Reticulatus, Bieb.}

A very small plant, with curious hooked, netted legumes, and bright blue flowers. A native of Middle Iberia. Introduced in 1828 .

\section{A. HAMOSUS, Lin.}

Flowers pale yellow, and plant prostrate. Seeds of this species are frequently sold under the name of caterpillars in the seed-shops, in allusion to the curious shape of the pods. This species is a native of the South of Europe, and was introduced about 1640.

There are many other species with pale-yellow flowers, all of which have been introduced; and the seeds of one of which are used in Hungary, after having been roasted and ground, as a substitute for coffee.

\section{$\Longrightarrow$ \\ GENUS $\nabla$. \\ CORONILLA, Lin. THE CORONILLA, OR SCORPION-SENNA.}

\section{Lin. Syst. DIADELPHIA DECANDRIA.}

Generuc Chunuctero-Calyx 5-toothed, two upper teeth approximate. Petals unguiculate. Keel acute.

Description, \&c.-The shrubs belonging to this order are well known, but the annual plants are very seldom seen in cultivation. The name of coronilla is from corona, a crown, in allusion to the disposition of the flowers in heads or umbels.

\section{1.-CORONILLA CRETICA, Lin. THE CRETAN CORONILLA.}

Synonymes.-C. parviflora, Manch.; Astrolobium creticum, Des. | acute ; leaflets 11-13, cuncated, setuse, the lower ones remote from Specric Canacrer.-Plant ascending, glabrous; stipules small, the stem; umbels 3-6 flowered.-(G. Don.)

Description, \&c.-A very pretty plant, with white flowers, the standard being streaked with red, and the keel dark purple. A native of Candia, Tauria, and Italy, on hills, introduced in 1731. This plant was formerly very common in flower-gardens, but it appears to have gradually gone out of cultivation, and we do not know where seeds are now to be procured.

\section{2.-CORONILLA SECURIDACA, Lin. THE HATCHET-VETCH.}

Snsosymas.-Securigera Coronilla, Dec.; Securidaca lutea, Mill.; | with rather prominent sntures, the seeds aeparated by spongy substance, 8. legitima, Gartn. not articulated, linear, ending in a long beak at the apex. Seeda Specific Craracter.-Plant prostrate. Legume compressed, flat, $8-10$, compressed. Flowers yellow, 3 or 4 in an umbel.

Though the name of this plant is found in every seedsman's catalogue, it is scarcely worth growing, from its coarse and spreading habit of growth. It is a prostrate plant, with coarse strong stems from a foot to two fect long, and divided into many branches. The leaves are pinnate, and are composed of seven or eight pairs of 
rather large deep green leaflets. The flowers are of a bright yellow, and are produced in a large cluster at the extremity of each peduncle. The pods are nearly four inches long, and are somewhat sword-shaped and furrowed. This plant is a native of Spain, and as it is mentioned by Gerard, it must have been introduced before 1596. Linnæus observes of this plant, that it sleeps with the leaflets bent back towards the base of the petiole, and not pointing forwards. The seeds slould be sown where the plants are to remain, as they do not bear transplanting; and when the plants come up, they should be thinned out so as to leave them at least a foot and a half or two feet apart, to allow room for tho widely-spreading branches.

$\overline{=}$

GENUS VI.

VICIA, Lin. THE VETCH.

Lin. Syst. DIADELPHIA DECANDRIA.

Genrajc Charactra.-Calyx tubular, 5-clefi, or 5-toothed, 2 superior teeth shortest. Stylo villous at the apex. Legume many-seeded. Usually climbing herbs, with the leaves generally ending in a bracched tendril. Flowers white, purple, or yellow.-(G. Don.)

\section{1.-VICIA ATROPURPUREA, Desf. THE DARK PURPLE VETCH.}

SynoNy ME? V. Nissoliana, Lin.

Exgnavings.-Bot. Reg. t. 871 ; and our fig. 8, in Plate 23.

base. Peduncles maoy-flowered, hardly the letigth of the lcaves. Specific Curacter. - Plant villous. Stems tetragonal. Tendrils thsn the tube. Style elongated, somewhat clayate, bearded at the very trifid. Leaflets oblong, mucronatc, numerous, opposite, and apex. Legumes oblong, compressed, very hairy. Seeds globose, black, alternate. Stipulcs lanceolate, semi-sagittate, usually toothed at the | rather velvety.-(G. Don.)

Description, \&c.-A very showy species, with dark purple flowers, a native of Algiers, where it was found by Desfontaines. It was introduced in 1815, from seeds sent from the Botanic Garden, Gottingen, by the late M. Fischer, to the London Hort. Soc.; but we do not know where seeds are now to be procured.

\section{2.-VICIA ONOBRYCHIOIDES, $L i n$. THE SAINTFOIN-LIKE VETCH.}

Engravings.-Bot. Mag. t. 2206 ; and our fig. 7, in Plate 23.

Spectric Character. - Stems striated. Tendrils almost simple. Leaflets numerous, linear, alternate or opposite, obtuse, and mucronate, with parallel nerves. Stipules linear, semi-sagittate, dentato. Pedun-

cles very long, many-flowered. Flowers distant. Calycine teeth lanceolate, length of the tube. Style clavate, bearded at the apex. Legumes lanceolate.-(G. Don.)

Description, \&c.-A handsome species, bearing some resemblance to the common tufted vetcl of the hedges, Vicia Cracca. It has commonly fourteen leaflets; the peduncles are three times as long as the leaves, and the flowers, of which there are ten or twelve on each pedunele, are three times as large as those of $V$. Cracca, and all disposed one way. The pod is compressed, lanceolate, and narrowed at both ends. It is a native of France and Switzerland, and it has also been found on Mount Atlas. It was introduced in 1759. The seeds are said to do best when sown in autumn; and when sown in spring they should be lightly covered, and well watered; they are, however, frequently several months before they vegetate. They should always be sown wherethe plants are destined to remain, as they do not bear transplanting well. They do best in a shrubbery, where their roots are sheltered from the sun, and where they hare a support to climb up. Only three or four seeds should be sown in cach patch; and where the plants have no natural supports near them, they should be carefully trained to 
stakes, as, if suffered to trail on the ground, they will produce very few flowers, and in wet seasons the stalks will rot. They look exceedingly well if suffered to elimb through the boughs of a thick bush, or low tree, so that their flowers may be relieved by a mass of leaves. The name of this Veteh is not in the seedsmeu's catalogues, but seeds might easily be obtained through M. Vilmorin, from Paris.

\section{OTIIER SPECIES OF VICIA.}

These are very numerous; but it does not appear to us that any of them require very particular description. The flowers and leaves all bear a great resemblance to each other, and the prineipal differences consist in the colours of the flowers, which vary from white, blue, and pinkish, to dark purple.

\section{GENUS VII.}

\section{LATHYRUS, Lin. THE LATHYRUS, OR ORNAMENTAL PEA.}

\section{Lin. Syst. DIADELPHIA DECANDRIA.}

Generic Cranacter.-Calyx campannlate, 5-eleft, 2 superior lohes shortest. Style flattened, dilsted at the apex, villous or pubescent in front. Legume many-seeded. Usually climbing tendrilled herhs, with purple, white, or yellow flowers.-(G. Don.)

Description, \&c.--The sweet pea and the other ornamental kinds of Lathyrus are so well known, and such universal favourites, that it is sufficient to mention their names, to eall up clear ideas of them to evcry mind. If well trained, they are very ornamental; but few plants have a more disorderly and untidy effect if they are neglected. They are thus well suited for the culture of a lady, as they require continual watering, tying up, and cutting off of dead flowers or bruised branches.

\section{I.-LATHYRUS OdORATUS, Lin. THE SWEET PEA.}

Engrafings.-Bot. Mag. t. 60; snd our fig. 1, in Plate 23.

VAnietres.-There are six distinct kinds of sweet pea in constant oultivation, all of which, with very fow exceptions, come true from seed. These are the purple, which has the standard of \& deep rich reddish purple, the wings pinkish, and the keel nearly white, and is a native of Sicily; the new Painted Lady, which has the standard deep rosecolour, the wings pale rose, snd the keel pure white, and is a native of Ceylon; the white sweet pea, which has the flowers a pure white; the Old Painted Lady, which has the winga and kecl white, and the

standard flesh-coloured; the blue, which has the wings and keel s palo hlue, and the standard dark bluish purple; snd the violet, which has the kecl a pale violet, the wings $\mathrm{s}$ deep violet, snd the standard a dark reddish purple.

Specific Cuaracter.-Plant hairy. Stems winged. Leaflets ovate, mncronulate. Stipules semi-sagittate, lanceolate, much shorter than the petioles. Peduncles 2-3-flowered, 'much longer than the leaves. Calycine teeth hroad, longer than the tube. Legumes oblong-linear, compressed, hairy. Seeds roundish.-(G. Don.)

Description, \&c.-The sweet pea is the plant that is said to have given to Linnæus the idea of calling all similarly shaped flowers, papilionaceous, from the great resemblance of its flower to a butterfly on the wing. However this may be, it is certain that this flower shows distinctly the wonderful manner in which every part of it has been contrived to fulfil the end in view. The formation of the pod requires that the whole of the pollen should be preserved, as unless there be a sufficient quantity to pass through the stigma down the tube to which the peas are affixed, so as to fertilise each, the seed would be imperfect. To preserve the pollen uninjured and undiminished, the anthers are enclosed in the keel; and the necessary openings for air in this are protceted by the wings; while the standard acts as a sail to keep the flower with its back to the wind, and thus a whole 



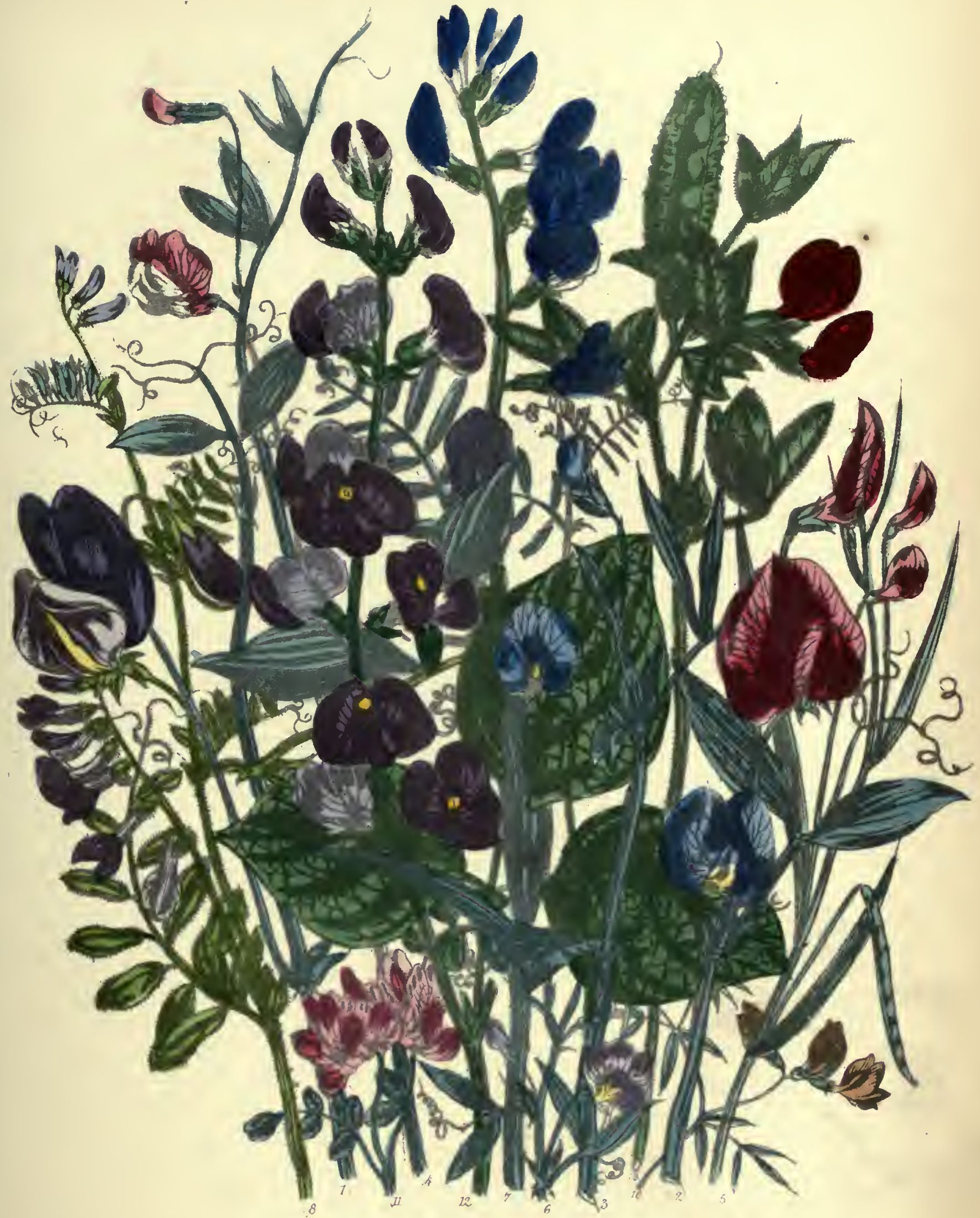



row of swoet peas may be seen occasionally with their blossoms turning and quivering in the breeze, till they look really like a flock of butterflies seeking for spots to deposit their eggs. "It is rather singular that these flowers, though the commonest kind is a native of Sicily, should never have been introduced till the beginning of the past century; the first sweet pea that was seen in England having blossomed in Dr. Uvedale's garden at Enfield, in the year i701, as we are told by Dr. Plukenet, who went to see it there. A few years afterwards (1713) we find it included in the list of ornamental flowers in the Botanic Garden, Chelsea. We may easily conccive the delight and wonder the first appearance of this flower, and its extraordinary sweetness, must have occasioned, and how proud Dr. Uvedale must have been of possessing it.

Sweet peas in the grounds of a nnrsery are generally planted in rows; but in flower gardens they are either sown in a circle, with a stake, or slight wooden frame in the middle, for them to be trained to; or suffered, as Cowper so elegantly expresses it, to

$$
\begin{aligned}
& \text { With clasping tendrils, and invest its branch, } \\
& \text { Else unadorn d, with many a gay festoon } \\
& \text { And fragrant chaplet, recompensing wcll } \\
& \text { The strength they borrow with the grace they lend." }
\end{aligned}
$$

The speds may be sown at different seasons; if sown in antumn, and protected by a mat or other slight covering thrown over the ground in severe frost, they will flowor early; or they may be sown in the same mannor in February, in which case they are said to produce the fincst flowers. The usual time of sowing is, however, April. The soil slould be rich and light, as the roots, though weak and slender, penetrate deeply; and for the same reason the seeds should always be sown where the plants are to remain, as it is hardly possible to take up the long slender roots without injuring them. Thinning ont should also be avoided, as pulling up one plant, loosens the earth round the roots of the others; thus each patch or pot should contain only three or four seeds.

The florists who raise flowers for sale in the London markets, derive a considerable portion of their trade from forcing sweet peas, and the quantity thus grown in pots every year is almost incredible. The seeds for this purpose are sown in pots in autumn, and then kept in hotbed frames, but without any manure; all that is necessary being to protect them from the frost. They require to be frequently watered with warm water. and to be covered up very closely after each watering, to prevent the possibility of the ground freezing while in a moist state. They may thus be kept with very little light or air; but when the blossom-buds begin to form. the pots must be placed in the window of a living room, or in a small greenhouse to give them colour. As soon as this is effected, the sweet peas are sent to market, where they sell from a shilling to half-a-crown a pot, according to circumstances; even a shilling being sufficient to afford a very handsome profit to the grower.

\section{2.-LATHYRUS TINGITANUS, $\operatorname{Lin}$. THE TANGIER PEA.}

Engravises.-Bot. Msg.t. 100; and our fig. 2, in Plate 23.

Specrme Crarueter. - Plsnt quite smooth. Stems winged. Leaflets ovate, obtuse, mucroulate. Stipules ovate, semi-sagittate, much shorter than the petioles. Peduncles two-flowered, longer than the leaves. Calyeine teeth nearly equal, shorter than the tube. Legumea obloug-linear, much reticulated, compressed, tomentose, with the sutures thick. Seeda hardly angular, variegated with black and brown. - (G. Don.)

Description, \&c.-The flowers of the Tangier pea are very splendid in appearance, but they want the sweetness that distinguishes those of the preceding species. The standard of the flower of the Tangier pea is of 
a brilliant crimson, haring all the richness of velvet : while the wings and keel are of a bright rose-colour. This pea was introduced in 1680, by Dr. Morisen, whe received it from Tangiers, and it has remained in cultivation ever since. Seeds may be procured at any seed-shop, and the plants requiro the same care as those of the sweet pea.

\section{3.-LATHYRUS aRticulatUS, Lin. THE JOINTED OR WINGED PEA.}

Engravings.-Bet. Mag. t. 253 ; and our fig. 4, in Plate 23. Spurich equal in length to the leaves. Calycine teeth nearly equal, shorter leafless, linear, acuminated, upper ones bearing 5-6 linear leaflets. at the seeds, having the seminiferous suture tumid. Sceds comprcssed, Stipulcs lanceelate, scmi-sagittate. Peduncleg 1-3-flowered, about dark purple, rather velvety.-(G. Don.)

Description, \&c.-The flower consists of a bright red standard with white wings and keel. This pea is a native of the south of Eurepe, and when it was first introduced, it was called the Spanish pea, because its sceds were sent from Spain to the Botanic Garden, Chelsea, in 1739. It is of rather lower growth than the commun sweet pen, seldem rising above three feet high, but it nay be sown and treated in the same manner.

\section{4.-LATHYRUS AMPHICARPOS, Lin. THE UNDER-GROUND OR EARTH-PEA.}

Evgravings.-Swt. Brit. Flow. Gard. t. 236 ; and our fig. 6, in Plate 23.

Sprciric Craractrr.-Stems winged, diffuse. Leaflets lanceelate. Tendrils simple. Stipules semi-sagittate, l-toethed, longer than the

petioles. Poduncles 1-flowered, longer than the lenves. Cauline as well as subterraneous legumes ovate, 2-winged in front, and a little compressed on the sides, 2-seeded.-(G. Don.)

Description, \&c.-This plant is grown more for its singularity than its beanty. The flowers which appear above ground are pink tinged with blue; but the underground stems bear flowers and pods, which are quite perfect, and exactly similar to those above-ground, except that every part of the underground plant is whitish. The plant is much smaller than any of the other peas, and rarely grows above a foot high. Seeds may be had in any of the seed-shops, and they should be sown in February in very light soil, to allow the underground shoots to make their way. The plants when nearly full grown are generally earthed up.

\section{5.-LATHYRUS SATIVUS, Lin. THE CHICKLING VETCH.}

Evaravings.-Bot. Mag. t. 115; and our fig. 3, in Plate 23. Specreic Character. - Plant smoothish. Stems winged. Leaflets linear-ebleng. Tendrils trifid. Stipules semi-sagittate, ovate, ciliated, hardly the length of the petioles. Peduncles l-flowered, longer than

the petioles, bracteolate snd articulated at the apex. Calycine scg ments lanceolate, foliaceous, almost three times the length of the tube. Legumes ovate, broad, short, irregularly reticulated, winged on the back. Seeds trigonal, smooth, rather truncate.-(G. Don.)

Description, \&c.-The flowers are bright blue, with a faint stain of pink hetween the standard and the wings. The pods are winged with a deep groove down the back. The plant seldom grows above two feet high, and is much branched. There is a variety with white flowers. This species is a native of France and Spain, where it is grewn fer feeding horses, and hence its specific name of "sativus," which significs cultivated. The flour made from the peas when ground, if mixed with an equal quantity of wheat flour, makes excellent bread, but taken alone it produces an extraordinary rigidity of the muscles. In the year 1671 , a famine having occurred in Wirtemberg on account of the failure of the wheat creps, the pensants made their bread entirely of this flour. After living upon it for some days, sume of them began to find themselves strangely affected; one man when he bent his arn could not straighten it again; and a neighbour who laughed at him found that he could not bring his mouth back to its original form, hut that he was doomed to wear an eternal grin. The medical men applied 
to by the afflicted and terrified people were at a loss how to act, for warm baths, and all the usual remedies for the rigidity produced by cold, seemed to have no effect. In the end, though no one died, yet as it was found impossible to restore the rigid muscles to their natural aetion, the evil was thonght 'se serious, that the Duke of Wirtemberg issued an edict forbidding the use of this flour in any emergency; and similar edicts have been issued by some of his successors. It was remarkable that at the very time that this flour was producing such unpleasant effects, the green herb was eaten by cattle without injury. Pigs fed on tlie meal, however, lost the use of their limbs, though they grew very fat lying on the ground. It was observed that the meal from plants grown on a rich strong soil, was much more injurious than that made from plants grown on a poor dry soil.

This Lathyrus was introdueed into England in 1739, and was grown in the botanic garden at Chelsea ; it, however, appears to have been lost, and to have been re-introduced within the last few years. It is now grown by Mr. Groom, of Clapham, and other florists, and is well deserving of a place in the flower-garden from the contrast afforded by its beautiful light blue flowers to the colours of the other species. The seeds should be sown in February or March, as they are frequently a long time before they vegetate; or the seeds may be soaked in water some days before sowing, and only put into the ground when the aril begins to erack and peel off.

\section{6.-LATHYRUS APHACA, Lin. THE YELLOW VETCHLING.}

EngaAving.-Eng. Bot. 1167,2 d edit. vol. vi. t. 1000 .

Specific Cuaracten.- Stems erect; tendrils cylindrical, filiform, leafless (rarely with two leaflets); stipules ovate, sagittate, large; peduncles 1-flowered (rarely 2-flowered), articulated at the apex, furnished

with a pair of small, narrow bracteas; ealycine segments twice the length of the tuhe; legumes much compressed, broad, few-seeded; sceds compressed.-(G. Don.)

Description, \&c.-A small yellow-flowered Britislı plant, "remarkable for the total abortion of the leaves, except in very young plants," what appear to be leaves being in fact only the dilated stipules. This vetchling is chiefly met with in the eastern counties of England, between the Thames and the sea. The seeds are very unwholcsome, and cause a violent headaclie if eaten. This plant is not worth cultivating in gardens, except in combination with the following species, when it produces a very striking and novel effect.

\section{7.-LATHYRUS NISSOLIA, Lin. THE CRIMSON GRASS VETCH.}

Exgravings._Eng. Bot. t. 112, 2nd edit. vol. vi. t. 1001; and flowers solitary, on long peduncles; peduneles artieulated at the apex, our fig. 5, in Plate 23.

Sprcific Снанастеr.-Stem erect; petioles dilated, foliaceons, bracteas; legumes compressed, narrow, nerved, reflexed.-(G. Don.) grass-like, 3-5-nerved; stipules small, subulate, usually wanting;

Description, \&c.-This beautiful little plant has bright crimson flowers, variegated with purple and white, while the stem and leaves loek so much like those of a kind of grass, that the plant can scarcely be detected, even by an experienced botanist, unless when in flower. It is generally found in shady lanes, in woods, or on the grassy banks of a rivulet, where they are sladed by trees; and in these situations, in the months of May and June, it is sure to attract attention by the splendeur of its flowers, which in early morning when eovered with dew-dreps, sparkle in the sun-beams like little rubies. The botanical peculiarities of this plant are that the leaves are simple, and not terminated by tendrils, and they thus afford a remarkable contrast to those of $L$ : A phaca, the tendrils of which are very long, and the stipules commonly dilated. Seeds of 'L.Nissolia may be procured at any seed-shop, and they require the same treatment as these of the other kinds of Lathyrus. 


\section{8.-LATHYRUS HIRSUTUS, Lin. THE ROUGH-PODDED VETCHLING.}

Engruvings,-Bot. Mag. t. 1255, Eng. Bot. t. 1255, 2nd edit. petiole; peduncles usually 2-flowered, hardly longer than the leaves; sol. vi. t. 1002 .

Specizic Charucter.-Stems winged; leaflets linear-lanceolate, 3-nerved; stipules semi-sagittate, linear, about equal in length to the calyx hairy; segments ovate, acuminated, length of the tube; legames oblong, hairy; seeds globose, warted.-(G. Don.)

Description, \&c.-The flower consists of a bright crimson standard, pale blue wings, and a white keel. It is a native of the south of Europe; but it has been occasionally found in England, in Essex, and between Bath and Bristol. It is very ornamental, and the seeds, which may be had in any seed-shop, only require the same treatment as those of the other species.

\section{OTHER KINDS OF LATHYRUS.}

L. SPH ERICUS, Rets.; syn. L. COCCINEUS, All.; L. AXILlaRIS, Lam.; L. ANGULATUS, Stev.

The flowers are of a beautiful crimson, and about the size of those of L.Nissolia; and the plant, which is a native of the south of Europe, was introduced in 1801.

\section{CICERA, Lin. THE DWARF CHICKLING VETCH.}

This plant is a native of Spain, and was introduced in 1633. It has purple and red flowers, and flat pods.

\section{ANNUUS, Lin.}

This species has winged stems, and yellow flowers. It is a native of Spain, and was introduced in 1621.

L. TURGIDUS, Lam.

A native of the south of France and the Levant. The flowers have a dark purple standard, and white wings and keel. It was introduced in 1817.

L. CILIATUS, Guss.

A native of the Calabrian hills. The flowers are greenish, strongly marked with purple veins.

L. ALATUS, Tenore.

A native of Italy, with winged stems, and very large purple flowers; introduced in 1823.

\section{OTHER SPECIES OF LEGUMINOS正.}

Several other ornamental annual plants belonging to this order might be enumerated; particularly the crown-bearing variety of the common pea (Pisum sativum), with its tufts of scarlet and white flowers, and several kinds of Melilotus, \&rc. Lord Anson's pea (Lathyrus Magellanicus) is included, by some seedsmen, in their lists of annuals; but it is a greenhouse evergreen shrub, which, so far from being an annnal, rarely ripens seeds in England. The seeds sold under the name of Lord Anson's pea, are generally those of the Tangier Pea, which we have already described. (See p. 131.) 
GENUS VIII.

\section{LABLAB, Adans. THE LABLAB.}

Lin. Syst. DIADELPHIA DECANDRIA.

Generic Charactrr.-Calyx tubnlar, 4-cleft, 3 lower divisiens | separated by a cellnlar substance. Twining herbe, with trifoliate acte. Vexillum with four callosities at the base. Stamens diadel- $\mid$ leaves, and white or purple flewers.-(G. Don.)

phous. Style compressed, bearded belew. Legume compressed. Seeds

\section{LABLAB VUlgaris, Savi. THE BLACK-SEEDED DOLICHOS, OR EGYPTIAN BEAN.}

Eneruvings._Bot. Mrg. t. 896, Bot. Reg. t. 830; Swt. Brit. | Speciric Chцnactrr.-Legumes obleng, ventricose, acinaciform; Flow. Gard. 2nd Ser. t. 236 ; and our fig. 12, in Plate 23.

Syмesymzs.-Doliches Lablab, Lin.; Lablavia vulgaris, D. Don. $\quad$ basilar, hemispherical, furrowed.-(G. Don.)

Description, \&c.-This splendid plant, though frequently marked in books as a stove perennial, succeeds perfectly well if treated as a hardy annual. The pods are dark purple, as well as the flowers, and the seeds are black. There is a variety with white flowers. A native of Egypt, and alse of China; and cultivated in the West Indies for its pods, which are boiled and eaten, as we eat kidney-beans. It was introduced in 1714, by the Duchess of Beaufort. The seeds may now be procured at any seed-shop, generally under the name of Dolichos Lablab. They should be raised on a hotbed, in pets, three seeds being sown in each pet, and planted out in May; care being taken to turn the earth out of the pot into a bole prepared for it without breaking the ball. The word Lablab signifies, in Arabic, a twining plant.

\section{CHAPTER XXIII.}

\section{BALSAMINACE 2 .}

Eserntul Cham cter. - Seppals 2, small, deciduong, opposite. Petals | bcaring 2-celled anthers, and the 2 upper ones 1-celied anthers. Style 4, cruciate; upper one arched and cmarginate; the lower one entire pone. Stignas 5. Capsules 5-valved; valves separating with esasand drawn eut into a spur. Stamens 5, hypegyneus; the 3 lower enes ticity. Placenta central. Albumen none.-(G. Don.)

Descriptrox, \&c.-The plants belonging to this order are all annuals with succulent stems and showy flowers. They are comprised in three genera, viz:-Balsamina, the commen balsam, the flowers of which are borne singly, each on a separate stalk; Tytonia, the species of which are aquatic stove plants, with the flowers semetimes produced three on one stalk, and sometimes each on a separate stalk; and Impatiens, the Nolime-tangere of the gardens, the flower-stalks of which are branched, and many-flowered. This order, according to botanical arrangement, should precede Tropocolacee, to which it is very closely allied.

\section{GENUS I.}

\section{BALSAMINA, Riv. THE BALSAM.}

Lin. Syst. PENTANDRIA MONOGYNIA.

Genkro Cunucran_-Anthers 5, 2-celled. Stigmas 5, distinct. Valves ef capsulo bending inwards elastically at the apex. Peduncies 1.flowered.-(G. Don.)

Description, \&c.-A genus of showy-flowered plants, with succulent stems, mostly natives of the East 
Indies; which have long been great favourites in our greenlsouses, and which we shall mention here, as they will also grow in the open air.

\section{1.-BALSAMINA HORTENSIS, Desp. THE COMMON OR GARDEN BALSAM.}

SrNonyme. - Impatiens Balsarnina, Lin.

Specific Cunacter.-Pedicels aggregate; leavea lanceolate, serrated, lower ones opposite; spur shortcr than the flower.-(G. Don.)

Description, \&c.-The common Balsam is so well known that it needs very little description; and its varieties are so numerous and so uncertain as to defy enumeration. The colours of these varieties are, white, rose-coloured, red, and purple; and these colours are occasionally mixed in stripes, spots, and other variegations. The varieties are also single, semi-double, and double. The species is a native of the East Indies, China, and Japan, and it was introduced before 1596, as it is mentioned by Gerard. The plants are generally kept in pots in greenhouses, but they will grow luxuriantly if planted out in a warm border in the open air. The seeds, which may be procured in any seed-shop, should be sown on a moderate hotbed in February or March ; and as soon as the plants are two or three inches ligh, they should be carefully transplanted into small pots, taking care to shade them for some time after transplanting. The pots should be plunged in the hotbed, but they should be allowed plenty of air, in the middle of the day when the weather is favourable. In about a fortnight or less, they should be removed into rather larger pots, without breaking the ball of earth round the roots; and afterwards as they grow, they should he transplanted into larger and larger pots, taking care that each pot is well drained by broken potsherds being put in the bottom, and that the plants are supplied with abundance of water. If the roots are kept warm, by the pots being plunged in the hotbed, and are supplied with abundance of water, which is prevented from stagnating round them by tlie pots being well drained, while the plants themselves are supplied with abundance of air, when the weather will permit, the growth of the plants will be luxuriant, and the flowers astonishingly fine. As soon as the flower-buds are formed, the plants should be placed in the greenlouse; or planted out, without breaking the ball of earth, in a warm border in the open ground. In the latter case, the plants should be shaded for a day or two after planting, and supplied abundantly with water. The seeds may be sown in a warm rich border in the open air; but in this case the plants do not flower till very late in the antumn, and the flowers are very seldom fine.

\section{2.-BALSAMINA COCCINEA, Dec. THE SCARLET BALSAM.}

Srmonyme.-Impatiens coccinea, Sims.

Engruvina.-Bot. Mag. t. I2j6.

Spscific Chanacter. - Pedicols aggregate. Leaves oblong-oval, serratcd. Spur incurrcd, about cqual in lengtb to the flower.-(G. Don.)

Description, \&c.-A splendid plant, with bright scarlet flowers remarkable for the great length of their spurs. The flowers are large, and are produced in great abundance ; they are sometimes streaked with white, but this is rather a variation than a permanent variety. The plant is a native of the East Indies, and was introduced in 1808, but we do not know where seeds are now to be procured. B. cornuta, thę Horned Balsan, a native of Ceylon, and Cochin-China, introduced in 1826 , closely resembles $B$. coccinea in the shape of its flowers, but their colours are dark purple or puro white. The leaves of $B$. cornuta are of a dusky green and sweet-scented, and a decoction of them is said to be used in Cochin-China as a wash for the hair. 


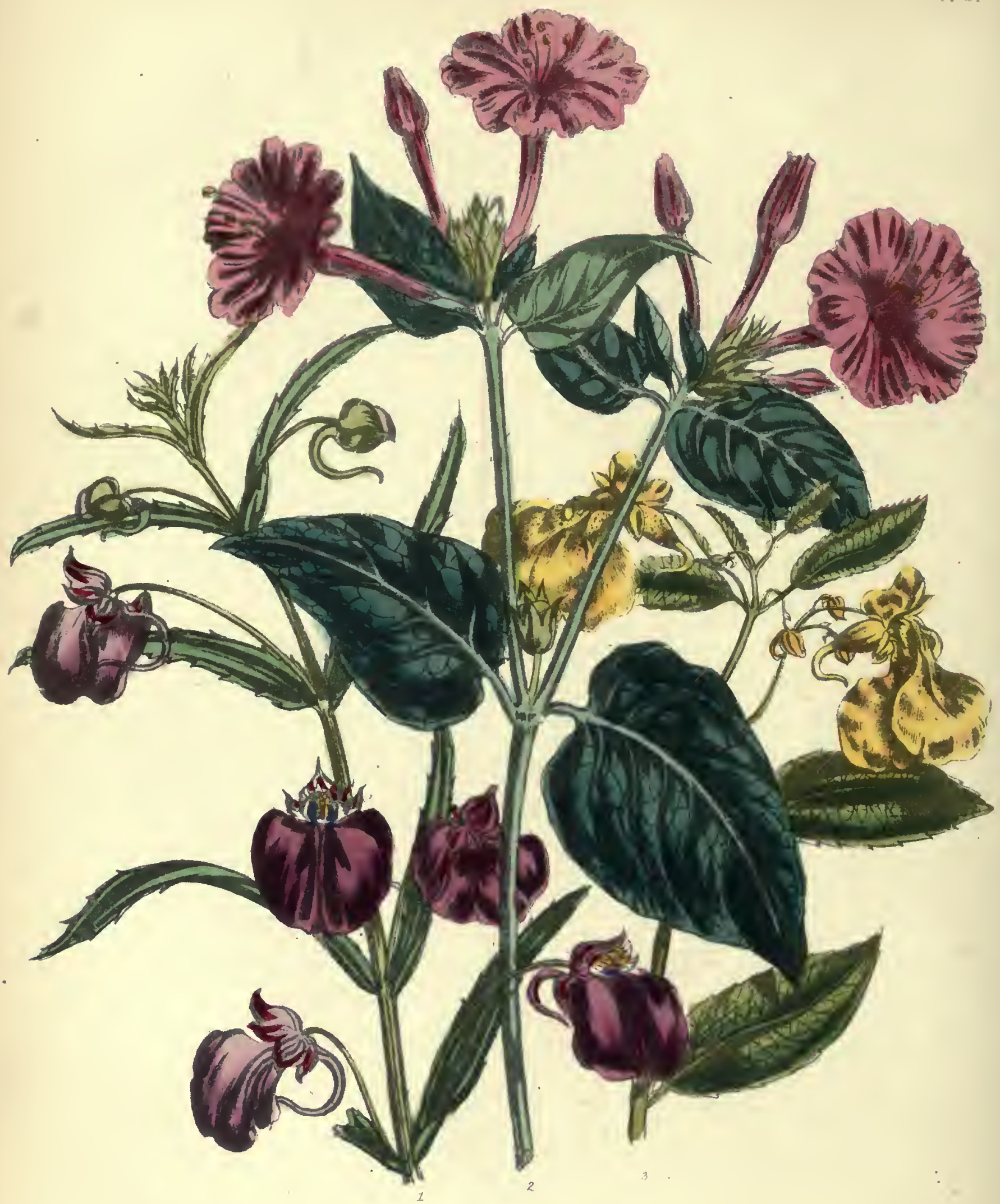

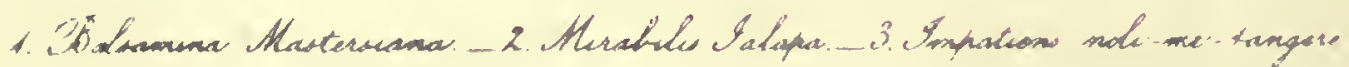





\section{3.-BALSAMina MASTersiana, Paxt. THE NEPAL BALSAM.}

Engravings.-Paxt. Mag. of Bet. vel. vi. p. 75 ; and our fig. 1, in Plate 24.

Speciptc Character. - Leaves opposite, linear-lanceolate, with remote, poioted serratures. Flowers large, of a purplish red, axillary, solitary. Spur curved, nearly the length of the flowur.-(Paxt.)

Descriptron, \&c.-This plant is evidently very nearly allied to $B$. coccinea and $B$. cornuta, and may probably be the same as the last-mentioned species, or a very slight variety of it. It was found by Mr. Gibson, collector to the Duke of Devonshire, growing on the Khoseea Hills, and seeds of it were sent by him to Chatsworth, in the autumn of 1837. The plant was named in honour of Mr. Masters, head gardener at the Botanic Garden, Calcutta. We do not know where seeds are to be procured; but as the plants raised at Chatsworth flowered abundantly during the whole sunımer of 1838 , and ripened abundance of seed, we liave no donbt seeds of this species have becn long plentiful in the seed-shops. The plant is perhaps rather hardier than the common garden balsam, and the culture is exactly the saine. "A light rich soil," says Mr. Paxton, "frequent shifting, a generous supply of water, due exposure to light, and a slight moist bottom heat, are the chief requisites previously to the appearance of the flowers." Mr. Paxton also recommends placing the plants, when removed from the hotbed, into a inoderately warm house, before putting them into the cool house, or open ground, where they are to flower. "The advantage of this transference will be apparent in the larger size, deeper colour, and greater duration of the blossoms. The art in cultivating balsams to perfection," Mr. Paxton continues, "is to keep them continually growing after the seeds have germinated." This is done by warmth and moisture; and this is the reason that balsams sown in the open air, for want of sufficient warmtl and moisture to their roots, seldom, if ever, attain the same beauty as those raised in a hotbed.

\section{GENUS II.}

\section{IMPATIENS, Riv. THE TOUCH-ME-NOT.}

\section{Lin. Syst. PENTANDRIA MONOGYNIA.}

Generic Charactrr.-Anthers 5, three of which are 2-celled, and two in front of the upper petal 1-celled. Stigmas 5, joined. Valves of capsule revolute, inwardly from the base to the apex. Peduneles axillary, branehed, many-flowered-(G. Don.)

Description, \&c.-All the plants belonging to this genus are remarkable for the elasticity of the valves of the capsules, which when touched throw out the seeds with great force. This quality is possessed in a greater or less degree by all the plants belonging to the order; and also by the plants belonging to the order Geraniacere, to which Balsaminaceos is very nearly allied, but it is more perceptible in Impatiens than in any other genus. The scientific name of Impatiens, and the popular names of Noli-me-tangere, or Touch-me-not, and Jumping Betty, allude to this property.

\section{1.-IMPATIENS NOLI-ME-TANGERE, Iin. THE COMMON NOLI-ME-TANGERE, OR TOUCH-ME-NOT.}

Eneravines,-Eng. Bot, t. 937, 2nd edit. vel. ii. t. 327; and our | leares, and spreading under them; flowers pendulous; spur recurved fig. 3, in Plate 24.

Spectic Charactra. - Peduneles 3-4-flowered, shorter than the (G. Don.)

Descriptiox, \&c.-The Noli-me-tangere is a well-known plant, so strikingly resembling the balsams in its stems and leaves, that it was formerly called the yellow balsam. The stem, which grows about two fcet high, is 
very succulent, and is thickened at the joints like that of the balsam; the flower is large and rather handsome, but the most remarkable part of the plant is the capsule. "This," says Sir J. E. Smith, "consists of a central angular column, surrounded by five elastic valves, so weakly attached at the base when ripe, that they spring from it at the slightest touch, at the same time curling up and scattering the few seeds they previously enclosed. The seeds so scattered will romain in the ground and certainly grow next spring, but if collected and allowed to dry before they are sown they fail to vegetate."-(Eng. Bot. 2nd edit. vol. ii. p. 57.) The elasticity of the valves of the capsule is so great, that even though prepared to expect it, few persons who touch the capsule for the first time can lielp starting. "The root is formed of brancbed and fleshy fibres," and these fibres are frequently seen above ground descending even from the first joint of the stem when the plant is kept moist. It is a native of most parts of Europe, and it is found wild in England in Westmoreland, \&c., and in Wales : in short, wherever there are moist rich valleys among mountains. It is said to be poisonous to most animals except goats, who eat it freely. In gardens it is rarely cultivated, partly on account of the difficulty of keeping the seeds sufficiently moist to regetate, and partly from its coarse and woedy habit of growth.

\section{OTHER SPECIES OF IMPATIENS.}

These have all been introduced, and are occasionally to be found in gardens, though liable to the same objections against their constant culture as the common Touch-mo-not. They have also all the fault of soon withering when gathered, so as to be quite unfit for bouquets. The culture of all is alike; the seeds merely require scattering on the ground, but the plants must be supplied with abundance of water, or they will soon wither.

\section{TRIFLORA, Willd.}

This species, which is a native of Ceylon, introduced in 1818 , has large pale red flowers, which it produces early in June.

1. FULVA, Nutt., Eng. Bot. 2nd edit. Suppt. t. 327*, syn. I. BIFLORA, Swt. Brit. Flow. Gard. t. 43.

The handsomest species of the genus, having dark yellow flowers with red spots inside. It is a native of North America, where it grows near springs and rivulets, in shady situations, and whence it was introduced in 1818, but it has lately been found wild on the banks of the river Wey in Surrey. It is generally considered to bear a great resemblance to the common Noli-me-tangere, and is often confounded with it. When, however, we saw the two species growing together in the grounds of W. Borrer, Esq., at Henfield, Sussex, in the autumn of 1838 , we were struck with the difference between them. Seeds of $I$. fulva may be purchased at Clarlwood's, and in othor seed-shops, under the name of I. biflora; but though they keep longer than those of $I$. Noli-metangere, they soon lose the power of vegetating.

\section{PALLIDA, Nutt.}

A.native of North America, introduced in 1817, with pale yellow flowers and bluisl-green leaves.

\section{PARVIFLORA, Dec.}

This is the species vulgarly called Jumping Betty; the flowers are very small and of a pale dingy yellow, but the capsules are large and spring asunder with great force when touched. It is quite hardy, and is found wild in Russia and also in North America. Seeds may be had at Charlwood's. 
I. TRIPETALA, Roxb.

A very slowy species with scarlet flowers having a deep yellow nectary. It is a native of the East Indies on the mountains of Silhet, and was introduced in 1825 .

\title{
I. CRISTATA, Wall.
}

The flewers are yellow, with very small purple dots, and the stem purple. The plant is a native of Chinese Tartary, and was introduced in 1827.

\section{CALYCINA, Wall.}

A native of Nepal. The flowers, which are very large, are yellow, and netted with purplo veins.

There are several other kinds natives of Nepal, with purple, yellow, or rose-coloured flowers, and one kind which is fragrant, and most of these have been introduced.

\section{$\longrightarrow$ \\ CHAPTER XXIV. \\ NYCTAGINACEE.}

Essmatua Canacter.-Perianth tubular, somewhat coloured, cootracted in the middle; its limb eutire or toothed, plaited in wstivation; becoming indurated at the base. Stameas defialte, hypogynous. Aathers 2-celled. Ovary superior, with a siagle erect ovule. Style 1. Stigma 1. Fruit, a thin utricle, eaclosed witlin the enlarged persistent base of the calyx. Sced without its proper integuments, its

\begin{abstract}
testa being coherent with the utricle; embryo with foliaceous cotyledous, wrapping round flowery albumen. Radicle inferior. Plumula inconspicurous. Leaves opposite, and almost always unequal; sometinues alternate. Flowers axillary or terminal, clustcred or solitary, baving an iovolucre which is either common or proper, in one piece or in several pieces, sometimes minute._Lindl.
\end{abstract}

\section{GENUS I.}

\section{MIRABILIS, Lin. THE MARVEL OF PERU.}

\author{
Lin. Syst. PENTANDRIA MONOGYNIA.
}

Grineric Canracter._Calyx infcrior. Corolla funeel-formed, superior. Ncctary globular, enclosing the germ.-( Lin.)

\section{1.-MiRABILIS JALAPA, Lin. THE COMMON MARVEL OF PERU.}

Engravings.-Bot. Mag. t. 371 ; and our fig. 2, in Plate 24.

Specific Character.-Flowers clustercd together, truncate, erect.- (Lin.)

Descriptron, \&c.-The Marvel of Peru, though generally treated as an annual, is in fact a tuberous-rooted perennial, the reots of which may be taken up in winter, like these of the Dahlia or the common potato, and planted out again in spring. It ripens seeds, howevcr, so abundantly, that few persons think it worth while to preserve the roots, particularly as the seedlings always flower the first year, and the flowers produccd by them differ very little from those preduced by the tubers, either in size or colour. The high-sounding name of the Marvel of Peru, seems very $\mathrm{ill}$ applied to this plant, as there is nothing very remarkable abent it. The plant, however, having been intreduced very scon after the discovery of Peru, when everything belonging to the new world was thought strange and wonderful, and being found to bear flowers of several different shades of colour at the same time, it received this name, and Gcrard tells us that it was also called the wonder of the world. The flowers, says this quaint writer, "rcmain open the whole day, and are clesed only at night, and se perish, one flower lasting but only one day, like the true Ephemerum or Hemerocallis. This marvellous variety doth not 
without cause bring admiration to all that observe it; for if the flowers be gathered and reserved in several papers, and compared with those flowers that will spring and flonrish the next day, you shall easily perceive that one is not like another in colour, though you shall compare one hundred which flower one day, and another which flower the next day, and so on during the whole time of their flowering." A much better description of this plant is given by Parkinson, who observes that the flowers are sometimes red and yellow on one plant, and sometimes purplisl, the colours being occasionally mixed and blended together. He also montions that there are numcrous varictics, some white, some yollow, and some purple, while the specics is gencrally a deep rose, as slown in our plate. Gerard is mistaken in asserting that the flowers always close at night; on the contrary, as Parkinson observes, the flowers frequently do not open till evening, and indecd in the West Indies, where the plant is common, it is called the four-o'clock plant, from its gencrally opening about that hour in the aftcrnoon. The fact is that the flowers will not bear intense lieat, and though under our cloudy skies they will generally remain open all day, they shrink from the powerful rays of the sun. The plant is a native of both the East and Wost Indies. It is not known when it was introduced, but it must have been early, as Gerard, writing in 1596, speaks of having had it for several years in cultivation in his garden. Linnæus changed Gerard's name of Miralilis Peruviana for this plant, to M. Jalapa, because finding that the tubers possessed a purgative property, he thought they were used in preparing the drug called jalap.

Seeds may be procured in any seed-shop; and if sown on a hotbod in March, the plants nay be turned into the open air in May or June, and will flower in July. If the seeds are sown in the open air in April, the plants will succeed equally well, but they will not flower bofore the latter end of August or Scptember. We may here repeat what we have before suggested for the conveniencc of those who have no regular gardener, and consequently do not wish the trouble of a hotbed, that all annual plants raised on one may be purcliased from the nurserymen. Our neighbour, Mr. Hopgood, of the Bayswater nursery, sells plants thus raised, ready for planting out into the open border, at from twopence to fourpence a dozen, according to their size and rarity; and we have no donbt that this is about the usual pricc. Thus at a very trifling expense, and with very little trouble, a garden may be supplied in April or May with the choicest flowers (varying in kinds, according to the taste of the purchaser), which will continue to adorn it till they are destroyed by frost.

\section{OTHER KINIS OF MIIRABILIS.}

\section{DICHOTOMA, Lin.}

This species, which is not so hardy as the common kind, has smaller flowers, and they do not vary from their original purplish red. This is a native of Mexico and the West Indics. It was formerly supposed that the tubers of this plant produced the Jalap, the name of which is said to be derived from Xalapa, in Mexico; but linnæus, as we have before observed, thought that this drug was made from the tubers of the common Marvel of Peru, and later botanists have attributed it to a species of Convolvulus or Ipomœa.

\section{M. 'LONGIFLORA, Lin.}

This spccics has long-tubed white flowers, that are very swect-scented, and it is common in our gardens. The stalks are hairy and clammy, and they are so weak that they would fall to the ground if not supported. This species is a native of Mexico, and was introduced in 1759 . 


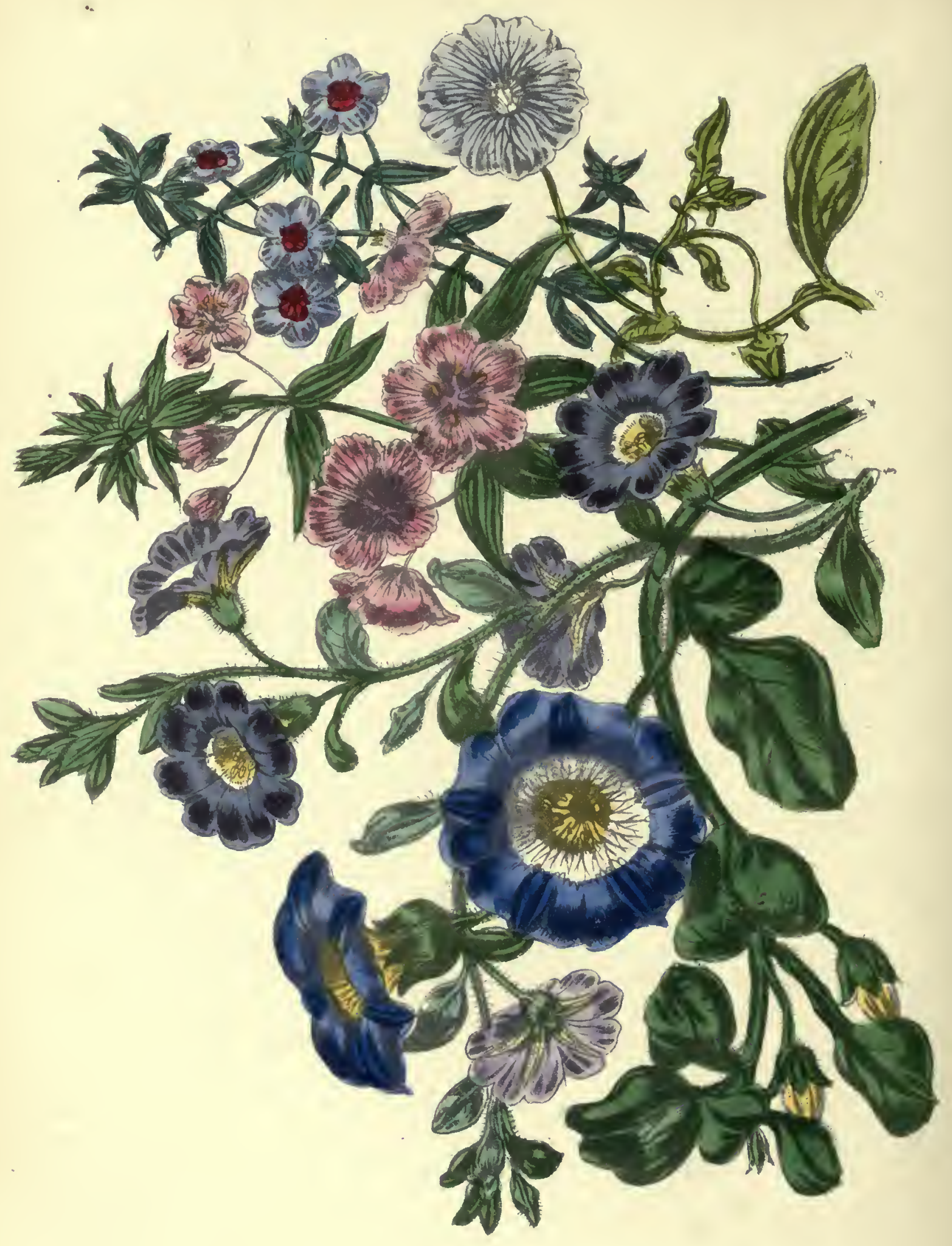



M. VISCOSA, Cav., syn. OXYBAPHUS VISCOSUs, Bot. Mag. t. 434.

This species, Curtis tells us, is an anuual, growing about two feet high. The whole plant is clammy, "and if bruised smells somewhat disagreeably. "The flowers do not open at any particular time like those" of the common Marvel of Peru, and each contains only three stamens. When the flowers fall, which they do very soou after expanding, "the calyx closes on the germen, enlarges, droops, and becomes deeply plaited; on the ripening of the seed it turns brown. expands, and is suspended like a little umbrella over the seed, wlich when perfectly ripe, drops out on the ground." This plant is a native of Peru, and it was first raised in England in 1796 from . seeds sent to the Marchioness of Bute, by Professor Ortega, of Madrid, who had obtained them from Peru.

\section{CHAPTER XXV.}

\section{PRIMULACE $A$.}

Essential Cnaracter.-Calyx 5-cleft, persistent. Corella regular, | contral. Seeds numerous, peltate. Albumen none.-Leaves usually monepetalous, 5-cleft. Stamens 5, epipetalous, opposite the segments of the corolla. Stigma capitate. Capsule valvate, l-celled. Placenta oppesite, rarely alternate, usually radical.-(G. Don.)

Descriptiox. \&c.-This order contains the primrose, cowslip, polyanthus, cyclamen, \&c., all well-known plants, but perennials. The genus Anagallis is indeed the only one belonging to the order which contains annuals, and even these might be called perennials, as most of them may, with care, be kept alive several years.

\section{GENUS I.}

\section{ANAGALLIS, Lin. THE PIMPERNEL.}

\section{Lin. Syst. PENTANDRIA MONOGYNIA.}

Geseric Сиnacter.-Calyx 5-parted. Corolla wheel-sbaped, 5-cleft, deciduous. Stamens 5. Filameuts bearded, distinct at the base. Capsule truncated.

Descriptron, \&c.-The genus Anagallis is remarkable for the beauty and elegance of its flowers. Even the common Pimpernel or Shepherd's Weather-glass (A. arvensis), is one of the prettiest of our common British weeds, and the Bog Pimpernel (A. tenella) is recommended for cultivation by Dr. Lindley, as a most delicate and elegant flower. (Seo Ladies'Botany, vol. ii. p. 161.) The flower of the Anagallis, though monopetalous, like all the Primulacer, is so deeply lobed that it seems to consist of five petals. The seed-vessel is also remarkable, as it resembles an egg-shaped box, opening in the middle, and the lid coming off like a little cap with a feather in it, and showing the seeds closely packed up in the remaining half of the box below. The stems of the Pimperuels are prostrate and angular; and the flowers, which are produced in great abundance, are generally very showy.

\section{1.-ANAGALLIS INDICA, Swt. THE INDIAN PIMPERNEL.}

Exeraving.-Swt. Brit. Flow. Gard. t. 132.

Specific.Craracter.-Stem ascending, branched, sligbtly winged. Leaves sessile, ovate-cordate, rougb at the margin, somewhat blunt, $\mid$ toothed.-(Sweet.)

Description, \&c.-A very pretty little plant having bright blue flowers, with a reddislı purple style, and golden yeliow anthers. The stem is nearly erect and angular; and the leaves, which are rather broad, 
are dotted on the under side. The plant is a native of Nepal, from which country its seeds were sent to England by Dr. Wallich, in 1824. It is very hardy, and if the seeds, which may be purchased in any seedshop, are sown in a light rich soil, in April or the first week in May, the plants will begin to flower in July, and will continue producing masses of bright blue flowers, and ripening abundance of seed, till killed by frest.

\section{2.-ANAGALLIS LATIFOLIA, Lin. THE BROAD-LEAVED PIMPERNEL.}

Eneravings.-Bot. Mag. t. 2389 ; and our fig. 2, in Plate 25.

Specric Craractra.-Leaves cordate, stem clasping. Stems compressed.-(Lin.)

Description, \&c.-A very pretty specics, a native of Spain; introduced in 1759 . It is as hardy as A. indica, and if sown in April will flower in July.

\section{3.-ANAGALLIS MONELLI, Lin. THE ITALIAN PIMPERNEL.}

Engrating. - Bot. Mag. t. 319 ; Bot. Gard. t. 399.

VARIETIFs.-A. M. 2. Willmoreana, Bot. Nlag. t. 3380. A very benutiful variety, with large dark purple flowere, which are pink on the under side of the petals. The stems ase long, and require support. It is a native of Madeira, whence it was introduced in 1834 , by John Willmore, Esq., of Oldford, near Birmingham.

A. M. 3. lilacina, D. Don, Brit. Flow. Gard, 2nd Ser. t. 377; and our fig. 1, in Plate 25. A very splendid varioty, with large pink flowers. The origin of this plant is not known, but it was brought into notice in 1827 by the Honourable W. Fox Strangways.

A. M. 4. Webbiana, syn. A. Webbiana, Penny; Bot. Gard. to 343. A native of the Canary Isles, introduced by P. B. Webb, Esq. in 1828; and which flowered first in the Milford nursery, near Godalming.

Specrirc Character,-Leaves lancoolate. Stem erect.-( $\boldsymbol{L}_{\text {in. }}$ )

Description, \&c.-A plant with pale blue flowers, generally treated in England as a greenhouse perennial, and propagated by cuttings. When grown as an annual the seeds must be raised in a hotbed in February, and planted out in May. It is a native of Italy and Spain, whence it was introduced in 1648. Clusius gave the specific name to this plant, in compliment to his friend Johannes Monellius.

\section{CHAPTER XXVI.}

\section{NOLANACEA.}

Essentua Character, -Corolla regular, monopctalous with a plicate | taining each a 2 or 4-celled bony nut. Embryo spiral,-DTrailing plants. astivation. Stamens 5, epipetalous. Drupe solitary or 5 together, con- $\mid$ Leaves alternate, undivided. Peduncles extra-axillary. $-(G$. Don.)

\section{GENUS I.}

NOLANA, Lin. THE NOLANA.

\section{Lin. Syst. PENTANDRIA MONOGYNIA.}

Generuc Character.-Calyz 5-cleft. Cosolla campanulate, regular. Drupes usually 5, containing each a 3-4-celled bony putamen. Seeds roundish-(G. Don.)

Descniption, \&c.-Few genera appear to have given more trouble to botanists than the genus Nolana, it laving been placed by different botanists in no less than three different orders, and now having an ordcr constituted expressly for it. Jussieu placed the Nolana in the order Boraginacece, but besides its bearing no natural resemblance to the commonest plants of that order, for example Viper's Bugloss and Forget-me-not, it differs 
botanically in having its corolla plaited in the bud, which the plants belonging to the order Boraginacee have not. To a common observer, the Nolana appears most naturally to belong to the Convolvulacea: indeed the resemblance between the flowers of Convolvulus tricolor and those of Nolana atriplicifolia is so striking, that they might easily be supposed varieties of one species. The capsule of the Convolvulus is, however, a dry berry, while that of the Nolana is a fleshy drupe; the difference between which terms will be readily perceived by remembering that a currant is a berry, and a plum a drupe. De Candolle placed the Nolana among the Solanaceco, but the fruit of the Solanacece is a fleshy berry, as, for example, the potato-apple, and very different from the Nolana, the fruit or capsule of which is fleshy, with a hard bony nut or stone. To obviate all these difficulties, Dr. Lindley formed the order Nolanacea, in wlich he has placed the genus Nolana and two other genera formerly considered to belong to Convolvulacere.

\section{1.-NOlana prostrata, Lin. the Prostrate nolana.}

Engmavivgs._Bot. Mag. 731 ; and our fig. 5, in Plate 25. | pyramidal, with triangularly sagittato segments, furnished with spurSpeciric Character.-Stems prostrnto; leaves ovate-oblong; calyx like processes at the base. Drupes 2-4-celled.-(G. Don.)

.Description, \&c.-This was the first species of the genus discovered, and from it Linnæus, who first named and described it, gave it the name of Nolana, from nola, a little bell, in allusion to the bell-shaped form of it3 corolla. The plant is a native of Peru, and seeds of it were first sent from that country to Spain. From Spain they were received by Professor Van Royen at Leyden, who sent them to Linnæus as the seeds of a kind of Belladonna or Nightshade. Abont the same time M. Forskahl, one of the persons employed by the king of Denmark to collect new plants in the East, having obtained some of these seeds (possibly from linnæus), sent them with a number of Egyptian seeds in $\mathbf{1 7 6 1}$ to Miller, who was then curator of the Chelsea Botanic Garden. The plant was at first supposed tender, but it is now found quite hardy, only requiring to be sown very thin, and to have the plants kept free from weeds when they come up. The plants will not bear transplanting except when very young, from the extraordinary length of the root, which in a flowering plant, though not branched and.very slender, has been often found three feet long. The stems are naturally prostrate, and if left to themselves, they will soon cover the bed on which they grow with a thick mass of leaves and flowers. The seeds should be sown in March or April, and tbe plants will come in flower in July.

\section{2.-NOlana ParadoXa, Lindl. The PaRAdoxical NOLANA.}

Engravings. - Bot. Reg. t. 865 ; and our fig. 3, in Plate 25. | pilose ; segments of ealyx triangular ; corolla campanulately funnelSpreific Character.-Stems prostrate, hairy; leaves ovate, obtuse, 1 shaped; drupes cumulated, 1-seeded.

Descniption, \&ro.-This species was named paradaxa by Dr. Lindley, from "the deviation in the structure of its fruit from that of the other species of Nolana." The fruit of $N$. prostrata consists of five flcshy carpels or drupes growing closely together, and each containing four cells, every cell having within it one seed. Now the fruit of $N$. paradoxa consists of twenty carpels, each of which contains one cell and one seed; thus forming an exemplification of the modern theory, that all fruits divided into cells are in fact only several distinct one-celled fruits grown together. The flower of $N$. paradoxa is paler than that of $N$. prostrata, and not so distinctly marked with dark veins. The plant is a native of Chili, and was introduced in 1823, by seeds presented to the London Horticultural Society by Francis Place, Esq. It is quite hardy, and its seeds may be procured in mcst of the seed-shops. The culture is exactly similar to that of $N$. prostrata. 


\section{3.-NOLANA TENELLA, Lindl. THE SLENDER NOLANA.}

Emaravincs.-Bot. Mag. t. 2604, Bot. Gard. t. 207, both under the name of $\mathrm{N}$. paradexa.

Synonymes.-N. paradoxa, ITook.; Violet-coloured Nolana.

petioles ciliatcd; leaves ovate, obtuse at both ends; calyx campanulate, 2-lohed, 5-angled, one of the lobes émarginate, the other triden-

;

Descniption, \&c.-The flower is funnel-shaped, of a blue, or violct-colour, with a white star in the centre. The calyx differs from that of $N$. prostrata in the want of the spur-like processes towards the base. The seeds of this plant were received from Chili in 1822, by Mr. Place, who also introduced $N$. paradoxa, and hence, probably, the confusion between the two species. N. tenella first flowered at the seat of the late John Walker, Esq., at Southgate, and its sceds are frequently sold in the seed-shops under the name of $N$. paradoxa. The culture is the same as for the other, with the exception of the seeds requiring to be sown thicker, as the plants generally send up an upright shoot, and do not spread so much as those of the other specics.

\section{4.-NOLANA ATRIPLICIFOLIA, $D$. Don. THE ATRIPLEX-LEAVED NOLANA.}

Engrapings. - Swt. Brit. Flow. Gard. 2nd Series, t. 305 ; and our fig. 4, in Plato 25.

SYNonYME.-N. grandiflora, Lehm.

Specific Character.-Stems procumbent, rather villous; calyx campanulate, with ovate-lanceolate, acute, connivent segments; leaves spatulate, radical ones large.-(G. Don.)

Description, \&c.-This is by far the most beautiful species. The flower is large and very handsome, with the three colours of bright blue, clear white, and yellow, distinctly marked. The leaves are broad and fleshy, and they are produced in such abundance on the procumbent stems, as soon to cover the bed, and thus afford a rich background to the splendid flowers with their bright clear colours, which every here and there rise up among them. We have already mentioned the resenblance between the flowers of this species and those of Convolvulus tricolor, and we have been lately much struck with it on comparing beds of the two flowers planted near together in the nursery of our neighbour Mr. Hopgood. The Nolana is however much the more beautiful, as the flowers are not only much larger, but their colours are clearer and more brilliant. The Nolana atriplicifolia is a native of Peru, introduced in 1834, and it seeds so abundantly tlrat it is already common in the seed-shops. It requires a rich loamy soil, in which it may be sown in March or April, when it will flower in July; or if wanted to flower earlier, it may be raised on a slight hotbed, and planted out the first week in May.

\section{OTHER KINDS OF NOLANA.}

The following kinds have not yet been introduced; but judging from the species we have already in our gardens, we think them so desirable, that we give their names in the hope of aiding in pointing them out to the attention of travcllers.

\section{N. SPATUlata, Ruiz el Pavon.}

Flowers very large, and white tinged with purple. Stem upright. A native of the hills in Peru, so probably quite hardy.

\section{N. CORONATA, Ruiz el Pavon.}

Flowers about the size of $N$. atriplicifolia; white, with a narrow blue border. Leaves slining, and on long footstalks. Capsules long and slender. Stem prostrate. A native of the hills of Peru, growing in dry sandy soil. 


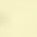




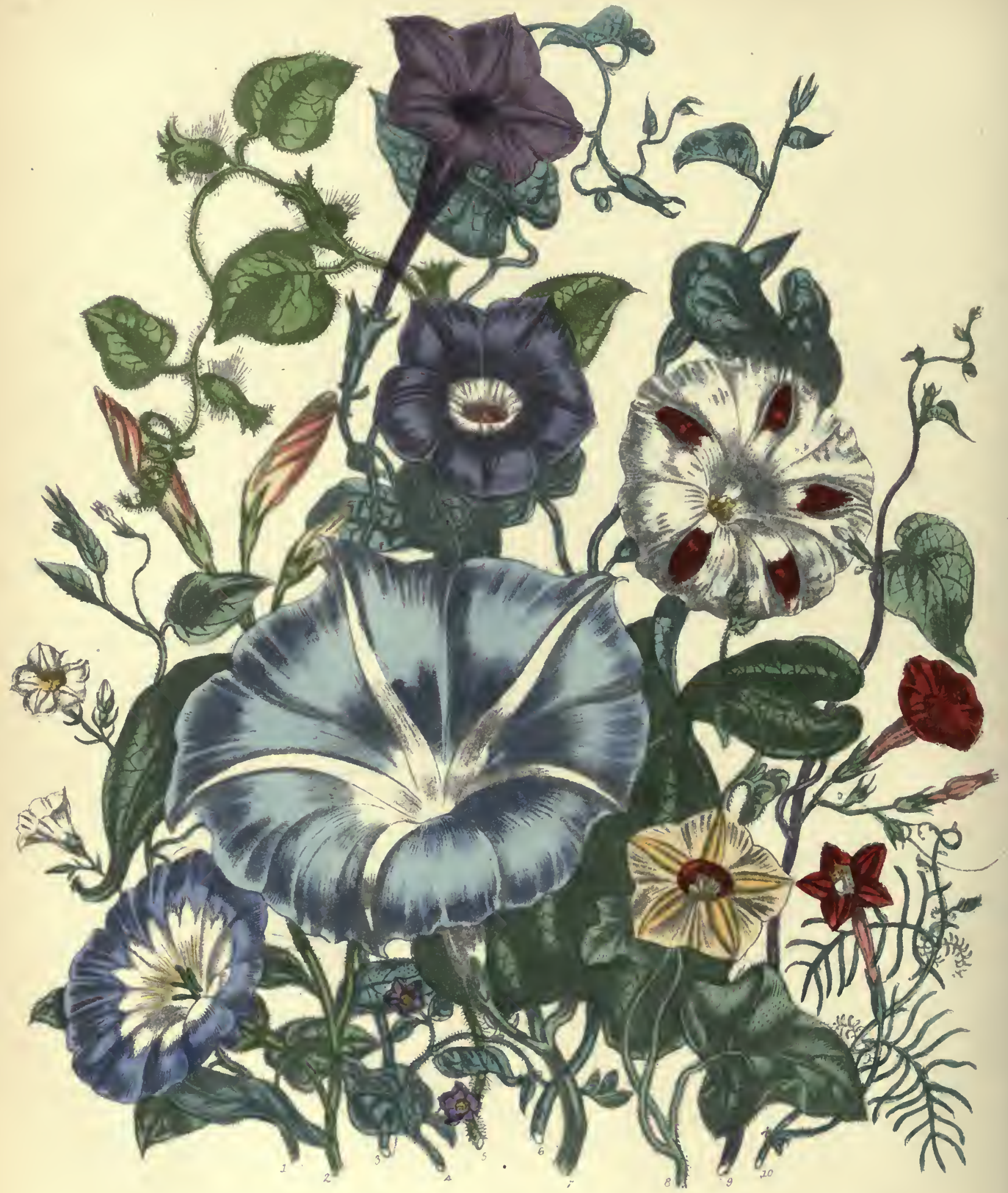

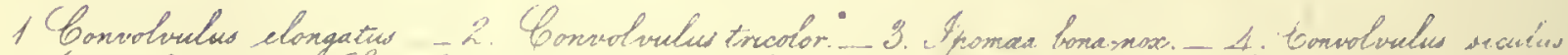

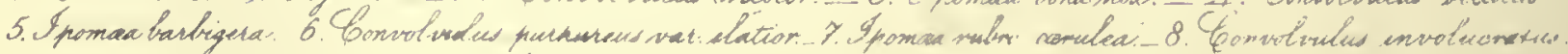



N. INflata, Ruiz et Pavon.

Flowers white, with blue anthers; calyx inflated. Stems purple and angular. Plant prostrate. Leaves downy and sinuated. A native of the sandy hills near Cumana.

\section{N. REVOLUTA, Ruiz et Pavon.}

Flowers large and of a bluish-violet, peduncles very short. Stems white and angular. Plant procumbent. A native of Peru in sandy places.

\section{CHAP'TER XXVII.}

\section{CONVOLVULACE正.}

Fsgential Cnaracter.-Calyx of 5 sepals, rarcly 5-toothed, per- | transversely. Seeds rounded on one side, and flattened on the other. sistent. Corolla monopetalous. Linb of five plairs of the lobcs, Albumen uucilaginous. Cotyledons corrugated.-Usually twining with a twisted æestivation. Stamens 5, ejipetalous. Hypogynons disk herbs. Lenves alternate, entire or lobed. Peduncles axillary or annular, surrounding the ovarium. Capsule dehiscing valvately, rarely $\mid$ terminal; one or many flowered.-(G. Don.)

Description, \&c.-The Convolvulacer are all twining plants, inost of which are lierbaceous, and many of these anmuls. They have all large showy flowers, and are of very ensy eulture. According to modern botanists, there are thirty-five in the order Convolvulacex, most of which contain annuals; but we shall confine ourselves to the two genera Convolvulus and Ipomøa (both of which were instituted by Linnæus), as under these names the plants are best known, and we shall only indicate the new names in the synonymes.

\section{GENUS I.}

\section{CONVOLVULUS, Choisy. THE CONVOLVULUS OR BINDIVEED. \\ Lin. Syst. PENTANDRIa MONOGYNia.}

Generio Chahacter.-Stamens inclosed. Stigma 2-lobed; lobes tcretely filitorm.

Descriptros, \&c.-The name of Convolvulus was given by Linnæus to a number of climbing, showyflowered plants, which since his time lave been divided into five or six different genera; but to prevent confusion, we shall describe these plants under their old name of Convolvulus, which alludes to the folding of the flowers in the bud.

\section{1.-CONVOLVULUS TRICOLOR, Lin. THE THREE-COLOURED CONVOLVULUS.}

Engantings.-Bot. Mag. L. 27, and our fig. 2, in Plate 26. Synonyar. -Convolvulus minor, Horl.

Specific Cnasictrn.-Stem declinate, terete, beset with small, soft, white hairs. Leaves ovate-lanceolate, spatulate, hairy, ciliated. Peduncles 1-flowered, bibracteate, longer tban the leaves. Sepals ovate-lanceolate, acute. - (G. Don.)

Description, \&c.-A beautiful flower with three distinct colours, yellow, blue, and white, well known under the name of Convolvulus minor, or the dwarf Convolvulus, in our gardens. There are two varieties of it; one white, and the other striped, but they do not always come true from seed. The species is a native of Spain, Portugal, Sicily, and the north of Africa; and it was introduced by Parkinson before 1629; as he calls it the small blue Spanish Bindweed in his Paradisus, and says he had the seed of "Guillaume Boel," who brought it from Portugal. Some botanists suppose this species to have been originally only found in Barbary; but whether introduced or indigenous, it is now a common weed both in Spain and Portugal. The flowers always folding in 
gloomy weatlıer and at night, the French call it Belle-de-Jour. The seeds are now common in every seed-shop. When the seeds are sown, a shallow drill should be made for them. forming a circle; or three or four straight drills should be made across a bed in which the seeds may be dropped and covered lightly over. When the plants come up, they should be thinned out so as to stand an inch apart. The plants require a dry situation, and rather a rich light soil. The usual time of sowing is April, in which case the plants will come into flower in July; but as they are quite hardy the seeds may be sown in autumn to stand the winter, when the plants will flower in May.

\section{2.-CONVOLVULUS PURPUREUS, Lin. THE PURPLE CONVOLVULUS.}

ENGGaviso.-Bot. Mag. t. I13.

Syconymes. - Pharbitia hispida, Choisy; Ipemœea glandulifera, Ruiz et Pavon; Convolvulua major, Hort.

VAkietues, - C. p. 2 elatior, Sims, Bot. Mag. t. 1005 ; and our fig. 6, is Plate 26. A most beantiful plane with whito flowern, marked with five spots like the eycs in a peacock'a tail, clegantly shaded with blue and carmiae. It comes true from seed, and is so distinct that Dr. Sims, who first described it, had marked it as a species, till on closer examination lie discovered that it did not possess charactera sufficient to establiah a specific difference. It is quite hardy, and only requires to be sowa in a warm sheltered siluatioo, and ia a rich light soil. It was first observed in 1804 in the Fulham nursery, and from its great beauty it soon became a favourite, but it is now rarely to be met with.

C. p. 3 variua, Sims, Bot. Mag. t. 1682 . A very distinct varicty marked with dark blue stripes on a white ground, and the rays red and white. This kind was introduced about 1810 by the Hon. and Rev. W. Uerbert, who received the seeds from Cadiz, and who informed Dr. Sima in 1815 (when the plant was figured in the Bot. Mag.) that the colours had come true from seed in Mr. Herbert'a garden for five generations.

Spectric Cfaracten.- - Leaves cordate, acuminated, eatire; auricles diverging. Peduncles usually exceeding the leavea, $3-5$ flowered, aomewhat umbellate. Scpals orate-lanceolate, acute-(G. Don.)

Descriptron, \&c.-The purple or major Convolvulus has long been a favourite in our gardens. It is a native of Asia and South America, and it appears to have been introduced into England at a very early period, as it is mentioned in 1629 by Parkinson, who calls it the greater blue Bindweed, or Bell-flower with round leaves. Parkinson also mentions that this kind and Convolvulus Nil were sent to England from Italy, "but whether they had them from the East Indies or some of the Eastern countries on this side," he adds, "we know not; but they thrive reasonable well in our country if the year be anything kindly." This species was placed in the genus Convolvulus by Linnæus; it was afterwards included in the genus Ipomœa by Zuccagni, who published some botanical works at Florence, in 1806; and lastly it was placed in the genus Pharbitis, of which indeed it may be considered the type, by Choisy a Swiss botanist, in 1821. The botanical differences between Convolvulus and Pharbitis are, that in the former the ovarium is two-celled and two-seeded, wlile in the latter the ovarium is three and sometimes four-celled, and three-seeded. The seeds of C. purpureus may be bought in any seed-shop under the name of Convolvulus major; and they should either be sown at the foot of a wall, or stuck like peas, as their long slender stems (which are sometimes ten feet or twelve feet high) require support. This species being more tender than C. tricolor, requires a warmer situation; and when wanted to flower early, the plants may be raised in a hotbed, and planted out in May. The flowers vary very much; displaying many shades and combinations of white, reddish purple, bluish purple, and violet, besides the decided varieties whicls we have already mentioned. The seeds should be sown in the same way as those of the minor Convolvulus.

\section{3.-CONVOLVULUS SICULUS, Lin. THE SICILIAN CONVOLVULUS.}

Engravikgs.-Bot. Mag. t. 445 ; and our fig. 4, is Plate 26.

Speciric Character. - Steosa trailing. Leavea cordate-ovate, auperior enes acute, all hairy. Peduncles I-flowered, shorter than the leaves. Bractcas lanceolate below the calyx. Sepals hairy, orite, acute.-Stems fliform, angular, beset with adpressed hairs above and apreading ones at bottom.-(G. Dnn.)

Description, \&r.-This species has smaller flowers than any otler of the genus. The stems are slender and 
twining a little, but not like the other species so much so as to require support. On the contrary the slender thread-like stems of this curious little plant lie on the ground, and only wind round each other. This species is a native of Sicily, the coast of Barbary, and Greece ; and it was introduced before 1640, according to Parkinson, by Mr. James Boel. It is quite hardy, and seeds may be had at Carter's. From the smallness of its flowers, however, it is rarely cultivated in flower-gardens.

\section{4.-CONVOLVULUS ELONGATUS, Will. BROUSSONET'S TRAILING BINDIVEED.}

Engruvings.-Bot. Reg. t. 498; and our fig. 1, in Plate 26. | 1-2-flowered, longer than the leaves. Bracteas linear-subulate. Specific Craractrr._Leaves cordate-ovate, cuspidate. Peduncles $\mid$ shorter than the pedicels. Calyxes ciliated.—(G. Don.)

Description, \&c.-This plant was first discovered in the Canary Isles by M. Broussonet, who supposed it to be a variety of $C$. siculus. It does indeed strongly resemble that species excepting that its flowers are white tinged with pink at the edges, and with the throat yellow inside. Willdenow, however, named it C. elongatus from the great length of the footstalks of the flowers. It is a trailing species, very hardy, and of the easiest culture, requiring no other care than that of sowing the seeds in the common garden soil ; but it is now very rarely met with in gardens.

\section{5.-CONVOLVULUS INVOLUCRATUS, Ker. THE LEAFY-CUPPED OR GUINEA BINDWEED.}

Engravings.-Bot. Reg. t. 318 ; Bot. Mag.t. 2205 ; and our fig. | Sprcific Character.-Stem villous. Leaves ovate-cordate, entire, 8 , in Plate 26.

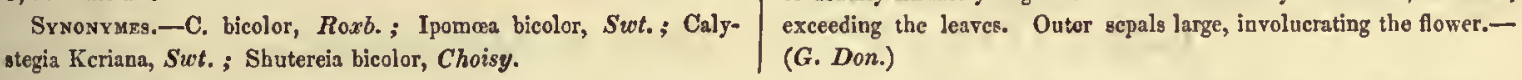

Description, \&c.-This is rather a remarkable species, from the very curious and leafy calyx. The flower, which somewhat resembles that of the Thunbergia alata, is of a pale yellow, with a deep reddish purple centre. The leaves are shining, but covered with fine hairs. The species is a native of Africa, but it has also been found in the East Indies. It was introduced in 1818, and was thought not likely to live ont of the stove. It is found however to flower beautifully with the common treatment of tender annuals; that is, raised in a hotbed, and planted ont when of snfficient size. As the plant is, however, rather tender, it is best in most situations to transplant it in May into a pot, and not to plant out in the open ground till June. The name of a two-coloured Convolvulus is in Carter's catalogue, but it can hardly be the same species, as it is described as a hardy annual.

\section{OTHER SPECIES OF CONVOLVULUS.}

All the following species have been introduced, but, with only one or two exceptions, we do not know where seeds of them are now to be procured.

$\therefore$

\section{PENTAPETALOIDES, $\operatorname{lin}$.}

This species, which is sometimes called the Majorca Convolvulus, resembles C. tricolor, but it is a trailing plant, and has much smaller flowers. It is a native of Majorca and the Ionian Isles, and was introduced in 1789.

\section{STRICTUS, Lehm.}

Has white flowers tinged with pink; and its habit of growth resembles that of $C$. tricolor. It is a native of Egypt, and was introduced in 1822. This is called the Egyptian Convolvulus. 


\title{
C. UNDUlatus, Cav. ; syn. C. Evolvuloides, Desf.
}

This species, which is generally called the African Convolvulus, has large flowers, resembling those of C. tricolor, except in the rim or limb, as botanists eall it, which is pink instead of blue; but there is a variety which is blue and white. It is a prostrate plant, and a free flowerer. It was introduced in 1810.

C. PerUviands, Spreng.; syn. IPOMdea Cuspidata, Ruiz et Paton; Pliarbitis cuspidata, G. Don.

The Peruvian Convolvulus has large purple flowers. It is a native of Peru, in stony places, and was introduced in 1732 .

\section{GENUS II.}

\author{
IPOMCEA, Lin. THE IPOMCEA. \\ Lin. Syst. PENTANDRIA MONOGYNIA. \\ Generic Chanacter.-Stigma 2-lobed. Lobes capitately globose.
}

Description, \&c.-The difference between the genera Ipomœa and Convolvulus is very slight, consisting principally in the shape of the lobes of the stigma, which in Ipomœe form a globose head, while in Convolvuins they are slender and thread-like. The division of the genera was made by Linnæus, and it has bcen followed by all subsequent botanists. Ipomoa signifies, to strike the sight,-in allusion to the bcauty of the flowers.

\section{1.-IPOMEA COCCINEA, Lin. THE SCARLET IPOMOEA.}

Engravings.-Bot. Mag. t. 221 ; and our fig. 9, in Plate 26.

Srnonrmes.-Quamoclit coccinca, G. Don.; Ipomea stylosa, Comm.; Convolvalus coccineus, Spreng.

VAR1Erifs.-I. c. 2 pubescens, Cham, et Schlecht. This variety has the leaves corered with a soft dense down, and never three-lobed.

It is a native of Mexico.

I. c. 3 luteola, Willd. ; syn. I. luteola, Jacq.; Quamoclit luteola, G. Don, has the flowers of a golden yellow.

Specific Character.-Leaves cordate, acuminated, angular at the base. Peduncles 3-6-flowercd. Caly xes wartcd, awned.-(G. Don.)

Description, \&c.-This species is a twining plant, with heart-shaped leaves, and bright scarlet flowers. It is a native of Carolina, and the West India Islands, whence it was introduced in 1759 , bcing first cultivated by Miller, when he was curator of the Botanic Garden, at Chelsea. Since then it has been generally grown in nurseries, thougl but seldom in private flower-gardens; partly, no doubt, from its being confounded with some of the tender kinds, which it strongly resembles. The scarlet Ipomon is, however, quite hardy, and only requires sowing in the open ground like other annuals. Three seeds are usually sown about four inches asunder in the form of a triangle; and when the young plants are about six or eight inches high, a stick is put in the centre for them to twine round. A slight iron frame with an umbrella-top, or any otlier frame in wire or latticework, may be adopted, or a piece of packthread stretched out for them, or the young plants may be trained against a wall or paling. They do best, however, without tying or nailing, and when suffered to twist themselves round anything that may be near them. We saw some in the autumn of 1838 in the Lewisham nursery, which had twisted themselves round some young apple trees, and which hung down in graceful festoons from the branches. Seeds of this species may be had at Carter's and other sced-shops; and if sown in Mareh or April the plants will flower in July or Angust. If wanted to flower early, the plants may be raised on a hotbed, and transplanted in March or April, when they will flower in May or June. They are said to snceed best in a very rich soil and in a warm sbelterel situation; but in these situations the flowers, thougl larger, are generally of a 
paler colour. Ipomœa phœnicea, Roxb.; Quamoclit phonicea, Choisy; I. caccinea, Bot. Rep. t. 449, the Crimson Ipomœa, which is sometimes confused with the Scarlet Ipomcea, is a hothouse climber, a native of the East Indies, which will not live in England in the open air. There are also several perennial Ipomceas with scarlet or crimson flowers which require to be constantly kept in a lothouse.

\section{2.-IPOMOEA QUAMOCLIT, LAm. TIIE COMMON QUAMOCLIT OR WIN JED-LEAVED IPOMOEA.}

Engraping6.-Bot. Mag. t. 244, and our fig. 10, in Plate 26. Synonymes.-Convolvulus pinnatus, Lam.; Quamoelit vulgaris, Segments linear, parallel, acite. Peduncles l-flowered. Sepals ovsteChoisy; Scarlet Jasmine.

VARIETY.-I. Q. 2 slbiflora, G. Don. Flowers white. lanceolate.-(G. Don.)

Description, \&c.-The flowers are scarlet, and in the shape of those of a jasmine, and tlue leaves are curious. The plant is a native of the East Indies and South America, and is much more tender tlan the scarlet Ipomcea. The kind from America is said to have two flowers on each footstalk instead of one, and to be hardier than the other; but the difference appears to be too slight, and too uncertain, to constitute a regular variety. The species was introduced before 1629, as it is mentioned by Parkinson. It is generally kept in the greenhouse, but if raised in a hot-bed, it may be planted out late in May or the beginning of June, in warm, sheltered situations and good soil. where it will flower freely, and if the summer be favourable it will ripen its seed. The plants intended to produce seed are, however, generally kept in the greenhouse or stove.

\section{3.-IPOMCEA CERULEA, Roxb. THE CELESTIAJ, BLUE IPOMCEA.}

ENomuving. - Bot. Reg. t. 276.

Sумомумпя,-Convolvulus Nil, Lin.; C. hedcraceus, Lin.; Ipomea Nil, Roth.; I. hepaticifolin, Hayne ; Pharbitis Nil, Choisy.

Specific Character.-IIalry; leaves cordate, 3-lobed; interme-

diate lobe dilated at the basc, and not contracted. Peduncles 2-3-flowered, commonly excecding the pctioles. Sepals ovate-lanceolate, bispid at the base.-(G. Don.)

Description, \&c.-This plant, which is supposed to be the true Convolvulus Nil of Linnæus, differs from the plant usually bearing that name, in having the segments of the limb of its corolla circular and very shallow, instead of deep and tapering to a point. The flowers also of a pale delicate celestial blue, softening into white, and, when fading, with a very slight admixture of pink. The leaves are curiously shaped, and the stems and the points of the sepals of the calyxes are of a dark red. Ipomoea carulea is a native of the East Indies, where it is generally found in lyedges and on old walls. It is also found wild in the tropical regions of Africa and Soutl America. It is supposed to be the species introduced before the time of Gerard (1596), which that author tells us the Arabians called Nil, and the Italians Campana azurea, and Fior de notti; but if this were the case, it had been long lost to our gardens, and was re-introduced from India in 1817, by Dr. Roxburgl. It is tender, and thougl it will flower in the open air, it should be raised on a hot-bcd, and not planted out till the middle of Junc. It rarely flowers till the latter end of August or beginning of September.

\section{4-IPOMCEA HEDERACEA, Jacq. THE IVY-LEAVED IPOMCEA.}

Engraying.-Bot. Reg. t. 85.

Synowymes.-I. batbata, Roth.; I.Nil, Pursh.; Convolvulus Nil, Michx.; I. scabra, Forsk.; Pharbitis hederacea, Choisy; P. Purshii, G. Don; P. barbata, G. Don; P. Forskeli, G. Don; P. Dillcnii, G. Don.

Virietirs.-I. h. 2 purpurea, Hort. Corolla funnel-sliaped and purple.

Pharbitis scabrida, G. Don. Corolla white.

I. h. 4. villosa, Hort. ? I. villosa, Ruiz et Pavon. Flowers very large.

I. h. 5. puactata, Hort. P I. punctata, Pers. Calyx dotted.

Specific Chaructrar.-Pubescent; leaves cordate, decply 3-lobed, lobes scruminated, central one yeotricose. Peduncles 1-3-flowered; tube of the calyx bearded. Bracteas laciniated and slightly recurved. Corolia

I. b. 3. scabra, Hort.: I. scabra Schultes: I. scabrids, Rom.: | somewhat funncl-slrapcd.

Description, \&c.-This flower, from the beautiful blue of its flowers, and from its being only seen to 
advantage when it has just opened them in the merning, is gencrally known in America by the name of "The Morning Glory." In England it is often called Convolvulus Nil; but there appears a great confusion respecting it and I.carulea. It is a native of North America, where it is found generally in Virginia and Carolina, in hedges and among trees near rivers. It was introduced in 1729 , and has since frequently been sent over under different names. Seeds of it may be procured at Carter's in Holborn (where there is an excellent collection of seeds of Ipomceas), under the name of $I$. hederacea; and they may be sown in a warm border in April or May, or they may be raised on a hot-bed in March. This species requires a light rich soil, not too dry, and it seldom flowers till August or September.

\section{5.-IPOMEA BONA NOX, Lin. THE NIGHT-FLOWERING IPOMEA.}

Engravincs.-Bot. Mag. 1. 752; aod our fig. 3, in Plato 26, of Ipomoa bona-nox purpurascens.

Synonymes.-Convolvulus boan-cox, Spreng.; Argyreia bonanox, Swt.; Calonyction speciosum, Choisy; ? Ipomcea loagiflora, Willd.

VARIETY.-I. b. 2 purpurascens, Ker., Bot. Reg. t. 290 ; I. muricata, Jucq.; I. turbinata, Lagas.; Coavolvulus muricatus, Lin.;
Calonyction boar-oox, var. muricatum, Choisy; C. muricatum, G. Don. Corolla purple. Stem and peduacles muricated from prickles.

Specific Character. - Leaves coldate, entire, acuminated, or hastately 3-5-lobed; corolla with a long cyliadrical tubc, and spreading limb. Lobes rouoded, mucrouate.

Description, \&c.-The species has a white delightfully fragrant flower with a ycllowish tube, ${ }_{2}$ whiclı only opens at sunset, and droops at sunrise. The variety figured in our plate, differs in having a purple flower. Both are natives of Persia and the East Indies; and were introduced about 1773 ; the seeds, wlich can be purchased at Carter's, may be sown, and the young plants treated exactly as directed for the other tender specics. They require a light rich soil, or a mixture of loam, peat, and sand. They should bo raised on a hot-bed. and not planted out till the middle of June; and then only in a warm sheltered situation open to the south, and sheltered by a wall.

\section{6.-IPOMOEA BARBIGERA, Swt. THE BEARD-BEARING IPOMEA.}

Engravinas.-Swt. Brit. Flow. Gard. t. 86; and our fig. 5, in |entire, hairy oa both surfaces, lind lobes rounded. Peduocles Plato 26.

Syмonyme.-Pharbitis barbigera, (G. Don.) l-fiowered, shorter than the petioles, bibractate near the calyx. Supals

acuminated, spreadiogly reflesed at the apex, and densely bearded at the

Specific Character. - Stem downy. Leaves cordate, acuminated, / base.-(G. Don.)

Description, \&c.-A beautiful species, bearing considerable resemblance to the ivy-leaved Ipomoea, but smaller. A native of North America, and quite hardy; only requiring to be sown in the open air, and furnished. with a prop to cling to, when of gufficient length.

\section{7.-IPOMCEA RUBRO-CERULEA, Hook: THE REDDISH-BLUE OR MEXICAN IPOMGEA.}

Enoravings.-Bot. Mag. t. 3297 ; Paxt. Mag. of Bot., vol. 3, p. 99 ; Botanist, No. 52; and our fig. 7, io Plate 26.

Synanymes.-I. Hookerii, G. Don. I. subro-cyanez, Hort. . Mr.

G. Doa suggests that it may he a species of Rivea.

Specinic Charactra.-Smooth; leaves ao long petioles, deeply

cordate, acuminated. Peduncles 3-4-flowered, fleshy, subracemosc, Calyx smooth. Sepals (small) erect, adpressed, lincar, awl-sbaped, with a whitish margin. Corolla, very largc, funael-shaped. Limb 5-angled, angles mucronatc. Stigma two lobed.-(Hook.)

Description, \&c.-This is by far the most splendid flower belonging to the genus. The corolla is very large, and while in the bud it appears red and white. but when it expands, it is of a most beautiful and brilliant blue ; and when it fades, which it does the same day that it expands, the limb of the corolla curls up, and becomes a bright rose-colour. The most extraordinary part of this change is thiat both the blue and rose-colour are quite bright and fresl, and that there is no intermediate shade of dingy purple or faded pink, as is the case generally witl blue flowers which change thcir colour in fading. This species is a native of Mexico, where it grows to an 
extraordinary size. It was discovered in 1831, by Mr. Samuel Richardson (an officer of the Anglo-Mexican Mining Association), and seeds of it were sent by him to J. D. Powles, Esq. of Stamford Hill, which were liberally distributed by that gentleman. It was first called Ipomcea mebro-cyanea, but in 1834, it was figured in the Bot. Mag., and its present name given to it by Sir W. J. Hooker. It is remarkable for tlie abundance of its flowers, and the great length of time during which it continues to produce them. Many persons are deterred from cultivating this beautiful plant from the idea that it. requires a stove to bring its flowers to perfection. This, however, is not the case, as it requires no more care in its cultivation than any other tender annual. In the spring of 1835, Mr. Rauch, one of Mr. Loudon's assistants, had some secds of this plant given to him. They were raised in a hot-bed in February; but only one plant came up, and this was bronght into the open air in May. In July it began to flower, and it continued producing a succession of large and magnificent blossoms of the most brilliant ultra-marine blue till October. The flowers opened every morning three or four at a time, and slurivelled up before night into what had the appearance of buds edged with deep rose colonr, and which had quite withered before the following morning. This plant produced several pods of ripe seeds. We have since heard of several plants succeeding under similar treatment. It must be observed, however, that the soil should be good and light, and the situation warm and sbeltered, and yet open to the sun. Seeds may be had from Mr. Kernan, Great Rnssell Street, Covent Garden, and other seedsmen.

\section{OTHER SPECIES OF IPOMEA.}

Nearly all the following species are marked as stove annuals; but as they aro all very beautiful, and seeds of many of them are to be obtained, we give some particulars of ench, that those who like to try them in the open air, may be able to choose which they would prefer. There are, indecd, very few stove annuals that will not succeed in the open air, if raised in a hot-bed, and not planted ont till the latter end of May or beginning of June. The situation should be a warm border open to the south, and backed by a wall, and the plants may be sheitered occasionally when thought necessary, by a hand-glass or flower-pot turned over them till their roots have taken possession of the soil. All tender annuals raised in a hot-bed or stove, sliould also be gradually exposed to a cooler temperature before planting out, and they may cven be set in the open air for a day or two in the flower-pots they were raised in, before turning them into the ground.

I. SEROTINA, Rem. et Schultes; syn. QUAMOCLIT SEROTINA, G. Don; CONVOLVULUS SEROTINUS, Dec.

This species, which has very large broad leaves, and was introduced in 1824 , is said to be nearly allied to I. coccinea.

I. HEDERIFOLIA, Lin.; syn. Q. HEDERIFOLIA, G. Don.

This species has ivy-shaped leaves, and long violet-coloured flowers. It is a native of the West Indies, and was introduced in 1773 .

I. TRILOBA, Lin.; syn. Q. TRILOBA, G. Don.

A native of South America; introduced in 1752. The flowers are somewhat cylindrical, and of a violet colour. Seeds may be had at Carter's.

I. TRIDENTATA, Roth. ; syn. EVOLVUlUS TRIDENTATUS, Lin. CONVOLVULUS VISCIDUS, Roxb., \&cc. \&c.

This species has small yellow flowers. It is a native of the East Indies, and was introduced in 1778. 
I. FILICAULIS, Blume; syn. I. DENTICULATA, R. Rr. Bot. Reg. t. 317, \&s., \&c.

Flowers pale yellow, leaves linear, and stens threadlike. A native of the East Indios, introduced in 1778.

$$
\text { I. INVOLUCRATA, Beauvais. }
$$

llowers large and dark rose-coloured, surrounded by two large bracteas, forming an involucre. A native of Guinen; introduced in 1822.

\section{SESSILIFLORA, Roth.; syn. CONVOLVULUS HISPIDUS, Vah., \&c., \&c.}

Flowers small, rose-coloured. There is a variety with white flowers, produced in round sessile heads. A native of Nepal, introduced in 1816.

I. OChracea, G. Don.; syn. CONvolvulus OCHRACEUS, Lindl., Bot. Reg.t. 1060.

The limb of the corolla is flat, witl crenulated lobes; the colour is an orange-yellow, having the tube deep purple inside. A native of Guinca on the Gold Const; introduced in 1826.

I. OBSCURA, Ker, Bot. Reg.t. 239; I. SOLANIFOLIA, Burm., \&c., \&c.

Nearly allicd to the last species, with pale yellow or cream-coloured flowers, having a red centre. A native of the East Indies ; first grown in England in Dr. Sherard's garden at Eltham, in 1732 ; but which is generally included in every parcel of seeds scnt by unbotanical collectors from India to this country.

\section{LEUCANTHA, Jaeq.}

A native of America, with white flowers; introduced in 1823.

\section{SIBIRICA, Jacq.}

Strongly resembling the common little wild Convolvulus of our fields and hedges, but with smaller flowers, which are white or very pale pink, with a yellow centre. A native of Siberia, introduced in 1779.

\section{VIOLACEA, Lin.; syn. CONVOLVULUS INDICUS, Miller's Dict., \&c.}

Flowers large, and of a pale purple. A native of South America, introduced in 1792.

I. PUDIBUNDA, G. Don; syn. CONVOlvUluUS PUDIBUNDUS, Lindl., Bot. Reg. t. 999.

Corolla of a fine rose colour; tube inflated. A native of St. Vincent's; introduced in 1822.

$$
\text { I. PILOSA, Sweet; syn. C. ALBICANS, Wall., \&c. }
$$

Flowers small, pink; plant hairy; leaves clothed with white wool beneath. A native of the East Indies; introduced in 1815.

\section{TRICIIOCARPA, Ell.; \&c., \&c.}

A native of Carolina; introdnced 1732. The flowers are very large, and of a pale purple, and the capsules are globose and hairy. Seeds may he procured at Carter's; and they may eitlier be sown in the open air in April, or raised on a hot-bed, and planted out in May. This species flowers in July and August.

I. DASYSPERMA, Jacq.; syn. I. TUBERCULATA, Ker, Bot. Reg. t. 86; C. DIGITATIS, Roxb., \&c., \&c.

Dark straw-colour flowers, with a pale purple tube. The leaves are deeply palmate, and the stems pink. A native of the East Indies; introduced in $\mathbf{1 8 1 5}$. This is probably the $I$. eriosperma of the seed-shops.

\section{DISSECTA, R. Br}

Leaves palmate, 7-parted ; flowers white. A native of New Holland; introduced in 1815. 


\section{PES-TIGRIDIS, Lin. ; \&ce. \&ce.}

Leaves shaped like a tiger's foot, whenee the name. Flowers purplish, in heads, and surrounded by long bracteas. A native of the Fast Indies; introduced in 1732 . Seeds may be had at Carter's.

I. HEPATICIFOLIA, Lin.; \&c. \&c.

A native of Ceylon and China, with purplish flowers; introduced in 1759. Seeds may be lıad at Charlwood's.

I. PARVIFLORA, Vahl.; \&c.

Small purplish flowers. This is the $I$. triloba and $I$. sanguinea of some gardens. A native of Santa Cruz; introduced in 1822 .

I. BUCHANANI, Choisy; I. SALICIFOLIA, Roxb.

- Flowers white. A native of Bengal; introduced in 1816.

\section{OTHER SPECIES OF CONVOLVULACE杘}

Notwithstanding the great number of showy ornamental plants which we have already enumerated as belonging to this order, there are many others, the principal of which (as we are confined for space) we shall give below, without entering into full botanical details respecting their different genera, in the same way as we have before done with some of the species of each genus.

\section{CALYSTEGIA GENICULATUS, Lehm.}

Flower pink, silky, and 5-lobed. Leaves downy. A native of Australia ; introduced in 1826.

PORANA RACEMOSA, Roxb., syn. DINETUS RACEMOSUS. Swt. Brit. Flow. Gard. t. I27; \&c. \&cc.

A twining plant, with small white starry flowers. A native of Nepaul; introduced in 1823 . It is quite hardy, and a very free flowerer, but we do not know where seeds can be obtained. There is another species witl largerrose-coloured flowers ( $P$. grandiflora) wlich has not yet been introduced. Both species are well deserving of cultivation in this country, from their hardiness, the great abundance of their flowers, and the extraordinary rapidity of their growtl. Porana signifies to spread.

\section{PHAREITIS DIVERSIFOLIA, Lindl., Bot. Reg. 1988.}

A very pretty species, about half the size of the common major Convolvulus, to which it is very nearly allied. The flowers are purple marked with briglit crimson rays, and the lenves are entiro when young, but become 3-lobed when fully grown. A native of Mexico, whence it was introduced in 1836 . It has been also found in Peru. The name Pharbitis is taken from a Greek word, signifying colour.

\section{CRESSA CRETICA, Lin.}

A low plant, with white flowers, which are produced in small heads. A native of the south of Europe; introduced in 1822 .

\section{EVOLVULUS LINIFOLIUS, Lin.}

A native of the West Indies and New Molland, with narrow caneseent leaves, and small blue flowers. Introduced in 1782. 
CUSCUTA EUROPAUS Lin., and C. EPITHYMUM, Lin. THE GREATER AND LESSER DODDER.

These curious parasites are, we believe, the only plants of that description which are natives of Britain. The seed germinates in the ground, but the plant soon begins to throw out short side roots, which twine themselves round any plant that may be within their reacl, and serve as montlis to suck nourishment from it. The original" root in the earth withers away as soon as the side roots have attached themselves, and the parasite is thus left. to depend for its sustenance entirely on the plant which affords its support. The Dodder has small pinkisl flowers. but no leaves; and, as it destroys whatever it attaches itself to, particularly oats, it is sometimes very injurious to the farmer.

\section{Verrucosa, Swt. Brit. Flow. Gard. t. 6. THE NEPAUL DODDER.}

This species is deserving, of cultivation for its pretty, white, bell-shaped flowers, which are delightfully fragrant, resembling the scent of violets and cowslips mixed. This plant is a native of Nepaul, and was brought to England in 1822. The seeds may be sown in a pot with some of the commoner kinds of Geranium (Pelargonium), or in the open ground near ivy. The plants will soon come up, and will send out a number of short roots like teeth, which they will fix into the plant near them, twining themselves round it in a very curious manner. We have seen this plant flowering abundantly in the nursery of the late Mr. Malcolm, at Kensington, and we have no donbt it may be procured from several of the London nurserymen.

Nearly all the plants belonging to the order Convolvulacece have numerous synonymes (though we have rarely given more than two or three), on account of the great number of ehanges that have taken place in the genera. In all cases, we have given the name by which the plant appears to be most generally known in the seed-shops as the principal one, in order to save our readers from having mueh trouble in identifying it.

\section{CHAPTER XXVIII.}

\section{POLEMONIACEE.}

Essentua Character._Calyx 5.eleft or 5-toothed. Corolla angular or compressed. Albumen fleshy.-Leaves alternate, simpie, rotate or funnel-shaped, 5-lobed. Stamens 5, epipetalous. Style long. Stigma 3-lobed. Capsule 3-celled, 3-valved. Placenta ceutral. Seeds $\mid$ solitary.-(G. Don.)

Description, \&c.- This order takes its name from the Greek Valerian (Polemonium), but many of the plants contained in it differ so much from this prototype as scarcely to be recognised. The genus belonging to this order, which contains the most beautiful flowers, is the Phlox, but the species are nearly all perennials. Gilia is another genus containing beautiful flowers, and most of these are anmuals. The Leptosiphons are very pretty hardy flowers. There are said to be some very handsome annuals in the genus Hugelia, Benth., which were seen by Douglas in California, but which have not yet been introdueed; the flowers of this genus resemble those of Gilia, but some are yellow and some a deep blue. Some other genera of Californian annuals described by Donglas, and which appear very ornamental, also belong to this order. 



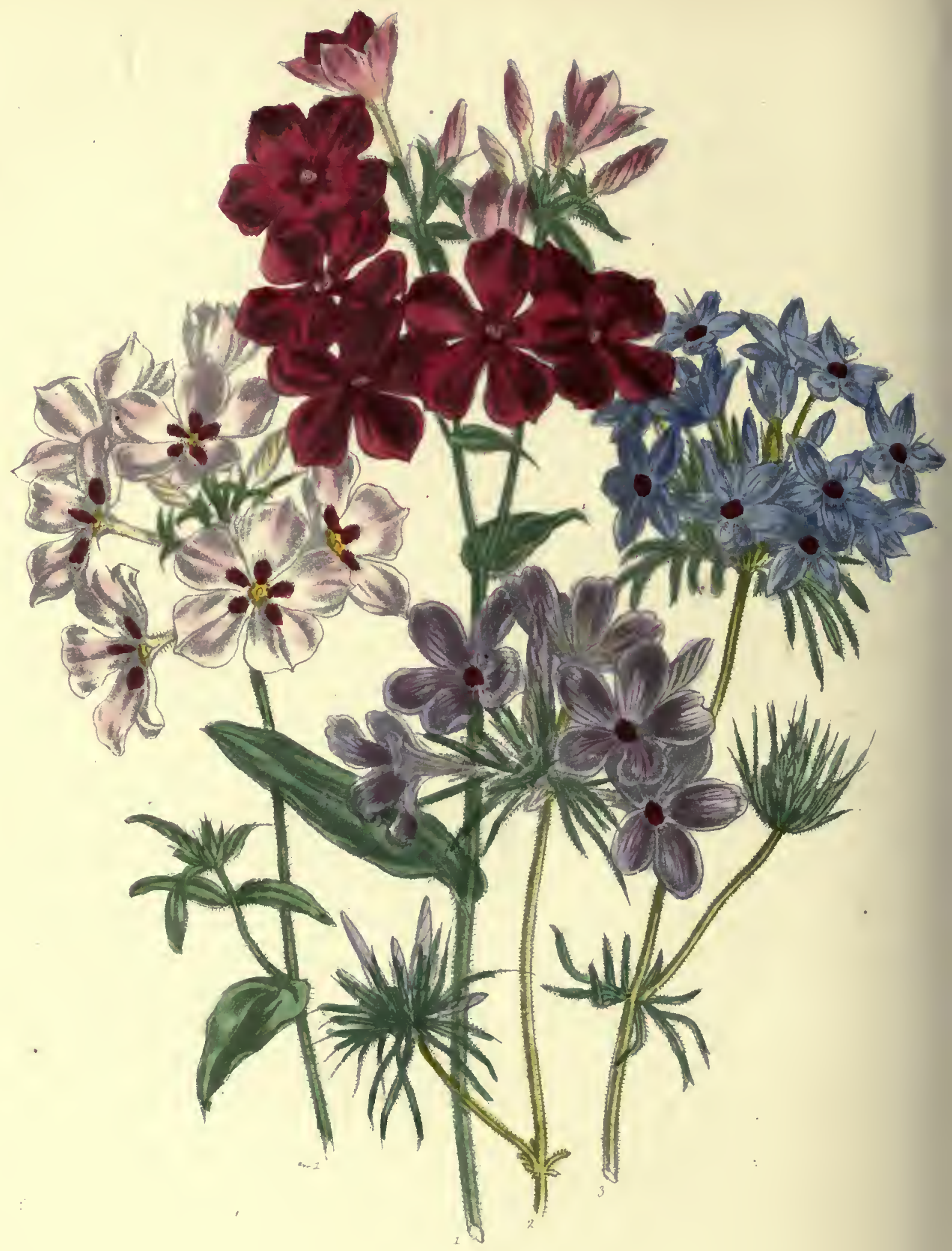





\section{GENUS I.}

\section{PHLOX, Lin. THE PHLOX.}

\section{Lin. Syst. PENTANDRIA MONOGYNIA.}

Geneaic Character.-Calyx deeply 5-cleft, connivent. Corolla salver-shaped; tube elongated; limb twisted in astivation, with cuneated segments. Stamens inserted above the middle of the tube. Cells of capsule l-seeded.-(G. Don.)

Description, \&c.-The word Phlex signifies flame, and it is supposed to have been applied to this genus in allusion to the flame-like shape of the bud. The species are all heautiful, and bear a grcat family likeness to eacli other. The only annual among them is Phlox Drummondi.

\section{PHLOX DRUMMONDII, Hook. DRUMMOND'S PHLOX.}

Engruvings.-Bot. Mag. t. 3441 ; Bot. Reg. t. 1949 ; Swt. Brit. Flow. Gard. 2nd Ser. t. 316 ; Botanist, No. 15; and our fig. 1, in Plate 27.

Specific Character.-Stems erect, simple at bottom, but a little branched at top, beset with spreading hairs, as well as the edges of the lcaves, calyres, bractens, \&c.; leaves ovate-lanceolate, half stem- clasping, all mucronate and downy, lower ones opposite, upper oncs alternate; panicle tricliotemously corymbose; flowers on very short pedicels; calycine segments linear-subulate, mucronate, a little reflexed; tube of corolla much curved, bairy, linee times longer than the calyx; segments of corolla imbricnte, cuneate obtuse, entire.-(G. Don.)

Descriptron, \&c.-Nothing can be a stronger proof of the great beaty of this species than the great number of times that it has been figured in the botanical periodicals, notwithstanding its very recent introduction. It is indeed one of the most beautiful annual flowers that we have; and it is remarkable, not only for the splendour of its celours, but for their very great variety. We have oursclves ten or twelve plants quite distinct in their colours, varying from a decp rose-colour velvet hue to a pale lilac-like pink, all raised from the seed of one plant, which ripened with us in the open air in the summor of 1838 at Bayswater. Two of these heads of flowers are copied in Plate 27. This splendid Phlox was discovered by Drunmond, a botanical collector sent out by the Glasgow Botanical Soeiety, at Texas in Mexico in 1835; and it is particularly interesting as it is one of the last plants that he sent over. Soon afterwards Mr. Drummend visited Cuba, where he was seized with fever, and died in the prime of life withont completing half the researches which he had contemplated. For this reason Sir W. J. Hooker has very judiciously named this plant Phlox Drummondi, that it may "serve as a frequent memento of its unfortunate discoverer." Though the seeds were first sent to England only in 1835, the plant seeds so freely, and has become so great a favourite, that it is already common overywhere. It was at first supposed to require a greenhouse, but it is now found to flower mucl better in the open air, and a more splendid sight than a bed of seedlings can searcely be imagined; every flower though of the deepest carmine has its petals of a pale blush celour on the under side, and every petal thougl of the palest pink has a dark carmine spet at its base. Thus the variety of colours displayed in a hed of these flowers almost exceeds description, and when they are seen under a bright sun, and agitated by a gentle breeze, the effect is extraordinarily brilliant. The culture of the Phlox Drummondi generally resembles that of the half-hardy annuals, though the plant itself is quite hardy. The seeds, which may be bought at any seed-shop, should be sown in pots in February, and placed in a gentle hotbed, or kept under shelter in the dwelling-house. Early in May the plants may be turned out inte the open berder, and in June they will be splendidly in flower; or by sewing the seed in pots and plunging the pots into a strong hotbed, or the tan-pit of a stove, flewers may be 
produced early in May or even in April. We saw some beautiful flowers in the first weck in May 1839, fully expanded, in the garden of Mr. Groom, florist, Walworth, which had been treated in this manner. If raised in the open ground, the sceds should be sown in A pril, and the plants will not flower till July. When any very splendid flower is produced, it may be propagated by cuttings, which must be kept in heat all tle winter and planted out in spring; but as plauts thus procured are very inferior to those raised from secd, it is better to take the cliance of a bed of seedlings, and select the best, if any should be wanted of peculiar beanty. Seedlings flower very well, kept singly in pots, and placed in a balcony, or under a veranda.

\section{GENUS II. \\ LEPTOSIPHON, Benth. THE LEPTOSIPHON.}

Lin. Syst. PENTANDRIA MONOGYNIA.

Generic Charactrar.-Calyx tubularly-campanulate. Lobes linear, subulate. Corolla funnel-gbaped. Tube very long, slender. Limb canpanulate, with oval obtuse lohes. Stamens inserted at the throat. Cells of capsule many-seeder.-(G. Don.)

Description, \&c.-These are some of the Californian annuals sent bome by Douglas, and they are valnable not only as being rery pretty, but as being quite hardy. The name of Leptosiphon signifies slender tube.

\section{1.-LEPTOSIPHON ANDROSACEUS, Benth. THE ANDROSACE-LIKE LEPTOSIPHON.}

Engravings.-Hiort. Trans. vol. i. New Ser., fig. 1 in t. 18 ; Bot. Mag. t. 3491 ; Bot. Reg. t. 1710 ; Bot. Gard. t. 593 ; Paxt. Mag. of Bot. vol. iii. p. 219 ; aod our fig. 3 , in Plate 27.
Specific Character.-Leaves 5-7-cleft. Segments oblong-linear. Tube of corolia 2_-3 times longer than the limb. Stamens 3 times shorter than the limb of the corolla.-(G. Don.)

Description, \&c.-The lively colours and numerous flowers of this little plant make it a desirable addition to our flower-gardens, but it has the great fault, common to many of the Californian annuals, of closing its flowers at an early hour of the day. The flowers vary from different degrees of lilac and blue to white, but tliey have always a black eye, and bright yellow anthers and stigmas, and the tube is usually red. This species is a native of Califurnia, and is one of the plants sent home by Douglas, in 1833. It is quite hardy, but as the lieat of the summer is apt to wither its roots, it does best when sown so as to flower in spring or autumn. Seeds may be procured at any seed-shop, and with regard to their culture, we cannot do better than copy some observations sent to us by the same intelligent and experienced gardener who assisted us with some remarks on flower culture at the commencement of this work.

"An economical way of rearing these, and probably all annuals which require to be sown very thick to make masses, is to sow the seeds in the autumn, say about the first week in September, on any trodden path, or other very hard bottom, first covering it about an inch thick with light soil. Here the young plants will grow all the winter; and as soon as the flower-beds are dug and prepared in spring, which is in February, March, or April, according to circumstances, the young seedlings should be taken up with the spade in patches, and laid on the flower-bed. All that remains is to fill up the openings between the patches with soil, and to press them gently down, so that the surface of the bed may be covered evenly. Of course by this process the beds may either be filled, each with one kind of flower, or with several kinds, according to the fancy of the gardener; and as the plants will be in full bloom early in May, they will have every advantage of sowing themselves, combined 
with the neatness attendant on spring sowing. To explain what is meant by this, it may be observed that at the latter end of autumn the flower-beds in every garden present a very untidy appearance; the ground is not only covered with dead leaves and stalks, but it has become rough and uneven from frequent rains, and to make it look well, it requires to be, what the gardeners call, dressed in October. This dressing, which consists of digging or forking the bed, and then raking it,.must of course disturb and indeed destroy the seedlings. It is, therefore, necessarily dispensed with in those gardens whcre plants are permitted to sow themselves, and the beds have consequently an untidy look tho whole year. The care of the seedlings also prevents the planting of crocuses, snow-drops, and the earlier kinds of Narcissus, as putting the bulbs into the ground would occasion blanks in the scedlings which would be very conspicuous when the plants came into flower. By the plan above mentioned of sowing the seeds of the Californian annuals in some remote corner of the garden, and bringing them by spadefuls to the beds when wanted in spring, the flower-garden may be kept in a state of beanty and neatness all the year. As soon as the annuals have done flowering, and the beds have been dressed in October, they mat be planted with wall-flowers bronght forward for the purpose and potted the preceding May, and which will give the buds a lively appearance during winter. When these have flowered, being biennials, they will die off, and may be clearcd away; and the beds, after being dressed, may be planted with the crocuses, \&c., which slionld lave bcen potted the previous August, and will soon flower after they are transferred to the open ground. When these are over, the beds may be smootlied for the Californian annuals, which are to be transferred to them by spadefuls as before directed. When these wither from the heat of summer, the beds may be filled with Petunias, Verbenas, \&c.; and when these fade they may be succeeded by fresh patches of Californian annuals. sown in spring as before directed for the antumn sowing, and which will keep the beds in beauty till October. Where Pctunias and Verbenas are not plentiful, spring-sown annuals may be made to supply their placc, and to succeed the autumn-sown ones."

$\because$.

\section{2.-LEPTOSIPHON DENSIFLORUS, Benth. THE CLOSE-FLOWERED LEPTOSIPIION.}

Emgravings.-IIert. Trans. vol. i. New Ser. t. 18, fig. 2; Bet. Specific Character.-Leaves 9-11-cleft. Sugmente subulate, Rig. t. 1725 ; Bot. Mag. t. 3578 ; Paxt. Mag. of Bot. vol. iii. p. 220 ; erect, with revolute margins. Tube of cesolla sherter than the limb. and eur fig. 2, in Plate 27. -(G. Don.)

Description, \&c.-The flowers of this species, though larger, are ncither so brilliant in their colours nor so elegant in their shape, as those of $L$. androsaceus. Tho want of brilliancy in the colour is occasioned by the centre or cyc being white, and the tube being short, thick, and pale; the petals also are round instead of pointed. The plant is a native of California, where it was discovered; and whence its seeds were sent to England in 1833 by Douglas, at the same time as those of $L$. ardrosaceus; the culture also is the same as for that plant.

\section{OTHER SPECIES OF LEPTOSIPHON.}

The following species were diseovered by Douglas, but bave not yet been introdueed.

L. GRANDIFLORUS, Benth.

Flowers large and blue, with a golden yellow or dark purple centre. 


\section{LUTEUS, Benth.}

Flowers yellow, with a deep orange-coloured centre.

\section{PARVIFLORUS, Benth.}

Flowers small, and of a pale yellow, with a darker centre. They are all low plants, flowering profusely the whole summer, or till killed by tho heat and dryness; and as they are all quite hardy, and resemble in habits the species already introduced, they would only require to be sown two or three times at different periods, to keep up a succession of flowors nearly all the year.

\section{GENUS III.}

\section{COLLOMIA, Nutt. THE COLLOMIA.}

\section{Lin, Syst. PENTANDRIA MONOGYNIA.}

Grenarc Casaactrin,-Calyx campanulate, 5.cleft. Corolla salver-shaped; tube slender; segments of the limb ebleng, entire. Stamens - inscrted towards the middle of the tube. Cclls of capsule 1-2-sceded.-(G. Don.)

Descriptron, \&c.-The word Collomia is derived from Collo, glue; in reference to the seeds being enveloped in a kind of gluey, sticking substance. The plants are all annuals, with small flowers, disposed in dense heads, and with very large bracteas. All the species have an untidy weedy appearance, and are scarcely worth cultivation.

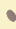

\section{1.-COLLOMIA HETEROPHYLLA, Hook. THE VARIOUS-LEAVED COLLOMIA}

Sxnonymz,-Gilia heterophylla, Doug.

\begin{tabular}{l|l} 
Engravings.-Bot. Mag. t. $2895 ;$ Bot. Reg. t. 1347. & $\begin{array}{l}\text { pionatifid. B } \\
\text { Specific Characten.-Plant prestrate, branched, clothed with }\end{array}$ \\
- (G. Don.)
\end{tabular}

glandular dowo. Lower leaves pinnatifid and cut. Upper oncs cuneated,

Descriptron, \&c.-The flowers are small, long in the tube, of a dingy purplish colour; and very few together in each licad. The stem is much branched, the leaves are sinall, and of different shapes; and like all the species of the genus, the whole plant has an untidy and weedy appearance. It was found by $\mathbf{A}$. Menzies, Esq. and afterwards by Dr. Scouler, near Fort Vancouver on the Columbia; but Douglas in 1826 discovered that it was a common plant on the hills of North America, growing in partially shaded places, and continuing in flower all the summer. It is one of the many Californian plants of which specimens were brought to England by Mr. Menzies in 1792, though the plants were not introduced till so many years afterwards. The plant is of the easiest culture, as it will grow in any soil or situation, and may be sown at any season whon the ground is not hard with frost.

\section{2.-COLLOMIA COCCINEA, Lehm. THE SCARLET COLLOMIA.}

Syмoxх мzs.-C. lateritia, D. Don.; C.Cavanilleaii, Hook et Arn.; | down. Leaves lanceolate-lioear. Upper ones ovate-lanceolate, quite Phlox linearis, Cav.; Phlox bifiora, Ruiz et Pavon.

Enganisgs.-Bot. Reg. 1622 ; Swt. Brit. Flow. Gard. t. 206 ; Bot. Mag. t. 3468.

Specific Character.-Plant erect, braoched, beset with glaodular entiro, or deeply 2-4-toothed at the apcx. Calyx semi 5-eleft, with bread-Ianceolate, obtuse scgmeots. Cerolla more than twice longer than the calyx. Cells of the capsule l-seeded.-(G. Don.)

Description, \&c.-This is unquestionably the handsomest species of the genus; and it in fact the only one worth growing as a garden flower. Even this, however, does not-look well unless sown in masses; and it should only be grown where there is abundance of space, and varicty is necessary. The flowers are of a bright 
scarlet, but they are so small, and the bracteas or involucral Jeaves so large, that scarcely any effect is produced by their brilliant colour. The leaves are remarkable from their being frequently divided into three sharp segments of unequal length. The plant is a native of Chili, from which conntry seeds were brought by Mr. Cuming in 1832. They are now common in all the seed-shops, and may be sown in the open border in March, when they will flower in June.

\section{3.-COLLOMIA LINEARIS, $N u t t$. THE LINEAR-LEAVED COLLOMIA.}

SYNoNYME, - C. parvifiora, HFook.

Engravings._-Bot. Reg. t. 1166 ; Bot. Mag. t. 2893.

Sprcific Cunasctex.-Plant erect, branched, clothed with glandular

hairs. Leaves ovate-lanceolate, quite entire, opaque, uniform, superior ones downy beneath. Calyx cup-sbaped, 5-parted. Corolla more than twice longer than the calyx. Cells of capsule 1-seeded.-(G. Don.)

Description, \&c.-The flowers are very small, and of a dingy purple; and they are so surrounded with the bracteas, and the dark green leaves, as to present very little beauty. This plant, which was the first described of the genus, was found by Nuttall on the banks of the Missouri river; but it was afterwards discovered in great abundance on the banks of the Columbia; and, in fact, its habitat appears to extend over a space of nearly sixteen lundred miles. It was introduced by Donglas in 1826 ; and it is now common everywhere. It is quite hardy, and only requires to be sown in the open border in March, to come into flower in May, and it continues flowering till July or August.

\section{COLLOMia GRANDIFLORA, Dougl. THE LARGE-FLOWERED COLLOMIA.}

Eneravings._Bot. Reg. t. 1174 ; Bot. Mag. t. 2394.

Specific Cruracter.-Plant erect, branched, rather downy at top. Leaves oblong.lanccolate, entirc, shining, ciliated with glands. Calyx 5-cleft, villons, glandular. Corolla ventricose. Limb spreading. Cells of capsule l.seeded.-(G. Don.)

Description, \&c.-The flowers of this species are much larger than those of any of the other kinds; but their colour when they first expand, is of a dingy yellow, becoming gradually of a nankeen or buff-colour, and they are surrounded with a glutinous substance, which renders them very unpleasant to the touch. The bracteas are also large, and the plant weedy-looking; but the stems are of a rich purple. The plant is a native of the country near the Columbia, where it was discovered and sent lome by Douglas in 1826. Seeds are now common in the seed-shops, and they only require sowing in March, to flower in May and June. Care must be taken, however, to sow the seeds in a poor soil and shady situation; as in a rich soil, the plants will produce more leaves than flowers, and in a hot, dry, exposed situation, they will wither without producing any flowers at all.

\section{5.-COLLOMIA GRACILIS, Doug. THE SLENDER COLLOMIA.}

SYwonYme. - Gilia gracilis, Hook.

Exerating.-Bot. Mag. t. 2924.

Specipic Cuaructra.-Plant erect, branched, clothed with glandular down. Leavcs lanceolate-oblong, obtuse. Calyx 5-parted. Calycine segments long, subulate. Stamens enclosed. Cells of capsule 1-seeded.(G. Don.)

Descniption, \&c.-A plant with small and insignificant dingy pink flowers, and very slender and numerous branches, bearing a much greater resemblance to the genus Gilia, than to that of Collomia. It is a native of California, where it was discovered in light soils, and on high grounds near the rivers. It was introduced in 1826 ; but we do not know where seeds are to be obtained. It is quite hardy, and its culture is the same as that of the other species. There are some other species of Colloraia; but they have not yet been introduced. 


\title{
GENUS IV.
}

\author{
GILIA, Ruiz et Paron. THE GILIA.
}

\section{Lin. Syst. PENTANDRIA MONOGYNIA.}

Genersc Character,-Calyx campannlate, 5-cleft. Corolla funnel-ahaped, or aub-campanulate; segments of the limb obovate. Stamen inserted in the throat. Cells of capsulo many-seeded.-(G. Don.)

Description, \&c.-The species of the genus Gilia are nearly all annuals, with the exception of the two beautiful plants called Gilia coronopifolia, syn. Ipomopsis picta, and G. aggregata, syn. I. elegans, which aro biennials, though the latter is frequently marked as an annual in botanical books and catalogues. The genus was named in honour of Philippi Salvador Gilio a Spanish botanist, and not in honour of Dr. Gillies, as is generally supposed.

\section{1.-Gilia INCONSPICUA, Dougl. THE INCONSPICUOUS GiLiA.}

Symonymes.-G. parviflora, Spreng.; Ipomopsis inconspicua, Smith; | the calyzes with glandular down. Leaves pinnatifid, lower ones biCantua parviflora, Pursh.

Engra ving.-Bot. Mag. t. 2883.

Specipic Cuaracten.-Stem mnch branclicd, and clothed as well as pinnate, aegments linear. Flowers solitary, terminal, panicled. Corolla about twice the length of the calyx.-(G. Don.)

Descriptros, \&c.-A little insignificant blue flower, introduced so long ago as 1793, when it was raised at Syon Housc, from American seed. It was first described by Sir James Edward Smith, and sought for by Pursh; but the exact locality of its native habitat was not known till it was found by Douglas on the banks of the Columbia in 1826. It is quite hardy, and grows best in a shady situation in sandy peat. We do not know where seeds are to be procured.

\section{2.-GILIA PUNGENS, Doug. THE SHARP-LEAVED GILIA.}

Synowyme,- Egochloa pungens, Benth.; Gilia squarrosa, Hook et Arm,; Hoitzia squarrosa, Esch.

Enoraving.-Bot. Mag. t. 2977.

clammy down. Leaves pinnate. Leaflets entire or crt, the lobes lanceolate-linear, very acute and spinose. Bractcas ciliately hairy, dilated at the base. Calycine segments lanceolate, nearly entire.

Spegrif Charactra.-Plant ereet, much brancbed, clothed with Corolla longer than the calyx. Stamens incloscd.-(G. Don.)

Description, \&c.-A very eurious plant of no beauty; with very small flowers, and a fetid smell. A native of California, where it was found by Douglas in moist valleys, and near the sources of the Mrulnomack river, one of the branclies of the Columbia. The plant was introduced in 1833 ; but we do not know where seeds are now to be procured.

\section{3.-GILIA ARENARIA, Benth. THE SAND-INHABITING GILIA.}

Sprcific Character, - Stem humble, clammy, nearly naked. Leaves pinnatifid, lobes ovate. Flowers somewhat glomerate; corolla three times longer than the calyx.-(G. Don.)

Description, \&c.-A very elegant little plaut with a slender stem, and delicate blue flowers. A native of California, and discovered there by Douglas. It was introduced in 1833 . A specimen of this species bas just been sent to us (August 16th, 1839), the flowers and buds of which are remarkably elegant and delicate; and judging from which, the species seems to us well deserving of cultivation. 


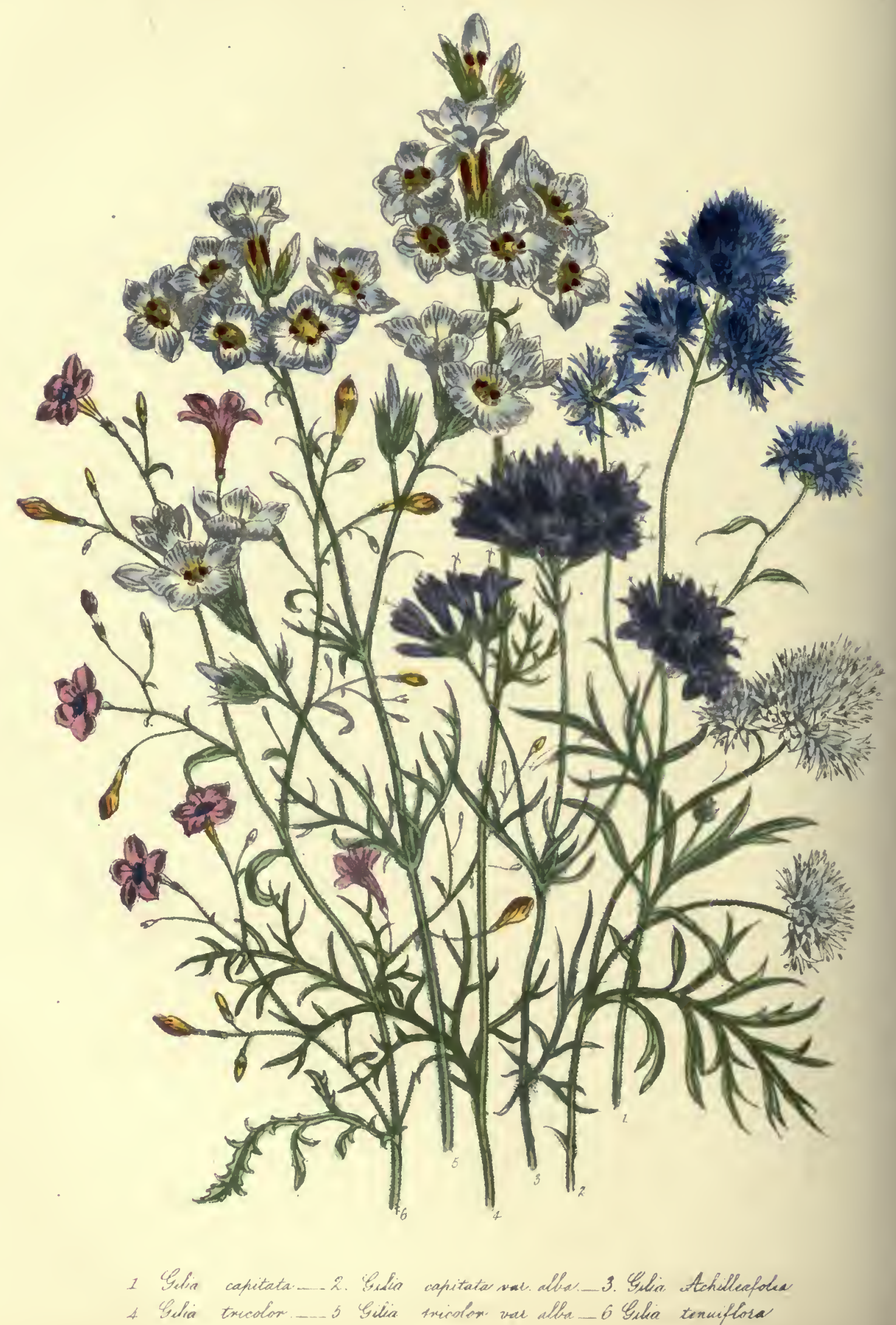





\section{4.-GILIA TENUIFLORA, Benth. THE SLENDER-FLOWERED GILIA.}

Exgravings,-Bot. Reg. t. 1888 ; and our fig. 6, in Plate 28. tary. Corymbs loose, on long peduncles. Corolla four timcs longer Sprctfic Character. - Sten erect, tall, clammy, nearly naked, than the calyx.-(Benth.) and paricled at top. Leaves glabrous, bipinnate. Fowers usually soli-

Descniption, \&c.-This plant is a striking proof of the difficulty of describing a plant accurately from dried specimens, as Mr. Bentliam, judging from the dried plant sent home by Douglas, called the flowers blue, while in fact they are of a beautiful pink. Dr. Lindley says, "the corolla is in reality of a rich, clear, uniform violet in the inside, and, on the outside, of a pale rose, but this colour is much affected by the presence of innumerable short deep-red lines, which are as delicate as if they were drawn with the point of a necdle." -Tlie "flowers change in drying from rose colour to blue." As there appears sometling remarkable about the colour of this flower we have transcribed Dr. Lindley's own words, and we have only to add that the colour of a living specimen which we received August 16, from Lee's Nursery, Hammersmith, was exactly that shown in our plate. It is a very pretty, delicate, and indeed beautiful flowcr, on long slender stalks, growing about two fect high and much branched. It was found by Donglas in California, and seeds were sent home by him in 1833, to the Horticultural Society's Garden at Chiswick, but only one plant was raised. It ripened, however, abundance of seeds, and is now grown as we have before observed at Lee's, and probably in some other nurseries. Seeds may be had also at Charlwood's. Douglas sent it hoine under the name of Gilia splendens, but we believe that name has never been adopted in England. The culture is the same as that of all the Californian annuals, see p. 156.

\section{5.-GILIA TRICOLOR Benth. THE THREE-COLOURED GILIA.}

Engrapings. - Hort. Trans. N. S. 1, t. 18, fig. 3 ; Bot. Reg. t. 1704 ; Swt. Brit. Flow. Gard. N. S. t. 264; Bot. Mag. t. 3463 ; Paxt. Mag. of llot, vol. i. p. 150; Bot. Gard. vol. vi. No. 509 ; and our fig. 4 , in Plate 28.

Varistres. -G. t: 2 alba, our $f g .5$, in Plate 28 ; syn. G. bicolor; G. t. 2 fl. albicantibus, D. Don.

Specific Character.-Stem erect, glabrous, leafy. Leaves bipinnate; leaflets or segments linear-subulate. Corymbs 3 to 6 -flowered, virgately panicled. Corolla about three times longer than the calyx.(Benth.)

Description, \&c.- This very pretty little annual is now so common in every garden, that it is not necessary to give any particular account of it, and the number of times that it has been figured during the six years that have passed since its introduction, shows the value that has been set upon it as an ornamental plant. It was found by Douglas in California, in 1833, and seeds were sent by him in that year to the Horticultural Society's Garden. The plant is of the easiest culture, and, if left to itself, will come up like a weed. It succeeds admirably, treated as we have recommended for the Leptosiphons, see p. 156; and by successive sowings in February, April, June, and August, beds of it may be kept in full flower the whole summer. Even if merely sown in February, and left to sow its own seeds as soon as they are ripe, it will produce a second crop the same year. Seeds may be procured in any seed-shop, and they are generally so thoroughly well ripened, that all that are sown will vegetatc. Gilia tricolor has a brilliant effect wben sown to form a bed by itself, but it also looks very well sown witl mignonette in the way directed for the Clarkias, see p. 57. The variety only differs in baving no lilac in the flowers; and as neither of the kinds grow above a foot high, they look very well sown together. Care should, however, be taken not to sow the seeds too thickly; as they look better when allowed to spread, than when drawn up. 


\section{6.-GILIA ACHILLEEFOLIA, Benth. THE MILFOIL-LEAVED GILIA.}

Esgravinas.-Bot. Reg. t. 1682 ; Bot. Mag. t. 3440; Swt. Brit. thrice pinuate; seginents or leaflets linear-gubulate. Corymbe Flow. Gard. N.S. t. 280 ; Paxt. Mag. of Bot. 1, p. I50; and our fig. 3 , in Plate 28.

Specipic Cuaracter. -Stem erect, smoothish. Leaves twico or capitate, many-flowered. on very long peduncles. Calyxes rather woolly. Corollas twice as long as the calyz. Stamens shorter than the corolla.-(Benth.) Flowers purplo.

Desuniption, \&c.-A pretty species of Gilia, not quite so well known as G. tricolor, but still tolerably common in gardens. It has smooth pale-green leaves, and a branching stem, seldom growing above a foot high ; and its flowers, though not so pretty as those of G. tricolor, are valuable from the long time they last. It is a native of California, whence its seeds were sent home by Douglas with those of G. tricolor. Its culture is the same as that of the other Californian annuals, and its seeds may be procured in every seed-shop.

\section{7.-Gilia CaPitata, Doug. THE ClUStered-FLOWERED GILIA.}

Engratings.-Bot. Mag. t. 2698 ; Bet. Reg. t. 1170 ; Swt. Brit. | Variesies._G. c. 2 alba, IIort., our fig 2, in Plate 28. Flowers Flow. Gard. t. 287; Bot. Gard. t. 202; and our fig. J, in Plate 28. white.

Descniption, \&c.-This species is very inferior in beauty to the other kinds. It las long slender stems three fect or four feet high, and the flowers, which are small, are produced in clusters. It was the first species of Gilia, introduced from California, having been sent home by Douglas in 1826. It only looks well in a large garden, where it should be in masses. $\mathbf{A}$ bed of it of considerable size has a very good effect, but a single plant has a very untidy, straggling appearance. The whito variety merely differs in colour from the species. Seeds are common in all the seed-shops, and they should be sown in the open border in March or April.

\section{OTHER SPECIES OF GILIA.}

Thicse are nearly all marked as having been introduced; but we bave never seen them in flower, and we do not know where seeds of them are to be procured.

\section{G. LINIFOLIA, Benth.}

This species has large white flowers and palmate leaves. It was found in California by Douglas, and seeds of it sent home in 1833.

\section{G. PHARNACEOIDES, Benth. But. Reg. 1622.}

Only differing froin the preceding in the flowers being about half the size. It was discovered in the sanc country, and sent home at the same time. It flowered for the first time in this country in $\mathbf{1 8 4 7 .}$

$$
\text { G. PUSILla, Benth. }
$$

Only differing in the flowers being still smaller than the last, and in the plant being prostrate. Found in Clili, by Dr. Bertero, and introduced in 1832.

\section{G. SESSEI, G. Don; syn. G. PINNATIFIDA, Sesse et Mooino.}

Stem dwarf, and much branched; leaves pinnatifid. Flowers produced in fascicles; corolla with a filiform tuhe, and brasteas long. A native of Mexico, not introduced. 


\section{G. LONGIFLORA, G. Don; ngn. CANTUA LONGIFLORA, Torrey.}

Plant quite smooth; leaves fnely pinnatifid. Stem much branched, panicled at top; flowers in loose corymbs; corolla salver-shaped, with a very long tube. A very remarkable species, haring very much the appearance of a Plilox. A native of the Canadian river, not yet introduced.

\section{G. CRASSIFOLIA, Benth.}

Leaves pinnatifid and woolly, flowers rather small and yellowish. The plant, which grows nearly two feet high, is a native of Chili, and was introduced in 1832.

G. LACINIATA, Ruiz et Pqvon; syn. CANTUA BREvifloRA, Juss.; THONNIA MULTIFIDA, Domb.

Flowers purplish, and jagged at the edges; leaves also much cut and pinnatifid. A native of Chili and Peru, but found also in California. Introduced in 1831.

\section{G. MULTICAULIS, Benth.}

Flowers blue, on very long peduncles; leaves bipinnate. A native of California, sent home by Douglas in 1833.

\section{CHAPTER XXIX.}

\section{LOBELIACE $\mathrm{E}$}

Essmantur Character-Calyx superier, 5-toothed, or 5-parted. like fringe. Fruit capsular or baccate; 1-2-celled; many-seeded. Corella menepetalous, irregular, inserted in the calyx. Limb 5.lobed, or 5-cleft. Stamens 5, perigynous. Anthers combined. Ovarium asually 2-celled. Stigma usually 2-lobed, surreunded by a cap.

Albumen fleshy. Milky berbs. Leares alternate, exstipulate. Flowers axillary, and terminal.-(G. Don.)

Description, \&c.-Nearly all the plants belonging to this order are remarkable for the beauty of their flowers, which are of the most splendid colours; but they are all dangerous in their qualities, on account of an acrid milk, in which they abound. The order consists of many genera; only a few of which contain annual plants.

GENUS I.

LOBELIA, Pohl. THE LOBELIA.

Lin. Syst. PENTANDRIA MONOGYNIA.

Generic Cgaracter.-Llmb of the calyx 5-parted. Corella with | bilabiate limb. Antbers cebering ; two lower ones usually beanicd. the tube eleft on the upper side, and thiekened at the base, with a Capsule 2-celled, 2-valved, dehiscent at the apex.-(G. Don.)

Description, \&o.-The genus Lobelia formerly included a great many flowers very dissimilar to each other; but it is now divided into several genera, nearly all the annual speoies, however, being still included in the true Lobelias. The name is taken from L'Obel, a Flemish botanist, who was appointed botanist of James I.; and it is interesting as being one of the first names bestowed in compliment to a living person. Pohl, who named the genus Lobelia, was indeed the first in modern times who introduced the practice, now so common, of complimenting individuals by naming plants after them with which they had no connexion. 


\section{1.-LOBELIA GRACILIS, Andr. THE SLENDER LOBELIA.}

Fingruvings. - Bot. Rep. t. 340 ; Bot. MLag. t. 741; and our fig. 5, | Racemes rather secund. Calyx length of filaments; superior isp of in Plate 29.

VARIETY,-L. g. 2 rosea, our fig. 6, in Plate 29.

Sprcific Cuaracter. - Plant glabrous, erect, branched a little.

Description, \&c.-A beautiful little plant, not growing more than six inches high, and flowering profusely. The species and variety were grown as edging plants in Forrest's Kensington nursery, and they produced a very good effect. The usual mode of planting them is, however, in a bed by themselves, so as to form a mass. This species was introduced in 1801, by George Hibbert, Esq., who raised it at Clapton, from seeds sent home by his collector, from the Cape of Good Hope. The seeds, which are now common in the seed-shops, should be sown in the open border in April or May, or they may be raised on a hot-bed, and planted out in May. They require a light rich soil, and sueceed best in a warm slıeltered situation.

\section{2.-LOBELIA HYPOCRATERIFORMIS, R. Brown. THE SALVER-FLOWERED LOBELIA.}

Enguvings.-Bot. Mag. t. 3075, and our fig. 3, in Plate 29.

Sצколуме.-Isotoma Brownii, G. Don.

Specific Charactra,-Glabrouls. Stems almost simple. Leaves

linear, quite entire. Corolla salver-sbaped, with an entire tube, and a somewhat uncqual limb. Flowers racemose.-(G. Don.)

Description, \&c.-This very beautiful species has been placed by Mr. G. Don in the genus Isotoma; and it does indeed appear rather to belong to that genus, than to the genus Lobelia. It is very handsome, and well deserves to be in general cultivation, but it is only rarely to be met with. It is a native of the south coast of New Holland; and it thrives best in a light rich soil.

\section{3.-LOBELIA RAMOSA, Benth. THE BRANCHING LOBELIA.}

Exgraviscs.-Botanist, No. 93; and our fig. 4, in Plate 29.

Synonymp.-L. colestina, Hort.

Specific Character.-Stem branched, nearly round, pubescent,

lower leaves pinnatifidly cut into segments ; upper leaves linear-lanceo-

late, slightly toothed. Peduncle like branches bearing one flower each. Corolla cut, with the middle of lower lip very broad, and slightly emarginate, smaller at the sides. Anthers all bearded. Capsule oblique.-(Benth.)

Description, \&c.-This very beautiful flower is remarkable for its brilliant colour ; and for the great length of time that it will continue in flower after it is cut. It grows two or three feet high, and continues in flower several months. It is a true annual, though it will last through the winter if preserved with care ; and it succeeds perfectly well if treated like Lobelia gracilis. It is a native of the Swan River, and was introduced in 1837. Seeds are not yet common in the seed-shops; but they may be had by members of the Horticultural Society from their garden at Cliswick, and from Mr. Low of Clapton, and some other nurserymen.

\section{OTHER SPECIES OF LOBELIA.}

The following species are all annuals, and nearly all well deserving of cultivation, but we do not know where sceds of them are to be obtained.

\section{CAMPORUM, Pohl.}

A dwarf plant, with blue flowers, a native of dry fields in the Brazils. 


\section{MOLLIS, Graham.}

Leaves eight lines long, and six lines broad. Calycine segment equal in length to the tube of the corolla, which is purplish, with the tube clcft along the npper side. Anthers purplish, having two short white awns projecting from their lower edge. Stigma almost simple, bearded (G. Don). This very distinct species is a native of St. Domingo, where it was collected by Dr. Krauss. It was introduced into England in 1828.

L. INFLATA, Lin. Swt. Brit. Flow. Gard. t. 99 ; syn. RAPUNTIUM INFLATUM, Mill.

A dwarf species with small pale-blue flowers; a native of North America, from Virginia to Canada, introduced in 1759.

\section{CHINENSIS, Lam.}

A creeping plant, with pale-blue flowers, on long footstalks; a native of China, near Canton.

\section{EXCELSA, Wall.}

A magnificent plant; growing ten or twelve feet high ; with large flowors, and leaves nearly a foot long. A native of Nepaul, not yet introduced.

\section{ROSEA, Wall.}

A plant from four to six feet high, with numerous rese-coloured flowers. A native of Nepaul.

\section{DEBILIS, Lin., jun.}

A little feeble plant, scarcely six inches high, with blue flowers. A native of the Cape of Good Hope, introdnced in 1774 ; and described by the younger Linnæus.

\section{CAMPANULATA, Lam.}

A dwarf plant, with blue, upright, bell-shaped flowers. Introduced from the Cape of Good Hope, in 1821.

\section{ANCEPS, Thun.}

A low plant with winged stems, and blue flowers. Introduced from the Cape of Good Hope in 1818.

\section{URENS, Lin.}

The flowers are purplish and not showy; and the wliole plant, if chewed, will be perceived to abound in a milky juice which excites an unpleasant sense of burning on the tongue. It is a native of England, in Deronshire, and it is also found in France and Spain.

\section{SERRULATA, Brot.}

A native of Gibraltar in sandy humid places; closely resembling L. urens; introduced in 1820.

L. TENELLA, Biv. ; syn. L. SETACEA, Smith; L. LAURENTIA, Brot.; L. MINUTA, Dec.

A prestrate plant, with the flowers greatly resembling those of Clintonia pulchella; a native of Portugal, introduced in 1821 . 


\section{GENUS II.}

\section{ISOTOMA, Lindl. 'THE ISOTOMA.}

\section{Lin. Syst. PENTANDRIA MONOGYNIA.}

Generic Chanacter. - Limb of calys 5-parted. Corolla salver- less; the two lower ones mucronate. Stigma capitate, protruding. shaped, or funnel-shaped, with sn entire or cleft tube, and a 5 -parted nearly regular limb. Filaments combined; anthers coheriag, beard-

Descriprion, \&c.-The name Isotoma slgnifics in equal sections; and it is given to this genus, from the segments of the cerolla being nearly equal.

\section{ISOTOMA AXILLARIS, Lindl. THE AXIL-FLOWERED ISOTOMA.}

ENGRaving8._Bot. Reg. t. 964 ; and our fig. 2, in Plate 29. |tifid, toothed; peduneles axillary, naked, elongated, I-flowered; Synonyme8.-Lobelia seneceides, Cunn.; L. senecionis, Spreng.

Sprcific Cyaractur. - Plant rather downy; leaves sessile, pinda. corella salver-shaped, with an catire tube.-(G. Don.)

Description, \&c.-One of the most elegant of border flowers. We have seldom been so much delighted with any flower as we were with this, when we saw it for the first time in the nursery of Mr. Hendersen, Pine Apple Place, Maida Hill. It is a native of the south coast of New Helland, whence it was introduced in 1824; but being supposed to be rather tender, and a perennial, it is only lately that it has come into general cultivation as a border annual. The seeds are now common in the seed-slops, and the plants do best raised on a hothed in February or March, and planted out in May. If sown in the open berder, it should not be till April or May ; in which case the plants will not flower till August or September.

\section{GENUS III.}

\section{MONOPSIS, Salis. THE MONOPSIS.}

\section{Lin. Syst. PENTANDRIA MONOGYNIA.}

Genzmic Ceurucrer.-Calyx tubular, 5-cleft. Corolla salrer-shaped, with a terete tube, which is cleft on one side, allowing the stamens to escape, and \& regular rotate limb. Anthers cohcring. Capsule 2-celled, many-seeded, debiscent.-(G. Don.)

\section{MONOPSIS CONSPICUA, Salis. THE CONSPICUOUS MONOPSIS.}

Engruvings.-Bot. Rep. t. 664 ; Bot. Mrg. t. 1499.

Synonymes.-Lobelia speculum, Andrews; Specularia, Solander.

Description, \&c.-This very curious little plant has been separated from the genus Lobelia on account of the regularity of its corolla, which in shape is more like a very small Convolvulus than a Lobelia. It is a prostrate plant, with very rich dark blue flowers, having yellew anthers, on very long naked footstalks. It is a native of the Cape of Good Hope, whence it was intreduced in 1812. It is not easy to say where seeds can be precured; but if they should be obtained, they should be sown on a hotbed in pots filled with peat and sand, and when planted vut in May, holes should be made in the border and filled with peat earth, into which they should be transplanted. 


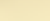

(.) - 


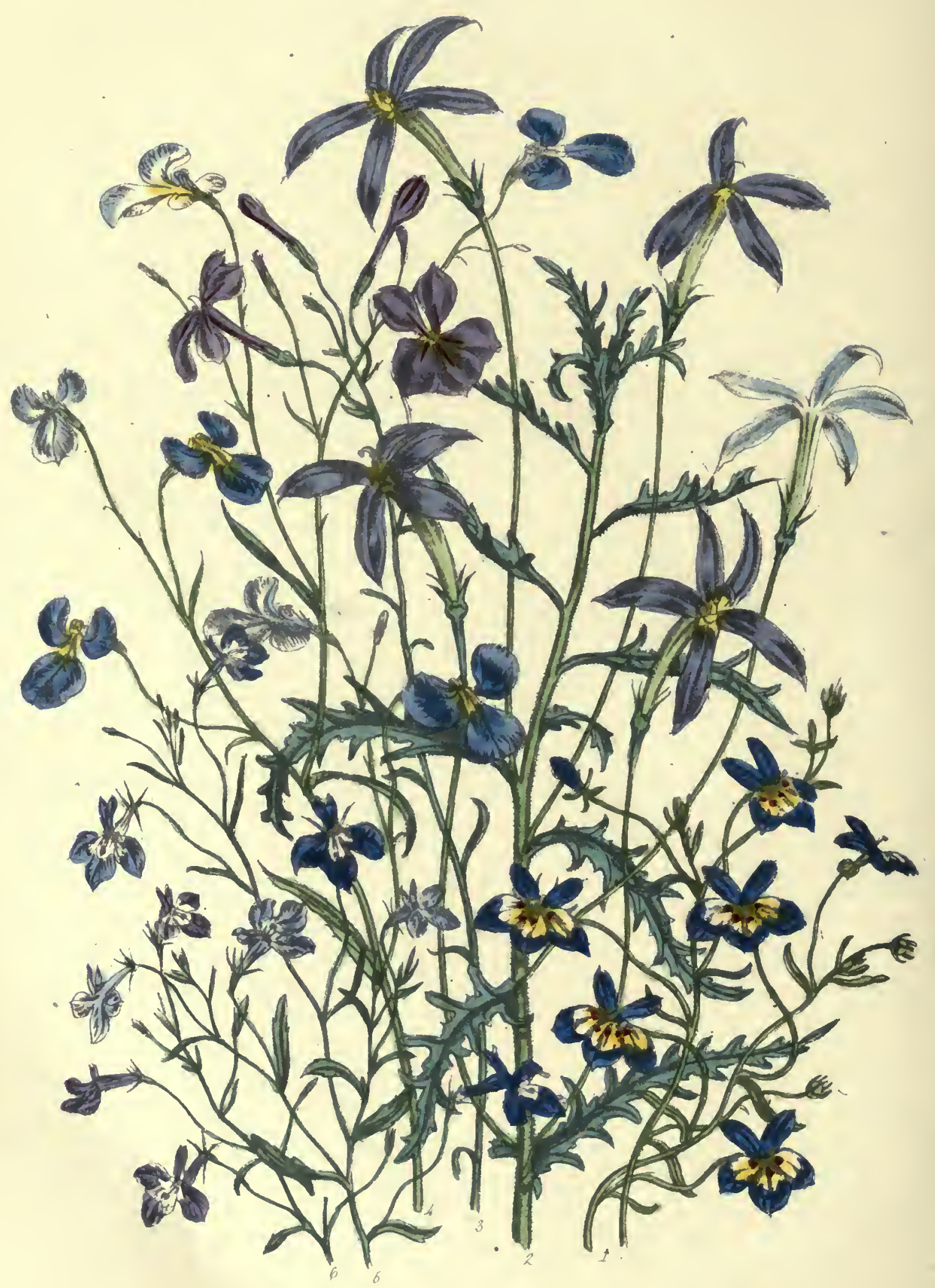

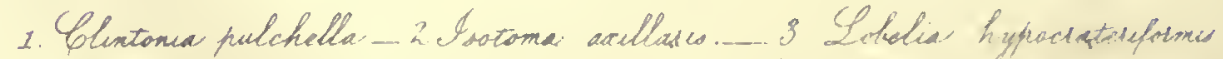





\section{GENUS IV.}

\section{CLINTONIA, Douglas. THE CLINTONIA.}

\section{Lin. Syst. PENTANDRIA MONOGYNIA.}

Gesersc Chanactek.-Limb of calyx 5-cleft. Corolla bilabiate, with hardly any tube. Anthers cohering; the two snperior ones bearded Capsule silique-formed, triangular, dehiscing by three loriform valves, many-secded. Seeds attached to two parietal placentas.-(G. Don.)

Deseniption, \&c.-Beautiful little plants, found by Douglas in North America, and named by him "in honour of the late De Witt Clinton, governor of the state of New York, and author of several ingenious treatises. on different branches of natural history."

\section{1.-CLINTONIA ELEGANS, Doug. THE ELEGANT CLINTONIA.}

Engruving. -Bot. Reg. t. 1241.

SpeciFic Character.-Glabrous, stem procumbent, brancbed, rather

sngular; leaves sessile, ovate, 3-veined; flowers solitary, axillary, scssile; ovarium sessile, long, acuminated.-(G. Don.)

Description, \&re.- When this plant was first found it was thought very beautiful, and Dr. Lindley deseribed it as looking, when sown in masses, like " $a$ earpet of silver and blue." It is now, hewever, so completely outshone by $C$. pulchella, that it is rarely to be met with. There is, nevertheless, eonsiderable general resemblance between the two species. C. elegans was found by Douglas near the Columbia river, and seeds of it were sent heme in 1827 , but they are not now to be preeured in the seed-shops.

\section{2.-CLINTONIA PULCHELLA, Lindl. THE PRETTY CLINTONIA.}

Encravings,-Bot. Reg. t. 1909 ; Swt. Brit. Flow. Gard. 2nd ser. t. 412 ; and our fig. 1, ln Plate 29.

Spectuic Character.-Leaves and sepals obtuse, upper lip of the

corolla divided into two ovato, acute, spreading segments; lower lip tripartite, and broad across the contre.

Description, \&c.-It is perhaps scarcely possible to imagine a more brilliant little flower than this, or one more ornamental for filling a bed, or a vase, or basket. It is alse remarkable for the length of time that it continues not only in flower, but in full beauty. Two vases fillcd with it in our garden at Bayswater have this year (1839) remained in full splendour since the month of May, till now, September 4; netwithstanding the heavy rains, violent winds, and other unfarourable circumstanees, which have tarnished the beauty of nearly all the other flowcrs in the garden. The plants appear still in a vigorous state, and they are ripening a few seeds, which are contained in long capsules, that appear at first sight to be the footstalks of the flowers. These curious capsules, when ripe, open on the sides, and show a number of very small seeds like dust. This beantiful little flower was discovered by Douglas in California in 1832, and seeds of it were sent home by him the same year to the London Hort. Soc. At first the seeds ripened se sparingly that it was feared the species would soon be lost; but a better method of treating it was soon discovered; and in 1838 , so great a quantity of it was grown for seed in Forrest's nursery, Kensington, and other places, that it is now common in nearly all the seed-shops. The species being quite hardy, the seeds may be sown in the open border with the other annual flowers; but it does best sown in a hetbed in March, and planted out in May. As it has a procumbent stem, and branches very 
much, a few plants will be suffieient to cover a small bed, or to fill a vase or basket. It is better suited for the latter purposes, or for rockwork, than for growing in the open border; as from the lowness of its stature the full beauty of its flowers cannot be so well perceived on the ground as when they are on a level with the eye, or lıanging graccfully over the edge of a basket or vase. In every situation, however, it is highly valuable.

\section{CHAPTER XXX. \\ CAMPANULACEÆ.}

Esegntua Chaructra.-Calyx usually 5-lobed. Corolla mono. free, rarely cembined. Stigma usually divided, with recurved lobos, petalous, regular, usually 5-lebed, with a valvate æestivation. Stamens $\mid$ Fruit superior, usually 5-cellcd, many-sceded, openiag at the sides or usually 5 , inscrted along with the corolla on the disc of the ovarium, aper. Albumen fleshy. Milky herbs. Leaves alternate, rarely and combined with it, but free from the corella. Aothers contigueus, epposite; inflerescence variable. Flowers usually drooping.-(G.Don.)

Description, \&c.-The genus Campanula of Linnæus, which gives its name to this order, used formerly to comprise nearly all the annual species; and though it lias been divided by modern botanists into several genera, we shall still describe the plants it contains by their old names, as being those they are most generally known by, giving the new ones among the synonymes. We shall, however, here say a few words on these new genera, and shall mention some of the reasons why they have been divided from the old genus. The word cumpanula, which signifies a little bell, refers to the shape of the flowers of the plants whicb are still retained in the original genus; while those with expanded corollas which shine in the sun, like the Venus's Looking Glass, are placed in a new genus called Specularia, from speculum, a mirror. Others that have long, prismatically-formed fruit, and erect flowers, like $C$. Prismatocarpus, are called Prismatocarpus; and others with beautiful star-like flowers like C. grucilis, and C.capensis, are now called Wahlenbergia. There are several others, the differences between which are not so easily pereeptible, making in all thirteen new genera, besides the old genus Campanula.

\section{GENUS I.}

\section{CAMPANULA, Fuchs. THE CAMPANULA, OR BELL-FLOWER.}

\section{Lin. Syst. PENTANDRIA MONOGYNIA.}

Grarric Cyaracter.-Corolla campanulate, fundel-shaped, or broadly tubular. Nectarium nene. Capsule 3-5-celled, net elongated. Cells when five, opposite the stamens and calycine segments. Herbs variable in babit.-(G. Don.)

Descriptiox, \&c.-Many of the most ornamental species of this genus are biennial, or perennial. The annual flowers are all quite hardy, and of the easiest culture. Their flowers, though bandsome, have, however, a degree of sameness in their appearance, as they are nearly all dark blue or purple, with some fcw varieties white.

\section{1.-CAMPANULA LOREYI, I'ohl. LOREY'S CAMPANULA.}

Exgravings.-Bot. Mag. t. 2581 ; Swt. Brit. Flow. Gard. 2nd Ser. t. 332 ; and our fig. 5 , io Plate $\mathbf{3 0 .}$

Synonymes.-C. Baldeosis, Balb. ; C ramossissima, Hort.

Variety.-C. L. 2 alba; and our fig. 5, ju Plate 30.

Specifis: Cunactrn,-Stem branched, few-flowcred. sessile, glabreus; lower ones obovate, crenated; middle enes oratelanceolate : superior ones lincar, entire. Calyx with a hispid tube, and long-acuminated, glabrous, apreading lobes, which are denticulnted at the base, leogth of corolla, which is somewhat retate. Capsule sphereid, deeply furrowed, and beset with strigose pili.-(G. Doni)

Description, \&c.-This very pretty species was named by the Italian botanist Pollini, in compliment to 



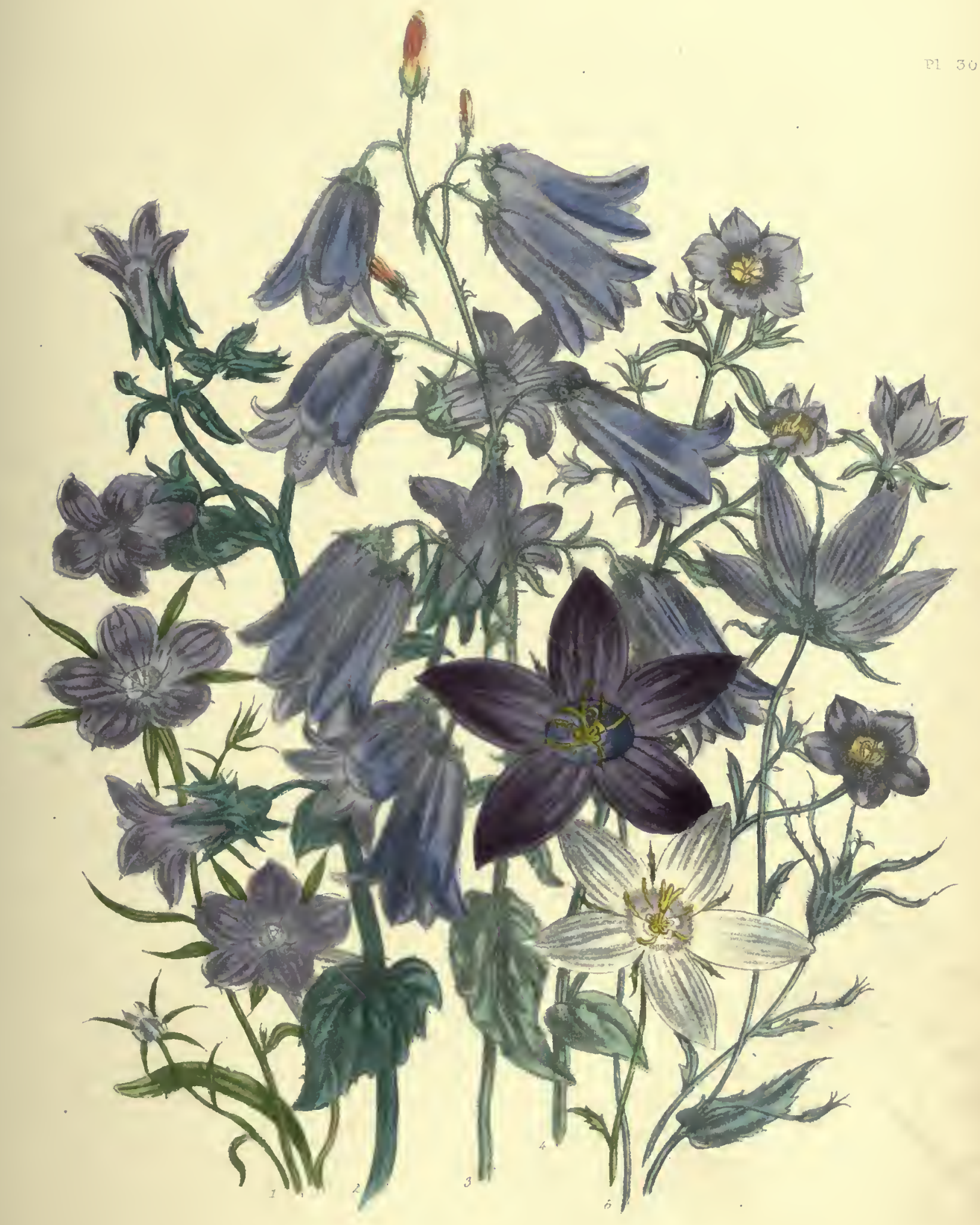



Dr. Lorey, who discovered it on Mount Baldo in the Veronese. It has since been found in several different parts of Italy, and was introduced in England about 1824. In the nurseries and seed-shops, it is generally called the new Venus's Looking Glass. It is quite hardy, and of the easiest culture; the seeds only requiring to be scattered on the border, and very slightly covered, to come up abundantly. The plants in dry weather require to be frequently noticed, as the roots are very slender, and are apt to wither up if not supplied with sufficient moisture. This species may be grown either singly in masses, or as an edging plant; for which last purpose it is very suitable, as nearly all the seeds will vegetate.

\section{2.-CAMPANULA DIVERGENS, Willd. THE SPREADING BELL-FLOWER.}

Sysenxmea,-C. spatulata, Waldst et Kit.; C. nutans, Vahl ; C. cernua, Balb.; C. pulcherrima, Hort.

Engruvings.-Swt. Brit. Flew. Gard., 2nd Ser., t. 256 ; and our fig. 3 , in Plate 30.

Specific Charactrr. - Plant pilese. Stem panicled; radical

leaves subspatulate, crenulated, narrewed at the base. Cauline leaves sessile, lanceolate, acuminated. Pedunclea many-flowered, diverging. Lebes of calyx bristly, long-acuminated, four times sherter than the corolla; appendages of the sinuses evate, obtuse, one half shorter tban the lobea,-(G. Don.)

Descriptron, \&c.-The flowers of this very handsome species are erect in the bud, but drooping in their expanded state. Many are quite smooth, and of a beantifully clear bright purple. The general appearance of the plant greatly resembles that of the common hiennial species, Campanula media, usually called the Canterbury Bell. C. divergens is a native of Hungary and Transylvania, and it has been also fonnd in Siberia. It was introduced in 1814; but it is not common in the seed-shops and nurseries. It is frequently considered a biennial, but if the seeds are sown very early in the season, say in February or March, in a light gravelly or chalky soil, or brought forward in a hotbed and planted out in April or May, the plants will flower early in June. Even if sown in the open border in April or May, they will generally flower the following Angust or September. The plants while growing should be well supplied with water; and if this be attended to, and the soil be such as to allow the free passage of the slender fibrous roots, the plants will grow with great luxuriance; and instances have been known of as many as fifty flowers having been produced from a single roat.

\section{3.-CAMPANULA SPECULUM, Lin. VENUS'S LOOKING-GLASS.}

Syvoxymes.-Specularia Speculum, Alph. Dec.; Prismatocarpus npeculum, L'Herit.; Campanula pulchella, Salisb. ; C. cordata, $V$ isioni.

Engravinga. - Bet. Mag. t. 102; and our fig. 4, in Plate 30.

VARIETX.CC. a. 2, alba. Flowers white.

Description, \&c.-No description appears necessary of this well-known flower, which has been grown in our gardens since the time of Gerard, 1596. It is a native of the south of Europe, and is of the easiest culture. If allowed to sow itself, it will flower nearly all the year without trouble; or it may be sown with the other annuals in spring.

\section{4.-CAMPANULA PENTAGONIA, Lin. THE LARGE-FLOWERED VENUS'S LOOKING-GLASS, OR FIVE-ANGLED BELL-FLOWER.}

SrNowYxys.-Priamatecarpua pentagenius, L'Herit.; Specularia pentagonia, Alph. Dec.

Engravinga._Bot. Reg. t. 56 ; and our fig. 1, in Plate 30.

Specific Character. - Stem branched, large. Flowers terminai,

solitary. Calyx beset with a fow stiff hairs, having a long prismatic tube, and long, linear-Janceolate, apreading lebes. Cerolla the length of the calycine lebes.-(G. Don.)

Description, 8c.-This species is frequently called, in the nurseries and seed-shops, the large flowered Venus's 
Looking Glass; and indeed it very much resembles C. speculum. The bud is curiously shaped, and distinctly 5-cornered, but when the flower expands, it is large, regularly-formed, and handsome. C. pentagonia is a native of the Licvant about Aleppo, and also of Greece. It was first cultivated in England by Ray, in 1686. It is quite hardy, and the seeds, which may be procured in any seed-shop, only require sowing in the open border. It lias a very good effect sown in masses, or patches; or it may be trained, by tying the stems to a slight wooden frame.

\section{5.-CAMPANULA DICHOTOMA, Lin. THE FORKED-BRANCHED BELL-FLOWER.}

Synowrmes.CC. mollis var., Willd.; C. Afra, Cav.; C. decipiens, | with dichotomous branches. Caulino leaves ovate, acnte, a little Ram. et Schultes.

ENGruvings._Swt. Bit. Flow, Gard, to 280 ; and our fig. 2, in Plate 30. crenated. Flowcrs sessile in the forks of the branches. Calycine lobes long, subulate, one-half shorter than the corolla. Appendages of the sinuses of the calyx subulate, one balf shorter than the lobes.Sprcific Cinaracter-Plant clothed with stiff haira. Stem crect | (G. Don.)

Description, \&c.-A rather curious plant, with an angular stem from six inches to a foot high, much branched ; and the brauches angular, spreading, hairy, and forked at the onds, which terminate in flowers. The flowers are dark blue; and, springing from the forks of the branches, they have a very singular appearance. This species, which is a native of the shores of the Mediterranean, was introduced about 1820 . The seeds, which may be procured at Charlwood's, and other seed-shops, should be sown in the open border in light rich soil, in March or April ; and the plants if too thick may be transplanted in May. They will not need any othcr care; but if it be thought advisable, they may be trained by tying the branches to a light wooden frame, so as to display the flowers.

\section{OTHER SPECIES OF CAMPANULA.}

The following species are marked as annuals in Don's Miller, but we do not know where seeds of them are to be procured.

\section{LINGULATA, Waldst et Kit.}

Root branched. Stems many from the same root. Leaves tongue-shaped. Flowers in dense terminal heaps. A native of Hungary; introduced in 1804.

\section{DRAB EFOLIA, Sibth. et Smith.}

The flowers are white, tipped with blue or violet-colour. The plant is of very low growth; it is a native of Greece, and was introduced in 1823.

\section{HERMINII, Hoff.}

A native of Portugal; introduced in 1823. The root is rather thick; the stem is upright and panicled at top; and the flowers are pale blue.

\section{RAMOSISSIMA, Sibth. et Smith.}

Very nearly allied to C. Loreyi. A native of Greecc; introduced in 1820.

\section{LOEFFLINGII, Brot.}

Flowers solitary, terminating the naked branchlets, loosely panicled, drooping. Corolla funnel-slaped, blue or violaceous, with a deeper coloured zone beneatli the middle, white at the basc, both inside and outside. A native of Portugal, in sandy places; introduced in 1818. 
C. FAICATA, Ræm. et Schultes; syn. PRISMATOCARPUS FALCATUS, Tenore; SPECULARIA FALCATA, Atph. Deo.

The flowers, which are rose-celeured, grow so close to the stem, and are so intermingled with the leaves, as to form a kind ef leafy spike. The lebes of the calyx are sickle-shaped. A native of the shores of the Neditcrranean; introduced in 1820.

$$
\text { C. HYBRIDA, Lin. ; P. HYBRIDUS, L'IIerit.; S. HYBRIDA, Alph. Deo. }
$$

A native of Britain, with small pinkish flowers.

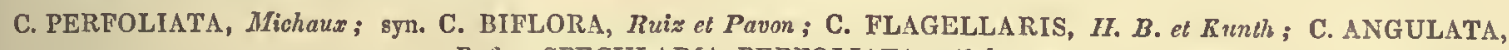
Rafin; SPECUlaria PERlioliata, Alph. Dec.

Flowers sessile, rising from the axils of the leaves, selitary, or $2-3$ tegether, and longer than the leaves. Corolla blue, always longer than the calycine lobes. A native of North America; introduced in 1680.

C. DEHISCENS, Roxb.; syn. WAHLENBERGiA DEHISCENS, Alph. Dec.

A Nepanl species, with small white flowers; introduced in 1818. There are several other species natives of Nepanl.

C. CAPENSIS, Lin.; Bot. Mag. 782 ; syn. C. ElongatA, Will, ROELla DECURRENS, And. Bot. Rep. t. 238 ; WAHLENBERGIA CAPENSIS, Alph. Dec.; W. ELONGATA, Schrad.

Flowers dark purple, and produced on very long footstalks. Plant from one foot to two feet high. A native of the Cape of Geod Hepe; introduced in 1803.

\section{CernuA, Thun.; syn. WAhlenbergia CernuA, Alph. Dec.}

Stem very leafy at the base. Peduncles crect, elengated, terminating in numereus I-flewered filiform pedicels. Corella funnel-shaped, with a white base, and blne lobes, dreoping in the bud state. A native of the Cape of Good Hope ; introduced in 1804.

C. LOBELIOIDES, Lin. \&c., \&c.

This species has very pale red flowers. It is a native of Madeira, and was introduced in 1777 . It has many synonymes.

\section{CHAPTER XXXI.}

\section{AMARANTHACEA.}

Essential Craractert.-Perianth 3-5-parted, persistent, usually | solitary or numerous; stigma simple or compound. Fruit an utriele. bibracteatc. Stansens $3-5$, distinct or joined, uswally having alter- Albunen farinaceous; embryo curved. Leaves alternate or opposite; nate, filiform, processes between. Ovarium free, l-celled; ovules exstipulatc. Flowers in heads or spikes. - (G. Don.)

Descriptios, \&c.-The genera comprised in this order which contain ornamental annuals are Amarantus, Celosia, and Gomphrena; plants differing so widely from each other that it is difficult for any one but a botanist to imagine any relationship between them. Seme ef these being seldem planted in the open ground, we shall not give their botanical details. According to Dr. Lindley's arrangement, the orders Amaranthacea, Chenopodiacea, and Polygonacece should have preceded Nyctaginacea. 


\section{GENUS I.}

AMARANTUS, Lin. THE AMARANTH.

\section{Lin. Syst. MONGCIA PENTANDRIA.}

Generic Character.-Caly 3 3 5 sepals; corolla wanting. Male stamens $3-5$. Femalo styles 3 ; capsule 1.cellcd, and opening herizontally. Secd 1.- (Lin.)

Descniptios, \&c.-The flowers of plants belonging to this genus are remarkable for their small size, and the brilliant effect which, notwithstanding this, they produce, from the great numbers of them that are clustered together. What we call a flower of Love-lies-bleeding, for example, is in reality a spike containing thousands of flowers, some male and some female, none of which have any corolla, but which produce their effect by their coloured sepals and bractea, the texture of which is so dry and thin, that the flowers, even after they are gathered, are a long time before they decay. This quality lias procured the genus the name of Amarantus, which is derived from two Greek words signifying never-withering. The Amaranth of the poets (Gomphrena globosa) is lowever now removed to another genus. The leaves of all the species of Amarantus are wholesome food, and several of them are eaten in their native countries like spinach.

\section{1.-AMARANTUS CAUDATUS, Lin. LOVE-LIES-BLEEDING.}

Sfecific Character.-Racemes compound, terminating, pendulous.

Description, \&C.-This species is easily distinguished from all the others belonging to the genus by its long, pendulous racemes of deep crimson flowers; the racemes having been frequently found to measure from two feet to three feet long. The plant is a native of the East Indies, but it appears to have been in cultivation in this country since the time of Elizabetli, as Gerard tells us that he received the seed of it from Lord Edward Zonch, and grew it in his garden. It was called Branched Flower Gentle, and Fleur-d'amour, a name that was afterwards corrupted into Floramore. In France it was called Discipline-des-religienses, and Queue-de-renard. The seeds, which are small, black, and slining, may be had in any seed-shop; and though formerly it was considered necessary to sow them on a hotbed, it is now found that they will succeed perfectly well if treated like those of Flos Adonis (see p. 5). When the plants come up they will require thinning, and frequent waterings in dry weather. The situation where the seeds are sown should be dry, warm, and open; and the soil should be very ricl, if it is wislied to grow the plants to a large size. The plant called the Tree Amaranth is considered by Miller to be a variety of this species.

\section{2.-AMARANTUS HYPOCHONDRIACUS, Lin. PRINCE'S-FEATHER.}

Specific Chsracter._Racemcs compound, crowded, ereet; leaves obleng-lanccolate, mucronate.-( Lin.)

Descruption, \&c.-The Prince's-feather differs from Love-lies-bleeding chiefly in its spikes of dark crimson flowers being much smaller and more upright. It is also much hardier, and when allowed to sow itself, it comes up in such abundance as to be quite a wced. It is a native of Virginia, and was introduced in 1739. There is a variety with green flowers, and another lately raised in Belgium which is much more branched than the common kind. The name of hypochondriacus, which signifies melancholy, is supposed to allude to the dull reddisll-green of the leaves, and to their dark dingy purple veins, which certainly give tlie plant a very gloomy appearance. 


\section{OTHER SPECIES OF AMARANTUS.}

\section{A. TRICOLOR, Lin}

This species takes its name from the brilliant colours of its leaves when kept in a hothouse, though they lose their brilliancy when the plant is grown in the open air. Some of these leaves are blue tipped with red, others red tipped with yellow, and others red, green, and violet. When a plant of this species is well grown, it assumes the shape of a pyramid, and is very handsome. It is a native of Ceylon and other parts of the East Indies, and was introduced before 1596.

\section{A. SPECIOSUS, Sims, Bot. Mag. t. 2227.}

This is a very showy species; the stem is erect, and much branched; the flowers are of a bright dark crinsson, and disposed on small lateral racemes, growing almost in whorls round the main one, in such a manner as to givo them a very graceful and featliery appearance, and the leaves are dark purple above and red beneath. This very handsome plant was raised from seeds received from Nepaul in 1820, by Sir George Staunton, at that gentlemanss beautiful seat, Leigh Park, near Havant; but it is not likely to become a general favourite, from the great heat required to bring it to perfection.

A. BLITUM, Lin., Eng. Bot. 2212.

This is a common British weed, which we only name here to prevent it from being confounded (as it often is) with the Strawberry blite.

\section{GENUS II. \\ CELOSIA, Lin. THE COCKSCOMB. \\ Lin. Syst. PENTANDRIA MONOGYNIA.}

Ganenuc Charucter.-Number of bracts uncertain, rough, acuminated, set under the flower. Calyx of five leaven, rough. Stamens ono shorter than the rest; filaments broadest at the baso. Stigma 3-cleft. Capsule truncated, many-seeded.-(Lindl.)

Description, \&c.-Tender annuals, with very curions flowers. The name of Celosia is said to be derived from a Greek word signifying something burnt, because the flowers look as if scorched, and dried up, by exposure to heat.

\section{1.-CELOSIA COCCINEA, Mill. THE SCARLET COCKSCOMB.}

Enoraving.-Bot. Reg. t. 1834.

furrowed; ears numerous, and compressed into the form of an acu-

Spвcinc Снциствn.-Leaves narrow, lanceolate, acuminate; stem minated pyramid; stamens shorter than the calyx.

Description, \&C.-A very curious plant, differing from the common Cockscomb not only in the looseness of the liead of flowers, but in its shape, which is that of a pyramid. It is also a much hardier plant, and only requires to be raised on a hotbed, and not planted out till May; after which, as Dr. Lindley observes, "it gocs on enlarging its glowing crimson tassels in the open border, till winter destroys it." This plant is supposed to be a native of China, from which country it is said to have been introduced before the time of Gerard, 1597 .

\section{CELOSIA CRISTATA, Lin.}

This very handsome and well-known plant derives its popular name of Cockscomb from its crested head of flowers, which resembles in form and colour the crest of a cock. It is a tender annual, a native of Japan, and other 
parts of Eastern Asia; introdueed in 1570. The seeds, which are small, black, and shining, like those of Love-lies-Bleeding, may be procured in any seed-shop, and the plants raised on a hotbed. The after culture is exactly like that of the garden Balsam; the size and beauty of the cockscomb depending upon the number of times it is shifted into different pots before it comes into flower. There is a drawing of a very large Cockscomb in the Library of the Horticultural Socicty in Regent Street. This plant, wlich was raised by the late T. A. Knight, Esq., at Downton Castle, was very large, the flower measuring eighteen inclies in width, and seven in height; but, in 1834, a much larger was sent to Mr. Loudon by Mr. John Pattison, gardener to Joseph Trueman, Esq. Grosvenor Housc, Walthamstow, Essex. This enormous Cockscomb, which was perhaps the largest ever grown, measured in licight two feet four inches; one of the leaves was one foot long and five inclies broad: and the flower was very nearly two feet in length, and fifteen inclies in breadth. It was also remarkably well-grown, with healthy lcaves, and a very handsome symmetrical flower; and, if we recollect rightly, it liad, in the course of its culture, been shifted successively into eleven diffcrent pots, each a little larger than the preceding one. There are several other annual species of Celosia; but it is said that they will none of them live but in the temperature of a stove.

\section{GENUS III. \\ GOMPHRENA, $R$. Br. THE GLOBE AMARANTH. Lin. Syst. PENTANDRIA DIGYNIA.}

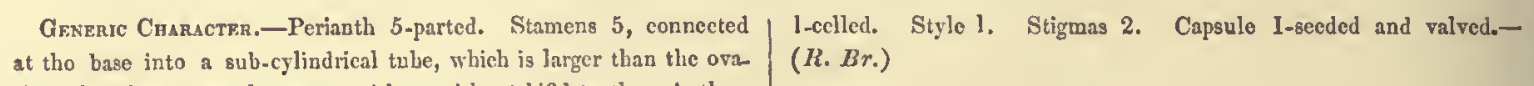
rium, but distinet at tbe apex; with or without bifid teeth. Anthers

\section{GOMPHRENA GLOBOSA, Lin.; Bot. Mag. t. 2815.}

This is evidently the true Amaranth of the pocts; as its flowers are as they describc, round, of a deep purple, and everlasting. Notwithstanding this, the plant when growing has but little beauty to recommend it; the sliape of the heads of the flowers resembles that of the heads of common clover, and they are produccd on long stiff stalks bare of leaves. When gathered and closely examined, the colour, texture, and structure of the flowers will be found very bcautiful. The most remarkable quality in the Globe Amaranth is its long duration. The calyx, which constitutes the flowcr, is indeed of so dry a texture that it seems dead even while it is growing, and it is to this fine thin membranous texture that the flowers owe their glossiness and beauty. The Globe Amaranth is a native of the East Indies; and though it was not introduced into England till 1714, it bas been long known on the Continent. It appears in cvery country where it has been known, to have been a favourite decoration for funerals. Homer describes the Thessalians as wearing crowns of Amaranths at the funeral of Achilles; and Milton, when speaking of the multitude of angels assembled before the Deity, says,-

$$
\text { " }
$$

With solemn adoration down they cast

Their crowns, in-wove with Amaranth and gold

Immortal Amaranth, a flower which once

In Paradise, fast by the tree of life,

Began to bloom, but soon for man's offence 
To heaven removed, where first it grew, there grows

And flowers aloft, slıading the fount of life.

And where the river of bliss, through midst of heaven,

Rolls o'er Elysian flowers her amber stream;

With these that never fade, the spirits elect

Bind their resplendent locks enwreathed with beams;

Now in loose garlands thick thrown off, the bright

Pavement, that like a sea of jasper shone,

Impurpled with celestial roses smiled."

In the churches on the Continent, the Globe Amaranth is generally used, as a symbol of eternity, to deck the shrines on fête days; and it is sold in Paris with the Gnaphalium, the Helichrysum, and the Xeranthemum, woven into wreaths, to hang on the tombs in the cemetery of Père la Chaise.

\section{CHAPTER XXXII.}

\section{CHENOPODIACE E.}

Essentua Craracter.-Perianth deeply divided, persistent, with the bottom of the cell. Style usually eleft. Pericarp valveless. an imbricato sestivation. Stamens inserted in the bottom of tho perianth; equal in number to its segments, and opposito to them, seldom fewer. Ovarium usually freo, one-seeded. Ovulum fixed to Albumen mealy. Embryo curved or spiral. Herbs, or undershrubs. Leavesalternate, rarely opposite. Flowers insignificant, often unisexual. -(G. Don.)

Description, \&c.-This order comprises several of our eommonest and most worthless weeds, with several valuable spinach plants. The flowers are greenish, and inconspicuous; and the only ornamental plants belonging to the order owe their sole beauty to their fruit.

\section{GENUS I.}

BLITUM, Lin. THE BLITE.

Lin. Syst. MONANDRIA DIGYNIA.

Generic Chumeter.-Calyx 3-eleft. Petals none. Fruit a berry.-(Lin.)

\section{1.-BLITUM CAPITATUM, Lin. THE BERRY-HEADED STRAWBERRY BLITE, OR STRAWBERRY SPINACH. \\ Spectife Character.-Wlleads spiked, terminal.-(Lin.)}

Description, \&c.-The plant grows generally two or three feet high, and spreads proportionately where it is allowed room. The leaves resemble those of spinach. The flowers appear in small heads at every joint, and at the termination of the twig; and, after they have dropped the bracts, swell like those of the pine-apple, and form a berry-like fruit, which when ripe has somewhat the appearanee of a wood strawberry, or rather of a red mulberry. The seed is black when ripe. The plant is a native of Central Europe, and was grown by Parkinson in 1633.

2.-BLITUM VIRGATUM, Lin. THE COMMON, OR SLENDER-BRANCHED STRAWBERRY BLITE.

$$
\begin{aligned}
& \text { ENGRArsms.-Bot. Mag. t. } 276 . \\
& \text { Specirio Cauracter.-Heads scattered, lateral.-(I, } i \text {. } .)
\end{aligned}
$$

Description, \&c,-Differing very slightly from the preceding species, but not having any terminal heads. It is a native of the south of Europe, and was introduced in 1759. Both speeies were formerly favourites in 
gardens, and the berries were used for colouring made-dishes in cookery. The seeds should be sown in March or April, and when the plants come up they should be thinned out; observing, however, that they will not bear transplanting after the flower-stem has begun to grow. They require frequent watering, and if the flower-stems are supported with sticks, so that the branches may spread out handsomely on each side, the plants will look very well when in fruit.

\section{CHAPTER XXXIII.}

\section{POL YG ONACE E.}

Hasential Character.-Perianth 1-leaved, divided, imbricated in farinaceeus; embryo inverted, generally on one side. Leaves alterastivation. Stamens deficite, inscrted la the base of the periantl. nate, sheathing at the haso or adnate to the intra-foliaceous sheath. Ovary free, l-secded; orule erect. Styles numerous. Albumen Flowers usually of separate sexcs, gencrally racemose.-(G. Don.)

Description, \&rc.-Several very well-known plants are classed by modern botanists in this order ; the most remarkable of which are the Buckwheat (Polygonum Fayopyrum), tart Rhubarh (Rheum undulatum), Docks and Sorrels, \&c. The only ornanental annual plants in the order are the Persicarias.

\section{GENUS I.}

\section{POLYGONUM, Lin. THE POLYGONUM.}

Lin. Syst. OCTANDRIA TRIGYNIA.

GrNeric Character.o-Calyx 5-parted, celeured. Cerolla nenc. Seed 1, angular,-(Lin.)

Description, \&c.-The genus Polygonum comprises many British weeds, particularly the Knot-grass ( $P$. ariculare), which is so common in garden walks; the showy-Water pepper ( $P$. amphibium), so abundant on the large piece of water in Kensington Gardens; and the common Persicaria. The Buck-wheat, as we have already observed, also belongs to this genus. The only plant, however, included in it which is cultivated in gardens, is the Garden Persicaria (P. orientale).

\section{1.-POLYGONUM ORIENTALE, Jacq. THE GARDEN PERSICARIA.}

Esgravings.-Bot. Mag. t. 213.

Sprcific Churacter.-Stem erect. Leaves ovate. Stamens 7, styles 2. Stipules hairy, and hypocratiform.

Description, \&c.--The Garden Persicaria is a very showy plant, growing, in favourable situations, eiglit or ten feet high, with loose branched spikes of deep rose-coloured flowers. The flowers are much larger than these of any other plant of the genus; and the stipules show plainly the peculiarity of their construction, which moderu botanists make one of the distinguishing characteristics of the order. This peculiarity is termed ochrece or boots, and it consists in the stipules being joined together round the stem, and forming a sort of tube for the joints to pass through. In the Garden Persicaria the stipules are so large, and so much wrinkled, that they look like deep ruffles. There are two varieties, one $d$ warf, and the other with white flowers. The species is a native of the East Indies, and also of $\Lambda$ sia Minor and Egypt; and it was introduced in 1707 , by the Ducless of Beaufort. Though a native of hot countries, it is quite hardy; and only requires sowing with the other annuals in March or April. It should be sowed thin, as the seeds keep well and generally all vegetate; and when it comes up it should be thinned out, or left in a mass, according as it is wanted to grow high or spreading. It is an excellent plant for London gardens where tnere is room for it to grow, as it is not in the least degree injured by smoke. 


\section{CHAPTER XXXIV.}

\section{COMPOSITA.}

Ejasentul Character.-Limb of calyx wanting or membranaceous, or divided into bristles, palex, or hairs. Cerolla 5-toethed or 5-lobed, tubular, ligulate, or bilabiate, inserted on the top of the ovarium. Stanens 5, distinct, perigynous. Anthers combined, seldom frec. Ovarium adhering to the tube of the calyx, 1-colled, l-seeded. Style one. Stigmas two. Fruit an achenium crowned by the limb of the calyx. Albumen none. Usually herbs, rarely slirubs. Ineaves exstipulate. Flowers disposed in heads on a receptacle, or surrounded by an iovolucrum, the scalcs of which are semetimes mixed with the flowers and are then called palcæ. $-(G$. Don. $)$

Description, \&c.-Composite flowers take their name from being each composed of a great number of small flowers or florets. Thus what we call a daisy, is in fact a head or cluster of small flowers, eacls perfect in itself, and each eapable of producing fruit or seed. These small flowers, or florets, are of two kinds: viz. those composing what is called the ray, and which in the daisy are white; and those composing the disk, which in the daisy, and many other composite flowers, are yellow. The florets of the ray are called ligulate, and are shaped somewhat like a cornet of paper, being widely open at top, and tubular only at the bottom; while the florets of the disk are called tubular, from thcir bcing tube-shaped throughout. In many of the genera, as for example in the Dandelion, the seeds or rather the fruit, are crowned with a kind of feather or wing, which botanists call the pappus. As the flowers belonging to this order are very numerous, botanists have classed them in several minor divisions; and the latest and most masterly of these modes of arrangement is that given by Professor De Candolle in the fifth, sixth, and seventh volumes of his Prodromus, in which all the Compositio are arranged in three great divisions; and these are again divided into cight distinct tribes. It would be uscless, in a work like the present, to enter into any detailed account of these tribes; particularly as several of them do not contain any ornamental annual flowers; and we shall therefore content ourselves with merely placing the flowers contained in each tribe together, and mentioning the name of the tribe before that of the first plant belonging to it that we describe. The generic and specific characters are greatly shortened; and we are indebted for them to our excellent friend Geo. Don, Esq., F L.S., whose merits as a botanist are too well known to need any eulogium from us. We liave generally retained the popular names of the plants, by which they are known in the nurseries and seed-shops, as the principal ones; and have given the new names as synonymes: but in some instances we have deviated from this rule; as for example in calling Madia splendens by its new name of Madaria; Rudbeckia amplexicaulis, Dracopis, \&c. ; because these names were attached to the figures of the flowers in our plates.

Before quitting the subject it may be as well to mention that the old arrangement of the composite flowers was into tlurce sections, the furst of which contained the radiate flowered plants, such as the aster, the sun-flower, \&c., the flower-heads of which consist of tubular florets in the disk and ligulate florets in the ray; the second, the thistle-headed plants, the florets in the flower-heads of which are all tubular, but spreading very wide at the mouth, as in the Centaurea or Bluebottle, Sweet Sultan, \&c. ; and the third, the succory-headed plants, the flower-heads of which are composed entirely of ligulate florets, such as the Tragopogon or Goat's Beard, Hawkweed, \&rc. 


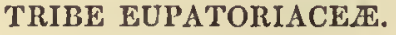

\section{GENUS I. \\ AGERATUM, Lin. THE AGERATUM. \\ Lin. Syst. SYNGENESIA RQUALIS.}

Generse Charaeter.-Head of many flewers, nesrly globose. Involuero consisting of many imbricate linear seales. Rereptrcle naked. Corolla 5-cleft. Fruit nearly pentagonal, attenuated at the baso. Pappus paleaceous.

\section{1.-AGERATUM MEXICANUM, Sims. THE MEXICAN AGERATUM.}

Srnonyme,-A. conyzoides, var. Mexicanum, Dec.

Erescir Character.-Stem hairy. Leaves ovate, bearly obtuse. and our fig. 1, in Plato 31.

the apex.

Description, \&c.-This very curions flower was introduced in 1822 from Mexico, by Mr. Bullock, so well known about that peried for his exhibition of rein-deer, \&c. The name of Ageratum is taken from two Greek words, signifying not to grow old; in allusion to the great length of time that the plant continues in flower without changing. Ageratum Mexicanum is generally considered as a half-hardy annual, and is raised on a hotbed in Fobruary, and planted out in May; and though the seeds may be sown in a warm border in April withont any danger of injury to the young plants from cold, it is generally better to raise them on a hothed, or to purchase the young plants from a nurseryman, as when the seeds are sown in the open border, the plants will not flower till late in autumn, and the seeds will rarely ripen. The seeds should be sown thickly, as many of them are generally imperfect and will not vegetate. The Ageratum is a valuable flower for a bouquet, from the great length of time that it remains without fading. As it grows from one and a half to two feet high, and spreads a good deal, it is more suitable for a large garden than for a small one.

\section{OTIIER SPECIES.}

There are several other species of Ageratum enumerated in the Hortus Britannicus, and other Catalogues of plants, all of which are annuals; but $A$. Mexicanum is the only kind now grown in flower-gardens.

TRIBE ASTEROIDEF.

GENUS II

ASTER, Lin. THE ASTER, OR STARWORT.

Lin. Syst. SYNGENESIA SUPERFLUA.

Granerse Cunactrr.-Flowers of the ray ligulate, female; those Iovolucral scales in three or four series; spreading and ciliated. Fruit of the disk hermaphrodite, tuhular. Receptacle rather convex. obovate, compressed. Pappus double, deciduous.

\section{1.-ASTER CHINENSIS, Lin. THE CHINA ASTER.}

Srnonrmes.-Callistemma hortense, Cass.; Callistephus chinensis, Nees and Dec.; Diplopappus chinensis, Less. ; Reino Marguerite, French.

Engraving. -Our Plate 36.

Varieties.-These are very numerons; varying not only in colour, but in the form of the potals, some of which are quilled, as in fig. 1, is Plste 36; others are quite dwarf, and very handsome. The red, $f g .3$, the blue, fig. 4, and the pink, fig. 5 , in Plate 36 , were the first kinds istroduced into Eagland; but the striped variety, fig. 2, which is of the kind called the German aster, is of quite recent introduction.

Specific Cnaracter.-Lower leaves spatulate, under oncs rhomboid, and upper ones oblong; all toothed, and somewhat eiliated. Branches elongated, oach bearing a solitary bead of flowers.

Description, \&c.-China Asters were first introduced into Europe by Father D'Incarville, a missionary in 




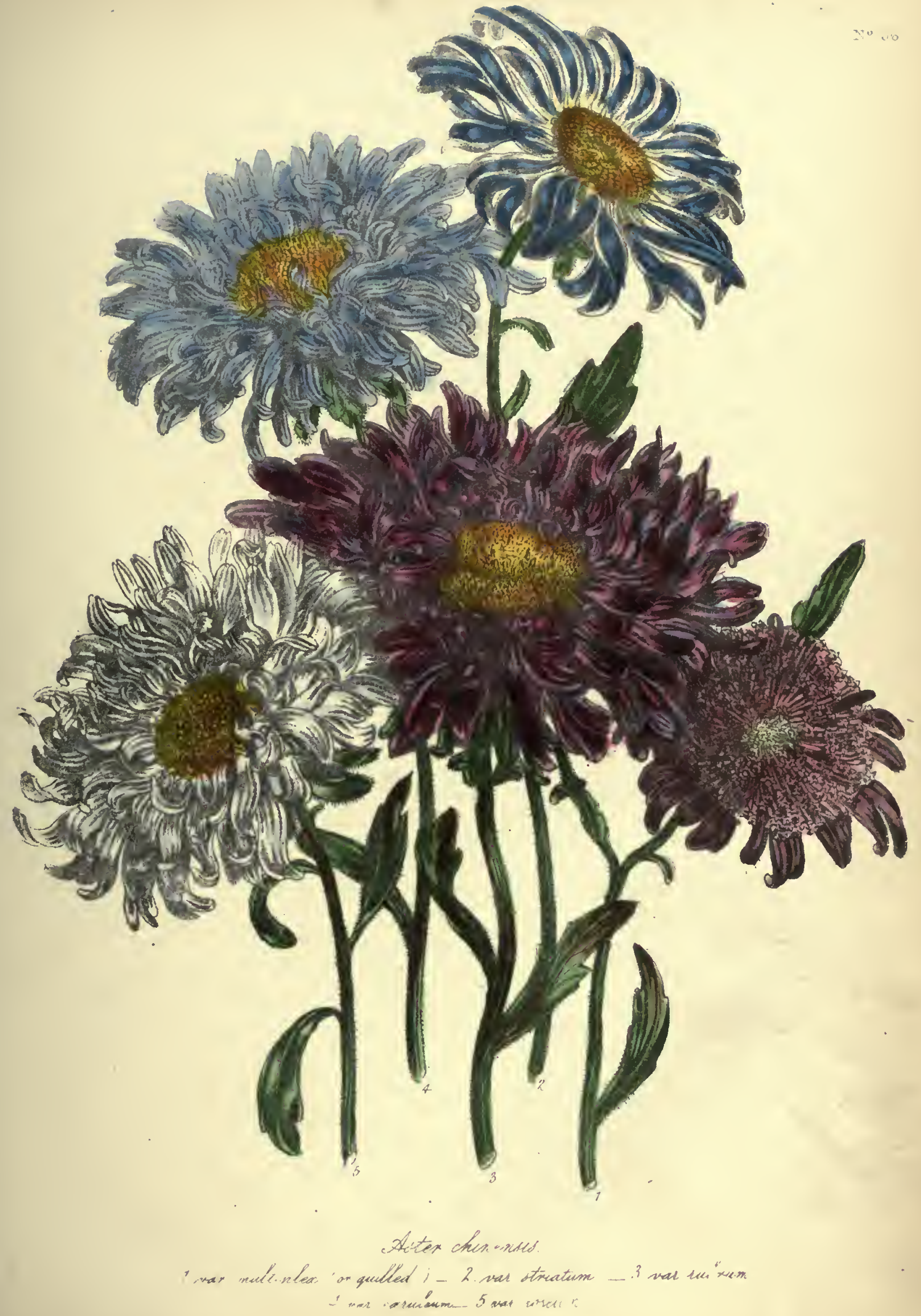




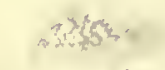

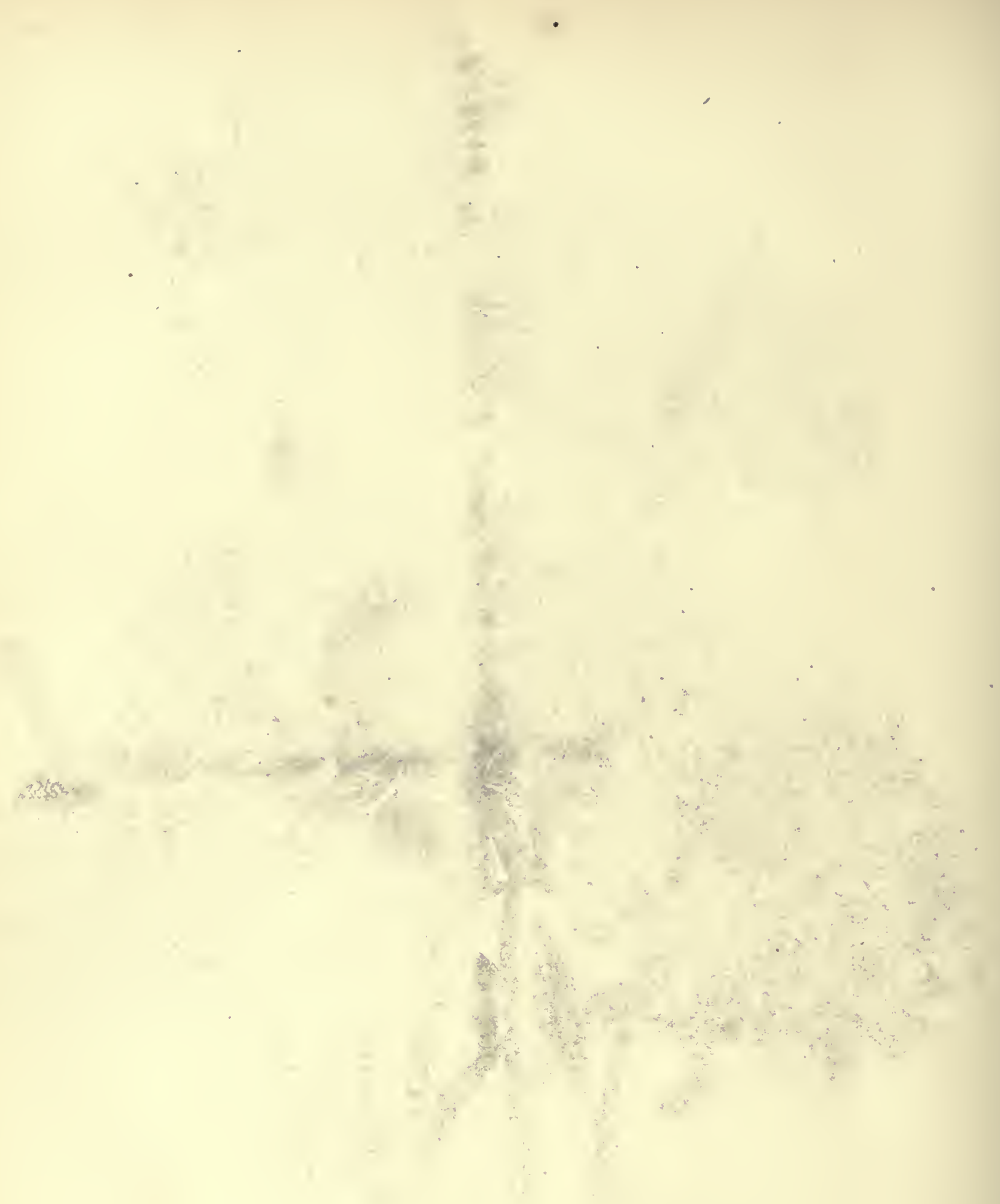


China, whose name was given by botanists to two species of handseme Chinese trumpet-shaped flowers, now ineorperated in the genera Tecoma and Bignonia. Father D'Incarville took the seeds of the China Asters from China to Paris in 1730, and in 1731 Miller reeived some seeds from the Jardin des Plantes in Paris, which he raised in the Botanie Garden at Chelsea. The first kinds intredueed were the single red and the single white; but the single blue, or rather purple, was obtained soon afterwards, and from these the numerous hybrids and varieties have been raised whieh deeorate our gardens. The kinds ealled German Asters, like the German Steeks (see p. 66, and p. 67), are merely bybrids and varieties raised in Germany; and exeellent German seeds may be had from Carter's, Holborn. The Freneh are particularly fond of China Asters, and grow them to great perfeetion. Their name for the flower is la Reine Marguerite, which is suppesed to mean simply the Queen Daisy, as the Frenel name for the Daisy is Marguerite, given to it, as it is said, from the fondness of Margaret of Valois for that common wild-flewer.

CuLture.-China Asters are generally raised on a hethed; and when wanted to flower finely, the young plants slould be purehased of a nurseryman in May. When raised in the open ground, the seeds sheuld be sown in a warm berder early in April, and the plants prieked out towards the end of May, or seoner; when they are about three inches high. In all cases, China Asters do best when transplanted; as, when left where they were sown, the flowers are generally poor. It is alse not theught advisable to grow China Asters twe years in succession on the same ground. When prieked out frem the seed-bed, the young plants should be put into a bed of very rieh soil, trenched at least a spade deep, and mixed with well-retten dung frem an old hotbed; though some eultivaters prefer ground that has been riehly manured the previous season. The plants in this bed of ricl earth, should be placed at least six ineles or a feet apart from each other every way, and shaded and well watered after transplanting. When they are to be plaeed so as to produee an effect by their celours, in ferming figures, \&c., they are generally again transplanted, just as they have formed their flower-buds, suffieiently for the colour to be distinguished; taking them up earefully with an instrument called a transplanter, used in removing tulips, so as net to break the balls of earth round the roots of eaeh plant. Chalked string is then stretehed over the beds, so as to form the figure required, and the Asters are earefully planted in stars, cireles, letters, crescents, rainbows, \&e., aceording to the fancy of the florist. We once saw in a Freneh garden, purple Asters planted among white ones, so as to form a dark purple star en a white greund, whieh produced a very striking and beantiful effcet. China Asters look very well on a bank planted in rews, one colour in each row ; or in rings of different eolours reund a circle; with the tallest plants in the eentre, and the dwarf plants nearest the edge.

\section{2.-ASTER TENELlUS, Lin. THE SLENDER ASTER, OR DWARF ANNUAL MiCHAELMAS DAISY.} Syrosymzs,-Felieia tenclla, Nees and Deo.; F. fragilis, Cass.;
Aster dentatus, Thun.; Kaulfussia ciliata, Spreng.; Cineraria
tencila, Link.

Engruving. - Bot. Nag. t. 33.

Spectric Character.-Leaves linear, eiliated. Branches naked, bearing each a single head of flowers.

Descriptien, \&c.-A very elegant little flewer, whieh, theugh intreduced se long baek as 1769 , has only Lately beeome a favourite in our gardens. It is a native of Nerth Ameriea, and was originally considered a greenhouse perennial; but it has been found to sueceed quite well treated as a hardy annual, and as such the seed is now generally sold in the seed-sheps. The seeds should be sown in March, and the plants will net need any furtber culture. 


\section{GENUS III.}

\section{KAULFUSSIA, Nees. THE KAULFUSSIA.}

\section{Lin. Syst. SYNGENESIA SUPERFLUA.}

Generic Craructer.-Flowers of the ray ligulate, female; those $\mid$ of the inncr series keelcd. Fruit obovate, compressed; those of the of the disk hermaphrodite, tubular. Receptacle honeycombed. Involucral scales in two series; those of the outer serics flat, and those $\mid$ of one series of capillary, plumose bristles.

\section{KAULFUSSIA AMELLOIDES, Nees. THE AMELLUS-LIKE KAULFUSSIA.}

Synonymes.-Charieis heterophylla var. Dec.; C. Neesii, Cass. | Sprcific Characrer._Lower leaves opposite, the rest alternate; ExGruvinos.-Bot. Mag. t. 2177 ; Bot. Reg. t. 490 ; and our fig. oblong and lanceolate; 3-curved at the base. Peduncles terminal and 3 , in Plate 31.

Description, \&c.-This very beautiful little plant is a native of the Cape of Good Hope, from which country it was introduced in 1820, and was first raised by Mr. Anderson in the Botanic Garden, Chelsea. It was formerly considered as only half-hardy, and was raised on a hot bed; but it is now found to succeed quite well if sown in the open border in April. It affords a powerful contrast to the Ageratum both in the development and duration of its flowers; and as that plant is remarkably slow in both, so is this remarkably quick. Plants of the Kaulfussia, the seeds of which were sown in April, will come into flower in May, or the beginning of June; and by the latter end of that month all their petals will be curled up, and tleir seeds beginning to ripen. In nurseries, the seeds are generally gathered early in July, and the plants removed. It is quite a dwarf plant, and beds of it appear one mass of flowers. The seeds are generally good and come up quickly, and the plants will bear transplanting if too thick; though this is rarely the case, as, from their small size, they do not look well unless near together. The flower heads, when they first appear, are yellowish; they then become of a pale blue, but before they curl up, they turn of a beautiful, rich, dark, mazarine blue, or almost purple.

\section{TRIBE SENECIONIDEA, Dec.}

In this tribe are included more than three-fourths of all the ornamental annual Compositæ.

GENUS IV.

\section{DRACOPIS, Cass. THE DRACOPIS, OR STEM-CLASPING RUDBECKIA.}

\section{Lin. Syst. SYNGENESIA FRUSTRANEA.}

Graneric Charactra.-Flowers of the ray, ligulate, neuter; those inner series composed of small adpressed scales. Fruit cylindrical, of the disk hermaphredite and tubular. Involucral scales in two scries; outer series composed of six or eight linear spreading scales; attenuated at the base ; pappus crown-formed, quite entire.

\section{DRACOPIS AMPLEXICAULIS, Cass. THE STEM-CLASPING DRACOPIS.}

Synonymes.-Rudbeckia amplexicaulis, Vahl; R. amplexifolia, Jacq.; R. perfoliata, Cav.

Engravings_-Bot. Mag. t. 3716 ; and our fig. 6 in Plate 32.

Spfcific Characten.-Plant glabrous, branched; stem-loaves alternate, cordate, stem-olasping, entire. Head terminal, solitary.

Description, \&C.-This plant, though introduced from Lonisiana so long ago as $\mathbf{1 7 9 3}$, appears to have been lost to our gardens till about 1835, when it was re-introduced by Drummond from New Orleans. There are two kinds; one with strongly-serrated leaves, figured by Jacquin, and the other the kind we have figured, with entire leaves and smaller flowers. The seeds, whicl may be had at Charlwood's, and other seed-shops, should be sown in March or April, and the stems of the plants tied up before they come into flower. 


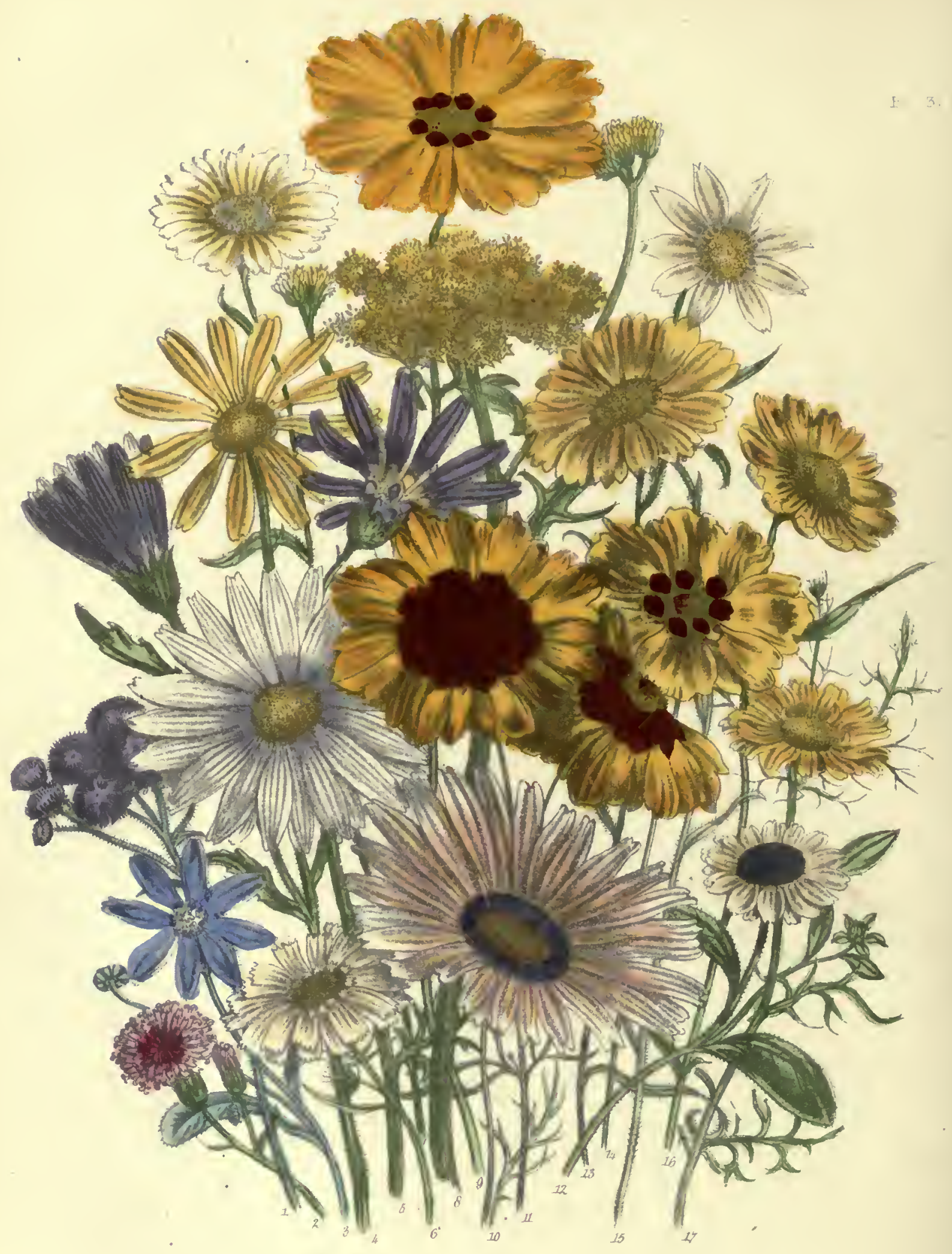

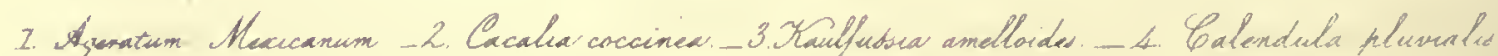

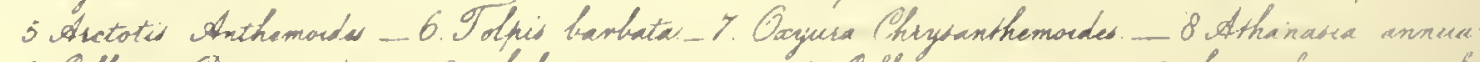

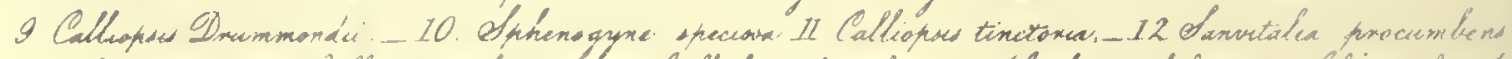

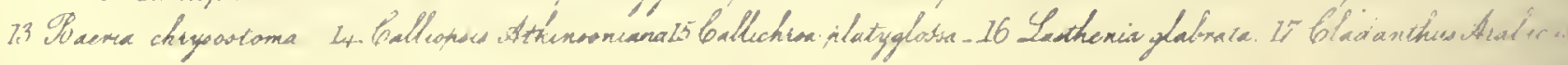



GENUS $\nabla$.

CALLIOPSIS, Reich. THE CALLIOPSIS.

Lin. Syst. SYNGENESIA FRUSTRANEA.

Gznersc Cusracter.-Flowers of the ray neuter, ligulate, 3 to $\mid$ inner series large, and erect. Receptacle flat, covered with linear 5-toothed; those of the disk hermaphrodite, tubular. Involucral deciduons pales. Fruit compressed, naked, truncate. scalcs in two serics; outer scries short and squarrose; those of the

Descriptron, \&c.-The plants contained in this genus have been separated from those retained in the genus Coreopsis, on account of the palea of the receptacle being in the one case deciduous and in the other persistent; but this difference is of course only discoverable by a botanist on dissecting the flower. The names of the two genera, though somewhat similar in sound, lrave, however, a very different origin : Coreopsis being derived from koris, a bug, and opsis, the look of, in allusion to the shape of the seeds; and Calliopsis being derived from kallistos, the Greek word for most beautiful, in allusion to the beauty of the flowers..

\section{1.-CALliopsis TINCTORIA, Dec. THE DYEING CALliOPSIS.}

Svмомумгs.-Coreopsis tinctoria, Nult.; Diplosastra tinctoria, | entire lobes ; upper leaves tripartitely multifid, with linear lobes. The Tausch ; Calliopsis bicolor, Reich.

Engravings.-Bot. Mag. t. 2512 ; Bot. Reg. t. 846 ; and our fig. 11 , in Plate 31. fruit is miautely tuberculated, and wingless.

Vınтsty.-C. t. 2 atrosanguidea, Maund's Bot. Gard. t. 538. The flowers are dark-red.

Specific Character.-Radical leaves pinnate, or bipionate, with

Description, \&c.-A very showy and well-known garden annual, with bright, orange-yellow flowers, more or less stained with blotches of dark-red; growing two or three feet high, much branched, and spreading widely in proportion to its height. It is a native of North America, where it was discovered in 1821, by Professor Nuttall, covering whole tracts of land in the Arkansas territory, between the Missouri and the Mississippi. It was particularly abundant on the vast plains of somewhat elevated ground near the Red River; and there the inbabitants used the dried flowers for dyeing red, on which account Nuttall gave the plant the specific name of tinctoria, signifying dyeing. Calliopsis tinctoria was first supposed to be tender, but it is now found quite hardy, so much so, indeed, that it may be sown in autumn, to stand through the winter, without any care. Thus treated, it will produce very large and fine plants, which will flower early in May. The common treatment is, however, to sow it in the open border in February or Marcln, and when the plants are two or three inches high, to thin them out, or transplant them, so as to leave the plants that are to flower at least six inches apart every way. Three plants will be quite sufficient for a tuft; and as they have very slender stenis, they should each be tied to two or three thin sticks painted green, which should be driven firmly into the ground; or, what is perliaps better, each plant may be drawn through a dahlia hoop.

\section{2.-CALLIOPSIS ATKINSONIANA, Hook. MR. ATKINSON'S CALLIOPSIS.}

Sysoryme.-Coreopsis Atkinsoniana, Dougl.

Eneravings.-Bot. Reg. t. 1376; and our fig. 14, in Plato 31.

stem-leaves pindate, with narrow subspatulate lobes. Fruit margined Specific Character. - Radical leaves bipinnate, with entiro lobes; with a short wing, quite smooth.

Description, \&c.-Very distinct fron C. tinctoria, in its flowers bcing of a pale yellow, less blotched, smaller, more cup-shaped, and more numerous. It is marked in the Bot. Reg. as a perennial, but we have always found it succeed quite well treated as an annual, and if sown at the same time as C. tinctoria, it generally comes into flower a few days before that species. It was found by Douglas in 1825 , growing abundantly on an island in the river Columbia in California. 


\section{3.-CALLIOPSIS DRUMMONDI, $D$. Don. DRUMMOND'S CALLIOPSIS.}

Syмоптмzs.-Coreopsis diversifolia, Hook.; C. auriculata, var. diversifolia, Elliott.

Engruvings.-Bot. Mag. t. 3474 ; Swt. Brit. Flow. Gard. 2nd Ser., t. 315 ; and our fig. 9, in Plate 31.

Spectric Charucter.-Plant hairy, or glabrous. Lenves ternate,

pinnato, and sometimes bipinnate. Leafiets roundish, obovate; obtuse, quite entire. Involueral seales with both series joined at the base. Flowers of the ray, quadrifid at the apex. Fruit oval, awnless, with a flat disk, and a thiekened margin.

Descniption, \&c.-When Mr. Drummond, the botanical collector, was at Texas, in Mexico, in 1834, he found large traets of land covered with different kinds of Calliopsis, among which was this beantiful annual, which appeared to him, as it really is, much larger and finer than any of its congeners. He sent seeds to the Botanic Garden, Glasgow, which arrived in February 1835, and being sown immedintely in the open air, produced flowers the following July. In the neighbourhood of London, sceds sown in Mareh generally produce their flowers in June. The plant itself is of the easiest culture; for as it does not grow above a foot, or a foot and a half high, and has a much stronger stem than $C$. tinctoria, it does not require staking and tying up. As it does not branch so much, it also will not require thinning out, unless the seed has been sown very thickly. The specimen figured in our Plate 31, gives a very unfavourable idea of the plant, as the flowers are generally nearly twice as large ; and certainly always larger, on an average, than those of the Sphenogyne speciosa, which is figured in the same plate as the Calliopsis.

\section{OTHER SPECIES.}

C. FILIFOLIA, IIook., Bot. Mag. t. 3505 .

One of the species of this genus, found by Drummond in Texas, and sent home by him with $C$. Drummondi. The flowers are smaller and more cup-shaped than those of that species; the florets of the ray are narrow, numerous, and quite yellow, and those of the disk are searlet. The leaves are long and very narrow. The name is in Charlwood's seed-catalogue.

\section{CORONATA, Hook.}

Another species found by Drummond in Texas. The florets of the ray are very numerous, and they are long, narrow, and sharply dentated. They are of a bright orange, with a very singular ring of dark red spots spreading round the centre of the corolla, at a considerable distance from the disk, which is yellow, and much smaller than the disk of these flowers generally is. The root is very small, and somewhat carrot-shaped, and the stem being very weak and slender, requires tying up. The name of this species is also in Charlwood's catalogue.

\section{GENUS VI. \\ HELIANTHUS, Lin. THE SUN-FLOWER. \\ Lin. Syst. SYNGENESIA FRUSTRANEA.}

Generic Charueter.-Head of many flowers. Flowers of the ray ligulate, neuter, those of the disk tubular, hermaphrodite; involueral scales irregularly imbricated; outer ones foliaceous, acute, appendieulated, inner ones smaller, palea-formed. Reeeptacle flat, or eonvex;

eovered with half-clasping oblong palex. Fruit compressed, or subtetragonal, villous or glabrous. Pappus generally of two small scales, or awns.

\section{1.-HELIANTHUS ANNUUS, Lin. THE ANNUAL SUNFLOWER.}

Spreiric Craructer.-Stem generally simplo. Leaves alternate, cordate, or nerved, coarsely serrated. Heads large, drooping. Scales of invo. luerum eiliated. Fruit of the disk furnished with tw̧o awns.

Description, \&tc.-The common sun-flower is a native of Peru, where it was regarded in the time of the Incas as a sacred flower, and imitations of it in gold were worn by the virgins of the sun, at their great festivals. 
This is the reason why this plant was called the sun-flower; a name before appropriated to the Helianthemum, or Sun-rose, which no doubt was the plant alluded to by Ovid, when he represented Clytia as pining herself to death for love of Apollo, and being changed by the pitying God into a flower, which always turned to the sun. The Italian Helianthemum is indeed of a pale yellow, admirably expressive of the complexion of a sickly girl pining herself away for love, which Ovid describes by saying that the flower retained Clytia's wan paleness; an expression which becomes absurd when applied to a flower of such a glowing colour as the Peruvian Sunflower. The Helianthemum also does turn to the sun, and only opens under the influence of its beams; while the Peruvian Sun-flower has generally its flowers turned in opposite directions. The common Sun-flower was cultivated by Gerard, before 1596; as he mentions it under the names of the Flower of the Sun, or the Great Marigold of Peru; and tells us that he had one which grew in his garden in Holborn, to the height of fourteen feet, and produced flowers which measured sixteen inches across.

The culture of the Sunflower is as simple as possible, as the seeds only require to be sown in any soil or situation, or at almost any season, to vegetate; and the stalk is too strong to require any training or tying up. It is, however, too large a flower for a small garden. The Sunflower has occasionally been cultivated both in Europe and America for commercial purposes; and Mr. Taylor, a London scedsman, has many acres covered with it, from which he has succeeded in making oil from the seeds, thread and paper from the fibre, and potash from the ashes of the refuse.

\section{OTHER ANNUAL KINDS OF HELIANTHUS.}

\section{H. INDICUS, Lin.}

A dwarf species, a native of Egypt, not growing more than eighteen inches or two feet high; introduced in 1785. De Candolle considers this kind, and the H. humilis of Persoon, as varieties of the common sunflower.

\section{H. PETIOLARIS, Nutt.; Swt. Brit. Flow. Gard. 2d. s. t. 75 .}

A very landsome species, a native of the sandy plains of the Arkansas; and fonnd there by Professor Nuttall in 1821, though it does not appcar to have been introduced into England till 1825. It is a very handsome species, greatly resembling the common perennial sunflower; but the flowers are larger, and have a rich dark purple centre. Seeds may be procured at Charlwood's.

\section{H. LENTICULARIS, Doug.; Bot. Reg. t. 1265.}

A vcry showy species, the flowers of which have an intenso yellow ray, and dark reddish purple disk. It was discovered in the Arkansas territory of North Ameriea, by Douglas, and sent to England in 1833; but we do not know where seeds are now to be procured.

\section{H. OVATUS, Lehm.}

This species is frequently sold in the seed-shops for $H$. petiolaris, but it is not so handsome, having a much paler disk. It is a native of Mexico.

\section{H. Macrocarpus, Dec.}

This is the kind usually sold by the French seedsmen, under the name of the hybrid long-seeded sunflower. The florets of the ray are large, and of a pale lemon colour, and those of the disk are yellow.

\section{H. PATENS, Rehm.}

The stem is strong and erect; and the branches widely spreading. The flowers have a rich purple disk, and a hright yellow ray. The plant is a native of the southern provinces of North America. 
H. SPECIOSUS, Hook.; Bot. Mag. 3295 ; syn. LEIGHIA SPECIOSA, Dec.; ? TITHONIA TAGETIFLORA, D. Don, Bot. Reg. t. 591.

This very singular flower has an orange scarlet ray, and a bright golden yellow disk. The flower stalk is swollen near the flower like that of a French marigold; and the appearance of the disk and ray somewhat resembles that of a Zinnia. It is a native of Mexico, and was introduced in 1834.

\section{GENUS VII. \\ BIDENS, Lin. THE BUR-MARIGOLD.}

Lin. Syst. SYNGENESIA FRUSTRANEA.

Generie Characrer.-Flowers of the ray ligulate, neuter; flowers $\mid$ Receptacle flattish, paleaceous. Fruit more or less compressed, priekly, of the disk tubular, hermaphrodite; involucral seales in two series. terminated by a beak, which ends in two or five stiff hairy awns.

\section{BIDENS STRIATA, Swt. THE STRIATED BUR-MARIGOLD.}

Eneravings.-Swt. Brit. Flow. Gard. t. 237 ; Bot. Mag. t. 3155. | ated, serrated. Heade corymboso, pedicillate, the outer seales of the Specific Canracter. - Stem somewhat tetragonal, striated, rather involucrum compressed. Fruit somewhat tetragonal, with seabrous downy. Leaves glabrous, ternate. Leaflets ovate-laneeolate, aeumin- $\mid$ angles, terminated by two bristles.

Description, \&c.-A vigorous-growing showy-annual, having rather small flowers, consisting of only five white florets in the ray, with a golden yellow disk. The plant is not suitable for a small garden, as the stem grows three or four feet high, with numerous branches, and a great number of rather large and coarse-looking leaves; though it looks well in a large garden from the great profusion of its flowers. It is a native of Mexico, and was introduced about 1830. We saw the plant growing in the garden of Mr. Harrison's beautiful little villa at Cheshunt, in the summer of 1839 ; but we do not know where sceds can be procured in the shops.

\section{2.-BIDENS GRANDIFLORA, Ball. THE LARGE-FLOWERED BUR-MARIGOLD.}

Srnonymes.-B. odorata, Dun.; B. diversifolia, Hort.; B. I Specinic Cuarucrer.-Stem cylindrical,glahrous. Leaves glahrous, serratula, Desf.; Coreopsia diversifolia, Jacq.; Kerneria serrulata, Cass. ; Cosmea lutea, Sims.

Encravings.-Bot. Mag. t. 1689 ; and our fig. 11, in Plate 32, pinnate, with three or five pairs of leaflets, some of which are oblong and serrated, or a little eut; others aro divided into linear lobes. Hcads pedicillate. Involucral seales eiliated. Fruit subtetragonal, glabrous; terminated by two or four awua.

Descniption, \&c.-A pretty yellow flower, a native of Mexico, brought to England by Lord Holland from Madrid in 1812. It was described and figured by Dr. Sims in the Bot. Mag., under the name of Cosmea lutea; but it is quite evidently a Bidens, and it is called so in De Candolle's new arrangement. Seeds may be procured at Charlwood's, under the name of Bidens diversifolia, and they should be sown in a warm border in March or April, when they will flower in July.

\section{GENUS VIII. \\ COSMEA, willd. THE COSMEA. \\ Lin. Syst. SYNGENESIA FRUSTRANEA.}

Generie Cuanacter.-Flowers of the ray ligulate, neuter. Flowers of the disk tubular, hemaphrodite. Involverum double; each composed of eight or ten seales, which are combined more or less at the base. Receptaclo flat, paleaceous. Paleæ membranous, each drawn out into a thread at the apex. Anthers each terminated by a scariose cordate appendage. Fruit tetrsgonal, beaked, and somotimes stipitato; crowned by $2-4$ scabrous deciduous awns.

\section{1.-COSMEA BIPINNATA, Will. THE FINE-LEAVED COSMEA.}

Synonyme.-Cosmos bipinnatus, Cav.

Engraving. -Bot. Mag. t. 1535.

Spectric Crurueter.-Quite glabrous. Leaves bipinnate, with romote, quito entire, linear segments. Fruit glabrous, beakcd; erowned by three awns.

Description, \&c.-This beautiful plant was discovered in Mexico, before 1789 ; as seeds of it sent to 
Madrid produced plants, which blossomed in that year in the Royal Botanic Garden of Spain. It was first described and figured in 1797, by Cavanilles, who called it Cosmos, from the Greck word Kosmos, beautiful ; but this name was afterwards altered by Willdenow to Cosmea, as being more consistent with the rules of botanical nomenclature. It does not appear to have been introduced into England till 1804; and then to have been soon lost. This is easily accounted for; as it is found that if the plants are not bronght forward by artificial heat, they will not be sufficiently advanced to ripen their seeds before the setting in of the frost. In Madrid, the plants did not come into flower till October, and did not ripen their seeds till December. Seeds of this species may be procured at Carter's, Holborn ; and they should be sown in January on a slight hotbed, or in a warm border, and covered with a hand-glass, being sheltered in frosty weather, and during cold nights with the addition of a bast mat. Plants thus treated will grow freely-some in Mr. Henderson's nursery in the Edgeware Road being, in the summer of 1838, ncarly six feet high; and they will produce their splendid large pink flowers in September and October. C. diversifolia, another Mexican species, has tuberous roots like those of a dahlia, and should be treated in the same manner.

\section{2.-COSMEA TENUIFOLIA. THE SLENDER-LEAVED COSNEA.}

Srrosvme.-Cosmus tenuifolins, Lindl.

Engruvings.-Bot. Reg. t. 2007 ; and our fig. 1, in Plate 32.

bipinoate. Lobes linear, remote, acute, entire or dividod. Involncrum with ovate, acuminate, extcrior scales. Fruit rough, beaked, and

Speciric Chanscrex.-The whole plant very smooth. Leaves crowned with from one to three bristics.

Descriptron, \&x.-Closely resembling C. bipinnata, but differing in the leaves being still more finely cut, and sometimes again divided at their points; in the scales of the involucrum being less acuminate; and in the fruit being rough, with a longer beak, and being frequently found with only one bristle. The flowers also are more purple or of a reddish lilac than those of C. bipinnata, which are deeidedly pink. C. tenuifolia is a native of Mexico, and requires the same treatment as the preceding species. It does not however grow so high, and is thercfore more manageable in a small garden.

\section{$\overline{\underline{2}}$ \\ GENUS IX. \\ SANVITALIA, Car. THE SANVITALIA.}

Lin. Syst. SYNGENESIA SUPERFLUA.

Generic Character.-Flowers of the ray ligulate, female, per- $\mid$ balf-clasping oblong palex. Fruit of the ray triquetrous, smootl, sistent; those of the disk, hermaphredite, tubular. Involucral scales in crowned by thrce thick awng; those of the disk compressed, of two two or three series. Scalcs adpressed, somewhat imbrieated, the inner forms, the outer ones muricated, the inuer ones winged, ciliated, and ones rather lunger than the rest. Receptacle conical, furnished with $\mid$ ending in two small awns.

\section{SANVITALIA PROCUMBENS, Lam. THE TRAILING SANVITALIA.}

Syrosymzs.-S. villosa, Cav.; Lorenten atropurpurea, Ortega. $\quad$ Specific Character._Stem procumbent, or diffuse. Leaves ovate. ENGRavisGs._Bot. Reg. t. 707; and our fig. I2, in Plato 31. $\quad$ Flowers of the ray exceeding the awns of the fruit.

Description, \&c.--This very beautiful little plant is a native of Mexico, from which country it was sent to Caranilles, at Madrid, and Lady Bute brought seeds of it from the Botanic Garden in that city to England in 1798. Notwitlstanding the number of years that it has been in the conntry, this flower was very little known till within the last few years, when it was accidentally brouglt into notice, and it has since bccome quite common in gardens and nurscries. It is a low, compact-growing plant, presenting a complete mass of flowers, 
which are renuarkable for their bright orange ray, and rich dark purple disk. It is quite hardy, and if the seerls are sown in February, March, or April, it will require no other eare; as frem its low and neat habit of growth it will not need either training or thinning.

\section{GENUS X. \\ TAGETES, Tourn. THE FRENCH AND AFRICAN MARIGOLDS. Lin. Syst. SYNGENESIA SUPERFLUA.}

Genenic Ciranacter.-Ilead madiate, semerwhat discoid. Involucral / Fruit elongated, attenuated at the base; coinpressed; tetragonal. scales in one serics, cembined into a campanulate, er cylindrical cup, which is toothed at the apcx. Receptacle somewhat honey-combed. $\mid$ base, others awned, elongated, and frec.

\section{1.-TAGETES PATUla, Lin. THE SPREADING TAGETES, OR FRENCH MARIGOLD.}

Exaksyuscs.-Bot. NIag. t. 150; and our fig. 8, in Plate 32. | pinnate, vith linear-lanecelate serrated segments ; the upper serratures Specific Curaracter.-Stem erect. Branches spreadiug. Leaves sometimes awned. Peduncles cylindrical, inveluerum smooth.

Descriprion, \&c.-The commonness of this flower prevents its exciting the admiration that its brilliant colours conld not fail to obtain, if the plant they belong to were either new or rare. There are numerous varieties of it botl single and double; and these display great variety in the stripes, and in the propertion of dark red in encls flower. Curtis, in the fifth volume of the Botanical Magazine, mentions that two principal varieties were then kept in gardens; the common dwarf sort, with a very strong disagreeable smell, and a larger kind, usually called the sweet-scented, but which possessed no other claims to that title than being rather less disagreeable than the other. The listory of this plant is involved in some obscurity; as the early writers on plants appear to have confeunded it with the upright or African Marigold. The striped Marigold is mentioned by Ifernandez as being a native of Mexico; and Gerard, who gives a good figure of it under the name of the French Marigeld, says that it was also called the carnation or Gilliflower of Peru. At any rate it appears to have been very early in cultivation as a garden fower, as Gerard speaks of it as being well known at the time at which he wrote, viz. 1596. It is still a favourite in many gardens, and is frequently raised on a hotbed, and planted out in May.

\section{2.-TAGETES ERECTA, Lin. THE ERECT TAGETES, OR AFRICAN MARIGOLD.}

Srecific Cuaracter.-Stem and branches crect. Leaves pindate, with lanceolate, serrulated segments ; the upper serraturcs sometimes awned. Peduncles ventricese at the apex. Inveluerum rather aogular.

Description, \&c.-.This well-known plant differs principally from the French Marigold in its colour, which is of a deep orange not striped with brownish-red. It is said to be a native of Africa, and to lave been introduced into Eurepe by the Emperer Cliarles V. on his return from lis expedition to Tunis in 1535. Fuclsius, in his History of Plants, the first edition of which was published in 1542, gives a very good figure of this Tngctes, under its old French name of Gyroflee-d'Inde; and describes it as a kind of Indian wormwood. He adds that " the flowers are at the extremity of the shoots, as yellow as saffron, and for beauty infcrior to none." He also mentions its laving been brought to France from Germany. It appears to have been introduced into England with the striped Marigold, as both are figured and described together in the old books on plants. The culture is the same for botl. 


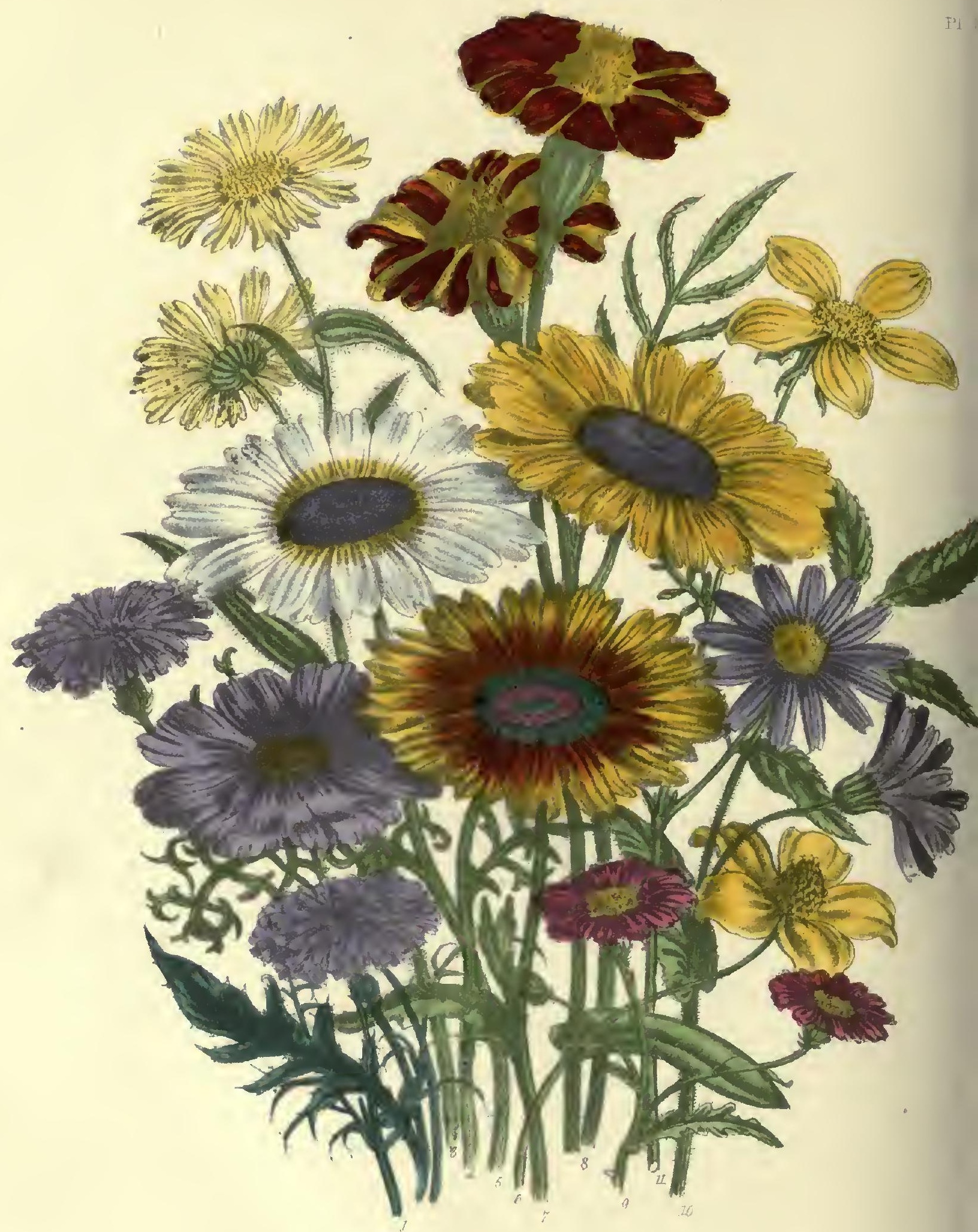




\section{.}





\section{OTHER SPECIES OF TAGETES.}

T. CORYMBOSA, Sut. Brit. F'l. Gard. t. 151.

This species has pink flowers. It is a native of Mexico, and was introduced in 1825. There is a yellow variety, but wo do not know where seeds of either the variety or the species are to be procured.

T. TENUIFOLIA, Cav., Bot. Mag. t. 2045.

A tall untidy-looking plant, with small, ill-shaped, yellow flowers. A native of Peru, introduced in 1797.

There are several other kinds of annual Tagetes, all with yellow flowers; but we have never seen them, and do not know whero they are to be procured.

\section{GENUS XI.}

GAILLARDIA, Foug. THE GAILLARDIA.

Lin. Syst. SYNGENESIA FRUSTRANEA.

Genenic Character-Flowers of the ray ligulate, neutcr, many- three series, each furnished with a leafy, acuminated appendix. Fruit nerved, glandular, trifid at the apex; those of tho disk hermaphrodite, ablong, villous. Palexe of the pappus one-ncrved and awned.

tubular. Receptacle convex, frioged. Involucral scsles in two or

\section{I.-GAILLARDIA DRUMMONDII, Dec. MR. DRUMMOND'S GAILLARDIA.}

Srnoкyмe.-G. bicolor, var. Drummondii, Hook.

ENGRAVING.-Bot. Mag. t. 2368.

Specific Chalucrzu.-Plant rather downy, Leaves lanceolate,

undivided or cut. Corollas hairy, longer than the pappus. Palex of the pappus dilated at the base; ray flowers cuneate at the base.

Deschiption, \&c.-This splendid flower was discovered by Drummond at Rio Braxas, in Texas, in the autumn of 1833. It is a very handsome plant, with dark brownish-red flowers, tipped with yellow, and will continue flowering for several months. The seeds should be sown in February or March, or the plants raised on a slight hotbed to bring them forward, as unless this is done they will not come into flower till the lattcr end of August, or beginning of September.

\section{2.-GAIllardia pUlchella, Foug. THE PRETty GAILlardia.}

Srsoxymes.-Gaillardia hicolor, Lour.; Calonnca pulcherrima, Buchoz.; Virgilia helodes, L'IIerit.; Gaillardia smara, Raf.; G. alternifulia, Rausch.

Enoravina.-Our fig. 7, in Plate 32, under the nawe of G. Drummondii.

Descniption, \&c.-Through the accidental misnaming of a specimen, this species las becn figured in our Plate 32 under the name of G. Drummondii, from which it differs considerably, and to which it is much inferior in beanty. Tlis species also differs considerably from the perennial plant figured under the name of $G$. bicolor in the Bot. Mag. t. 1602, and which, in Professor De Candolle's new arrangement, is called G. lanceolata. G. pulchella is a native of Louisiana, introduced about 1812; and it is the kind generally sold in the seed-shops as G. bicolor. The seeds should be sown in February or March, and the young plants sheltered in cold nights by a flower-pot being turned over them, or with a hand-glass, and they will flower in August.
Specific Cuaracter.-Plant rather bairy. Corollas of the disk villous, length of pappus. Palex of the pappus stiff, narrowed at the base. Ray flowers very narrow at the base, spotted.

\section{B B 2}




\section{GENUS XII. \\ LASTHENIA, Cass. THE LASTHENIA. \\ Lin. Syst. SYNGENESIA SUPERFLUA.}

Grererc Cunructer. - Flowers of the ray female, few, small, tubular, | ciliated. Fruit compressed, puhescent. Palex of the pappus 5-10; and obliquely truncate. Receptacle conical, papillose. Involucral toothed at the apex. scales in one series, combined into a 5,8 , or 15-toothed cup; the tceth

\section{1.-LASTHENIA CALIFORNICA, Lindl. THE CALIFORNIAN LASTHENIA.}

Syмonyme - L. glaherrima, Dec.

ENGนAVING. -Bot. Reg. 1823.

Specrfic Character.-Plant quite glabrous; involucrum with 15 teeth. Pappus of 5 palex.

Description, \&cc.-This very pretty plant was discovered by Douglas in California, and sent home by him in 1835. Since that time it las seeded so freely, that it has become common in the nurseries and seed-shops. It is generally planted with Nemophila insignis in flower-horders, and it may be treated like the other Californian annuals, as described in p. 156, under the head of Leptosiphon. It is often confounded with Burrielia gracilis.

\section{2.-LASTHENIA GLABRATA, Lindl. THE GLABROUS LASTHENIA.}

Sxкonyme.-Hologgmne glabrata, Bartl.; and Hook. in Bot. Mag. | Specrfic Cuaracrer.-Plant quite glabrous. Involucrum of 15 Engruvings.-Bot. Reg. t. 1780 ; Bot. Mag. t. 3730 ; and our fig. teeth. Pappus wanting. Fruit muçronate. 16, in Plato 31.

Description, \&c.-This species only differs from the preceding one in wanting the pappus, and in the manner in which the peduncles or footstalks are united to the involucre. In $L$. californica, the involucre is impressed at the base with a little cavity for the reception of the flower-stalk, and is thus cup-shaped; while in L. glabrata, the involucre tapers gradually into the flower-stalk, like a goblet, or an old-fashioned wine-glass, without any perceptible point of union. Both species differ from the Burrielia-a plant often sold instead of them-in their involucres being always entire, and only cut into broad, spreading teeth at the apex, while the involucre of the Burrielia is divided into a duable series of lanceolate scales. The seeds of $L$. glabrata may be purchased at any seed-shop, and they should be treated like those of $L$. californica.

\section{GENUS XIII. \\ BURRIELIA, Dec. THE BURRIELIA. Lin. Syst. SYNGENESIA SUPERFLUA.}

Gencric Churucter,-Head of many flowers. Flowers of the ray ligulate, obovate, female; those of the disk tubular, hermaphrodite, and soretimes sterile by abortion. Involucrum campanulate, with oval acuminated scales. Receptacle apaleate. Achenim subtetra-

gonal; those of the ray nearly compressed, furnished with a two or three-awned pappus; those of the disk having a three or four-leaved pappus.

\section{1.-BURRIELIA GRACILIS, Dec. THE SLENDER BURRIELIA.}

Synonyme.-Lasthenia Californica, Hort.

Engrutina -Bot. Mag. t. 3758.
Specipic Charactrr.-Scales of involucrum eight; flowers of the ray eight.

Description, \&c.-This genus, as already observed, is distinguished from Lasthenia by the different structure of the involucre, which is composed of several lanceolate scales in double scries, whereas, the involucre of the Lasthenias is entire, and only cut into broad spreading tecth at the apex. The plant is a native of 
California, and its seeds were sent home by Douglas with those of the Lasthenias, with which it is generally confounded, the flowers closely resembling those of that genus. Seeds of the Burrielia are seldom to be procured under their proper name; but when they are, they should be treated like these of the Lasthenias; and all the three kinds of plants, like all the Californian annuals, will come into flower at any time during the spring, summer, or autumn, about six weeks after sowing.

GENUS XIV.

HELENIUM, Lin. THE HELENIUM.

\section{Lin. Syst. SY NGENESIA SUPERFLUA.}

Gzxzrac Chasucter.-Flowers of the ray in one series, ligulate, | series : outer scales many, deflexed or spreading; inner ones fewer rarely tubular; those of the disk hermaphrodite, tubular, 4 or 5-toothed. and shorter, similar to the palexe of the receptacle. Fruit obovate, Receptaclo convex, globose or oblong, naked. Involucral scales in two villous. Palese of pappus 5 or 6 , mcmbranous.

\section{1.-HELENIUM QUADRIDENTATUM, Lab. THE FOUR-TOOTHED HELENIUM.}

Syronymes.-Rudbeckia alata, Jacq.; Helenium Millerii, Schult.;

Srzctric Craracter.-Plant nearly glabrous. Stem erect, branched at the apex. Leaves decurrent, oblong-linear; lower ones pinnatifid, upper ones quite entire. Involucrum very short.

Eneruving. -Bot. Rcg. t. 598.

Description, \&c.-A very handsome plant with a bright orange-celoured ray, and elevated disk like that of a Rudbeckia. The stems are curiously shaped, and winged, and the leaves stem-clasping. The name of Helenium was originally applied to the Inula Helenium, the elecampane, which, in allusien to its cosmetic properties, was dedicated to Helen. The present plant is a native of Louisiana, from which country it was brought in 1790 by the $\Delta$ bbé Pourret. It is a hardy aunual, which only requires sowing in March or April to flower in August or September. Theugh the stems are tolerably streng, yet, as the root is fibrous and slender, it is advisable to tie it up, if the situation in which it grows is at all exposed to the wind.

\section{GENUS XV. \\ SOGALGINA, Cass. THE GALINSOGEA. Lin. Syst. SYNGENESIA SUPERFLUA.}

Generac Churucterr. - Flowers of the ray female, bilabiate : onter lip large, toothed at apex; inner lip divided into two linear segments. Howers of the disk hermaphrodite, tubular. Involucrum hemi-

spherical; scales in two serics; oval, blunt. Rceeptacle coovex, furnished with oval, acuminated paleæ which clasp the flowers. Fruit almost cylindrical. Palex of pappus in one scries, pinnate or pluniose.

\section{1.-SOGALGINA TRILOBATA, Cass. THE THREE-LOBED GALINSOGEA.}

Srwostrme.-Galinsogea trilobata, Cav.

Esgruving.-Bot. Mag. t. 1895.

Sprcific Chafacter.-Flowers of the ray cuneated, having the inner lip bipartito. Palex of the pappus shorter than the fruit.

Description, \&c.-This showy annual is a native of Mexico, from which country it was sont to Madrid, where Cavanilles supposing it to resemble the Galinsogea quinque radiata of Ruiz and Pavon, a Peruvian plant, gave it the name of Galinsogea trilobata. It has since been found to differ in the form of the florets of the ray, the shape of the receptacle, the colour of the flowers, \&c., and it is now placed in another genus under the name of Sogalgina, which is an anagram of Galinsogea. The heads of flowers of the true Galinsogeas are small with a 
yellow disk and a white ray, while those of Sogalgina are rather large, and both disk and ray of a bright yellow. The name of Galinsogea was given to the original genus in honour of Dr. Martin de Galinsoga, first Physician to the Queen of Spain, and Director of the Royal Botanic Garden at Madrid, and wo have retained it as the English name, as it is that by which the plant is known in the seed-shops and nurseries: It was introduced in 1797 by the Marchioness of Bute, and having been lost, it was re-introduced from Madrid by Lady Holland, about 1812. It is of very easy cultivation. The seeds, which may be bouglt in any seed-shop, should be sown in March or April, aud the plants will need no other culture, except thinning out if the seed was sown too thiekly.

\section{GENUS XVI. \\ SPHENOGYNE, R. Br. THE SPHENOGYNE.}

\section{Lin. Syst. SYNGENESIA NECESSARIA.}

Generic Character.-Head of many flewers. Flewers of the ray fof many series of imbricated scales. Anthers terminated by a heartligulate, neuter. Flewers of the disk tubular hermaphrodite. Rceep- shaped appendage. Fruit nearly cylindrical, surreunded by hairs. tacle paleaceous, palex clasping the flowers. Involucrum campanulate Pappus paleaceeus.

\section{1.-SPHENOGYNE ANTHEMOIDES, $R$. Br. THE CHAMOMILE-LIKE SPHENOGYNE.}

Srnerxmes.-Aretetis anthemeides, Iinn.; A. pinnata et A. Speciric Craractra_Plant glabreus. Leaves irregularly bipinnate, ceruun, Thun.; $\Lambda$. paradoxa, Ait.; Ursinia antbemeides, Poir.

Engravings.-Bet. Mag. t. 544 ; and our fig. 5, in Plate 31, under the name of Aretotis anthemeides. with filiform segments. Pedicels elengated, naked. Paleæ of the pappus truncatc. Ray flewers few.

Description, \&c.-This flower is remarkable for being of a dark purple on the under side, and a bright yellow inside. The buds hang down modestly, but when the flowers expand, they hold themselves erect as though proud of thcir full vigour and beauty. When the plants decay the flower droops, till the secds become ripe, when it again raises itself, and the crown of the seed expanding at the same timo, it seems to have unfolded another flower, which has a corolla of five white petals and a brown star in the centrc. This singular appearance is occasioned by the florets of the disk remaining attached to the seed, after they have witherce and become whitish, and the florets of the ray have fallen. The stem branches very much at the base, and thins each plant bears a great many flowers. The leaves greatly resemble those of the Clamomilo, and the whole plant has the same odour as that herb; whence the name of Anthemoides or Chamomile-like. The name of Sphenogyne is compounded from Sphenos, a wodge, and gyenos, female, and alludes to the wedge-shaped stigmas. The specics in question is a native of the Cape of Good Hope, and was introduced in 1774. The seeds are common in the seed-shops, and they only require sowing in March or April to produce abundance of flowers from June till September or October. The plant is of low growth, seldom exceeding six inches; and from this circumstance and the great number of flowers which it produces from each root, it is admirably adapted for forming a mass of yellow, in a flower-garden the beds of which make a geometrical figure. There were some beds of it in the Kensington nursery, in the summer of 1839 , which produced a splendid effect.

\section{2.-SPHENOGYNE SPECIOSA, Hort. THE BEAUTIFUL SPHENOGYNE.}

Srnonyme.-S. versicolor, Dec. Engravises.-Flor. Cab. vol. 2, p. 131; and our fig. 10, in $\mid \begin{aligned} & \text { linear segmonts. Pedicels elengated, wearly naked. Ray flowers } \\ & \text { numerens. }\end{aligned}$
Plate 31.

Description, \&c.-This beautiful flower is easily distinguished from the preceding species, by the ray 
florets being much more numerous, and each blotched at the base with a rich purplish-brown so as to form a ring inside the flower round the disk. When the florets of the ray fall, the same peculiarity is observable in the florets of the disk as was described in the preceding species, excepting that they are much less dry. The species is a native of the Cape of Good Hope, and was introduced about 1835. Its seeds are now common in the seed-shops, and they should be sown in February or March, covering them at night, if the weather should bo cold, with a flower-pot or glass, when they will come into flower in May. Mr. Hopgood, of the Bayswater nursery, has some plants of this species still beautifully in flower this day, October 7th; though the specimen figured in our platc was gathered from one of the samo plants early in May.

\section{GENUS XVII.}

\section{OXYURA, Dec. THE OXYURA.}

\section{Lin. Syst. SYNGENESIA SUPERFLUA.}

Generic Charucter.-Head of many flowers. Flowers of the ray the base, convolute, clasping the fruit of the rays ; each terminated by a ligulnte, female. Flowers of the disk tubular, hermaphrodite, many of leafy appendage. Reeeptacle furnished with membranous palere. the central ones abortive. Involucral scales in one series, cil d at Fruit somewhat eompreased, obovate, glabrous.

\section{1.-OXYURA CHRYSANTHEMOIDI . THE CHRYSANTHEMUM-LIKE OXYURA.}

Engratings.-Bot. Reg.t. 1850 ; Botanist, No. I28; and our fig. 7, in Plate 31.

Sprcific Снaracteh.—Stem glabrous. Leaves al ternate, ciliated, pinnatifid. Bracteas few, ciliated.

Descriptrox̀, \&C.-This beautiful little plant is one of those which we owe to the exertions of poor Douglas, it having been sent home by him from California in 1835. It is quite hardy, and should be sown in March or April, when it will come into flower early in June. It does not, however, last long; and the seeds are generally ripe in July or August.

\section{GENUS XVIII.}

\section{MADIA, Mol. THE MADIA.}

Lin. Syst. SYNGENESIA SUPERFLUA.

GrNeric Character.-Flowers of the ray ligulate, female, and f the back, involving the achenia of the ray. Receptacle flat, beariog sometimes tubular; those of the disk tubular and hermaphrodite. lovolucrum nearly globose, of ono series of seales; scales keeled on nne or two series of paleæ between the ray and the disk. Fruit compressed, glabrous, 4 or 5 -angled.

\section{I.-MADIA SATIVA, Mol. THE CULTIVATED MADIA.}

Synonymes,-M. viscosa, Cav.; M. mellosa, Jacg,

ENGMavisG.-Bot. Mag. t. 2574.

Specific Charactgr.-Plant covered with glandular clammy hairs;

lower leaves opposite; upper ones alternate, oblong, entire, stem clasping. Heads on short petioles, disposed in racemes. Sceds oily.

Description, \&c.-The plant is of no beauty; but we notice it on account of its having been lately cultivated on a large scale both in England and Germany, for the purpose of crushing the seeds for oil. In Germany, it has been cultivated near Stuttgard, and in England, in Norfolk, by Mr. Taylor; in both instances, the experiment has been attended with success. The plant is a native of Chili, whence it was introduced in 1794 by Archibald Menzies, Esq. In its native country this plant is celebrated for producing oil, and indeed the name of Madia is 
said to signify oil-producing. When cultivated for oil in Europe, the seedlings are transplanted as soon as they unfold their second pair of leaves, into very rich soil, where they are planted ten inches or a foot apart. When the seeds begin to ripen, which is known by their turning black, the plants are reaped like corn, and set up to dry. They should, however, be thrashed out as soon as possible, as the succulent stems of the plauts, if suffered to lie long, will begin to ferment, and would soon spoil the seeds. One acre of land in Germany sown with Madia will produce about 442 ponuds of oil; while one acre sown with pappies, will praduce only 264 pounds of oil, and the same quantity of land sown with rape only 240 pounds. The produce in England, however, is probably mueh less, on aecount of the eomparative coldness of our summers.

\section{$=$ \\ - GENUS XIX. \\ MADARIA, Dec. THE MADARIA. \\ Lin. Syst. SYNGENESIA SUPERFLUA.}

Genarue Charucter.-Flowers of the ray ligulate, female; thoso series of scales hetween the ray and the disk, fringed or hairy in the of the disk tubular, male, or sterile. Involuerum nearly glohose, centre. Acheois of the ray compressed, 4 or 5-2.ogled, glabrous; thoso torulose, of ove series of scales. Scales complicate, involving the achenia of the ray. Recoptacle rather convex, bearing one or two of the disk abortive.

Descrirtion, \&c.-The plants composing this genus were, till latcly, considered to belong to Madia, but they have been separated from that genus principally on account of the florets of the disk producing no achenia or fruit, and, consequently, no seeds. The name Madaria, is from maderos, bald; in allusion to the fruit being deroid of pappus.

\section{1.-MAdaria ELEGANS, Dec. THE ElEgaNT MADARIA.}

Synonyms,-Madia olegans, Don 2 Madia splendens, Hort.

Engruvings.-Bot. Reg. t. 1458 ; Bot. Mag. t. 3548 ; and our fig. 3 , in Plate 32.

Description, \&cc.-A very strong and coarse-growing plant, from two to three fect higli, with large woolly lenves. The flowers are produced in great abundance, and are very shawy, the disk being surrounded by a distinctly-marked ring of brownish red. The plant is a native of California, whence it was sent home by Douglas in 1830. It will not bear either very hot weather or very rich soil, and Dr. Lindley, in the Bot. Reg., recommends it to be sown about June, so as not to come into flower till the heat of summer is passed. The reason for this, the doctor adds, is, " that its flowcrs are so impatient of exposure to light, that they are searcely expanded in bright sunshine, before they contract again, and the rays curl inwards, hiding the bright yellow and brown on which their beauty entirely depends." We sowed it at Bayswater in April, and as our little garden is full of large trees, it did not appear to suffer from the heat, but blossomed splendidly. The only objection we had to it was its large size and excessivcly vigarous growth, which occasioned the destruction of all the finer and more delicate plants near it. It does not require either staking or thinning, as the thick strong stalks of the more vigorous plants will not only stand alone, but will overpower and destroy the weaker ones near them. The specimen figured in our plate was not a good one, as in general the ring of brownish-red is quite as conspicuous as in Sphenogyne speciosa, figured in Plate 31. 


\section{GENUS XX.}

\section{CALLICHROA, Fisch, et Meyer. THE CALLICHROA.}

Lin. Syst. SYNGENESIA SUPERFLUA.

Generie Character.- - Head hetcrogamons. Flowers of the ray $\mid$ the edge. Aehenia somewhat fusiform : these of the ray glabrous, and female, ligulate, in two series; those of the disk tubular, hermaphro- a little compressed; those of the disk elongated, and somewhat trundite. lovolucrum double, of many nearly equal scalcs. Rcceptacle cate. Pappi setrecous, deotieulated, in one scrics. icpressed, fringed, or furnished with two or three rows of palcæ along

\section{1.-CALlichroa PLATYglossa, Fisch, et Mey. THE BROAD-RAYED CALLiChroA.}

Engravings. -Swt. Brit. Flow. Gard. 2nd ser., t. 373; and our fig. 15, in Plate 31.

Specipic Character.-Leaves alternatc, sessile. Heads solitary, pedunculate; ray-flowers euneate.

Descriptios, \&C.-A very showy plant growing about a foot high, with slender branching stems, bearing a profusion of large golden-yellow flowers, with dark purple anthers to the flowers of the disk. The brilliant colcur of these flowers gives the name to the genus; as Callichroa is derived from two Greek words signifying beautiful colour. The flowers do not look quite so well when gathered as when in the bed, from the stems and leaves being covered with rather long hairs; but this is only a trifling objection. The species is a native of the Russian colony of Ross in New California, whence it was first sent to the St. Petersburg Botanic Garden in 1835 ; but it was not introduced into England till 1837. It is quite hardy, and may be treated like the other Californian annuals (see p. 156), or sown in the open border in March or April. It is well adapted for forming a yellow bed in a geometrical flower garden. Though so recently introduced, it seeds so freely that it may already be purchased in most of the seed-shops. As it has a descending root, care should be taken in transplanting to keep as mucl earth as possible about the fibres, as when injured they are not so readily renewed as those of spreadingrooted plants.

\section{GENUS XXI.}

BAERIA, Fisch. et Mey. THE BAERIA.

Lin. Syst. SYNGENESIA SUPERFLUA.

Genenic Character.- Head heteroganous, radiate. Scalcs of in - fomale, ligulate, in one scries. Fruit fusiform, eompressed, somewhat voluerum about ten, cqual, flat, and in two serics. Receptacle conical, tetragonal, obtuse, terminated by a small areola. nulked. Flowers of the disk hermaphrodite, tubular; those of the ray,

\section{BAERIA CHRYSOSTOMA, Fisch et Ifey. THE GOLDEN-ANTHERED BAERIA.}

Engravings.-Swt. Brit. Flow. Gard. 2nd scr., to $395 ;$ sod our fig. 13, in Plate 31.

Sppclfic Craracter.-Plant slender, creet, braoched, rather hairy. Leaves opposite, sessile, lioear, quite entire. Heads teroninal, solitary.

Descriptias, \&c.-This genus is nearly allied to that of Callichroa; and it is a native of the same place, having been sent to Europe at the same time. Though there are many botanical distinctions, the principal popular differences between the genera consist in the shape of the rays, which are pointed in Baeria, and wedgeshaped in Callichroa, and in the anthers of Baeria being all yellow. The genus was named in honour of Professor De Baer of the University of Dorpat. Though it was introduced at the same time as the Callichroa, yet from not seeding so freely, it is not included in any of the catalogues of the seed-shops, and we do not knuw where it is to be procured. 


\section{GENUS XXII. \\ CLADANTHUS, Cass. THE CLADANTHUS}

\section{Lin. Syst. SYNGENESIA SUPERFLUA.}

Genemic Character.-Head beterogamous. Flowers of the ray ligulate, neuter; those of the disk tubular, lermaphredite. Receptacle conical. paleaceots. Paleæe acute, mixed with thresds. Involucrum in one serics; scalcs scarious at top. Achenia compressed, glabrous.

Description, \&c.-The species now comprised in this genus were formerly considered to belong to the same genus as the Chamomile, viz. Anthemis, but they have been separated on account of the shape of the receptacle, and the botanical construction, in some other particulars, being quite different.

\section{1.-CLADANTHUS ARABICUS, Cass. THE ARABIAN CHAMOMILE.}

Srnonymes.-Anthemis arabica, Lin.; A. prolifera, Pers.; Chamamelum proliferum, Manch; Asteriscus sp. Shaw; Cladanthus proliferus, Dec.

Engruving. -Our fig. 17, in Plato 31.

Description, \&:c.-A pretty little flower, strongly resembling Chamomile in its leaves and general habit of growth. The stem is at first upright, but it is soon so weighed down by the profusion of its flowers, that it. becomes prostrate. The flowers are produced not only at the extremity of the stems, but in the axils of all the branches; and hence the name, Cladanthus signifying a flowering branch. The plant is a native of Barbary, whence it was introduced by Dr. Shaw in 1759; but it was soon lost, and it was re-introduced in 1790 , having been procured from Carlsruhe by Mr. Lee of the Hanmersmith nursery. It is however quite hardy, and the only reason why it is difficult to keep, is the great length of time it takes to perfect its seeds. On this account, when it is grown for seed, it is generally sown the previous autumn. It is very ornamental, from its light chamomile-looking leaves, and profusion of bright yellow flowers. A great quantity of it to form a mass, was grown with very good effect in the summer of 1838, in the Kensington nursery. Seeds may be had in all the seed-shops; and when it is grown merely for its flowers, it is sown in March or April.

\section{GENUS XXIII. CHRYSANTHEMUM, L. THE CHRYSANTHEMUM. Lin. Syst. SYNGENESIA SUPERFLUA.}

Gexeric Character.-Heads heterogamous. Flowers of the ray | ceptacle fiat or convex, gencrally naked. Achenia of the ray trizuein one series, femsle, ligulate; those of the disk tubular, hermaphro- trous, or three winged; those of the disk cempressed, or nearly cylindite. Involucrum imbricated, campanulate, with scarieus scales. Rc- drical. Pappus wanting, or crown formed.

\section{1.-CHRYSANTHEMUM TRICOLOR, And. THE THREE-COLOURED CHRYSANTHEMUM.}

Synoniones.-C. carinatum, Schous; Ismelia versiceler, Cass. | Leaves pinnatifid, fleshy. Lobes linear, acute, toothed at top. Scalcs Engruvings.-Bot. Rep. 2, t. 109; and our fig. 5, in plate 32. Speciric Character.-Glabrous. Stem erect, branched, diffusc. of iovolucrum kceled.

VARIETY.-C. t. anreum, C. aureum, Hort.; our fig. 4, in Plate 32.

Description, \&c.-A well-known garden flower; which, with its yellow variety, makes a splendid show in autumn. It is a native of Bombay, where it is found on the sandy banks of rivers. It was introduced in 1796 , and at first kept in the greenhouse, but it was soon found quite hardy. The yellow-flowered variety was raised in 1799. Seeds of both speeies and variety are common in the seed-shops; the latter being generally called the new Golden. The word Chrysanthemum signities golden tlower. 


\section{2.-CHRYSANTHEMUM VISCOSUM, Desf. THE CLAMMY CHRYSANTHEMUM.}

Srwoxymes.-Centrospcrmum Chrysanthemum, Spren. ; IIeteranthemis viscido-hirta, Schott; Pinardia anisocephala, Cass.

Specific Character.-Plant covered with clammy down. Leaves rather fleshy; lower ones balf stem-clasping, oblong, somewhat pinna. tifid; upper ones eordately stem-clasping, toothed; each tooth tcrminated by an acute rigid point. Heads terminal, solitary.

Descriprrov, \&c.-A native of the south of Spain, and also of the sandy plains near Algiers. It is a dwarf plant with heads of yellow flowers, introduced in 1823. The seeds may be purchased at Charlwood's; and they should be sown in March or April, in a warm dry border, and rather sandy soil. Its common name in the seedshops is Centrospermum Chrysanthemum; Centrospermum signifying a spur-shaped seed.

\section{3.-CHRYSANTHEMUM CORONARIUM, Lin. THE GARLAND-FLOWERED CHRYSANTHEMUM.}

Syмокума.-Cbrysanthemum segetum, Forsk.; Matricaria coro- Leaves auijculately stem-clasping, bipinnatifid; lobes lanccolate, naria, Dest.

Sercific Character. - Glabrous. Stem erect, diffused, branched. at the apex.

Descriptron, \&c.-There are several varieties of this species grown in gardens; the double white, the yellow, and the quilled, are, however, the most common. They aro all ornamental, from the great profusion of their flowers, which make the plants of the white variety almost like bushes covered with clusters of large doubleflowered cherry blossoms. The species is a native of the south of Europe, and north of Africa; and it was introduced before 1629. The seeds are common in all the seed-shops; and they may eitler be sown in the open border in April or May, or raised on a slight hot-bed, and planted out in the latter month. They should, in fact, be treated like the Frencl marigold; but will require staking and tying up. This and all the common plants which have been for many years raised every season on slight hot-beds, may be grown equally well in the open border, by watering them every morning with warm water; and turning a flower-pot over them during cold nights, while they are yet yoüng.

\section{4.-CHRYSANTHEMUM ROXBURGHII, Desf. DR. ROXBURGH'S CIIRYSANTHEMUM, OR THE EAST INDIAN FEVERFEW.}

Sy⿳onYmFs.-Pyrcthrum indicum, Roxb ; Glebionis Roxburghii, Involucrum campanulate, having the inner scales each drawn eut into Cass.; Chrysanthemum senecioides, Dunal; Matricaria oleracea, a reundisb scarious appendage.

Ham.; Pinordia Roxburghii, Less.

ENcranne.-Bot. Mag. t. 1521.

Specifuc Craracter.-Glabrous. Stem erect, cylindrical, branched. Leaves auriculately stcm-clasping, pinnatifid. Lobes entire er tootherl.

VARIETIES,-C. R. 2 breviradiatum, Dec.; C. breviradiatum, Ledebour; Flowers with a short ray. Introduced in 1818. C. R. 3 radiatum, Dec. ; flowers with a long ray.

Deseription, \&C.-The species is a very singular flower with no disk, well known in our gardens under the name of Pyrethrum indicum. It is a native of the East Indies; whence the seeds were sent by Dr. Roxburgh to Mr. Lambert in 1810. Seeds may be purchased in any of the seed-sliops, under the name of Pyrethrum indicum. The culture of the plant is the same as that of $C$. coronarium, except that it does not require either staking or tying up.

\section{5.-CHRYSANTHEMUM SEGETUM, Lin. THE CORN MARIGOLD OR YELLOW OX-EYE.}

Srsosyme, -Pyrethrum segetum, Mcench.

Enoravinas.-Eng. Bot. t. 540, 2nd. cdit. vol. 6, to 1172.

Spreifie Character. - Glabrecig. Stem excct, branchcd. Leaves

Descriprion, \&c.-If this beautiful flower were rare, and difficult to be cultivated, it wonld be lighly ralued; but being a common English weed, few persens notice it except the farmers, and they wage war against it. It is particularly abundant in corn-fields, where the soil is sandy ; and in such situations, it is very difficult 
to eradicate it. The flowers are large, and of a golden yellow ; and the peduncles are naked, and thickened at the apex, like those of the African marigold. When cultivated in a garden, the seed only requires to be sown in a dry sandy soil, in March or April.

\section{GENUS XXIV. \\ DIMORPHOTHECA, Vaill. THE CAPE MARIGOLD.}

Lin. Syst. SYNGENESIA SUPERFLUA.

Granric Cruractrr.-IIeads radiate. Flowers of the ray female, | Achenia naked; those of the ray obconical, sometwhat triquetrous, and ligulate; those of the disk tubular, hermayhhrodite, centre ones abor- tuberculated; those of the disk flat and winged.

tive. Involuerum in one scries. Receptaclo flat, naked or paleaceous. I

Descriptron, \&c.-The species now composing this genus, were at first supposed to belong to Calendula, the common NIarigold; but according to the new arrangement of the Compositæ, they not only form a different genus, but are actually placed in another tribe: the Cape Marigolds being included in the Senecionidece, or radiate-flowered tribe, and the common Marigolds being placed in the Cynurece or artichoke-flowered tribe.

\section{1.-DimoRPHOTHECA PLUVIALis, Monch. THE GREAT CAPE MARIGOLD.}

Synonymes.-Calendula pluvialis, Linn.; C. hybrida, Swt.; Spectric Character.-Stem branched, leafy. Leaves narrow, lanC. seabra, and C. decurrens, Thunb. ; Mleteorina gracilipes, Cass.

Engruvings._Swt. Brit. Flow. Gard. t. 39 ; and our fig. 4 in

Plate 31, uuder the oame of Calendula pluvialis.

reolate, toothed. Peduncles eyliudrical. Fruit glahrous; outer ones tuberculated.

Description, \&c.-This very curious species has the florets of its ray of a pure white, sliaded with a violet colour at the base, inside the flower-head, but of a dark purple on the outside. The flower closes in rainy weather, and hence the specific name pluvialis, which signifies slowery; it also closes at sunset, and, in fact, only opens to the sun-beams. It is one of those flowers, the footstalk of which stands erect while the flower is likewize expanded, but droops during the fading of the florets, though it again erects itself when the seeds are ripe. The name of Dimorphotheca is Greek, and signifies two forms in one sheath.

This species is a native of the Cape of Good Hope, whence it was introduced before 1726 , as in that year it was grown by Miller in the Chelsea Botanic Garden. There is a variety wlth lyrate leates, and another with the hacks of the ray florets of a dark brownish orange, instead of purple. The culture of this plant requires a little attention, as, though it is quite hardy, and does not succeed well if raised on a hot-bed, it is very liable to be injured by spring frosts. For this reason it should be sown in the open border, about the latter cnd of April or beginning of May; only four or five seeds in a patch, or if to cover a bed, very sparingly, as it will not bear transplanting. It requires no other culture but watering and keeping it free from weeds; and as it is of low growtl, and covered witl flowers, it is very suitable for filling a bed in a geometrical flower-garden, where it will form a white bed in sunshine, and a dark purple one in gloomy weather.

\section{2.-DIMORPHOTHECA HYBRIDA, Dec. THE HYBRID CAPE MARIGOLD.}

Synonymғs.-D. inerassata, Muench.; Neteorida crassipcs, Cass.; | oblong, linear; radical ones sinuated, cauliue ones toothed. PedunCalendula bybrida, Linn.

Sprcific Chanseter.-Stem branched, scabrous, leafy. Leaves

Description, \&c.-Closely resembling the preceding species; but with rather smaller flowers, and differently shaped seeds. The species figured under the name of Calendula hyorida in Sweet, is, according to De Candolle, D. pluvialis. The culture is the same as that of the great Cape Marigold 


\section{GENUS XXV. \\ COTULA, Lin. THE COTULA.}

Lin. Syst. SYNGENESIA SUPERFLUA.

Generic Chanacren.-Hend dikeeld, heterogamous. Flowers of the ray in one series, apetalous, fenale, those of the disk hermaphrodite, having tlie tube a little compressed, and usually bicalearate at the hase, and the limb with four erenatures. Reeptacle flat, bractless, bearing distinet papillæ after the falling of the fruit, which are probably nothing lyt the remains of the pedieels. Aehenia compressed, mar. ginate, without pappus, glabrous; these of the ray stipulate, and these of the disk sessile and narrower.

\section{1.-COTULA AUREA, Lin. THE GOLDEN COTULA.}

Synonymr. - Anacjelus aurens, Lam.

Spremple Chunactzu,-Glabrous. Stem ascending. Leaves ha]f stem-ciasping, with a linear rachis, and very s]ender, aeuminated,

parted, or undivided lobes; heads terminal, the peduneles scarcely rising above the ultimate leaf.

Description, \&c. - A curions little flower, the heads of which look like small golden balls. A native of Spain, introduced in 1818 , and now common in the nurseries. The seeds only require scattering on the ground in March or A pril, and the plants need no other culture.

\section{GENUS XXVI.}

LONAS, Adan. THE ANNUAL ATHANASIA.

\section{Lin Syst. SYNGENESIA RQUALIS.}

Generte Chapacter.-Head discoid, homogamous. Receptacle / brieated. Achenia angular, furnished with a glaod en ene sido at the sonical, elongated, paleaceous. Inveluerum campanulate, seales im- apex. Pappus otliquely crown-formed, membranous, entire.

\section{1.-LONAS INODORA, Gartn. THE SCENTLESS LONAS, OR ANNUAL ATHANASIA.}

Synonymps.--Athanasia annua, Lin.; Aehillea inodora, Lin.; | Engravings.-Bot. Mag. t. 2276 ; and our fig. 8 in Plate 3 ), under Lonas minima, Cuss.; Elichrysum inodorum, Magn.; Hellis afri- the name of $\Lambda$ thanasia aqua.

carn, Moris.; Santolioa afrieana, Tourn.; Ageratum africanum, Specrfie Chnraerer.-Plant glabrous. Leaves pinnatifid. Lobes $n m y$.

aeuminated. Ilcads of flowers disposed in eymous umbels.

Descniptios, \&c.-A rambling plant, remarkably untidy in its appearanee, from its widely•spreading jagged leaves, and the long naked footstalks of its flowers. The flowers themselves have notling to recommend them, excopt the great length of time that they remain unfaded when cut. 'This quality, and the great length of the footstalk, made this flower a favourite about a century ago, when it was the fashion to set large beaupots flled with flowers in the climney-places during summer. The name of Athanasia, which signifies never-dying, alludes to the length of time that the flowers will remain unfaded; and this is so great, that Ray, who first cultirated the plant in England, states that some flowers which expanded with him in the begiuning of July, were in full vigour at the time lie was then writing, the twentietl of October. The species is a native of Barbary, and was introduced before 1686. The seeds are common in the seed-shops; and they shonld be sown in April or May, in a warm, dry, sandy, border. The name of Lonas is one of those invented by Adanson, anthor of the Familles des Plantes; and, like all his botanic names, it has no meaning. 
GENUS XXVII.

AMMOBIUM, $R$. Br. THE AMMOBIUM.

Lin. Syst. SYNGENESIA RQUALIS.

Genzase Curactrn,-Head homogamong. Receptacle broad, appendage. Corollas tubular, five-loted. Anthers bisetaceous at the conical, furnished with oblong, acuminated, denticulated paleæ. In. volucrum hemispherical. Scales imbricated, coriaccous, with membranous margios, cach terminated by a scarious, convex, spreading base. Stigmas pilose at the apex. Achenia or fruit somewhat com. pressed, tctragonal, 4-tootbed at the apex; the two larger tecth drawn out into two hristles.

\section{1.-AMIOBIUM ALATUM, $\boldsymbol{R}$. Br. THE WINGED-STALKED AMMOBIUM.}

Engravings.-Bot. Mag. t. 2459 ; and our fig. 9, in Plate $33 . \quad$ leaves oblong, on long petioles. Cauline leaves running along the Sfrcific Character.-Plant erect, branched, canescent. Radical stem. Involuctum white.

Description, \&c.-A kind of everlasting flower, discovered near the shores of the Huntor River in New South Wales in 1804, by Dr. Brown, who gave it the name of Ammobium, or sand-flower, because he discovered it growing in pure sand. It was not introduced till 1822 , and was at first supposed to be a perennial, but it is now found to be an annual. Seeds may be had at Charlwood's and most other sced-shops, and they only require sowing in the open border in March and April. The plants remain a long time in flower.

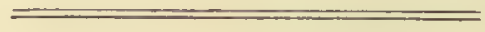 \\ GENUS XXVIII. \\ RHODANTHE, Lindl. THE RHODANTHE.}

Lin. Syst. SYNGENESIA EQUALIS.

Grantic Cuaructrr. - Head homogamous. Involucrum turhinated, colonred. Receptacle naked. Coro!la 5-cleft. Achenia bidentate, imbricated. Sealea menbranous, ovate, acute; outer ones silvery, woolly. Pappus in oue series, plumosc.

bractæform; middle ones adpressed; uppermost ones spreading, rose-

\section{1.-RHODANTHE MANGLESI, Lindl. CAPTAIN MANGLES' RHODANTHE.}

Engravings.-Bot. Reg. t. 1703; Bot. Mag. t. 3483 ; Swt. Brit. Fiow. Gard. 2nd Scr. t. 295; and our figs. I and 3, in Plate 34.

Spresric Chaructrr. - Plant erect, branched, glabrous. Leaves obloog, obtuse, entire, stem-clasping. Ileads terminal, solitary.

Description, \&c.-One of the most beautiful plants ever introduced. The beautiful silvery hue of the lower scales of the involucrum, the fine rose-colour of those immediately surrounding the disk, which may be said to form the ray of the flower, and the golden yellow of the florets of the disk, form a striking combination of bcauties unequalled perhaps in any other flower. The Rhodanthe is a native of the Swan River colony in New South Wales; whence seeds of it were brought in 1834 by our excellent friend Captain Mangles, who has done so much for floriculture in various ways. Had the Captain, however, never introduced anything but the Ruodanthe, he would well have merited the gratitude of all lovers of flowers. The derivation of the name of Rhodanthe is stated by Sir W. J. Hooker to be from two Greek words, signifying "rose-flower." We think, however, that the name has probably a much more peetical origin, and that the flower must have been christened after Rhodanthe, a queen of Corinth, who was so beautiful, that ler subjects were never weary of lcoking at her. This lady, disliking so much admiration, hid herself in a temple dedicated to Diana and Apollo; and when forced ly the cries and repcated acelamations of her subjects, who actually besieged the tcmple, to -present herself to their gaze, she was so modest that sho blushed herself to death. The whole story is told 


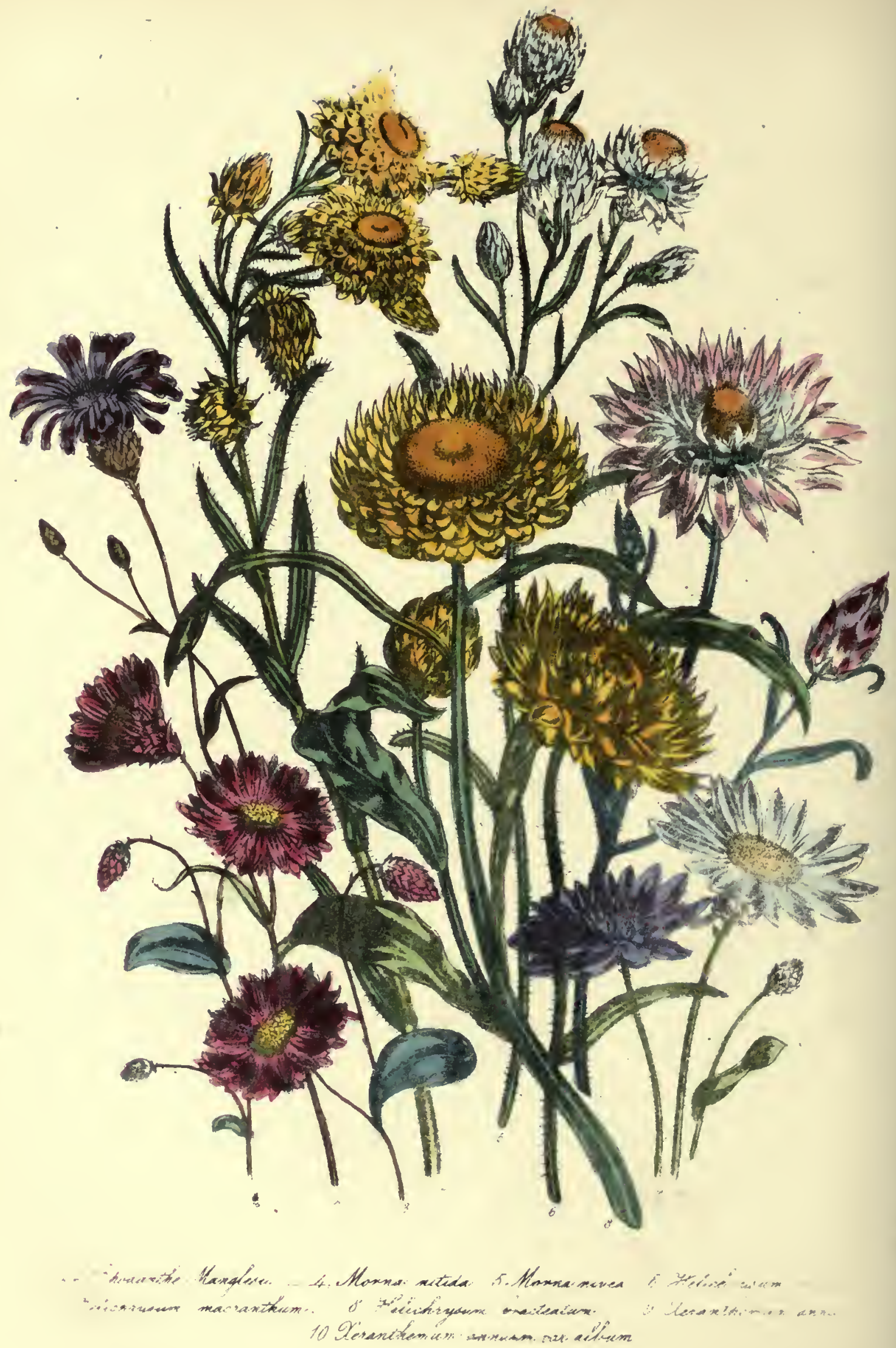




in a Latin poem, entitled "The Gardens," written by a French author, named Rapin, a century or two ago. Rapin adds, that Rhodanthe, after her death, was changed by the pitying Apollo into a rose, of which some of the troublesome crowd became the thorns; while a few of the most persevering were changed into grubs, caterpillars, bees, and butterflies, which still haunt the rose in admiration of her beauty.

The ordinary culture of the Rhodanthe is simply sowing it with other half hardy annuals on a lotbed in February, and planting it out in May; but we have a most magnificent plant, presented to us by Captain Mangles himself, which was raised in Henderson's Nursery, Pine Apple Place, Edgeware Road, by his foreman Mr. Goode, and treated in the following manner. The seed was sown April the 5th, in pots filled with three parts peat or rather heath-mould, and one of loam. In the first week of May, when the plants were still in the seed-leaf, they were pricked out into small thumb pots, or sixties. In a wcek's time they were shifted into rather larger pots; and this shifting was repeated six times, always into rather larger pots, till the middle of August, when the plants were in pots No. 16, and when they were first allowed to flower. On the fourteentl of September, when one of these plants was sent to us by Captain Mangles, it was one and a half feet high, above four feet in circumference, and had a thousand expanded flowers upon it besides innumerable buds, which have continued expanding ever since; and it is still (November 1 ) a blaze of beauty. It is watered every morning with a little warm water; and the dead flowers are cut off as they fade. "The great art," says Mr. Goode, in the MS. directions sent us by Captain Mangles, "is to prevent the plant from growing upwards, and to cause it to increase and expand in breadth instead of length." To do this, all that is required is "to watch it well, and the moment the roots liave nearly filled the pot, to transplant it into a larger one. By constantly attending to this, the plants will grow thick and shrubby in their character; and while the shoots will be strong and capable of bearing a most profuse floration, the beauty of the plants in shape will be very greatly improved." Seeds of the Rhodanthe Manglesii are common in all the seed-shops.

\section{$=$ \\ GENUS XXIX. \\ MORNA, Lindl. THE MORNA. \\ Lin. Syst. SYNGENESIA RQUALIS.}

Graneric Character.- - Head homogamous. Receptacle flat, naked. Pappus scabrous, in one series, setaceous, cqual, and pubescent at the Involucral scales in many series, dry, coloured, imbricated, petiolate. base.

Anthers bicalcarate at the basc. Achenia glabrous, compressed, beaked.

\section{1.-MORNA NITIDA, Lindl. THE SHINING MORNA.}

Fingravings. - Bot. Reg. t. 1941 ; and our fig. 4, in Plate 34. $\mid$ rather hroadest at the base; mucronate, pubescent. Involucral scales Specific Chaнистеr.-Stem pubescent, corymbose. Leaves linear, yellow, acute, serrulated.

Description, \&c.-A beautiful everlasting flower, with, as Dr. Lindley describes it, "starry heads of a most rich and transparent yellow, having quite a metallic brilliancy when illuminated by the sun." It was named by Dr. Lindley after "Morna, one of the heroines of the Northern romances, who was a beautiful lady, confined in a golden hall, guarded by a thousand golden lances, and attended night and day by knights, whose sole office was to do her bidding in all things, except allowing her to escape from her splendid thraldom." Morna nitida is a native of the sandy country near the Swan River, whence seeds of it were sent home by Sir James Stirling in 1835. Seeds may be had at Charlwood's, and other seed-shops. They should be sown in pots of peat and 
leaf-mould with a little sand, in February, and transplanted into other pots, as they require shifting; in the same manner as was directed for the Rhodanthe, till the end of May or beginning of June, when they may be plauted in the open border. Thus treated they will not flower before August or September; but if sown in September, and kept in the greenhouse all winter, they will flower in the following May or June. In this case they may be turned into the open border in April, but it should be without breaking the ball of earth in the pot; and the plants should be kept covered with a hand-glass, particularly at night, till the beginning of June.

\section{2.-MORNA NIVEA, Lindl. THE SNOWY MORNA.}

Engravings.-Bot. Reg. for 1838, t. 9 ; and our fig. 5, in Plate 34.

Specific Character. - Stem pilosc, corymbose, rather woolly at the base. Leaves linear, obtuse or acute. Involucral scalcs white, quite entire.

Description, \&c.-If the yellow Morna resembled the enchanted nympl of the Seandinavian Romance sitting in her golden hall, and surronnded by the golden lances of her knights; this white Morna may be compared to Ossian's heroine of the same name, who was fair as "the snow upon the heatl," with yellow hair, "like the mist of Cromla, when it curls upon the rocks, and shines in the beam of the west." The involucral scaies of this species are white, shining like silver, and surrounding a golden yellow disk. It is a native of the Swan River colony, introduced in 1837 ; and in its durability and culture it exactly rescmbles M. nitida. Botlı species are very difficult to grow; and Dr. Lindley observes that "in a greenhouse they require particular attention, as too much or too little watering will in a few hours destroy the healthiest plants." When turned into the open border, a pit, at least a foot deep, and a foot in diameter, should be dug, and filled with equal parts of peat, vegetable mould (decayed leaves), and river sand; and into the centre of this the ball of earth contained in the pot should be planted, without breaking it or disturbing the roots of the plant in the slightest degree. The plant should then be very sliglitly watered with warm water, and covered with a liand-glass for a few days; putting the glass on again every night, even after the plant is well established, as long as there is the slightest danger of frost. As different kinds of earth are necessary for the culture of this plant, it may perhaps be here useful to mention for the benefit of those who have no gardener, that peat, vegetable mould, and sand may be purchased in small quantities (sixpenuyworth or a slillingswortl, for example) of most of the Loudon nurserymen.

\section{GENUS XXX. \\ PODOLEPIS, Labill. THE PODOLEPIS. \\ Lin. Syst. SYNGENESLA SUPERFLUA.}

Genfric Charscrer.-Hend heterogamous. Flowers of the my | Authers setiferous at the base. Aehenia oblong, with a lateral areola. female, ligulate, or nearly tubular; those of the disk hermaphrodite and Pappus in one series; the setæ scarious, and rather combined at the tubular. Receptacle paleaccous. Involucrum campanulate, of "many base.

series of scales. Outer seales sessilo, diaphanous; inner ones stipitate.

\section{1.-PODOLEPIS GRACILIS, Graham. THE SLENDER-STALKED PODOLEPIS.}

Sצможчмe. - Stylolepis grucilis, Lehm.

Emgravings._Sut. Brit. Flow. Gard. t. 285 ; Bot. Mag. t. 2904 ; and our fig. 2 , is Plate 34 , where it is erroneously referred to, as one of the spceimens of Rhodan the Manglesii.

Specific Cnaracten.-Plant glabrous, branehed. Cauline lentes aurieled, the aurieles adnate to the stem. Scales of involucrum obtusc, glandular aloog the stipe.

Description, \&c.-A very elegant little plant, which, though a true annual, is quite woody at the base of the stem. The flowers are generally of a pinkish lilac, but there is a variety nearly white. It is a native of the 
sandy plains, ncar King George's Sound, and was introduced in 1827. The seeds, whiclı may be purcliased in any seed-shop, may either be sown on a hotbed in February and planted out in May, or sown in April or May in the open border; or the plant may be grown in pots as directed for Rhodanthe Manglesii, when it will attain an enormous size.

\section{GENUS XXXI}

\section{HELICHRYSUM, Vaill. THE EVERLASTING FLOWER.}

\section{Lin. Syst. SYNGENESIA SUPERFLUA.}

Granfic Charucter.- Head homogamous, having all the flowers / cated, with scarious scalce. Receptacle flat, naked er honejcembed, tubular and hermapbroditc, or heterogamons with the ray-flowersio one or fringed. Achenia beakless, sessile. Pappus in ope series, bristles series, slender, and a very few of them female. Iovolucrum imbri- $\mid$ scabrous, free, or cembined at the base.

Description, Sc.-The everlasting flowers were formerly nearly all classed witl those of the genus Gnaphalium or cudweed; from which they differ essentially in wanting the woolly herbage from which the genus Guaphalinm takes its name. Most of these are now called Helichrysum, sometimes erroneously spelt Eliclirysnm, as it is derived from Helios, the sun, and chryson, gold. The common Everlasting-flower, which is so much sold in Paris under the name of Immortelle, and which Linnæus called Gnaphalium orientule, is now found to belong to Helichrysum.

\section{1.-HELICHRYSUM BRACTEATUM, Will. THE BRACTEATED, OR LARGE GOLDEN EVERLASTING.}

Svжoкчмes.-Xeranthcmum lucidum, IIank.; Elichrysum bractea- $\mid$ with from 1 to 3 foliaceous bracteas. Involucral scales glabrens, tum, Vent. ; II clichrysum chrysanthemum, Pers.

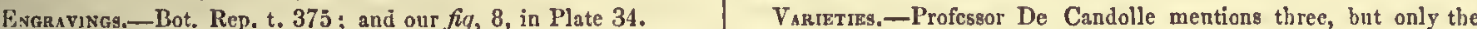

Specinic Cuaracter. - Plant erect, branched, rather scabrons. following is known in British gardens: H. b. 2 albidnm, Dec. The Ieaves lanceolate, repand, acumioated. Heads terminal, furnished invelucral scales which form tho ray are white, witl a golden yellow disk.

Description, \&c.-A very handsome Everlasting-flower, with bright yellow golden-looking scales, whiclı have quite a metallic lustre in the sun. It is a native of the eastern and central parts of New Holland, whence it was sent home in 1799. Secds are common in the seed-shops under the names of Xeranthemum lucidum and Elichrysum bracteatum, and they are generally sown on a hotbed in February or March, to plant out in May. They will, however, do very well if sown in the open border in April or May; and in sheltered situations if allowed to sow themselves, the young plants will live through the winter uninjured. The flowers when gathered will keep for several years without undergoing any change.

\section{2.-HELICHRYSUM BICOLOR, Lindl. THE TWO-COLOURED HELICHRYSUM.}

Exanuvings._Bet. Reg. t. 1814 ; aod our fig. 6, in Plate 34 . | lanccelate; lower oncs obtuse at tho base, ciliated; npper caes subuSpecific Charscrer.-Stem furrowed, brauched. Leaves linear- late. "Involucral scales acute.

Description, \&c.-This species, which differs very little in general appearance from $H$. bracteatum, derives its nane of $H$. bicolor from a slight copper-coloured tinge on the tips of the outer series of involucral scales. It is a native of Van Diemen's Land, and quite hardy; but we do not know where seeds are now to be procnred. It was however introduced by Mr. Low of the Clapton nursery in 1835, and probably sceds may still be purchased there. 


\section{3.-HELICHRYSUM MACRANTHUM, Benth. THE LARGE-FLOWERED HELICHRYSUM.}

Enaravings.-Bot. Reg. for 1838, t. 58 ; Botanist No. 92; and our fig. 7 , in Plate 34.

Spreific Character. -Stem erect, scabrous. Leaves oblong-lanceo-

late, or lower ones spatulate, obtusc, and quito entire, stem-clssping at the base, and rather scabrous. Involucral scales radiant, ovate, nbtuse, mucronate.

DESCRIPTion, \&rc.-A very beautiful flower, the involucral scales of which are white, tipped with pink. It is a native of tho Swan River colony, and was introduced in 1837. It is quite hardy and robust-growing; and we saw it flowering luxuriantly in the open ground in the nursery of Mr. Rogers in Eaton Square. Seeds of it are to be procured at Kernan's, James Street, Covent Garden, and other seed-shops. The seeds may either be sown in the open ground in March or April, or brought forward on a hotbed, and planted out in May; the principal advantage in the latter case being that the plants will flower sooner. The soil should be composed of peat, sand, and leaf mould, and it should be thoroughly well drained.

\section{GENUS XXXII. \\ CACALIA, Linn. THE CACALIA. \\ Lin. Syst, SYNGENESIA EQUALIS.}

Grakric Character.-Heads homogamous. Flowcrs all tubular, of the style terminsted by a short hispid cone. Aclienia oblong, penfive-lobed, lobes lincar, elongatcd. Receptacle flat. Involucrum ovate, tsgonal, sngles lispid. Pappus in msny series.

cylindrical, in one serics. Scales lincar, and st length refiexed. Branches

\section{1.-CACAlia COCCiNea, Curt. THE SCARLET CACALja.}

Svnonvmes.-Emilis sagittata, Dec.; E. flammea, Cass.; Cacalia sagittata, Vahl.; C. sonchifolia, Hort.

Esgravings.-Bot. Mag. t. 564 ; and our fig. 2, in Plate 31.

Specific Chanacter.-Stem erect, a little branched. Lower

cauline leaves spatulate, narrowed at tho baso, the rest sagittate, stemclasping, and minutely toothed. Heads diaposed in terminal corymbs, outer florets of the head curved.

Description, \&c.-A very curious plant with bright scarlet flowers. Its stalks, which are very slender, grow two or three feet high, and reyuire support. It is a native of the East Indies, and the Philippine Islands. It was introduced in 1800; and the seeds, which may be had in any seed-shop, may either be sown in a hot-bed, or in the open air in April.

\section{GENUS XXXIII. \\ SENECIO, Less. THE GROUNDSEL. \\ Lin. Syst. SYNGENESIA SUPERFLUA.}

Generic Cunacter.- Head discoid or heterogamous. Flowers of Receptacle naked, or honeycombed. Styles of the hermaphrodite flowers the ray ligulate, female. Involucrum in one series, naked or calyculate. pencilled. Achenis bcakless. Pappus pilose, in many series, caducous.

Description, \&c.-This genus perhaps contains more plants than any other of the Compositæ; but most of them are common and insignificant weeds. Some are, however, showy flowers; as, for example, the purple Jacobæa.

\section{1.-SENECIO ELEGANS, Thun. THE JACOB压A, OR PURPLE RAGiVORT.}

Synony mes.-S. pseudo-elegans, Less.; Jacobæa elcgans, Moench. Jittle rounder than the rest. Heads disposed in sub-racemous corymbs. Engravings.-Bot. Mag. t. 238; and our fig. 9, Plate 32.

Speciric Charactra.-Ercet, much branched. Leaves pintatifid, Involucrum calyculated with foliaceous scales.

VARIETIEs. - The double purple is the most common; but there lobes ovate, obtuse, bluntly toothed; terninal lobe roundish, or a are also several of a paler shade, and some almost white.

Description, \&C.-The double purple Jacobæa, is a benutiful and very favourite flower; and though it is not so handsome in its single state, it is still very pretty, and deserving of cultivation. There are several varieties; 



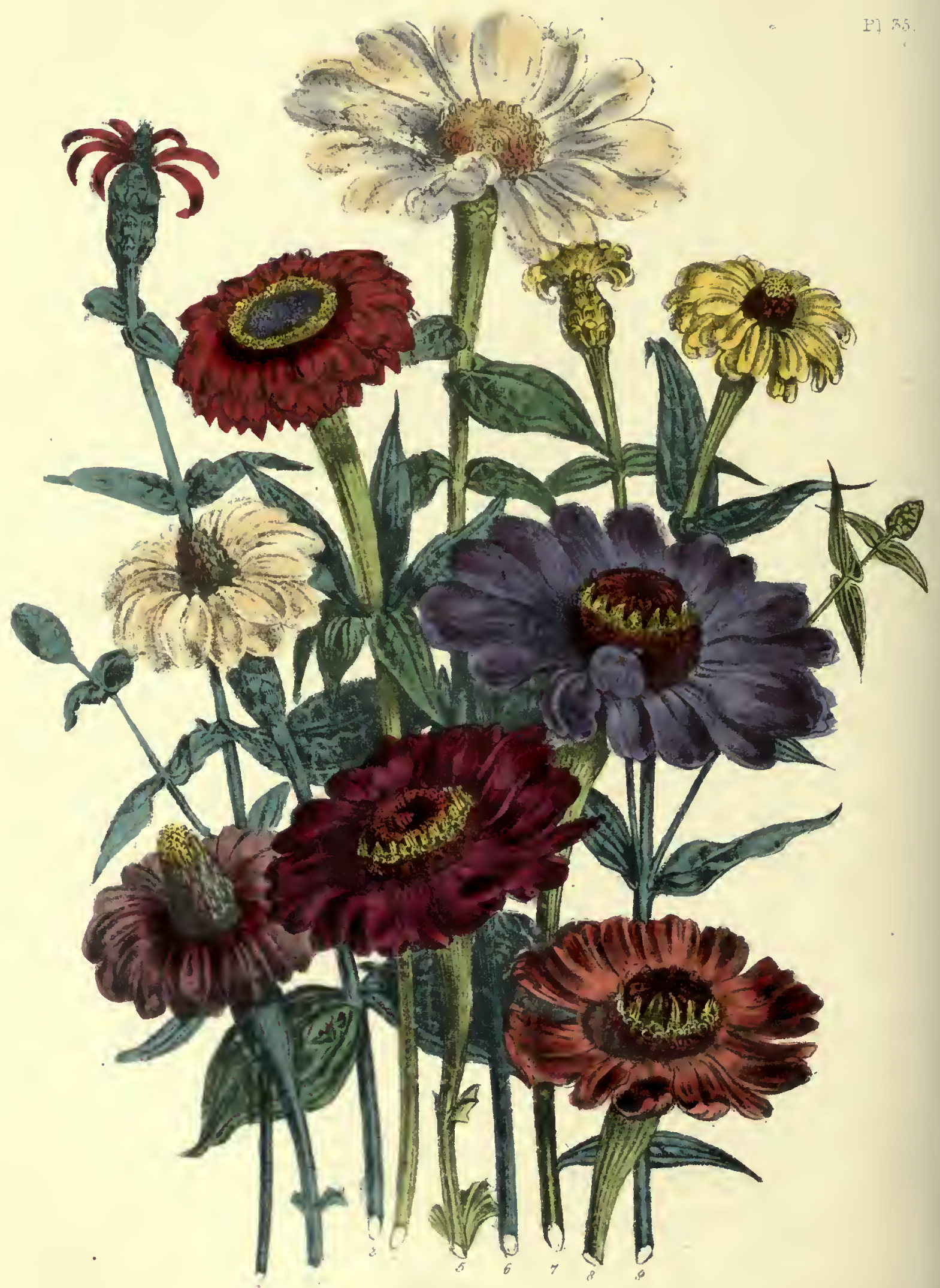

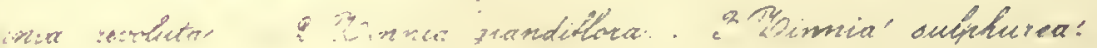

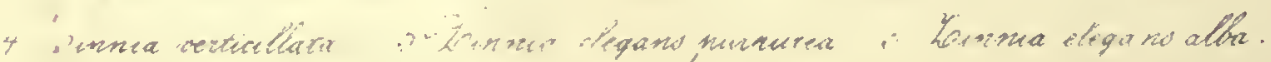



and one, of a beautiful blush colour, and very double, which we saw in the Lewisham nursery, in the summer of 1838, struck us particularly. The species is a native of the Cape of Good Hope, and was introduced in 1700, by Charles Dubois, Esq., one of the patrons of gardening in the time of Peter Collinson. The culture of the Jacobæa is exactly the same as that of other tender annuals ; viz., it must be raised on a hot-bed, and planted out in May ; but it is best for the possessor of a small garden, to purchase half a dozen or a dozen plants in that month from a nurseryman, and to plant them singly, or three together, in holes prepared for the purpose, and filled with a mixture of peat earth, or heath mould, and loam. When first planted they should be shaded for a day or two ; and covercd evcry night with a flower-pot turned over them for a week or fortnight. If the weather be dry, they should be watered every day slightly with warm water; and thus treated, they will make magnificent plants.

\section{2.-SENECIO TUSSILAGINIS, Less. 'THE COLTSFOOT-LEAVED RAGWORT.}

Sysonyurs, -Cineraria tussilaginis, L'Herit،; Pericallis tussilaginis, D. Don.

Exgrapisgs.-Bot. Reg. t. 1550 ; Swt. Brit. Flow. Gard. t. 228; and our fig. 10, in Plate 32 .

Description, \&c.-A handsome plant with star-like flowers, strongly resembling those of the genus Cineraria.

A native of Teneriffe, introduced in 1831. The culture is the same as that of Senecio elegans.
Spectric Character.-Petioles auriculatedly cordate at the base, the rest naked. Leaves reniformly cordate, angled, toothed, clothed with hoary tomentum beneath. Heads disposed in panlcled corymbs. Scales of involucrum glabrous, striated.

\section{GENUS XXXIV. ZINNIA, Lin. THE ZINNIA \\ Lin. Syst. SYNGENESIA SUPERFLUA.}

Grantc Character.-Head radiate. Flowers of the ray female, the disk. Achenia corticate, membranous, and a little wingcd; ligulate, thoso of the disk tubular, hermaphroditc. Ievolucrum imbri- those of the ray somewhat tetragonal; outer onca of the diak also catcd, scalea ovatc, roundiah, margined with black. Receptacle conical somewhat tetragonal, but inner ones compressed, and furnisbed with or cylindrical. Palca oblong, complicated, involviag the flowers of one or two awns at the apex, bidentated, or mutic.

Descniption, \&c.-This genus was named by Linnæus, in honour of Professor Zinn, the pupil aud successor of Haller at the University of Gottingen; and it consists of a number of very showy Mexican aunuals, which require to be raised on a hot-bed, and not planted out in the open air till May. Zinnia is indeed one of thoso annuals which will not succeed when sown in the open air; as a certain degree of heat and moisture appears neccssary to make the seeds vegetate. There are numerous species; all with splendid flowers, and highly worthy of cultivation.

\section{1.-ZINNIA REVOLUTA, Cav. THE REVOLUTE-FLOWERED ZINNIA.}

Sצмокуме.-Z tenuiforn, Jacq.

Engravixcs. - Bot. Mig. t. 555 ; and our fig. 1, in Plate 35.

date-lanceolate. Peduncles long, cylindrical. Iovolucrai acales adpressed. Ligula lincar-oblong, uaually revolute. Palea of receptacle Specific Character. - Stem erect. Leaves on ahort petioles, cor- quite cntire. Achenia of the diak each furnished with one awn.

Description, Sc.-This species is less sbowy than any of the other Zinnias; but it is curious from the clawlike curving of its ray florets, and their brilliant colour. It grows two or three feet high, and divides into several branches. It has been only found in Mexico, and was introduced about the year 1800. The seeds, which are common in the seed-shops, should be sown on a hot-bed in February, and planted out about the middle of May; or in cold situations, not till June. 


\section{2.-ZINNIA VERTICILLATA, Andr. THE WHORL-LEAVED ZINNIA.}

SY NONYME. - Z. hybrida, Hort.

Engravings.-Bot. Rep. 3, t. 189; and our fig. 4, in Plate 35.

Spreific Character. - Stem erect, rather bairy. Lesves oblong-

lanceolate, sometimes crowded in s vertieillate manner, and sometimes

placed spirally. Peduncles short, obconical, hollow, and striated. lnvolucrum campanulate, with adpressed scales. Ligulæo obovate, emarginate at the apex, usvally in two or three series. Paleæ of receptacle quite entire, acutish. Achenia of the disk furnished with one swn.

Description, \&c.-This species of Zinnia affords a striking contrast to the last, in the shape of the flower, and in the number and disposition of the florets of the ray. It is also very strongly marked by the whorl of leaves at the base of the peduncle, and by its thickened apex. It is a native of Mexico; and was introduced in 1789. Its culture is the same as that of $Z$. revoluta.

\section{3.-ZINNIA MULTIFLORA. THE MANY-FLOWERED ZINNIA.}

Exeravina. -Bot. Mag. t. 149.

Spectific Character.-Stem erect, brsnehed, rather hairy. Leaves searcely petiolate, ovate-lanceolste. Petioles obconical, hollow, and striated. Involucrum campanulate, with sdpressed sesles. Ligulne

\author{
obovate, obtuse, or emarginatc. Palese of receptacle quite entire, \\ obtuse. Achenia of tho disk furnighed with one awn. \\ VARIETY.-Z. m. 2. lutea, our fig. 9, in Plate $35 ; Z$. pauciflors, \\ Lin.: Z. lutee, Gortn.; ? Z. m. 2 flava, Kunth. Flowers yellow, \\ or pale orange.
}

Description, \&c.-The flowers of the specics are scarlet, and those of the variety yellow; but they differ very little in any other respect. They have both been common in British gardens since 1770 , and require the same treatment as the other species of the genus. Z. multiflora was sent to England from Louisiana, of which country it is a native; but it is also found wild in Brazil, Mexico, and the Mauritius.

\section{4.-ZINNIA HYBRIDA, $R$. et Pav. THE HYBRID ZINNIA.}

SyxoNrMes, $-Z$, grandiflora, Hort.

Excruvings.-Bot Mag. t. 2123, and our fig. 2, in Plste 35, under the nsme of $Z$. grandiflora.

Specific Craracten.-Stem erect, pubescent. Leaves cordate-ladr. ccolate, sessile, stem-clasping. Peduneles tcrininal, solitary, shorh obconical, hollow. Involucral scales adpressed. Palex of receptacle acute, entire. Achenia bidentately-awned.

Description, \&c.-This species is supposed to be a hybrid, between Z.elegans and Z. multiflora ; and it las, indeed, the large flower of the one species, and the conical disk of the other. It is not, however, a very desirable species to grow, on account of the dull dingy colour of the flowers. It is a native of South America, where it was discovered by Ruiz and Pavon, and described by them. It was introduced in 1818 ; and its culture is the same as that of the other species.

\section{5.-ZINNIA SULPHUREA, Hort. THE SULPHUR-COLOURED ZINNIA.}

Symonyaz. -? Z. angustifolia, Hum. ; ? Z. hybrida var. sulphures. ; ovate, scuminated. Peduncles cylindrical. Involucral scales squarrone. ExGhaving._-Our fig. 3, in Plate 35.

Sprcific Character. - Stem erect, pubescent. Leaves sessile, hispid, $\mid$ nia of the disk emarginately-bidentated, ciliated.

Description, \&c.-This plant so strongly resembles $Z$. hybrida in the shape of its flowers, and its conical disk, that it is probably only a variety of that species; or it may be the Z. angustifolia of Humboldt, with the leaves become broader by cultivation. Z. angustifolia is a native of Mexico, and is stated to have been introduced in 1824. The name of $Z$. sulphurea is not mentioned in any of the botanical catalogues. 


\title{
6.-ZINNIA ELEGANS, Jacq. THE ELEGANT ZINNIA.
}

Srnowym. -Z. violacea, Cav.

Evchavings.-Bot. Mag. t. 527 ; Bot. Rep. 1, t. 55 ; aod our fig. 7. In Plate 35, under the name of Z. e. violacea.

Specific Charucter.-Stem erect, hairy. Leaves sessile, stemclasping, cordate, ovate. Peduncles solitary, longer than the leaves, cylindrical. Involucral scales ovate-obtuse; upper ones margined with black. Palex of receptacle serrated. Achenia of the disk mutic, scarcely bidentated. Ligules obovate.

VARietirs.-Z. e. 2 alba, Dec.; and our fig. 6, in Plate 35. The flowers are whitish, or rather a very pale yellow. Z. e. 3 purpurascens, Dec. ; and our fig. 5. The flowers are of a very rich dark crimson. Z. e. 4 coccinea, Dec. ; Bot. Reg. t. 1295.; and our fig. 8. The flowers are scarlet.

Descniption, \&c.-This is by far the handsomest of all the Zinnias. Like the others, it is a native of Mexico, and requires to be raised on a hot-bed in this country ; but when planted out, it grows more luxuriantly than any of the other kinds, and is, perhaps, the only one truly deserving of cultivation by amateurs. All the varieties are as handsome as the species; and they all come true from seed. Seeds are common in all the seedshops.

\section{TRIBE CYNAREA.}

\section{GENUS XXXV.}

CALENDULA, Neck. THE MARIGOLD.

\section{Lin. Syst. SYNGENESIA NECESSARIA.}

Generic Craructer.-Flowers of the ray ligulate, female; those of the disk tubular, male. Corollas hispid. Involucral scales in two вeries. Receptacle nakcd, flat. Anthers subulate, tailed. Style eoding in a hispid bifid cone. Achenia of the ligular flowers without pappos ; middle ones echinated on the back; drawn out on the sides into as entire, or concave, flat, toothed membrane; inncr ones annular, incurved, muricated on the back.

\section{1.-CALENDULA OFFICINALIS, Lin. THE COMMON MARIGOLD.}

\author{
Sצмомчмвs,-Cal tha officinalis, Manch; C. vulgaris, C. Bauh. \\ Esgravisc.-Bot. Mag. t. 3204. \\ Sprciric Crasuctra,-Leares puhescent; lower ones entire, spatu- \\ late; upper ones lanceolate, stem-clasping, and a little tootbod. Achenis \\ all curved, muricated at the back.
}

Description, \&c.-The common marigold was, a century ago, a common flower in every garden; and it is only since so many finer flowers have been introduced, that it may be said to have gone out of faslion. The double variety is still, however, very generally grown. It is a native of the south of Europe, but it was introduced into England before 1573. It only expands its flowers in broad sunshine. Shakspeare describes it as

\section{"The Marygold that goes to bed wi" the sun,}

And with him rises weeping."

The popular English name is said to have been corrupted from Mary's gold ; and to allude to the great use made of this plant as a pot-herb, by the wives of cottagers. Souci, the French name, Sir. W. J. Hooker tells us in the Bot. Mag., is derived from Solsequium to follow the course of the sun; and Calendula from Calends, because, from the great length of time the plant continues in flower. it may be said to bloom every month. The flowers of the Marigold, taken internally, are said by the old herb-doctors to be "great comforters of the heart and spirits." The common Marigold is quite hardy. 


\section{2.-CALENDULA STELlata, Cav. THE STAR-LIKE MARIGOLD.}

SYNoNYME.-C. crista-galli, Vahl.

Specific Character. - Stems scabrous. Leaves ovate-oblong, nous toothed margins; the five inner ones boat-sliaped, and amooth on toothed, a little ciliated; lower ones attenuated at the base; upper I the back; the rest angular, and muricated on the back.

Description, \&c.-A handsome plant, with orange flowers, a native of Bombay, introduced in 1795 . It is quite hardy, and only requires sowing in the open borders in March or April.

\section{GENUS XXXVI. \\ CRYPTOSTEMMA, R. Br. THE CRYPTOSTEMMA. Lin. Syst. SYNGENESIA FRUSTRANEA.}

Generic Character.-Head radiate; flowers of the ray neuter, and filaments scabrous. Achenia clothed with a long and very denso and ligulate or difformed by being palmately parted, or biligulate; pubescence. Pappus in one series, the scarious palese hidden by the those of the disk tubular, 5-toothed, and hermaphrodite. Receptacle wool of the achenia.

honey-combed. Involucral scales free, and in many series. Stamens

Description, \&c.-The species belonging to this genus, were formerly considered to belong to Arctotis; but they were separated from that genus, and the name of Cryptostemma given to them by Dr. Brown, on account of the long dense wool of the seed, which nearly conceals the pappus with which it is crowned. The name Cryptostemma is from the two Greek words, Kryptos, hidden, and stemma, a crown.

\section{1.-CRY PTOSTEMMA CALENDULACEUM, $R$. Br. THE MARIGOLD-LIKE CRYPTOSTEMMA.}

Synonymes.-Arctotis Calendula, Lind.; A. calendnlacea, Jacq. | Specrric Charactra. -Ligulæe entire, or toothed at the apex, with Engruving.-Bot. Mag. t. 2252. two or three very short teeth.

Description, \&o.-A showy plant, with bright golden-yellow flowers, and lairy stems. It is a native of the Cape of Good Hope, and was introduced in 1752. It was at one time very common in gardens, but it seems now to have fallen out of cultivation, as its name is not in any of the seedsmen's catalogues that we have. The seeds should be raised on a hot-bed, or not sown till May, as they are rather tender; and the plant requircs a warm situation, and a light and rather sandy soil.

\section{2.-CRYPTOSTEMMA HYPOCHONDRIACUM, $R$. Br, et Less. THE MELANCHOLY-LOOKING} CRYP'TOSTEMMA.

Synosyses.-Arctotis tristis, Lin.; A. hypochondriaca, Willd.; Cynotis hypochondriaca, $H_{0}$ f $m$.

Speciric Cantacter.-Ligulæ all or mostly 3 or 5 -parted; lobes

linear, subpalmate, rarely subbilobate; leaves lyrate, woolly, or cobwebbed, on botb sides.

Descriptron, \&o.-This plant, being much haruher than the last species, still keeps its place in gardens, and is in all the scedsmen's catalogues under the name of Arctotis tristis. It is rather singular that a plant so well known does not appear to have been ever figured. The flowers of the ray are yellow inside, and of very dark purple, almost black outside ; whence the name of tristis. The plant is a native of the Cape of Good Hope, and was introduced in 1731. The culture is the same as that of the preceding species; and both, though they should be grown in dry soil, require, like all the Cape plants, frequent and abundant watering to bring them to perfection. There is another species, C. rincinatum, the leaves of which resemble those of the Dandelion. 


\section{GENUS XXXVII.}

\section{ECHINOPS, Lin. THE GLOBE-THISTLE.}

\section{Lin. Syst. SYNGENESIA SEGREGATA.}

Genrarc Craracter.-Heads l-flowered, cembined, or collected on $\mid$ or with the ovarium. Flowers all hermaphrodite, fertile; tube of a globose receptacle, sessile. Proper invelucrum of many series of corolla terete, inflated st the throat; stigmas naked. Fruit clothed ccales ; outer seales hair-formed and weolly at the base; middle ones with silky villi. Pappus cemposed of free, shert bristles.

fringed er eiliated at the margins; inner ones eften combined together,

\section{1.-ECHINOPS S'TRIGOSUS, Lin. THE MEAGRE, OR ANNUAL, GLOBE-THISTLE.}

Engraving.-Bet. Mag. t. 2109.

Specific Characten.-Leaves pinnatifid, strigose, and clothed with

hoary tomentum beneath as well as the stem. Scales of partial invo-

lucrum bristle-formed and numerous. Fruit pentagenal, clothed with silky villi.

Description, \&c.-This is the only annual species of Globe-Thistle; and though it has no beauty to boast of, it is curious as being the plant from which the Spanish Moxa is made. The Amadou, or common vegetable tinder, is a fungus growing on the beech; but the Moxa, or Spanish tinder as it is called, and which is used like the Amadou for lighting cigars, is said to be made from the pubescence of this plant. The annual Globe-Thistle is a native of Spain, and was introduced in 1729. It was, however, soon lost, but was re-introduced in 1819 , by A. B. Lambert, Esq., to whom the botanical world owes so much, and in so many different ways. Seeds are not common in the seed-shops; but when they are procured, they should be sown in the open border in March or April.

\section{GENUS XXXVIII. \\ XERANTHEMUM, Toum. THE XERANTHEMUM. \\ Lin. Syst. SYNGENESIA SUPERFLUA.}

Generic Cnaracter.-Heads heterogamous. Involucral scales bilabiate. Anthera linear, bicornute at the base. Fruit of the herimbrieated, acarious. Paleæ of reeeptacle scarieus, tripartite. Flowers maphrodite flowers silky, with persistent paleaceous pappus.

of the disk hernaphrodite, 5-toothed; these of the ray female,

\section{1.-XERANTHEMUM ANNUUM, Lin. THE ANNUAL XERANTHEMUM.}

Sxnonymes.-X. radistum, Lam.; Centaurea dubia, Gmel.; X. | inner leares mueb longer than the rest. ornatum, Cass. ; X.inodorum, Meench.

Speciric Characten. - Invelucrum hemispherical, quite glabrous; album fig. 10, in Plate 34.

Description, \&c.-This is by far the most elegant of all the Everlastings. It is a native of the South of Europe, and was first cultivated in the Oxford Botanic Garden about 1658. It requires no other care than sowing the seeds in the open horder in February or March, or in Autumu; as it will stand through the winter, unless very severe; and autumn-sown plants are always stronger and flower earlier than those sown in spring. If gathered as soon as the flowers are expanded, these flowers may be kept for years; and when the brilliancy of the colour of the lilac kind has faded, Philips, in his "Flora Historica," tells us that it may be restored by holding the flowers in the vapour of any acid. He also mentions that the seeds, or fruit, when dry, sometimes become detached from the receptacle in a very beautiful manner. Being kept together by the feathery nature of the pappus, the wlole mass first swells into " a kind of domc, the feathers being attached to each other in the most delicate manner imaginable with the seeds downwarủs; after whicl, as they loosen themselves, the effect is still more delicate and singular, as it resembles, in miniature, a number of stars being thrown out of a circular piece of fire-work." 


\title{
GENUS XXXIX. \\ CENTAUREA, Lin. THE CENTAURY.
}

\author{
Lin. Syst. SYNGENESIA FRUSTRANEA.
}

Generic Charucter.-Involucral scales various. Corollas of the ray large, sterile, or bermaphrodite. Achenla compressed. Pappns composed of subfiliform bristles, scabrous, usually in many series; nnacr series small and somewhat connivent. A very polymorphous geaus.

Description, \&cc.-This genus is weil known from the English weeds, Knapweed, Bluebottle, and StarThistle, which belong to it. The flowers are all very striking in their forms, though they differ widely from ench other. The name of Centaurea is said to have been given to this genus because one of the species was used in medicine by the centaur Chiron.

\section{1.-CENTAUREA CYANUS, Lin. THE CORN-BLUEBOTTLE.}

ENGruvings.-Eag. Bot. t. 277 ; 2nd. edit., vol. 6, t. 1188 ; and | toothed, or pinnatifid. our fig. 8, in Plate 33.

SPECIFIC Cure numerous; but those most geaerally

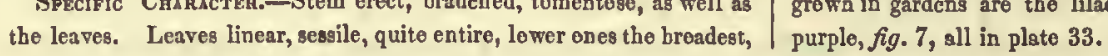

Description, \&c.-The beauty of this flower is so great that it is in common .cultivation in gardens, notwithstanding its frequency in our corn-fields. "No artificial colour," observes Sir J. E. Smith, "can equal tho brilliancy of the blue of the outer florets of the Cyanus." It may be sown at any season; but generally February or March is preferred, or the seeds are sown in autumn and the plants are loft to stand through the winter.

\section{2.-CENTAUREA CROCODYLIUM, Lin. THE CROCODYLIUM, OR BLUSH-CENTAURY.}

Engruving.-Our fig. 1, in Plate 33. $\quad$ almost glabreus, pinnatifid; outer lobe larger than the rest, in the Specific Character.-Stem erect, sparingly branclied. Leaves lower leaves ovate, in the upper oacs oblong or linear.

Description, \&c.-A curious and beautiful plant, not now so much cultivated as it ought to be. It is a native of the Levant, and was introduced in 1777. The name is in the seed-catalogue of Forrest and Black, at Kensington, and we have seen magnificent specimens of the plant growing in the Hammersmith Nursery.

\section{3.-CENTAUREA AMERICANA. THE AMERICAN CENTAURY.}

Synonymes__C. Nuttallii, Spreñgs; C. grandiflora, Sesse et Moc.; Plectocephalus americanus, $D$. Don.

Engraving.-Swt. Brit. Flew. Gard. 2nd ser. t. 51.

Specific Character.-Leaves oblong, membraneous, undivided. Peduncles ventricese at the apex. Outer invelucral scales abeut s third of the length of their appendages.

Description, \&c.-A very splendid and singular plant, having a large star-like flower. The ray flowery are lilac, and those of the disk nearly white. It is a native of the Arkansas territory, where it was discovered by Nuttall. It was introduced in 1823; and seeds may be procured at all the seed-shops. The seeds should be sown in March, or thcy may be raised on a hot-bed, and planted out in the beginning of April. The flower is very large and showy, and it is not suitable for a small garden.

\section{4.-Centaurea depressa, Bieb. The prostrate Centaury.}

SYNONYME.-C. PYgmæa, Hoff $m$.

ENGRAVING.-Bot. Mag. t. 3662.

Specific Character.-Stem braachcd from the base, declinate, or

simple and erect ; clothed with white tomentum, as well as the leares. Cauline leaves ebloog, sessile, quite entire, lower ones a little teothed. Umbilicus of the fruit bearded. Pappus equal in length.

Description, \&c.-In the shape of the flower, this species strongly resembles the common corn-bluebottle of the fields; but its colours are far more brilliant, and its stems are not above six or eight inches long. The whole plant is covered with a white down. It is a native of Iberia and Persia, and seeds of it were sent to England by Dr. Fischer, carly in the spring of 1838. It flowcred in August the same year, in the Glasgow Botanic Garden, in the open border, and may consequently be considered quite hardy. Seeds are not yet common in the seed-shops. 



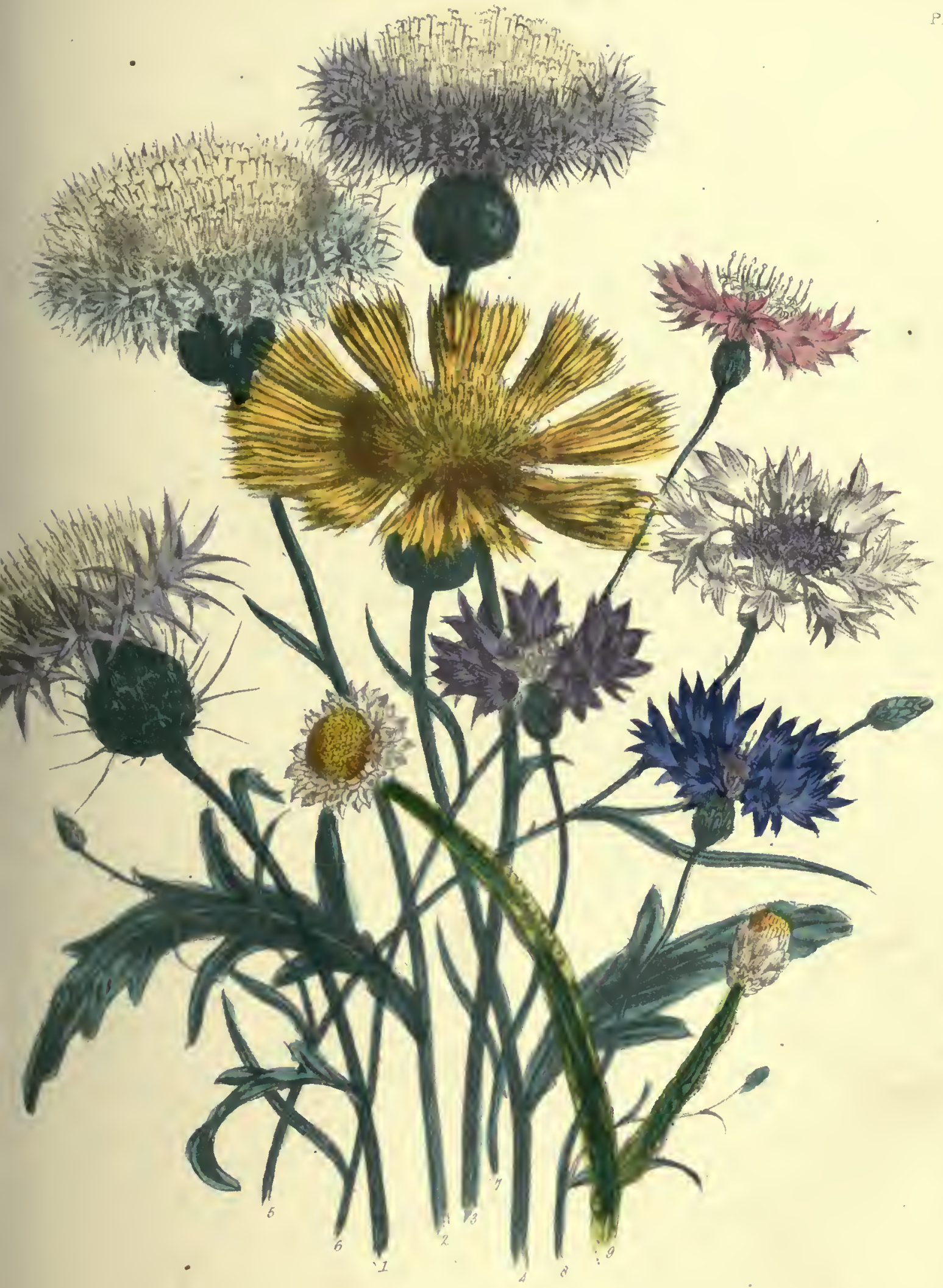





\section{GENUS XI. \\ AMBERBOA, Dec. THE SWEET SULTAN.}

Lin. Syst. SYNGENESIA FRUSTRANEA.

Gexeric Canracter.-Invulucral scalcs various. Corollas of the ray ample, sterile. Stamens with puberulous, or papillose filaments. Fruit compressed or turbinatcd, with a lateral or basilar areola. Palese of pappus oblong or obovate, rarely wanting.

Description, \&c.-The Sweet Sultans were formerly eonsidered to belong to the genus Centaurea, but have been separated from it by De Candolle. Amberboa is the Turkish name for A. moschata.

\section{1.-AMBERBOA ODORATA, Dec. THE Yellow SWEET SUltaN.}

Synonyme.-Centaurea suaveolens, Lin.

Engravings. -Swt. Bit. Flow. Gard. t. 51; sed our fig. 4, in fruit l'late 33.

Specific Cuaractra.-Corollas of the ray wideved upwards, longer has purple flowers.

Description, \&e.-The honey-seent of this flower and its beauty, have long made it a favourite in gardens. It is a native of Persia and the Levant, and it was introdueed in 1689. It is generally thouglit tender, and raised on a hot-bed; but will do quite well in the open border if sown in April or May.

\section{2.-AMBERBOA MOSCHATA, Dec. THE COMMON SWEET SULTAN.}

Synonyme.-Centaurea moschata, Lin.

Engraving.-Our fig. 3, in Plate 33.
Specticic Character.-Corollas of the ray wide, not exceeding throse of the disk. Pappus nouc.

VARIETY.-A.m. 2 alba, our fig. 2, in Plate 33.

Deseription, \&rc.-The smell of this flower is so overpowering from its honev-like sweetness, that it is almost impossible to bear it in a room. It is very handsome. It is a native of Persia and Turkey, whence it was sent to England shortly before 1629 .

\section{GENUS XLI. \\ CARTHAMUS, Lin. THE CARTHAMUS.}

\section{Lin. Syst. SYNGENESIA RQUALIS.}

Gexmic Chabactfar.-Heads homogamous. Outer involucral seales foliaccous, spreading; middle ones erect, oval, expanded at the apex into an ovate appendage, which is spiny along its margin; the inner ones oblong, entire, each ending in a pungent point. Receptacle fringed. Corollas 5 -cleft, almost regular, the tube expanding above the disk. Anthers each terminated by an obtuse appendage. Stigmas scarcely distiuct. Achenia obovate, tetragonal, glabrous. Psppus wanting.

\section{I.-CARTHAMUS TINCTORIA, Lin. THE DYER'S CARTHAMUS, OR SAFFLOWER.}

Synony mes.-Cnicus vulgaris, Chus.; Bastard Saffroo.

ENGRAYINGs.-Bot. Reg. t. 170 .

Specric Character.-Plant glabrons. Csuline leaves uvatelanceolate, spinosely serrated.

Deseniption, \&c.-The flower of this plant is not very beautiful, as, indeed, it very much resembles that of the Globe Thistle, and what is remarkable, though it is of a yellowish-orange, the eolour it produces is a beautiful pink. It is a native of Egypt; but it was introdueed into England in 1551, and was once cultivated to some extent in Gloucestershire. It still forms an artiele of eommeree as a dyer's drug ; and it is said to be the principal ingredient in the cosmetic called Vegetable Rouge, or Spanish Vermilion. In Spain, and along the shores of the 
Mediterranean, the leaves are eaten as a kind of vegetable. The seed was formerly used as a medicine, and it is still called Parrot's Corn, as it is said to be particularly wholesome for those birds, though injurious for most others. The seeds are common in the English seed-shops, and they may be sown at almost any season, and in almost any soil.

\section{2-CARTHAMUS OXYACANTHA, Bieb. THE SHARP-SPINED CARTHAMUS.}

Speciric Craracter.-Plant rather villous. Leaves oblong-lanccolato, with spiny margins. Fruit ovate-compressed.

Description, \&c.-A plant with yellow flowers and spiny leaves, growing about three feet high. A native of Caucasus. Introduced in 1818.

\section{GENUS XLII.}

\section{RENTROPHYLLUM, Neck. THE KENTROPHYLLUM OR WOOLLY.CARTHAMUS.} Lin. Syst. SYNGENESIA EQUALIS.

Generic Cinaractern,-Head homogamous. Involucral sealcs ovate, | thick, obovate, and somewhat tetragonal, glabrous, denticulated at the outer ones folinceous, pinnatifid, spinoso; inner ones oblong, scarcely toothed, but ending in a spioose point. Receptacle thick, fringed. Corollas 5.cleft, regular; the ray ones sometimes very few, sterile, and filiforn. Filnuments furnished with a ring of hairs. Anthers ternainated cach by au obtuse appendage. Stignas combined. Achenia apex, with an obligue areola. Pappus in the marginal flowers wanting, in the rest palcaccous, the outer palex mcmbranous, eiliated on the margins, imbricated; tho inser oncs very short, in one scrics, truncate, and tootbed.

\section{I - KENTROPHYLLUM LANATUM, Dec. THE WOOLLY KENTROPHYLLUM, OR YELLOW} DISTAFF-'THISTLE.

Srvorvmes.-Cartlanuus lanatus. Lin.; Cirsium lanatum, Dec.; Il cracantla lanata, Link.

Engraving.-Bot. Mag. t. 2142.

Specific Character. - Stem pilose at the base, and cobwcbbedat the top; lower leaves pinnatifidly toothed; upper ones stenl-elasping, pinnatifidly toothed. Involucrum more or less woolly.

Descniption, \&c.-A curious plant, somewhat resembling a thistle in its flower, but having its stem clothed with a downy pubeseence, which hangs down from the head and upper part of the stalk, like the wool from a distaff used in spinning. It is supposed to be the Aretractylis of the ancients. It is a native of the sonth of Europe, and was cultivated in England before 1596, as it is mentioned by Gerard as growing in lis garden in that year. It is quite hardy, and will grow in any soil and situation.

\section{'TRIBE CICHORACEX.}

GENUS XLIII.

\section{TOLPIS, Biv. THE PURPLE-EYED YELLOW HAWKWEED.}

\section{Lin. Syst. SYNGENESIA AQUALIS.}

Generuc Gharacter.-Involncral scales in few series, calyculated by linear setaceous bracteas. Receptacle honey-combed. Achenia turbinated, striated, beakless. Pappus in one series.

\section{1.-TOLPIS BARBATA, Gartn. THE BEARDED TOLPIS, OR PURPLE-EYED HAWKWEED.}

Synonymes. - Crepis barbata, Lin.; Drepania barbata, Dec.; Sprcific Сниялетеr._Stem erect, branched, lcafy. Leaves lanceoIlicrscium prolifcrum, Bauh.

Enoravings.-Bot. Mag. t. 35; and our fig. 6, in Plate 31.

late, toothed. Bractens excecding the scalcs of the involucruss.

Description, \&C.-A very well-known flower, which, though introduced in 1620 , has maintained its place 
in our gardens ever since. It is a native of the Soutls of lirance, and the seeds will come up, and generaliy produce abundanee of flowers, if sown in any soil and situation, and at almost any season. Seeds are sold in the seed-shops under the name of Crepis barbata.

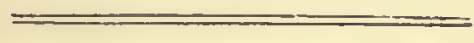

GENUS XLIV.

BOERKHAUSIA, Bøll. THE BOERKHAUSIA, OR REDDISH-LILAC HAWKWEED. Lin. Syst. SYNGENESIA RQUALIS.

Gexemic Cunfacter.-Involucrum calyculated, rarely subimbricated. Receptacle ncarly naked, or finged. Achenia terete, some of tbe centerl ones attenuated inte a leng beak. Pappus in many scries, pilese.

\section{BOERKHAUSIA RUBRA, Link. THE REDDISH BOERKHAUSIA.}

Synesymes.-Crepis rubra, Lin.; Barkbausia rubra, Moench. | naked at tep. Leaves ususlly rsdical, and ruminately lyrate, petielate; Engiuqing.-Our fig. 2, in Plate 32. cauline ones sessile, lincar, cut at the basc. Outcr scales of involucrum

Specific Cnaracrer...Stems leafy from the base snd branched, lanceelate, acuminate, glabreus; inner ones ratber scabrous.

Descriptron, \&c.-A tall-growing plant with very slender stems and lilac flowers, which are generaliy double. It is a native of Italy, whence it was introduced in 1632. It is quite hardy, and should be sown in the open border; but always where it is to remain, as it will not bear transplanting unless when very young. When the plant seuds up its flower-stalks, they are so long and slender that they slould be staked and tied. Seeds are to be procured in nearly all the seed-shops, under the name of Crepis rubra.

GENUS XIV.

PICRIDIUM, Desf. THE POPPY-LEAVED VIPER'S-GRASS.

Lin. Syst. SYNGENESIA RQUALIS.

Generic Craractra.-Iuvelucrum evate, imbricated, the seales white at the margin. Receptacle naked, heneycombed. Acbenia quadrangular, prismatic, transverscly tuberculated, trunculate and beakless at the apex. Pappus in many series, pilose.

Description, \&c.-The species comprised in this genus have been separated by Professor De Candolle from the genus Scorzonera. Picridium is from a Greek word signifying bitter, and alludes to the taste of the plants.

\section{PICRIDIUM TINGITANUM, Dec. TANGIER SCORZONERA, OR POPPY-LEAVED VIPER'S-GRASS.}

\section{Synonymes.-Dcorzonera tingitans, Sims.; Senchus tingitanus, Lin.}

Sfectfic Charscter.-.Stem brsuched. Leaves all runcinate, half stem-clasping. Pcduncles scaly. Outcr scales of the invelucrum squarruse.

Description, \&c.-A showy plant with a head of yellow flowers, and stem-clasping leaves. It is a native of Tangiers, and was introduced in 1713. It is quite hardy, bnt the seeds should be sown in a dry soil. The Howers soon fade when exposed to the sun, and they are seen to most advantage in cloudy weather. Seeds may be had at the Kensington nursery and in otber seed-shops; and they should be sown with tho otner annuais in spring. 


\section{OTHER ANNUAL COMPOSITÆ.}

The following have all been introdnced, and many of them are to be met with in nurseries and seed-shops, but they are by no means in general cultivation.

Centratherum INtermedium, Dec.; AMPherephis INTERMedia, Link., Swt. Brit. Flow. Gard. t. 225.

A weedy-looking plant, with small heads of purple flowers. It is a native of Brazil, and requires to be raised on a hotbed. It was introduced in 1821 . There are two other species, C. punctatum and C. muilicum, both introduced about the same time, and both natives of South America.

LAGASCEA MOLLIS, Willd, Bot. Mag. t. 1804.

A tender aunnal, a native of Cuba, requiring to be kept in the stove in England. The flowers are whitish, and are produced in heads like those of the clover, but are much smaller. Introduced in 1815.

EVAX PYGME, Dec.; FILAGO PYGMAA, Willd.

A little insignificant plant, with brownish flowers, a native of the south of Europe, introduced in I629. There are three other species.

\section{MICROPUS SUPINUS, Dec.}

A little trailing plant, with silvery leaves, and the flowers in heads. M. erectus differs principally in having tho flower-stalks erect. Both are natives of the south of Europe, and were introduced more than a century ago.

\section{AMBROSIA.}

There are several species mentioned in nurserymen's seed eatalogues, but they are none of them wortly of cultivation, though they have all a slight fragrance like that of new hay. One species, $A$.maritima, is a native of Italy, and was introduced in 1570, but the others are nativcs of America.

\section{PARTHENIUM IIYSTEROPHORUS, Willd.}

An insignificant plant with very small white flowers; a native of Jamaica, where it is called wild wormwood. It was introduced in 1728 , but having no beauty it has never been grown but in botanic gardens.

SIMSIA FICIFOLIA, Dec.; COREOPSIS FETIDA, Cav.; XIMENESIA FCETIDA, $K$. $S$. .

A yellow-flowered plant resembling a Coreopsis, but with a very unpleasant smell. A native of Mexico, introduced in 1799 .

MATRICARIA CHAMOMILLA, Smith. THE WILD CHAMOMILE.

This is rather a pretty English weed. $M$. inodorum, the corn-feverfew, is also pretty, but neither of them are thought worth cultivating except in botanic gardens.

CALENDUla ASTERIAS, $\boldsymbol{F}$. $M$. THE STARRY MARYGOLd.

A most beantiful species, a native of Barbary, introduced in 1836 , but at present very little cultivated. We do not know where seeds are to be proeured.

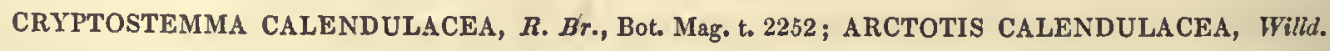

A very pretty little plant, with bright yellow flowers, and lyrate-shaped leaves. It is a nativo of the Cape of Good Hope, and was introduced in $\mathbf{1 7 5 2 .}$ 


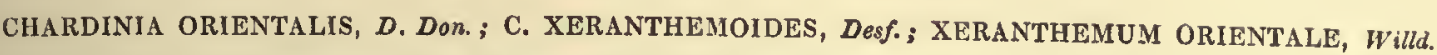

A kind of white everlasting flower, a native of the Levant; introduced in 1713 , but very seldom to be met witl in gardens.

Centa urea PUlchella, Dec.

A very pretty purple flower, a native of Persia, introduced in 1836.

TRIPTILION CORDIFOLIUM, Log., Bot. Reg. t. 853.

A very eurious little plant with white flowers, a native of Chili, introduced in 1823.

SCOLYMUS MACULATUS, Dec. THE GOLDEN-THISTLE.

A native of the south of Europe, introduced in 1633. The flowers are yellow.

There are many other species, but the above are the most ornamental.

\section{CHAPTER XXXV.}

\section{DIPSACEE.}

Essential Character.-Calyx adherent, with a variable limb. | l-seeded, crowncd by the limb of the calyx. Seed pendulous, albumen Corolla monopetalous, inserted near the top of the calycine tube, fleshy. Herbs or undcr shrubs, with alternate or verticcllate, variable nsually unequal, 4 or 5-clcft. Stamens 4, epipetalous. Style one, leaves. Flowers disposed in dense heads girded by involucra.anplo. Fruit indehiscent, membranous or submentaceous, l-celled, $($ G. Don.)

\section{GENUS I.}

KNAUTIA, Coult. THE KNAUTIA.

Lin. Syst. TETRANDRIA MONOGYNIA.

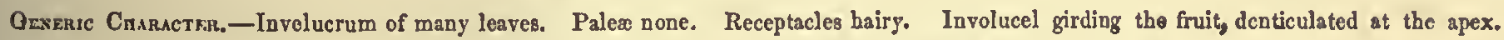
Limb of calyx cup-shaped. Corolla 4 or 5 -cleft. Stamens $4 .-($ G. Don. $)$

\section{1.-KNAUTIA ORIEN'IALIS, Lin. THE ORIENTAL KNAUTIA.}

Syмosymes. - Seabiesa orientalis, Lag.; Knautia trichotoma, cylindrical, of 5 to I0-erect leaves; corellas 5 to 10 in each head; Monch. outer once radiating, lenger than the involucrum; teeth of invelucel

Spreivic Character.-Leaves oblong, cut or entire; involucrum 12 to 15, very short; ciliæ of calyz obsolete.-(G. Don.)

Descnıption, \&c.-A very pretty little plant, with pink flowers, looking very much like a kind of Lychnis or Silene. It is a native of the Levant, and was introduced in 1713. As it seeds freely and will grow in any soil and situation, it has kept its place in gardens, while much handsomer flowers have fallen out of cultivation. 'There are several other annual species, but this is the only kind grown in British gardens. The name of Knautia was given to this genus in honour of Dr. Knant, a Saxon physician, residing at Halle, who died in 1694. 


\section{CHAPTER XXXVI.}

\section{VALERIA NACE A.}

Essemtial Character.-Calyz adberent; limb variable in the hisccnt, crowned by the limb of the calyx, one or three-cellcd; ul en different genera. Corolla monopetalous, usually 5-lobed, having the tube gibbous or spurred at the base. Stamens one to five, adnate to the corolla at the base. Stgle one, crowned by two or three free or confined stigmas. Fruit membraneous or subsucumentaceous, indethe latter is tbe case, the two lateral ones are abortive. Sced pendulous. Albumeu none. Annual or perennial herbs, with variablc. opposite, exstipulate leaves, and cymose corymbs of flowcrs.- $(G$. Don.)

\section{GENUS I.}

FEDIA, Manch. THE PURPLE-STEMMED VALERIAN, OR LAMB'S-LETTUCE. Lin. Syst. DIANDRIA MONOGYNIA.

Genemic Character. - Limb of calyx witb four unequal subulate lobes. Corolla filiform, with an unequally 5-lobed subringent limb. Stamens two. Stigma bifid. Fruit spongy, indeliscent, 3-celled.-(G. Don.)

\section{FEDIA CORNUCOPIA, Gartn. THE HORN-LIKE FEDIA.}

Synonymzs.-F. incrassata, Manch ; Valeriana cornucopiæ, Lin. ; V. indica, Clus.

Engravings._Bot. Keg. t. 155; and our fig. 4, in Plate 38.

Specific Character.-Leaves ovate-oblong, tootbed; Iower ones potiolate; upper ones sessilo; flowers corymbose, in fascicles; pedurcles thickencd, fistular. $-(G$. Don.)

Description, \&c.-This is the plant which is sold in the seed-shops under the name of Horns, from the curious shape of the seed-pods, which resemble those of the scarlet-flowered Loasa (Caiophoru). The plant is rather coarse-growing, with a thick purple stem, and heads of rather protty small pink flowers. It is a native of the shores of the Mediterranean, and was introduced in 1596. The seeds should be sown in the open border in March, in rather a light soil, and they will require no other care. The name of Fedia is derived from an ancient Latin word signifying a kid; and it is applied to this plant, because goats are said to be fond of browsing on it.

\section{GENUS II. \\ PLECTRITIS, Dec. THE PLECTRITIS \\ Lin. Syst. TRIANDRIA MONOGYNIA.}

Generic Craracten.- Limb of calyx entire. Corolla gibbous at the base in front from a short spur, wilh a 5-Jobed bilabiato limb.

Stamens 3. Capsule cartilagioous, 1-celled, 2-winged.-(G. Don.)

PI.ECTRITIS CONGESTA, Dec. THE CROWDED-FLOWERED PLECTRITIS, OR PINK VALERLAN.

Srnonyme. - Valerianella congesta, Lindl.

ENGruvisg.-Bot. Reg. t. I094.
Specific Character.-Flowers crowded, in whorls. Bractcas nul. tifid, with subulate segments.

Description, \&c.-A rather curious plant, with whorls of dark rose-coloured flowers. A native of the North-west coast of America, where it was found on the shore near the mouth of the Columbia, and sent home by Douglas in 1826. It flowers in July. The seeds should be sown in light soil, and the plants should be often watered, but they will require no other care. They will not bear transplanting. 


\title{
GENUS III. \\ CENTRANTHUS, Dufr. THE SPURRED VALERIAN.
}

\author{
Lin. Syst. MONANDRIA MONOGYNIA.
}

Gensate Charactra. - Limb of calyx involute at the time of and a regular 5.lobed limb. Stamen oae. Fruit indehiscent, l-cellod. fowering, but aftcrwards evelute and deciduous, ef many feathered bristles. Corella with a narrow tube, which is spurred at the base, and 1-sceded at maturity.-(G. Don.)

\section{CENTRANTHUS CALCITRAPA, Dufr. WATER CALTROP-LEAVED SPURRED VALERIAN.}

Syvosy srs.-Valeriana calitrapa, Lin.; V. annua, Gray;? V. I Sprcifrc Churacter.-Radical leaves ovate, entire, or lyrate; upper orbiculata, Sib. et Smith.

encs pionatifi; flowers rather panicled; apur very short. - (G. Don.)

Description, \&c.-Closely resembling the beautiful red-spurred Valerian, so common on the claalk cliffs near Greenhithe and Gravesend, but with white flowers tinged with pink. A native of the banks of the Mediterranean, introduced in 1683. The seeds are common in the seed-shops, and they do best sown in light calcareous soil, in an open airy situation. They require abundance of light and air, and hut little water.

\section{CHAPTER XXXVII.}

\section{HYDROPHYLLACE $\approx$.}

Fasestial Chanacter_-Calyx 5-eleft, persistent, the recesses | herbs, but hairy like these of Boraginaces. Leaves alternate, 18ually between the segmenta usually furnished with reflexed appendages. Corolla mosopetalous. Stamens 5, perigynous. Anthers versatile. Style bifid. Capsulo 2-val red, often 2-celled, in consequence of the large placenta filling the capsule. Albumen cartilagisous, Elegant lobed, the lower onea oppoaite. Flowers blue or pink, diaposed in ene-sided, somewhat dichotomoua spikes or racemes, whtch are scarpeid before the expansion of the flowers, - (G. Don.)

Description, \&c.-This order was comparatively unknown to the lovers of ornamental flowers till the beautiful Californian annuals belonging to it were sent home by Donglas, but now everybody who bas seen the Nemophilas, Eutocas, and Phacelias, will feel an interest in the order to which they belong. The name of Hydrophyllaceoe is derived from that of the genus Hydrophyllum, literally Water-leaf, in allusion to the plants having leaves so eurved as to retain water standing in them. All the plants belonging to the order grow best in moist shady situations.

\section{GENUS I.}

\section{ELLISIA, Lin. THE ELLISIA.}

Lin. Syst. PENTANDRIA MONOGYNiA.

Genzrjc Charucten.-Calyx witbout appendages. Corolline preceses 10, short, or waoting. Stamens rather ahorter than the cerolli, Placeotas large, biovulate.-(G. Don.)

\section{ELLISIA NYCTELEA, Lin. CU'T-LEAVED ELLISIA.}

Synonyar.-Polemonium Nyctelea, Ehret.

Specinc Charactrk.-Petioles without appendagea; leaves pianatifid, with cut lobes; calys increasiog much after floresceasn.-(G. Don.)

Description, \&c.-A low plant, with large downy leaves, and star-like flowers, which are white, with very small purple dots. It is a native of Virginia, and was introduced in 1755. The genus was named by Linneus 
in honour of lis friend and cerrespondent John Ellis, F.R.S. The plant is now rarely to be met with, and is probably lost; but it deserves to be re-introduced. It is of the easiest culture, as notling mere is necessary than to strew the seeds on the greund in any tolerably moist and shady situatien, and the plants will need ne farther care.

GENUS II.

\section{NEMOPHILA, Barton. THE NEMOPHILA.}

\section{Lin. Syst. PENTANDRIA MONOGYNIA.}

Generje Cuaracter. - Sinuses of the calyx furnishcd with reflexed teeth. Corolline processes 10, short or wanting. Stamens rather sherter than the corolla. Placentas large, 2 to 12 -ovulate.-(G. Don.)

\section{1.-NEMOPHILA PHACELIOIDES, Bart. THE PHACELIA-LIKE NEMOPHILA.}

Synonyme-N. Nuttallii, Coll.

Engravings.-Bot. Mag. t. 2373 ; Swt. Brit. Flow. Gard. 1, t. 32 ; Bot. Reg. t. 740 ; Bot. Gard. No. 586 ; and our fig. 8, in apc Plate 37.

Specific Characten.-Petioles witheut appendages; corolla excecding the calyx a little; sinuses of tho calyx furnished with lanceolate appendages, which equal in length one half of the calyx; placentas biovulate. -(G. Don.)

Description, \&c.-The flewers are large and of a pale lilac; the plant has streng stems growing at least a foot high, and the calyxes are furnished with narrew leafy appendages. This specics was the first Nemophila discovered, and it was found by Nuttall in shady places on the banks of the Missouri in the Arkansas territory, in North America. Seeds of it were sent to England in 1822, and it flewered in several gardens; it was, however, soon after lost, and not re-introduced till abont 1837. It is still rather scarce, bnt we saw it flowering beantifully in the garden of Mrs. Marryat at Wimbleden House in the summer of 1839, and we there ebtained the specimen from which our drawing was made. The culture resembles that of other annuals, except that it should not be thinned out, and that it should always be kept in the shade.

\section{2.-NEMOPHILA AURITA, Lindl. THE EAR-SHAPED NEMOPHILA.}

Escravings.-Bot: Reg. 1601; Bot. Gard. No. 666; and our fig. Specific Crraracter.-Petioles auriculately dilated at the base; 6 , in Plate 37. sinuses of the calyx furnished with elongated appendages; corolla twice as long as the ealyx; placentas biovulate.-(G. Don.)

Description, \&c. - The beanty of this species depends entirely on the manner in which it is trained, as the stems, though thick and rather coarse-looking, are much toe weak to support tbemselves. The flowers are purple, and are very pretty when they are displayed to advantage; the calyx is curiously shaped, and is lengthened out into large appendages, something like these that distinguish the genus Malope from the genus Malva. The leaves are very strengly marked; they are semewhat arrow-shaped, and deeply lobed, the lobes pointing towards the stems; they are also ear-sbaped at the base. This species is a native of California, where it was discovered and sent hөme by Douglas in 1831, and as it seeds freely it is now commen in the seed-sheps. The seeds should be sewn. as soen as they are ripe, in order that they may stand the winter, or in January or February, as the young plants are quite hardy and bear celd better than they do heat. When they come up they should be thinncd out to three or four in each patch, and a sliglit frame formed of three painted sticks, placed in the centre, or over them, to wlich the stems may be tied. Sometimes only one plant is left, and this is trained to a pyramidal ladder-iike 



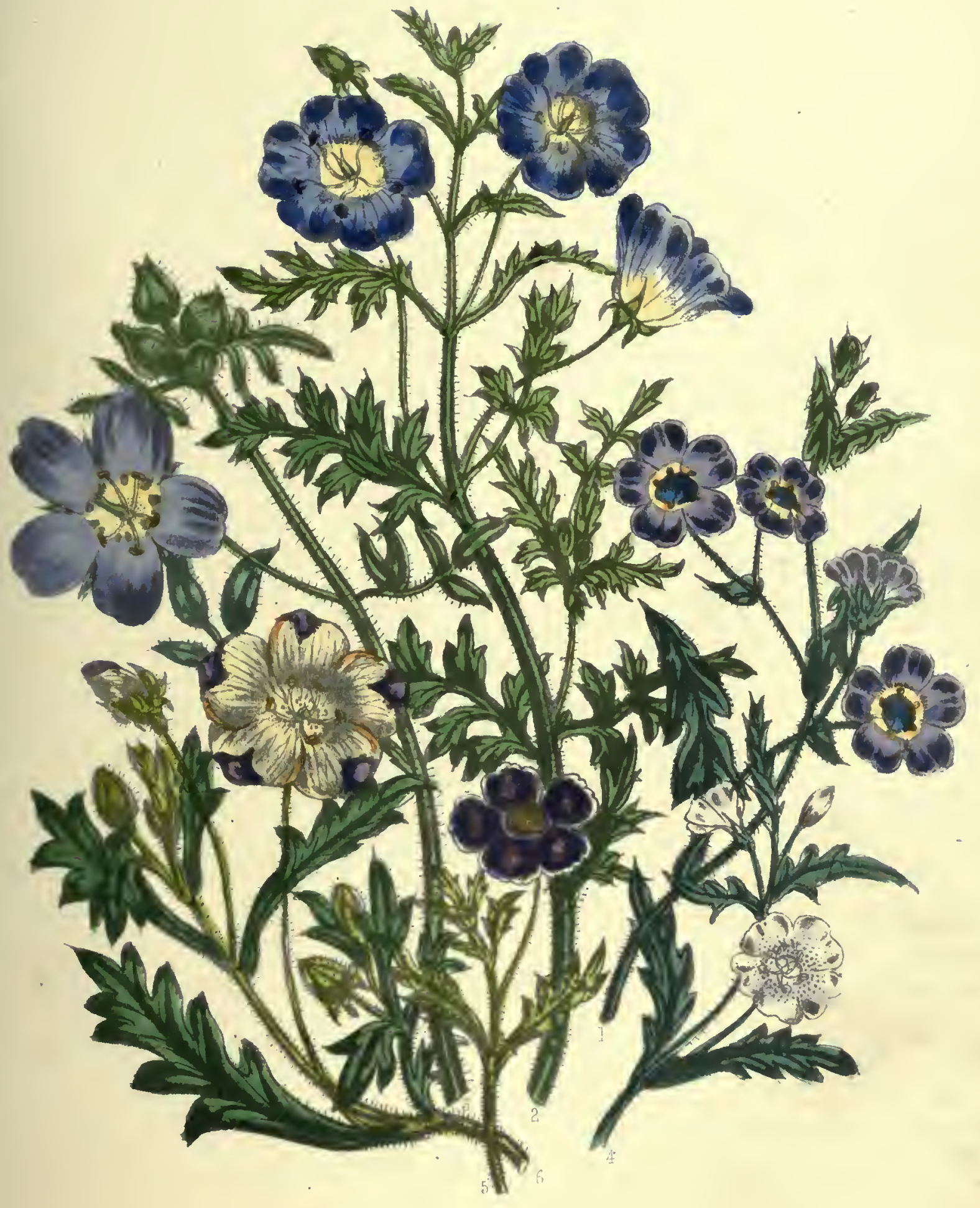





$$
\text { . }
$$





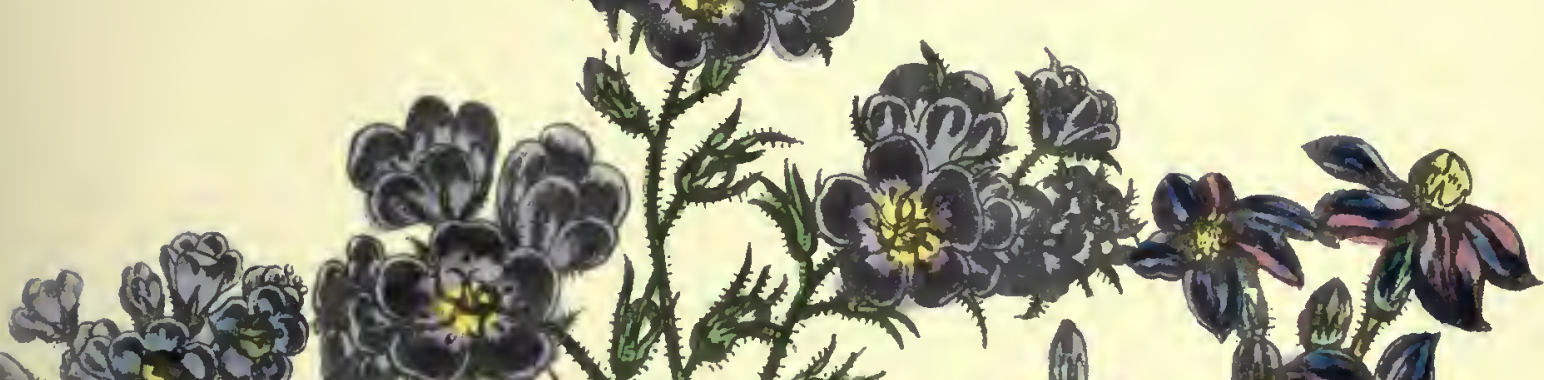

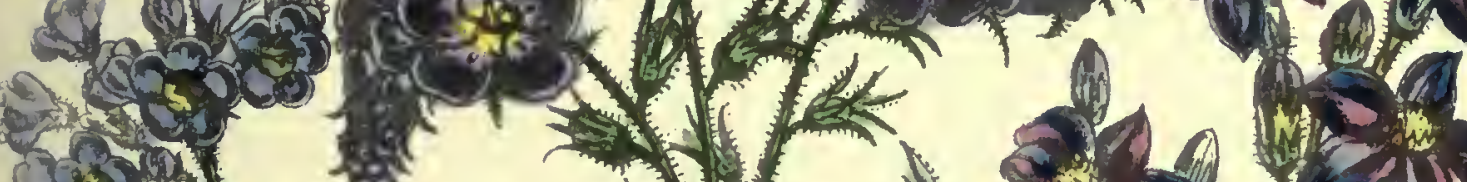

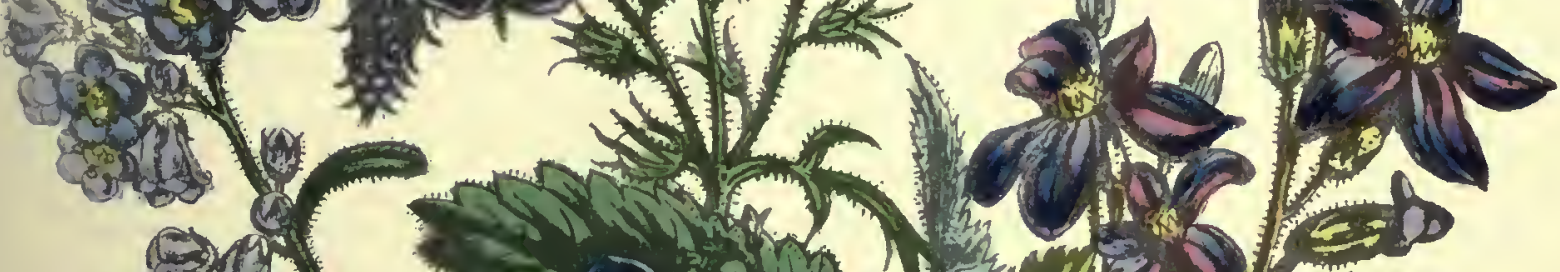

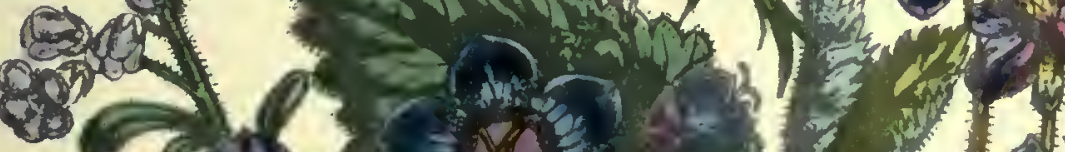

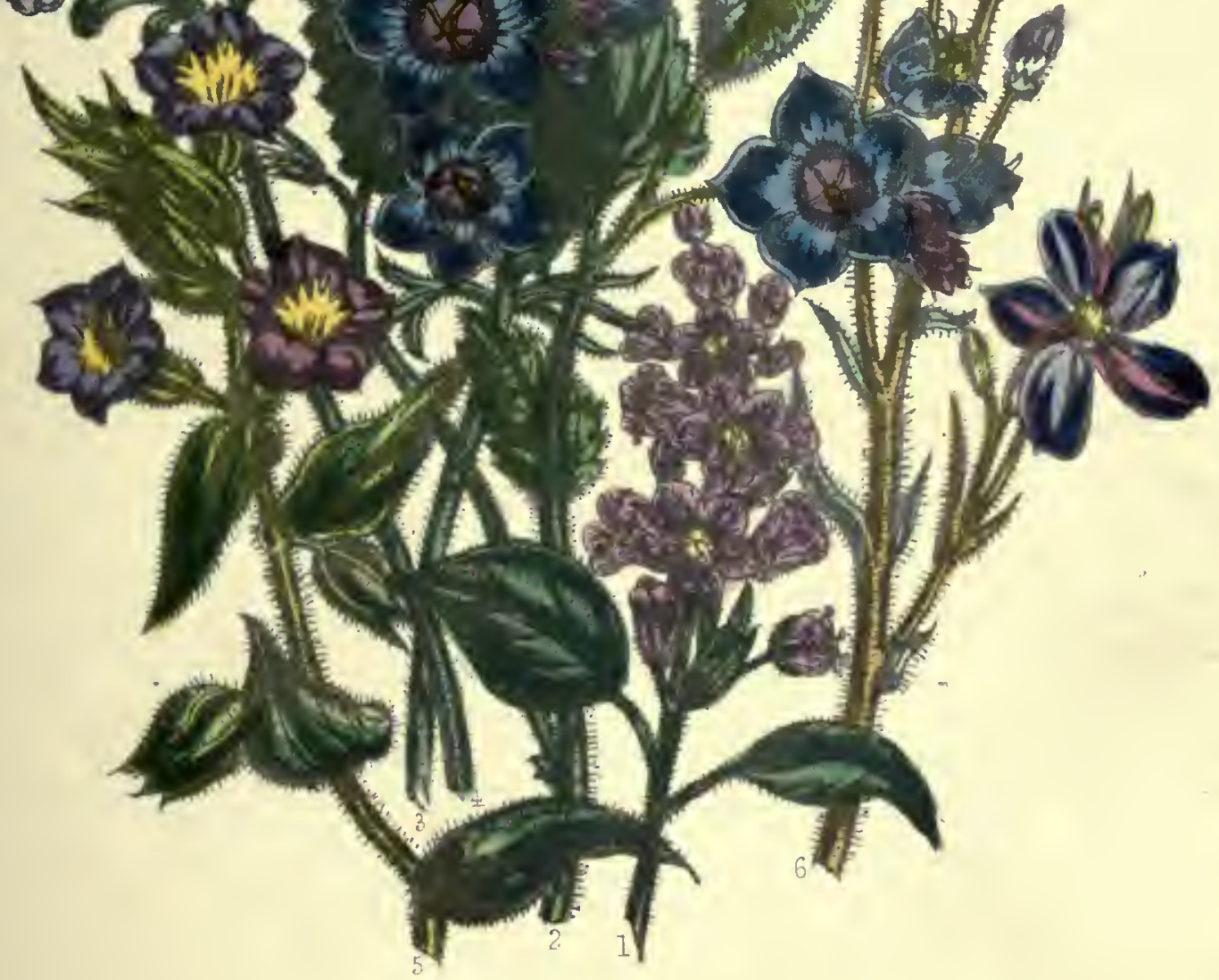

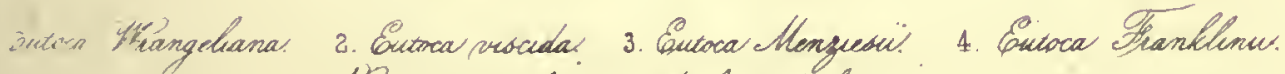

Annea vesicolor 6. Anchusa italua! 

frame, made of slender strips of laths. Of course, the mauner of training may vary aecording to taste; and the plant looks very well nailed against a wall or wooden paling : all that is necessary is to give it some support, as it not only never flowers well if it is suffered to lie on the ground, but the stems, which are very succulent, soon become rotten and decay. When well trained, and grown in a moist sliady situation, the flowers will not only he large and beautiful, but will be produced in greater abundanee and for a much longer period than is generally the case with the Californian annuals.

\section{3.-NEMOPHILA INSIGNIS, Doug. THE SHOWY NEMOPHILA.}

Engravings.-Bot. Reg. t. 1713; Bot. Mag. t. 3485; Swt. Brit. S Specific Character.-Pctioles without appendages; corolla twice Flow. Gard. 2nd scr., t. 329 ; Bot, Gard. No. 635 ; Paxt. Mag. of
Bot. vol. iii. p. 151 ; and our fong as the calyx; in Plate 37. .

Description, \&c.-It is not possible to imagine a more beautiful blue than is displayed in this lovely little flower. It is like the finest ultra-marine, softened in the centre into white; and a bed of it has a most beautiful effect in a geometrical flower-garden, where the beds are designed ench to present a rich mass of colour, and to be strongly contrasted with each other. In such a garden, where the scarlet is represented by the Verbena Melindres pegged down so as to cover the bed; the purple by the Petunia phonicea; the white by Petunia nyctaginiflora; and the yellow by Lasthenia glabrata or californica, the blue may be filled with equal effect by the Nemoplita insignis; and such a garden, well kept (like that at Dropmore), with a bright sun shining on it, will present a blaze of beauty almost too dazzling for tho eye to rest on. In all gardens, however, this Nemophila is exceedingly valuable for the extraordinary beauty of its flowers; and, accordingly, it las become an almost universal farourite. It is a native of California, where it was found by Douglas in 1832 . Common, however, as this plant now is, and easy as its culture appears, there are some difficulties in it which it is necessary to guard against. The name of the genus Nemophila, which signifies literally a lover of the woods, seems to point out the kind of situation in which all the species should be placed; but at the same time, it is found by experience, that in a very dark and shaded situation they will not long continue to thrive. The fact is, that the blossoms do not expand well unless they have plenty of light, thongh the roots of all the Nemophilas being very weak, and their stems just at the collar very slender, the plants are easily destroyed if these tender parts are ever suffered to become too dry. A few hours' bright sunsline on the collar of a plant of Nemophila insignis will be sufficient to kill it, however large and thriving it may be, as the roots will wither as soon as they become thoroughly dry, and there is not vigour enough in the collar to enable it to throw out fresh roots. Thus many persons who have grown the Nemophila insignis, have been surprised to find their plants die while yet full of buds, and before they have ripened a single seed; and that this death has taken place suddenly, and without any apparent cause. Fresh seeds have been procured and sown, they have rapidly germinated, and, in a month or six weeks, have produced flowers, which have continued for a long time in beauty, and been followed by a sucession of others, even to the middle of winter. The reason for this apparent contradiction exists in the greater power of the sun on the roots of the carly flowering plants; while those of the second sowing, not coming to perfection betore autumn, were less likely to be injured by the drought and heat. Notwithstanding the necessity which thus evidently exists for keeping the roots of the Nemophilas moist and in the shade, it must be observed, not only that the flowers require sun, but that too much moisture at the roots, without proper drainage, is apt to make the collar rot, in which case the plants damp oft. The best way of guarding against both evils is to make 
several sowings of the Nemophila throughout the year, so that there may be spring-flowering, summer-flowering, and autumn-flowcring plants. For the first of these, Nemophila insigris succeeds exceedingly well treated like the other Californian annuals, as directed under the liead of Leptosiphon (see p. I56). It would also probably succeed admirably, grown singly in a pot and frequently shifted, as directed for Rhodanthe Manglesii (sec p. 199); and for the summer-flowering plants care must be taken to peg down the stems, so that they and the leaves may al ways cover the collar, and to prevent tho earth about the roots from ever becoming quite dry.

\section{4.-NEMOPHILA ATOMARIA, Fisch. et Meyer. THE SPECKLED NEMOPHILA.}

Engravings.-Bot. Reg. 1940; Swt. Brit. Flow. Gard. 2nd sor., | almost entire; peduncles sxillary, elongated,; corolla rotate, with a t. 376; Paxt. Mag. of Bot. vol. v. p. 99 ; and our fig. 4, in Plate 37. very pilose bottom, and obovate segments; placcntas sbout 10-orulate; Specjfic Character.-Leaves opposite, pinnatifid; lobes 5 to 9 , sceds strophiolate, smooth.-(G. Don.)

Description, \&c.-This species closely resembles $N$. insignis, except in the colour of the flower, which is white, dotted or speckled with very small purple spots, which are so dark that they appear at a little distance to be black. N. atomaria is a native of the Russian colony of Ross in New California, and seeds of it were sent to England from the botanic garden at St. Petersburgh in 1836. Like all the Nemophilas, it requires a shady situation, and to be grown in peat or some other very light soil ; and indeed its culture may be exactly the same as that of $N$. insignis.

\section{OTHER SPECIES OF NEMOPHILA.}

\section{N. MACULATA, Benth. ; our fig. 6, in Plate 37.}

The flowers are whitish, with a deep riolet blotch in each lobe of the corolla. The species is a native of the Nortll-west coast of America, and was introduced in 1848 by Mr. Hartweg, who found it in great abundance in California.

N. DiSCOIDaLis, Hort.; our fig. 5, in Plate 37.

This species is said to have been first observed in the nursery of Messrs. Rollisson, at Tuoting, about 1840, but its origin is unknown.

\section{GENUS III.}

\section{EUTOCA, $R . B r$. THE EU'TOCA.}

Lin. Syst. PENTANDRIA MONOGYNIA.

Grisaric Character.-Corolla deciduous, ovarium pilose. Placentas linear, 4, or many-ovulate. Capsule half 2-celled.-(G. Don.)

\section{1.-EUTOCA VISCIDA, Benth. THE CLAMMY EUTOCA.}

SYNoNYME. - E. viscosa, Hook.

Engravings.-Bot. Reg. t. 1808 ; Bot. Mag. t. 3572; Swl. Brit. Flow. Gard. 2nd ser., t. 368 ; Bot. Gard. No. 569 ; and our fig. 2 , in Plate $97 *$

Speific Character.-Clotbed with clammy pilli; stem erect, branched; leaves cordate-ovate, a little sugulsr, scrrated; raccmes elongated, forked and simple; placentas many-ovulate.-(G. Don.)

Description, \&c.-An upright coarse-growing plant, with flowers of a most vivid and intensely dark blue. The leaves are coarse and of a dnll green, and the whole plant is entirely covered with clammy hairs, which, 
Dr. Lindley observes in the Bot. Reg., have "little black heads filled with a viscid secretion, and stick to the fingers like those of the Henbane; these are so crowded about the pedicels as to give them quite a sooty appearance." With regard to the flowers, Dr. Lindley observes in the same place that he knows "of no plant better adapted for bouquets; for it will go on growing and flowering in water for two or three wceks after being gathered." This species is a native of California, where it was found by Douglas, and introduced in 1834 . The seeds should be sown in very poor gravelly or sandy soil, to prevent the plants from producing more leaves than flowers. The plants are quite hardy, and require no other eare.

\title{
2.-EUTOCA FRANKLINII. R. Br. CAPTAIN FRANKLIN'S EUTOCA.
}

\author{
Engravings.-Bot. Mag. t. 2985 ; and our fig. 4, in Plate 37 ". \\ Specreic Charactra. - Ercet ; leaves pinpatifid, or bipinnatifid; ovula 20 or more to each placenta.-(G. Don.)
}

Description, \&c.-This species has small pale blue flowers, produced in racemes, arising from the axils of the leaves, and a good deal resembling those of a Polemonium. The flowers themselves, though small, are pretty, from the bright clear blue of the corolla contrasting strongly with the golden luve of the anthers. The stem of the plant is erect, and rather stiff, having scarecly any branches, and the root is fusiform witl very few fibres. It is a very interesting plant, Sir W. J. Hooker observes in the Bot. Mag., from its having been "discovered by Dr. Richardson during the first over-land arctic expedition, growing abundantly amongst trees that had heen destroyed by firc, on the banks of the Mississippi," and also by Mr. Drummond, "in burnt woods, extending from the Great Rapid to the Rocky Mountains." It was introduced in I827, but we fear it is lost, as wo do not know where seeds of it are now to be procured.

\section{3.-EUTOCA DIVARICATA, Benth. THE SPREADING EUTOCA.}

Evgraying.-Bot. Reg. t. 1784.

Spectfic Charactrr.-Stems diehotomously divaricate; leares all ovate, undivided; placentas 12-20-ovulate.-(Benth.)

Description, \&c.-A very pretty little plant, with bright violet flowers softening into white in the centre. It has a decumbent spreading stem, but it will not bear-pegging down so as to cover a bed, on account of the brittleness of its stems. It is a native of California, and was introduced in 1835.

\section{4.-FU'TOCA MENZIESII, $R$. Br. MR. MENZIES' EUTOCA.}

Sysonyses.-E. multiflore, Doug.; E. eongesta, Lehm. Fingravings.-Bot. Reg. t. 1180 ; Swt. Brit. Flow. Gard. 2nd ser., quite entire, sometimes trifid, or pinnatifid; placentas 20, or manyt. 3.34 ; and our fig. 3 , in Plate $37 *$. quite entire, sometimes
ovulate.-(G. Don.)

Description, \&c.- $\boldsymbol{\Lambda}$ very beautiful species, with a profusion of violet-coloured flowers. Like all the Eutocas, it produces a great quantity of seeds; the name of Eutoca signifying fruitful, and that circumstance constituting the chief botanical difference between the genera Eutoca and Nemophila. E. Mcnziesii was found by Douglas on the bauks of the Columbia, growing in open situations, fully exposed to the sun ; and it was named by Dr. Brown in compliment to our mucli esteemed friend Archibald Menzies, Esq. It was introduced in 1826. Sceds of this species are common in the seed-shops, and they only require sowing in a dry sandy soil, and in an open situation exposed to the sun. As the Eutocas do not thrive in stiff soil, whenever the natural soil of the garden in which they are to be sown is of that nature, a barrowful of sand should be procured, and a pit dug in 
the border about a foot in diameter, and to the same depth, which should be filled with sand, mixed with a sunall proportion of the common soil of the garden, and in which the seeds of the Eutoca should be sown. This should bo done wherever a patch of these flowers is required; and a similar hole should be dug and filled with peat for every patch of Nemophilas. Eutoca Menziesii is of a compact and somewhat dwarf habit of growth, and from this circumstance, and the profusion of its flowers, it is well adapted to form a mass of colour in one of the beds of a regular flower-garden.

\section{5.-EUtoca Wrangeliana, Fisch.et Meyer. Baron WRANGel'S EUTOCA.}

Eisgraprescs.-Swt. Brit. Flow. Gard. 2nd Ser., t. 362; Past. | entirc. Corollas about twico as long as the calyx, and about equal in Mag. of Bot., rol. 5, p. I99; and our fig. I, in Plate $37{ }^{\circ}$.

Specific Cuaracter.-Diffuse, downy. Leaves ovate, acute, quite

Description, \&c.-A very landsome species, with dark purplish blus flowers, and a dwarf compact lanbit of growth. It is a native of the Russian colony of Ross in New California, and seeds were sent to this country from St. Petersburg in 1836. It was named by Fischer and Meyer, in honour of a Swedish nobleman, who was employed by the Russian government in exploring the North West coast of North America. Sceds are common in the seed-shops, and the eulture is the same as that of the other Californian annuals (see p. 156.) When sown in the open border, it will grow well in any common garden soil.

\section{OTHER SPECIES OF EUTOCA.}

\section{E. DOUGLASSII, Benth.}

The leaves grow nearly all near the root, and the flower-stalks ascend nearly naked, with a eluster of flowers at the top. The flowers are of the same size and colour as those of Nemophila insignis. A native of California, not yet introdueed.

\section{E. CUMINGII, Benth}

Has small flowers, and is a native of the Andes of Chib.

E. BRACHYLOBA, Benth.

This is probably the same speeies as E. Cumingii, modified by its being a native of a colder climate, as it was found wild in California by Douglas. Neither of these species is introduced.

E. Parviflora, $\boldsymbol{R}$. Br.; PHACElia PARviflora, Pursh; POlemonium dubiUM. Will.

The thowers are small, and of a pale blue; and the plant, whieh is a native of Pennsylvania, was introduced in 1826.

E. MEXICANA, Benth.

Resembles E. parviflora, but has larger flowers. A nativo of Mexico, not introduced.

E. GRANDIFLORA, Benth.

Flowers an inch and a half in diameter; leaves largo and wrinkled. A native of California, where it was found by Douglas. Introduced in 1838; there are seeds at Cbarlwood's, 


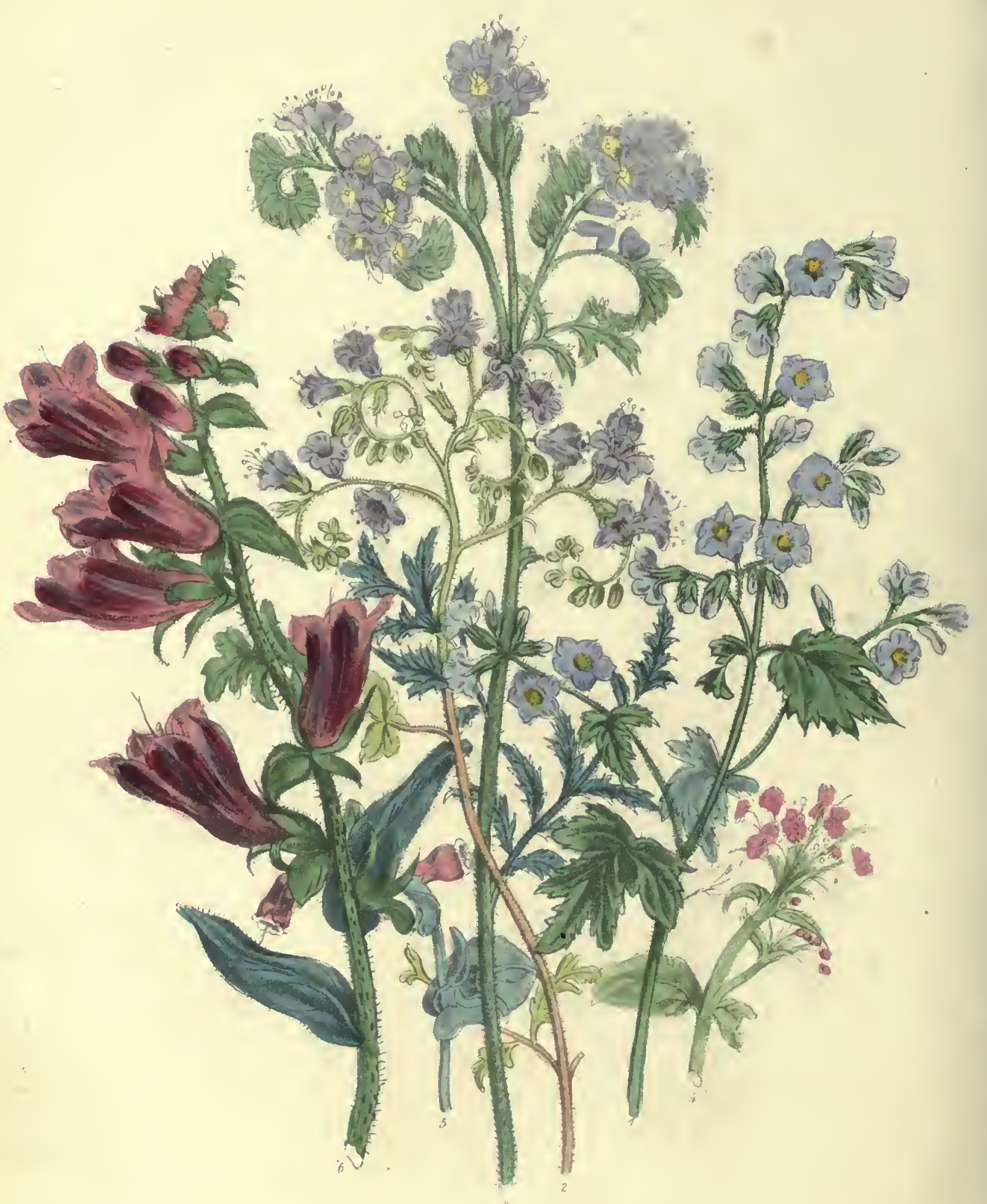





\section{E. PHACELIOIDES, Benth.}

Closely resembling a species of Placelia. A native of California.

\section{E. LOASEFOLIA, Benth.}

Erect, and with almost the habit of a Phacelia. Every part of the plant is covered with long stiff hairs intermixed with clammy down. It is a native of California, where it was discovered by Douglas.

\section{= \\ GENUS IV. \\ PHACELIA, Juss. THE PHACELIA. \\ Lin. Syst. PENTANDRIA MONOGYNIA.}

Generrc Character.-Corella deciduous. Ovarium pilose. Placentas lincar, 2-ovulate. Capsule falsely two-celicd.-(G. Don.)

Description, \&c.-The difference between this genus and Eutoca is very slight; and it consists principally in the greater quantity of seeds contained in the capsule of the Entocas. The name Phacelia signifies a fascicle. or bundle, and it was given to the genus in reference to the flowers being produced in fascicles.

\section{1.-PHACELIA TANACETIFOLIA, Benth. THE TANSY-LEAVED PHACELIA.}

\begin{tabular}{l|l|l} 
Engrıvinas._-Bot. Reg. t. 1696; Bot. Mag. t. 3703; Swt. Brit. & $\begin{array}{l}\text { Leave bipinnatifid. Leaflets oblong, dentately pinnatifid. Calycino } \\
\text { segments oblong-linear, hispid. Stamens exscrted.--(G. Don.) }\end{array}$
\end{tabular} Specric Character.-Clothed with scabrous pubcscence or bispid.

DEscription, \&c.-The appearance of this plant is very remarkable from the bundles or rather strings of flowers which appear to have been just unrolled, the long black hairs with which every part of it is covered, and the etamens which project far beyond the corollas of the flowers. Indeed, though the plant is by no means remarkable for its beauty, few persons see it for the first time without being struck with it. The flowers are of 3 pale purple or violet, and are pretty in themselves; but the whole plant has a coarse and weedy aspect. It is quite hardy, and will thrivo in any soil and situation; and as the stem is sufficiently strong to keep it erect, it requires no care but sowing. A slight variety of this species is sometimes called $P$. bipinnatifida in the nurseries.

\section{2.-PHACELIA CONGESTA, Hook. THE CROWDED-FLOWERED PHACELIA.}

Engruvinos.4Bot. Mng. t. 3452; Swt. Brit. Flow. Gard., 2nd bristly hairs. Leaves bipinnatifid. Segments ovate-oblong, acute, Ber. t. 327 ; Bot. Gard. t. 632 ; and our fig. 2, in Plate 38.

Sprciric Charactrr.-Clothed with hairy down, intermixcd with exserted.-(G. Don.)

Description, \&c.-A pretty plant with pale blue flowers, and almost trifid leaves. It is a native of Texas, in Mexico, whence it was sent home by Drummond; it is however quite hardy, and will grow in any soil and situation.

P. VINIfOLIA, Paxt. Mag. of Bot. vol. v. p. 121; and our fig. 1, in Plate 38.

This plant appears very nearly allied to $P$. congesta, and is probably only a variety of that species. The specific name should probably have been Vitifolia, signifying Vine-leaved. The seed from which it was raised was sent by Drummond from Texas; and tle plant was first raised in the Manchester Bot. Gard. 


\section{CHAPTER XXXVIII.}

\section{BORAGINACE E.}

Essentral Character.-Calyx usually 5-parted, persistent. Corolla $/$ Herbs or shrubs, harsh from asperities, witlı alternate exstipulato monepetalous, usually 5-cleft, imbricate in sestivation. Stamens usually leaves, and having tho flowers generally dispesed in one sided spikes or 5. Fruit of four distinct or combined achenia. Albumen none. racemes, seldom in panicles or corymbs.-(G. Don.)

\section{GENUS I.}

\section{CERINTHE, Tourn. HONEYIVORT.}

\section{Lin. Syst. PENTANDRIA MONOGYNIA.}

Generic Canructer.-Corolla tubular; throat nakcd. Anthers hastate, connected, having the lohes spirally twisted at the base. Nuts 2, 2-eelled, or 4, eombined hy twos, imperforated at the base.-(G. Don.)

\section{1. - CERINTHE MAJOR, Lin. THE GREATER HONEYWORT.}

Synomyeq.-C. glabre, Mill.; C. glauca, M anch.

Engravings.-Bot. Mag t. 333 ; and our fig. 5, in Plate 38.

Specific Character. - Stem branched. Lcaves cordate-ovate,

denticulately ciliated. Cerollas ventricose at tep, 5-toothed. Teeth very short, acuminated, reflexed.-(G. Don.)

Description, \&c.-A plant, the flowers of which are more curious than beantiful; but they are said to abound in honey, and hence the English name Cerinthe signifies Wax-flower. The species is a native of the south of Europe and Barbary; and it was formerly so common in Italy, that Virgil calls it, " that ignoble weed Cerintle." It was introduced in 1596. Seeds are common in -all the seed-shops, and no particular care is required either in sowing them, or in the after culture of the plant.

\section{OTHER SPECIES OF CERINTHE.}

\section{ASPERA, Roth.}

This species is distinguished hy its leaves being rough with white warts. The corollas are long, and yellow, with a brownish purple tube. It is a native of the south of Europe, and was introducod in 1633.

\section{RETORTA, Smith.}

This species has its leaves beset with white warts on both surfaces. It is a native of the Peloponnesus, and was introduced in 1825. The flowers are small, with a yellow tube and a violet-coloured limb. There are two other annual species, $C$. purpurea and $C$. alpina, but thoy have not been introduced.

\section{GENUS II.}

\section{ECHIUM, Pliny. VIPER'S BUGLOSS.}

\section{Lin. Syst. PENTANDRIA MONOGYNIA.}

Generic Character.-Corolla funnel-shaped. Throat wide, naked. Segments of the limb in many species ulequal. Nuts turbinate, gigartoid, scahreus.-(G. Don.)

Description, \&c.-All the species liave showy flowers, somewhat variable in colour, and frequently changing from blue to pink, like the differcnt kinds of Bugloss (Auchnsa). The name of Echium is derived from echis, 
a viper; and the seeds of the plant are not only supposed to resemble the head of that reptile, but the juice of any plant of the genus was formerly thought a certain cure for a viper's bite.

\section{1.-ECHIUM AUS'TRALE, Lam. THE SOUTHERN VIPER'S BUGLOSS.}

Synenrmss.-E. diffusum, Smith; E. grandiflorum, Desf.; E. | Sprcific Character.-Stem herbacceus, pilese. Leaves evste, macrantham, Rom. et Schullz.

Enaravings.-Swt. Brit. Flow. Gard. to 101 ; and nur fig. 6, in attennated st both ends. Cerollas equalling the stamene, which are villons at the apex.-(G. Don.) Plate 38.

Description, \&c.-This plant grows about a foot or eighteen inches higb, with numerous stems, rising from the same root, so as to make the plant spread widely. The leaves are ovate, tapering at both ends; and with the upper side covcred with small white tubercles, while the under side, which is strongly veined, is clothed with small rigid liairs. The flower-stalks have the flowers all on one side, and lengthen as the flowers expand. The flower is large, tubular, and of a reddish purple, changing to blue as it fades, strongly ribbed, and hairy. The stamens are shorter than the tube of the flower, but the style, which is red, projects beyend it. This species is a native of the south of Europe, and was introduced in 1824, but modifications of it under different names lave been introduced at various periods. The secds may be procured at Charlwood's, and other seed-shops, and they should be sown in patclies of only a few seeds together, in March or April ; tlinning the plants out when they come up so as not to leave more than three in a patch, and these may be afterwards again thinned out to one; or rather, the three may be taken up and spread widely apart. The reason for this is, that when the plants are allowed room, they will spread widely in all directions; but when left near together, they become drawn up and straggling. All the Echiums should be grewn in a warm dry border, open to the sun. E. grandiflorum, Desf., appears to be the same as this species.

\section{2.-ECHIUM VIOLACEUM, Lin. THE VIOLET-COLOURED VIPER'S BUGLOSS.}

Srresymes.-E. creticum, Lam., net of Lin.; E. floribundum, | obleng; upper ones lanceolate, cordate at the base, stem-clasptng, Leh. ; ? E. plantaginettm, Lin.

Srecivic Character.-Stem herbaceeus, branched; lewer loaves 1 in leugth to the cerolla, which is irregular.-(G. Don.)

Description, \&c.-The principal apparent difference between this species and $E$. australe is, that the flowers are blue with a tinge of violet, instead of reddish : there is, however, anether rather important difference, which is, that the root of $E$. violaceum is fusiform, and that consequently this species will not bear transplanting, except when very young. It is a native of the south of Europe, and was introduced in 1658. 'The culture is the same as for $E$. australe, except that three plants may be left in a patch together; and that, as they grew from one foot to two feet high, they look best tied to slender stakes. Seeds may be had at Charlwood's, and other seed-shops. E. plantagineum differs very little from this specics, except in the colour of the flowers, which are either white or purple, and always reddish before they expand. The flowers of $E$. floribundum are blue, and the plant is a native of North America.

\section{OTHER SPECIES OF ECHIUM.}

E. MARITIMUM, Willd.

Flowers blue. A native of the shores of the Mediterranean. Introduced in 1815. 


\section{E. TENUE, Roth.}

Flowers small, and of a fine blue, reticulately veined. $\Lambda$ native of Barbary. Introduced in 1824.

\section{E. Partiflorum, Manch.}

Root fibrous. Stens many, and procumbent. Tubercles on the leaves white, and hairy. Flowers blue. A native of the shores of the Meditcrranean. Introduced in 1798.

GENUS III.

NONEA, Monch. THE ALKANET.

Lin. Syst. PENTANDRIA MONOGYNIA.

Generic Character.-Calyx at length inflated. Corolla funncl-shaped; tube straight; throat bearded. Stamens inclosed. Stigma simple. Nuts with parallel stripes.-(G. Don.)

Description, \&c.-The species now included in the genus Nonea were removed from the genus Anchusa bccause their flowers are tube-shaped like the Convolvulus, while those of the Anchusa are flat or salver-shaped as is shown in onr fig. 6, in Plate 37, of Anchusa italica.

\section{1.-NONEA VERSICOLOR, Swt. THE CHANGEABLE-COLOURED ALKANET.}

Synonymas.-Anchusa versicolor, Steo.; Lycopsis rosen, Reich. | Specific Cranacter.-Pilose or strigose; stems prostrate ; leavos Engraping._Bot. Mag. t. 3477; and our fig. 5, in Plate 37.*

Description, \&c.-The Howers of this plant are remarkable for the striking clanges of colour that they undergo. They are red in the bud; then they turn to reddisli-purple when they first expand; and afterwards to a bright blue with a yellow eye, like a small convolvulus, which indeed the shape of the flower greatly resemblcs. The plant is a native of Caucasus, and was introduced in 1820. Seeds may be purchased in the seed-shops under the name of Anchusa versicolor, and they may be sown in any common garden soil, as they are so hardy that they will grow in any soil and situation.

\section{OTHER SPECIES OF NONEA.}

There are several other annual species, with pink, yellow, white, very dark purple, and striped flowers, all of which are said to have been introduced, but none of them are common in British gardens. The most remarkable are: $-N$. picta, with blue flowers, marked with dark blue veins; a procumbent plant, introduced in 1800 from Siberia. N. ciliata, a native of the Levant, introduced in 1804, and having dark yellow flowers. $N$. rosea, a procumbent plant, with rose-coloured flowers, introduced from Siberia in 1823. N. decumbens, with very dark purple flowers, having a yellowish tube; a native of the south of Europe, introduced in 1686 ; and $N$. lutea, a native of France, with pale yellow flowers; introduced in 1805. 
. 


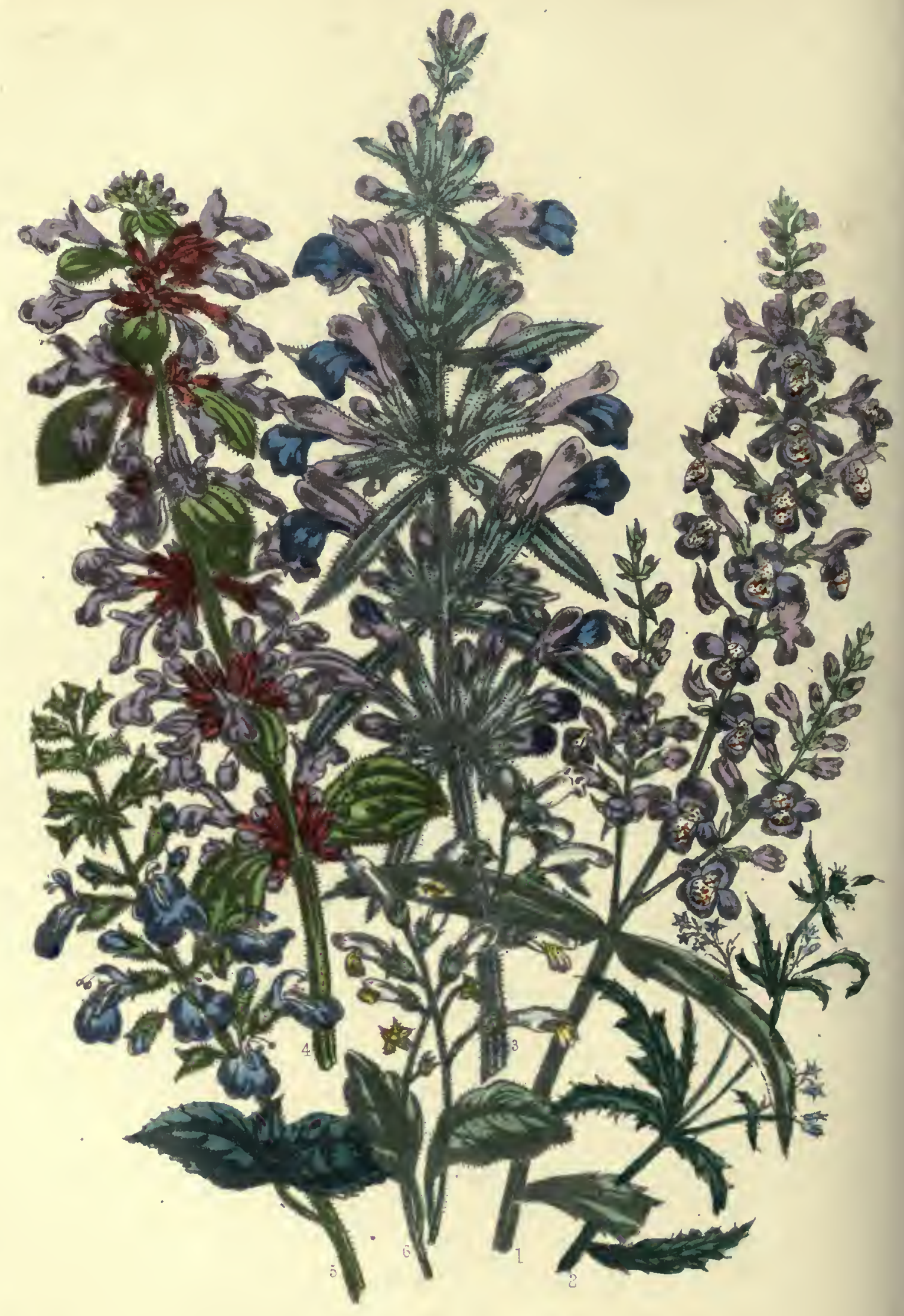





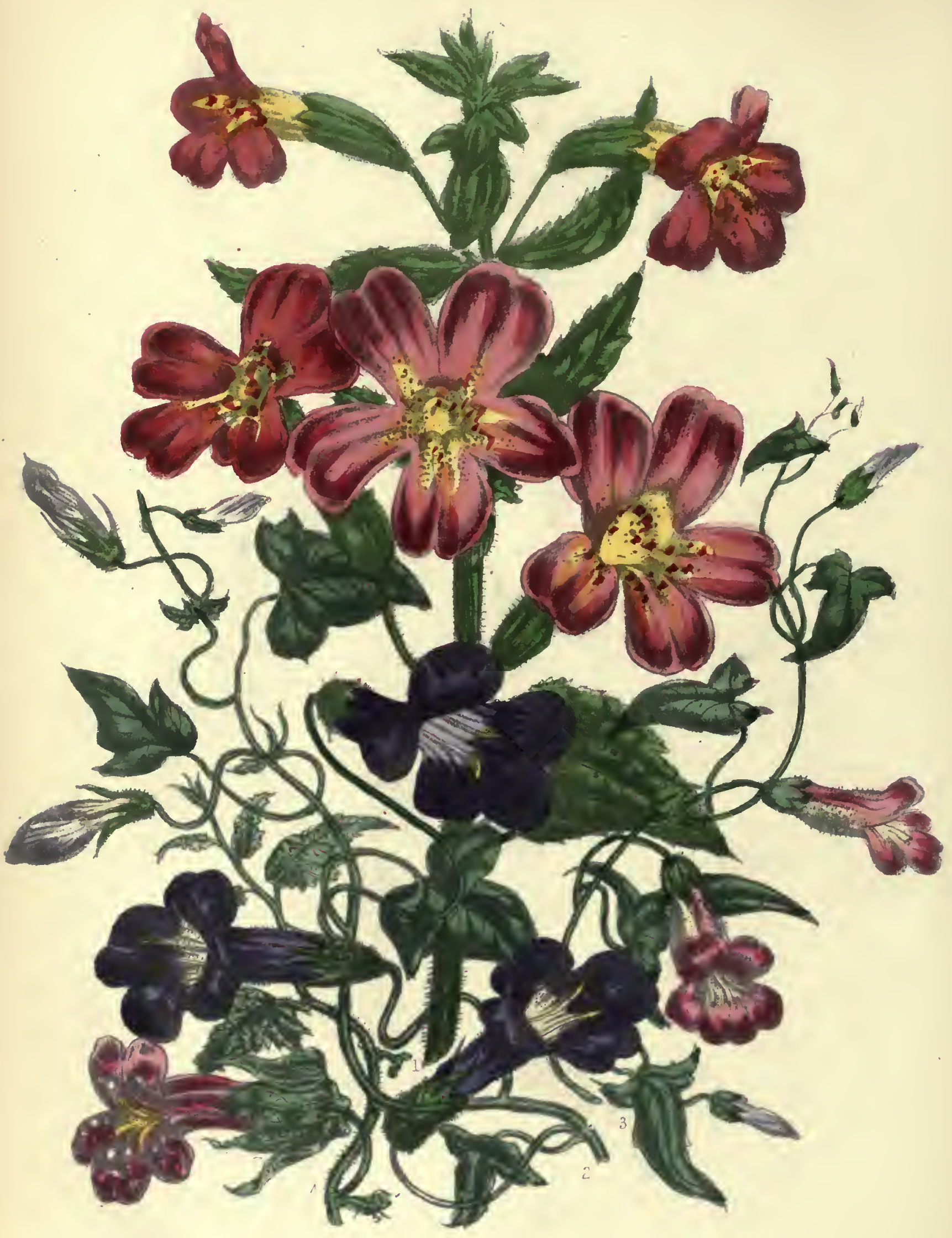






\section{CHAPTER XXXIX.}

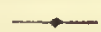

LABIAT AE.

Eseentur Character.-Calyx persistent, 5-cleft, or fivo to tentoothed, regular or bilabiate. Corolla monopetalous, tubular, with a bilabiate limb. Stamena 4, didynamous, two of which are sometimes sterile, inferted under the sinuses of the lower lip. Stigma bifid.
Fruit of 4 or fewer distinct achenia. Albumen usually wanting Leaves opposite, and exatipulate. Flowers opposite, verticillate, or capitate, or spicate racemose or aolitary; axillary or terminal.(G. Don.)

\section{GENUS I.}

\section{SALVIA, Lin. THE SAGE.}

Lin. Syst. DIANDRIA MONOGYNIA.

Grneric Character.-Conncetive drawn out under the insertion, and naked or bearing a cell behind.-(G. Don.)

\section{1.-SAlvia Foliosa, Benth. THE leafy SAGE.}

Srmonymes. -S. rhombifolia, Ruiz et Pavon; S. pilosa, Vahl. Engrapinga.-Bot. Reg. t. 1429 ; and our fig. 5, in Plato 39.

Specific Character._Stem herbaceous, crect, branched, pubescent ; leaves petiolate, broad-ovate, or rhomboid, subcordato at the base, pubcscent; floral leaves ovate-lanceolate, deciduous; racemes simple,

few-flowered; whorls about 6-flowered, remote; calyx ovate, pubescent, the upper lip entire, and the tecth of the lower lip ovate, acuto; corolla lialf as long again as the ealyx; tuhe enclosed, ventricose; middle lobe of the lower lip emarginate; atyle glabrous.- (G. Don.)

Description, \&c.-A rather pretty plant with blue flowers, a native of Mexico, whence it was sent to England in 1830 by Mr. Graham, to whom we are also indebted for Salvia fulgens, and other handsome species of the genus. It is quite hardy, and requires no other culture than sowing, and thinning out the plants if they should eome up too thickly. We do not know where seeds can be obtained.

\section{2.-SALVIA HORMINUM, Lin. THE PURPLE-TOPPED CLARY.}

Srsoxyses._S. colorata, Thore; Horminum sativum, Mill.; H. coloratum, Mench.

VIRIETY.-S. H. 2. rubra, the red-topped Clary.

Specfic Churacter.-Stcm erect, villous. Leaves petiolate, ovaloblong, rounded at the base, or cuneated, obtusc, crenated, villous; supcrior ones ovate-cordate; floral leaves very broad, acute, permancrit,

rather than longer than the calyzea ; uppermost ones membranaceously dilated, coloured, comose. Racemes aimple. W'horla distant, about 6 -flowered. Calyx pubescent, reflexed in the maturo state, and plicately striated; teeth of the lower lip lanceolate, acute. Corolla onehalf longer than the calyx, with an enclosed tube. $-(G$. Don.)

Description, \&c.-These plants are cultivated not for their flowers, but for the vivid colour of their bracteas, which in the species are of a bright purple, and in the variety, pink. The flowers are quite insignificant. Seeds are common in the seed-shops, and when once sown, the plants require no after culture.

\section{OTHER ANNUAL SPECIES OF SALVIA.}

S. VIRIDIS, Lin.

This species closely resembles the purple and red-topped Clary, except that its bracteas are of a vivid light green. The flowers are small and blue. It is a native of the shores of the Mediterranean, in dry, gravelly places, and was introduced in 1759.

\section{S. LANCEOLATA, Willd.}

A native of Mexico, with narrow leaves and blue flowers; introduced in 1813.

There are scveral other species marked as annuals in botanical books, but most of them have not been introduced; the others are, properly speaking, biennials, as they never flower till the second year after sowing. 


\section{GENUS II.}

\section{DRACOCEPHALUM, Lin. THE DRAGON'S HEAD.}

Lin. Syst. DIDYNAMIA GYMNOSPERMIA.

Generic Cruracrer. - Calyx bilabiate, or the upper tooth is large, or the bracteas are cillately toothed.-(G. Den.)

\section{1.-DRACOCEPHALUM CANESCENS, Lin. THE WOOLLY-LEAVED DRAGON'S HEAD.}

Sужоктме-Zornia capescens, Moench.

Enamvings.-Swt. Brit. Flow. Gard. t. 38 ; and our fig. 3 , in Plate 39.

Speciric Character,-Stem erectish, branched, clothed with fine boary tomentum. Leaves petiolate, lower ones ovate or oblong, rather

deeply creasted; floral ones lanccolate, almost quito extire, all canescent from fino tomentum. Whorls distinct, disposed in long racemes, usually 6-flowered. Bracteas ovate-cuneated, aristatelytoothed. Calyx hoary, having the upper tooth ovate, and tho lower one lanceolate. Corolla twice as long as the calyx.-(G. Don.)

Description, \&c.-A very showy, vigorous-growing plant, about two feet high, and spreading in proportion. The leaves are white, from the down with which they are clothed; and the flowers, which are of a very dark purplish blue, are produced in great abundance. The species is a native of the Levant, whence it was introduced in 1711. The seeds should be sown early in March, and the plants, when they come up, should be transplanted so as to stand singly, as they require a great deal of room.

\section{OTHER SPECIES OF DRACOCEPHALUM.}

\section{MOLdAVICUM, Lin.; MOLDAVICA PUNCTATA, Mench.}

This species, which is generally called Moldaviun balm in British gardens, has either blue or white flowers, and a very strong smell. It is a native of eastern Siberia, and it was introduced before 1596.

\section{NUTANS, Willd.; and our fig. 4, in Plate 39.}

This species is a native of Siberia, whence it was introduced in 1823 . There are two varieties ; une with white, and the other with flesh-coloured flowers.

\section{GENUS III.}

PHySOSTEGIA, Benth. THE PHYSOSTEGIA.

\section{Lin. Syst. DIDYNAMIA GYMNOSPERMIA.}

Generuc Chaructrr.-Calyx abscurely veined, inflated after florescence. Corolla much exserted, with an ample throato-(G. Lon.)

\section{PHYSOSTEGIA TRUNCATA, Benth. THE BLUNT-CALYXED PHYSOSTEGIA.}

Engravings.-Bot Mag. t. 3494; and our fig. 1, in Plate 39.

- Sprcific Character.-Calyx truncate, obscurely 3-5-lobed. Lohes very broad, denticulated.-(Benth.)

Description, \&c.-A very showy plant, growing ncarly two feet high, and producing several spikes of its very elegant and delicately-marked flowers. It is a native of Texas, where it was found by Drummond in 1834, and seeds sent to the Glasgow Botanic Garden. Though at first supposed to be a perennial, it proves to be decidedly an annual, and only requires the same culture as the annual kinds of Dracocephalum. 
GENUS IV.

MOLUCELLA, Lin. MOLUCCA BALM.

Lin. Syst. DIDYNAMIA GYMNOSPERMIA.

Grapric Character.-Limb of calyx ample, oblique, with 5-10 mucrones or spines. Filaments naked at tho babe,-(G. Don.)

\section{1.-MOLUCELla LeVis, Lin. THE SMOOTH MOLUCCA BALM.}

Svxonyme.-Molucella levis, Riv.

Engraving. -Bot. Mag. t. 1852.

Specizic Character. Limb of calyx large, membranaceons, subpentagonal, with 5 very short mucrones or tecth.-(G. Don.)

Description, \&c.-The pretty pink and white flowers appear seated in their large calyxes; and underneath each calyx is a singular whorl of spiny bracter. The whole plant has a strong smell. It is a native of Syria, and it was first cultivated in England in 1570 , by L'Obel, botanist to James I. It requires to be sown on a hotbed, and planted out in May, when it will flower in July or August.

\section{2.-MOLUCELLA SPINOSA, Lin. THE SPINY MOLUCCA BALM.}

Synonymes. - M. armsta, Sieb. ; Cbasmonia incisa, Presl; | Specific Cuaracter.-Limb of calyx short, coriaceous, sub-bila.' Molucea spinosa, Moench.

Engraving.-Bot. Reg. t. 1244. biate, with 8 spines.-(G. Don.)

Description, \&c.-A very coarse-growing plant, with a square stem, and white gaping flowers, with curiously cut, thorn-like calyxes. The leaves are on long footstalks, and they are deeply cut, and covered with spines. It is a native of the shores of the Mediterranean, and was introduced in $\mathbf{1 5 9 6 . ~ I t ~ h a s , ~ h o w e v e r , ~ b e e n ~}$ lost and re-introduced several times. It is quite hardy, and only requires sowing in the open air. We do not know where seeds of this species are to be obtained.

\section{$=$ \\ GENUS $\nabla$. \\ AMETHYSTEA, Lin. THE AMETHYSTEA. \\ Lin. Syst. DIANDRIA MONOGYNIA. \\ Gexeruc Cruractra.-Superior gtamens abortivo.-(G. Don.)}

Description, \&c.-This genus differs very slightly from that of Teucrium, the Germander.

\section{AMETHYSTEA CARULEA, Lin. THE BLUE AMETHYSTEA.}

Engruvincs. - Bot. Mag. t. 2448 ; and our fig. 2, in Plate 39.

Specific Cranacter.- Herb erect, brancbed, glabrous, often bluisb. Leaves petiolate, 3-5-parted; segments obloug-lanceolale, deeply toothed; floral leaves smaller; upper oncs minute. Cymes pedun- cled, loose, racemosely pauicled. Bracteas minute. Calyzes erect. bluish, quite glabrous, with lanceolate, acuto teeth. Corolls bluo, scarcely exceeding the calyx.-(G. Don.)

Description, \&c.-The stem is square and purplish, growing from one foot to two feet high; the leaves are three-parted and on channelled footstalks; the flowers are small, blue, and in leafy corymbs; and the whole plant is very fragrant. It is a native of Siberia, introduced in 1759 , and quite hardy, growing well in any soil or situation. Seeds are in all the sced-shops; and the only care necessary is to transplant the young plants while in the seed-leaf, as they will not bear it afterwards. 


\section{CHAPTER XL.}

PEDALINEA.

Essential Character. - Calyx 5-parted. Corolla bilabiate. Stamens 4, didynamons. Orarium surrounded by a glandular disk. Stigma undivided. Fruit drupaceous, dry, usually muricated, of several spurious cells. Seeds pendulous. Albumen none. Erect brasched herbs with opposite eaves, and axillary, solitary, bibracteato flowers.(G. Don.)

Description, \&C.-All the plants in this order aro remarkable for the oiliness of their seeds. The Indian grain Sesame mentioned in the story of the Forty Thieves in the Arabian Nights' Entertainments belongs to it. The order takes its name from the genus Pedalium (Pedalion signifying the rudder of a ship), in reference to the dilated angles of the fruit.

\section{GENUS I.}

\section{MARTYNIA, Houst. THE MARTYNIA.}

Lin. Syst. DIDYNAMIA ANGIOSPERMIA.

Graeric Character.-Drupe oblong, bicornute at the spex; the anterior horn sulcately-tootbed, containing a 4-celled nut; cells few-seeded.-(G. Don.)

Description, \&c.-The genus Martynia, which was named by Honston in honour of Professor Martyn, editor of Miller's Dictionary, \&c., is nearly allied to the genera Bignonia and Tecoma; and the species are remarkable for their showy flowers, horny eapsules, and oily seeds.

\section{1.-MARTYNIA PROBOSCIDEA, Glox. THE HORNY, OR PROBOSCIS-LIKE MARTYNIA.}

Svwonymeg. - M. alternifolia, Lam.; M. annua, Lin.; M. Engravings.-Bot. Mag. t. 1056; and our fig. 1, in Plate 40. Louisiana, Mill.; Proboscidea Jussieuii, Schmidt.

VARIETr.-M. p. 2 triloba, G. Don; 11. triloba, Cham. et cordate at the base; etamens 4, all fertile.-(G. Don.) Schlecht, smaller than the species.

Descriptron, \&c.-A very curious plant, covered with glutinous hairs. The flowers are somewhat bellshaped, and are dotted and variegated with several shades of colour; the lobes of the stigma are irritable, and clpse when touched. The capsules or seed-vessels are a kind of nut, quite hard and woody, and terminating in two beaks or horns. The plant was a native of Louisiana (where it was first discovered on the banks of the Mississippi), and Mexico, and was introduced about 1759; seeds of it being sent by Richard, the French king's gardener at Versailles, to the celebrated Miller, who was then curator of the botanic garden at Chelsea. It was first kept in the hothouse, and treated as a half. hardy annual ; hut it is now found to succeed in the open border, if sown in April or May, in a light rich soil and warm situation. The seeds, like those of all oily plants, do not keep well; and thus, generally, only a few of those sown come up. The plant has a strong erect stem, and does not require sticking. Seeds may be procured at Carter's, Holborn, and other seed-shops.

\section{2.-MARTYNia LUTEA, Lindl. THE YELLOW MARTYNia.}

Engrupings.-Bot. Reg. t. 934; and our fig. 3, in Plate 40. | Leares opposite, cotdate-orhicular, toothed, clothed with glandular Sprcific Coaructer, - Stem branched, clothed with glandular down. $\mid$ down. Beaks much longcr than the pericarp.-(G. Don.)

Description, \&c.-The habit of the plant resembles that of $M$. proboscidea, but the flowers are of a bright orange yellow. It is a native of Brazil, introdueed in 1825. The culture is the same as that of the preceding species. 



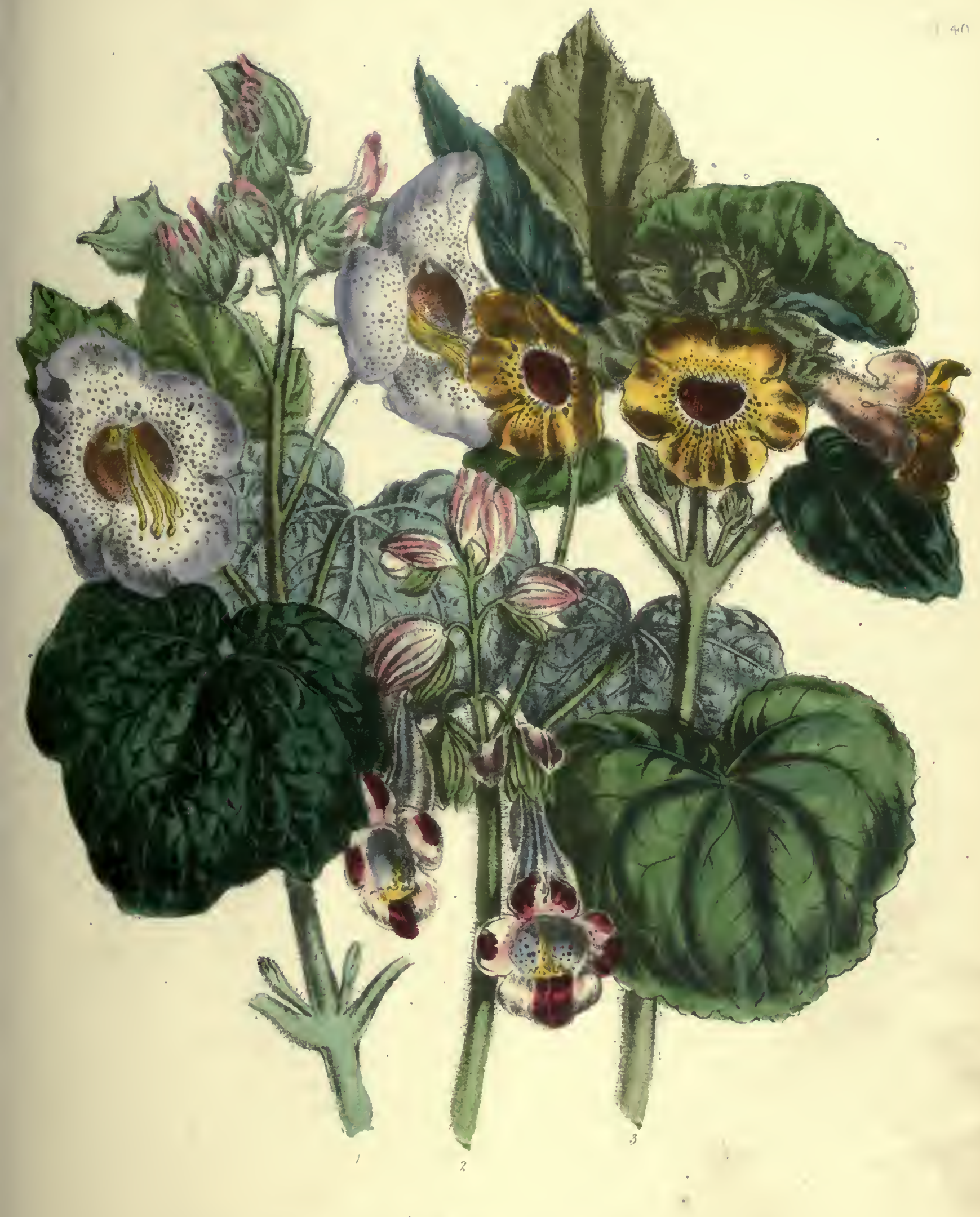

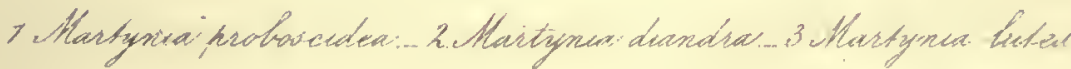





\section{3.-MARTYNIA DIANDRA, Ghox. THE DIANDROUS MARTYNIA.}

Synonymrs.-M. angulosa, Lam.; M. reliq., Houst. Engravines.-Bot. Reg. t. 200I; Bot. Rep. t. 575; and our fig. cordate at the base; stamens 4, two of them sterile.-(G. Don.) 2 , in Plate 40.

Description, \&c.-The spike of flowers of this species grows differently to that of all other kinds; and instead of being terminal, it always springs from a fork between the stem and branches. The flowers are very curiously marked. The leaves and calyxes are of a pale green, and the latter have a sort of involucro formed of two delicate membranous bracteas of a beautiful pale pink. The whole plant has rather an unpleasant smell. It is a native of Vern Cruz, Mexico, and was introduced in 1731. It is rather more tender than the other species, but in favourable situations it grows above two feet high, while the others rarely exceed a foot or eighteen inches. It should be grown in rich light soil, in a warm border in front of a south wall.

\section{LONGIFLORA, Lin.; M. CAPENSIS, Glox.}

The flowers of this species are very long, and purple. It is a native of the Cape of Good Hope, and was introduced in 1781 , but has long been lost to our gardens.

CHAPTER XLI.

\section{SCROPHULARINE.}

Essential Character.-Calyx persistent, 4 or 5-parted. Corolla 1 rarcly baccate, 2-celled, 2 or 4-valved, many-seeded. Albumen deciduous, bilabiate. Stamens 2 or 4 ; when the latter number, copions. Herbs very various in babit and inflorescence, with generally ustrally didynamous. Stigma simplo or two-lobed. Fruit capsular, | opposite leaves.-(G. Don.)

\section{GENUS I.}

COLLINSIA, Nutt. THE COLLINSIA.

\section{Lin. Syst. DIDYNAMIA ANGIOSPERMIA.}

Generic Character.-Corolla gibbous above the base; limb very irreguler. Capsule 2-valved; valves bipartite.-(G. Don.)

Description, \&c.-A genus of very handsome Californian annuals, named by Professor Nuttall in honour of Mr. Zaccheus Collins, Vice-president of the Academy of Natural Seiences in Philadelphia

\section{1.-COLLINSIA VERNA, Nutt. THE SPRING-FLOWERING COLLINSIA.}

Sysoxy mrs,-C. grandiflora, Lindl.; Antirrbinum tenellum, Pursh. | Sprcific Canacter.-Stem erect, branched. Leavcs lanceolate, Engrayings.-Swt. Brit. Flow. Gard. t. 220; Bot. Reg. t. 1107; lower ones sometines spathulate. Pedicels verticillate; calyx Bot. Gard. No. 391 ; and our fig. I, in Plate 4I, under the name of about balf the length of the corolla. C. grandiflora.

Description, \&rc.-Collinsia verna was the first species of the genus discovercd, and it was found by Nuttall in the spring of 1810 , growing in the alluvial soil on the borders of Lake Erie. He unfortunately lost the specimens he gathered, but the plant was found about the same period on the banks of the Missouri and Mississippi rivers by Mr. John Bradbury. In the spring of 1816, Nuttall undertook another journey in search of this plant; and after seeking for it in vain, during a journey of more than a bundred miles, he at last 
succeeded in finding a withered speeimen on the banks of the Olio, from which he procured some seed. In 1826 a kind of Collinsia was found on the banks of the Columbia, which was at first supposed a different species, and ras described in the Bot. Reg. as Collinsia grandiflora; but it has been since found that the differences discoverable between the specimens are not sufficiently constant to be relied on. The plant is quite bardy and will grow in any soil or situation, but it does best treated as direeted for Leptosiphon. When sown in spring it should be in February, as, if the sowing be delayed till the latter end of Marels or the beginning of April, the plants generally wither without flowering. All the Collinsias bear cold much better than heat. A rather curious proof of the hardiness of this species happened a year or two ago in the garden of a friend of ours. Some Collinsia verna had been sown in the autumn, and after it had flowered the plants were pulled up and thrown on a heap of very stiff clay which had been provided for puddling a pond. This was about November, and in April, when the clay was wanted for use, it was found covered with a splendid mass of flowers of this species, which were as fine, and as brilliant in colour, as thongh the seeds had been sown in the best prepared bed. This species was introduced in 1826, and seeds of it are common in the seed-shops both as C. verna and C. grandiflora.

\section{2.-COLlinsia BICOLOR, Benth. THE TWO-COLOURED COLLINSIA.}

Engravings.-Bot. Reg.t. 1734 ; Bot. Mag. t. 3488 ; Swt. Brit. Specific Character.-Stcm erect, downy. Leaves glabrous, ovateFlow. Gard. 2nd Ser. t. 307; Bot. Gard. No. 689; Paxt. Nag. of lanccolate, subcordate at the base. Pedicels verticillate, racemose.Bot. vol. 3, p. 195; and our fig. 3, in Plate 41. (G. Don.)

Description, \&c.-A very showy annual, but one which differs so much, according to the soil and situation in which it is grown, as seareely to be recognised as the same plant. If the seeds are sown in autumn, as direeted for the Leptosiphon, and transplanted, or rather removed, in spring to a bed of rich and rather strong soil, where the roots will be shaded from the sun and kept rather moist, the plant will grow two feet high with a strong ereet stem, and will produce a profusion of splendid flowers, large in size and elear and brilliant in colour; while if the seeds are sown in April or May, about the usual time of sowing flower-seeds, the flowers will be poor and the stems weak; and if the roots are exposed to the sun, the plants will wither and die without any apparent cause, in the same manner as those of Nemophila insignis do under similar circumstances (see p. 217). This species differs considerably from $C$. verna, particularly in the shape of the leaves, and in the colour and disposition of the flowers. It is a native of California, where it was discovered by Douglas in 1833; and notwithstanding its recent introduction, seeds are already common in all the seed-shops.

\section{3.-COllinsia heterophyla, Graham. The VAriable-Leaved Collinsia.}

Encrutincs.-Bot. Mag. t. 3695; and our fig. 2, in Platc 41. |a glandular pubescence. Segments of the corolla rounded at the apex, Specific Charactra.-Lower leaves trilobate; upper ones orate. crenate, middle tube of the lower lip subacute, border of the upper lip acuminate. Peduncle shorter than the flower. Calyx covered with nearly entire.-(Graham.)

Description, \&c.-This species very closely resembles $C$. licolor, but the flowers are larger, and differ slightly in the colour. The lower leaves are also three-lobed; but altogether the botanical differences do not appear more than were supposed to exist between $C$. verna and $C$. grandiflora. The general appearance of the plants, however, is tolerably distinct. The culture of botl species is the same. C. heterophylla is a native of California, where it was found on the banks of the Columbia, and it was introduced in 1838. Seeds may be liad at Carter's, but they are at present rare in the seed-shops. 
, 



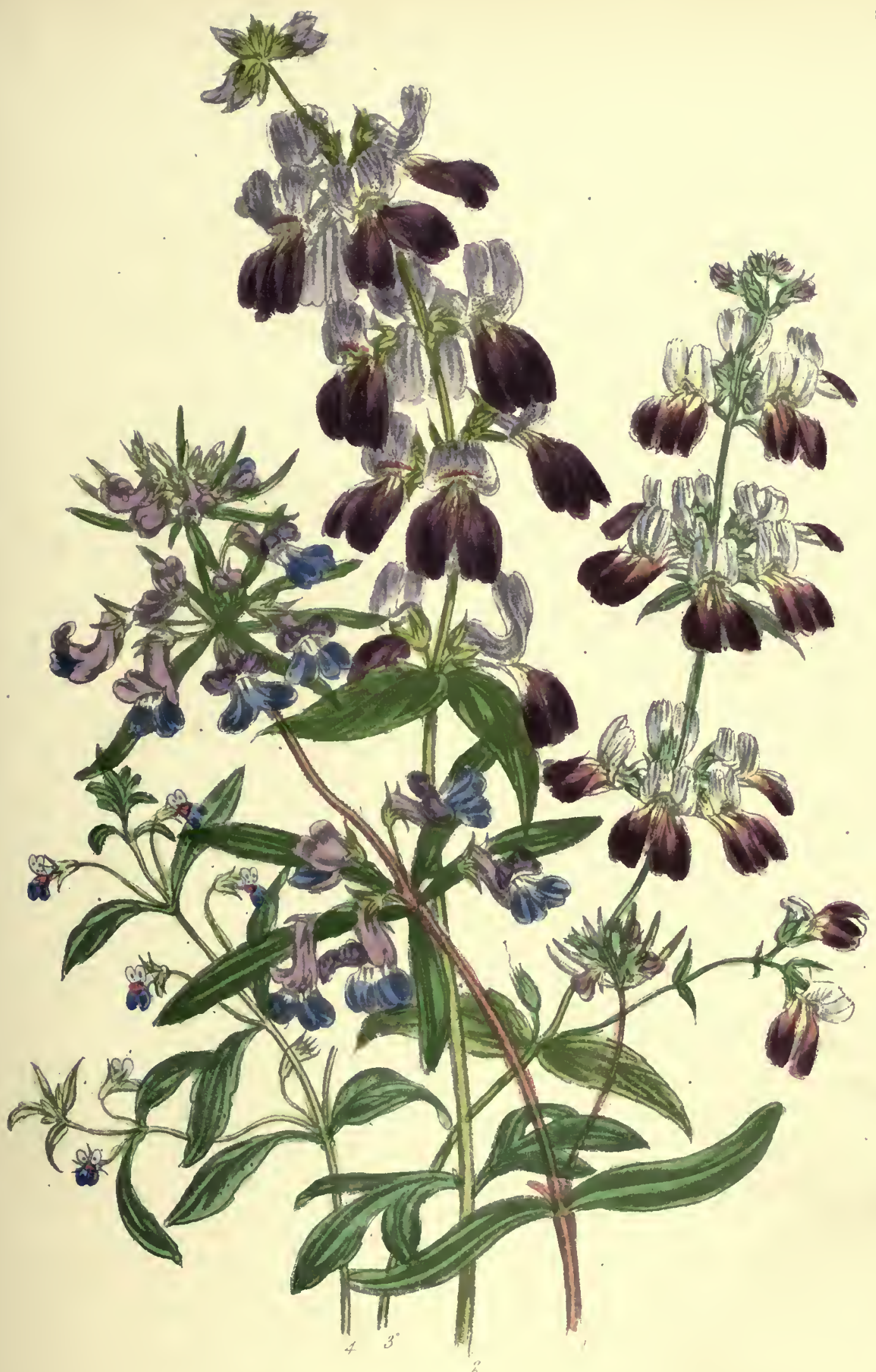

1. Collensia grandiflora:-.- 2. Gollinsue ketisnthylla 




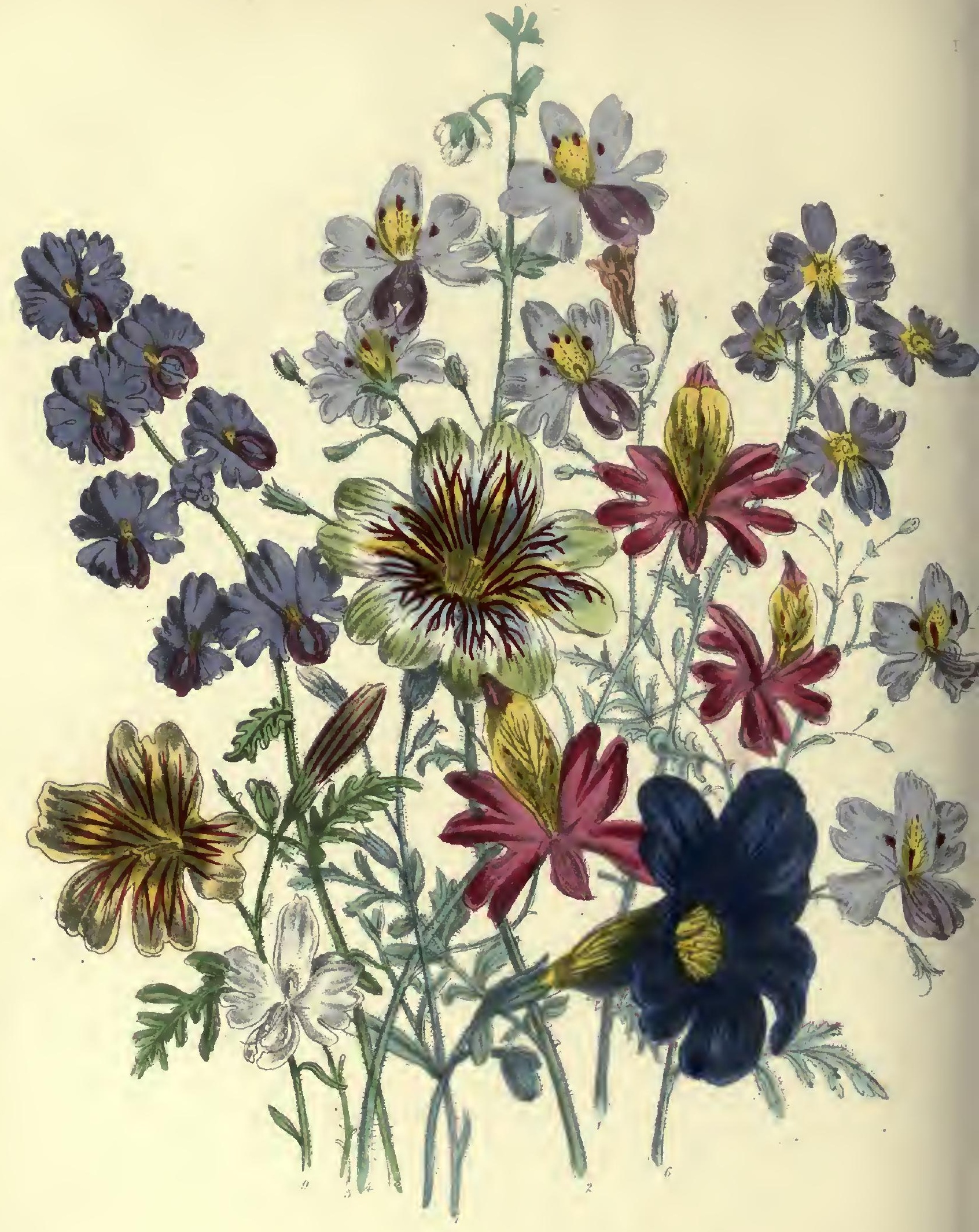


•

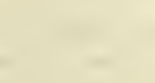

$\therefore$ 



\section{4.-COLLINSIA PARVIFLORA, Lindl. THE SMALL-FLOWERED COLLINSIA.}

Engravines.-Bot. Reg. t. 1082 ; and our fig. 4, in Plate $41 . \mid$ the flowers. Segments of corolla acutish, entire. Calyx dowuy, about Speciric Character.-Stem prostrate, downy. Leaves ovate-oblong, equal in length to the corolla.-(G. Don.)

nearly entire, downy. Pedicels axillary, solitary, much longer than

Description, \&c.-A little insignificant plant scarcely worth growing. A native of the banks of the Columbia, introduced in $\mathbf{1 8 2 7}$. The stem is prostrate, and consequently, as one plant covers a considerable space, the seeds should be scwn very sparingly, or the plants thinned out as soon as they appear. In other respects the culture is the same as for the other species.

Several other Collinsias are said to have been discovered, but they have not yet been introduced.

\section{GENUS II. \\ $\therefore \quad$ SCHIZANTHUS, $R$. et $P$. THE SCHIZANTHUS. \\ Lin. Syst. DIANDRIA MONOGYNIA. \\ Generic Chamactra.-Calgx 5-parted. Limb of the corolla 4-parted, lobed, irregular. Stamens 4, two upper ones sterile. Stigma compressed, obtuse.-(G. Don.)}

Description, \&c.-A genus of very beautiful flowers, comprised by Professor De Candolle in the order Solanaceos; but placed by most botanists, among whom is Dr. Lindley, whose arrangement we have hitherto followed, in the order Scrophularina. The name of Schizanthus signifies literally cut-flower. The stamens of these plants are said to start forward when touched, and the stem and leaves are covered with glandular hairs, which give out a peculiar and acid secretion, a fact which was first discovered by Miss Murray. All the species require a light soil and abundance of light and air.

\section{1.-SCHIZANTHUS PINNATUS, Ruiz et Pav. THE PINNATE-LEAVED SCHIZANTHUS.}

Everavings.—Bot. Reg. t. 725 ; Bot. Mag. t. 2404 ; and onr fig. introduced in 1831 from Chil..

1 , in Plate 42.

VARSFTY.-S. p. 2. humilis, Lindl.; Bot. Reg. t. 157; Swt. Brit. Flow. Gard. 2d Ser. t. 197; Paxt. Mag. of Bot. vol. 2, p. 198 ; and our fig. 3 , in Plate 42. Racemes of flowers crowded. A dwarf plant,

Specific Character.-Fructiferous peduncles inflexed at top, secund; lateral segments of the lower lip of the corolla longer than the intermediate one, whicb is obcordate; upper segment of the corolla coneate, emarginate.-(G. Don.)

Description, \&c.-In favourable soils and situations this plant grows nearly two feet high, though with a slender stem that requires support, and which throws out numerous branches, each terminating in a panicle of flowers. The leaves are pinnate, and they, as well as the stem and branches, are thickly clothed with short glandular hairs. The flowers are very pretty, and from their rather long and slender footstalks, they have a peculiarly light and elegant appearance. This very graceful plant was discovered by Micssrs. Ruiz and Pavon in the course of their botanical researches in Chili, and it was figured in their splendid work on the plants of that country. It was not, however, introduced till 1822, when seeds of it were first brought to England by Lady Cochrane, and the following year it flowered in several collections. Seeds of it are now common in all the seedshops, and they may either be sown in autumn to stand the winter, like the Californian annuals (see p. 156); or sown in the open ground in February or March. At whatever season the seeds may be sown care should bo taken to select a light rich soil and a sheltered situation for the young plants; as this species is perhaps more 
liable than any other annual to be broken by the wind, on account of the tenderness of its shoots. The collar of its stem should never be exposed to the sun, as when it is, it is liable to die off like the Nemophila (see p. 217). The culture of the variety is the same as that of the species; except that, from its dwarf stature and eompact habit of growth, it will not require either tying up or being sleltered from the wind.

\section{2.-SCHIZANTHUS PORRIGENS, Graham. THE SPREADING SCHIZANTHUS.}

Engruvings.-Bot. Mag. t. 2521; Bot. Gard. No.126; Swt. Brit. | Sprciric Charucter._Fructiferous pedicels spreading, straightish. Flow. Gard. t. 76 ; and our fig. 2, in Plate 42.

VARIETy.-S. por. 2 Strachani, our fig. 6 in Plate 42. Tube of corolla shorter than the calyx ; lateral segments of the lower lip longer than the middle one; upper segment oblong, obtuse.-(G. Don.)

Description, \&c.-The principal apparent difference between this plant and S. pinnatus, consists in its spreading habit of growth, and in the flowers having a yellow star in the upper lip. It is a native of Chili, introduced in 1823. The variety, which was raised from seed of the species in the garden of J. A. Strachan, Esq., at Teddington Grove, is particularly light and elegant. The culture of hoth species and variety in the open air is the same as that of $S$. pinnatus; but they may be grown to great advantage in pots in the same way as directed for Rhodanthe Manglesi (see p. 199). The soil should be equal parts of peat, rotten dung, and sandy loam.

\section{3.-SCHIZANTHUS RETUSUS, Hook. THE RETUSE-FLOWERED SCHIZANTHUS.}

Engrupings.-Bot. Mag. t. 3045 ; Bot. Reg. t. 1544; Swt. Brit. | longer than the calyx; lateral segments of the lower lip shorter than Flow. Gard. 2nd Ser. t. 201 ; Bot. Gard. No. 521 ; Paxt. Mag. of the middle one, which is aagittate; upper scgment rhomboid-oblong, Bot. vol. i. p. 5 ; and our fig. 4, in Plate 42.

Specrfic Character.-Fructiferous pedicels crect. Tube of corolla retuse.-(G. Don.)

Description, \&o.-The most splendid of all the species. We have seen it in the open air in Henderson's Nursery, Pine Apple Place, Edgeware Road, between three and four feet high, and spreading in proportion This species is, like the others, a native of Chili ; and it was introduced in 1831. The seeds may either be sown in autumn to stand through the winter, or in February or March, in light soil not too rich (the best soil is one composed of equal parts of peat and sandy loam); and the plants should never be grown two seasons on the same ground. In pots they should be treated like the Rhodanthe.

\section{OTHER. SPECIES OF SCHIZANTHUS.}

S. PRIESTII, Paxt. Mag. of Bot., rol. i. p. 31 ; and our fig. 5, in Plate 42.

A rery beautiful plant, raised from seed supposed to be of $S$. pinnatus or $S$. porrigens, in 1833, by Mr. Priest, a nurseryman of Reading. The shape of the flower is that of $S$. pinnatus; but the habit of the plant resembles that of S. porrigens. The colour of the flower is white, stained with bright yellow.

S. HOOKERII, Gillies; Bot. Mag. t. 3070 .

The corolla is of a pale rose colour, with a blotch of yellow on the upper segment. A native of Chili, introduced in 1828 .

S. GRAHAMII, Hook; Bot. Mag. t. 3044.

Corolla lilac, except the upper lip, which is yellow, tipped with lilae. A native of Chili, introduced in 1831. 
GENUS III.

\section{- SALPIGLOSSIS, Ruiz et Pavon. THE SALPIGLOSSIS.}

\section{Lin. Syst. DIDYNAMIA ANGIOSPERMIA.}

Gimsate Charactra.-Calyx 5-angled, 5-eleft. Corella funnel- |rudiment of a fifth betwcen the two lenger ones. Style tongue.slaped sliaped, 5-lobed; lobes 2-lobed. Stancns didyaamous, with the at the apex. Stigma truncatc, transversc.-(G. Don.)

\section{SALPIGLOSSIS SINUAT $\Lambda$, Ruiz et Pavon. THE CUT-LEAVED SALPIGLOSSIS.}

SyxoNYME.-S. atrepurpurea, Graham.

Enoluvisgs.-Bot. Nag. t. 281] ; Bot. Reg. 15I8; Swt. Brit. Flow. Gard. t. 271 ; and our fig. 8, in Plate 42 , as S. atropurporea.

Varieties.-S. 8. 2 pictr, G. Don ; S. piota, Swt.; Brit. Flow. Gard. t. 258; S. straminca, var. picta, Hook., Bot. Mag. t. 3365 ; and our fig. 7, in Plate 42. The painted Salpiglossis. Corolla variegated with yellow, blue, and purple. Raised by Dr. Neill from eecls received from Chili, in 1825.

S. s. 3 straminea, G. Don; S. straminea, Hook.; Swt. Brit. Flow. Gard. t. 231; Bot. Gard. No. 3:33; and our fig. 9, in Plate 42. The straw-colourcd Salpiglossis. Curolla straw-coloured, reined with purple. Raised in the garden of Mrs. Marryat, at Wimbledon, from sceds reccived troun Valparaiso, about I824.

S. 8. 4 Barclayana, G. Don; S. Barclayna, Cameron; Swt. Brit. Flow. Gard. 2d Sor. t. 112; S. intcrmedia, Swt. A very bcautifu] plant, a hybrid between $\mathbf{S}$. picta and $\mathbf{S}$. atropurpurea ; raised at Bury Hill, the seat of Charles Barclny, Fyq.u abent 1830. The flewers are of a brilliant ycllew, veined and cdycd with purple.

Specific Character. - Plant elothed with glandular hairs, Lower leaves petiolate, elliptic-oblong, sianatcd. Upper oucs sessile, lanccolatelinear, quite entiro. Stem pasicnlatcly branched at top. Braches racemose, dichotomous. Filameots glandularly pilose.-(G. Don )

Description, \&c.-The genus Salpigiossis seems to have puzzled botanists where to place it, as well as in the arrangement of its speeies. It was first supposed to belong to Bignoniacece, from its trumpet-shaped corolla; it was then placed in Solanacece, from its apparent allianee to Petunia; the resemblance between the genera being in fact so great, that several species, now eonsidered as Petunias, were first supposed to belong to Salpiglossis. Dr. Lindley, however, thinks that "its real affinity is with Digitalis" (the foxglove), and he has aecordingly placed it in Scrophularine, considering it to form one of the connecting links between that order and Solanacece. Wherever it may be placed, there ean be ne donbt of its near alliance to $S$ chizanthus, and accordingly it is always kept next to that genus, in botanical works.

All the kinds of Salpiglossis differ only in the eolour of their flowers; and for this reason Mr. George Don, in his large work entitled $A$ General History of the Dichlamydeous Plants, has made them all varieties of one species. The nanc of Salpiglossis, which signifies a tongue in a tube, is supposed to allude to the shape of the stigma, which is plainly seen in the centre of the tube-shaped corolla. The species is a native of Chili, and was introduced in 1824. All the kinds of Salpiglossis appear to agree in many respects with the Schizanthus; but the former are the most tender. Thus the seeds of Salpiglossis are generally sown on a hotbed in February, and the young plants kept in pots till May, when they may be planted in the open ground. The soil should be two thirds of loam, and one third of peat, without any manure. The Saliziglossis is apt to die suddenly, if the sun withers the collar of the stem, like the Sclizanthus; and it is also apt to damp off, if the collar be exposed to stagnant moisture. When grown in pots, it may be treated like the Rhodanthe; and will flower splendidly. It varies very mucl according to the soil and situation in which it is grown. The varieties require the same trentment as the species. All the kinds may be kept through the winter in pots in a greenhouse; and they will all become partially woody like the mignionette. They will rarely, however, live longer than two or three years, and will seldom flower well more than once. Many gardeners sow the seculs in autumn, and keep the plants in frames during the winter, when they will flower early in spring. 


\section{GENUS IV.}

\section{ANTIRRHINUM, Juss. THE SNAPDRAGON.}

Lin. Sysl. DIDYNAMIA ANGIOSPERMIA.

Generic Charactra.-Corolla personate, saceate, or gibbous at the base. Capsule opeaing by threc valvate pores under the apex, rarely by two irregular holes.-(G. Don.)

\section{ANTIRRHINUM GLANDULOSUM, Lindl. THE GLANDULAR SNAPDRAGON.}

Synonyme--? A. rytidocarpum, Fisch. et Mey. | hairs. Leaves alteroate, ovate-lanceolate, narrowed with pet!oles. Eneravings. - Bot. Reg. t. 1893 ; and our fig. 3, in Plate 43. Raceme of flowers dense and leafy. Lobes of ealyx linear-laneeolate, Specific Character._Spriakled over on every side with glandular $\mid$ unequal._( Lindl.)

Description, \&c.-An upright-growing plant about two feet high, with a very dense, leafy raceme of pink flowers, and covered all over with glandular, and somewhat viscid, hairs. The leaves are rather succulent, and they are loug and lanceolate, narrowing into a petiole at the base. The plant itself is curious as being the only snapdragon as yet found truly wild in the New World. The species is a native of California, where it was found by Douglas, and seeds of it sent home in 1825. It is supposed to be the same as A. rytidocarpum, a native of Caucasus, the seeds of which were sent to England from St. Petersburgh in 1835; but as the flowers of A. rytidocarpum are stated to be blue, while those of $A$. glandulosum are pink, the Russian kind appears more likely to be a variety than exactly the same species. The culture is the same as that of the other Californian plants, ail of which are more injured by heat than cold.

\section{OTHER ANNUAL SPECIES OF ANTIRRHINUM.}

A. ORONTIUM, Lin.; Eng. Bot. t. 1155, 2d. edit. vol. 5, t. 875.

This is a British weed commonly called Calves Snout, from a fancied resemblance between the seed-pod and the head of an animal. The word Antirrhinum has nearly the same mcaning, being compounded of Anti like, and Rhin a snout.

\section{A. CALYCINUM, I.our.}

A Portuguese plant with whitish flowers curiously marked with purple or rose-coloured veins. Introduced in 1810 .

\section{A. INDICUM, Royle.}

Flowers reddish; bracteas and floral leaves very long. A native of India, in the province of Delhi.

\section{GENUS V.}

\section{LINARIA, Vent. TOAD-FLAX.}

Lin. Syst. DIDXNAMIA ANGIOSPERMIA.

Generse Canacter.-Corolla personate, spurred at the bsse. Capsule opeoing by two lids at the top, or by 4-10 tooth-formed, or valve-formed parts.-(G. Don.)

Description, \&c.-Many of the species now considered as belonging to this genus were formerly included in the genus Antirrhinum. The genera, indeed, only differ very slightly; in Antirrhinum the corolla is gibbous at 


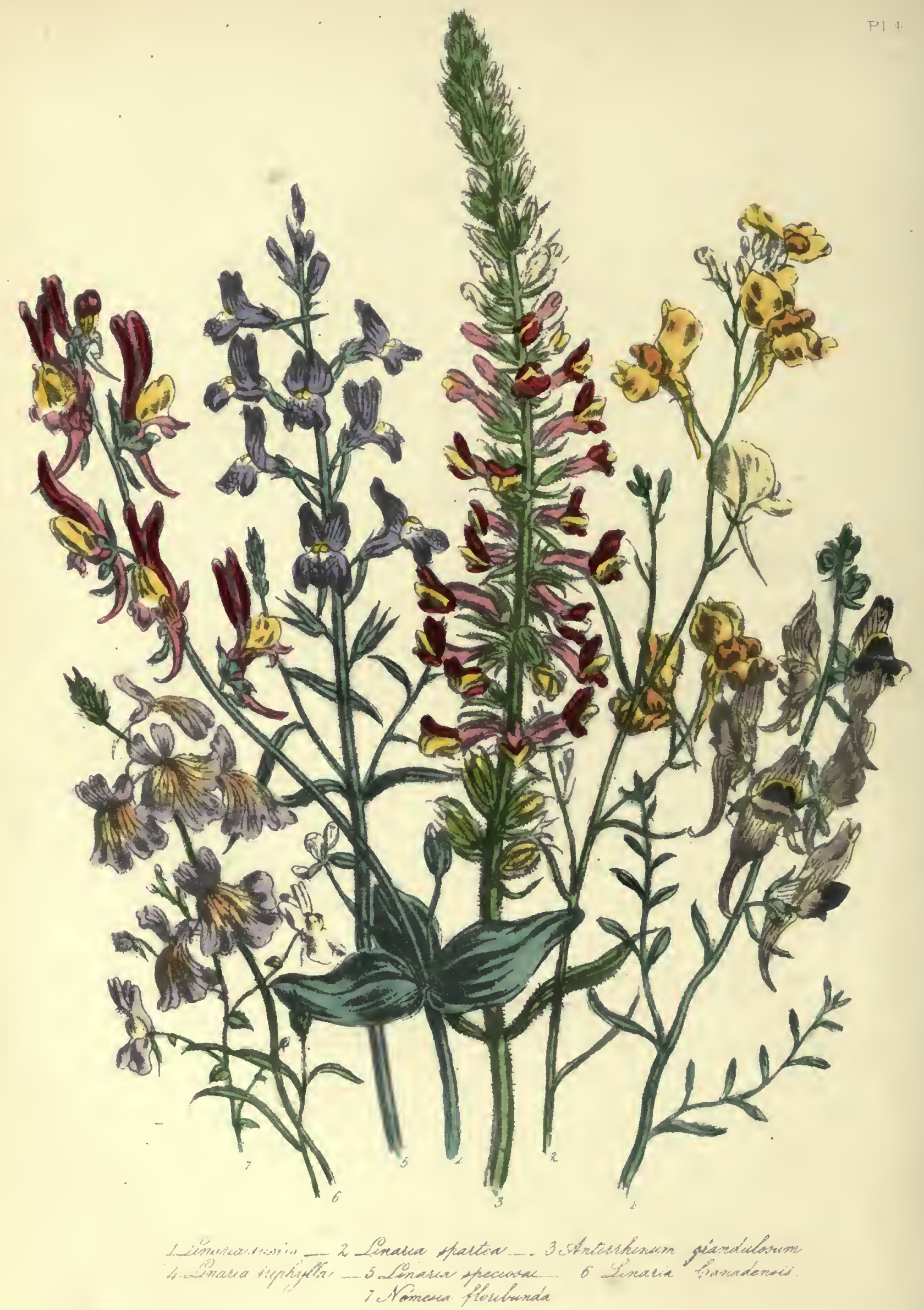


$-$ 

the base, and in Linaria it is spurred; there is likewise a little differenee in the capsules. The pecnliarities of the two genera will be easily discovered hy comparing the common toad-flax, Linaria vulgaris, with the common snapdragon, Antirrhinum majus. All the Linarias are tall-growing plants with showy flowers, and all of the ensiest culture in any common soil. The principal eare they require is to thin them out, to prevent them from becoming drawn np, and weak; as few plants look more straggling and untidy when this precaution is not attended to. Where time is not an object, a few plants of Linaria may be grown so as to produce a splendid effect by raising them in pots, and frequently slifting them, as directed for Rhodunthe, till they are ready to go into flower, when they should be turned out of the pot, without breaking the ball of earth, into the open ground; thus treated, the planits will present so different an appearance as scarcely to be recognised, and their flowers will be splendid.

\section{1.-LINARIA TRIPHYLLA, Mill. THE THREE-LEAVED TOAD-FLAX.}

Srvenymes. -L. glabrata, $H . B$. and $K$ th.; L. neglecta, Clarke and Guss.; Antirrhinum tricolor, Hort.; A. triphyllum, Lin.

Engravings.-Bot. Mag. t. 324 ; and our fig. 4, in Plate 43.

VARIetifa,-L. t. 2 crerulea, Chav, has the corollas nearly all blue; the leaves narrower, and the plant more slender. L. t. 3

peleria, Ræm., has the corellas shaped like those of the Peloria, or deformed variety of the commen tead-flax.

Spreific Character.-Quite glabrous, glaucous, erect or ascending. Leaves ovate and elliptic, usually 3 in a whorl. Flowers disposed in dense, spicate racemes. Calyoine segmenta oblong, or ovate-lanceolate; obtuso, sherter than the capsule.-(G. Don.)

Description, \&c.-This species of Toad-flax is easily distinguished from all the others by the peculiar disposition of its leaves, which grow three together, just at the base of the flower-stalk; whence it has received the specific name of triphyllum, literally three-leaved. The colour of the flower is a less certain mark of distinetion; as thongh it is generally three-coloured, that is, purple, white, and yellow, it sometimes varies to all purple, and sometimes to all yellow. It is a native of Sieily and Spain; and it was introduced from the latter country before 1629, as Parkinson mentions it in that year, calling it the "Tode Flaxe of Valentia." It is quite hardy, and requires no other care than sowing in March or April. When the plants come up, thcy sbould be thinned ont, as if suffered to remain many together they become drawn up and weak; whereas, if they are allowed room, several flower-stalks will spring from one root. The flowers shonld be eut off as soon as they fade, as, if the seed be suffered to ripen, the capsules will burst and seatter it; and self-sown plants will spring up in such abundance, that it will be found very difficult to eradicate them. The seeds are generally sold in the seed-shops, under the uame of Antirrlinum iriphylla.

\section{2.-LINARIA SPARTEA, Rchb. THE BRANCHING TOAD-FLAX.}

Sумолумғ8.-I. juncea, Desf.; L. præcox, IIoffm. et Link. ; late, erect, quite glabrous; lewer ones often three in a whorl; superior Antirrbinum junceun, Lam.; A. spartcum, Lin.

Engravings.-Bet. Mug. t. 200 ; and eur fig. 2, in Plate 43.

Speciric Character.-Plant erect, branched. Leaves linear-lanceo.

Description, \&c.-The flowers of this species are of the most brilliant golden yellow, and where the plants are allowed pleuty of room to spread, they make a beautiful bed in a regular flower-garden. The specieg is a native of the shores of the Mediterranean, and the Canary Islands; and it was introduced in 1772 . The seeds may be purchased in any seed-shop, generally nnder the name of Antirrhinum sparlea, and they only require sowing in February or Mareh in the open border. When the plants come up they should be thinned out, and if the weather be dry, they should be frequently watered. Thus treated, they will become short, thick, branching plants, and be covered with a profusion of flowers. 


\section{3.-LINARIA SPECIOSA, Jacq. THE SHOWY TOAD-FLAX.}

Syмon mes.-L. bipartita, Willd.; L. ccerulea, Hort.; Antirrhi- | Specrrtc Chaructrr.-Glabrous. Leaves linear, or lincar-lancronum orchidiflorum, Hort.; A. bipartitum, Vent. ; A. speciosum, Doun.

Engravings.-Swt. Brit. Flow. Gard. t. 30 ; and our fig. 5, in late, flat, alternate or verticillate; those of the sureuli broader, and three in a wherl. Flowers disposed in loose racemes. Segments of the calys almost lanccolate, acute, with membranous edgos. (G. Don.) Plate 43.

Descriprion, \&c.-This plant has very beautiful flowers when closely examined, though they are not so slowy in a mass as those of L. spartea. The stem is slender and branching, and seldom, under any circumstances, rises more than a foct high. The plant is a native of Morocco, and was intreduced in 1815. The seeds are common in every seed-shop under the name of Antirrhinum speciosum, and they require no other care than sowing, not too thick, in rather poor and sandy soil.

\section{4.-LiNaria CaNADENSis, Dum. The CaNAdian, OR AMERICAN TOAD-FLAX.}

Synonymes.-Antirrhinum Cazadense, Lin.; A. paucifornun, Pepp.

Esgnavisgs.-Bot. Mag. t. 3473 ; and our fig. 6, in Plate 43.

Specific Characten. - Leaves lincar, remote, glabrous, usually alternate; those of tibe sureuli broader, opposite, or three in a whorl, Raceme loose, slender, attenuated upwards. Pedicels longer than the bracters. Calycine segments acute, downy.-(G. Don.)

Description, \&c.-This elegant little plant is not half so much cultivated as it deserves to be, from its large, delicate, pale-violet flowers, and elegant, though slender habit of growth. The plant. though called Canadian, is a native of both North and South America; and though knowu to and described by Linnæus, it was not, as Sir W. J. Hooker informs us, introduced into our gardens till the spring of 1835 ; when Mr. Drummond sent seeds (as well as specımensı from Texas, which produced flowers tne ensuing summer. The seeds differ frem the other species in being brown instead of black, and much furrowed; they are not yet common in the seed-shops, but when procured, they should be sown in a sandy loam in March or April. The plant is quite hardy, and well deserving of cultivation. It is the only species of Linaria that has been discovered in America. The seeds are sold at Charlwood's and in other seed-shops, under the proper name of the plant, Linaria Canadensis.

\section{5.-LINARIA TRISTIS, Mill. THE SAD-COLOURED TOAD-FLAX.}

Sysoryme, - Antirrhinum triste, Lin.

Engravings.-Bot. Mag. t. 74; ard our fig. 1, in Plate 43.

Sprciric Character.-Glaucous, downy at top; leaves linear, or

linear-obloug; lower ones 3 or 4 in a whorl, upper ones opposite,

or alternate ; flowers approximate, sonsetimes nearly opposite; bracteas deflexed; calyeine segments linear-subspathulate, obtuse, downy.-(G. Don.)

Description, \&c.-The colour of the flowers of this species is a fine rich purplish brown, so that they do not deserve the epithet applied to them in the specific name, as they only look dark or sombre at a distance; and when examined closely, it will be found to be curiously and beautifully marked. It is a native of the neighbourlood of Gibraltar, whence it was introduced in 1722. It is generally treated as a greenlouse perennial, as it is too tender to live through the winter in the open air; but it will do quite well in the open border if treated as ail annual.

\section{OTHER SPECIES OF LINARIA.}

The following are mentioned in Charlwood's Catalogue as kinds of which seeds may be procured. The shape of the flowers and the culture of the plants are the same in all 


\section{LATIFOLIA, Desf.; A. LATIFOI,IUM, Willd.}

A native of Barbary, with large yellow flowers; introduced in 1800 . A handsome plant, frequently growing as a large bush, two feet ligh. The seeds are sold under the name of Antirrhinum.

\section{REFLEXA, Desf; ; A. REFIAXUM, Lin.}

A beautiful species with delicate pale blue or white and yellow flowers. A native of the south of Europe, introduced in 1810. The plant is procumbent and well adapted for rock-work. Seeds may be lad at Charlwood's under the name of Linaria.

\section{VERSICOLOR, Meench.; A. VERSICOLOR, Lin.}

A native of the south of France, introduced in 1777. The plant is of low growth, and the flowers are of a pale yellow and a rich brown. This and all the following kinds are called Antirrhinums in the seed-shops.

L. VISCOSA, Dum.; A. VISCOSUM, Lin.

The flowers, are brown, the stem rather low, and covered with a clammy down, and the root yellowish, spreading and twisted. The species is a native of Spain, and it was introduced in 1786.

L. BipUnCtatA, Dum.; A. BIPUNCTATUM, Lin.

The fiower is yellow marked on the palate with two very dark purple spots. A native of Spain, introduced in 1749 .

GENUS VI.

NEMESIA, Vent. THE NEMESIA.

Lin. Syst. DIDYNAMIA ANGIOSPERMIA.

Graneric Churactrr.-Corella persenate, spurred at the base. Capsule compressed, truccate at apex.-(G. Don.)

\section{I.-NEMESIA FLORIBUNDA, Lehm. THE MANY-FLOWERED NEMESIA.}

Syconyme.-N. affinis, Benth. $\quad$ orate; upper ones subsessile ovate, oblong, or lanceelate, all frequently Eingravings.-Bot. Reg. for 1838, t. 39 ; and our fig. 7, in Plate 43. toothed in the margin. Racemes terminal, very loose. Capsules Sfecrfic Character.-Erect, subglabrous. Lewer leaves petiolated, ovate, or oblong ; nearly straight.

Deschiption, \&c.-A very pretty little low-growing, widely-spreading plant, covered with abundance of white flowers slightly stained witl yellow and blue. A native of the Cape of Good Hope, introduced in 1837, and requiring the same culture as the Linarias. We do not know where to procure seed.

\section{2.-NEMESIA BICORNIS, Pers. THE TWO-HORNED NEMESIA.}

Sy NoxYMF.-Antirrbinum bicorne, Lin.

Spectric Craracter.-Leaves oppesite, ovate-oblong, serrated, stem erect. Flowers racemoso. Capsule 2-horned, subdivaricate.-(G. Don.)

Descriprion, \&c.-CThis species is generally grown in a greenhouse; but it will grow quite well in the opcn air. It somewhat resembles $N$. floribunda, but it grows higlıcr, and is remarkable for its two-horned capsule. It is a native of the Cape of Good Hope, and was introduced in 1774. 


\section{GENUS VII.}

\section{MAZUS, Lour. THE MAZUS.}

Lin. Syst. DIDYNAMIA ANGIOSPERMIA.

Generic Characten.-Calyx campanulate; tceth spreadiug. Lower lip of cerolla papillosely bigibbous at the base.-(G. Don.)

\section{MAZUS RUGOSUS, Lour. THE WRINKLED OR CHINESE MAZUS.}

Svnonymps.-M. bicolor, Benth.; Hernemannia bicolor, Willd.; Specific Cusracter.-Hardly stoloniferous; leaves all oblung Gratiola goodeniæfolia, Horn.; Lindernia Japonica, Thun.

Engruvings.-Swt. Brit. Flow. Gard. t. 36 ; and our fig. 6, in Plate 39. cuneated, coarsely toothed; segments of the calyx ovate-lanceolate, or lanceolate, acute, equal in length to the tube ; corollas hardly twice the length of the calyx. - (G. Don. $)$

Description, \&c.-A little creeping plant very suitable for rock-work; a native of Nepaul, introduced in 1780. Though a nativc of India, it is quite hardy, and requires no other care than scattoring the sceds on rockwork, or in any dry sandy soil. The flowers are produced in great abundance, growing in little round tufts only an inch or two from the ground. The seeds should not be sown in the open ground till the latter end of April or even May, but they may be sown on a slight hotbed in February or March.

\section{GENUS VIII. \\ TORENIA, Lin. THE TORENIA. \\ Lin. Syst. DIDYNAMIA ANGIOSPERMIA.}

Genaric Cruracter.-Calyx plicate, obliquely' 5 -teothed. Two lower filaments appendiculate, or gibbous at the basc. - (G. Don.)

\section{TORENIA CORDIFOLIA, Roxb. THE CORDA'TE-LEAVED TORENIA.}

Engrapings.-Bot. Mag. t. 3714 ; and our fig. 6, in Plate 44. | sub-faseicled, or solitary. Corollas about twice the length of the calyx, Spreific Character.-Leaves ovate-cordate. Peduncles axillary, $\mid$ which is ovate and rounded at the base.-(G. Don.)

Description, \&c.-A little plant, with pale bluish purple flowers, and almost prostrate stem. A native of moist pastures in India, where it flowers during the cold season. It was introduced in 1837, but seeds of it are not yet common. It flowered in the store at Glasgow; but will succeed quite well if raised on a slight hotbed, and transplanted in May to a moist, shady, and sheltered sitnation.

\section{GENUS IX. \\ MIMULUS, Lin. THE MONKEY-FLOWER.}

Lin. Syst. DIDYNAMia ANGIOspermila.

Generuc Character.-Calyx 5-toothed. Corolla personate. Capsule 2-valved, with flattish margins.-(G. Don.)

\section{1.-MIMULUS FLORIBUNDUS, Dougl. THE ABUNDANT-FLOWERED MONKEY-FLOWER.}

Enonavings.-Bot. Reg. t. 1125 ; and our fig. 4, in Plate 44. | Calyx small, ovate-tubular, almost equally truncate, with very short, Specticic Chaнастеr.-Diffuse, loosely pilose, clammy. Leaves acute teeth.-(G. Don.) petivlate, broad-ovate, a littlo toothed, truncate at the base, or rounded.

Description, \&c.-A pretty little plant, greatly resembling the musk-plant in its flowers, but growing more erect. The plant is a native of California, where it was discovered by Douglas on moist rocks near the Columbia. 
It is quite hardy, and grows readily in a warm dark situation and peat earth. The seeds should be sown very thinly; but from their small size it is very difficult to do this without mixing them with sand, or wood-ashes before they are sown. When the young plants come up, they should be thinned out. The flowers are produccd in great abundance; but they are generally of very short duration, and usually close about mid-day.

\title{
OTHER SPECIES OF MIMULUS.
}

M. MOSCHATUS, Lindl.

A procumbent plant, rooting at the joints, and producing abundance of yellow flowers, and growing frcely from seed.

M. HARRISONII, Paxt. and our fig. 1, in Pl. 39*.

A very strong plant, growing about three feet high, a hybrid between $M$, cordinalis and $M$. roseus. Like all the plants belonging to the genus, it seeds freely; but the flowers raised from seeds of the same plant vary exceedingly.

\author{
GENUS $\mathrm{X}$. \\ ALONSOA, Ruiz el Pavon. THE ALONSOA, OR MASK-FLOWER. \\ Lin. Syst. DIDYNAMIA ANGIOSPERMIA. \\ Generic Character. - Corella subrotate, resupinate frem the twisting of the pedicels.
}

\section{1.-ALONSOA LINEARIS, Ruiz et Pavon. THE LINEAR-LEAVED ALONSOA, OR MASK-FLOWER.}

Synonymes.-Celsia linearis, Jacq. ; Hcmimeris coccinea, Willd.; H. linarixfolia, H. B. et Kunth; Hemitomus fruticosus, L'Herit.

Denivation. - The genns is named in honour of Don Zanoni Alonso, a Spanish consul in Seuth America.
Exaravings._Bot. Mag. t. 210 ; Swt. Brit. Flow. Gard. 2nd Ser., t. 240 ; ? Bot. Cab. t. 1456 ; and our fig. 7 , in Plate 44.

Spfcific Casracter.-Glabrous; leaves opposite, or three in a whorl, linear, entire, or remotely deaticulated.- (G. Don.)

Description, \&c.-Nothing can exceed the brilliant colours of the flowers of this little plant, which, though generally considered a greenhouse shrub, is found to succeed quite well when grown as an annual in the open air. It is a native of Peru, whence it was introduced in 1790 , and was at first called Celsia linearis, by which name it is still generally known in the nurseries and seed-shops. It was first treated as a hothouse slirub; it was then removed to the greenhonse, and afterwards, being found to ripen abundance of secds, it was grown as a tender annnal; but it is now found to succeed even if sown in the open ground. To secure a fine show of flowers, it is, however, generally thought bcst to raise the seeds on a slight hotbed, and to plant them out in May, and thus treated, the plants will produce a succession of brilliant flowers throughout the whole summer. A. intermedia, Lodd. Bot. Cab. t. 1456, is a hybrid between this and the following species, A. incisifolia.

\section{2.-ALONSOA INCISIfolia, Ruiz et Pavon. THE CUT-LEAVED ALONSOA, OR MASK-FLOWER.}

Synonymes.-Celsia urticifolia, Curt. ; Hemimeris urticifolia, Will. ; Alonsoa grandiflora, Hort.

Engraving.-Bot. Mag. t. 417.

Sprcific Craracter._Glabrous; leaves oppositc, ovate, acute, deeply toothed, or serrated.-(G. Don.)

Description, \&c.-Larger and stronger-growing than A. linearis, but with rather darker and less splendid flowers. It is a native of Chili, introdnced in 1795, and requires the same treatment as the preceding species, hut is hardier. Both kinds require a loamy soil and an open situation. Seeds may be purcbased in the seedshops under the name of Alonsoa grandifiora. 


\section{GENUS XI.}

\section{MAURANDYA, Ortega. THE MAURANDYA.}

Lin. Syst. DIDYNAMIA ANGIOSPERMIA.

Generic Cinaracter,-Corolla personate, gibbous at the base. Capsule dehiscing by ten teeth at the apex.-(G. Don.)

Description, \&c.-This genus is named in honour of Dr. Maurandy, a botanical professor at Carthagena. All the species are climbing plants, and continue flowering all the summer.

\section{1.-MAURANDYA BARCLAYANA, Lindl. MR. BARCLAY'S MAURANDYA.}

Evaravivas.-Bot. Reg. t. 1108 ; and our fig. 2, in P1. $39 *$.

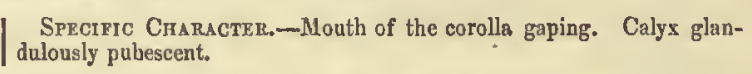

Descriptrox, \&c.-Seeds of this beautiful climber were imported from Mexico by Robert Barclay, Esq. (in honour of whom it is named), in 1826. It is always propagated by seeds, which may be sown on a hotbed in February, or as soon as they are ripe. The young plants sliould be put into the open ground in May, and those raised from seeds sown in autumn will flower in June, abont a month sooner than the others. They are also much stronger plants. There is a white-flowered variety of this species, which is very beautiful.

\section{OTHER SPECIES OF MAURANDYA.}

M. SEMPERfLORENS, Ortega : our fig. 3, in Plate 39*.

This species may be propagated by cuttings as well as seeds, as when preserved in a greenhouss through the winter, it becomes shrubby at the base. It may, however, be raised from sceds, which ripen abundantly, in the same manner as M. Barclayana, and it flowers about the same time. It is a native of Mexico, and was intruduced in 1786.

\section{GENUS XII.}

\section{LOPHOSPERMUM, D. Don. THE LOPHOSPERMUM.}

\section{Lin. Syst. DIDYNAMIA ANGIOSPERMIA.}

Generio Cunacter.-Corolla bilabiate; tube wide, gibbons at the base. Capsnle dehiscing irregularly under the apex.-(G. Don.)

Description, \&c.-Very beautiful climbing plants. Lophospermum signifies a crested seed.

\section{1.-LophospermuM ERUBEscens, D. Don. THE BLUSHiNg LOPHOSPERMUM.}

Srrotrme.-L. scandens, Hort. $\quad$ Engravisgs.-Bot. Mag.t. 3037, and t. 3038; Swt. Brit. Flow. Gard. VARIETIFs.-L. e. 2. spectabile, Paxt. Mag. of Bot. vol. viii. p. 75 ; 2nd ser. t. 68; Bot. Reg. t. 1381.

and our fig. 4, in Pl. 39*. The fowers are spotted. L. e. 3 Hendersonif, Hort. The flowers are of a very rich dark crim- equally serrated, pubescent. Segments of the calyx obloug, mucronulate. son.

Description, \&c.-This plant is very frequently confounded in the nurseries with $L$. scandens, or rather it is known by the name of that plant; the true $L$. scandens being very rarely to be met with. The seeds of the present species were collected in thickets near Jalapa, in Mexico, in September 1829, and sent to Dr. Neill, of Ediuburgh, in whose garden tle plant first flowered in 1830. In 1838, the spotted variety we have figured was raised in the Canden nursery, Canden Town; and in 1840 a very beautiful kind, with dark crinson flowers, was raised by Messrs. Henderson of Pine-apple Place, Edgware Road. All the kinds raised from $L$. erubescens seed freely, and flower the first year, but if preserved during the wiuter they become slurubby at the base. L. scandens lias a tuberous root, like a Dahlia. 


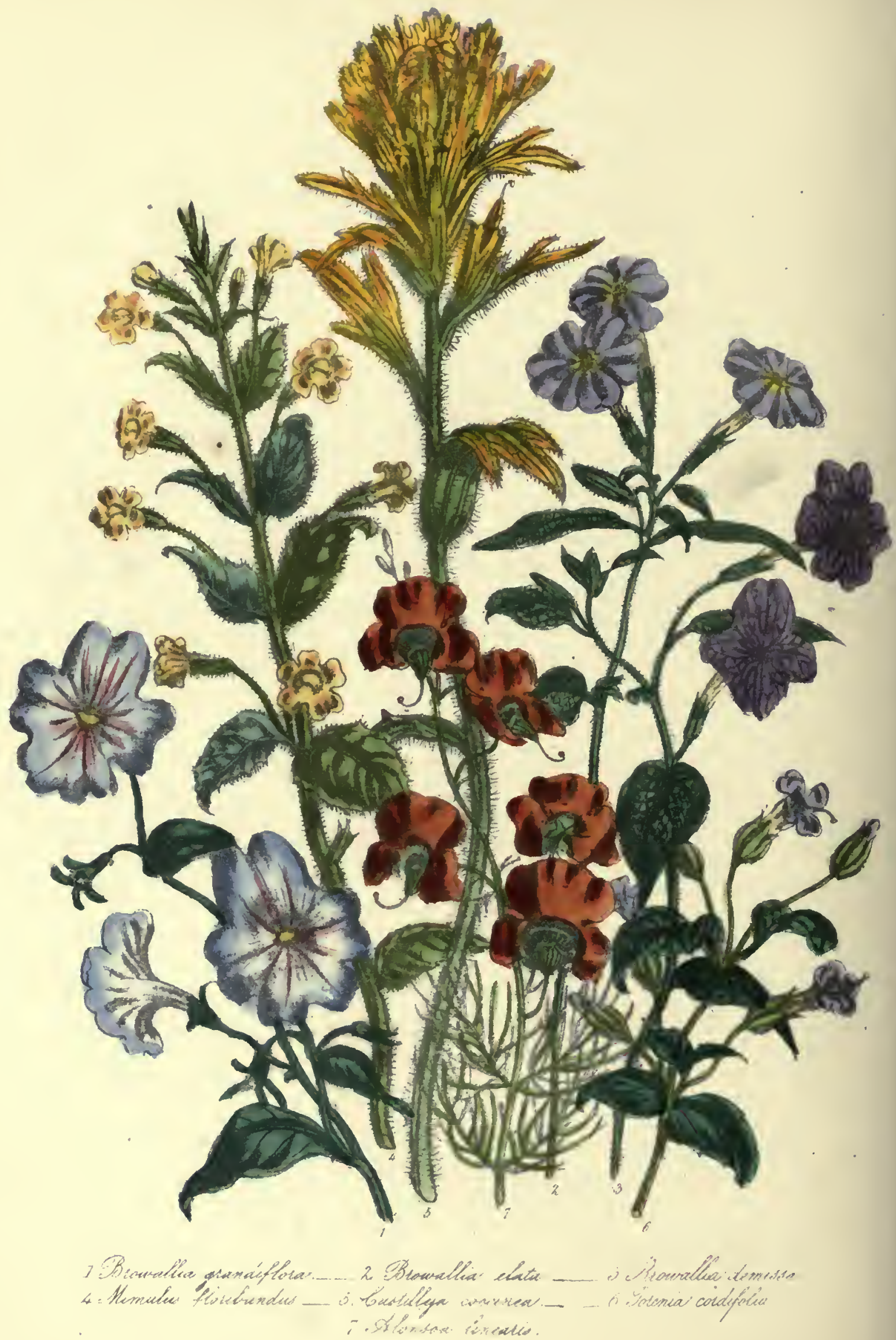


. 



\section{GENUS XIII. \\ CAS'I'ILLEJA, Lin. THE CASTII.LEJA, OR PAINTED CUP.}

Lin. Syst. DidyNAMIA ANGIOSPERMIA.

Cenenic Character.-Calyx compressed, bifid or quadrifid, cleft on one sile. Upper lip of corolla linear, channelled, entirc. Cclls of antliers unequal.-(G. Don.)

CASTILLEJA COCCINEA, Spreng. THE SCARLET-PAINTED CUP.

Synony yms.-Bartsia roccinea, Lin.; Euchroma coccinea, Nutt. F.neravines.-But. Reg. t. 1136 ; and our fig. 5 , in Plate 44

Specific Character.-Lcaves, as well as the colouicd bracteas,

divaricately trifid, Calyx bifid, nearly cqual with the corolla. Segments retuse and emarginate.-(G. Don.)

Description, \&c.-This very singular plant was discovered in several parts of North America almost at the same time by different botanists, and was introduced as early as 1787 ; but it was soon lost, and was not restored to Britisl gardens till 1826, when seeds were sent home to the Horticultural Society's gardens by Douglas.

When first discovered, it was supposed to belong to the genus Bartsia, the Marsh-eyebright, and it was there placed by Linnæus, who, thongh he established the genus Castilleja in honour of D. Castillejo, a botanist of Cadiz, did not consider this species to belong to it. In Ameriea, Castilleja coccinea is called the painted cup; a name it well deserves from its bright yellow flowers and bright searlet bracteas. The speeies is scarce, and easily lost, as it ripens few seeds in England; but it is so abundant in almost every part of the United States, that seed is always easily to be proeured from that country. "Tlie plants," Dr. Lindley observes in the Bot. Reg., "slıould be grown in gravel, or peat and sand, and not in loamy soil." They are quite hardy, and require no other care than sowing very early in spring (say February or March), or in autumn, to stand the winter, like the other Californian annuals. .

GENUS XIV.

\section{BROWALLIA, Lin. THE BROWALLIA.}

\section{Lin. Syst. DIDYNAMIA ANGIOSPERMIA.}

Generuc Сианастеr.-Calỵ 5-toothed. Corolla salver-shaped, tcsupinate. Stigma 2-lohed, 4-tubercled. Capsale 2-celled. Dissepiment contrary; placentas fleshy.-(G. Don.)

Desoniption, \&c.-The plants belonging to this genus are all half-hardy annnals, natives of South America, generally kept in greenhouses, but which, if reared in a slight hotbed, will grow well in a sheltered sitnation in the open air. The genus was named by Linnæus, in honour of his friend Browallius, the bishop of Aboa, who wrote in defence of Linnæus' system, against some of the numerous enemies whieh the newness of the doctrines broached in it raised up against its author. Before the time of Linnæus, botanists had no means of distinguishing plants, but by long Latin descriptions, which were so tiresome and so inconvenicnt, that we now wonder how botanists conld submit to be annoyed witl them. They had, however, many partisans, and when Linnæus first proposed his simplifying system, the innovation was vehemently opposed. It is not surprising that Linnæus wished to show his gratitude to a friend who had had courage to support him when so many persons were opposed to lim; but it is lamentable to find that in the end the friends quarrelled, and that Linnæus is said to lave named the different species to commemorate this friendship and this quarrel. Thus, B. elata is said to express the extent of their friendship; $B$. demissa, its deerense; and $B$. alienata, their final quarrel. The first two names are, however, so well aecounted for by the habits of the respective plants, that this origin for them appears too funciful. 


\section{1.-BKOWALLIA DEMisSa, Lin. THE DWARF, OR SPREADING BROWALlia.}

lingravings.-Bot. Mag. t. 1136 ; and our fig. 3, in Plate 44. | the base. Pednncles axillary, I-flowered, and are, as wcll as the Specific Cinarter.-Lenves ovate-oblong, acnoinated, oblique at branclies, downy. Calyx glabrons.-(G. Don.)

Descriptron, \&c.--The leaves of this plant are hairy, and the flowers vary from a bright but pale blue to purple or red, and sometimes there are flowers of all the three colours on the same plant at once. The species is a native of Sonth America, where it is called Botanera. It is a low-growing plant, seldom rising above six inches high. It was introduced in 1735 , under the name of Dalea, as it was supposed to belong to that genus, and was first cultivated by Philip Miller, the author of the well-known Gardener's Dictionary, when he was curator of the Botanie Garden at Chelsea. Seeds are common in the seed-shops, and they sloonld be sown in a hotbed, then transplanted into pots, and not planted out till June.

\section{2.-BROWALLIA ELATA, Lin. THE TALL BROWALLIA.}

Engruvings - Bot. Mag. t. 34; and our fig. 2, in Plate 44.

VaneTv.-B. e. 2 alba, Hort.; has the flowers white.

\author{
1 Specific Character.-Leaves oval, acuminated. Peduncles axillary, \\ i one or many-flowered.-(G. Don.)
}

Description, \&c.-A tall, uprighth-growing plant, with corymbs of dark blue flowers; the stem is strong and much branched, and the whole plant, when allowed room to grow, is very handsome. It is a native of Peru,

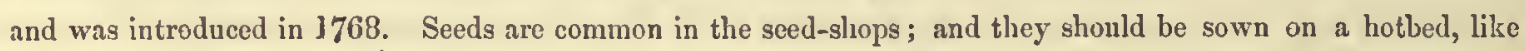
those of B. demissa. The plants are generally grown in pots for placing under a veranda or in a greenhouse; but they are quite hardy enough for planting out in the open air in MLay or June, and they are very ornamental.

\section{3.-BROWALLIA ELONGATA, H. B. et Kunth. THE ELONGATED BROWALLIA.}

\begin{tabular}{l|l} 
Symonyme-B. lacten, Hort. & bnse. Pcduncles 1-flowered, axillary. Branchlets, pedunclce, aod
\end{tabular} Specirtc Craracter.-Leaves ovate, acnminated, ronnded at the 1 calyzes, clothed with hairy pubescence.-(G. Don.)

Descriptron, \&c.-The flowers of this speeies are blue, spotted wwith a peculiarly dead white, which looks as tlough a few drops of milk had been sprinkled on the flower. The stem and branches rather angular and downy; and the leaves are hairy. The plant is as tall as $B$. elata, but with a weaker stem.

\section{4.-BROWALlia gRANDiflora, Graham. THE LARGE-FLOWERED BROWALLiA.}

F.xgravinos.-Bot. Mag. t. 3069 ; and our fig. 1, in Plate 44. Spreific Character.-Lenves ovate, acute, attenuated into the petiolcs at the base. Peduncles 1-flowered, axillary, racemose at

the tops of the branches. Branches and adult calyxcs glabrous.(G. Don.)

Descriptron, \&c.-This species is one of the tallest of the genus, as it generally grows two feet high, and branches in proportion; the flowers are also very large, though they are not so landsome as most of the otlier kinds, on account of their pale colour. The species is a native of Peru, but it is ratler hardier than the others, and will thrive well even if sown in the opon border. Seeds are to be procured at Charlwood's and other seed-sliops. 


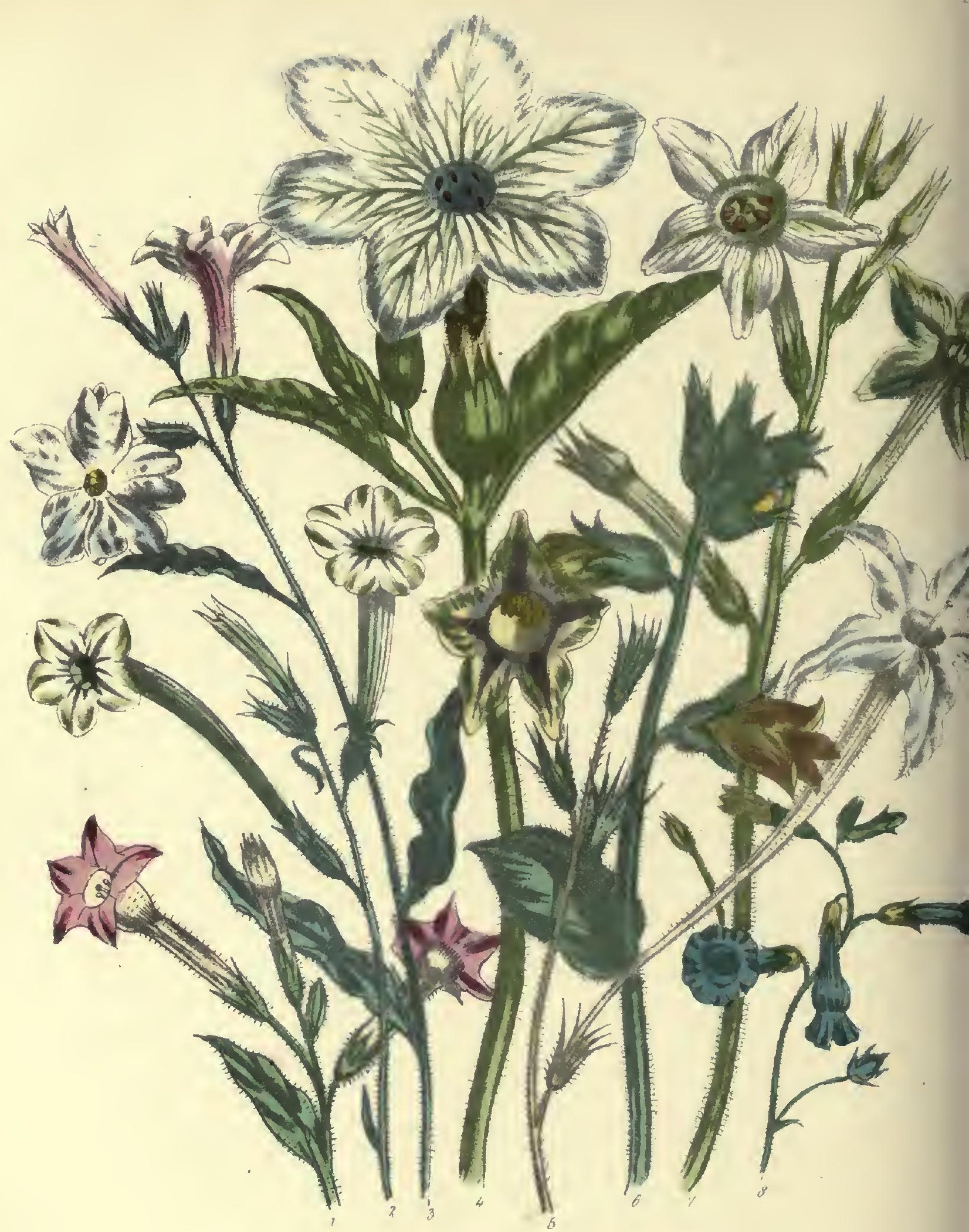

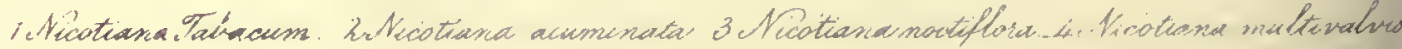

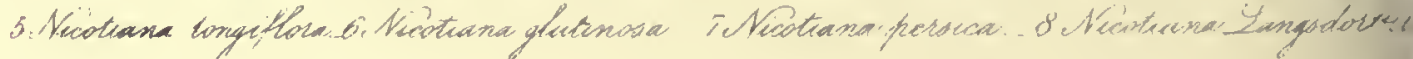




5.-BROWALLIA CORDATA, G. Don. THE CORDATE-LEAVED RROWA LLIA.

SX NoNYME. - B. grandiflura, Lindl.

Engraving.-Bot. Reg. t. 1384.

Sprcific Character.-Leaves cordate-ovate, aeuminated. Pedun- cles ]-flowered, raeemose at the tops of the branches. Branches and adult calyxes glabrous. - (G. Don.)

Description, \&e.-This is the plant figured under the name of B. grandiflora in the Botanical Register, but it differs considerably from the plant to which the same name is given in the Botanical Magazine. The flowers are much smaller, they are of a deeper blne, or of pure white, with a dark yellow eye, and the under side of the petals is yellow; the leaves are cordate, and of a dull green; and the whole plant is smaller. It is a native of Peru, and was introdueed in 1829 . The culture is the same as that of the other species.

\section{CHAPTER XLI.}

SOL A N A C E A.

Fssential Craractrr.-Calyx usually 5-eleft, persistent. Cerclla $\mid$ Albumen fleshy. Herbs or surubs with a peculiarly nauseous smell. "sually 5-eleft, menopetalous, nstally regular. Stamens usually 5, Leaves alternate. Inflorescence variable, but generaljy extra-axillary. epipetalons. Style ene. Fruit capsular er baecate, 2 to 4-celled. - (G. Don.)

Drscription, \&c.-The order Solanaceæ is a very interesting one, as it contains not only many useful plants, such as the commen potato, the capsicum, and the tomato, but some of our most splendid flowers, such as the Daturas and Brugmansias, the Petunias, and the different kinds of Tobaceo. Many botanists include the genera Salpiglossis, Schizantlıus, and Browallia, in the Solanaccr; but others place them, as we have lune, in the Scrophularinæ. Several of the plants belonging to Solanaceæ are narcotic poisons; as, for example, the deadlynightshade, the heubane, and the thorn-apple. All the species require a rich free soil, and they are all robust and vigorous.growing, taking up a great deal of room, and being therefore quite unfit for small gardens.

\section{GENUS I.}

\section{NICOTIANA, Tourn. THE TOBACCO. \\ Lin. Syst. PENTANDRIA MONOGYNIA.}

Generic Character.-Calyx tubular. Corolla funnel-shaped, or sauver-shaped; Jimb equaJ. Stamens rather unequal, inelosed or exserted. Capsule dehiseing by 4 parts at the apex; placentas free.-(G. Don.)

Descniption, \&c.-The different kinds of Tobaceo have all ornamental tube-shaped flowers, and very large thick leaves, whicl are used for making tobacco and snuff. They are cultivated for these purposes abroad, and sometimes even in England; though in this country they are generally grown for their flowers, and, in faet, no person is here permitted to grow more than half an acre of tobacco without purehasing a licenco from the Exeise. The different kinds of Tobaceo are by no means common in gardens, partly on aceount of the room they take up from their thick and branching stems and tne large size of their leaves, and partly on account of their rapidly exhausting the soil. The name of Nicotiana was given to the genus by Tournefort, in honour of MI. Nicot, the Frencl ambassador to Portugal, who introduced the first species of it into Franee; and that of 'Tobaeco. from the name given by the native Indians to the pipe they used in smoking. The principal species grown for their leaves are, $N$. tabacum, the Virginian tobaceo; N. macrophylli, the Oroonoko tobacco; and $N$. rustica, the common tobacco.

$$
\text { I } 12
$$




\section{1.-NICOTIANA TABACUM, tin. THE VIRGINIAN TOBACCO.}

Synonymes.-N. Havanensis, Lag.; N. Virginiana, Hort. | Sprelfic Character.-Leaves seasile, oblong.laneculate, acumiEngravings.-Wood Metl. Bot. t. 69 ; Stev. et Churcl. Med. nated; lower ones desurrent; thront of the corolla inflately veutuscose; Bot. 1, t. 37 ; Bot. Gard. No. 160 ; and our fig. 1, in Plato 45.

segnents of tho limb acuminated.-(G. Don.)

Descriptiox, \&c. - A very vigorons plant, growing from four to six feet ligh, with very large leaves and pink flowers, which appear rather small in proportion to the size of the plant. This specics was the first discovered, and, aceording to Linnaus, it was brought by tho Spaniards to Europe in 1560. About the same period it appears to have been cultivated by the first Englisin settlers in Virginia, who had observed the use made of the leaves by the Indians (who imagined that smoking would cure several diseases), and wished to insitate their example. About $160 \%$, tobacco was in such request in Virginia that it passed generally in licu of money ; and a man who had a roll of tobacco in his pocket, conld purchase a dinner or procure a bed, as well as one who had a purse of money. Tobacco was brought to England, in the reign of Elizaleth, by Sir Walter Raleigh. The story of Sir Walter at first kceping the use of the plant a secret, and of its being discovered by a scrvant, who when he saw smoke coming out of his master's mouth thought he was on fire and threw water in lis face, is well known, as is the work writton by James I. against smoking. James, however, was not the only sovereign opposed to tobacco, as the Emperor of the Turks, the Graud Duke of Moscow, the King of Persia, and Pope Urbin VIII. all issued similar prohibitions; and in 1689, an ediet was issued in Transylvania, threatening those who should plant tobacco with the confiseation of their estates. At present, tobacco is cultivated to a great extent, chiefly in the West Iudies and the Soutliern states of North America. When grown as an article of commerce, the plants are raised in beds, and then planted out in the fields three feet apart; and when they send up a flower-stalk, its top is nipped off, to strengthen the leaves. When the leaves become brittle, they are cut with a knife close to the ground; they are then carried to the drying-shed, where they are huug up in pairs to dry. They are afterwards laid in heaps, and covered with blankets, to heat them, and on the nicety of this operation the goodness of the tobacco depends; as if the leaves are overheated, they are spoiled,-and if not sufficiently, they are deficient in the intoxicating propertics for which the tobacco is cliefly valued. When no more heat is perceivable in the heaps, the leaves are packed in casks for exportation. The manufacture of the tobacco into snuff, \&c., gencrally takcs place in England, though some cigars are made in Cuba and other places. The leaves are first carefully cleansed from any earth or other impurities that may have become attached to them, and all their deeayed parts are picked ont; they are then moistened with salt and water, or a decoction of liquorice and salt, \&c., and the midrib of each leaf is cut out. The most perfect leaves are then rolled up to form cigars, a reed or iron pin being $\mathrm{kcpt}$ in the centre of the cigar, and the leaves rolled round it by a kind of machine. Some of the remainder of the tobacco is then spun into cords, or twisted into rolls for chewing; and another part is cut into shreds by an instrument like a straw-cutting machine, for smoking in pipes. Snuff is made by drying the leaves, and grinding tliem in a mill; and there are many different kinds, differing in their fineness and in the scents mixed with them. What is called shag tobacco, is made by drying the leaves on copper. The coarser leaves are used for unaking tobaceowater, or for fumigation, to destroy insects.

There are many varieties of the Virginian tobacco, but the species is the kind usually grown in British gardens, where, thougl its leaves are sometines gathered and dried for use, it is principally cultivated as a handsome border flower. It requircs a light but rich soil. The sceds should be raised on a slight hotbed, or in 
a warm border; and the plants, wheu removed to tlie bcds where they are to flower, should be planted about three feet apart every way. While the plants are young, the joints of the leaves should be frequently examincd. lest they should be attacked by a caterpillar, which often destroys the young opening leaves, and consequently the beauty of the plant.

\section{2.-NICOTIANA MACROPHYLLA, spreng. THE LARGE-LEAVED, OR OROONOKO TOBACCO.}

Synonvmes.-N. latissima, Mill.; N. gigantea, IIort.; N. ! at the base; throat of corolla inflately reutricose; acguents of the tabacurn, var, macrophyllun.

Specific Charactrr. - Leaves stem.clasprng, ovate, acute, auricled

Descriptios, \&c.-This is the largest species of tobacco, as it frequently grows seven or eight feet higl, with enormous leaves and pink flowers. The whole plant bears a great resemblance to the common Virginian tobacco, except that it is larger in all its parts. This is much grown in Cuba, and its leaves are used for making the larger and coarser kinds of Havannah cigars. In England it is generally confounded with $N$. tabacum, and the year of its introduction is uncertain.

\section{3.-NICOTIANA RUSTICA, Lin. THF ROBUST, OR COMMON ENGLish TOBACCO.}

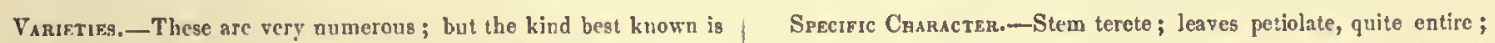
N. r. 2, Asiatica, Schultes; 8yn. N. Sibirica, Hort.; N. Tatarica, tube of corolla cylindrical, longer than the calyx; segmedts of the Hort.; N. scabra, Cav.; N. rigosa, Mill. leaf roundish, obtuse.-(G. Don.)

Descriptron, \&c.-This is the hardiest of all the kinds; and, indced, when once sown, it is so difficult to eradicate, that it may be almost considered a weed. It was one of the first species introducce, having been brought to England in 1570; and it is the plant known among the Indians by the name of Petun. It is a plant of no beauty, the flowers being of a dirty grecnisl-yellow, and the whole plant bcing covered witl clammy hairs, extremely disagreeable to the touch. It is, however, very generally grown in large kitchen-gardens for the leaves, which, from their strong, rank odour, are considered very efficacious for fumigating insects, \&c. Sceds are common in all the sced-shops, and they only require to be sown in the open border.

\section{4.-NICO'TIANA LANGSDORFII, Wein. LANGSDORFF'S TOBACCO.}

Esaravings.-Bot. Mag. t. 2221, and t. 2555 ; and our fig. 8 , in ; petiolate; superior ones almost scssile, decurrent; tube of eorolla Plate 45.

Specific Character.-Stem branched; lower leaves ovate, obtuse, clavate; segmeats of the limb obtuse.-(G. Don.)

Description, s.c.-A very handsome plant, growing about three feet high, with clear yellowislı-green flowers. This species is a native of Brazil, from which country it was sent to Europe by M. Langsdorff, the Russian consul at Rio de Janciro. It was introduced into England in 1819, but it is by no means common in collections.

\section{5.-NICOTIANA LONGIFLORA, Cav. THE LONG-FLOWERED TOBACCO.}

Everavings.—Swt. Brit. Flow. Gard. 2ud Scr. t. 196; and our fg. 5 , in Plate 45.

cordate-tanceolate, acuminated; thbe of the corolla long, filiform, fivo limes longer than the subfoliaceous calyx; lobes of corolla ovateSpecific Character.-Scibrous; cauline leavcs stem-clasping, lanceolate, acute.-(G. Don.)

Description, \&c.-A very clegant species, from the great length and slenderness of the tube of the corolla, which is delicately white on its inner surface, and greenish outside. The plant is of rather low growth, razely exceeding two feet, and the lcaves are of much feebler texture than those of most of the other species. The 
Hlower docミ not expand till evening, or in eloudy weather. This speeies is a native of Clili and Bucnos Ayres, and it was introdueed in 1832. Seeds may be pureliased at any of the seed-shops ; and they slould be raised on a slight lotbed in March, and planted out in May, when they will come into flower in July, and continue producing a succession of blossoms till Oetober, or till killed by the frost.

\section{6.-NICOTIANA NOCTIFLORA, Hook. THE NIGITT-FLOWERING TOBACCO.}

Synenyme,- - ? N. undulata, Vent.

Evgravings. -Bot. Mag. t. 2785 ; Swt. Brit. Flow. Gard. t. 262 ; and our fig. 3 , in Plate $\mathbf{4 5 .}$

Sprcinc Character.-Glandular and elamny, and beset with

adpressed hairs. Leaves petiolate. obleog-laaceolate, acute, nndulately curled. Tube of corolla cylindrical, much Jonger than the calyx; segments of eorolla equal, obeordately emarginate.-(G. Don.)

1)Escriptron, \&c.-A very interesting species, growing about two feet high, with an erect, but somewhat Iender, braneling stem. The leaves are small, and much waved at the margin. The flowers, which are produced in panicles, do not cxpand till evening; the corollas are whitc, and purple beneatl. The flowers when expanded are very fragrant; but the plant is elotlued with numcrous short, elaminy hairs, which have a very disagreeable smell when touched. The species is a native of the Andes, whence seeds of it were sent home by Dr. Gillies and Mr. Cruikshanks, in 1826. It sueceeded quite well in the open border in the Glasgow Botanio Garden, where it flowered in the month of August. During the day, the plants made but little show; but towards evening, the flowers, which were during the day curiously folded up, slowly expanded, displaying by degrees their pure white surface, and yiclding a delightful fragrance. Seeds may be procured in the principal seed-shops

\section{7.-NICO'TIANA PERSICA, Lindl. THE PEISIAN, OR SHIRAZ TOBACCO.}

Engravings.-Bot. Reg. 1592 ; and our fig. 7, in Plate 45.

Sprocific Chaнacter.-Clothed with clammy down. Radical leaves oblong-spatulate; cauline ones sessile, half stem-clasping, acunaionted,

hardly repand. Calyx acutely 5-toothed. Corolla salvcr-shaped, with a leng elavate tube, aud ovate, obtuse, edarginate, rather uoequal segments. - (G. Don.)

Description, \&c.-The flowers of this species arc very handsome, being green on the outside, and white within; they are produced in racemes, and are very sweet-scented at night. From the leaves is made the celehraterl Shiraz tobacco, which is valued in proportion as the leaves of which it is composed are thick, tough, and uniformly yellow. To obtain this result, the plants are continually watered while they are growing; and when they have attained their full size, each plant is eut off close to the root, and stuck firmly into the ground. This is in September, when the heavy night-dews fall, and these soon change the leaves from green to the desired yellow. The leaves are then laid in heaps to heat, after which the stalks and midribs are thrown away, and the leares are formed into eakes, which are pressed firmly together and paeked in bags. When grown merely for ornament, the Shiraz tobaceo is quite hardy, and only requires sowing in the open border.

\section{8.-NiCOTIANA ACUMinata, Sims. THE POINTED-LEAVED TOBACCO.}

Synonrus.-Petania acuminata, Gralam.

Everaving.-Our fig. 2, ia Pl. 45.

nated, undulated, nn longish petioles. Panicles few-flowered. Calyx clothed with glindular down. Calyeine segmeats aarrow. Corolla

Sfecirto Cuaracter.-Downy. Leaves broad, lanceolate, ncumi- with an elongated tabe, and rundish obtuse segments.-( $G$. Don.)

Description, \&c.-The flowers are whitish, and not very handsome. The species is a native of Valparaiso, whence it was introduced in 1828 , by Dr. Gillies. It requires no other eare than sowing in the open bnrder, but we do not know where seeds are to be procured. 
9.-NICOTIANA REPANDA, Willd. THE WAVED-LEAVED HAVANNAH TOBACCO.

Sxoovmes.-N. lyrata, H. B. et $K t h$.

ish, repandly undulated, somctines lyrate. Tube of the corolls slender,

Engravings.-Bot. Mag. t. 2484.

Specific Character. - Leaves stem-clasping, cordate-spatulate, round-

very long. Segments of the livub ovate, acutish. $-(G . D o n$.

Description, \&c.-The flowers are of a pale pink, and rather small; and the leaves are smootl, instead of being downy, as is generally the case with most of the other species. This species is a native of Cuba, particularly near Havannah, whence it was introduced by Mr. G. Don, in 1820 ; and the small Havannah cigurs, sometimes called Queen's, are made from its leaves. It is hardy, and only requires sowing in the open border.

\section{0.-NICOTIANA NANA, Lindl. THE DWARF TOBACCO.}

Engaving.-Bot. Reg. t. 833. $\quad$ longer than the solitary flowers. Corolla longer than the calyx, with Srecifie Character.-Leaves lanceolate, pilose. Radical ones obtuse segments.-(G. Don.)

Descriptron, \&c.-A very curious little species, not growing more than three or four inches high, with pure white flowers which rise from the axils of the leaves, and leaves of very delicate texture, from which tho Portuguese prepare their finest tobacco. The Indians also set a high value upon it as a medicine. The species is rather rare, being only found on rocky mountains, where it flowers in June. It was introduced in 1823.

\section{1.-NICOTIANA MULTIVALVIS, Lindl. THE MANY-VALVED TOBACCO.}

Engravings.-Bot. Reg. t. 1057 ; snd our fig. 4, in Plute 45.

Sfecific Ceanacter. - Clothcd with viscid buirs or down. Leavcs

fleshy, ovate-lanecolate; lower oncs petiolate. Flowers axillary,

solitary. Calyx msny-parted. Capsules many-celled. Segments of corolla obtuse, decply veined.-(G. Don.)

Descrtpriov, \&c.-This species, though it has showy flowers, has leaves of a peculiarly rank and almost fetid odour. It is, however, preferred to all others for smoking by the Indians on the banks of the Columbia. The calyx is inflated and ribbed, and when ripe, it divides into several valves. The plant grows two or three feet high, and flowers in August or September. The seeds should be raised on a hotbed in February, then transplanted into pots in March, and finally transferred to the open border, without breaking the ball of earth round the roots, in April or May; or they may be sown in the open border in March or April. It is a native of California, and was introduced in 1826.

\section{2.-NICOTIANA GLUTINOSA, Lin. THE GLUTINOUS TOBACCO.}

Synonymes.-Sairanthus glutinosus, G.Don; Nicotiana militaris, Willd, ; Tabacus viridis, Mœneh.

F.ngravings.-Bot. Rep. t. 484 ; Swl. Brit. Flow. Gard. t. 107 ; and our fig. 6, in Plate 45.

Description, \&c.-A very singuląr plant, which, though agreeing with the Tobaceos in most particulars, yet differs from them so much in the sliape of its corolla, as to belong properly to another class and order, according to the Linnæan system (viz. Didynamia Angiospermia, instead of Pentandria Monogynia). To reconcile this discrepancy, Mr. Don has formed of this species a new genus, which he calls Sairanthus, - from sairo, to clean, and anthos, a flower; in allusion to the ringent corolla, which constitutes the distinctive mark of scparation between this plant and the true Nicotianas. The plant grows from two to four feet high; its flowers arc of a dull red, and it is covered with clammy hairs, very disagreeable te the touch. It is a native of Peru, and was introduced in 1759. The seeds are common in the seed-shops, and they require no other care than sowing in the open border, and thinning out if necessary. 


\title{
OTHER SPECIES OF NICOTIANA.
}

The following have been introduced into our gardens.

\section{N. LANCIFOLIA, Will.; N. YBARRENSIS, H. B. et Kunth.}

A native of Quito, with purple, bell-shaped flowers. Introduced in 1823 . The plant grows from two to three feet ligh, and is clothed with clammy hairs.

\section{N. PUSILLA, Lin.; N. HUMILIS, Ehret.}

A low plant, not growing more than a foot high, with small yellowish-green flowers. A native of Vera Cruz. Introduced in 1733.

\author{
N. PANiCUlatA, Lin.; N. VIRIDIfloRA, Cav.
}

Flowers green, and produced in terminal panieles. A native of Peru. Introduced in 1752.

\section{N. CERINTHOIDES, Horne.}

Flowers greenisl-yellow; eapsule conical. A native of America. Introduced in 1821.

N. DILATATA, Link.

Flowers white, leaves large; the lower ones being generally a foot long and four inches broad. Introduced in 1820 .

$$
\text { N. PLUMbaginifolia, Viv.; N. CRISPA, Jacq. }
$$

Plant scabrous and hairy, with narrow leaves and white flowers, which are of a rusty lue beneath. A native of South America. Introduced in 1816.

\section{N. VISCOSA, Lehm.}

Flowers white, and, as well as the whole plant, clammy. A native of Buenos Ayres. Introduced in 1821.

$$
\text { N. BONARIENSIS, Lehm. }
$$

Flowers white; plant downy, but not clammy. A native of Buenos Ayres. Introduced in 1821.

$$
\text { N. QUADRIVAlviS, Pursh, Bot. Mag. t. } 1778 .
$$

The whole plant clammy, with an unpleasant smell. Flowers white, and capsule four-valved. A native of the banks of the Missouri. Introduced in 1811.

$$
\text { N. A LATA, Link et Otto. }
$$

A native of Brazil. Introduced in 1829 . The stem is winged; whence the name.

\section{GENUS II.}

\section{SOLANUM, Tourne. THE SOLANUM, OR NIGHTSHADE. \\ Lin. Syst. PENTANDRIA MONOGYNIA.}

Grneric Charactrr.-Calyx 5-cleft, rarcly 4-cleft. Corolla rotate, rarely campanulate, usually 5-cleft. Anthers connivent, dehiscing by pores at the apex. Berry 2, rarely 4-celled.-(G. Don.)

Description. \&c.-The flowers of all the species bear a great resemblance to those of the potato, which we should probably think very ornamental if they were not so common, and the berries are generally very showy. There are many annual species; but some of them, such as the Egg-plant, require the protcction of a stove, and others are not yet introduced, or have been lost to our gardens; we shall therefore describe very few. 



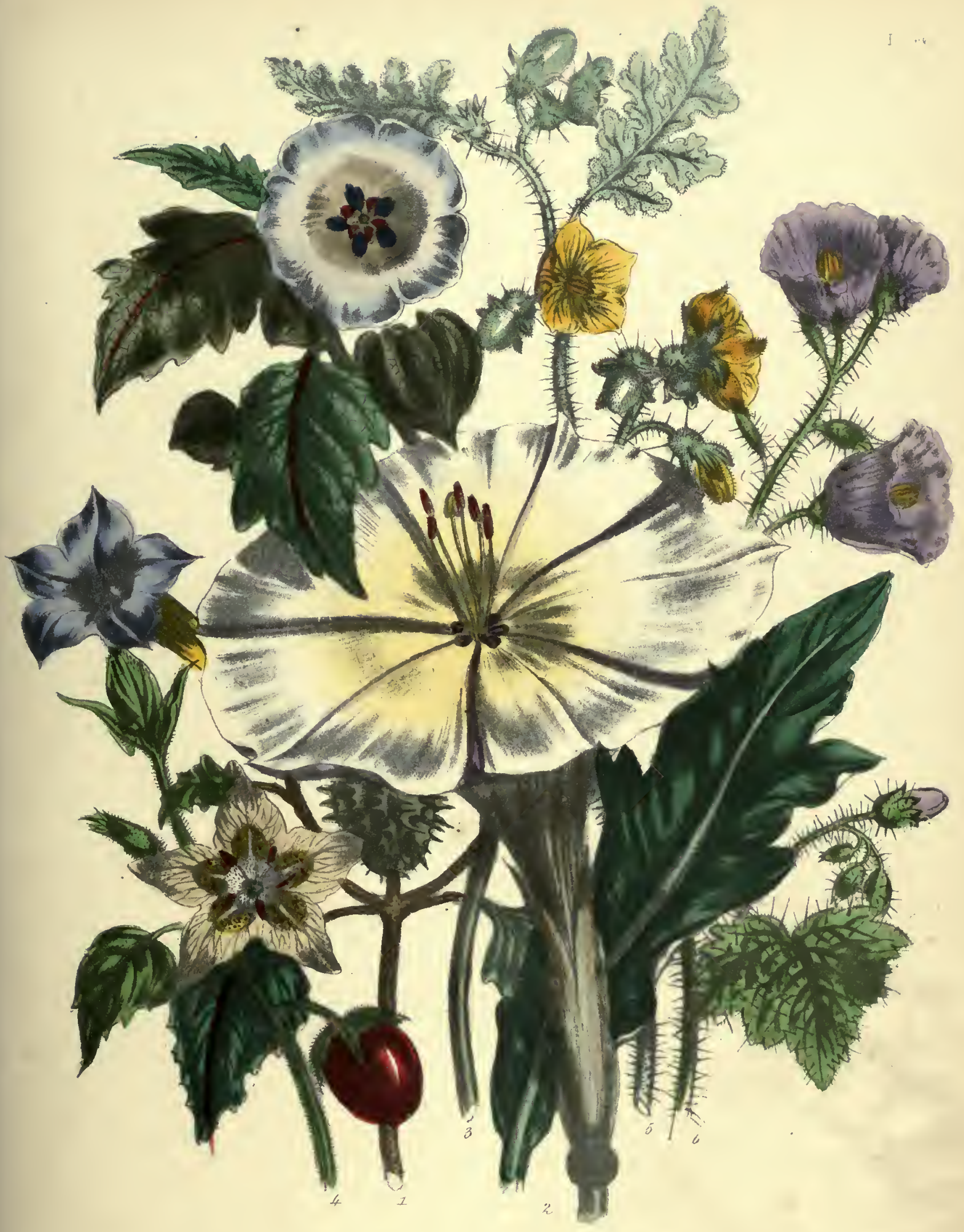

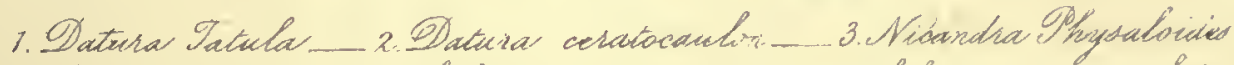

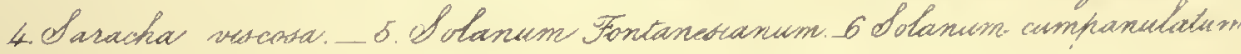





\section{SOLANUM FONTANESIANUM, Dunal. DESFONTAINES' NIGHTSHADE.}

Sxnonyme. - Nycterium Fontanesianum, Loud. Hort. Brit. Engruvings.-Bot. Reg. to 177 ; and our fig. 5, in Plate 46. SPecific Character.-Stem rather woody, though annual, prickly, pilose. Leaves deeply pinnatifid. Segnents sinusted. Corolla almost regulsr. Anthers small ; lower one a little curved at the apex, brown.-(G. Den.)

Description, \&c.-A coarse weedy-looking plant, growing three or four feet ligh, with yellow flowers and spiny calyxes. The stem and branches are also covered with strong spines; and the leaves are very rough, mucl waved or curled at their edges, armed with prickles, and covered with a whitish down. The plant is supposed to be a native of Brazil, and it was introduced in 1813.

\section{2.-SOLANUM CAMPANULATUM, R. Br. THE BELL-FLOWERED NIGHTSHADE.}

Engravings.-Bot. Mag. t. 3672 ; and our fig. 6, in Plate 46. | ovate, angularly-lobed, hairy, very prickly on both surfaces, as well as Specific Character. - Priekles crowded, straight, subulate. Leaves $\mid$ tbe cnlyxes. Racemes simple, armed. Corollas campanulste-(G. Don.)

Descniption, \&c.-A very handsome species, a native of New Holland, near Port Jackson, whence it was introduced in 1819 , but being soon lost, it was re-introduced in 1837 .

\section{OTHER SPECIES OF SOLANUM.}

\section{S. RACEMIFLORUM, Don.; S. SCABRUM, Jacq.}

Flowers white, but rose-coloured beneath; berries large and red. A very handsome species, the native country of which is not known; introduced in 1818.

\section{S. ETHIOPICUM, Lin.; LYCOPERSICUM RTHIOPICUM, Mill.}

The flowers are white and drooping; and the fruit is large, red, and resembling that of the Tomato or Loveapple. There are several varieties; one with lilac flowers and large white fruit, another with dark purple fruit, and another with small yellow berries not larger than peas. The species is an old inhabitant of our gardens, having been introduced before 1597 .

\section{S. DILLENII, Schultes.}

A native of Hungary, with small white flowers, and the berries marked with white dots. Introduced in 1818.

\section{S. GUINEENSE, Lam.}

The flowers are whitish, or of a pale violet colour ; and the berry is round, about the size of a small cherry, and black and sliny when ripe. A native of Guinea, introduced in 1817.

\section{S. NIGRUM, Lin. THE GARDEN NIGHTSHADE.}

This plant is common as a weed in gardens, and also in waste ground, throughout Europe. Its flowers are white; and its berries, which resemble black currants, are poisonous. This is the Yerba mora of the Spaniards, and the Morelle à fruits noirs or Morelle crève-chien of the French. There are several varieties, natives of the South of Europe; but none of sufficient beauty to be deserving of cultivation.

\section{S. FISTULOSUM, Rich.}

The stems are hollow, but in other respects this species resembles $S$. Guinbense. There are two varieties, one with black berries and the other with red ones. The species is a native of the East Indies, and was introduccd about 1820. 


\section{S. INCERTUM, Dun.}

There are many varieties of this species; some with black, some with red, and some with yellow fruit, a natives of India. The species was introduced in 1823.

\section{S. RUBRUM, Mill.}

A native of the East Indies, generally with the bcrries red or coppcr-coloured, introduced in 1817. There are above twenty other kinds which have been introduced, but which appear to be now lost.

\section{GENUS III. \\ SARACHA, Ruiz et Pavon. THE SARACHA. Lin. Syst. PENTANDRIa MONOGYNia.}

Generic Character.-Caljx 5 -cleft. Corolla campanuiately rotate, refiexcd. Stamene bearded. Anthcrs separate, dehiscing lengthwise. Berry 2-celled, covered by the calyx to the middle.-(G.Don.)

\section{1.-SARACHA PROCUMBENS, Ruiz et Pavon. THE PROCUMBENT SARACHA.}

Synonymes.-Atropa procumbena, Cav.; A. plicata, Roth.; Sola- | Specific Charucter.-Leaver twin, unequal, ovate, quite entire, uum procumbena, Dec.; Phyalia solaaacex, Ment.; Bellioia procumbena, Ræm. et Schulles. glabrous in the adult state, but when young, villous on the margins and back. Flowers umbellate, drooping. Filaments glabrous.-(G.Don.)

Description, \&c.-A procumbent plant, the flowers of which are cream-coloured, with a green margin, and the berries. small and shining. A native of Peru, introduced in 1822. The genus Saracha was named by Ruiz and Pavon in honour of Isidore Saracha, a Benedictine monk, and a good botanist, who was the means of introducing many plants to the Botanic Garden at Madrid. The genus differs very slightly in a botanical point of view from Solanum, and the culture is the same as that of the different kinds of nightshade. We do not know where sceds aro to be procured.

\section{2.-SARACHA UMBELLATA, Dec. THE UMBELLATE-FLOWERED SARACHA.}

Synonymes.-Atrapa umbellata, Roth.; A. Rothii, Poir.; Bellinia | Specific Character.-Erect, hairy, much bianched. Leaves ovate, unibellata, $R x m$, et Schultes.

Engravings.-Swit. Brit. Flow. Gard. t. 85. wriakled, entire, shining, acute, scabrous; floral onea twin. Flowers umbellate, draoping. Filamenta bearded at the base.-(G. Don.)

Description, \&c.-This is the most common species of Saracha. It is a strong, vigorous-growing plant, with a thick, deeply channelled stem. The flowers, which are produced in umbels, are smaller than those of S. procumbens, but they are of the same colour. The berry is of a dark purple.

\section{3.-SARACHA VISCOSA, Schrad. THE CLAMMY SARACHA.}

Engrapings. -Swt. Brit. Flow. Gard., 2od Scr. t. 323; and our | cardate, acuninated, ainuately toothed, and sometimes entire. Pedunfig. 4 , in Plate 46.

Specific Character,_Clothed in every part with glandular pubeacence, and viscid. Stem erect, suffruticose. Leaves twin, cles umbellate. Throat of corolla woolly. Frnetifcrous calyx coloured.-(G. Don.)

Descriprion, \&c.-A very handsome plant: the stems are slender and graceful, growing about a foot high; the flowers large, cream-coloured, and marked with numerous olive-coloured spots; and the berry large and of a bright scarlet. The plant is a native of Mexico, whence it was introduced in 1835 . It was at first treated as a greenhouse perennial; but it is now found to succeed best as an annual in the open air. The seeds are not common, but when they can be obtained, they only require sowing in March or April in the open border. 


\section{GENUS IV.}

NICANDRA, Adan. THE ALKEKENGI, OR KITE-FLOWER.

Lin. Syst. PENTANDRIA MONOGNYIA.

Generuc Character.-Calyx 5-parted, inflated. Segments sagittate. Corella campanulate. Stamens incurved. Berry fleshy, 3-5-celled, covered by the ealyx.-(G. Don.)

NICANDRA PHYSALOIDES, Gartr. THE ALKEKENGI, OR KITE-FLOWER.

Srxonymss.-Atropa physaloides, Lin.; Physalis peruviana, Mill.; I Specifie Craracten.-Plant glabrous, much branched. Leaves

P. daturefolia, Lam.; Calydermos erosos, Ruiz et Pavon.

Encruvings.-Bot. Mag. t. 2458 : and our fig. 3, in Plate 46.

twin. Flowers extra-axillary, solitary, drooping.

Description, \&c.-A very strong, vigorous plant, growing from four feet to six feet high in favourable sitnations, and sending out numerous branches. The flowers are large and showy, and the fruit resembles that of the winter cherry, being enclosed in a large inflated capsule. The stem is purple, and the branches are reddish, the colour becoming brighter in the petioles or footstalks of the leaves, and often spreading down the mid-ribs. The plant is a native of Peru, from which country it was first sent to France. It was introduced into England in 1759 , and it has ever sinee been a favourite in large gardens and shrubberies, though it should never be grown except where there is abundance of room. The name of Nicandra was given to this genus by Adanson in honour of the memory of Nicander, a Greek physician, who lived about a hundred and fifty years before Christ; physaloides alludes to the great resemblance between the berries of this plant and those of physalis, the winter cherry; and Alkekengi is its Peruvian name. The seeds are common in all the seed-shops, and they only require to be sown in rich earth in March or April, and then thinned out and transplanted, so as to leave those remaining in the bed at least three feet apart every way. This species is sometimes called the Peruvian Winter Cherry.

GENUS V.

DATURA, Lin. THE DATURA, OR THORN-APPI.E.

Lin. Syst. PENTANDRIA MONOGYNIA.

Genzre Chanacter.-Calyx angular, 5-toothed, dcciduous. Corolla conically funnel-skaped. Stigma 2-lobed. Capsule smooth, or echinatod.-(G. Don.)

\section{1.-DATURA STRAMONIUM, Lin. THE STRAMONIUM, OR COMMON THORN-APPLE.}

Sy noxvmis. - Stramonium vulgare, Moench.; S. vulgatum, I Specific Chanacten.-Lenves ovate, angularly toothed, cuuelforu Gorin.; S. futidum, Scop. ; S. spinosum, Lam.

Evarurings. - Eng. Bot. t. 1288, 2nd ed. vol. ii. t. 315. at the basc, smootlish, green. Capsule furnished with nearly equalsized spines or prickles.-(G. Don.)

Description, \&c.-A very remarkable plant, which, though not a true native of England, has now become common as a weed in this country, among rubbish, or on dunghills; being always found, however, near tlic habitations of men. It is a strong narcotic poison, but it has been much used as a medicine, and about twenty or thirty years ago, smoking part of the dried roots and stem was considered excellent for the asthna Tiko 
many other supposed remedies, it has however fallen into disuse; and the Stramonium is now seldom grown, except in shrubberies, or other places where there is abundance of room, and where a plant with large showy leaves is wanted to produce an effect.

\section{2.-Datura TAtUla, Lin. The tatula, OR PURle ThorN-APPLE.}

Srnonyme,-Stramonium Tatula, Mrench.

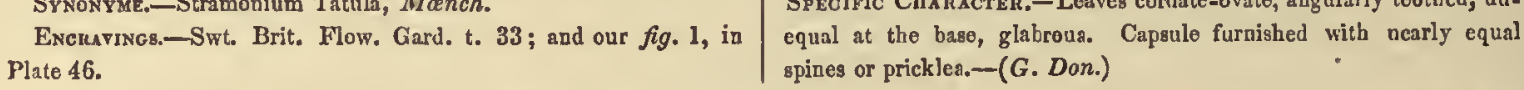

Description, \&c.-The stem is erect, much branched, and from a foot to eighteen inches high, of a dark purple, but marked with a few lighter-coloured spots. The leaves are very handsome, with dark red veins and margin. The flowers are of a pale purple or lilac, with dark-brown calyxes; and the fruit is erect and very thorny. The plant is found in great abundance on the meuntains of the Caraceas; but it is also common over great part of North America. It was introduced before 1629, as it is mentioned by Parkinson. The seeds, which are common in the seed-shops, may be sown in the open border in April or May; or in Marel, if protected from frost by a land-glass or flower-pot being put over them at night. They are sometimes raised on a sliglit hotbed, but they do better in the open ground, and they never flower well unless in the open air. They succeed best in a warm border of light rich earth, sheltered from the north; and in such a situation they will continue in blossom the whole summer, and indced till late in autumn, ripening abundance of seeds.

\section{3.-DATURA FASTUOSA, Mill. THE MAGNIFICENT THORN-APPLE.}

Specific Character.-Leaves ovate, acuminated, repandly toethed, unequal at the base, and, aa well as the atem, downy. Fruit tubercled.-(G. Don.)

Description, \&c.- $\Lambda$ magnificent plant, growing four feet or five feet lighl, with very large flowers, a native of the East Indies, Egypt, and South America. There are several varieties; one of which, a native of the East Indies, has double flowers, erimson on the outside and white within; another, a native of Malabar, has semidouble flowers, of a dark-purple on the outside and white within. This species was introduced before the time of Parkinson, 1629 ; but it is now seldom seen in our gardens, though one of its varieties may be procured in the seed-shops, under the name of the double purple Stramonium.

\section{4.-DATURA METEL, Lin. THE METEL, OR HAIRY THORN-APPLE.}

Escruving.-Bot. MIag. t. 1440. Sercific Character-Leavea cordate, quite cntire, or a little 10 -toothed. Calyx tcrete. Capaule furnished with prickles.-(G. Don.)

Description, \&c.- One of the commonest and smallest of the Daturas, seldom growing more than a foot or eighteen inches high. The flowers are white, and, like those of most of the other speeies, they fold up at night, the leaves rising to enshroud them. The flowers are erect, but when they fall, the capsule becomes drooping; it is very thorny, and part of the ealyx which remains on, forms a curious kind of hood to it. This species is a native of the East Indies, Africa. and the Canary Isles. The seeds are common in the shops, and they require the same culture as the other species, with the exeeption that they will flower best when sown on a sliglit hotbed in February or March, and planted out in May. 


\section{5.-DATURA CERATOCAULON, Ortega. THE hORNY-STEMMEd THORN-APPLE.}

Synonym,-D. macrocaulis, Roth.

Enorayives.-Bot. Reg.t. 1031 ; Bot. Mag. t. 3352 ; and our fig. Sprciric Character.-Stem terete, purplish, dichotomous, horn2, in Plate 46.

(G. Don.

Description, \&c.-A magnificent plant, growing four feet or five feet high, with a round stem, which is horn-shaped at its extremities. The flowers are very large, whitc stained with purple, and sweet-scented. The capsule is smaller than in most of the other species, and not thorny. It is a native of Mexico, whence it was introduced in 1805 ; and it has also been found in Cuba. The culture is the same as that of D. Tatula.

\section{OTHER SPECIES OF DATURA.}

\section{FEROX, Lin.}

Closely resembling D. Stramonium, except in the capsule being furnished with much larger and stronger prickles. A native of Cochin-China and Nepaul, introduced in 1731.

\section{QUERCIFOLIA, H. B. et Kunth.}

Nearly allied to $D$. Tatula, but with the leaves shaped like those of the common onk. The whole plant is slightly hairy. A native of $\mathbf{M e x i c o , ~ i n ~ t h e ~ m o s t ~ t e m p e r a t e ~ c l i m a t e s , ~ a n d ~ c o n s e q u e n t l y ~ q u i t e ~ h a r d y ~ i n ~ E n g l a n d . ~}$ Seeds may be had at Charlwood's, and they should be sown in the open border in March or April.

\section{MURICATA, Bernh.}

Flowers long and white; capsule warted; but not prickly. Introduced in 1820, and supposed to be a native of the East Indies.

\section{GUAYAQUILENSIS, H. B. et Kunth.}

Very nearly allied to $D$. Metel, of which it is probably a variety. The flowers are white, and the stem and leaves downy. A native of humid places near Guayaquil, introduced in I826. Seeds may be had at Charlwood's.

There are several other annual species of Datura, natives of South America, which have not yet been introduced. All the species are very handsome, and of very easy culture. The shrubby or tree specics are now formed into a genus called Brugmansia, from several botanical differences in the flower and its calyx, and from the fruit of the Brugmansia being always smooth, while that of the Datura is generally prickly. All the species are poisonous; and it is probably from this circumstance, united to the beauty of the flowers, that the Datura is considered in floral language to represent deceitful charms. The word Datura is said to be a corruption of Tatorah, the Arabic name of one of the species. Metel and Tatula are the names of the plants so called, in thcir native countries. Stramonium is a syncope of the Greek name for the Mad-apple (a kind of Niglitshade), from a supposed resemblance between the fruit of the two plants. 


\section{GENUS VI. \\ HYOSCYAMUS, Tourn. THE HENBANE.}

\section{Lin. Syst. PENTANDRIA MONOGYNIA.}

Greneric Cunacter.-Calyx ventricose. Corolla campanulatcly funnel-shaped. Limb uvequal, with one of the segments largor than the rcst. Stamens inclinate. Capsule immersed in the calyx, operculate. Placentas adnate.-(G. Don.)

\section{1.-HYOSCYAMUS NIGER, Lin. THE BLACK OR COMMON HENBANE.}

ExGruvings.-Eng. Bot. t. 591, 2nl Edit. vol. ii. t. 316; and | scmi-decurrent, stem-clasping, sinuated. Flowers almost sessile our fig. 5 , in Plate 47.

Specipic Character.-Clothed with clammy villi. Leaves sessile,

Corolla reticulated. Teeth of the calyz mucronate. $-(G$, Don.)

Description, \&c.-The flowers of the Henbane, though not so showy as those of the Datura, are yet sufficiently handsome to seem very unsuitable to so poisonous a plant. The lcaves, however, have a very strong and disagreeable smell, especially when burnt; and it has been observed of them, that when burning, they throw out sparks as though they had been sprinkled with salt. No animal can eat this plant with impunity, except perhaps the goat; and it is particularly destructive to poultry. It is a narcotic poison like opium, and it is used in medicine for the same purposes as that drug. The two plants also resemble each other in another point ; viz. that the seeds of the Henbane, like those of the poppy, may be eaten with perfect safety. Among the medical uses of Henbane is one very remarkable one; it is, that oculists employ extract of Henbane to dilate the pupils of the eyes, when they want to perform any operation of peculiar delicacy; and they apply it by dropping a little of the solution into the eye. The pupil in a short time becomes fearfully dilated ; and the effect of the Henbane continues several hours, without doing the least injury to the sight. The plant is a native of Britain, and it requires no other care than sowing the seeds in March or April in the open border.

\section{2.-Hyoscyamus AUREUS, Lin. THE GOLDEN HENBANE.}

Synonym.-H. Creticus, Park.

\begin{tabular}{l|l} 
Engrayings.-Bot. Mag. t. 87; and our fig. 6, in Plate 47. & corolla undulated.-(G. Don.) \\
Specific Character._Lcavcs petiolate, cordate-ovate, acute, an- &
\end{tabular}

Description, \&c.-A very beautiful specics, usually grown as a greenhouse perennial, but which, if treated like a tender annual, and raised on a slight hotbed, will flower beautifully in the open air. It is a native of the south of Europe, and it was introduced before 1640. The plant is not above a foot high, and it will flower from March till October. It is very seldom found in collections; and we do not know where seeds can be obtained.

\section{OTHER SPECIES OF HYOSCYAMUS.}

H. AGRESTIS, Kit.; Swt. Brit. Flow. Gard.t. 27 ; H. NIGER, Roxb.; H. NIGER, var. AGRESTIS, Nees. ; H. NIGER, var. ANNUUS, Sims. Bot. Mag. t. 2394 ; H. BOHEMICUM, Schmidt.

Flowers rather smailer than those of $H$. niger, and darker in colour. A native of Bohemia, introduced in 1820 ; probably a variety of $H$. niger, and requiring the same culture 
- 



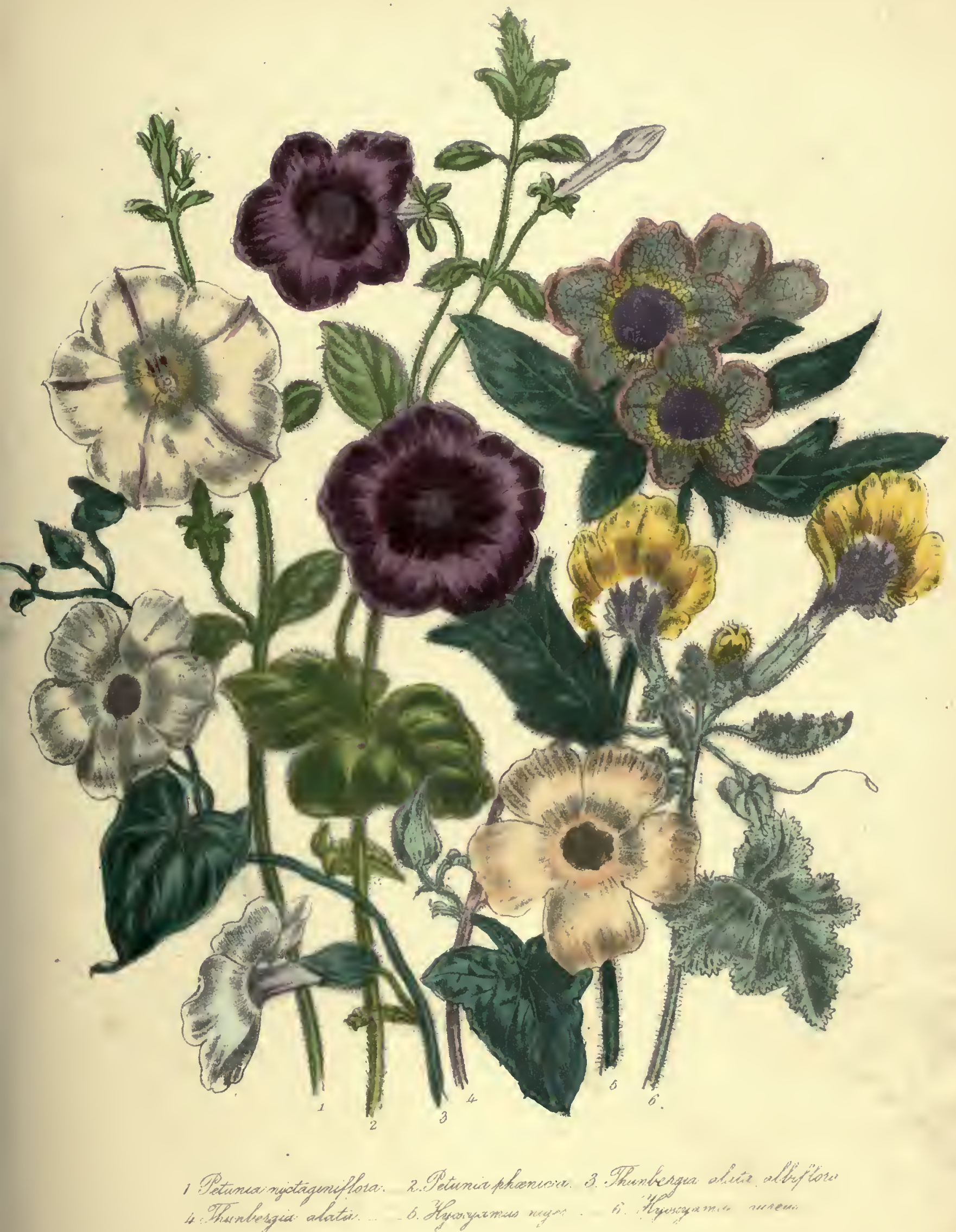



H. PALLINUS, Waldst, et Kit.

Flowers pale ycllow, without any dark veins. A native of Hungary, introduced in 1815.

H. ALBUS, Lin.

Flowers of a greenish yellow, with spots of green at the base of each petal. A native of the south of Europe, introduced in 1570 .

H. MAJOR. Mill.

Flowers pale yellow, with dark purple spots at the base of the petals; a native of the Archipelago, introduced before 1596.

H. MUTICA, Lin.

Flowers dark purple on the inside, and dark purple on the outside; the limb cleft, and the two lower segments white; stamens purple. A native of Egypt, introduced in 1822.

\section{H. PUSILlUS, Lin.}

A dwarf plant, not above six inches high, with the flowers small, and yellow, with a violet-coloured base. A native of Persia, introduced in 1691.

\section{H. AURICULATUS, Tenore.}

Flowers of a bright yellow, veinell with dark purple. A native of Naples, introduced in 1823.

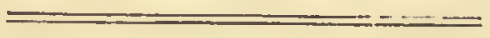

GENUS VII.

PETUNIA, Juss. THE PETUNIA.

Lin. Syst. PENTANDRIA MONOGYNIA.

Gexrric Charucren.-Segments of the calyx foliaceots, spatulate. Corolla with a sbort tube, and a dilated, rather unequal limb. Stameus unequal, enclesed. Placentas adrate.-(G. Don.)

\section{1.-PETUNIA NYCTAGINIFLORA, Juss. THE MARVEL OF PERU-FLOWERED, OR COMMON WHITE PETUNIA.}

Srnonyмes.-Nicotiana axillaris, Lam.; N. nyctaginiflor, Lehm. the potioles at the base. Fleral leaves sessile, cordate-0vate, opposite, Engravings.-Swt. Brit. Flow. Gard. 2nd Ser. t. 119 ; Bot. Mag. t. 2552 ; and eur fig. 1, in Plate 47.

Specr fic Chaructra.-Diffuse, clothed with elammy glandular villi; lower leaves alternate, ovate-oblong, obtuse, pubeseent, attenuated into Flowers axillary, peduneulate. Corolla large, having the tube $3-4$ times longer than the calyx, and the limb broad and obtuse.(G. Don.)

Description, \&c.-The white Petunia is so general a farourite, and so common everywhere, that it seems difficult to believe that thirty years ago its very existence was unknown among us. It is a native of South America, near the mouth of the Rio de la Plata, where it was discovered, and seeds of it were sent to Europe in 1823. It was first treated as a greenliouse plant; but as it was found to ripen abundance of seeds, and to propagate readily from cuttings, it was tried in the open air, and found to grow freely as a border flower. The seeds are sometimes raised on a hotbed; but this is unnecessary in the climate of London. They require a light peaty soil, or where this canuot be procured, a sandy loam; and their roots shonld never be suffered to become quite dry, as they are easily withered by exposure to heat. Too much wet is, however, very injurious, and when the Petunias are grown in pots, they should be frequently watered (say twice a day in hot dry weather), but they should never be suffered to stand in saucers. Petunia is from Petun, the name of Tobacco in Brazil. 


\section{2.-Petunia violacea, Lindl. The purple petunia.}

Synonymes.-Salpiglossis integrifolia, Hook. ; Nierembergia phonicea, D. Don; Petunia phoenicea, IIort.

Engravings.-Bot. Mag. t. 3113 , and t. 3556 ; Bot. Reg. t. 1626 ; Swt. Brit. Flow. Gard. 2nd Ser., t. 193; and our fig. 2, in

Plate 47, under the name of $P$. phonicea.
Specimic Character.-Prostrate, clothed with clammy hairs or down. Leaves ovate, on short petioles, acute. Corolla ventricese, with ovate, acute segments. Flowers solitary, axillary, pedunculate. -(G. Don.)

Description, \&c.-Perbaps no flower ever became a greater favourite in a short time than this. Only a few years ago, in the auturn of 1830, Mr. Tweedie, a botanical collector, discovered it in Buenos Ayres, growing on the banks of the river Uruguay, and sent seeds of it to the Botanic Garden at Glasgow. It flowered there for the first time in Great Britain in July 1831; and it was soon after figured in the Bot. Mag. under the name of Salpiglossis integrifolia. As it was found to propagate readily both by cuttings and seeds, it soon spread over England, and became a general favourite. Not so strong in its stems as Petunia nyctaginiflora, it was more manageable; and it was found to succeed equally well in a greenhouse and in the open air. So that its fine hairlike roots were permitted to grow in light fine soil, and that they were kept moist, without being suffered to get too wet, the plant might be trained in any form the grower pleased; and so that it was allowed plenty of light and air, it was sure to reward its cultivator with a profusion of rich dark purple blossoms. The common modes of training this Petunia are against a trellis or wire frame, which it will soon cover, or over a bed in the open ground; the latter being the mode now most generally adopted. When the Petunia is wanted for covering a bed in a geometrical flower-garden, the seeds are generally sown in autumn, or early in February ; and the young plants are kept in pots till they are ready for planting out in May. In planting the balls of eartl out of the pots, they are generally laid on one side, so that the plants are ready for pegging down without bending them. In about a fortnight, the bed over which the Petunias were pegged down, will be covered with a number of upright shoots, each rising only a few inches from the ground, and each producing a succession of blossoms. As the old flowers drop off, fresh ones will expand, and the bed will continue to present a splendid mass of rich dark purple from May or June till the plants are destroyed by frost. There are many hybrids and varieties of this species, as it is found to bybridizc freely with the white Petunia, and as new kinds are being continually raised from seed. Some of these hybrids, or varieties, are very large, of a pale lilac, and very fragrant; and others (particularly that generally called Petunia splendens) are of a rich dark crimson shade of purple. They are all of the easiest culture, and merely require scattering the seeds on any common garden soil, to grow and flower freely; though no plant better repays care bestowed on its cultivation. The Petunias with a dark centre are generally partly derived from $P$. bicolor, the flowers of which have a dark centre, and are curiously streaked and veined; but all these are much more tender than the others, and more difficult to propagate by seed. All the kinds strike readily from cuttings, without any artificial heat.

\section{OTHER ANNUALS BELONGING TO THE ORDER SOLANACEÆ.}

The Tomatoes (Lycopersicum), some of the kinds of Capsicum, several of the kinds of Winter-cherry (Pliysalis), and the Egg-plant (Solanum Melongena), are all more or less ornamental in their fruit, though they are seldom cultivated solely on that account. Very beautiful preparations may be made from the fruit of the winter-cherry, the common thorn-apple, and the kite-flower, by macerating them; that is steeping them in water, till only the fibrous part of the calyx remains, which looks like a net enclosing the fruit. 


\section{CHAPTER XLII.}

\section{ACANTHACEA.}

Essintial Cusracter. - Calyx ugually 5-Jeaved, persistent. Corolla monopetalous, the limb ringent, er 2-lipped, the lower lip over-lapping the upper in xstivation. Stamens mestly two, both betring anthers, hypogynous. Stigma 2-lobed, rarely undivided.
Capsule 2-celled, the cells two or many seeded, bureting elastically with 2 valves. Seeds roundish, hanging by the aseending processes of the placenta; testa loose; albumen none. Herbs or shrubs chicfly tropical.

\section{GENUS I.}

\section{THUNBERGIA, Lin. THE THUNBERGIA.}

\section{Lin. Syst. DIDYNAMIA ANGIOSPERMIA.}

GFafric Character.-Caly 8 deuble ; exterier in 2 leaves, interier shorter than the ether, and laciniated with 12 awl-shaped teeth. Corolla campranulate, trute iuflated, limb 5-lobed, equal. Stigma 2-lobed. Capsule globose, beaked, and divided into 2 cells.

Description, \&c.-The genus Thunbergia contains several splendid hothonse climbers; two of which, and perhaps more, will succeed perfectly if treated as annuals and grown in the open air. All the species are very handseme, and they are of different and very opposite colours; one species ( $T$. grandiflora) having purplishblue flowers; another ( $T$. coccinea), scarlet; another ( $T$. fragrans), white; and another ( $T$. aurantiaca), bright orange, while the commonest kind, $T$. alata, is of a pale buff. They are nearly all natives of the East Indies, and are all well deserving of cultivation.

\section{1.-THUNBERGIA ALATA, Bojer. THE WINGED THUNBERGIA.}

Engravings.-Bot. Mag. t. 259 I ; Bot. Cab. t. 1045 ; Paxt. Mag. of Bot., vol. ii. p. 2 ; and our fig. 4 , in Plate 47.

VAmexy.-T. a. 2 albiflera, Hook's Bet. Mag. t. 3512 ; T. a. var. alba, Paxt. Mag. of Bot., vol. iii. p. 28; and our fig. 3, in Plate 47. An sccidental variety raised from secds of $\mathrm{T}$. alata in the Clapton
Nursery in 1836, and only differing from the species in the coleur of its flowers.

Spectfic Charactfr.-Sten twining. Ieaves triangularly-cordale, sinuately toothed, 5-nerved. Petioles winger.

Description, \&c.-The extraordinary beanty of Thunbergia alata has long rendered it a general favourite ; and the gardeners generally give it the pet name of Black-eyed Susan. The only objections to its culture were that it was at first supposed to require the heat of a stove, and that it was found to be peculiarly liable to the attacks of the red spider (Acarus telarius). The first of these objections was soon obviated, as it was first found to thrive in the temperature of the greenhouse, and afterwards to succeed when treated as an annual in the open air ; but the second objection still retains its force, as we know of fow plants more liable to be infested by the red spider, or from which it is more difficult to dislodge it. The best mode of getting rid of this little enemy is to syringe the plant well and frequently over the leaves with hot water, heated to $120^{\circ}$, as a less heat will not destroy the insects. When the plants are grown in the open air, they have, however, much fewer red spiders on them than when they are grown in a stove.

Thunbergia alata is a native of the East Indies, and seeds of it were first sent to this country in 1823, from the Mnuritius, by Mr. Telfair, to the late Mr. Barclay of Bury Hill, by whom so many interesting plants were introduced into England. When the plant is treated as a greenlonse elimber, it is generally propagated by cuttings; but when it is grown as an annual, the seeds are gathered as soon as they are ripe in October, and they 
are kept in their hard, horned capsule till January. The seeds are curiously shaped, and look as if they were covered with net-work; they should be sown in a soil composed of nearly equal parts of peat-carth, or vegetable mould, and sand. The earth in which the seeds are sown should be kept constantly moist; but it should be well drained, as the plants will wither if either the roots are suffered to beoome quite dry, or if they are kept in stagnant water. The plants are generally raised on a slight hot-bed, and planted out in May; but in warm sheltered situations, they may be sown where they are intended to remain. As to their after culture, when sown in the open ground, they may either have the points of their shoots repeatedly taken off, so as to make them form bushy plants, or the long slender stems, instead of being twined round any object, may be laid over the bed, and pegged down at the joints. Where trouble is not an object, the plants may be grown in pots and slifted many times, as directed for Rhodanthe Manglesii. Seeds are common in the seed-shops. The variety appears more tender than the species.

\section{CHAPTER XLIV.}

\section{GENTIANEÆ.}

Essential Canactra,-Calyx 4-5-cleft, permanent. Corolla | Capsule (sometimes a berry) many-sceded, 1-2-eelled, usually 2mooopetalous, with an equally-parted limb; imbrieate in sestivation. valved. Embryo straight, enclosed in tbe axis of a soft fleshy albu. Stameas epipetalons, equal in number to the segments of the corolla, mea. Herbs, rarely shrubs, usually glabrous. Leavcs opposite, and alternating with them, some of them abortive. Stigmas I-2. entire, exstipulate. Flowers terminal, or axillary.

\section{GENUS I.}

\section{GENTIANA, Lin. THE GENTIAN.}

Lin. Syst. PENTANDRIA MONOGYNIA.

Generic Charactar,-Corolla eampanulately funnel-sbaped, 4-5-cleft. Stigma 2-lobed. Seeds ronadish or obloog.-(G. Don.)

Description, \&c.-All the different kinds of Gentian are remarkable for the beauty of their flowers, and many of them for the medicinal properties of their roots. The genus Gentian of Linnæus has been divided into several genera; but we shall retain the old names, as they are those under which the species are distinguished in Plate 48, marking, however, the new names as synonymes. The name of Gentiana is perhaps the oldest example extant of the eustom of naming plants after some person; as it is said to have been named in honour of Gentius, King of Illyria, whose health had been restored by the use of the root of one of the species as a tonic.

\section{1.-GENTIANA QUINQUEFLORA, Lin. THE FIVE-FLOWERED GENTIAN.}

Srronymzs.-G. amarclloides, Pursh.; Hippion quioqueflorum, elasping, oval, acute, 3-nerred. Flowers terminal and lateral, Schmidt.

Engravings.-Bot. Mag. t. 3496 ; and our fig. 4, io Plate 48. 3-5 together, on short pedieels. Corolla tubularly campaoulate, 5-eleft. Throat aaked. Segments lanceelate, aen minated with simple Specific Cuaracter.-Stem tetragonal, branched. Leaves stem- plics. Calyeino segments very short, nartow.-(G. Don.)

Description, \&c.-A very pretty plant, growing about a foot high. It was originally introduced in 1824, but it was soon lost, and it was not reintroduced till 1835. It is a native of North America, where it was found in abundance, growing on the grassy banks of streams among the Alleghany Mountains. It requires no other care than sowing in the open border, and occasional waterings if tho weather should prove dry. 


\section{2.-GENTIANA AMARELLA, Iin. THE BITTER, OR AUTUMNAL GENTIAN,}

Srnonymps.-G. lancifolia, Raf.; G. tetragonia, Mayer ; G. campestris, Geners.; G. pyramidalis, Willd.; G. axillaris, Kehb.; Hippien axillare, Schmidt.; Swertia corniculata, Barrel.; Eurgthalia amarella, Bork.

Engravings. - Eng. Bot. t. 235, 2od ed. vel. ii. t. 377; and onr fig. 6 , in Plate 48.

Description, \&c.-This plant has been plaeed by modern botanists in the genus Eurythalia. It is a native of Britain, and takes its specifie name of Amarella from its intense bitterness. It is a dwarf plant, seldom, if ever, rising ligher than six inches, and it requires no other eare than sowing in any dry exposed sitnation. A calcareous soil suits it best. There are many varieties of this speeies.

\section{3.-GENTIANA NIVALIS, Lin. THE SNOWY, OR SMALL ALPINE GENTIAN.}

Stnonyugs.-Erieala nivalis, Bork.

Engravings.-Eag. Bet. t. 896, 2nd ed. vel. ii. t. 376 ; and our fig. 5 , in Plate 48.

Spectfic Chasacter.-Stem simple or branched. Branehes slter- bifid.-(G. Don.)

Description, \&rc.-A most beantiful little plant, with vivid dark-blue fowers. A native of Scotland, and indeed found in every part of Europe, from Lapland to the Pyrenees. There are many varieties, the most striking of which is one with white flowers. This species, from the brilliant colour of its flowers, its erect, though dwarf habit of growth, and the neatness of its foliage, is very ornamental, and it is well adapted for filling a bed in a geometrie flower-garden. The seeds should be sown in a light peaty or sandy soil, well drained, and they will requiro no other culture. Modern botanists consider this plant as belonging to the genus Ericala.

\section{OTHER ANNUAL SPECIES OF GENTIANA.}

G. AUREA, Lin.

The flowers of this species beeoming yellow when dry, Linnæus gave it the name of the Gentrana aurer, literally Golden Gentian ; bnt, according to Wahlenberg, the flowers are white. It is a native of Lapland, and it is said to have been introduced in 1823 .

\section{G. GERMANICA, Willd.; EURYTHALIA GERMANICA, Mayer.}

The stem is purplish, and angular ; the root is yellow, and the flowers of a purplish blue with a white beard. It is a native of Germany, and it was introdueed in 1818. The four following kinds are also comprehended in the modern genus Eurythalia.

\section{G. OBTUSIFOLIA, Willd.}

This speeies, which is sometimes called the Mountain Gentian, is a native of Switzerland. where it covers large tracts with its bright purple flowers, that assume a yellowish hue when they fade. It is very nearly allied to G. Germanica. It was introduced in 1826.

\section{G. PRAETENSIS, Frol.}

Nearly altied to G. Germanica, but taller and more branched. A native of Russia, introdueed in 1817. 


\section{G. CAMPESTRIS, Lin.}

The common or field Gentian is a British plant, with purplish blue or white flowers; so bitter, that the country people use it when dry instead of hops to their beer. It is also occasionally used as a tonic in medicine.

\section{G. GLACIALIS, Vill.}

A bcautiful little plant, with dark blue flowers, very nearly allied to G. nivalis. A native of Lapland, introduced in 1819 .

G. CARINTHIACA, Frol.; SWERTIA CARINTHIACA, Wulf.; PLEUROGYNiA CARINTHIACA, G. Don.

The flowers are of a pale blue above, and white or lilac beneath. A native of Carinthia, introduced in 1817

\section{G. UTRICULOSA, Lin.; ERICALA UTRICULOSA, Bark.}

The flowers are saiver-shaped, of a beautiful blue, with the tube striped with blue and white. The calyx is inflated, and las five prominent wings; and the root is fusiform and yellow. A native of Europe, from the Baltic to the Mediterranean, introduced in 1822.

GENUS II.

CHLORA, Ren. THE YELLOW-WORT, OR YELLOW CENTAURY. Lin. Syst. OCTANDRIA MONOGYNIA.

Generic Character.-Calyx 4-8-parted. Corolla salvcr-shaped, 4-5-parted. Stamens 8. Filaments very short. Anthers linear. erect. Stigma 2-4-cleft. Capsule oval-oblong. Seeds minute.-(G. Don.)

\section{CHLORA PERFOLIATA, Lin, THE PERFOLIATED YELLOW CENTAURY, OR COMMON YELLOW WORT.}

Encravings.-Eng. Bot. t. 60 , 2nd Edit. vol. iii. t. 561 ; and our | tomous, cylindrical. Flowere corymbose, with a flower in each fork. fig. 2, in Plate 48.

Specrfic Character. - Glauccus. Leaves perfoliate. Stem dicho(G. Don.)

Description, \&c.-This plant, though a native of Britain, requires so much care to cultivate it, that it is very seldom grown; though it is so pretty that it well deserves to become a garden flower. It requires an open hilly situation, and a loamy soil, with a substratum of ohalk or linestone; and without these advantages it seldom succeeds in the open garden, though it may be grown tolerably well in calcareous soil and in welldrained pots. Chiora is from the Greek word Chloros, pale.

\section{INIPERFOLIATA, Lin}

This species differs from $C$. perfoliata in the leaves being not perfoliate; they are aaid to be perfoliate when the stem appears to pass through them, like the leaves and stem of the common honeysuckle, C. aprifolium imperfoliala. It is a native of Italy, and was introduced in 1823. 

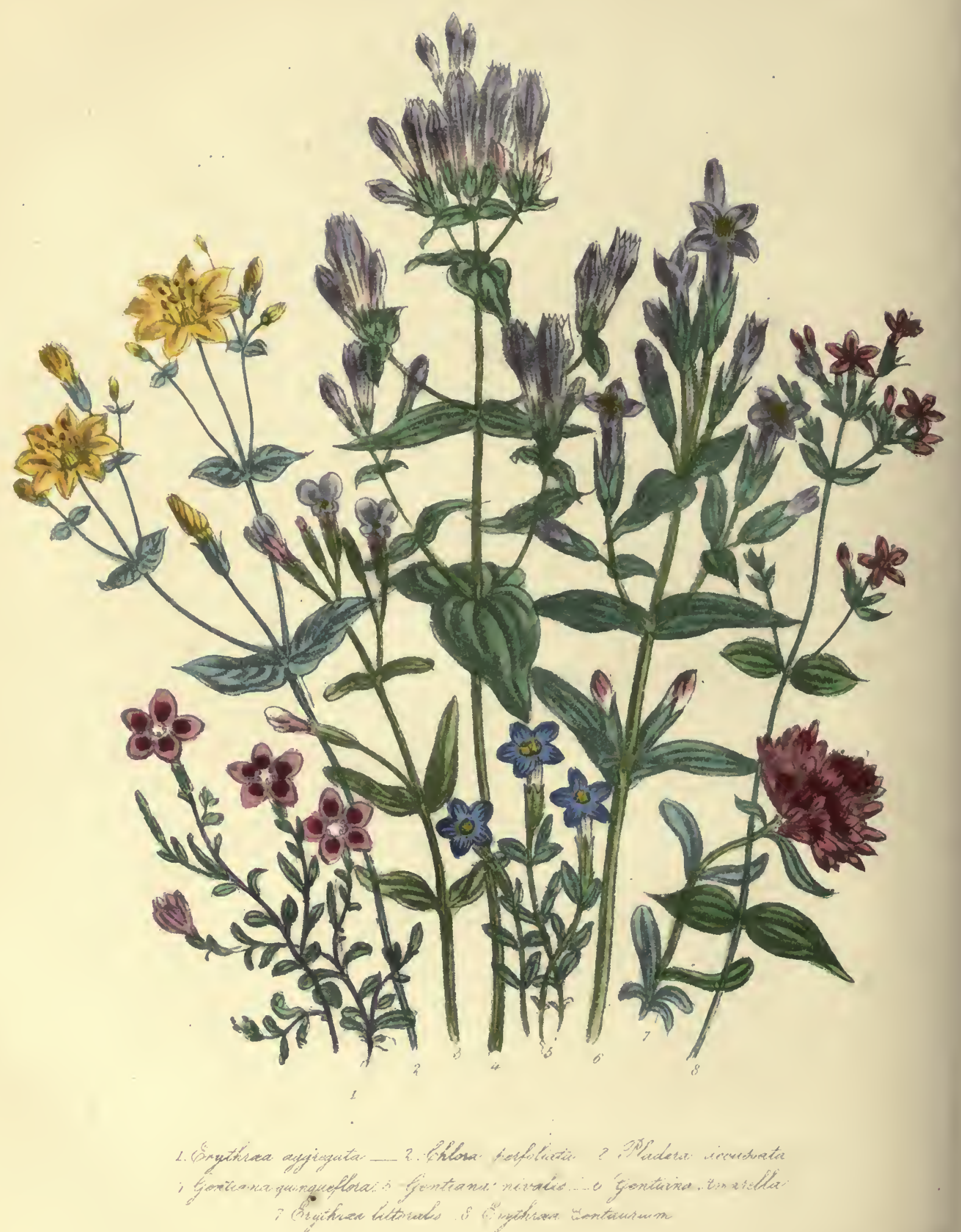


GENUS III.

PLADERA, Solander. THE PLADERA

Lin. Syst. TETRANDRIA NONOGYNIA.

Genmesc Charactrk. - Calyx tubular, 4-toethed. Corolla funnel-ahaped, limh irregular. Ono of the stamens is shorter than the rest. Stigma 2-lobed. Capsule 1-celled, 2-valved. Seeda numcrous.

\section{1.-Pladera DeCussata, Roxb. The Decussate pladera.}

ENgravings.-Bot. Mag. t. 3066 ; and our fig. 3, in Plate $48 . \quad$ latter cross-armed. Leaves ovate-lanceolate, acute, 3.nerved, sessilo Synonymes.-Canscora decussata, Wall.; Exacum alatum, Roth. terminal peduncles trichotomous. Flowers pedicellato; axillary ones Specific Character.-Erect. Stem sud branches 4-winged, the solitary.-(G. Don.)

Description, \&c.-An East India plant of very littlo beauty, introduced in 1816, and growing about a foot high. It is rather tender; and it requires to be raised on a hotbed, and not planted out till June. "Pladera signifies a moist place.

\section{P. VIRGATA, Roxb.}

This plant has many synonymes. It is a native of the East Indies, whenee it was introduced in 1820 , and it has small rose-coloured flowers.

\section{P. PERFOLIATA, Roxb.}

This species has large, pale rose-coloured flowers, and grows about two feet ligh. It is a native of Malabar, where it is called Kansjan cora, and where the native women use it to ornament their hair. It has not yet been introduced.

\section{GENUS IV.}

ERYTHRAA, Renealm. THE LESSER CENTAURY.

Lin. Syst. PENTANDRIA MONOGYNIA.

Generic Cunnscrfr.-Calyx 5-cleft. Corolla fuancl-sbaped, with a short 4-5-parted limb. Anthers apiral in the old state. Style erect. Stigmas 2, rouadish.-(G. Don.)

\section{1.-ERYTHRæA CENTAURIUM, Pers. THE COMMON LESSER CENTAURY.}

Synonymes._Chironia Centaurium, With. ; Gentiana Centaurium, $L$ in.

Engravings.—Eng. Bot. t. 417, 2nd edit. rol. ii. t. 320; Wood. Med. Bot. t. 157 ; and our fig. 8, in Plate 48.

Description, \&c.-A British plant, with pink flowers, of which there are many varieties. The species grows about a foot high, in dry gravel or chalk; but it perishes if transferred to a soil richly manured. It is a powerful bitter; and when steeped in gin, or any other strong spirit, it is taken as a tonic by the labouring classes. As a garden flower, it is only suitable for rock-work, or hard gravelly banks, where scarcely anything else will grow. Erythræa is from Erythros, red flowers.
Specific Charscter.-Stem tetragoeal, dichetomously paniclod, corymbose. Leapes ovate-laoceolate, 3-perved. Calyx shorter than the tube of the cerolla. $-(G, D o n$. 
2.-NRY'THRAA LITTORALIS, Fries. THE SEA-SHORE, OR DWARF-TUFTED CENTAURY.

Synonymes,-Chironia littoralis, Turn. et Dill.; C. pulchella, Speciric Cuaracter. - Stem simplo or branched, dwarf, tetragonal. Don. Leaves ovate-oblong, obtuse. Flowers crowded, sessile, fasciculate.

Eneravings.-Eng. Bot. t. 2305, 2nd edit. t. 321 ; and our fig. $i$, in Plate 48. Calyx about equal in length to the tube of the corolla.-(G. Don.)

Descriptron, \&c.-A very beautiful little British plant, with tufts of pink flowers, growing on the sea-coast. It is well deserving of cultivation, and is admirably adapted for rock-work.

\section{3.-ERYTHR ȦA AGGREGATA, Sweet. THE CLUSTER-FLOWERED ERYTHR FA.}

Engravinge.-Brit. Flow. Gard. t. 137; and our fig. 1, in Plate 48.

Specizic Craracter.-Stems tetragonal, much hranched, decumhent; hranches dichotomous, aggregate, few.flowered. Flowers sessile.
Leaves spathulate, ohtuse, l-nerved, tapering into the petioles at the hase. Bracteas linear, obtuse, rather longer than the calys. Calyx twice shorter than the tube of the corolla.-(G. Don.)

Description, \&c.-A beautiful little plant, growing in tufts about three inches high, with dark rose-coloured flowers. A native of the south of Europe; introduced in 1824. It is admirably adapted for rock-work, or it may be grown in small pots, in sandy loam and peat. It does best sown in autumn, and kept in pots during the winter, under a hand-glass, or in a cold frame. Thus treated, it will come into flower in March, and will continue producing a succession of blossoms till November.

\section{OTHER SPECIES OF ERYTHRÆA.}

\section{E. CACHONLABUM, Rem. et Schultes; GENTIANA PERUVIANA, Lour.}

This species yields the celebrated tonic medicine of South America, called there Cahan laguen, and mentioned by Humboldt. It is a nativo of Chili and Peru, and was introduced in 1825 .

\section{E. SPICATA, Pers.; GENTIANA SPICATA, Lin.}

This is the only species of Erythrea that has its flowers disposed in spikes; their colour is pink or white, and they are very ornamental. The species is a native of Italy, and it was introduced in 1820.

\section{E. LATIFOLIA, Smith.}

This is a British species, which only differs from $E$. littoralis in the leaves being broader.

\section{E. PULCHELLA, Fries.}

A British species, the flowers of which close at 11 o'clock in the evening, and which has been for this reason included in the floral clock, described by many writers.

\section{E. MARITLMA, Pers.}

A native of Tangiers on the sea-side, with bright yellow flowers. It was introduced in 1777 , and as it never grows above four or five inches high, it is a valnable flower for rock-work.

E. LUTEA, Rom. et Schultes.

Closely resembling the preceding species, but a native of Italy on mountains. 


\section{N D E X.}

$S c h$ is pronounced like $s k$; $c h$, like $k$; and $g$, before $e$ and $i$, as in gentleman.

Ácantuacera, 257

Acarus tellárius, 59, 257

Adònis, fig. 3 , in Plate 1,1

African Mlarigeld, 186

Ageratum, Plate 31, 178

A grostémma, Plate 20, 112

Alkanct, 224

Alkekengi, Plate 46, 251

Alonsòa, Plate 44, 239

Alpine Gentian, 250

Alysanm eslycinum, 73

Anagállis, Plate 25, 141

Anchùsa, Plate $37 *, 224$

A'n the mis arábica, 194

Antirrlìnum, Plate 43, 234

Amadou, 207

Amaranthacer, 171

Amaranth of the Poets, 174

A marántus, 172

Anberböa, 209

Amhròsia, 212

Amcthystea, Plate 39, 227

Ammobium, Plate 33, 198

Amphcréphis, 212

A'robis vérna, Plate 13, 73

Arctò' is (sphenogyne) snthemòides,

$$
\text { Plate 31, } 190
$$

Arctōtis ealendulàcea, 206

Arctòtis triatis, 206

Argenidné, figs. 4 sod 5, io Plate 5, 27

Aster, 178

Astrágal 118,127

Athanàsia (Lònas), Plate 31, 197

Atròpa, 250

Baèria, Plate 31, 193

Balsam, 135

- culture of, 136

Bartònis, 64

Bastard Saffrnn, 209

Bcll-flower, Plate 30, 168

Bcllinia, 250

Bldens, Plate 32 , as Cosmea lutea, 184

Bindwced, 147

Bird's-foot Trefoil, 124

13iscutélla, 78

Bishop's-wort, 10

Bitter Gentian, 259

J3lark-secded Dólichos, 135

Bladder Fumitory, 42

Bladder Kotmin, Plste 16, 95

Bìind Poppy, 22

Blitum, 175

Blue-bottle, Plate 33, 208

Blumeabachia, 63
Blush Centaury, Plate 33, 208

Boerkhaùsia, Plate 32,211

Boaz Nox, 150

Branching Larkspur, 6g. 5, in Plate 3,5

Brássica arvéngis, 76

Browállia, PInte 44, 24]

Buckler Mustari, 78

Bùnias Cakile, 78

Bur-marigold, 184

Burrèilia, 188

Cacalia, Plate 31, 202

Caióphora, 60

Cakilc, 78

Calındrínia, Plate 18, 101

Calóndula, 205

Caléndula pluvialis, Plate 31, 196

Californitun annuals, culture of, 156

Californian Poppy, 31

Callichròn, Plate 31, 193

Calliópsis, Plate 31, 181

Callistèma, 178

Callístephus, 178

Cál tha officieàlis, 205

Calves Snout, 234

Calystèria, 147, 153

Campáula, Plate 30, 168

Canary-bird flower, Plate 21, 116

Candy-tuft, Plate 12, 69

Canscóra, 261

Cantua, 160, 163

Cape Marigold, Plate 31, 196

Capparídes, 80

Cardámine Lunària, 79

Carnation Poppy, fig. 5, in Plate 4, 23

Cárthemus, 209

Cárthamivs lanàtus, 210

Castilleja, Plate 44, 24

Catchfly, Plate 19, 105

Celdsia, 173

Célsia (Alonsda) lineària, Plate 44, 239

— - urticifólia, 239

Centaurèa, Plate 33, 208

Centaury, Plate 33, 208

Centráothus,

Centrathèrum, 212

Centrospérruum, 195

Cerintlie, Plate 38, 222

Chardínia, 213

Charieis, 180

Chasmònis incísa, 227

Cheiranthus, 66

Chelidonium, 29, 30

Chenopodiàcex, 175
Chickling Vetch, 132

Chilino Nettle curious effect of, 132

China Aster, Plate 36,178

cultivation of, 179

Chinese Pink, Plate 20, 111

Chirònia, 261

Chlora, Plate 48, 260

Chrysánthemum, Plate 32, 194

Cbryseis, 31

Cigars, mote of making, 243

Cinerària tenélla, 179

Cincrària tussilágım, Plate 32, 203

Clodanthus, Plate 31, 194

Clárkia, Plate 9, 56

Clary, 225

Claytòia, 104

Cleòme, figs. 5 and 6 , in Plate 15, 80

Clintònia, Plate 29, 167

Cockacomb, 173

Collínsia, Plate 41, 229

Collòmia, 158

Compositx, description of, 177

Cenvólvulus, Plate 26, 145

Convolvulus Nil, 149

Cequelicot, meaning of, 23

Corcópis, Plate 31, 181

Corn Blvebottle, Plate 39, 208

Corn Cockle, 113

Coro Poppy, 23

Ceronília, 128

Corydalls, 41

Cósmea, Plate 32, 184

C6́tula, 197

Crèpis (Tólpis) barbsta, Plate 31, 210

Crepia (Borkhaùsis) rubm, Platc 32, 211

Créssa, 153

Crimson-winged Pca, Plate 24, 126

Crotelària, 108

Cruciferæ, 65

Cryptostémma, 206

Cucùbalus, 107

Cùphea, Plate 17, 97

Cuscuta, 154

Cysticápros, 42

Datùra, Plate 46, 251

Delphíaium, Plate 2,5

Deptfurd Pink, 112

Devil in a busli, Plate 2, 10

Díathua chinénais, l'late 20, 111

Didíseus, fig. 3 , in Plate 7,42

Dielỳtra, 42

Dimerphótbecs, 196

Dinetus, 153 
Diplopáppus, 178

Dipsàceæ, 213

Discoé́pnos, 42

Distaff-thistle, 210

Dólichos Ĺblab, fig. 12, in Plste 23, 135

Dodder, 154

Double Jarkspur, 7

Dracocéphıalum, Plate 39, 226

Dracopis, Plate 32,180

Dragon's Head, Plate 39, 226

Earth Pea, 132

E'chinops, 207

E'chium, Plate 38, 223

Egg Plant, 256

Egochloa, 160

Egyptian Bean, 135

Elecampane, 189

Elichrýsum, Plate 34, 201

Ellisia, 215

Emília (Caealia), 202

Ericàla, 258

Frythræ' a, Plate 48, 261

Erýsinumu, 79

Eschsch6́ttzia, figs. 1 and 2, in Plate 6, 31

Eucharídium, Plate 9, 58

Eurythalia, 258

Eutíca, Plate 37," 218

Eváx, 212

Evcning Primrose, Plate 8, 46

Evcrlasting fiowcr, Plate 34, 201

Evólvulus, 153

Fedia, Plate 38, 214

Fellcia ten $\in$ Ila, 179

Fennel-fower, Plate 2, 9

Feverfew, East Indian, 195

Ficdider, 99

Fig Marigold, Plate 18, 99

Filago, 212

Flax, Plate 15, 83

Flos Adjois, fig. 3, in Plate 1, 1

Flower Gentle, 172

Francòn, 44

French Marigold, Plate 32, 186

Fumdria, 42

Fumitory tribe, 38

Gaillárdia, Plate 32, 187

Galinsògea, 189

Garden Fenne] flower, 9

Garden Nightshade, 249

Garden Persicària, 176

Garidélla, fig. 2, in Plate 1, 15

Gariep, meaning of the word, 25

Gaúra, 58

Gentian, 258

Gentidna, Plate 48, 258

German Aster, Plate 36, 178

German Larkspuri, 7

German Paste, 21

German Stocks, 66

Gília, Plate 28, 160

Gith, 10

Githàgo, 113

Glatucium, figs. 2 and 3, in Plate 3, 28

Globe Amaranth, 174

Globe Thistle, 207

Glỳeé marítima, 73

Godètia, Plate 8, 52

Golden Thiatle, 213

Golden Thistle of Petn, 27

Gomphrèna, 174
Good night at noon, 96

Grass Vetch, 133

Groundsel, 202

Gypsóphila, 110

Hatchet Vetch, 128

Hawkweed, 210

Heads of Poppies, 22

Heartsease, 85

— culture of, 87

of, 86

eliánthemum, 182

Helènium, 189

Helichrysum, Plate 34, 201

Heliophild, figs. 6 and 7 , in Plate 13, 76

Henbane, Plste 47, 254

Herb Trisity, 87

Hésperis, 66

Hibíscus Africànus, Plate 16,96

Holtzia, 160

Hológymné, 188

Honeywort, Plate 38, 222

Hórminum, 225

Horned Poppy, figs. 2 and 3, in Plate 5, 28

Hornemdnnis blcolor, 238

Hotbeds, to make, 34

Hugèlia, 42

Hundeminia, 33

Hydrophyllàceæ, 215

Hyoscyàmus, Plato 47, 254

Hypecoum, fig. 4, in Plate 7, 39

Iberis, Plate 12, 69

Impatiens, fig. 3 , in Plate 24, 137

Ipome'a, Plate 26, 148

Ipomoe' a rìbro-coerùlea, Plate 26, 151

Isatis pionàta, 78

Isótoma, Plate 29, 166

Jacolo'a, Plate 32, 202

Jalap, plant produciog it, 140

Jointed Pea, 132

Jumping Betty, 188

Kaulfússia, Plate 31,180

Kentrophýllum, 210

Koáutia, 213

Konlga, 73

Kiss behind the garden gate, 87

Kite-flower, Plate 46, 251

Labiàtæe, 223

Láblab, fig. 12, in Plałe 23, 135

Lablàvia vnlgaria, 135

Lagáscea, 212

Lamb's Lettuce, 214

Larkspur, Plate 2, 5

Lasthènia, Plate 31,188

Lathyrus, Plate 23, 13i)

Laudanum, 20

Lavatèra, Plate 16, 94

Legend of Rhorlathe, 198

Lequminos: 117

Lepidium frìgrans, 73

Leptosiphon, Plate 27, 156

Lesser Centauly, 2f 1

Ligulate Flowers, 177

Limnanthes, 114

Lindria, Plate 43, 234

Lisum, Plate 15, 83
Loàsa, Plate 10, 60

- culture of, 62

Lobelia, Plate 29, 168

Lobel's Catchfly, fig. 4, in Plate 19, 107

Lòns (Athaaàsia), Plate 31, 197

Lopèzia, 59

Lnrd Anson'a Pca, 134

Lophospermum, Plate $39 *, 240$

Iotus, Plate 23, 124

Love sad Idleness, 87

Love in a Mist, Plate 12,9

Love in Idleness, 87

Love lies Hleeding, 172

Lunària Ricòtia 79

Lupine, Plate 22, 119

Lupinus, Plate 22, 119

If́chnis, cœ'li ròsa, 112

If́chnis læ'ta, 113

Lfchnis prostratta, 105

Lycupérsicum (Wolfs peash), 256

Lythràceß, 97

Madària, Plate 32, 192

Màdia, 191

Malcomia, fig. 5 , in Plate 61,68

Maleshérbia, figs. 3 and 4 in Plite 15,82

Mallow, Plate 16, 91

Málope, Plate 16, 93

Má]va, Plate 16,91

Malvaccœ, 91

Marigold, Common, 205

Martýuia, 228

Marvel of Peru, fig. 2, in Plate 24, 139

Mask-flower, 239

Mathiòla, Plate 11, 66

Matricària, 195

Maurándya, Plate 39*, 240

Mazus, Plato 39, 238

Menonvillea, 78

Mesembryanthemum, Plate 18, 99

Mète], 252

Michael mas Daisy, 179

Micropus, 212

Mignoactto and Clarkia, 57

$\longrightarrow, 89$

Milk Yetch, 127

Mímulug, Plate 44, 238

Mirábilis, fig. 2, in Plate 24, 139

Moldavian Balm, 226

Molucca Balm, 227

Molucélla, 227

Monkey-flower, Plate 44, 238

Monópsis, 168

Moricándia, 76

Morpline, 20

Morna, Plate 34, 199

Morning Glory, 150

Moxi, 207

Musk Mallow, 91

Naming Anruals, 3

Nastúrtinm, Plate 2], 1]4

Nemèsia, Plate 43, 237

Nemóphila, Plato 37,216

N. insignis, culture of, 217

Nicáodra, Plate 46, 25

Nicotiàna, Plate 45, 243

Nigélla. Plate 2, 9

Nightshade, 248

Nolì-me-tangeré, Plate 24, 13 \%

Nonen, Plate 37*, 22

Nyctaginàce, 139

Nycterium, 249 
Onagràcex, 4.5

Enóthera, Plate 8, 46

Oil made from the Sunflower 183

- fion Madia sativa, 192

- frum Poppies, 21

Opium, 19

Oxybáphıs, 141

Oxyùra, 1'iate 31,191

Painted-cup, Plate 44, 24]

Paldvia, Plate 16, 96

Pansy, 87

Papnvardcee, 17

Papaver, Plato 4, 17

Papilicaaceous flower, Descriptien of the parts of, 119

Partlénium, 212

Pedalincx, 228

Pcricállis, 203

Persichria, 176

Peruvian Wioter Cherry, 251

Petùnia, Plate 47, 255

- , culture of, 256

Phacèlia, Plate 38, 221

Pharbltis, 146 aod 153

Pheasant's-e ye, Plate 1, 1

Phlox Drummóndi, fig. 1, in Plate 27, 155

Phesphorus, frem the Nasturtium, 116

Physalis Peruviàna, 251

Physalis Selandece, 250

Physóstegia, Plate 39,226

Picrídium, 2]1

Pimpernel, Plate 25, 141

Piak, chinense, Plate 20, 111

$\longrightarrow$, Deptford, 112

Valerian, 11

Pládera, Plate 48, 260

Platystemen, fig. 1 , io Plste 1,15

Platystízma, fig. 3 , in Plate 6,30

Plectecéphalus, 208

Plectrìtis, 214

PodŚlcpis, fig. 2, in Plate 34,200

Polemenialecte, 155

Polýgonum, 176

Poppy, Plate 4, 17

- culture of, 22

Pordoa, 153

Portulacex, 10

Prickly Peppy, figs. 4 and 5, in Plate 5, 27

Primulàcex, 141

Prince's Feather, 172

Prismatocárpus, 168

Purple Herned Poppy, fig. 1, io Plate 5, 30

Purple Petuaia, Plate 47, 256

Purple Ragwert, 202

Purple-stemmed Vslerian, 214

Pyrèthrum fodicum, 195

Quámeclit, Plate 24, 148

Ragwort, 202

Ranunculacca, 1

Rapistrum marítum, 78

Red or Purplo IJawkwced, 211

Red Spider, 59 sad 257

Reìco Margucrite, 178

Réseda oderàta, 89

Rhedhathe, Plate 34, 198

Ricotia, 79

Rockot Larkspnr, figs. 2, 3, aod 4, in Plate 3,7
Reèlla, 171

Romèria, fig. I, 1 Plate 5, 30

Rose Campion, 112

Rose of Heaven, Plate 20, 112

Rudbéckia, 180

Rudbéckia alàta, 189

Safflevier, 209

Sige, Plate 39, 223

Sairánthus, 247

Salpiglóssis, Plate 42, 233

Salvia, Plate 39,225

Sanvitalia, 185

Sapondria, fig. 19, 109

Saráchs, Plate 46, 250

Scabiosa oricutalis, 213

Scarlet Jasmine, 149

Schizánthus, Plate 42, 231

Scbizopétalon, 77

- culture of, 77

Sc6́lymus maculàtus, 213

Scerpien Senaa, 128

Scorzonèra tingitìna, 211

Scrophularineæ, 229

Scypháthus, 65

Sea Recket, 78

Secuirdàca, 128

Securígera, 128

Seeds of the Poppy, uses of, 21

Senècio, 202

Sesàmé, 228

Shiraz Tebacco, maoufacture of, 246

Silenàcer, 105

Silèoé, Plate 19, 105

Simsia, 212

Sisfubrium, 73

Sleep ef plants, 129

Snapdragon, plate 43, 234

Soewy Gcutian, 259

Souff, mede of makiog, 244

Seapwort, fig. 19, 109

Sogalgloa, 189

Soil for tender sonuals, 36

Seil, mede of introducing any particular klnd of soil for growing delicste plants, 8

Selaadcex, 243

Solànum, 248

Sold̀num Melongèna, 256

Seldnum procumbens, 250

Seuci, 205

Sewing annuals, 3

Syanish Nigella, figs. 3 and 4 , in Plate 2, 11

Spanish tioder, 20

Specularis, 168

Sphenógyae, 190 disk, 191

Spurred Valerian, 215

Starry Msrigeld, 212

Starwert, 178

Stègia, 94

St. Katherine's Wheel, 10

Steck Gilliflewer, 66

Stramenium, 251

Stramberry Blite, 175

Streptáatlus, figs. 3 snd 4, in Plate 13, 75

Sunflawer, 182

Sunflexer of the Aecients, 183

Sweet Alýssum, 73

Sweet Pca, Plate 23, 130

Sweet Pea, Plate 23,130

Sweet Saffren, Plate 33, 209

Swértia, 260

Syrian Ifoesty, 79

Syrup of Peppies, 23
Tsbacus viridie, 247

Tagètes, Plate 32, 186

'Tallnun, 101

Tame Larkspur, 6

Taogicr Pea, 131

Tátula, Plate 46, 252

'Tender anunsls, culture of, 33

T'ender annusls, mode of ebtaining casily, ith

Ten-week Stock, Plstc II, 66

Tetragonblobus, 126

Thale Cress, 73

Thinning out, 3

Thlâpsi, 68

Thorn Apple, Plato 46, 25]

Thunbérgis, Plate 47, 257

culture of, 25

Tead-flax, Plato 43,234

Tobacce, 243

Tomstes, 255

Torèuia, Plate 44, 238

Tracbymèné, fig. 3 , io Plate 7,12

Transplating, 12

Treacle Mustard, 79

Tribe Asteroidcæ, 178

Tribe Chicherdces, 210

Tribe Cynarèx, 205

Tribe Eupatcrialcce, 178

Tribe Senecionídex, 180

Triptíllon, 213

Trope'olum, Platc 21, 114

Tufted Ceataury, 261

T'́rrritis, 73

Twe Faces uoder a Jlood, 8 ;

Tying up plants to stakes, \&c., 6

Valeriana calitràpa, 215

- coroucopia, 214

Valerioélla, 216

Valezis, 113

Vcgetable Rouge, 209

Venice Mallow, 96

Veaus's Locking-glass, 168

Vesicaria, figs. 1 aud 2, in Plate 13, 7 i

Veteb, 129

Vetchling, 133 and 134

Vicia, 129

Viola triccler, Plate 14, 85

Virginiso Stock, fig. 5, in Plste 1 , 68

Virriaian Tebacce, 244

Viper's Bugloss, Plate 38, 223

Viper's grass, 211

Wahlenbérgia, 168

Wall cress, 73

Watering, reasons for, 13

Water-pepper, 176

White Petuoin, Platc 47, 255

IVild Chamonile, 212

Wild Sweet William, 107

Wiater Cherry, 251 sad 256

Woolly Carthamus, 210

Xerácthcmum, 207

Ximéosia, 212

Yellow Centaury, 259

Yellow lTawk weed, $21 \mathrm{C}$

Yellew Larkes hecles, 115

Yellew Nigella, fig. 6, in Plate 2, 13

Yellew Vetchling, 133

Yellow wort, 259

Zíunia, Plate 35, 203 



\section{GLOSSAR Y.}

Agortive. Imperfectly developed, not fertile. Arvensis. Field.

Achenium. A dry fruit which does not open Aspera. Rough.

when ripe, and contains only one seed.

Aconite. From Aconitum, the botanic same of the Monkshood.

Acumen. A long taper point.

Acuminated. Ending in a long sharp point.

Adnate. Adhering to. Adnato anthers are when they are attached to the filaments throughout their whole leagth.

Adpressed. Closely pressed together.

Aduncum. Hooked.

Astivation. In the bud.

Equalis. Composite flowers, in which all the florets are biscxual.

Aggregate. Clustered.
Ajacis. From the name of the Grecian bero Ajax. See p. 8.

Alse. The wings of a pea-flower.

Alata. Winged.

Alba. White.

Albicaulis. White-stemmed.

Albumen. The white part of the seed.

Alyssum. Madwort; becauso it was supposed to cure Hydrophobia.

Ambiguum. Doubtful.

Anagallis. From Anagelao, to laugh; because the plant was anid to cure despondency.

Androsace. From aner, a man, and sakos, a buckler, in allusion to the form of the calyx. Angiospermia. Bearing the sceds in a capsule. Anther. The pollea-bearing part of the stamca. Anthephorum. As elongated receptacle, on which the petals, stamens, and oviry, are seated.

Annual. Lasting only ode year.

Anoular. King-shaped.

Apaleato. Wishout palexo.

Apex. Top, highest part.

Appendages. Those parts of a flower which do not come under any of the regular divisions.

Appendiculate. IIaving appendages.

Approximating. Approaching near to.

Arabis. Because some of tho species were found is Arabia.

Arenate. Curved, or bent like a bow.

Arenarium. Sand.

Areola. A little space betwees two raised places.

Argemonc. From Argema, a cataract of the eye.

Aril. $\Lambda$ thick tough covering to the seed.

Aristata, Bristled.

Aristately. Bristly.

Articulated. Distinctly jointed so as to separato rcadily in the hand.
Assurgent. Rising upwards.

Attenuated. Narrowing gradually.

Aurantiacum. Orange.

Anreum. Golden yellow.

Auricled. Eared.

Autumoalis. Autumn.

Awned. Terminating in a long bristle, like the ears of barley.

Axillary. Springing from the axils or fork of the lenves or branches.

Baccate. Berry-like; that is, the sects buried in a flesliy substance like those of the gooseberry and currant.

Bartonia. In honour of Dr. Barton, Professor of Butany at Philadelphia.

Beaked. Eoding in a hard, beak-like point.

Bibracteated. With two rows of bracteas.

Bicalcarate. Two-spurred.

Bicoruate. Two-horned.

Bifid. Divided into two parts, or two-cleft. Bifrons. Two-faced.

Bigibbous. Having two protuberances.

Bilabiatc. Two-lipped.

Bilamellate. Having two plates, or being divided into tro parts.

Bilobed. Two-lobed.

Biovulate. Containing two ova, or incipient seeds.

Bipinnste. Trice piñate.

Biscutate. Resembling two bucklers.

Biscutella. From bis, double, and scutella a sacer, in allusion to the shape of the seedpod.

Bisexual flowers. Those that lave both stamen and pistils.

Blumenbachia. In lionour of Dr. Blumeabach, Professor of Medicine at Gottingen.

Bractcas. The small leaves or membranes just below the flower.

Bracteoles. Small bracteas.

Cakilc. The Arabie word used for the plant so called.

Calcarate. Spurred.

Callous. Hardened.

Calycine. Belonging to the calyx, or part of it. Calyculated. Having the bractens so placed as to resemble an additional calyx.

Calyptrate. Shaped like an extinguisher.

Campanulate. Bell-shaped.

$$
\text { si } 32
$$

Cacescent, Covered with very short white dона.

Capitate. Spreading so as to form a head.

Capsule. A dry seed-vessel.

Carpels. Sced-vesscly.

Cardiopetalum. Heart-shaped petals.

Carina. The keel of a pea.flower.

Cartilaginous. Gristly.

Caulescent. With a kind of stem.

Cauline leaves. Those groxing on the stem.

Chalaza. Tho projecting point in a seed opposite the hilum, with which it is connected by a sliglit cord-like projection, called a mpha. These parts are very conspicuous in somo seeds, as in those of the orango; but scarcely vieible in others.

Channelled. Marked witli decp furrows.

Ciliated, Fringed with hairs like eyclashes.

Citrina Lcmon-coloured.

Clarkia. In honour of Captain Clarke, it: discoverer.

Clazate. Club-shaped; beeoming thicker towards the apex.

Claviculate. Somewhat club-shaped.

Claw. A long narrow part of the petal Inserted in the calyx, like the petals of the pink and the carnation.

Cleome. From Kleio, to shut.

Coarctata. Campressed, and crowded together.

Coclileate. Twisted, so as to resemble the shell of a snail.

Cohere. Grow together.

Cohering. Adhering together.

Commissure. The smooth inside of an articulated joint.

Comose. Hairy, covered with coma, that is,

tufts of fine sljort hairs.

Compacta. Compact.

Compost. Soil composed of several ingredients,

Concrete. Formed into one mass; joined together.

Connate. Joined together at the base.

Connective. A part of the stamen, distinct from the filament, whicl attaches the cells of the anthers to each other.

Consiving. Converging, or inclining together.

Connivent. Iying very close together.

Consolida. Healing.

Convolute. Rolled outwards, or two parts rolled torether over each other.

Coriaccous, Leathery.

Corniculato. Horned.

Corolla. The whole of the petals of the flower.

Coralline. Bclonging to the corolla

Coronopifolia. Buckhorn-leaved.

Corrugated. Wrinkled. 
Certicate. Like bark.

Corymb. A bead of flowers, the top of which is Dearly flat, the footstalks of the outer flowere being longer that those in the eentre. Cetyledons. Tho solid parts of the seed, which afterwards divide, and become the seedleaves.

Crassipes. Fleshy.

Crenated. Notched.

Crenatures. Notehes.

Crenulated. The edge cut into small round notehes.

Cruciate. In the form of a Maltese cross.

Crustaceous. IIaving a hard brittle covering.

Cucullate. Hooded.

Cumulated. Thrown together in heaps.

Cuneated. Wedge-sbaped.

Cuphea, From Kuphos, eurved, alluding to the forol of the eapsule.

Cuspidate. Suddenly tapering to a point.

Cyanæa. Blue, like the colour of the Cyanus or Cors hluebottle.

Cymes. When the flowers form a flattened panicle; and are produced on short branches grewing from one foot-stalk. The flowers of the Elder and Laurustiaus are produeed in cymes.

Cymose. Flowering in cymes.

Damascena. Damascus.

Decandria, Having ten stamens.

Deciduous. Losing its leaves in wintel.

Deelining. Bending downwards.

Dccompound. Twice or thrice compound.

Decumbent. Lying on the ground.

Decurrent. Running down, is for example when a leaf extends along the petiole.

Decussate. With the brauches forming right angles.

Deflexed. Bent downwards.

Debiscent. Opening naturally, as the pods of peas, \&c., do when over ripe.

Dentata. Toothed.

Denticulated. Teothed

Diadelplia. Where the etamons are eonneeted into two distinct bundles.

Diaphanous. Transpareat.

Dichotomous. In tro rows, or in pairs.

Didiseus, With two disks.

Didymeus. Twin, two united.

Diffuse. Spreading looscly.

Digynia. With two stylcs

Discoid. Flat and round, like a disk.

Disk. A round flat surface, sometimes applied to a head of flowers, and sometimes to the reeeptncle. In eomposite flowers the disk is the ceutre; as for example, it is tae yellow part of a dais

Dissepiments. The partitions by which a seed vessel is divided internally.

Divaricate. Straggliog; spreading widely in different direetions.

Diverging. When two parts grow close together at their base, and divide, turning differen ways, so as to be widely apart at their summit.

Dodecandrin. Having twelve stamens.

Drupaceous. Where the seed is enclosed in a stone in the centre of a pulpy eovering, as the plum or eherry.

Dubium. Doubtful

Echinated. Covered with prickles, like a hedgehag.

Eluta Tall.
| Frnarginate. Having a small netch at the extremity of the leas.

Emliryo. Germ of the young plant.

Enelosed. Not projecting beyond the flower.

Eosiform. Shaped liko a sword with a straight blade.

Epigynous. Growing upen the style, or ovary. Erysimum. From Eryo, to draw, because it will raise blisters.

Eucharidium. From Eueharis; agreeahle.

Evolute. Not folded.

Exserted. Projecting considerably.

Exstipulate. Without stipules.

Faleate. Curved like a sickle.

Farinaceous. Floury.

Fascicles. Bundles.

Fastigiate. The branches growing upright, and clese together, like thuse of a Lombardy poplar.

Feather-Derved. When the veins of the leaves are disposed regularly, like the feathery part of a pen.

Fenale flowers. Those that have only pistils and no stamens.

Fibrils. Small roots.

Filament. The stalk part of the stamen, which supports the anther.

Filiform. Thread-like.

Fistular. Full of hollow pipes, or small tubes.

Flammea, Flame-celoured.

Flavum. Yellow.

Floral leaves. Those on the flower-stalk.

Fleribundum. Many-flowered.

Foliaceoua. Leafy.

Francoa. In honour of Don F. France, of Valebcia, a patren of botaoy in the sixteenth eentury.

Friable. Crumbling.

Fructiferous. Fruit-bearing.

Frustrabea. With the forets of the disk bisexual, and those of the ray neuter.

Funicle. A little stalk by which the seed is attached to the placenta.

Fugiform. A descending root, like that of a carrot.

Gallieum. Frenclı.

Gavra. From Gauros ; superb.

Gjgartoid. Seeds baving a half transparent membrane round them, like the seed of the grape.

Glabrous. Smooth, destitute of wool, bair, or down.

Glaucescent. Heary and bluish, or sca-green.

Glancium. Frem Glaucous ; a pale bluish, or sen-green.

Glancous. A bluish-green.

Godetia. Origin not known.

Grandiflora. Large-flowered.

Gymnobases. A fleshy receptacle, bearing separate fruits.

Cymnospermia. Having the seeds at the bottom of the calyz, aud not in a eapsule.

\section{IIastate. Halbert-shaped.}

Hermaphrodite flowers. Those that have hoth stamens and pistils.

Heterogamous. Of varjous kinds.

Heteropbyllum. With leaves of various shapes.

IIexandria. With six stamens.

IIibiscus. From lbis, a sterk.
Hilum or Hylum. The scar or mark on the seed which shows where it adhered to the placenta.

Iispanica. Spansh.

IIispid. Covered with short stiff hairs

llomogamous. All of one kipd.

1Tumilis. Of low growth.

Hybridum. Hybrid.

Hypogynous. Growing from heneath the ova rilim.

Iberis. Frem Iberia, the ancient name of Spain. Imbricate. Laid over each other like scales.

Imperforated. Apparently full of holes wher held up to the light, like the leaf of the myrtle.

Incumbent. Lying upon.

Incurved. Bending inwards.

adefinite. Varying in number in different planta.

Indehiscent. Not opening naturally when ripe.

Ioferior. Below the base of the stamens.

Integrifolia. Entire-leared.

Inter-valvular. Between the valves, or parts into whien the seed-vessel is divided.

Involuere. The floral leaves when they surround the flowers.

Invelute. Rolled inwards.

Isecasdria. Having twenty, or more stamens.

Junceum. Reed-like.

Keeled. When two petnls are joined together, or one is mised and eurved in the centre, like the keel of a boat.

Koniga. In honour of Charles Konig, Esq., F.R.A., \&c.

Lavigatum. Very smoeth.

Laciniated. Decply cut in to small parts.

Laterally. On the sides.

Latifolin. Broad-leaved.

Lavatera. In hoveur of Lavater, the eelebrated physiognomist.

Legume. A seed-ressel which resembles that of the pea.

Ligulate. Flowers shaped like a cernet of paper, open at the top and jeined at the hattom.

Limb. The sprending part of a flower, in opposition to the tubular part, or the claws.

Linear. Line-like, leng and slender.

Linearo. Linear-leaved.

Loam. A soil consisting of equal parts of clay and some much lighter soil; as for example, a sandy loam consists of clay and sand, and a calcareous loam of clay and chalk.

Loasa. A fancifu] name coined by $\mathbf{A d a n s o n .}$

Lobules. Small lobes.

Loculieidal. From each cell. When the carpels of a fruit do not part from eacli other when ripe, but each opens down the midrib, like the fruit of the Martagen lily.

Loperia. In hopour of Lopez, a Spavish botanist.

Loriform. Slaped like a thong, or strap.

Luteum. Yellow.

Lyrate. A lobed leaf, in which the terminal lohe is larger than the side lobes

Macrantha. Large-flowered.

Maculata. Spotted. 
Malcomia. In bonour of Mr. Malcolm, a Patula. Spreading widely. nurseryman at Kensington.

Pedicels. Foot-stalks to tho flowers.

Resupinate. Inverted; turned in an epposite Iale flowers. Th and no pistils.

Malesherbia. In hooour of M1. de Malesherhes, a French botanist.

Peltate. A leaf is peltate whon the foot-stalk is fixed in the centro, like the leaf of tho Nasturtium.

Pontaglottis. Five-tongued.

Mathiola. In honour of P. A. Mathioli, an Pentagynia. Five styles.

Italian physician.

Peregrioum. Pilgrim-like, or wandering.

Meoonvillen. In honour of M. Thiery de Pcrenoial. Lasting several years

Menoovillc, a French oaturalist. $\quad$ Perfoliate. Where the stalk scems to pass

Mericarps. The two parts into which tlic seedvessel of umbelliferous plants is divided.

Miorantha. Small-flowered.

Microcarpa. Small-fruited.

Miniata. Small

Minima. The smallest.

Monandria. With only one stamen.

Monopsis. One-faced.

Morieandia. In honour of S. Moricnod, an Italian botanist.

Mucro. A little sharp point, terninating a leaf.

Mucronate. Ending in a sharp point, termed a mucro.

Multifid. Many times divided.

Muricated. Covered with warts, or any shert, hard excrescences.

Mutic. Pointless.

through the middlo of the leaf, like that of the Honeysuckle.

Perianth. The entire flower, includiag the calyx.

Pericarp. The fruit, or covering of the soedvessel.

Perigynous. Inserted in the calyx, or in the disk adhering to the caly $x$.

Persistent. Remsiniog on a loug time.

Personate. When the flower is somethiog liko a mouth, as the Stapdragoo.

Petals. Leaves of the flower.

Petioles. Footstalks to the leaves.

Phoniceum. Crimson.

Pilosc. Hairy.

Pionate. Consisting of several pairs of leaflets.

Pinne. The leaflets of a pionate leaf.

Pistil. The sced-beariog part of a flower. $\dot{A}$ pistil consists of the ovary, the style, and the stigma.

Naked. A naked seed is one without wings, \&c. ; and a naked branch, one without hair, down, leaves, \&c.

Nerves. Veins of the leaves.

(a)

A membrane to which the seeds are at tached in the capsnle or pod.

Plicate. Folded.

Necessaria. Composite flowers, in which the Plumose. Feathery.

florets of the disk are male, and those of the Plunula. The part of a sced wlich afterwards ray female.

Nocturna. Night.

Nodes or Nodi. Swelled articulations of the

stem, or knotted joints.

Nodosum. Knotted.

Numentaccous. Producing nuts.

Nyctelca. Froun Nykteris, a bat. becomes the ascending shoot.

Pollen. The fertiliziug dust, or yeliow powder, horne on the anthers.

Polyandria. Many stameos.

Polygyuia. Maoy styles.

Polymorphous. Of many forms.

Polyspermous. Containing maoy seeds.

Porrigens. Widely-spreading.

Pinoula. The leaflets of a doubly pinnato lenf.

Obcordate. Inverscly cordate, or heart-8haped. Otovate. Egg-shaped, with the hroad end uppermest.

Obsulctc. Scarcely perceptible.

Obtusifulium. Obtuse-leaved.

Ouhrolenea. Yellowish-white; from ochrace. ous, the colour of yellow ocbre, and leukos,

the Grcek word for white.

Octandria. With eight stamens.

Odorata. Fragrant.

Oliverianum. From the aame of Oliver, a travelles in the East.

Orhicular. Rouad, orb-like.

Orientalis. Fastern.

Ovaria. Iocipent seed-vessels.

Prismatic. Shaped like a prism.

Profoundly. Deeply.

Puberulous, Covered with spreading dowo.

Pubcscent. Covered with a soft whitish down.

Putancn. A uut of many cells.

Quadrangular. Four-sider.

Quadrivuloera. Four-wounded.

Raceme. When the flowers are dispersed rou ad a central stalk or racbis, each being on a short stalk.

Racemose. When the flowers sre produed in

racemes. Rachis. The central axis of

Radiatc. A composite flower, consisting of disk and ray flowers, like the Datisy.

Radical. Rising from the root.

Radical leaves. These rising from the root.

Ray. That part of a compositc flower the florets of which are ligulate.

Recptacle. Thic part at the upper end of the pedicel or foot-stalk that supports the different parts of the flower.

Reflexed. Bent back.

Reniform. Kidncy-shaped.

lepand. Undulated and dilated iu the margin. direction to what is usual.

Retorta. Twisted, turned back.

Retuse. Appearing as if bitten off.

Rhoeas. From tho Greck word for a Wild Poppy, or from the Sixon for red.

Ricotia. Derivatiou not known.

Ringent. Gaping, liko the flower of the Sage.

Rotatc. Whecl-shaped.

Rudimeatary. Imperfectly developed.

Runciate. Whon the lobes of a leaf ere hooked back, and gradually diminish to the base.

Sacoate. Bngged, projectiog at the base in the form of a bag or pouch.

Sagittate. Arrow-shaped.

Salicifolia. Willow-leaved.

Sativa. Cultiveted.

Scabrous. Rough or scahby.

Scariose or Scarious. Membranous and dry.

Scorpoid. Broom-like.

Seyphanthus. From Seyphos a cup, and Anthos a flower.

Sccund. Arranged on one side only.

Segetum. Corn.

Segments. The cut divisions of a leaf or flower.

Segregata. Composite flowers in which cach floret has its own involucre.

Sempervirens. Evergreen.

Sepals. Leaves of the calyx, or outer covering of the flower.

Septicidal. Dividing into sevoral parts. When a seed-ressel is composed of screral diatinet cernels, which part from each ather whon the secd is ripe, like the fruit of the Rhododendron.

Serrated. Cut like the teeth of a saw.

Sessilc. Without any foot-stalk.

Setose. Bristly.

Silene. From the beathen deity Silenus; tho fruth on the plants beiug compared to that from the moutl of a drunken man.

Silique. A long slender pod, like that of tho Radish or Cabbage.

Siliquosa. Having the secds in long round pods, like the Cabbage.

Sillicle. A small short pod, like that of tho radish.

Sinuate. Hollowed out or scalloped.

Sinuseg. Scallops, or hollowed-out parts.

Spathe. A brond leaf eowrapping and cnelosing the flowers beforc they expaod.

Spatulate. Shaped like the broad pointed knife used by druggists io spreading plasters.

Spike. Wheo the flowers aro disposed round a central stalk or axis, without soy sljort stalks.

Spikelets. Snall spike-like limoclies, divergiog from a spike of flowers.

Spirate. Twisted outwardly in the shape of a screw, like the bud of the Ipomen.

Spoogiole. The soft poreus part at the $\mathrm{cx}$ tremity of each root, intended to imbibe mojsture for the nourishenent of the plant.

Squarroso. Spreading stiffly at right angles.

Stamens. Thread-like substances found in the ceotre of evcry flower, which produce the fertilizing dust called the pollen, and which consist of two parts, the filamenta and the anther.

Stellatc. Star-like; gencrally applied to litclo tufts of liair or down.

Sterile filaments. Withuut aothers.

Sterilc. When applied to stamens or snthers, signifies deroid of pollen. 
Strige. Stiff upright hairs, swelled out at the $/$ Taraxacifolia. Dandelion-leaved,

base. The upper part of the pistil, intended
Stigma. Th to receive the pollen and convey it dewn the style to the ovarinm.

Stigmata. Stigmas, or the divisions of the stigma.

Stipe. The littlo stern that supports the seedvessel or ovary in the eentre of the flower.

Stipate. Furnished with a stipe.

Stipules. Swall leaves or membrancs at the baso of the petioles, or foot-stalks, of the leaves.

Stoloniferous. With the roots extending under the ground, like those of the Couch-grass.

Striatum. Striped.

Style. That part of a flower which is between the ovary aud the stigma.

Suaveolens. Very sweet-scented.

Sub. Somewhat, or rather.

Subnucumentaceous. Producing a few auts

Subulate. Awl-shaped, tapering to a point.

Succulent. Easily broken and full of juice.

Suffruticose. Half shrubby.

Superflua, Composite flowers which have the florets of the disk hisexual, and those of the row female.

Supcrior. Above the base of the stameus.

Surculi. Young shoots.

Suture. Where the seed-vessel opens maturally on only one side, like the pod of the pea, \&e. Syagesia. Composite flowers.

Tap-root. A long descending root, liko that of the Carrot.
Terate. Rcund and long, eylindrical.

Terminal. At the extremity of the shoots and branches.

Testa. The skin or cevering of the seed.

Tetradynamous. Having six stamens, four of which are longer than the other two.

Tetragonal. Four-sided.

Tetragynia. With four styles.

Tetra-bexandria. Sometimes four and sometimes six stamens.

Tetraedria. With four stamens.

Tetra-polygyuia. With four or many styles.

Tetraptera With a four-angled capsule.

Tomentose. Woolly.

Torulose. Cueven, alternately elevated and depressed.

Torus. The part or receptacle which spreads out below the ovarium, and supports the rest of the flower.

Trachymene. From two Greek words signify ing a rough membrane, in allusion to the coat of the fruit.

Transversely. Across.

Trichotumous. Produced in threes.

Trifid. Threc-cleft.

Trigynia. Threo styles.

Trilobum. Three-lobed.

Triquetrous. Three-cornered.

Triternate. A leaf composed of three parts, each eeasisting of three leaflets.

Trivalve. Three-valved: that is, with three valve-like openings.

Truncated. Appearing as if the cad had been cut off.
Tubercles, Warts.

Tubular. Joined together so as to form a tube, applied to the hidden part of the Convo:vulus, \&ce.

Tumid. Swollen.

Turbinate. Having the figure of a top.

Turgid. Tough, not brittle.

Umbellata. Umbel-like.

Umbilical cords. The strings hy whieh the seeds are sometimes attached to the ovary, as in the Magnolia.

Umbilicus. The part by which the seed is attached to the placenta.

Unarmed. Without prickles.

Undulata. Waved.

Unguienlate. Clawed; wher the petals of a flower become suddonly narrow, like those of the Pink or Caraation.

Unilateral. One-sided.

Usitntissimum. Much-used.

Utric ${ }^{\top}$. A little thin bladder or membrane.

Vernalis. Spring.

Versatile. Hung so lightly on the stalk as to move with every breath.

Verticillate. Whorled.

exillum. The upper erect part or staudard of a Pea-flower.

Villons. Clothed with soft long hairs.

Violaceum. Violet-coloured.

Virgate. Rod-like.

Vulgaris. Common.

\section{AUTHORITIES AND'BOOKS REFERRED 'TO.}

Adan. Adaoson, a Freach lotanist, author of the Familles des Plantes, \&e.

Ait. William Aitoa, Esq., Direetor of Royal Gaxdeus, and author of the Hortus Kewensis. All. Allioni, an ltalian botanist, author of many works.

Alp. Dec. M. Alphonse De Candolle, son of Professor De Candolle, of Geocva.

Andr: Audrew's, autlor of the Botanieal Repository and other works.

Balb. Signor Baltis of 'Turin, author of Flora Taurinensis, \&c.

Banks. Sir Joseph Banks.

Bartos. Two American botanists:

Bauh. Bauhin, two brothers, both eminent botanical authors.

Beauvois. A French botarist, who published a work on the plants of Africa in 1818 .

Benth. George Bentham, Esq., Secretary to the London Horticultural Socicty.

Berg. Borgeret, a Freneh botanist, author of a work on the plants found on the Pyrences.

Bieb. Maschall de Bicberstein, author of the Flora Taurico-Caueasica, and other works,

Biv. Bivona of Palermo, a Siciliao botanist.

liut. Gurd. See Maund.

But. The Botanist, conducted by B. Maund, Esq., 2 vols. to the end of 1839.
Bot. Nag. The Botanical Magazine; conSims, and now by Sir W. J. Hooker. 65 vols. to 1839 .

Bot. Reg. The Botanical Register, 25 vols, to 1840 ; now eondueted by Dr. Lindley.

Brot. Brotero, a Portuguese, author of the Flora Lusitanica.

Bucboz. A French botanical author.

Bull. Bulliard, a French botanical author.

Burchell. Author of Travels in Soutb Africa, \&re.

Cass. Cassini, an Italian botarist.

Cav. Cavanilles, Professor of Botany at Madrid.

Cliam. Chamisso, a German naturalist, who has long resided in Russia.

Chav. Clievanues, author of Monographic

des Aptirrhinées, published at Geneva.

Choisy. A Swiss botanist.

Church. Churchill's Medical Botany, 2 vols. Clarke. Autlior of Travels in various countriez of Europe, \&c.

Cuult. Coulter, author of Mémoiro sur les Dipsacées, published at Geneva.

Crabtz. A German hotanist, author of many works.

Curtis. A nurseryman at Lambeth, auther of many works, and who established the Bot. Mag, in 1787 .
Curt. Fl. Lond. Curtis's Flora Londineosis, 2 vols. 1777.

Cuon. Cunningham, an English botanist, well known for his researches in Australia.

D. Don. Professor of Botany in the King's College, and Lihrarian to the Lin. Soc.

Dec. Professor De Candolle, of Geneva, author of many botunical works.

Del. Delessert, a French botanical author.

Deppe. One of the writers in the Linnæa.

Desf. Des Fontaines. A French botanist, who travelled ia Afica; author of many works.

Dom. Dombey, a French botanist.

Donn. Author of Hortus Cantabrigiensis, \&e

Dougl. Douglas, a collector sent out to California hy the London Horticultural Society.

Dufr. Dufresae, author of Histoire Naturelle, \&c., de la Famille des Valerinnées.

Dum. Du Mont de Courset; a French hotanist, who had a splendid collection of plants in his gardeu acar Boulogue.

Dun. Dunal, a Frencb botanist, author of several works.

Elret. Author of Planta et Papilimes rariores. London, 1748. 
Ell. Elliot, author of a Sketch of the Botany of Snuth Carolins and Georgia.

Eng. Bot. English Botany, 36 vols. By Sir J. E. Smith, the plates by Sowerby. The second edition of this work is arranged according to the Linuean system.

Fisch. et Meyor. Fischer and Meyer, Russian botanists.

Fl. Cab. Floral Cabinet, conducted by Messrs. Knowles and Westcott, 3 vols.

Fl. Hist. Flora Historica, by Phillips, 2 vols London.

Forsk. Forskaol, a Danish betanist, author of several warks on the Flora of Egypt, \&c.

Foug. Fongeroux de Boudaroy, a French botanist.

Fuchs or Fuchsius. A German botanist, author of a Latin history of Plants, published a Basil iu 1542 .

Gart. Gärtner. Thero are two botanical anthors of this name, father and son.

Gault. Dr. Gaulthicr, s Freach writer on maple sugar.

G. Don. George Don, Esq., author of a General System of Botany, \&c. \&c.

Gill. Dr. Gillies, a traveller io South America.

Glox. Gloxin, author of Observationes Betanica, Strasburg.

Gmel. Gmelin. There were several botanists of this name, one of whom wrote the Flora Sibirica.

Craham. Dr. Graham of Edinburgh.

Guss. Gussone, a Neapolitan writer on plants.

Han. Dr. Buchanan, who afterwsrds tnok tho name of Hamilton. A writer ou Nepal plants.

Hayne. A German botavical author.

II. B. et Kunth. Humboldt, Bonpland, and B. et Kunth. Humts of South America.

Ifoff. G. F. Hoffman, a German botanist.

Huffm. et Link. IIoffman and Link, authers of the Flore Portugaise.

Hook. Sir W. J. Hooker, Professer of Botany at Glasgow, and Editor of the Bot. Mag.

Hook et Arnott. Sir W. J. Flooker, and Dr. Arnort, in a work on the Plants of South America.

Hom. Horneman, a Danish trotanist, one of the antliors of tbe Flora Danica.

Hort. Berol. Hortus Berolinensis, Catalogue of Plunts in the Berlin Garden.

Hort. Duro. Hortus Duroverni, a Catalogue of the Plants, \&c., in the Canterbury nursery.

Hortis Kowensis, A work in 5 vols., containing a Catalogue of the Plants cultivated in the Botanic Garden at Kew.

Hort. Hortus, or Hortnlanus, of gardens, or of gardeners; meaning a natue common in gardens before it was recorded in any book.

Houston, author of seme papers in Pbil. Trans.

Jacq. The Baron Von Jicquin, of Vicaua, allthor of many botanical worke.

Juss. Jussicu, the establisher of the Natural System of Botany. er. H. Bellenden Ker, Esq., for somo time Popp. Poppig, author of Travels in South Conductor nf the Bot. Reg.

unth. Author of the Flora Berolinensis, and ther works.

Knowl. et West. G. B. Kuowles and F. Westcott, Esqra., Conducters of the Floral Cabinet.

Lag. La Gssca, Profcssor of Botany at Madrid in 1811 ; author of many works.

La Llave et Lexarsa. Spanish botanista, who wrote on the plants of llexico.

Lam. Lamarck, s Freach botanist, one nf the suthors of tiıe Eucyclopédie Méthodiquo.

Lapey. La Peyrouse, snthor of the Histery of the Plants of the Pyrenees, \&c. \&c.

Ledeb. Ledebour, a Prussian botanist, suthor of Flora Altaica, \&c.

Lehm. Lehman, a German botanist, author of many works.

Leyss. Leysser, a Germso betanist.

L'Herit. L'Heritier, \& Freuch botsuist, author of many works.

Liadl. Dr. Lindley, author of the Ladies Botauy, and mayy other Botaoical works.

in. Linrazus.

in. juo. The son of Linnæus.

in. Syst. Linnean System.

Link. Professer of Botany at Gottingen.

Link and Otto. Professor Link, sad M. Otto, curator of the Berlin Bot. Gard., suthers of several works.

Lour. Loureire, anthor of the Flora Cechinchinensis, Lisbon, 1790.

Mart. Mill. Prefessor Martyn's edition of Miller's Dictionary, published in 1787.

Maund's Bot. Gard. The Botanic Garden, conducted by B. Maund, Esq., 8 vols. to the end of 1839.

Michx. Michanx, father and son; two French botanists, whe wrote on the plants of North America.

Mill. Philip Miller, suthor of Miller's Dictionary.

vill. Dict. The Gardener's Dictionary.

Ioc. et Sess. Mocino and Sessé, two Spanish botanists, who published the Flora Mexicana. Mauch. A German botanist, suthor of many works.

teris. Morison, sn old English botanical author in the 17 th ceotury.

Murr. J. A. Murray, Esq., an English botanist, whe published a work on the Linnen System, \&a.

N. Burm. Nicol Burmana, a Dutch botanist, snthor of several works.

Neck. Necker, auther of Elementa Betanica, $8 \times c$

Necs von Essenbach. Anthor of Horre Physica Berolineosis, \&c. Bonu, 1820.

Nute. Nuttall, an American bntanist, suther of several works.

Ortega A spanish botanist, anthor of the Continuation of the Flora Espanols.

Pers. Persoon, anthor of $\mathrm{s}$ work on Fuugi, \&c. Pliay. The aucient Roman oaturalist. Amcrien.

Pohl. Author of Plantarum Brasiles, \&c. published at Vienna.

Poir. Poiret, a French botanist, one of the suthors of the Encyc. Méthodique.

Pursh. The author of a Flors of Nerth A merica.

Ræusch. Ræuschel, suthor of an enumeration of plants, \&c., published at Loipsig.

Raf. Rafincsque, an American ; suthor of tho Medical Flora of the United Statcs, \&c.

R. Br. Dr. Rebert Brown, suthor of many works.

Reich. Reiclard, stuther of several botanical works published at Frankfort.

Retz or Retzins. A German botanical auther.

Rich. Richard, father and sou, Freach botanist, suthors of maay works.

Riv. Rivinus, a German suthor of several werks.

Rom. et Schultes. Romer a Swiss, and Schultes a German, who wrote conjeintly Systema Tegetabilum, 7 vols., \&c.

Roth. A German botanical suthor.

Roxb. Dr. Rexburgh, suthor of Hertus Beugalensis, \&ce.

Ruiz et Pavou. Two Spanish botanists, who wrote the Flora Peruviana, \&c.

Sal. R. A. Salisbury, Esq., suther of severs] botanical works.

Schlecht. Professor Schlechteoda] of Berlio, conductor of the Linnen, and suther of maey botanical works.

Schmidt. Autlor of Florn Bohemica, \&c.

Schott. A German botanist residing at Leipsig.

Schou, Schousboa, \& Swedish botanist, who wrote on the plants of Morocco.

chrad. Schrader, s Hanoverian botanist, suthor of several works.

Scop. Seopoli, author of the l'lors Carninlica, \&c. \&c.

Shaw. Author of Travels in Barbary and the Levant, \&c.

Sib. et Fis. Dr. Sibthorp, s celebrated botanical traveller, snd one of the authers of the Flor Graca ; snd Dr. Fischer, Director of the Imperial Botanic Garden at St. Peteraburgh.

Sib, et Smith FI. Grace. Dr. Sibthorp and Sir James Edward Smith in the Flora Graca.

Sims. Dr. Sims, for many years editer of the Bot. Mag.

Smith. Sir James Edward Smith, suther of many botanical works.

Spach. A German botanist residing in Paris, cclebrated for making many new species aod geacra.

Spreng. Sprengel, a German hotanist, author of many botanical works.

Stev, Steven, anthor of several works on the plants of Russia.

Swt. Brit. Flow. Gard. The British Flower Garden, by Robert Sweet, 7 vols.

Swt. Robert Swcet suthor of the British Flower Garden, snd several lotauical works.

Tsusch. Author of several botanisal worke, published at Pragne. 
Tenore. Author of the Flora Neapolitana, Vahl. A Danish botanist, author of many Walds. et Kit. Waldstein and Kitaibel, who \&rc.

Thore. Author of Observations in the Journal Botanique.

Thun. Thunberg, author of the Flora Japonica, \&e. \&c.

Tourne. Tournefort, a botanical author, who published a System of Plants founded on

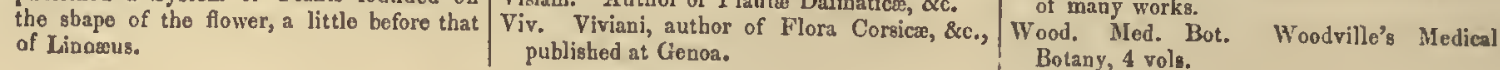
Veut.

Veut. Ventenat, a French botanist and Wallr. Wallroth, a German botanist.
botanical author. wrote on the Plants of Hungary.

Vig. Viruier, a French batt. Walter, author of the Flora Caroliniana. g. Wiguer, a French botanist, who wrote Wein. Weinmana, a German botanist, author the Natural History of Poppics and Arge- of several works. mones.
Visiani. Author of Plantæ Dalmatice, \&c. Willd. Willdenow, a German botanist, author
Viv, Vo many works. published at Cienoa.

THE END. 


